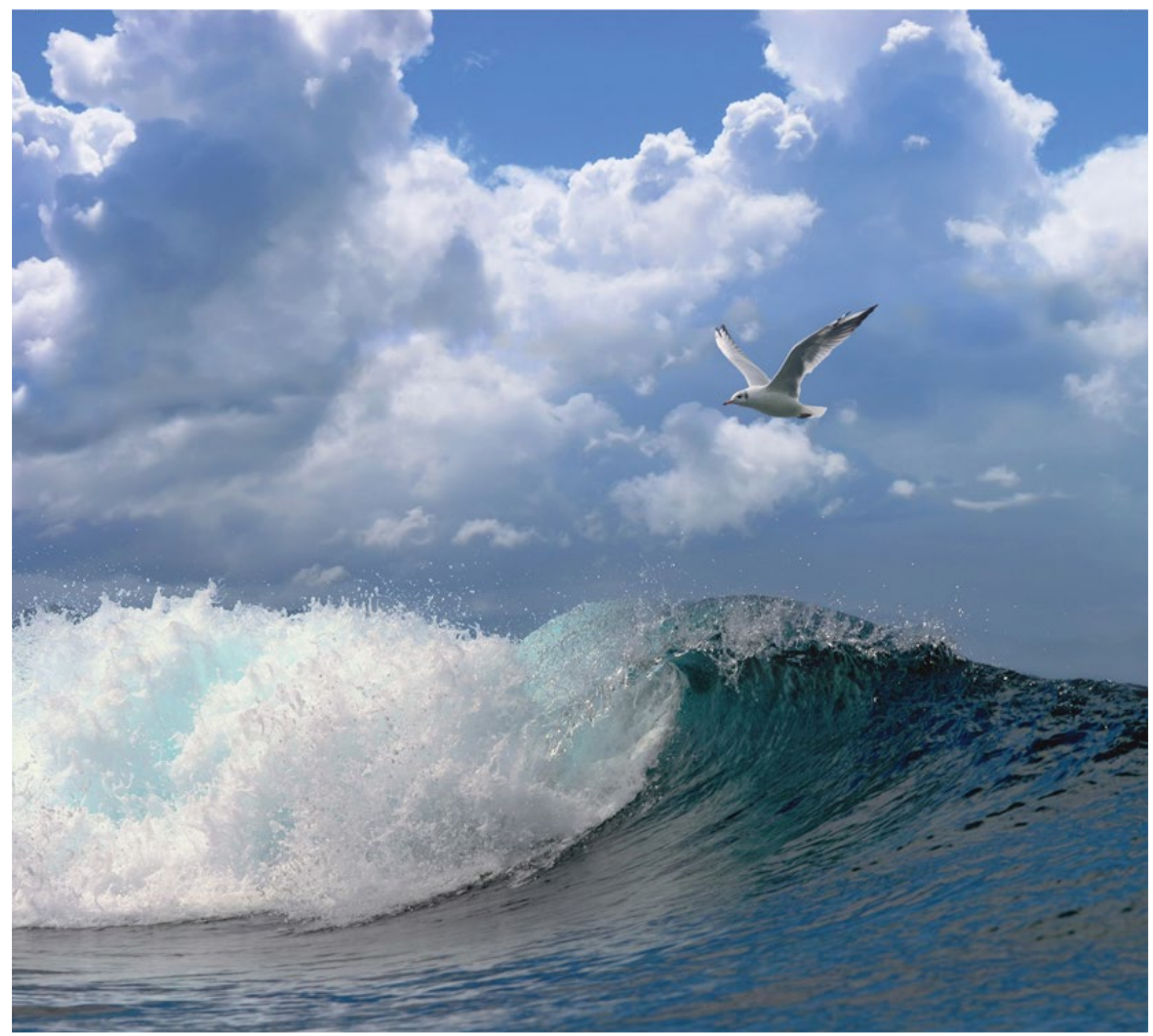

\title{
Syntheserapport PMR NCV
}

Redactie: I. Tulp ${ }^{1}$, T.C. Prins $^{2}$, J.A.M. Craeymeersch ${ }^{1}$, S. IJff ${ }^{2}$, M.T. van der Sluis ${ }^{1}$

${ }^{1}=$ Wageningen Marine Research, ${ }^{2}=$ Deltares 


\section{Syntheserapport PMR NCV}

Versie 30 maart 2018

Redactie: $\quad$ I. Tulp, T.C. Prins, J.A.M. Craeymeersch, S. IJff, M.T. van der Sluis

Publicatiedatum: 30 maart 2018

Opdrachtgever:

Rijkswaterstaat WVL, t.a.v. Mennobart van Eerden

Postbus 17

8200 AA Lelystad 


\section{Titel}

\section{Opdrachtgever}

RWS-WVL

\section{Kenmerk}

Wageningen Marine Research: C014/18

Deltares: $1230156-000-Z K S-0004$
Pagina's

281

\section{Samenvatting}

In dit Syntheserapport worden de relevante bevindingen uit het onderzoek en de monitoring binnen het monitorings- en onderzoeksprogramma PMR NCV gecombineerd om tot een eenduidig antwoord te komen op een aantal onderzoeksvragen.

Bij aanvang van het monitoringprogramma van PMR-NCV in 2009 zijn in het Monitoring- en Evaluatie Programma (MEP-NCV) de vragen geformuleerd waarop het monitoringprogramma van de natuurcompensatie een antwoord dient te geven.

De synthese van de resultaten en het onderliggende monitoring en onderzoek is uitgevoerd door een consortium onder leiding van Wageningen Marine Research en Deltares.

Het doel van de monitoring van de natuurcompensatie in de Voordelta is om antwoord te kunnen geven op de vraag of, middels extra bescherming in de vorm van visserij beperkende maatregelen en de instelling van extra rustgebieden voor zwarte zee-eenden en sterns, voldoende wordt gecompenseerd voor de destijds voorspelde significante effecten als gevolg van de aanleg en aanwezigheid van Maasvlakte 2 .

\begin{tabular}{|c|c|c|c|c|c|}
\hline Versie & Datum & Review & Paraaf & Goedkeuring & Paraat \\
\hline & 30 Maart 2018 & Dr. R.G. Jak & & Drs. J. Asjes & \\
\hline
\end{tabular}

30 Maart 2018 Dr. L.A. van Duren

Dit rapport is gratis te downloaden van https://doi.org/10.18174/496768

Wageningen Marine Research verstrekt geen gedrukte exemplaren van rapporten. Wageningen Marine Research Wageningen UR is ISO 9001:2008 gecertificeerd.

\section{(C) 2019 Wageningen Marine Research}

Wageningen Marine Research, instituut binnen de rechtspersoon Stichting

Wageningen Research, hierbij

vertegenwoordigt door Dr. M.C.Th.

Scholten, Algemeen directeur

KvK nr. 09098104,

WMR BTW nr. NL 8113.83.696.B16.

Code BIC/SWIFT address: RABONL2U

IBAN code: NL 73 RABO 0373599285
Wageningen Marine Research aanvaardt geen aansprakelijkheid voor gevolgschade, noch voor schade welke voortvloeit uit toepassingen van de resultaten van werkzaamheden of andere gegevens verkregen van Wageningen Marine Research opdrachtgever vrijwaart Wageningen Marine Research van aanspraken van derden in verband met deze toepassing.

Alle rechten voorbehouden. Niets uit deze uitgave mag weergegeven en/of gepubliceerd worden, gefotokopieerd of op enige andere manier gebruikt worden zonder schriftelijke toestemming van de uitgever of auteur. 


\section{Auteurs}

H 1: M.T. van der Sluis ${ }^{1}$, T.C. Prins ${ }^{2}$, S.D. IJff ${ }^{2}$, I. Tulp ${ }^{1}$

H 2: M.T. van der Sluis ${ }^{1}$, T.C. Prins ${ }^{2}$

H 3: S.D. IJff ${ }^{2}$, J. Adema ${ }^{3}$, T.C. Prins ${ }^{2}$

H 4: N.T. Hintzen ${ }^{1}$, N.S.H. Tien ${ }^{1}$

H5: I. Tulp ${ }^{1}$, J.A.M Craeymeersch ${ }^{1}$, L.J.Bolle ${ }^{1}$, V.L. Escaravage ${ }^{1}$, S.T. Glorius ${ }^{1}$, C. Chun ${ }^{1}$, A.F. Zuur ${ }^{9}$

H 6: S. Dirksen ${ }^{4,7}$, P.W. van Horssen ${ }^{4,8}$, E. van der Zee ${ }^{4}$, K. van de Wolfshaar $^{1}$, T.C. Prins ${ }^{2}$

H 7: I. Tulp ${ }^{1}$, R. Fijn ${ }^{5}$, W. Courtens ${ }^{6}$, E. Stienen ${ }^{6}$

H8: T.C. Prins ${ }^{2}$, I. Tulp ${ }^{1}$, S.D. IJff ${ }^{2}$, M.T. van der Sluis ${ }^{1}$

1: Wageningen Marine Research

2: Deltares

3: Arcadis

4: Altenburg en Wymenga

5: Bureau Waardenburg

6: Instituut voor Natuur- en Bosonderzoek

7: Sjoerd Dirksen Ecology

8: Greenstat

9: Highland Statistics Ltd. 


\section{Inhoud}

\section{Inhoud 4}

$\begin{array}{lr}\text { Monitoring Natuurcompensatie PMR NCV } & 8\end{array}$

Passende beoordeling en Compensatiemaatregelen $\quad 9$

Monitoring- en Evaluatie- (MEP-) vragen $\quad 9$

$\begin{array}{lr}\text { Uitvoering } & 10\end{array}$

De Voordelta $r$

$\begin{array}{ll}\text { Ontwikkelingen in de visserij } & 11\end{array}$

H111012

Sterns 17

$\begin{array}{ll}\text { Zwarte zee-eend } & 20\end{array}$

$1 \quad$ Inleiding $\quad 23$

$\begin{array}{lll}1.1 & \text { Aanleiding } & 23\end{array}$

1.2 Doel van dit rapport, rol in synthese en evaluatie 23

$\begin{array}{lll}1.3 & \text { Afbakening onderzoeksgebied } & 24\end{array}$

$\begin{array}{lll}1.4 & \text { De Voordelta als Natura } 2000 \text { gebied } & 25\end{array}$

$\begin{array}{lll}1.5 & \text { Compensatiemaatregelen } & 27\end{array}$

$\begin{array}{lll}1.6 & \text { Organisatie PMR-NCV } & 29\end{array}$

1.6.1 Tijdlijn Monitorings- en onderzoeksprogramma PMR NCV 29

$\begin{array}{llr}1.7 & \text { Leeswijzer } & 30\end{array}$

2 Monitoring $\quad 31$

2.1 Het monitoringsprogramma en aanpassingen daarin $\quad 31$

$\begin{array}{lll}2.1 .1 & \text { BACI ontwerp } & 32\end{array}$

$\begin{array}{lll}2.1 .2 & \text { Benthos } & 33\end{array}$

$\begin{array}{lll}2.1 .3 \text { Vis } & 35\end{array}$

$\begin{array}{lll}2.1 .4 & \text { Vogels } & 38\end{array}$

$\begin{array}{lll}2.1 .5 & \text { Abiotiek } & 42\end{array}$

$\begin{array}{lll}2.1 .6 & \text { Gebruik } & 43\end{array}$

$3 \quad$ Beschrijving Voordelta $\quad 44$

3.1 Morfologische ontwikkeling van de Voordelta 44

3.2 Abiotische omgevingsfactoren 4

$\begin{array}{lll}3.2 .1 & \text { Water- en luchttemperatuur } & 47\end{array}$

$\begin{array}{lll}3.2 .2 & \text { Stormen en bodemschuifspanning } & 48\end{array}$

$\begin{array}{lll}3.2 .3 & \text { Rivierafvoer en saliniteit } & 51\end{array}$

$\begin{array}{lll}3.3 & \text { Ecologie } & 54\end{array}$

$\begin{array}{lll}3.3 .1 & \text { Bodemfauna } & 54\end{array}$

$\begin{array}{lll}3.3 .2 \text { Vis } & 55\end{array}$

$\begin{array}{lll}3.3 .3 & \text { Vogels } & 56\end{array}$

$\begin{array}{lll}3.4 & \text { Menselijk gebruik } & 60\end{array}$

$4 \quad$ Ontwikkeling in de visserij $\quad 63$

4.1 Ontwikkeling visserij-inspanning in de Voordelta 63

$\begin{array}{lll}4.2 & \text { Garnalenvisserij binnen en buiten de Voordelta } & 67\end{array}$

$\begin{array}{lll}4.3 & \text { Langetermijntrends boomkorvisserij } & 68\end{array}$

$\begin{array}{lll}4.3 .1 & \text { Voordelta } & 68\end{array}$

$\begin{array}{ll}\text { 4.3.2 Noordzeebreed } & 70\end{array}$

$\begin{array}{lll}4.4 & \text { Beantwoording onderzoeksvragen } & 70\end{array}$

$\begin{array}{lll}4.4 .1 & \text { Discussie } & 73\end{array}$ 
5.1 Benthos $\quad 75$

$\begin{array}{lll}5.1 .1 & \text { Onderzoeksvragen } & 75\end{array}$

5.1.2 Beantwoording van onderzoeksvragen: parameters 76

5.1.3 Combineren bodemschaaf en box corer data 76

5.1.4 Van BACI-experiment naar analyse van correlaties $\quad 77$

$\begin{array}{lll}5.1 .5 & \text { Leeswijzer analyses } & 78\end{array}$

5.1.6 Algemene beschrijving veranderingen in tijd en ruimte 79

5.1.7 Veranderingen in bodemfauna in relatie tot abiotiek en visserij: habitatmodellering $\quad 85$

5.1.8 Veranderingen in bodemfaunagemeenschap: multivariate analyses 93

5.1.9 Trait based approach 102

5.1.10 Vergelijking veranderingen in bodemfauna eigenschappen tussen locaties met $\begin{array}{ll}\text { een contrast in visserijdruk } & 110\end{array}$

5.1.11 Lange termijn veranderingen in bodemfauna in de Voordelta en langs de $\begin{array}{ll}\text { Hollandse kust in relatie tot visserij } & 122\end{array}$

5.1.12 Vergelijking natuurlijke versus visserijverstoring $\quad 131$

$\begin{array}{ll}5.1 .13 & \text { Discussie }\end{array}$

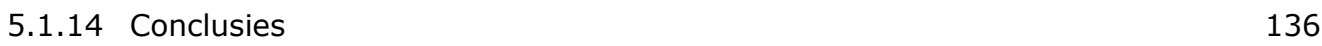

5.2 Vis $\quad 136$

$\begin{array}{lll}5.2 .1 & \text { Onderzoeksvragen } & 136\end{array}$

5.2.2 Beantwoording van onderzoeksvragen: parameters 137

5.2.3 Van BACI experiment naar analyse van correlaties $\quad 138$

$\begin{array}{ll}\text { 5.2.4 Ecologie van vis in de Voordelta } & 139\end{array}$

5.2.5 Algemene schets ontwikkeling vis en epibenthos in de Voordelta en langs de $\begin{array}{ll}\text { Hollandse kust } & 139\end{array}$

5.2.6 Veranderingen in dichtheden in relatie tot abiotiek en visserij 142

5.2.7 Veranderingen in vis/epibenthos gemeenschap 149

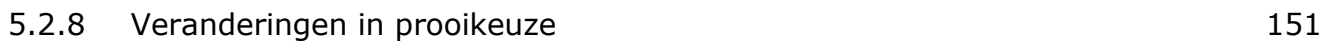

5.2.9 Veranderingen in leeftijdsopbouw $\quad 154$

5.2.10 Veranderingen in groei 156

5.2.11 Veranderingen in conditie $\quad 158$

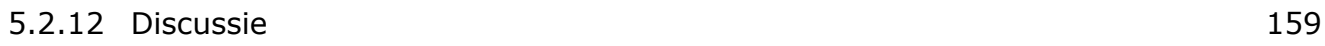

$\begin{array}{ll}5.2 .13 \text { Conclusies } & 160\end{array}$

$\begin{array}{lll}5.3 & \text { Huidige stand van zaken kennis effecten garnalenvisserij } & 161\end{array}$

$\begin{array}{lll}\text { 5.3.1 Achtergrond } & 161\end{array}$

5.3.2 Effecten garnalenvisserij Natura2000 gebieden $\quad 161$

5.3.3 Experiment Voordelta 162

$\begin{array}{lll}5.3 .4 & \text { BENTHIS } & 162\end{array}$

$\begin{array}{lll}5.3 .5 & \text { VIBEG } & 162\end{array}$

5.3.6 KBWOT RIBS 163

5.3.7 Ontwikkeling bodemfauna in referentiegebied Rottum 163

5.3.8 Monitoring Viswad gebieden Waddenzee 163

$\begin{array}{ll}\text { 5.3.9 overige literatuur } & 163\end{array}$

5.4 Voortschrijdend inzicht effecten van sleepnetvisserij op de zeebodem en het benthische $\begin{array}{ll}\text { ecosysteem } & 164\end{array}$

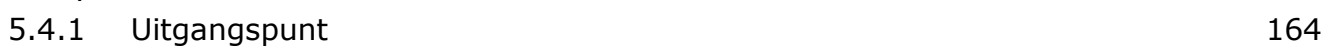

5.4.2 De stand van kennis in $2005 \quad 164$

5.4.3 Kennisontwikkeling sinds $2005 \quad 165$

$\begin{array}{lll}5.4 .4 & \text { Biological trait analyse } & 165\end{array}$

5.4.5 Visserij impact van verschillende vistuigen 166

5.4.6 Meta-analyse van benthos sterfte en herstel 166

5.4.7 Studies op het Nederlands Continentaal Plat 167

$\begin{array}{ll}5.4 .8 & \text { Voedselweb effecten } \\ 5.4 .9 & 167\end{array}$

5.4.9 Impact assessment methode $\quad 168$

5.4.10 Discussie 168

$\begin{array}{ll}5.4 .11 \text { Conclusie } & 169\end{array}$ 
6.1 Onderzoeksvragen $\quad 171$

6.2 Korte beschrijving van de uitgevoerde monitoring en onderzoek 172

6.2.1 Monitoring $\quad 172$

6.2.2 Modellering van potentiële aantallen zwarte zee-eenden $\quad 174$

6.3 Het effect van het verdwijnen van het Maasvlakte 2 gebied 175

6.3.1 Historische waarnemingen 176

6.3.2 Waarnemingen in de TO 177

$\begin{array}{ll}\text { 6.3.3 Voedselaanbod in de T0 } & 177\end{array}$

6.3.4 Modelberekening potentiële aantal zwarte zee-eenden in het Maasvlakte2 $\begin{array}{ll}\text { gebied } & 178\end{array}$

$\begin{array}{lll}\text { 6.3.5 Conclusies } & 178\end{array}$

6.4 De potentiële functie van de Voordelta en het instellen van het
bodembeschermingsgebied

6.4.1 Waarnemingen van zwarte zee-eenden in de Voordelta $\quad 178$

6.4.2 Voedselaanbod voor zwarte zee-eenden in de Voordelta 181

6.4.3 Het effect van verstoring 184

6.4.4 Het effect van schelpdier-soortensamenstelling $\quad 185$

6.4.5 Potentiële aantallen zwarte zee-eenden in de Voordelta 186

6.4.6 Ontwikkelingen in gebieden buiten de Voordelta; Nederland 191

6.4.7 Ontwikkelingen in gebieden buiten de Voordelta; NW Europa 193

6.4.8 Conclusies 194

6.5 De potentiële functie van de Voordelta en het instellen van de rustgebieden 194

$\begin{array}{lll}6.5 .1 & \text { Gebruik rustgebieden } & 195\end{array}$

6.5.2 Conclusies 199

$\begin{array}{llr}6.6 & \text { Discussie } & 199\end{array}$

$\begin{array}{lll}6.7 & \text { Conclusies } & 202\end{array}$

$\begin{array}{llr}7 & \text { Grote stern en visdief } & 204\end{array}$

$\begin{array}{lll}7.1 & \text { Onderzoeksvragen } & 204\end{array}$

7.2 Korte beschrijving van uitgevoerde monitoring en onderzoek 206

7.3 Het verdwijnen van het Maasvlakte 2 gebied: consequenties voor grote stern 207

$\begin{array}{lll}7.4 & \text { De functie van de Voordelta voor de grote stern } & 210\end{array}$

7.4.1 Aantallen en verspreiding foeragerende grote sterns 210

7.4.2 Voedselbeschikbaarheid aan de hand van visbemonstering 217

$\begin{array}{lll}7.4 .3 & \text { Broedsucces in relatie tot voedsel } & 220\end{array}$

$\begin{array}{lll}7.4 .4 & \text { Zandspiering } & 224\end{array}$

$\begin{array}{lll}\text { 7.4.5 Invloed van andere factoren op broedsucces } & 228\end{array}$

$\begin{array}{lll}7.5 & \text { De functie van de rustgebieden in de Voordelta voor de grote stern } & 230\end{array}$

7.6 Het verdwijnen van het Maasvlakte 2 gebied: consequenties voor visdief 238

$\begin{array}{lll}\text { 7.6.1 Gebruik Maasvlakte gebied } & 238\end{array}$

7.6.2 Effect vergroten vliegafstand visdieven van Maasvlakte 2-kolonie $\quad 241$

$\begin{array}{lll}7.7 & \text { De functie van de Voordelta voor de visdief } & 243\end{array}$

$\begin{array}{lll}\text { 7.7.1 } & \text { Broedsucces in relatie tot voedsel } & 247\end{array}$

7.7.2 Invloed van andere factoren op broedsucces $\quad 249$

$\begin{array}{lll}7.8 & \text { De functie van de rustgebieden in de Voordelta voor de visdief } & 250\end{array}$

7.9 Discussie $\quad 253$

$\begin{array}{ll}7.10 & \text { Conclusies } \\ \end{array}$

$8 \quad$ Slotbeschouwing en aanbevelingen $\quad 257$

8.1 MEP vraag 1; kwaliteit habitattype H1110 258

8.1.1 Aanbevelingen $\quad 259$

8.2 MEP vraag 2; zwarte zee-eend 259

$\begin{array}{ll}\text { 8.2.1 Aanbevelingen } & 261\end{array}$

8.3 MEP vraag 3 en 4; grote stern en visdief $\quad 261$

$\begin{array}{lll}\text { 8.3.1 Aanbevelingen } & 262\end{array}$ 
Verantwoording

Bijlage 1 Onderzoeks- en MEP-vragen

Bijlage 2 Monsterprogramma Benthos

279

Bijlage 3 Soorten en parameters perceel vis

281 


\section{Samenvatting}

\section{Monitoring Natuurcompensatie PMR NCV}

In 2006 is door het toenmalige kabinet een planologische kernbeslissing genomen over het Project Mainportontwikkeling Rotterdam (PMR), met onder andere de doelstelling om de mainport Rotterdam te versterken, door het ruimtetekort voor haven- en industriële activiteiten in het Rotterdamse havengebied op te lossen. In dit kader is in 2008 in de Voordelta aansluitend aan Maasvlakte 1, Maasvlakte 2 aangelegd.

In 2008 is de Voordelta aangewezen als Natura 2000-gebied. Voor Natura 2000-gebieden zijn, op grond van de Vogel- en Habitatrichtlijn, kenmerkende leefgebieden en soorten aangewezen, waarvoor speciale bescherming geldt. Vanwege de mogelijkheid dat de aanleg van de Tweede Maasvlakte significant negatieve effecten veroorzaakt op deze beschermde natuur, is compensatie verplicht op grond van de Natuurbeschermingswet 1998.

Als compensatiemaatregel zijn rustgebieden en een bodembeschermingsgebied (BBG) aangewezen. Hier gelden beperkingen voor vormen van visserij die de zeebodem verstoren. Het doel van de monitoring natuurcompensatie Voordelta is om vast te stellen of de getroffen compensatiemaatregelen de daadwerkelijk optredende negatieve effecten van de aanleg van de Tweede Maasvlakte op de Voordelta voldoende compenseren.

Dit jaar wordt de effectiviteit van de compensatiemaatregelen geëvalueerd conform de afspraken in de UitWerkingsOvereenkomst (UWO). In 2020 vindt de uiteindelijke evaluatie plaats in het kader van de PKB (Planologische KernBeslissing, 2009-2019). De evaluatie in 2018 kan worden gezien als een tussentijdse evaluatie. Het doel van deze evaluatie is "het aantonen van de effectiviteit van de in voorschrift 23a van de in de Nbwet-vergunning opgenomen compensatieopgave voor het habitattype H1110B, de zwarte zee-eend, de grote stern en de visdief' (brief Ministerie EZ aan HbR d.d. 22 december 2015).

De betrokken overheidspartijen hebben afgesproken om, door middel van een serie Monitoring en Evaluatie Programma's (MEP's), met een vergelijkbare aanpak en opzet, op een eenduidige en gestructureerde wijze vorm te geven aan de rapportage over het grotere geheel van PMR en de deelprojecten.

Het Monitoring- en Evaluatie Programma (MEP-NCV), waarin de effecten van de compensatiemaatregelen in de Voordelta worden gemonitord, is in 2004 van start gegaan met de nulmetingen. In 2009 is de eerste fase van de monitoring gestart. Tijdens de eerste fase en de overbrugging naar de tweede fase was de monitoring binnen het onderdeel MEP-NCV ondergebracht in een aantal percelen: Benthos, Vogels, Vis, Abiotiek en Gebruik. Deltares leidde het consortium met Wageningen Marine Research (voorheen IMARES) (Benthos en Vis), Lievense CSO (Gebruik), Arcadis (Alkyon) (Abiotiek), INBO (Vogels), NIOZ (Benthos) en Bureau Waardenburg (Vogels), in opdracht van Rijkswaterstaat WVL. In 2014 is uitgebreid gerapporteerd over de resultaten van de $1^{\mathrm{e}}$ fase.

$\mathrm{Na}$ een Europese aanbestedingsprocedure is in 2016 de tweede fase van de monitoring natuurcompensatie gestart, met een nieuw consortium van onderzoeksbureaus onder leiding van Wageningen Marine Research (voorheen IMARES) en Deltares als partner. In de tweede fase is het onderzoek ondergebracht in de percelen Benthos, Abiotiek, Vis, Zwarte zee-eend en Sterns. Een deel van de monitoring en onderzoek wordt door Wageningen Marine Research (Benthos en Vis) en Deltares (Abiotiek) zelf uitgevoerd en een deel door de onderaannemers: Eurofins AquaSense met partner E-coast (Benthos), Arcadis (Abiotiek), Altenburg en Wymenga met partners Bioconsult, Greenstat en Sjoerd Dirksen Ecology (Zwarte zee-eend) en Bureau Waardenburg met partner INBO (sterns). 
Dit syntheserapport vormt de wetenschappelijke basis voor de tussentijdse evaluatie in 2018. Het eerste Syntheserapport PMR-NCV 2e fase (2016-2020) is een samenvattende rapportage van de monitorings- en onderzoeksresultaten die tot nu toe (2018) binnen het project PMR-NCV zijn gegenereerd.

\section{Passende beoordeling en Compensatiemaatregelen}

In de Passende Beoordeling die in 2007 is uitgevoerd is een aantal effecten van de aanwezigheid van Maasvlakte als significant negatief beoordeeld. Die effecten, als gevolg van ruimtebeslag en morfologische veranderingen in het Natura 2000-gebied Voordelta zijn dat:

- $\quad 2.455$ hectare van habitattype $\mathrm{H} 1110$ (ondiepe zeeën met zandbanken die permanent onder water staan) verloren gaat (In de Evaluatie in het kader van MEP Aanleg Maasvlakte 2 is in 2013 geconcludeerd dat het daadwerkelijke areaalverlies van habitat $\mathrm{H} 1110$ iets minder is dan destijds in MER en PB voorspeld);

- $\quad$ negatieve effecten optreden op de foerageerfunctie voor de grote stern van $1,7 \%$, op de foerageerfunctie voor de visdief van $5,9 \%$, en op de foerageerfunctie voor de zwarte zee-eend van $3,1 \%$.

Ter compensatie van deze effecten is binnen de Voordelta een aantal maatregelen getroffen. De maatregelen betreffen het instellen van:

- een bodembeschermingsgebied;

- een aantal rustgebieden binnen het bodembeschermingsgebied (Bollen van de Ooster, Bollen van het Nieuwe Zand en de Hinderplaat);

Het in 2008 ingestelde Bodembeschermingsgebied (BBG) bestrijkt ca 25.000 ha, tien maal de omvang van het areaal zeegebied dat als gevolg van de aanleg van Maasvlakte 2 verloren is gegaan. In het BBG worden boomkorvissers met wekkerkettingen (>260 pk) sinds 2008 geweerd om de kwaliteit van habitattype $\mathrm{H} 1110$ te verbeteren. Het BBG is overigens wel grotendeels toegankelijk voor de garnalenvisserij.

Voor de zwarte zee-eend, grote stern en visdief zijn rustgebieden ingesteld: de Bollen van de Ooster, Bollen van het Nieuwe Zand (zwarte zee-eend) en de Hinderplaat (grote stern en visdief).

In de aangewezen rustgebieden geldt een verbod op, of beperking van, menselijke activiteiten om het verlies in foerageerfunctie als gevolg van de aanleg van Maasvlakte 2 voor zwarte zee-eend, grote stern en visdief te compenseren.

Tijdens de evaluatie in 2013 is gebleken dat de zwarte zee-eenden in de Voordelta zich voornamelijk buiten de rustgebieden Bollen van de Ooster en Bollen van het Nieuwe Zand bevonden. De begrenzing van de rustgebieden voor de zwarte zee-eend is daarop per 1 november 2016 aangepast: op basis van habitatmodellering is een aangepaste begrenzing voorgesteld voor beide rustgebieden. Naast de begrenzing is ook de openstelling van de rustgebieden aangepast: het rustgebied Bollen van het Nieuwe Zand is jaarrond gesloten voor alle vormen van bodemberoerende visserij. Voor het rustgebied de Bollen van de Ooster wordt een uitzondering gemaakt voor de garnalenvisserij. De garnalenvisserij is toegestaan in het gebied in de periode van 1 november tot 15 december.

\section{Monitoring- en Evaluatie- (MEP-) vragen}

Bij aanvang van het monitoringprogramma van PMR-NCV in 2009 zijn in het Monitoring- en Evaluatie Programma (MEP-NCV) de vragen geformuleerd waarop het monitoringprogramma van de natuurcompensatie een antwoord dient te geven.

De hoofdvragen uit het MEP zijn:

1. Wordt het verlies aan habitattype H1110 als gevolg van de aanleg van Maasvlakte 2 voldoende gecompenseerd?

2. Wordt het verlies aan foerageergebied van de zwarte zee-eend als gevolg van de aanleg en het gebruik van Maasvlakte 2 voldoende gecompenseerd? 
3. Wordt het verlies aan foerageergebied van de grote stern als gevolg van het ruimtebeslag en het gebruik van Maasvlakte 2 voldoende gecompenseerd?

4. Wordt het verlies aan foerageergebied van de visdief als gevolg van het ruimtebeslag en het gebruik van Maasvlakte 2 voldoende gecompenseerd?

\section{Uitvoering}

Binnen het langlopende monitorings- en onderzoeksprogramma PMR-NCV kunnen verschillende fases worden onderscheiden. Tussen 2004 en 2007 zijn de nulmetingen verricht. Van 2009-2013 vond de eerste fase plaats van de monitoring van natuurcompensatie in de Voordelta. Het monitoringsprogramma kende twee overbruggingsjaren in 2014 en 2015 waarin de monitoring gedeeltelijk is voortgezet en waarin daarnaast aandacht is besteed aan verschillende desk studies. In 2016 is de tweede fase van start gegaan met een aangepast monitoringsprogramma.

\section{De Voordelta}

De Voordelta is het gebied bestaand uit de ondiepe kustwateren voor de delta van Zuid- Holland en Zeeland. Door de ligging voor de Zuid-Hollandse en Zeeuwse delta wijkt het gebied af van de kustwateren die verder noordelijk voor de Hollandse kust liggen.

De Voordelta is sinds 2008 een Natura 2000-gebied en het grootste deel (ruim 87.000 ha na aanleg van Maasvlakte 2) is gekarakteriseerd als habitattype $\mathrm{H} 1110$ (permanent overstroomde zandbanken). Een klein deel (ongeveer 2.200 ha) bestaat uit habitattype H1140 (slik- en zandplaten).

De aanleg van de Deltawerken heeft grote effecten gehad op de processen in de buitendelta's van de (voormalige) estuaria, de gebieden van ondiepten en geulen aan de zeezijde van de mondingen.

De Voordelta wordt door de ondiepe ligging in de zuidwestelijke Delta gekarakteriseerd door een grote dynamiek in abiotische kenmerken zoals stroomsnelheid, sedimentsamenstelling en zoutgehalte.

De grote natuurlijke dynamiek in de Voordelta is bepalend voor de soorten die in de Voordelta voorkomen.

Door de sterke invloed van de rivieren is de Voordelta, evenals de rest van de Nederlandse kustwateren, een hoog productief gebied met relatief hoge concentraties voedingsstoffen en fytoplankton.

Abiotische omstandigheden zijn cruciaal in de dynamiek van de diergroepen die bestudeerd zijn: bodemfauna, vis en vogels. Daarom is in dit project uitgebreide aandacht besteed aan het meten en modelleren van abiotische parameters. Zo is de zoetwaterafvoer door het Haringvliet een sterk bepalende factor voor de saliniteit in de Noordelijke Voordelta. In de monitoringsperiodes hebben zich geen periodes met sterk verhoogde rivierafvoeren voorgedaan, leidend tot sterk verlaagde zoutgehaltes in de Voordelta.

Strenge winters kunnen van grote invloed zijn op de overleving van bodemdieren en op de broedval. De winters in de monitoringjaren voor PMR-NCV waren normaal (2009-2013) of zacht tot buitengewoon zacht (2004-2008, 2014-2017).

Zware stormen kunnen leiden tot omwoeling van de bodem in ondiepe delen waardoor bodemdieren worden losgewoeld. In de PMR-NCV monitoringjaren is een zware storm alleen voorgekomen in januari 2007.

Voor bodemfauna is ook de bodemschuifspanning een bepalende variabele. De bodemschuifspanning vertoonde een sterk seizoenspatroon met hogere waarden in de wintermaanden, maar weinig jaar-opjaarvariatie. Wel kwamen hoge piekwaarden in de winter van 2011/2012 frequenter voor dan in andere jaren.

De Voordelta functioneert als kinderkamer voor jonge vis en garnalen. Door het relatief warmere zeewater, het rijke voedselaanbod en de mogelijkheid beschutting te zoeken voor roofdieren kan de jonge vis hier veilig opgroeien. 
De visgemeenschap wordt niet alleen door lokale factoren bepaald, maar ook door de aanvoer van eieren en larven, die met de zeestroming worden getransporteerd vanuit paaigebieden elders, zoals de zuidelijke Noordzee of het Kanaal. Jonge pelagische vis is belangrijk als stapelvoedsel voor grote stern en visdief, dit zijn in de Voordelta met name de soorten zandspiering, haring en sprot.

De Voordelta is een belangrijk gebied voor een groot aantal soorten vogels. Voor de Natuurcompensatie zijn de zwarte zee-eend, grote stern en visdief van belang.

Zeevogels die de Voordelta een deel van het jaar gebruiken als foerageergebied (zoals de zwarte zeeeend) maken deel uit van een grotere, NW Europese populatie. Grote stern en de visdief die in de nabijheid broeden en de Voordelta als foerageergebied gebruiken, worden gekenmerkt door sterke veranderingen in plaats en omvang van broedkolonies.

De Voordelta wordt intensief gebruikt voor visserij, recreatie en scheepvaart. Recreatie in de Voordelta vindt plaats in verschillende vormen, waaronder verschillende soorten watersport (vooral kitesurfen) en plaatbezoek. Strandrecreatie vindt langs de gehele kust plaats. Beroepsscheepvaart, maar ook recreatievaart, wordt vooral in de diepere delen van de Voordelta waargenomen, in de vaargeulen en de routes naar Westerschelde, Neeltje Jans en Stellendam. In de Voordelta komen van oudsher verschillende vormen van visserij voor.

\section{Ontwikkelingen in de visserij}

Op basis van VMS (Vessel Monitoring through Satellite)- en logboekgegevens van de schepen en interviews van vissers zijn de ontwikkelingen van de visserij in de Voordelta en in het BBG in kaart gebracht. De visserij door platviskotters in het gebied van het latere BBG was al vrijwel verdwenen, voordat het BBG in werking trad in 2008. De boomkorvisserij is grotendeels verdwenen uit de hele Voordelta en is de meest recente jaren alleen nog rondom de Oosterscheldemond en in de noordwestelijke hoek van de Voordelta aanwezig.

De afname in de boomkorvisserij lijkt Noordzeebreed plaats te hebben gevonden: de platviskotters zijn in hun hele visgebied minder gaan vissen in de periode 2004-2015. Binnen de Voordelta lijkt er wel een extra grote afname te zijn. Echter, het begin van deze Voordelta-specifieke afname lijkt eerder ingezet dan in de periode 2004-2015 en heeft daardoor waarschijnlijk niet te maken met het instellen van het BBG in 2008. De visserij-inspanning in de Voordelta is wel rond 2008/2009 op een laag en basaal niveau gestabiliseerd. Het is mogelijk dat de komst van het BBG en de Maasvlakte 2 hier een rol bij hebben gespeeld door grotere fragmentatie en verlies aan visserijgrond. Het instellen van het Bodembeschermingsgebied kan dus een kleine, aanvullende rol hebben gespeeld in de afname van de bodemberoerende visserij in het gebied. Ook uit de meeste interviews bleek dat de instelling van het BBG niet echt invloed lijkt te hebben gehad op de boomkorvisserij.

De enige andere bodemberoerende visserij van betekenis in dit gebied, door garnalenkotters, is juist toegenomen sinds de instelling van het BBG. Ook binnen het BBG heeft een toename van garnalenvisserij plaatsgevonden. De ontwikkeling in de garnalenvisserij zoals we die zien in de Voordelta volgt nauw de ontwikkeling van de hele vloot in de andere kuststreken van Nederland en lijkt dus niet beïnvloed te zijn door de instelling van het Bodembeschermingsgebied.

Met behulp van informatie uit logboeken, VMS en discard-monitoringsprogramma's zijn in de tweede fase van de monitoring, schattingen gemaakt van de onttrekkingen (aanlandingen en discards) van vis.

De onttrekking heeft een verwaarloosbare invloed op de visbestanden waarvoor bestandschattingen beschikbaar zijn; dit komt doordat het leefgebied van deze bestanden Noordzee-breed of groter is en de bestanden veel groter zijn dan wat er in de Voordelta leeft. De invloed van de Voordelta-visserij is dus relatief klein. Een uitzondering hierop is garnaal, hierbij is de invloed van de visserij op het bestand substantieel. De invloed op de overige Noordzeebestanden, de bodemfauna en residente vissoorten - waarvoor geen bestandschattingen beschikbaar zijn - kunnen we niet bepalen. In de Voordelta is de totale onttrekking door de platvis- en garnalenkotters aan vis tussen de periode voor de instelling van het bodembeschermingsgebied en de periode erna verminderd van 1031 ton naar 
517 ton. De onttrekking aan garnaal en bodemfauna is in dezelfde periode toegenomen van 1748 naar 2409 ton.

\section{H1110}

Voor het onderdeel H1110 is er onderzoek uitgevoerd vanuit verschillende invalshoeken met als doel antwoord te kunnen geven op de volgende vragen:

1) Wordt het verlies aan habitattype H1110B als gevolg van de aanleg van Maasvlakte 2 voldoende gecompenseerd?

c) Zijn er positieve trends waar te nemen in kwaliteit van het Habitat 1110B (zoals deze wordt gedefinieerd in het profieldocument $\mathrm{H} 1110$ (versie 18 december 2008)), in de Voordelta sinds het begin van de afname van de boomkorvisserij uit de Voordelta rond de laatste eeuwwisseling? d) Zijn de waargenomen trends toe te schrijven aan de afgenomen bodemberoering ten gevolge van de afname van de grote boomkorvisserij met wekkerkettingen in de gehele Voordelta of ook aan andere factoren?

\section{BODEMFAUNA}

\section{Hypothesen}

De onderzoeksvraag gaat om veranderingen in kwaliteit van H1110. De compensatie-opgave betrof een $10 \%$ verbetering in kwaliteit gemeten in totale bodemfauna biomassa. Daarom is deze parameter bij aanvang van het onderzoek aangewezen als de parameter op basis waarvan de evaluatie van de compensatie uitgevoerd zou worden. Vanwege de compensatie-opgave voor zwarte zee-eend is in de eerste fase daarnaast ook de verandering in de biomassa als voedsel voor vogels onderzocht. Naast deze twee parameters is nog een hele reeks andere parameters onderzocht. Uitgangspunt is geweest te redeneren vanuit hypotheses over de verwachtte veranderingen als gevolg van de veranderingen in de bodemberoerende visserij. Hierbij is ook belangrijk dat het effect van beide bodemberoerende visserijen anders door kan werken op de bodemfauna.

De verwachting was dat het uitsluiten van de boomkorvisserij zou leiden tot een toename in totale biomassa en biomassa als voedsel voor vogels. Bij een afname in bodemberoerende visserij en sterfte als gevolg hiervan, verwachten we ook een verandering in de gemiddelde of maximale lengtes van schelpdieren, het gemiddeld individueel gewicht waarbij de verwachting is dat dieren ouder en dus ook groter en zwaarder kunnen worden als gevolg van uitsluiten van de boomkorvisserij. Ook kan het totaal aantal soorten of het aandeel grote soorten toenemen. Daarnaast kunnen ook taxonomische en/of functionele verschuivingen in de bodemdiergemeenschap duiden op een respons van de bodemfauna op het uitsluiten van de boomkorvisserij. De verwachting is dat een vermindering van visserijdruk resulteert in een verbeterde overleving van de voor visserij gevoelige soorten.

\section{Uitgevoerd onderzoek}

De bodemfauna is na de aanleg van Maasvlakte 2 bemonsterd op ca 400 monsterpunten verspreid over de Voordelta, waarvan 170 in het Bodembeschermingsgebied en 240 erbuiten (in de T0 is ook in het later ingepolderde gebied bemonsterd). Op elk punt is gemonsterd met zowel bodemschaaf als boxcorer in de periode 2004-2017. In alle analyses is per monsterpunt de combinatie van de twee monstertuigen gebruikt zodat de meeste representatieve doorsnede verkregen wordt door de hele bodemfaunagemeenschap (zowel grote als kleine organismen). In deze rapportage is gerapporteerd over de periode 2004-2015, de data van de laatste twee jaar zijn nog niet beschikbaar.

Bij aanvang van het onderzoek was de verwachting dat de boomkorvisserij zou verdwijnen uit het Bodembeschermingsgebied, maar niet uit het omringende zeegebied. De opzet van het onderzoek aan zowel bodemfauna als vis was dan ook gestoeld op een gebiedsvergelijking van ontwikkelingen in het Bodembeschermingsgebied en een of meerdere referentiegebieden middels een BACI (Before After Control Impact) opzet. Aangezien 1) het grootste deel van de boomkorvisserij al verdwenen was bij instelling van de maatregel in 2008 en 2) de boomkorvisserij niet alleen uit het Bodembeschermingsgebied maar ook uit de referentiegebieden verdwenen was en 3 ) de 
garnalenvisserij in het Bodembeschermingsgebied sterk is toegenomen, is de oorspronkelijke BACI opzet losgelaten. Deze ontwikkeling maakte het onmogelijk om aan de oorspronkelijke analyse vast te houden: immers er was geen contrast meer in behandeling tussen controle en impact gebied. Daarom hebben we noodgedwongen de analyses anders ingestoken dan voorzien bij aanvang.

In plaats van een vergelijking in ontwikkeling tussen twee gebieden, onderzoeken we nu direct de relatie tussen visserij inspanning en bodemfauna/visdichtheden op de bemonsterde plekken, los van het feit of deze plekken in het Bodembeschermingsgebied liggen of niet. In de uitgevoerde statistische analyses zijn telkens de effecten van abiotische omstandigheden en de verandering in visserijdruk op de bodemfauna in samenhang onderzocht. Dat is op een aantal verschillende manieren gedaan, waarbij we begonnen zijn met 1) alle monsterpunten in het hele gebied mee te nemen. Omdat er in deze set weinig contrast was in bevissingsintensiteit zijn er ook analyses uitgevoerd op 2) deelsets (een voor elke visserij) waarbinnen dit wel het geval was. Aanvullend hierop zijn voor beide visserijen ook nog 3) specifieke sets punten geselecteerd die wel bevist zijn (als behandeling) en die niet bevist zijn (als controle). Dit kan feitelijk beschouwd worden als een achteraf geselecteerde BACI analyse.

Daarnaast hebben we ook de Voordelta in breder perspectief bekeken. Dit is gedaan door, op basis van gegevens uit de WOT schelpdiersurvey, trends in relatie tot bevissingsintensiteit te analyseren in gebieden buiten de Voordelta langs de Hollandse kust, over een langere periode dan op basis van de PMR-NCV monitoring mogelijk is (>1995). Hierbij is informatie over bevissingsintensiteit uit VMS (sinds 2006) en logboekdata gebruikt (sinds 1995).

Naast de analyses op basis van de verdeling over soorten, hebben we ook de Trait Based Approach toegepast. In plaats van individuele soorten wordt de bodemfaunabiomassa gegroepeerd op basis van hun life history kenmerken (traits) die meer of minder gevoelig zijn voor verstoring. De verdeling over de verschillende trait modaliteiten geeft dan een meer mechanistisch inzicht over hoe verstoring door bodemberoering doorwerkt op de bodemfauna.

Afgezien van verstoring door visserij, vindt er in de Voordelta ook veel natuurlijke verstoring plaats. De verhouding tussen die twee en de ruimtelijke overlap wordt ook beschreven aan de hand van abiotische data.

\section{Veranderingen in bodemfauna in samenhang met visserijdruk en abiotiek}

De effecten van boomkorvisserij op het de bodemfauna in relatie tot abiotische variabelen (afkomstig uit modellering uit het perceel Abiotiek), zoals dat onderzocht is in de diverse (habitat)analyses (univariaat en multivariaat) laten een vrij uniform beeld zien. Vergeleken met de variatie die door ruimte en tijd wordt veroorzaakt, is de bijdrage van de abiotische factoren en visserijdruk gering. De biomassa als voedsel voor vogels is hoger, en het aantal taxa en de maximale lengte van Ensis directus is lager op punten met een hogere visserijdruk door boomkorvisserij. Drie van de zes onderzochte responsvariabelen (totale biomassa, biomassa voor vogels en aantal taxa) laten een positieve relatie zien met visserijdruk door garnalenvisserij en de overige drie vertonen geen verband.

Ingezoomd op de voor de boomkorvisserij relevante gebieden en periodes (>10 m diep, 2004-2005) laten de analyses voor alle parameters (behalve max. lengte Ensis directus) een positief verband met boomkorvisserij zien. De deelselectie van punten ( $<10 \mathrm{~m}$ diep, 2009-2015) gericht op garnalenvisserij laat voor geen enkele parameter een verband met garnalenvisserij zien.

De analyse waarbij gepoogd is gebieden met een verschil in bevissing te contrasteren liet zien dat bij aanvang de beviste en onbeviste garnalenlocaties erg vergelijkbaar waren, maar dat de beviste en onbeviste plots uit elkaar gingen lopen vanaf het moment van de intensivering van de garnalenvisserij in 2009. Dit bleek zowel uit de veranderingen in de gemeenschap als uit de zes geanalyseerde parameters. De door garnalenvisserij beviste punten hadden hogere dichtheden van de schelpdieren Amerikaanse zwaardschede (Ensis directus) en witte dunschaal (Abra alba), de borstelworm Capitella en overige slib-minnende borstelwormen (Lanice, Owenia) vergeleken met de controle locaties. De beviste en onbeviste boomkorlocaties lieten geen verschil in ontwikkeling zien in de gemeenschap, maar wel in het gemiddelde individuele gewicht en de totale bodemdieren biomassa, met hogere waardes in de beviste locaties. Ook in deze analyse bleek weer dat de populatiedynamiek van de 
Amerikaanse zwaardschede van grote invloed is op de univariate benthosparameters door de dominantie van die soort.

Concluderend leveren bovengenoemde analyses een beeld dat op plekken met veel visserij (zowel boomkor- als garnalenvisserij) een hogere benthosbiomassa voorkomt. De vraag is natuurlijk of hier sprake is van een causaal verband. Ofwel de biomassa neemt toe als gevolg van visserij, ofwel de visserij concentreert zich op plekken met veel bodemdierenbiomassa. Daarbij is de Amerikaanse zwaardschede veruit de belangrijkste component van de biomassa.

Veel soorten uit de WOT schelpdiersurvey laten de laatste 10 jaar een toename zien zowel in de Voordelta als langs de Hollandse kust. Op basis van de VMS data (vanaf 2006) zijn geen significante relaties met boomkor of garnalenvisserij gevonden. De serie is echter erg kort voor deze analyse en de power waarschijnlijk te laag. Voor een aantal soorten worden op basis van de wat langere serie (vanaf 1995) met visserijgegevens op basis van logboekdata significante correlaties met de visserijdruk door de boomkorvisserij gevonden, maar de verbanden zijn zowel positief als negatief: vier soorten (Amerikaanse zwaardschede, rechtsgestreepte platschelp, nonnetje, stevige strandschelp) positief, drie soorten (otterschelp, slangsterren, halfgeknotte strandschelp) in sommige gebieden positief, in andere negatief. De aasetende soorten lijken samen te fluctueren maar voor geen van de aasetende soorten zijn significante relaties met de boomkorvisserij gevonden.

De trait-based approach liet zien dat in de Voordelta de voor verstoring meest gevoelige groep bodemdieren (K2 strategen) en de groep van soorten die aangepast zijn aan een hoge frequentie van verstoring (A strategen) weinig voorkomen. De bodemfauna in de Voordelta wordt gedomineerd door $r$-strategen. De verwachting is dat bij een afname in bodemberoerende visserij er een verschuiving optreedt van $r$ en $\mathrm{A}$ naar $\mathrm{K}$ strategen. In de onderzochte tijdserie zien we dit niet.

Ook het grootste deel van de variatie in de analyses op basis van traits werd verklaard door abiotiek. De relaties met de intensiteit van boomkorvisserij en garnalenvisserij waren statistisch significant, maar gezien het lage percentage verklaarde variantie waarschijnlijk biologisch niet relevant. Het gevonden verband tussen soortkenmerken en visserijdruk door boomkor- en garnalenvisserij was tegengesteld aan de verwachting: de kenmerken die toenamen met hogere visserijdruk waren: grotere, langlevende, diep ingegraven, filtrerende sessiele soorten. Dit wordt waarschijnlijk vooral veroorzaakt door Ensis: weliswaar groot en langlevend, maar ook diep ingegraven, waardoor ze toch bestand zijn tegen bodemberoering. Ook hier komt dus weer de belangrijke rol van Ensis naar voren.

Uit de analyse van de natuurlijke verstoring in de Voordelta bleek verder dat de gebieden met de meeste natuurlijke verstoring sterk overlappen met de gebieden die het intensiefst bevist worden door de garnalenvisserij.

\section{De dominante rol van de Amerikaanse zwaardschede (Ensis directus)}

Uit vrijwel alle analyses komt de dominante rol van Ensis naar voren. 60-80\% van de totale biomassa bestaat uit Ensis directus. Deze soort lijkt geen last te hebben van boomkor- en garnalenvisserij, sterker nog, in een aantal analyses is een positief verband gevonden met visserijdruk. Veel van de kenmerken van Ensis maken dat deze soort aangepast is aan het leven in sterk dynamische omgeving. De ingraafdiepte en het snelle reactievermogen zorgen ervoor dat ze geen last lijken te hebben van de bodemberoerende visserij, en de snelle manier van verplaatsen geeft ze de mogelijkheid om nieuwe (open gevallen) plekken te koloniseren.

\section{VIS}

\section{Hypothesen}

We hebben in de diverse analyses onderzocht of er veranderingen te zien zijn in de visfauna die gerelateerd kunnen zijn aan een verandering in visserijdruk. Hierbij is onderzocht of er veranderingen in dichtheid, soortensamenstelling, prooikeuze, leeftijdsopbouw, groei en conditie zijn opgetreden. Naast een verandering in dichtheden kunnen ook verschuivingen in de vis/epibenthosgemeenschap duiden op een verandering in de bodemfauna. Bij een afname in bodemberoerende visserij en sterfte als gevolg hiervan, verwachten we ook een verandering in de leeftijdsopbouw: een verschuiving van een gemeenschap oververtegenwoordigd door kleine en jonge vissen naar een gemeenschap met een 
evenwichtiger leeftijdsverdeling. Door vermindering van visserijdruk is de verwachting dat dit resulteert in een verbeterde overleving van de residente soorten en een toename van de oudere leeftijdsgroepen. Als het prooiaanbod (door veranderingen in het benthos) verandert, kunnen sommige soorten daarvan meer profiteren dan andere soorten. Wanneer biomassa, dichtheid, productie en/of samenstelling van benthos verandert als gevolg van de verminderde bodemberoering, zou dat mogelijk kunnen doorwerken in het dieet van vissen, de groei en/of conditie.

\section{Uitgevoerd onderzoek}

Vanwege dezelfde reden als genoemd bij bodemfauna hebben we in de tweede fase de analyses anders ingestoken. In plaats van een vergelijking in ontwikkeling tussen twee gebieden, onderzoeken we nu direct de relatie tussen visserijinspanning en visdichtheden op de bemonsterde plekken Voor het visonderzoek is aangesloten bij de Demersal Fish Survey, waarbij voor PMR-NCV het standaardprogramma van 11 trekken is uitgebreid met 13 extra trekken. Naast dichtheden worden ook gegevens over leeftijd en conditie verzameld. Dieetonderzoek is alleen in de eerste fase is uitgevoerd. Om de ontwikkelingen in de Voordelta in breder perspectief te plaatsen zijn ze ook vergeleken met de ontwikkelingen langs de Hollandse kust.

Met het gebruikte vistuig worden naast vissen ook epibenthossoorten zoals krabben en zeesterren gevangen. In een aantal analyses zijn ook de gegevens van het epibenthos gebruikt.

In plaats van individuele vissoorten zijn ecologische groepen (gildes) geanalyseerd waarvan met name de resultaten van marien juveniele (kinderkamer) en residente soorten gepresenteerd worden. Middels habitatmodellen is onderzocht of de dichtheden van ecologische groepen veranderd zijn rekening houdend met variatie in abiotiek. Ook hebben we de visgemeenschap als geheel (multivariaat) geanalyseerd samen met kwantitatief belangrijke groepen epibenthos in relatie tot abiotiek en visserij. Relaties met mogelijke veranderingen in het prooiaanbod zijn onderzocht in dieetanalyses. Veranderingen in leeftijdsopbouw zijn onderzocht aan de hand van otolieten.

\section{Veranderingen in visfauna in samenhang met visserijdruk en abiotiek}

Sinds 1970 hebben zich grote veranderingen voorgedaan in de visgemeenschap in de Voordelta en langs de hele Nederlandse kust. Ten eerste is het groottespectrum veranderd naar gemiddeld kleinere vissen. Dat komt deels door het verdwijnen van grote exemplaren, maar ook de opkomst van klein blijvende soorten. De dominante rol van schol is overgenomen door schar. Zandspieringen vertonen een opvallende toename in de laatste decennia. Gezien de sterke relatie van zandspieringen met de bodem en hun sterke voorkeur voor een bepaalde sedimentsamenstelling is hiervoor een aantal mogelijke verklaringen: de zandsuppleties en het verdwijnen van de boomkorvisserij. Een opvallende ontwikkeling is de sterke toename van slangsterren in de Voordelta sinds 2009. Ook in de benthosbemonstering zien we deze ontwikkeling, maar minder prominent. Deze toename is niet zichtbaar langs de Hollandse kust.

De habitatmodellen op basis van de ecologische groepen (gildes) laten zien dat de dichtheden, rekening houdend met variatie veroorzaakt door abiotiek, geen relatie met de lokale visserijinspanning (zowel boomkor- als garnalenvisserij) in de Voordelta vertonen. Uit de statistische trendberekeningen van de ecologische groepen blijkt dat de trends in de Voordelta over het algemeen goed overeenkomen met die langs de Zuid-Hollandse kust. Kinderkamersoorten vertonen in alle gebieden relatief hoge dichtheden in de periode 1980-1990 gevolgd door een afname die zich langer voort heeft gezet langs de Noord-Hollandse kust dan in de Voordelta. Voor geen van de onderzochte ecologische groepen is er een statistische relatie gevonden tussen de trend in aantalsontwikkeling en visserij-inspanning. De relatief korte tijdserie (alleen data over visserij-inspanning voor 2006-2016) kan hier een oorzaak van zijn.

Ook de multivariate analyses laten zien dat de bodemgemeenschap (vis en epibenthos) in de loop van de periode is veranderd, maar de ontwikkelingen in Voordelta, Zuid-Hollandse en Noord-Hollandse kust gaan in dezelfde richting. In de Voordelta zijn diverse abiotische factoren en de inspanning door boomkorvisserij en garnalenvisserij significante voorspellende variabelen voor de verandering in de gemeenschap, maar de abiotische variabelen verklaren een veel groter deel (10.8 en $22 \%$ ) van de variantie dan de visserijdruk ( $0.7 \%$ boomkor en $6.9 \%$ garnalen). 
Uit de combinatie van maaganalyses en het beschikbare benthos op de plekken waar de vissen gevangen waren, bleek dat vissen actief prooisoorten selecteren (dus meer dan op basis van het voorkomen verwacht zou worden) die resistent zijn voor visserij. Bodemfaunasoorten die gevoelig zijn voor visserij bleken ook relatief weinig voor te komen in het gebied.

Drie van de vier commercieel beviste soorten (schol, tong, bot) lieten geen verandering in leeftijdsstructuur zien in de periode 2002/2008-2016. Bij schar nam het aandeel oudere vis duidelijk toe zowel in de Voordelta als langs de Hollandse kust. Van twee van de vier klein blijvende nietcommerciële vissoorten (kleine pieterman en dwergtong) nam het aandeel oudere vis juist af in de periode 2009-2016. De andere twee (pitvis, schurftvis) vertoonden geen veranderingen. De waargenomen patronen zouden te maken kunnen hebben met de veranderingen in de visserij in het kustgebied: de toename in de garnalenvisserij en de afname in de boomkorvisserij, maar zouden ook andere oorzaken kunnen hebben, zoals bijvoorbeeld veranderingen in zeewatertemperatuur. In de garnalenvisserij lopen met name de kleinere soorten een groot risico lopen bijgevangen te worden.

Een fenomeen dat zich op grote (Noordzeebrede) schaal voordoet, is de afname in lengte op een bepaalde leeftijd, een aanwijzing dat ze minder goed groeien. Dit zagen we ook terug bij schol, tong en schar in de Voordelta en langs de Hollandse kust. Diverse hypothesen zijn voorgesteld over de mogelijke oorzaken hiervan. Mogelijke sturende factoren zijn: toenemende temperatuur, afnemende nutriënten, visserij-effect, dichtheidsafhankelijke effecten (bij huidige hoge aantallen platvis neemt concurrentie om voedsel toe).

De conditie van de soorten schol, tong, schar en bot laat geen duidelijke toe- of afname zien in de periode 1995/2004-2016. Er zit wel een duidelijk jaarsignaal in, dat parallel loopt tussen Voordelta en Hollandse kust. Dit suggereert dat de voedselsituatie, temperatuur of andere groeibepalende factoren wel variëren tussen jaren, maar dat dat op een vrij brede ruimtelijke schaal gesynchroniseerd is.

\section{De resultaten in perspectief}

Op basis van de voortschrijdende kennis sinds de start van het Voordelta onderzoek, vergaard in andere projecten, kunnen we de van te voren gedefinieerde verwachtingen over het effect van het instellen van het bodembeschermingsgebied bijstellen. Op basis van de huidige kennis over de mechanismen waarmee sleepnetten het benthos beïnvloeden verwachten we dat sterke afname in intensiteit van boomkorvisserij zal resulteren in een toename van het benthos dat kwetsbaar is voor bodemvisserij, met name in gebieden met lage natuurlijke dynamiek en daarmee een lagere natuurlijke verstoring. We verwachten dus een verandering in de benthossamenstelling (meer kwetsbare soorten) en toename van de soortenrijkdom in de meer beschutte gebieden van de Voordelta. Of de totale biomassa van bodemdieren zal toenemen is afhankelijk van de processen in het voedselweb (predatie door vis en competitie om voedsel) die het benthos reguleren. In hoogdynamische delen van de Voordelta waar de zeebodem regelmatig wordt verstoord door natuurlijke processen is het onzeker of de biomassa en soortenrijkdom van het benthos zal herstellen omdat het onzeker is of de boomkorvisserij hier een negatief effect heeft op het benthos. In deze delen van de Voordelta bestaat het benthos namelijk uit soorten die minder gevoelig zijn voor verstoring door natuurlijke dynamiek of visserij.

Voor het feit dat de bovengenoemde bijgestelde verwachtingen niet te zien zijn in de waargenomen veranderingen in het benthos is een aantal mogelijke verklaringen:

- Het deel van de Voordelta waar, met name in de T0 jaren, nog boomkorvisserij met relatief hoge intensiteit voorkwam, is klein. Er zijn daarom maar weinig monitoringpunten met hoge visserijintensiteit, waardoor er weinig contrast is in visserijdruk en de meetbaarheid van het effect van visserij op de bodemdierengemeenschap klein is.

- Echter, vanwege het grotendeels verdwijnen van de boomkorvisserij uit de Voordelta zou een verandering in het benthos (in de richting zoals boven beschreven: meer kwetsbare soorten) sinds de T0 verwacht kunnen worden. Dat deze verandering over de periode 2004-2015 niet waarneembaar is, kan door verscheidene factoren veroorzaakt zijn:

- de grote natuurlijke jaarlijkse variatie in het benthos beperkt de meetbaarheid van een trend 
- de verstoring door natuurlijke processen is zo groot dat er geen verandering in het benthos naar meer kwetsbare soorten optreedt

- door de dominantie van Ensis directus, die mogelijk minder gevoelig is voor verstoring door visserij en natuurlijke dynamiek, treedt er geen verandering op of is de meetbaarheid gering

- continue verstoring door garnalenvisserij heeft tot gevolg dat er geen verandering optreedt

- voedselweb interacties tussen vis en benthos compliceren het verband tussen bevissing en de biomassa en samenstelling van het benthos

Het is niet mogelijk om, op basis van de beschikbare gegevens en analyses, een uitspraak te doen over welke van deze verklaringen het meest plausibel is.

\section{Sterns}

\section{Onderzoeksvragen grote stern}

3 Wordt het verlies aan foerageergebied van de grote stern als gevolg van het ruimtebeslag en het gebruik van Maasvlakte 2 voldoende gecompenseerd?

a) Hoe is, op basis van voortschrijdend inzicht, de inschatting van het effect van de aanleg van Maasvlakte 2 op het instandhoudingsdoel voor deze soort?

i) Wat was, in kwalitatieve termen, de betekenis van het verdwenen foerageergebied.

ii) Wat is, in kwalitatieve termen, de betekenis van het nieuwe kustgebied na aanleg van Maasvlakte 2

b) Leidt het instellen van het bodembeschermingsgebied tot een gelijkblijvende potentiële functie van de Voordelta voor de grote stern in termen van voedselbeschikbaarheid?

i) Treden veranderingen op in broedsucces, het voedsel, de verspreidingspatronen en het aantal vogeldagen van de grote stern t.o.v. de situatie vóór de aanleg van Maasvlakte 2?

ii) Zijn deze veranderingen toe te schrijven aan (veranderingen in) de voedselbeschikbaarheid of zijn andere factoren van (groter) belang?

iii) Is er een correlatie tussen de verschillende vormen van bodemberoerende visserij en de aanwezigheid en dichtheid van zandspiering in de Voordelta. Is het aannemelijk dat het om een causaal verband gaat?

c) Draagt het instellen van de rustgebieden bij aan het instandhoudingsdoel van de grote stern?

i) Worden de droogvallende platen in de rustgebieden gebruikt door de aanwezige grote sterns, en/of worden andere gebieden gebruikt om te rusten? En in welke periode houden zij zich hier op?

ii) Wat is het relatieve belang van de Voordelta voor de grote stern, welke factoren spelen daarbij een rol en wat is de jaar tot jaar variantie en zijn hierin grote veranderingen waarneembaar?

\section{Onderzoeksvragen visdief}

4) Wordt het verlies aan foerageergebied van de visdief als gevolg van het ruimtebeslag en het gebruik van Maasvlakte 2 voldoende gecompenseerd?

a) Hoe is, op basis van voortschrijdend inzicht, de inschatting van het effect van de aanleg van Maasvlakte 2 op het instandhoudingsdoel voor deze soort?

i) Wat was, in kwalitatieve termen, de betekenis van het verdwenen foerageergebied

ii) ii) Wat is, in kwalitatieve termen, de betekenis van het nieuwe kustgebied na aanleg van

Maasvlakte 2

b) Leidt het instellen van het bodembeschermingsgebied tot een gelijkblijvende potentiële functie van de Voordelta voor de visdief in termen van voedselbeschikbaarheid?

i) Treden veranderingen op in broedsucces, het voedsel, de verspreidingspatronen en het aantal vogeldagen van de visdief in de Voordelta t.o.v. de situatie vóór de aanleg van Maasvlakte 2? Het gaat hierbij om inzicht in het functioneren van de gehele Voordelta voor deze soort. 
ii) Zijn deze veranderingen toe te schrijven aan (veranderingen in) de voedselbeschikbaarheid of zijn andere factoren van (groter) belang?

c) Draagt het instellen van de rustgebieden bij aan het instandhoudingsdoel voor de visdief?

i) Worden de platen in de rustgebieden gebruikt door de aanwezige visdieven? In welke periode houden zij zich hier op en wat is de functie van de aanwezigheid van droogvallende platen?

ii) Wat is het relatieve belang van de Voordelta voor de visdief, welke factoren spelen daarbij een rol en wat is de jaar tot jaar variantie en zijn hierin grote veranderingen waarneembaar?

\section{Uitgevoerd onderzoek}

De ontwikkelingen (aantallen, gebiedsgebruik, verspreiding) van grote stern en visdief in de Voordelta zijn onderzocht door middel van vliegtuigtellingen, zenderwerk en landwaarnemingen. Daarnaast is er vanaf 2009 broedbiologisch onderzoek gedaan in diverse kolonies (Scheelhoek en de Slijkplaat in het Haringvliet, Markenje in de Grevelingen). Onderzoek aan de visdief is uitgevoerd in diverse kolonies in Haringvliet, Grevelingen, op de Maasvlakte en op het visdiefeiland in de Slufter.

Vanuit schuilhutten is vastgelegd wat er aan prooien werd meebracht voor de jongen en uit faeces is het dieet van de adulten onderzocht. Gedurende het onderzoek werden seizoensgebonden en jaarlijkse veranderingen in de samenstelling van het voedsel van zowel oudervogels (grote stern) als kuikens (grote stern, visdief) gemeten, en de effecten daarvan op de groei en overleving van de kuikens en het foerageergedrag van oudervogels. Dieet, groei en foerageergedrag zijn vergeleken met die in een referentiekolonie (Zeebrugge).

Het broedsucces van grote stern en visdief werd bepaald door onderzoek in enclosures in een aantal kolonies van de legselgrootte, de conditie van kuikens en het aantal vliegvlugge jongen, die indicatief kunnen zijn voor de relatie met voedselbeschikbaarheid. Er zijn geen systematische directe metingen aan voedselbeschikbaarheid op zee gedaan. Informatie over de voedselsituatie is afgeleid uit de aangebrachte prooien en het dieetonderzoek.

Gegevens van veldwaarnemingen (landwaarnemingen en luchtwaarnemingen) zijn gebruikt om het gebiedsgebruik rond de ingestelde rustgebieden in beeld te brengen. In kaarten is het waargenomen gebruik ruimtelijk weergegeven, waarbij vooral het plaatbezoek tot verstoring van sterns leidt. De resultaten van de vliegtuigtellingen zijn gebruikt om te onderzoeken of er indicaties zijn van toenemende verstoring van de vogels in de rustgebieden.

\section{Het verdwijnen van het Maasvlakte 2 gebied: consequenties voor grote stern}

3a) Grote sterns doorkruisten het verdwenen zeegebied waar Maasvlakte 2 is aangelegd op weg tussen foerageergebieden en broedgebieden. Daarnaast foerageerden grote sterns in mindere mate langs de zachte zeewering van Maasvlakte 1 en rustten ze op de zeewering. Tijdens de aanleg van Maasvlakte 2 rustten grote sterns vooral op de stille delen van Maasvlakte 2. Na aanleg foerageerden grote sterns langs de gehele zeewering en rustten de dieren met name op de zuidpunt. De aantallen rustende sterns waren voor de aanleg gemiddeld iets hoger dan daarna, maar deze daling is niet significant.

Het instandhoudingsdoel voor grote sterns in het Deltagebied is behoud van kwaliteit en omvang van het leefgebied. Over het behoud van kwaliteit is maar beperkt data verzameld (geen informatie over voedselbeschikbaarheid en geen kwantitatieve data over recreatie). Maar het gebied had geen essentiële foerageerfunctie, en het aantal rustende sterns is niet significant afgenomen. Het rustgebied is groter geworden (het aantal kilometer potentieel rustgebied is toegenomen), maar dit is samen gegaan met een intensivering van de recreatie.

\section{De functie van de Voordelta voor de grote stern}

3 b) De aantallen broedparen van grote sterns fluctueren sterk van jaar op jaar, maar lijken de laatste jaren enigszins af te nemen. Voor de aanleg van Maasvlakte 2 waren aantallen broedparen van grote sterns in het Deltagebied lager dan gemiddeld over de periode na de aanleg. Het totaal aantal geproduceerde jongen varieerde sterk tussen jaren; gemiddeld zijn er na de aanleg van Maasvlakte 2 meer jongen geproduceerd dan ervoor, echter het aantal metingen en jaren verschilt sterk tussen beide perioden. Het totaal aantal geproduceerde jongen in de Noordelijke kolonies (Slijkplaat, Scheelhoek en Markenje, die afhankelijk zijn van het gebied rond Maasvlakte 2) was hoger na de aanleg van Maasvlakte 2 ten opzichte van de periode daarvoor. In de periode 1997-2016 nam het 
broedsucces in het hele Deltagebied af. Er is echter geen trendbreuk in het broedsucces van grote sterns tussen de periode vlak voor en na de aanleg van Maasvlakte 2 . Het gemiddeld aantal grote stern vogeldagen in de Voordelta is niet veranderd tussen de periode voor en na de aanleg van Maasvlakte 2. Het regionale instandhoudingsdoel voor grote stern werd zowel voor als na de aanleg regelmatig gehaald. Tijdens en na de aanleg (2009-2017) lag het gemiddeld aantal broedparen boven het instandhoudingsdoel voor de Delta.

Het voedselaanbod is niet direct gemeten, maar de aanvoer van voedsel in de kolonie is gebruikt als maat voor het voedselaanbod. In de periode na de aanleg van Maasvlakte 2 traden jaarlijkse variaties op in het voedsel, zowel wat betreft de grootte van pelagische vis als de beschikbaarheid. Voor haringachtigen wordt deze variatie waarschijnlijk eerder verklaard door abiotische factoren en ook voor zandspieringachtigen kan abiotiek een rol spelen. Een groot deel van de prooien wordt buiten het Natura 2000 gebied gevangen.

De kuikenconditie en het uitvliegsucces van grote sterns zijn sterk afhankelijk van de kwaliteit en de kwantiteit van het voedselaanbod in de Voordelta en daarbuiten. Vooral de aanvoer van haringachtigen is bepalend voor de conditie en de overleving van de kuikens. Deze aanvoer houdt waarschijnlijk rechtstreeks verband met de beschikbaarheid van de prooisoorten in de foerageergebieden. Zandspieringen bleken minder belangrijk voor de kuikens dan haring. Niettemin spelen deze bij gebrek aan of moeilijke vangbaarheid van haringachtigen een belangrijke rol als voedsel voor de kuikens. Zandspieringachtigen zijn de belangrijkste voedselbron voor adulte grote sterns tijdens de eerste weken van het broedseizoen. Het foerageergebied van grote sterns op de Scheelhoek strekt zich in de meeste jaren waarschijnlijk uit tot ver buiten het Natura 2000 gebied. De grotere haring die aan de kuikens gevoerd wordt, komt ook weinig voor in de visbemonstering en wordt waarschijnlijk van verder op zee uit dieper water gehaald.

Het beheer van de kolonies is van grote invloed op de vestigingskans van grote sterns, maar had minder effect op het broedsucces tijdens de onderzoeksjaren. De invloed van weersomstandigheden op het broedsucces is complex (direct effect op de kuikenconditie, indirect via verminderde energieaanvoer). Niettemin hadden de weersomstandigheden in een aantal jaren zeker een effect op het broedsucces in de onderzochte kolonies.

Het voorkomen van diverse zandspieringsoorten vertoont negatieve correlaties met visserij inspanning door boomkor-of garnalenvisserij. Sediment, diepte en stroomsnelheid zijn belangrijke verklarende abiotische factoren voor de verspreiding van zandspiering. Vergeleken met de variatie die verklaard kan worden door ruimtelijke patronen is de verklaring door abiotische variabelen en visserij relatief gering. Of er sprake is van een (negatief) causaal verband tussen visserij en de verspreiding van zandspiering is op basis van de analyses niet te zeggen.

\section{De functie van de rustgebieden in de Voordelta voor de grote stern}

3 c) De grootste aantallen rustende grote sterns zitten buiten de aangewezen rustgebieden. Veruit de grootste aantallen rustende sterns zitten elk jaar op de Verklikkerplaat/het Verklikkerstrand (sinds 2015 geen aangewezen rustgebied meer). Tijdens de paarvorming en tijdens de doortrek lijkt dit gebied een belangrijke rol te vervullen. Het rustgebied op de Hinderplaat wordt relatief weinig gebruikt door rustende grote sterns, maar het rustgebied op de Bollen van de Ooster wordt elk jaar relatief intensief gebruikt vlak na het uitvliegen. Het ingestelde rustgebied de Middelplaat (als rustgebied aangewezen voor zeehonden) wordt maar zeer zelden gebruikt. Buiten de ingestelde rustgebieden worden relatief veel rustende sterns op de zuidpunt van Maasvlakte 2 gezien. Grote sterns uit de Delta verblijven tot zo'n vier weken na het uitvliegen van de jongen in de Delta, echter een groot deel vliegt direct naar noordelijkere foerageergebieden. De Bollen van de Ooster en de Middelplaat worden het minst verstoord. Verstoring van andere gebieden komt ook niet veel voor. Alleen langs de zachte zeewering van Maasvlakte 2 en het Verklikkerstrand komen veel bezoekers. Ook door sterns van buiten de Delta wordt gebruik gemaakt van de Voordelta en de rustgebieden. Of de aangewezen rustgebieden essentieel zijn voor de grote stern in de Voordelta kunnen we niet kwantificeren. Dat hangt er vanaf of de ruimte die buiten de rustgebieden beschikbaar is voldoende rustmogelijkheid biedt voor de aanwezige sterns.

Het verdwijnen van het Maasvlakte 2 gebied: consequenties voor visdief 4a) Het verdwenen zeegebied diende als foerageergebied voor visdieven en er werd in mindere mate op met name de zachte zeewering van Maasvlakte 1 gerust. Tijdens de aanleg foerageerden visdieven zeer veel in het zeegebied van Maasvlakte 2 en dan vooral rond de suppletieschepen. Na aanleg werd 
er langs de gehele zeewering gefoerageerd door visdieven en rustten de dieren met name op de zuidpunt. Hier concentreren ook de kite-surfers zich. De aantallen rustende visdieven zijn sterk afgenomen. Het instandhoudingsdoel voor visdieven in de Voordelta is behoud van kwaliteit en omvang van het leefgebied. Over het behoud van kwaliteit is maar beperkt data verzameld (geen informatie over voedselbeschikbaarheid of kwantitatieve data over recreatie). Het gebied had een essentiële foerageerfunctie voor broedende visdieven op de Maasvlakte en die functie lijkt overgenomen door de nieuwe zeewering van Maasvlakte 2. Het leefgebied is wel groter geworden (het aantal kilometer potentieel rustgebied en misschien ook foerageergebied is toegenomen), maar dit is samen gegaan met een intensivering van de recreatie.

\section{De functie van de Voordelta voor de visdief}

4 b) De aantallen broedparen fluctueren sterk van jaar tot jaar, maar lijken de laatste jaren enigszins af te nemen in de Delta. De aantallen broedparen op de Maasvlakte zelf zijn relatief stabiel. Deze kolonie is de enige waarvan de vogels in de buurt van het aanleggebied foerageren en waarvan dus een effect van Maasvlakte 2 te verwachten is. Een trendbreuk in het broedsucces van visdieven tussen voor- en na de aanleg van Maasvlakte 2 is niet waarneembaar, wel neemt het broedsucces de laatste decennia af. Broedende visdieven op de Maasvlakte hadden voor de aanleg een hoger broedsucces dan daarna, echter deze trend maakt onderdeel uit van een overkoepelende neergaande trend in het gehele Deltagebied. Het instandhoudingsdoel voor visdief met betrekking tot het aantal broedparen in de Delta wordt niet gehaald, maar dit lijkt los te staan van Maasvlakte 2 omdat het merendeel van de kolonies ver van Maasvlakte 2 liggen.

Uit energetische berekeningen op basis van waarnemingen uit 2017 blijkt dat de toegenomen vliegduur als gevolg van de aanleg van Maasvlakte 2 een negatieve invloed gehad kan hebben op de kuikenconditie en het uitvliegsucces. De belangrijkste aanvoerroutes van visdieven op het Visdiefeiland liepen via het zuid- en het noordwesten. De noordwestelijke route over Maasvlakte 2 was op energetisch vlak de belangrijkste route. Het is echter onbekend of de voedselbeschikbaarheid langs de zachte oevers anders is dan die in het foerageergebied voor de aanleg.

De waterstand op zee en het beheer van de Haringvlietsluizen heeft invloed op de voedselbeschikbaarheid van zoetwatervis en daarmee ook op de foerageerfunctie van de Voordelta voor de visdieven van de Scheelhoekkolonie.

Niet aan voedsel gerelateerde factoren zijn vaak de belangrijkste oorzaak van een laag broedsucces. Vooral de groeisnelheid van de vegetatie, periodes met harde neerslag (voornamelijk voor jonge kuikens) en in het bijzonder kuikenpredatie hadden vaak een erg ingrijpende invloed op het broedsucces. Als gevolg van de diversiteit en de schijnbare flexibiliteit van het visdiefdieet, de sterke invloed van niet aan voedsel gerelateerde factoren, de relatief beperkte hoeveelheid data over dieet en het ontbreken van gegevens over het voedselaanbod, kan geen eenduidig antwoord worden gegeven op het belang van voedsel voor het broedsucces van visdieven.

\section{De functie van de rustgebieden in de Voordelta voor de visdief}

4 c) Rustende visdieven worden met name aangetroffen op de Verklikkerplaat, Bollen van de Ooster, Hinderplaat/Westplaat en de stranden van Maasvlakte 2. Met name de Verklikkerplaat en de Bollen van de Ooster worden gebruikt door ouders met jongen na het uitvliegen. Op deze plaat worden jongen ook gevoerd door hun ouders. Visdieven maken weinig gebruik van het ingestelde rustgebied op de Middelplaat. Buiten de ingestelde rustgebieden worden relatief veel rustende visdieven op de zuidpunt van Maasvlakte 2 gezien en op de Westplaat. De aantallen rustende visdieven op de stranden van Maasvlakte 2 lijken af te nemen, echter deze afname is niet significant. Er zijn aanwijzingen dat lokaal broedende visdieven langer in het Deltagebied blijven hangen dan grote sterns. De Bollen van de Ooster is het gebied met de minste verstoring voor visdieven. Verstoring in andere gebieden komt weinig voor. Alleen langs de zachte zeewering van Maasvlakte 2 en het op het Verklikkerstrand komen veel bezoekers en daar worden visdieven verstoord door wandelaars.

\section{Zwarte zee-eend}

De vraag die centraal staat is MEP-vraag: 
2) Wordt het verlies aan foerageergebied van de zwarte zee-eend als gevolg van de aanleg en het gebruik van Maasvlakte 2 voldoende gecompenseerd?

Bij deze vraag zijn vier deelvragen geformuleerd:

a) Hoeveel potentieel foerageergebied is er daadwerkelijk verloren gegaan a.g.v. het ruimtebeslag van MV2, de ontwikkeling van de erosiekuil en het gebruik van MV2?

b) Leidt het instellen van het bodembeschermingsgebied tot een gelijkblijvende potentiële functie van de Voordelta voor de zwarte zee-eend in termen van voedselbeschikbaarheid?

c) Draagt het instellen van rustgebieden, specifiek voor de zwarte zee-eend, bij aan een gelijkblijvende potentiële functie van de Voordelta als foerageer- en rustgebied?

d) Is de aangepaste begrenzing van de extra rustgebieden vanuit PMR-NCV juist gekozen om bij te dragen aan het instandhoudingsdoel?

\section{Monitoring en modellering}

De ontwikkelingen (aantallen, gebiedsgebruik, verspreiding) in de populatie zwarte zee-eenden in de Voordelta zijn in de eerste en tweede fase onderzocht door middel van vliegtuigtellingen en door gedragsobservaties vanaf land (alleen eerste fase). Dit is aangevuld met waarnemingen van zwarte zee-eenden langs andere delen van de Nederlandse kust.

Onderzoek naar het dieet van zwarte zee-eenden is in de eerste fase uitgevoerd door veldwaarnemingen van foeragerende zee-eenden, en door de maaginhouden te analyseren van, op stranden aangespoelde, dode zee-eenden. Informatie over de voedselbeschikbaarheid is verkregen uit de bodemfaunabemonsteringen. De belangrijkste prooien voor de zwarte zee-eend in de Voordelta zijn de Amerikaanse zwaardschede Ensis directus en de halfgeknotte strandschelp Spisula subtruncata. In de eerste fase zijn verschillende factoren die de aanwezigheid van zwarte zee-eenden in de Voordelta kunnen bepalen in een habitatmodel geanalyseerd. De factoren die in beschouwing zijn genomen zijn het voedselaanbod, de verstoring door vissersschepen(AIS-data (Automatic Identification System)), de stroomsnelheid bij de bodem en de diepte.

Omdat de aanwezigheid van zwarte zee-eenden in de Voordelta niet alleen bepaald wordt door de omstandigheden in de Voordelta, maar ook door omstandigheden elders langs de vliegroute is in de tweede fase de draagkracht van de Voordelta voor zwarte zee-eenden bepaald. Met behulp van een energetisch model kunnen op grond van gegevens over voedsel en verstoring (AIS-data), diepte en stroomsnelheden, de potentiële aantallen zwarte zee-eenden waarvoor in de Voordelta voldoende voedsel en rust is, berekend worden. Daarmee is meer inzicht verkregen in de potentiële functie van de Voordelta als foerageer- en rustgebied voor zwarte zee-eenden, los van het feit of de eenden daadwerkelijk overwinteren in het gebied.

Om mogelijke verstoring van zwarte zee-eenden in kaart te brengen, is in de eerste fase het gebiedsgebruik door mensen in en rond de ingestelde rustgebieden in de Voordelta bepaald door landen luchtwaarnemingen.

\section{Resultaten en beantwoording onderzoeksvragen}

Voor de beantwoording van vraag $2 a$ is gebruik gemaakt van historische telgegevens en de gegevens uit de TO en van modelberekeningen van het potentiële aantal zwarte zee-eend in het Maasvlakte 2 gebied. In tellingen die zijn uitgevoerd sinds de jaren 70 zijn geen zwarte zee-eenden in het zeegebied waar nu Maasvlakte 2 ligt, waargenomen. In het routine monitoringprogramma van Rijkswaterstaat dat sinds 1994 is uitgevoerd zijn ook nooit zwarte zee-eenden in dit gebied geteld, evenmin als tijdens de tellingen in de T0. Modelberekeningen die gebaseerd zijn op het voedselaanbod in de T0 jaren (2004, 2005) laten zien dat in dit gebied de beschikbaarheid van voedsel (biomassa van bodemdieren) te laag was voor zwarte zee-eenden.

Voor de potentiële functie van de Voordelta als foerageergebied (vraag 2b) zijn onder meer de resultaten van vliegtuigtellingen in de Voordelta gebruikt. Die tellingen laten zien dat de maximale aantallen zwarte zee-eenden in de Voordelta in de jaren vanaf 2009 lager zijn dan in de T0. Het aantal vogeldagen is echter een betere indicator voor het gebruik van het gebied omdat die een geïntegreerd beeld voor de gehele winter en voorjaar geven. Het aantal vogeldagen varieert sterk tussen jaren maar vertoont geen statistisch significante trend, niet in de winterperiode (oktober-maart) en evenmin in het voorjaar (april-mei). De hoeveelheid beschikbaar voedsel in de delen ondieper dan $15 \mathrm{~m}$ (waar de zwarte zee-eend in de Voordelta foerageert) bestaat vooral uit schelpen van de Amerikaanse zwaardschede. De laatste jaren neemt de halfgeknotte strandschelp weer toe in aantal. 
Het potentiële aantal zwarte zee-eenden, berekend op basis van het voedselaanbod en verstoring door scheepvaart, vertoont evenmin een trendmatige verandering die samenhangt met Maasvlakte 2 . Uit de modelberekeningen kan worden afgeleid dat er in principe ruim voldoende voedsel in de Voordelta is om het instandhoudingsdoel van 10.000 vogels te halen.

Uit de tellingen blijkt dat slechts een klein deel van de zwarte zee-eenden die overwinteren in Nederlandse wateren, in de Voordelta verblijven. Het aandeel van de Voordelta is niet veranderd. Er zijn dus geen aanwijzingen dat de potentiële functie van de Voordelta als foerageergebied is veranderd sinds de aanleg van Maasvlakte 2.

Voor wat betreft de functie van de rustgebieden, blijkt uit de vliegtuigtellingen en statistische analyse dat zwarte zee-eenden worden waargenomen in gebieden waar weinig verstoring door scheepvaart is. Dit is deels binnen de rustgebieden, maar deels ook buiten de rustgebieden, in relatief rustige delen van de Voordelta. Iets minder dan $50 \%$ van de vogeldagen wordt in de rustgebieden doorgebracht. Uit de modelberekeningen blijkt dat verstoring van invloed is op het potentiële aantal zwarte zee-eenden in de Voordelta, maar dat het effect van verschillen in voedselaanbod tussen jaren veel groter is. Het is nog niet mogelijk om al iets te concluderen over het effect van de aangepaste begrenzing van de rustgebieden, omdat de periode sinds de wijziging slechts een jaar omvat. 


\section{$1 \quad$ Inleiding}

M.T. van der Sluis ${ }^{1}$, T.C. Prins ${ }^{2}$, S.D. IJff ${ }^{2}$, I. Tulp ${ }^{1}$

${ }^{1}$ Wageningen Marine Research, ${ }^{2}$ Deltares

In 2018 vindt een tussentijdse evaluatie plaats van de natuurcompensatie voor de aanleg van Maasvlakte 2 in de Voordelta. Het hier voorliggende syntheserapport is de eerste samenvattende rapportage in de tweede fase van het monitorings- en onderzoeksprogramma naar de natuurcompensatie in de Voordelta. Dit syntheserapport zal de wetenschappelijke basis vormen voor de tussentijdse evaluatie in 2018.

\subsection{Aanleiding}

In 2006 is door het toenmalige kabinet een planologische kernbeslissing genomen over het Project Mainportontwikkeling Rotterdam (PMR), met onder andere de doelstelling om de mainport Rotterdam te versterken, door het ruimtetekort voor haven- en industriële activiteiten in het Rotterdamse havengebied op te lossen. Dit betrof meer concreet de aanleg van Maasvlakte 2. In het Milieueffectrapport (MER) en de Passende Beoordeling (PB) die ten behoeve van de besluitvorming voorafgaand aan de aanleg van Maasvlakte 2 zijn opgesteld, is ingeschat dat hierdoor een oppervlakte van in totaal 2.455 hectare aan zeebodem verloren zou gaan. In deze schatting is naast het ruimtebeslag van Maasvlakte 2 zelf, ook het bodemverlies door de erosie ten gevolge van een veranderende sedimenthuishouding en een toegenomen getijslag meegenomen.

Dit verlies aan habitat impliceert ook een afname van foerageer- en leefgebied van de soorten waarvoor instandhoudingsdoelstellingen gelden in de Voordelta. In de PB zijn de effecten op het habitattype $\mathrm{H} 1110$ en de doelsoorten zwarte zee-eend, grote stern en visdief als significant beoordeeld en hiervoor moet net als voor het verlies aan bodemoppervlak worden gecompenseerd.

De compensatiemaatregelen die hiervoor zijn ingezet zijn de instelling van een bodembeschermingsgebied en rustgebieden voor de zwarte zee-eend en de sterns (zie ook paragraaf 1.5). Bij aanvang van het monitoringprogramma van PMR-NCV in 2009 zijn in het Monitoring-en Evaluatie Programma (MEP-NCV) de vragen geformuleerd waarop het monitoringprogramma van de natuurcompensatie een antwoord dient te geven (VenW 2009).

De hoofdvragen uit het MEP zijn:

5. Wordt het verlies aan habitattype H1110 als gevolg van de aanleg van Maasvlakte 2 voldoende gecompenseerd?

6. Wordt het verlies aan foerageergebied van de zwarte zee-eend als gevolg van de aanleg en het gebruik van Maasvlakte 2 voldoende gecompenseerd?

7. Wordt het verlies aan foerageergebied van de grote stern als gevolg van het ruimtebeslag en het gebruik van Maasvlakte 2 voldoende gecompenseerd?

8. Wordt het verlies aan foerageergebied van de visdief als gevolg van het ruimtebeslag en het gebruik van Maasvlakte 2 voldoende gecompenseerd?

\subsection{Doel van dit rapport, rol in synthese en evaluatie}

Het syntheserapport vormt de wetenschappelijke basis voor het evaluatieproces: In het syntheseproces worden alle monitorings- en onderzoeksresultaten uit de nulmetingen, de eerste en tweede fase betrokken alsmede resultaten uit ander relevant onderzoek om de onderzoeksvragen te beantwoorden. De koppeling van de resultaten uit de deelonderzoeken met ander relevant onderzoek wordt in de hoofdstukken $5 \mathrm{t} / \mathrm{m} 7$ per MEP vraag beschreven. Bij deze MEP vragen zijn deelvragen en specifieke onderzoeksvragen geformuleerd (Bijlage 1). Voor iedere onderzoeksvraag worden relevante 
bevindingen uit de verschillende onderzoekspercelen gecombineerd om tot een eenduidig antwoord te komen (zie paragraaf 1.6).

In de komende jaren zal op twee momenten worden geëvalueerd, te weten in 2018 conform de afspraken in de UitWerkingsOvereenkomst (UWO) en in 2020 in het kader van de PKB (Planologische KernBeslissing, 2009-2019). De evaluatie in 2018 kan worden gezien als een tussentijdse evaluatie die nog van invloed kan zijn op een deel van de uit te voeren werkzaamheden voordat in 2020 de PKB evaluatie plaats vindt. Het doel van deze evaluatie is "het aantonen van de effectiviteit van de in voorschrift 23a van de in de Nbwet-vergunning opgenomen compensatieopgave voor het habitattype H1110B, de zwarte zee-eend, de grote stern en de visdief" (brief Ministerie EZ aan HbR d.d. 22 december 2015).

\subsection{Afbakening onderzoeksgebied}

De Voordelta is het gebied bestaand uit de ondiepe kustwateren voor de delta van Zuid- Holland en Zeeland. Het betreft ruwweg het gebied vanaf de Westerscheldemonding tot aan de Nieuwe Waterweg. Door de ligging voor de Zuid-Hollandse en Zeeuwse delta wijkt het gebied af van de kustwateren die verder noordelijk voor de Hollandse kust liggen. De Voordelta als watersysteem omvat ook de Westerscheldemonding (Kohsiek \& Mulder, 1989), terwijl de begrenzing van het Natura 2000-gebied Voordelta de Westerscheldemonding niet meeneemt (figuur 1.1).

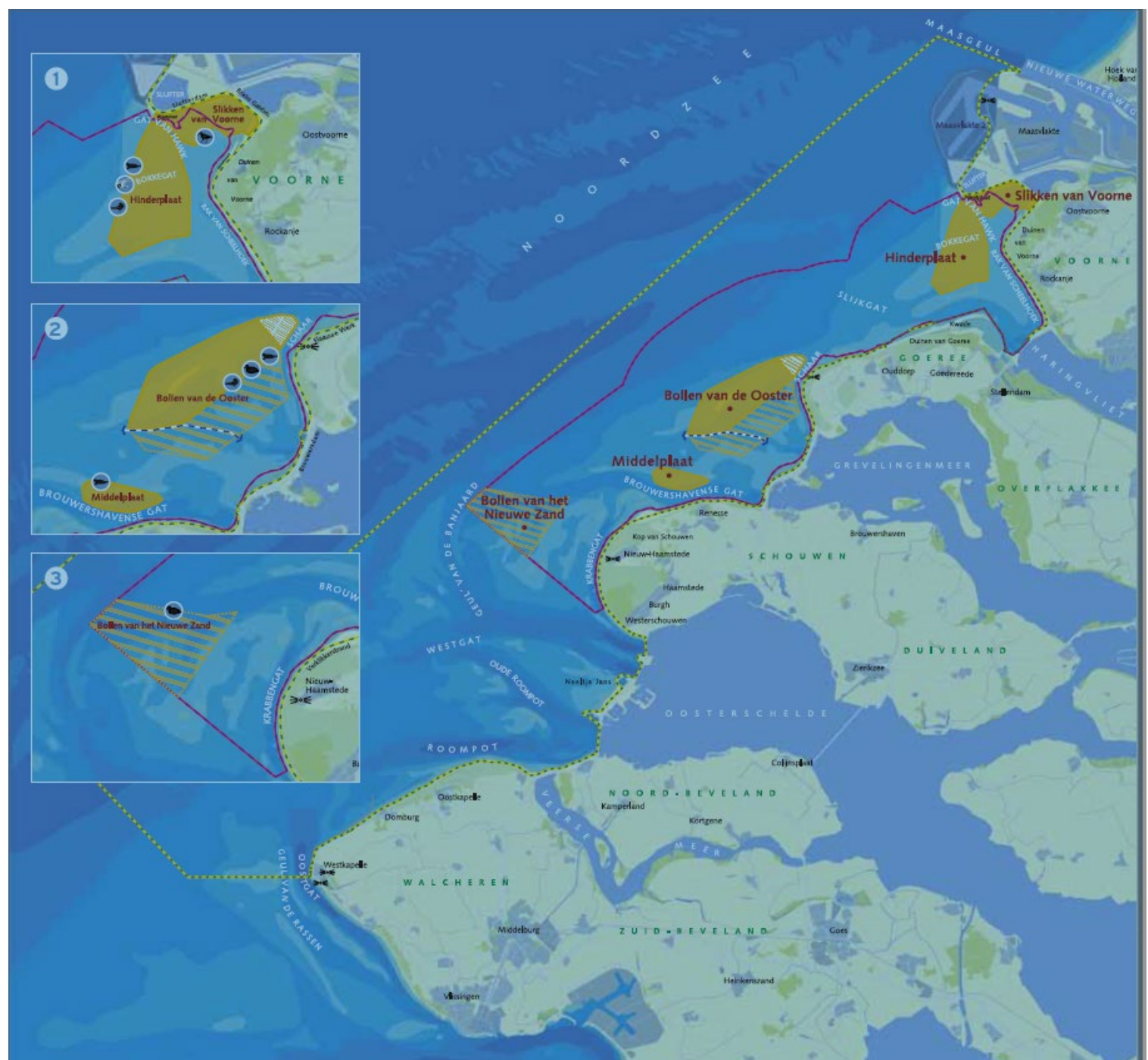

Figuur 1.1 Begrenzing Natura-2000 gebied Voordelta, met bodemdiepte, platen en topografie (RWS 2016). De gele stippellijn geeft de begrenzing van het Natura 2000 gebied Voordelta aan, de rode lijn het Bodembeschermingsgebied. Het Bodembeschermingsgebied is een van de compensatiemaatregelen (paragraaf 1.5), dit deel van de Voordelta is gesloten voor de boomkorvisserij. 


\subsection{De Voordelta als Natura 2000 gebied}

De Voordelta is sinds 2008 een Natura 2000-gebied en het grootste deel (ruim 87.000 ha na aanleg van Maasvlakte 2) is gekarakteriseerd als habitattype $\mathrm{H} 1110$ (permanent overstroomde zandbanken). Een klein deel (ongeveer 2.200 ha) bestaat uit habitattype H1140 (slik- en zandplaten). Tabel 1.1 en 1.2 tonen een overzicht van alle habitattypen, habitatsoorten en vogelsoorten waarvoor een instandhoudingsdoelstelling geldt in de Voordelta.

Tabel 1.1

Habitatrichtlijn - Habitattypen en habitatsoorten waarvoor instandhoudingsdoelstellingen gelden in het Natura 2000-gebied Voordelta (RWS 2016)

\begin{tabular}{|l|l|}
\hline Habitattypen (verkorte naam) & Habitatsoorten \\
\hline H1110 Permanent overstroomde & H1095 Zeeprik \\
zandbanken & H1099 Rivierprik \\
H1140 Slik- en zandplaten & H1102 Elft \\
H1310 Zilte pionierbegroeiingen & H1103 Fint \\
H1320 Slijkgrasvelden en zilte & H1364 Grijze zeehond \\
H1330 Schorren en & \\
graslanden & \\
H2110 Embryonale duinen & \\
\hline
\end{tabular}

Tabel 1.2

Vogelrichtlijn - Vogelsoorten waarvoor instandhoudingsdoelstellingen gelden in het Natura 2000gebied Voordelta. Het betreft voor alle soorten een doelstelling als niet-broedvogel (RWS 2016).

\begin{tabular}{|l|l|l|}
\hline A001 Roodkeelduiker & A054 Pijlstaart & A137 Bontbekplevier \\
A005 Fuut & A056 Slobeend & A141 Zilverplevier \\
A007 Kuifduiker & A062 Topper & A144 Drieteenstrandloper \\
A017 Aalscholver & A063 Eider & A149 Bonte strandloper \\
A034 Lepelaar & A065 Zwarte zee-eend & A157 Rosse grutto \\
A043 Grauwe gans & A067 Brilduiker & A160 Wulp \\
A048 Bergeend & A069 Middelste zaagbek & A162 Tureluur \\
A050 Smient & A130 Scholekster & A169 Steenloper \\
A051 Krakeend & A132 Kluut & A177 Dwergmeeuw \\
A052 Wintertaling & & A191 Grote stern \\
& & A193 Visdief \\
\hline
\end{tabular}

Het eerste beheerplan Voordelta 2008 - 2014 had als doel het 'in stand houden van de beschermde natuur in de Voordelta, compenseren van verlies aan beschermde natuur bij aanleg van Maasvlakte 2 en binnen deze natuurbescherming ruimte bieden voor recreatie, visserij en andere activiteiten' (VenW 2009). In 2013 is een evaluatie uitgevoerd van het Beheerplan Voordelta 2008-2014 (Van Oostveen \& Koolmees 2013). Dit evaluatierapport beschrijft de ontwikkelingen in het gebied in de periode 20082014 en geeft antwoord op de vraag of de extra natuurbescherming heeft geleid tot verbetering van de kwaliteit van de natuur in de Voordelta. Uit de evaluatie komt naar voren dat het oppervlak permanent overstroomde zandbanken (H1110) tussen 2007 en 2012 met 2111 hectare $(2,4 \%)$ is afgenomen. Dit komt grotendeels door de aanleg van Maasvlakte 2. Het oppervlak slik- en zandplaten ( $\mathrm{H} 1140)$ is daarentegen iets toegenomen (16 hectare, 0,7\%) (Tabel 1.3 ) (Royal HaskoningDHV, 2013a). Over de instandhoudingsdoelen voor zoogdieren en vogels is ook gerapporteerd. Zo neemt het aantal volwassen grijze zeehonden al jaren toe in de Voordelta, hoewel het aantal pups klein is en een grillig verloop vertoont. Ook de gewone zeehond neemt in aantal toe (zowel de volwassen dieren als de pups). Over het algemeen is er sprake van een stabiele of positieve aantalsontwikkeling bij de visetende vogels (waaronder de visdief en grote stern) (zie Hoofdstuk 7). De bodemdiereters (waaronder de zwarte zee-eend) tonen in de periode 2009 t/m 2012 een afname in aantallen (zie Hoofdstuk 6).

In het Beheerplan zijn de maatregelen benoemd die nodig zijn voor het behalen van de instandhoudingsdoelen in de Voordelta. De maatregelen, die zijn benoemd in het eerste beheerplan Voordelta (VenW 2009), zijn de instelling van een bodembeschermingsgebied, een vijftal rustgebieden, het verlenen van vrijstellingen en een gedragscode voor menselijke activiteiten (tabel 1.4). 
Sinds het eerste beheerplan Voordelta zijn er, op basis van evaluatie en tussentijdse resultaten van het Project Mainport Development Rotterdam Natuur Compensatie Voordelta (PMR-NCV), wijzigingen doorgevoerd voor een aantal van de beheermaatregelen. In 2012 is het toegangsbeperkingsbesluit voor rustgebied Verklikkerplaat gewijzigd: het rustgebied is komen te vervallen en de Middelplaat is als alternatief rustgebied aangewezen (Van Oostveen \& Koolmees 2013). Door dynamische ontwikkelingen is de Verklikkerplaat aan het strand vastgegroeid en hebben de meeste zeehonden zich verplaatst naar de nabij gelegen Middelplaat om daar te rusten bij laagwater.

Uit de evaluatie van het beheerplan in 2013 blijkt dat de genomen maatregelen bijdragen aan de natuur en dat voortzetting van de genomen maatregelen nodig is om de kwaliteit van de natuur in stand te houden (Van Oostveen \& Koolmees 2013).

Op basis van de evaluatie 2013 en een gebruikstoets, waarin nieuwe en/of in belangrijke mate gewijzigde activiteiten zijn getoetst (van Oostveen et al. 2014), is het huidige Natura 2000 beheerplan geschreven voor de periode 2015 - 2021 (RWS 2016). In dit nieuwe beheerplan zijn een paar aanpassingen doorgevoerd, zoals het instellen van een winterrustgebied bij de Middelplaat voor de roodkeelduiker (RWS 2016). Verder is het rustgebied Slikken van Voorne robuuster gemaakt door het Gat van Hawk bij het gebied te betrekken en de grenzen aan te passen. Steltlopers, visdief en de grote stern kunnen hiervan profiteren. De begrenzing van de rustgebieden voor de zwarte zee-eend (Bollen van de Ooster en Bollen van het Nieuwe Zand) is aangepast.

\section{Tabel 1.3}

De instandhoudingsdoelstellingen (IHD), landelijke staat van instandhouding in 2006 (SvI), oppervlaktes en doelbereik van de aangewezen mariene habitattypen van het Natura 2000-gebied Voordelta (Van Oostveen \& Koolmees 2013)

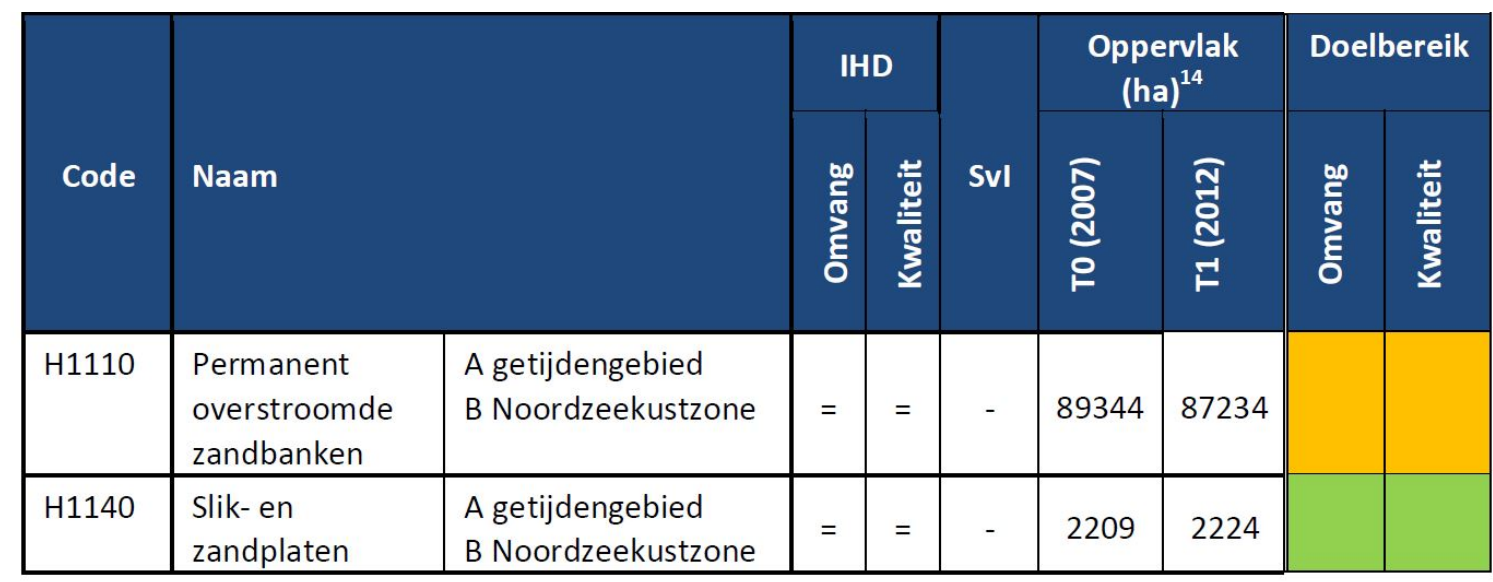

\begin{tabular}{|l|l|l|}
\hline Legenda & \multicolumn{2}{|l|}{ Doelbereik } \\
\hline IHD: Instandhoudingsdoelstelling & & Doel bereikt \\
\cline { 2 - 3 }$=$ behoud omvang en kwaliteit & & Doel nog niet bereikt / Aandachtspunt \\
\cline { 2 - 3 } & & Doel niet bereikt \\
\hline $\begin{array}{l}\text { Svl: Landelijke staat van instandhouding (2006) } \\
\text { - matig ongunstig }\end{array}$ & \\
\hline
\end{tabular}




\subsection{Compensatiemaatregelen}

Tabel 1.4

Toelichting van maatregelen uit Beheerplan Voordelta 2008-2014 (Van Oostveen \& Koolmees 2013)

\begin{tabular}{|c|c|c|c|}
\hline Maatregel & Toelichting & Doel & $\begin{array}{l}\text { Onderdeel natuur- } \\
\text { compensatie? }\end{array}$ \\
\hline Bodembeschermingsgebied & $\begin{array}{l}\text { In dit gebied mag de } \\
\text { zeebodem niet verstoord } \\
\text { worden. Dat betekent dat er } \\
\text { beperkingen zijn voor de } \\
\text { visserij en scheepvaart. }\end{array}$ & $\begin{array}{l}\text { Kwaliteit en aanwezigheid van } \\
\text { voedsel in en op de zeebodem } \\
\text { verbeteren. }\end{array}$ & Ja \\
\hline $\begin{array}{l}\text { Rustgebieden: } \\
\text { o Slikken van Voorne } \\
\text { o Hinderplaat } \\
\text { o Bollen van de Ooster } \\
\text { o Middelplaat2 } \\
\text { o Bollen van het Nieuwe Zand }\end{array}$ & $\begin{array}{l}\text { In deze gebieden mogen de } \\
\text { zeehonden en/of vogels niet } \\
\text { verstoord worden. Dat } \\
\text { betekent dat er beperkingen } \\
\text { zijn voor visserij, recreatie, } \\
\text { scheepvaart, baggeren, } \\
\text { vliegverkeer en militaire } \\
\text { activiteiten. }\end{array}$ & $\begin{array}{l}\text { Rust voor de gewone zeehond en } \\
\text { grijze zeehond. Rust en voedsel } \\
\text { voor steltlopers en eenden, } \\
\text { waaronder de scholekster en } \\
\text { zwarte zee-eend. Rustige } \\
\text { zandplaten in zee voor onder } \\
\text { andere de grote stern en visdief. }\end{array}$ & $\begin{array}{l}\text { Deels: } \\
\text {-Bollen van de } \\
\text { Ooster en Bollen } \\
\text { van het Nieuwe } \\
\text { Zand (zwarte zee- } \\
\text { eend) } \\
\text {-Hinderplaat (grote } \\
\text { stern en visdief) }\end{array}$ \\
\hline Vergunningen & $\begin{array}{l}\text { Voor alle activiteiten in de } \\
\text { Voordelta wordt getoetst of } \\
\text { er een vergunning nodig is. } \\
\text { Bepaalde activiteiten zijn } \\
\text { toegestaan, mits er een } \\
\text { vergunning is afgegeven. }\end{array}$ & $\begin{array}{l}\text { Menselijke activiteiten beperken } \\
\text { in bodembeschermingsgebied en } \\
\text { rustgebieden. }\end{array}$ & Nee \\
\hline Gedragscode & $\begin{array}{l}\text { De beheerders van het } \\
\text { gebied stellen een } \\
\text { gedragscode op en zien erop } \\
\text { toe dat iedereen zich eraan } \\
\text { houdt. }\end{array}$ & $\begin{array}{l}\text { Menselijke activiteiten beperken } \\
\text { in bodembeschermingsgebied en } \\
\text { rustgebieden. }\end{array}$ & Nee \\
\hline
\end{tabular}

Het bodembeschermingsgebied en een deel van de rustgebieden (Bollen van de Ooster, Bollen van het Nieuwe Zand en de Hinderplaat) behoren tot de compensatiemaatregelen van PMR-NCV.

De realisatie van de natuurcompensatie is relevant voor verschillende instandhoudingsdoelstellingen van het Natura 2000-gebied Voordelta (H1110, zwarte zee-eend, grote stern, visdief). Daarom zijn de compensatiemaatregelen opgenomen in het Natura 2000 Beheerplan Voordelta (tabel 1.4).

Begrenzingen en regimes van de rustgebieden worden juridisch verankerd door het nemen van toegangsbeperkingsbesluiten. Het in 2008 ingestelde Bodembeschermingsgebied (BBG) bestrijkt ca 25.000 ha (figuur 1.1). Voor deze grootte is gekozen omdat dit tien maal de omvang betreft van het areaal zeegebied dat als gevolg van de aanleg van Maasvlakte 2 verloren is gegaan. In het BBG worden boomkorvissers met wekkerkettingen (>260 pk) sinds 2008 geweerd om de kwaliteit van habitattype $\mathrm{H} 1110$ te verbeteren. Het BBG is overigens wel grotendeels toegankelijk voor de garnalenvisserij.

Voor de zwarte zee-eend, grote stern en visdief zijn rustgebieden ingesteld: de Bollen van de Ooster, Bollen van het Nieuwe Zand (zwarte zee-eend) en de Hinderplaat (grote stern en visdief).

Tijdens de evaluatie van de compensatiemonitoring in 2013 is geconcludeerd dat de zwarte zeeeenden in de Voordelta zich voornamelijk buiten de rustgebieden Bollen van de Ooster en Bollen van het Nieuwe Zand bevonden (Van Oostveen \& Koolmees 2013).

Op basis van habitatmodellering is een aangepaste begrenzing voorgesteld voor beide rustgebieden. De aangepaste begrenzing van de rustgebieden voor de zwarte zee-eend is per 1 november 2016 effectief. Zie figuur 1.2 voor de nieuwe begrenzing van de rustgebieden. 
Naast de begrenzing is ook de openstelling van de rustgebieden aangepast (EZ 2016): het rustgebied Bollen van het Nieuwe Zand is jaarrond gesloten voor alle vormen van bodemberoerende visserij. Voor het rustgebied de Bollen van de Ooster wordt een uitzondering gemaakt voor de garnalenvisserij. De garnalenvisserij is toegestaan in het gebied in de periode van 1 november tot 15 december onder de volgende voorwaarden:

- De afstand tot de drooggevallen platen is minimaal $250 \mathrm{~m}$.

- De maximale vaarsnelheid is 7 knopen $(13 \mathrm{~km} / \mathrm{u})$.

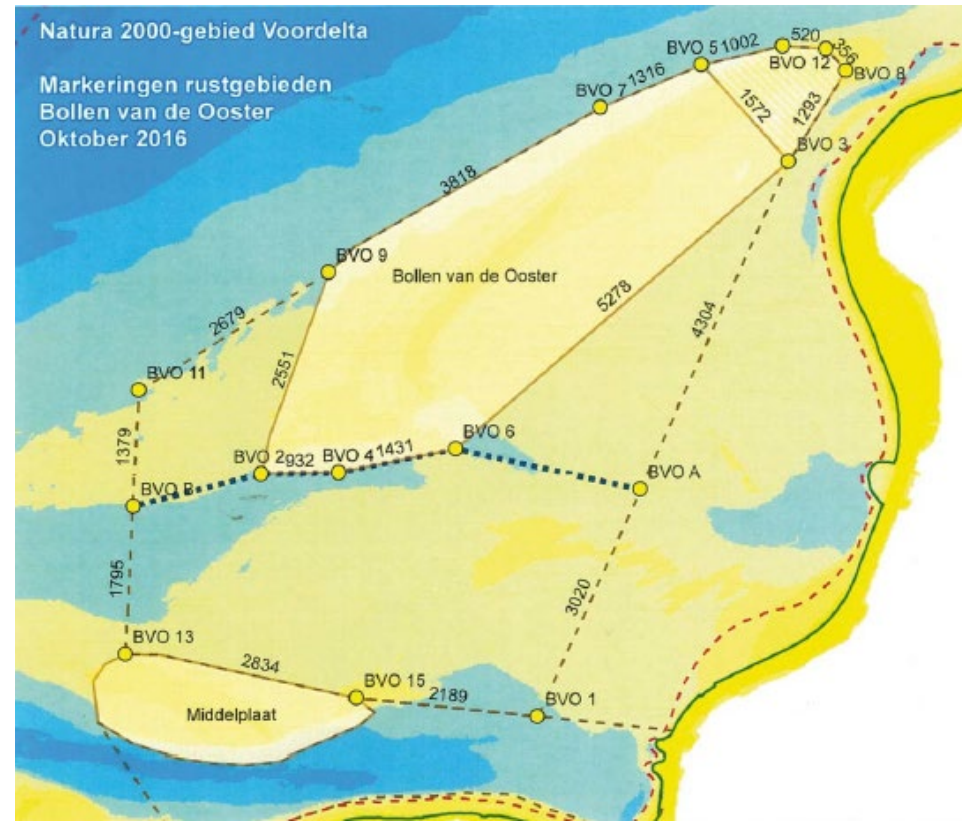

\section{Legenda}

\section{Markeringen}

Jaarrond rustgebied voor bodemberoerende activiteiten

Winterrustgebied (1-11 tot 15-05)

Afstand tussen boeien ( $m$ )

Grens Voordelta

B.J Bodembeschermingsgebied

Bodemdiepte (m+ NAP)
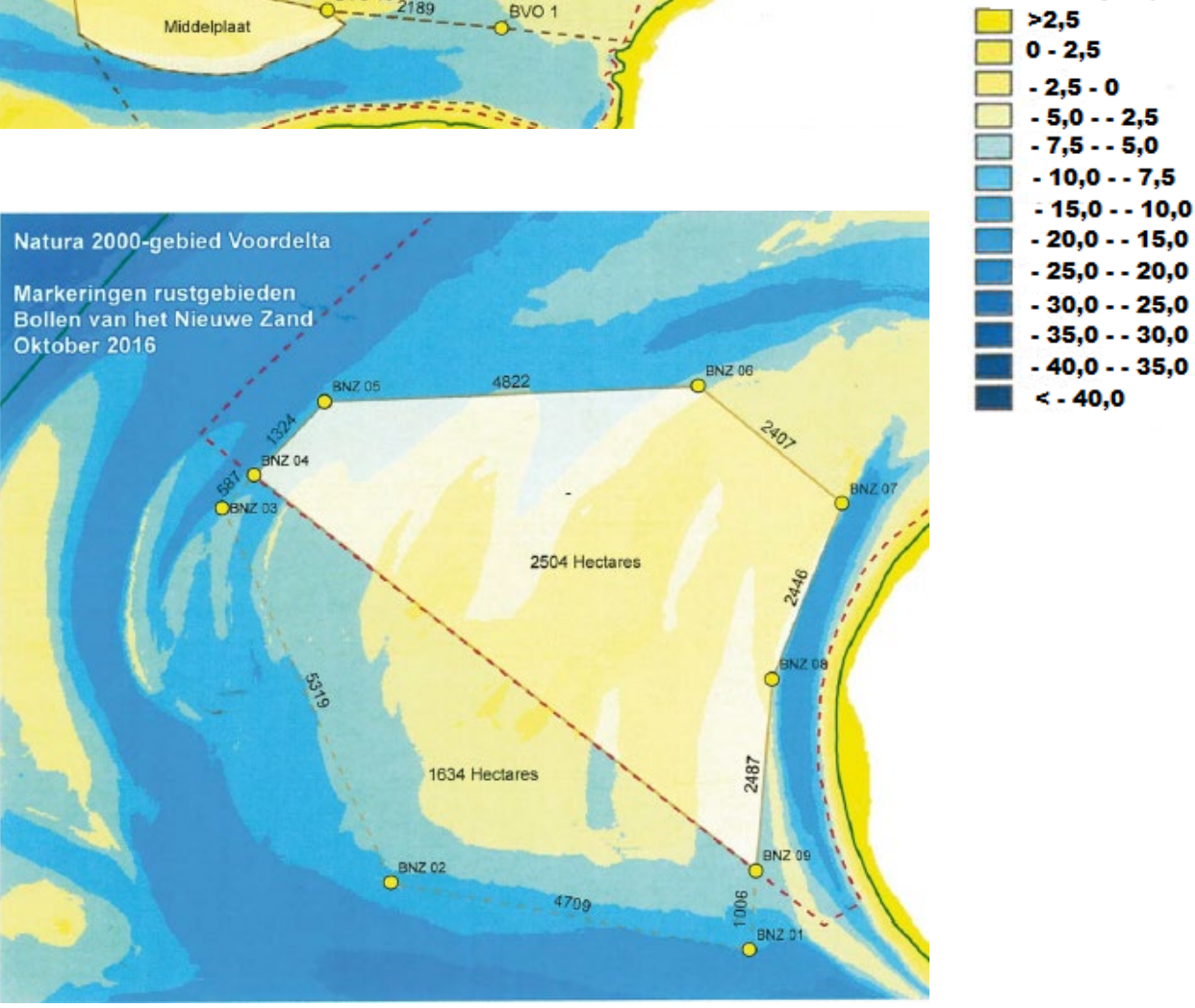

$<-40,0$

Figuur 1.2 Locatie van de rustgebieden voor de zwarte zee-eend. Voor de ligging binnen het Natura 2000 gebied, zie de overzichtskaart in figuur 1.1.) De kaart geeft de locatie en begrenzing van de rustgebieden aan na de wijzigingen o.b.v. de evaluatie in 2013 (EZ 2016). 


\subsection{Organisatie PMR-NCV}

Het project PMR bestaat uit twee deelprojecten. Het grootste deelproject betreft de aanleg van Maasvlakte 2 en de bijbehorende natuurcompensatie, die verplicht is op grond van Nederlandse en Europese bepalingen. Het andere deelproject betreft een serie projecten onder de noemer Bestaand Rotterdams Gebied.

De monitoring en evaluatie van beide PMR-deelprojecten is op een eenduidige wijze vormgegeven, door middel van een serie Monitoring en Evaluatie Programma's (MEP's), met een vergelijkbare aanpak en opzet.

De T0 monitoring was gericht op waarnemingen van bodemdieren, vis, diverse soorten vogels (futen en duikers, meeuwen en sterns, zee-eenden) en menselijk gebruik. Tijdens de eerste fase en de overbrugging naar de tweede fase (zie paragraaf 1.6.1) was de monitoring binnen het onderdeel MEPNCV ondergebracht in een aantal percelen: Benthos, Vogels, Vis, Abiotiek en Gebruik. Deltares leidde het consortium met Wageningen Marine Research (voorheen IMARES) (Benthos en Vis), Lievense CSO (Gebruik), Arcadis (Alkyon) (Abiotiek), INBO (Vogels), NIOZ (Benthos) en Bureau Waardenburg (Vogels), in opdracht van Rijkswaterstaat WVL.

In 2016 is de tweede fase van de monitoring natuurcompensatie van start gegaan, met een nieuw consortium van onderzoeksbureaus onder leiding van Wageningen Marine Research (voorheen IMARES) en Deltares als partner. In de tweede fase is het onderzoek ondergebracht in de percelen Benthos, Abiotiek, Vis, Zwarte zee-eend en Sterns. Een deel van de monitoring en onderzoek wordt door Wageningen Marine Research (Benthos en Vis) en Deltares (Abiotiek) zelf uitgevoerd en een deel door de onderaannemers: Eurofins AquaSense met partner E-coast (Benthos), Arcadis (Abiotiek), Altenburg en Wymenga met partners Bioconsult, Greenstat en Sjoerd Dirksen Ecology (Zwarte zeeeend) en Bureau Waardenburg met partner INBO (sterns).

In deze tweede fase wordt voor wat betreft de rapportage van de resultaten een iets andere werkwijze gevolgd. In plaats van dat jaarlijks een serie perceelrapporten en een rapport met een samenvatting van de belangrijkste resultaten door het consortium wordt opgeleverd, zal in de periode 2016-2020 tweemaal een zogenaamd syntheserapport verschijnen, te weten in voorjaar 2018 en voorjaar 2020. Deze syntheserapporten leveren input voor de MEP-evaluaties NCV in 2018 en 2020 (PKB). De verschillende percelen leveren jaarlijks datarapporten op: een technische rapportage over de uitvoering van het praktische werk. Deze rapporten bevatten geen toetsing van hypothesen, inhoudelijke conclusies, interpretatie of discussie in relatie tot achterliggende onderzoeksvragen. Het is van belang dat de tijdens het onderzoek opgedane inzichten ook in de niet-synthesejaren optimaal kunnen bijdragen aan het onder verantwoordelijkheid van Rijkswaterstaat uit te voeren evaluatietraject en het (eventueel) op details aanscherpen van monitoring en onderzoek, c.q. analyses. Gedurende de hele tweede fase voeden het synthesespoor (consortium) en het evaluatiespoor (RWS, C4 werkgroep NCV) elkaar tijdens bijeenkomsten in de vorm van workshops, maar ook tijdens overleggen van de C4 werkgroep NCV, waar de consortiumleiding bij aanschuift.

\subsubsection{Tijdlijn Monitorings- en onderzoeksprogramma PMR NCV}

In figuur 1.3 staat de tijdlijn van het monitorings- en onderzoeksprogramma PMR NCV weergegeven met daarin de verschillende fasen van monitoring en onderzoek en de belangrijkste mijlpalen. 


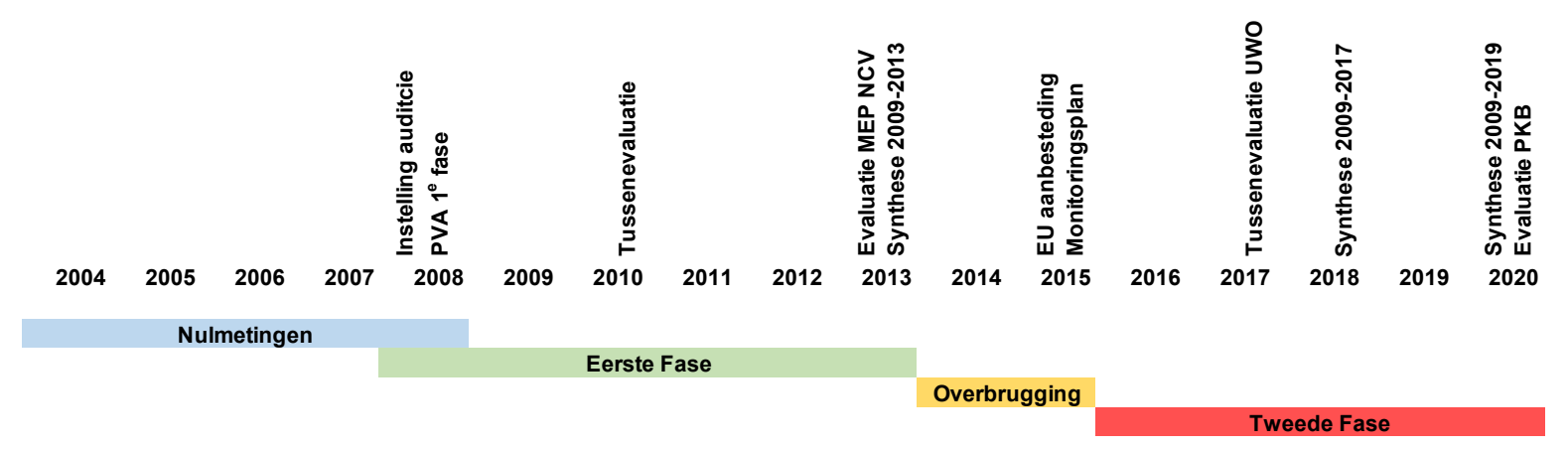

Figuur 1.3 Tijdlijn monitoring en onderzoeksprogramma PMR NCV.

\subsection{Leeswijzer}

Het eerste Syntheserapport PMR-NCV 2e fase (2016-2020) is een samenvattende rapportage van de monitorings- en onderzoeksresultaten die tot nu toe (2018) binnen het project PMR-NCV zijn gegenereerd.

In Hoofdstuk 2 wordt de monitoring- en onderzoekaanpak binnen de verschillende fasen (T0, T1 en T2) besproken.

In hoofdstuk 3 van het syntheserapport wordt de ecologie en morfodynamiek van de Voordelta beschreven. Ook wordt in dit hoofdstuk het beheer en menselijk gebruik beschreven. Deze achtergrond is van belang, omdat ook zonder het aanleggen van Maasvlakte 2 er in de Voordelta voortdurend veranderingen plaatsvinden als gevolg van (grootschalige) natuurlijke processen en eerdere menselijke ingrepen.

In hoofdstuk 4 komt de ontwikkeling van de visserij in de Voordelta sinds 2004 aan bod. In hoofdstuk 5 tot en met 7 behandelen we achtereenvolgens de MEP vragen 1 (habitat H1110); 2 (zwarte zee-eend) en 3/4 (sterns) door de resultaten afkomstig van de verschillende percelen in samenhang te bekijken. Hoofdstuk 8 bevat een discussie van de resultaten. In Hoofdstuk 9 volgen een aantal aanbevelingen ten aanzien van het vervolg van de monitoring en het onderzoek in de tweede fase in de jaren 2018-2020. 


\section{$2 \quad$ Monitoring}

M.T. van der Sluis ${ }^{1}$, T.C. Prins ${ }^{2}$

${ }^{1}$ Wageningen Marine Research, ${ }^{2}$ Deltares

Binnen het langlopende monitorings- en onderzoeksprogramma PMR-NCV kunnen verschillende fases worden onderscheiden (tabel 2.1). Tussen 2004 en 2007 zijn de nulmetingen verricht. Van 2009-2013 vond de eerste fase plaats van de monitoring van natuurcompensatie in de Voordelta. Het monitoringsprogramma kende twee overbruggingsjaren in 2014 en 2015 waarin de monitoring gedeeltelijk is voortgezet en waarin daarnaast aandacht is besteed aan desk studies. In 2016 is een tweede fase van start gegaan met een aangepast monitoringsprogramma en een andere werkwijze. Waar voorheen jaarlijks een geïntegreerd rapport werd uitgebracht van de belangrijkste resultaten, is er in de tweede fase voor gekozen slechts op twee momenten een syntheserapport uit te brengen.

Tabel 2.1

Verschillende fases Monitorings- en onderzoeksprogramma PMR-NCV

\begin{tabular}{|l|l|}
\hline Periode & Monitoringsfase \\
\hline $2004-2008$ & T0 \\
\hline $2009-2013$ & Eerste fase effectmonitoring \\
\hline 2014 & $\begin{array}{l}\text { Overbruggingsjaar (deskstudies; veldonderzoek } \\
\text { beperkt tot sterns) }\end{array}$ \\
\hline 2015 & Verlenging eerste fase effectmonitoring \\
\hline $2016-2020$ & Tweede fase effectmonitoring \\
\hline
\end{tabular}

\subsection{Het monitoringsprogramma en aanpassingen daarin}

Volgend uit het principebesluit voor aanleg van Maasvlakte 2, dat is vastgelegd in de Planologische Kernbeslissing-plus Mainportontwikkeling Rotterdam (PKB + PMR) deel 4 van september 2003, is een monitoringprogramma gestart om de beginsituatie (T0) in de Voordelta vast te leggen. De opzet, methodiek en resultaten van dit monitoringprogramma zijn vastgelegd in een reeks van achtergrondrapporten (Asjes et al. 2004, Craeymeersch et al. 2004, Grift \& Tulp 2004, Craeymeersch et al. 2005, Poot et al. 2005, Alkyon 2006, Poot et al. 2006, Seegers et al. 2006, Steenbergen \& Escaravage 2006, Tulp et al. 2006, Couperus et al. 2007, Kater 2007, RIKZ 2007, Couperus et al. 2008, Leopold et al. 2008). De T0 monitoring was gericht op waarnemingen van bodemdieren, vis, diverse soorten vogels (futen en duikers, meeuwen en sterns, zee-eenden) en menselijk gebruik. De To metingen zijn uitgevoerd in de jaren 2004-2007, waarbij opgemerkt wordt dat vrijwel alle metingen betrekking hebben op 1 of 2 jaar in die periode.

Na de definitieve besluitvorming in 2007 over de aanleg van Maasvlakte 2 en de te nemen compensatiemaatregelen, is in 2008 gestart met de aanbesteding van het monitoringprogramma voor de effecten van de natuurcompensatie (PMR-NCV). De $1^{\text {e }}$ fase van deze monitoring (2009-2013) is gestart in 2009, en beschreven in een plan van aanpak (Heessen \& Jak 2009, Holzhauer \& Prins 2009). De monitoring in de $1^{\mathrm{e}}$ fase heeft zich gericht op een vergelijking van de ontwikkeling van bodemdieren en vis in het bodembeschermingsgebied en referentiegebieden, monitoring van zwarte zee-eend, grote stern en visdief, menselijk gebruik en beschrijving van de abiotische omstandigheden in de Voordelta in de T0 en T1 periode. De vragen die vastgelegd zijn in het Monitoring- en Evaluatieprogramma Natuurcompensatie Voordelta (MEP-NCV) waren leidend bij de uitvoering van de monitoring.

Gedurende deze $1^{\mathrm{e}}$ fase is het monitoringprogramma op verschillende momenten aangepast. In de oorspronkelijke opzet van het monitoringprogramma was niet voorzien in het gedetailleerd beschrijven van de visserij-frequentie van bodemberoerende visserij. In 2010 werd door het beschikbaar komen van analyse van VMS (Vessel Monitoring System) data (Bierman et al. 2009), duidelijk dat meer informatie over de intensiteit van de boomkorvisserij in de Voordelta nodig was. Uit die analyse bleek, 
dat de boomkorvisserij in het bodembeschermingsgebied al in de T0 (2005-2007) beperkt was in intensiteit, en ook in de referentiegebieden sterk afgenomen was vanaf 2004.

Daarnaast zijn er diverse andere aanvullende onderzoeks- en monitoringactiviteiten uitgevoerd, zoals bemonstering van bodemdieren op zee-eendlocaties en analyse van scheepvaart-intensiteit via AIS (Automatic Identification System) data ten behoeve van de zee-eend monitoring, en GPS-onderzoek aan grote sterns.

In 2013 is de $1^{\mathrm{e}}$ fase afgerond en gerapporteerd (Prins \& Van der Kolff 2014, Prins et al. 2014c). De resultaten gaven aanleiding tot wijzigingen in het monitoringprogramma. Geconcludeerd werd dat de oorspronkelijke aanpak voor de beantwoording van MEP vraag 1 (verbetering kwaliteit habitattype $\mathrm{H} 1110$ ) die bestond uit een vergelijking tussen bodembeschermingsgebied en referentiegebieden (paragraaf 2.1.1), door de ontwikkeling in de boomkorvisserij niet meer bruikbaar was. Op grond daarvan is besloten in het vervolg die gebiedsvergelijking los te laten, en het onderzoek meer te richten op het vinden van relaties tussen visserij-intensiteit en ontwikkelingen in bodemdieren en vis. Voor die aanpak was het ook nodig om de intensiteit van zowel boomkorvisserij als garnalenvisserij op basis van VMS data te kwantificeren.

In 2014 is ook een overbruggingsjaar ingelast met minder inzet op monitoring (Prins et al. 2015), om een aantal specifieke analyses uit te voeren (Hintzen et al. 2014, Poot \& Van Horssen 2014, Van Calsteren-De Bruijn 2014, Prins et al. 2015, Tulp 2015b, Van Kooten \& Janssen 2015, Prins et al. 2016a). In 2015 is de monitoring zoals die in de $1^{\text {e }}$ fase werd uitgevoerd, weer grotendeels hervat (Prins et al. 2016b). Wel zijn er wijzigingen doorgevoerd in de monitoring van bodemdieren. Hierbij is rekening gehouden met de gewijzigde begrenzing van de rustgebieden Bollen van de Ooster en Bollen van het Nieuwe Zand en het vervallen van meetlocaties in de monding van het Haringvliet waar boomkorvisserij nooit heeft plaatsgevonden (Craeymeersch et al. 2016b).

$\mathrm{Na}$ een aanbestedingsprocedure is in 2016 de $2^{\mathrm{e}}$ fase van PMR-NCV gestart. Belangrijkste wijzigingen ten opzichte van de $1^{\mathrm{e}}$ fase zijn dat voor de visbemonstering is aangesloten bij de al lopende Demersal Fish Survey (DFS) monitoring, en voor de zwarte zee-eend naast veldwaarnemingen, ook ingezet wordt op een modelmatige aanpak (Tulp et al. 2015b).

\subsubsection{BACI ontwerp}

Bij de opzet van de monitoringprogramma's voor bodemdieren en vissen is het zogenaamde "BACI design" gevolgd (Green 1979). In een BACI design (Before-After-Control-Impact) wordt het ecologische effect van een ingreep in een gebied bepaald door metingen voor en na de ingreep uit te voeren (Before-After). Daarnaast worden ook metingen verricht in referentiegebieden waar de ingreep niet plaats vindt (Control-Impact). Op deze wijze kunnen de effecten van 'autonome' ontwikkelingen worden onderscheiden van de effecten van de ingreep (Green 1979, Underwood 1992; 1996).

Om zoveel mogelijk te corrigeren voor de variatie veroorzaakt door natuurlijke omgevingsfactoren, is in de analyse van bodemdieren en vissen gebruik gemaakt van een habitatmodel. Factoren die onderzocht zijn op voorspellende waarde zijn onder meer diepte, doorzicht, saliniteit, stroomsnelheid, bodemschuifspanning van golven, bodemschuifspanning van stroming, waterstand, stroomrichting, temperatuur en mediane korrelgrootte van het sediment. Overigens zijn veel van deze abiotische factoren onderling sterk gecorreleerd, zodat in de uiteindelijke habitatmodellen voor bodemdieren en vis met een selectie van factoren gewerkt is.

De biomassa in het bodembeschermingsgebied en de referentiegebieden is voor en na het instellen van het bodembeschermingsgebied vergeleken aan de hand van een lineair model, met als verklarende factoren een aantal abiotische parameters, het gebied (referentiegebied vs.

bodembeschermingsgebied), het tijdstip (voor of na het instellen van het bodembeschermingsgebied), en de interactie tussen de twee laatste factoren (Prins et al. 2014c).

Als deze interactieterm significant is, kan dit wijzen op een effect van de maatregel.

In aanvulling op de BACI analyse zijn de veranderingen in biomassa (van bodemdieren) en dichtheden of aan-/afwezigheid (van vis) per monsterpunt vergeleken. Dit is gedaan met een non-parametrische toets (Wilcoxon signed rank sum toets).

Voor bodemdieren is per gebied een vergelijking gemaakt van de biomassa in T0 en T1, waarbij geanalyseerd is of er een significante toe- of afname is opgetreden op de locaties binnen een gebied. 
Met dezelfde methodiek is voor vis per soort geanalyseerd of de mate van verandering in dichtheid van T0 naar T1 in het bodembeschermingsgebied verschilt van die in het referentiegebied.

De opzet van de monitoring had als doel een vergelijking van de ontwikkelingen vóór en na de instelling van het bodembeschermingsgebied. Het verschil in verandering tussen het bodembeschermingsgebied en de referentiegebieden zou inzicht geven in het effect van de compensatiemaatregelen. Echter omdat de boomkorvisserij ook in de referentiegebieden sterk afgenomen is, ontbreekt enig contrast tussen de referentiegebieden en bodembeschermingsgebied en is er geen duidelijk behandelingseffect. Hierdoor is aan de voorwaarde voor een goede BACI-opzet niet voldaan.

\subsubsection{Benthos}

\section{Monitoring}

De ontwikkelingen in de bodemdierengemeenschap zijn onderzocht aan de hand van gegevens van de infauna (die wordt bemonsterd met een box-corer) evenals van de epifauna en grotere infauna (die wordt bemonsterd met een bodemschaaf). De bemonsteringen zijn jaarlijks in het najaar uitgevoerd (Tulp 2015b). De indeling van het bemonsteringsgebied in de deelgebieden Noord-Midden-Zuid en een stukje Haringvlietmond, is terug te zien in figuur 2.1.

Omdat de vragen die beantwoord moeten worden met dit monitoringprogramma, betrekking hebben op het totale bodemdierenbestand, is een methode ontwikkeld om de beide datasets samen te voegen. Op basis van de gecombineerde gegevens van box-corer en bodemschaaf kan een geïntegreerd beeld van de bodemdierengemeenschap beschreven worden.

In bijlage 2 is een overzicht terug te vinden van de verschillende bemonsteringen die tijdens de nulmetingen en eerste fase per monitoringsjaar binnen het benthosperceel zijn uitgevoerd.

In 2007 is er geen bemonstering met de bodemschaaf uitgevoerd. In 2009 is het referentiegebied aangevuld met 30 nieuwe vakken van $1 \mathrm{~km}^{2}$ gelegen aan de westrand van het bodembeschermingsgebied binnen het toenmalige zoekgebied voor het bodembeschermingsgebied. Dit referentiegebied is vooral gekozen met het oog op de aanwezigheid van bodemberoerende visserij (Rijnsdorp et al. 2006) en de daar voorkomende bodemdierengemeenschap (Craeymeersch et al. 1990). Daarnaast is ten zuiden van het bodembeschermingsgebied nog een extra referentiegebied gekozen, inclusief twee extra monsterpunten (t.o.v. de T0) ter hoogte van de Zeehondenplaat en Petroleumbol (buitendelta Oosterschelde), vanwege de aanwezigheid van zwarte zee-eenden in dit gebied.

In 2014 heeft er binnen PMR-NCV geen monitoring van bodemdieren plaatsgevonden.

In 2015 is het surveyprogramma teruggebracht van 411 naar 238 locaties. Alle locaties in de monding van het Haringvliet en een deel van de locaties in het referentiegebied aan de westrand van het bodembeschermingsgebied (figuur 2.1) vormen sindsdien geen onderdeel meer van het programma: voor de Haringvlietmonding is het argument voor het schrappen van de locaties, dat in dit gebied geen effect van de maatregel te verwachten is, omdat er nooit boomkorvisserij heeft plaatsgevonden. Voor referentiegebied aan de westrand van het bodembeschermingsgebied is het argument dat gebleken is dat ook in dit gebied de boomkorvisserij vrijwel geheel verdwenen is. Daarnaast is de benthosbemonstering uitgebreid met een meer gedetailleerde bemonstering van de rustgebieden voor zwarte zee-eenden, waarvan de begrenzing opnieuw is vastgesteld in het najaar van 2015.

\section{Onderzoek en analyses}

In tabel 2.2 is een overzicht terug te vinden van al het onderzoek en de analyses die in de eerste en tweede fase van het Monitorings- en onderzoeksprogramma PMR-NCV binnen het perceel benthos zijn uitgevoerd. Binnen het perceel benthos zijn in de eerste fase de meeste analyses uitgevoerd in een opzet waarbij de ontwikkeling in de betreffende parameter is vergeleken tussen het Bodembeschermingsgebied en een referentiegebied (BACI analyse). De habitatmodellen zijn ook uitgevoerd zonder onderscheid tussen de gebieden. In de tweede fase is de BACI opzet niet meer gehanteerd: omdat de boomkorvisserij voorafgaand aan de instelling van het BBG al vrijwel verdwenen was uit de Voordelta, is er geen verschil in impact van de boomkorvisserij tussen het bodembeschermingsgebied en het referentiegebied. 


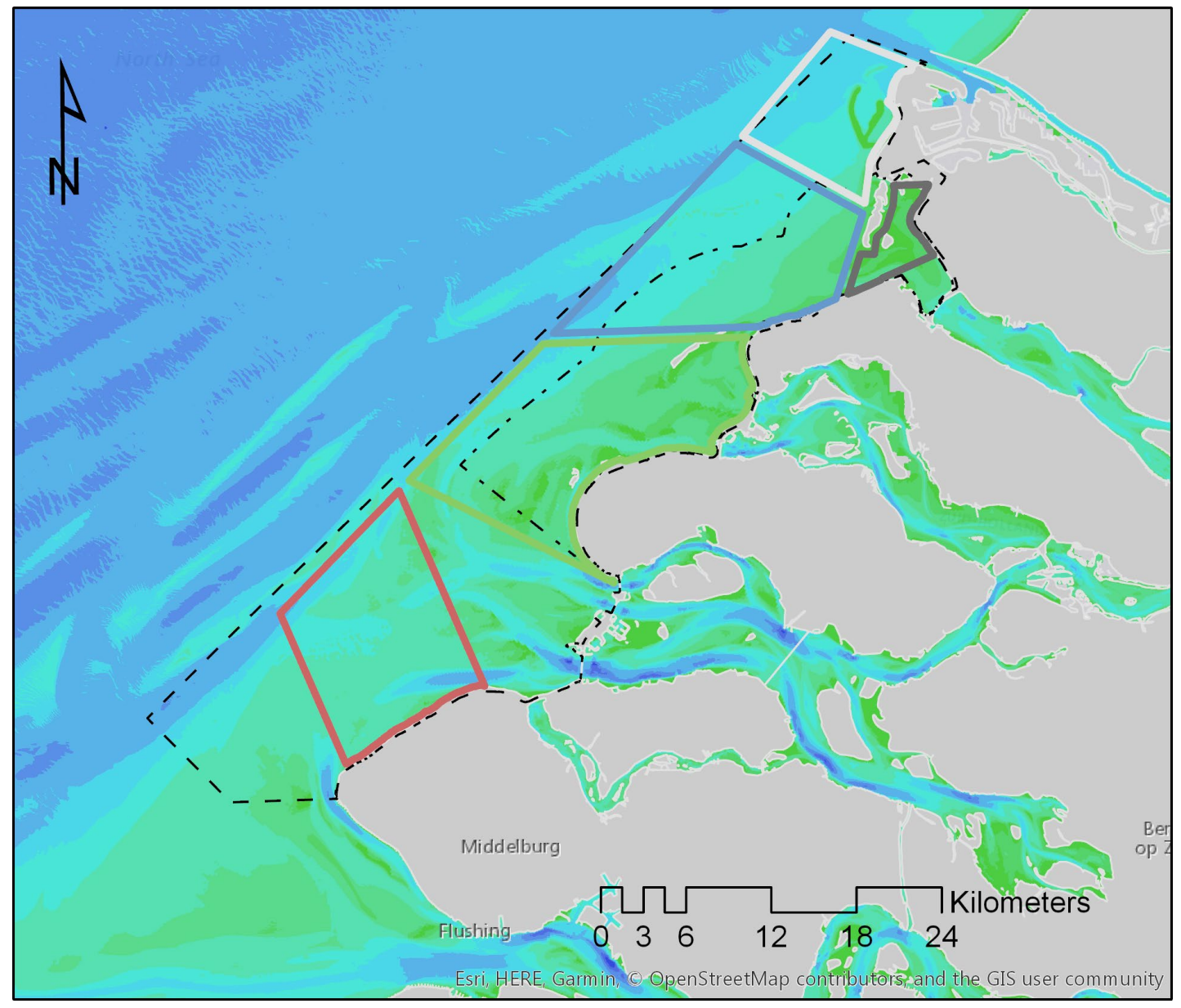

Legenda

Diepte (in meter)

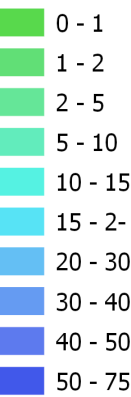

Figuur 2.1 Indeling Voordelta voor de benthosbemonstering: Natura 2000 gebied Voordelta (----), bodembeschermingsgebied ('--·) en de deelgebieden Landaanwinningsgebied (wit) Haringvlietmonding (grijs), Noord (blauw), Midden (geel) en Zuid (rood). 


\section{Tabel 2.2}

Overzicht van alle onderzoek en analyses in de eerste en tweede fase van het Monitorings- en onderzoeksprogramma PMR-NCV binnen het perceel benthos en de jaren waarvan onderzoeksgegevens in de analyse worden meegenomen.

\begin{tabular}{|c|c|c|}
\hline analyse/figuur & Eerste fase & Tweede fase \\
\hline verspreidingskaarten & 2004 t/m 2013 & $2004 \mathrm{t} / \mathrm{m} 2015$ \\
\hline frequentie van voorkomen & 2004 t/m 2013 & $2004 \mathrm{t} / \mathrm{m} 2015$ \\
\hline lengte-frequentieverdelingen & 2004 t/m 2013 BACl & $2004-2015$ \\
\hline dichtheden op monsterpuntniveau vergeleken & 2004 t/m $2012 \mathrm{BACl}$ & - \\
\hline $\begin{array}{l}\text { Habitatmodel } \\
\text { - } \quad \text { totale biomassa } \\
\text { - } \text { biomassa als voedsel voor vogels } \\
\text { - } \text { productie K2 strategen(alleen fase 1) } \\
\text { - } \text { gem ind gewicht } \\
\text { - } \text { aantal soorten } \\
\text { - } \text { aandeel grote soorten } \\
\text { incl. abiotiek en correlaties met lokale visserij } \\
\text { inspanning }\end{array}$ & 2004 t/m $2012 \mathrm{BACl}$ & 2004 t/m 2015 \\
\hline $\begin{array}{l}\text { analyse lange termijn serie binnen en buiten } \\
\text { Voordelta van verschillende soorten: WOT } \\
\text { schelpdiersurvey binnen en buiten Voordelta } \\
\text { met covariaten incl. correlaties met visserij } \\
\text { inspanning }\end{array}$ & 1995 t/m 2013 & 1995 t/m 2016 \\
\hline $\begin{array}{l}\text { analyse lange termijn serie binnen en buiten } \\
\text { Voordelta van verschillende soorten aaseters: } \\
\text { WOT schelpdiersurvey binnen en buiten } \\
\text { Voordelta en covariaten incl. correlaties met } \\
\text { visserij inspanning }\end{array}$ & & 1995 t/m 2016 \\
\hline $\begin{array}{l}\text { analyse benthosgemeenschap: multivariaat } \\
\text { met covariaten Voordelta incl. correlaties met } \\
\text { visserij inspanning }\end{array}$ & 2004 t/m 2013 & 2004 t/m 2015 \\
\hline $\begin{array}{l}\text { Bodemdierenproductie in relatie tot } \\
\text { natuurlijke verstoring versus verstoring door } \\
\text { visserij }\end{array}$ & 2004 t/m 2013 & \\
\hline Biological Trait Analysis: Typologiën & & $2004 \mathrm{t} / \mathrm{m} 2015$ \\
\hline $\begin{array}{l}\text { Biological Trait Analysis: multivariate analyse } \\
\text { van trait modaliteiten }\end{array}$ & & 2004 t/m 2015 \\
\hline $\begin{array}{l}\text { Vergelijking ontwikkeling gebieden met } \\
\text { contrast in visserijdruk }\end{array}$ & 2004 t/m 2013 & 2004 t/m 2015 \\
\hline
\end{tabular}

\subsubsection{Vis}

\section{Monitoring}

De ontwikkelingen in de demersale visgemeenschap zijn tijdens de nulmetingen en eerste fase onderzocht door bemonsteringen in voor- en najaar met behulp van een garnalenkor.

Alleen in het eerste bemonsteringsjaar 2005 is naast de reguliere survey met de Luctor ook met een commercieel schip, de G058, met een boomkor gevist in de diepere delen van het onderzoeksgebied vooral gericht op de grotere, commercieel interessante vis. Voor de bemonstering van de trekvis is in dat jaar gebruik gemaakt van fuiken. Deze beide laatste vangsttechnieken zijn na 2005 niet meer gebruikt vanwege financiële overwegingen (Prins et al., 2014). 
Visbemonsteringen zijn uitgevoerd in het bodembeschermingsgebied, het referentiegebied ten zuiden daarvan voor de kust van Walcheren en een referentiegebied direct ten westen van het bodembeschermingsgebied (figuur 2.2).

In 2011 is geen najaarsbemonstering uitgevoerd. In 2014 heeft er binnen PMR-NCV geen monitoring van vis in de Voordelta plaatsgevonden.

De soorten die in de eerste en tweede fase zijn bemonsterd, de gegevens van deze soorten die zijn verzameld en de metingen die uitgevoerd zijn terug te vinden in Bijlage 3.
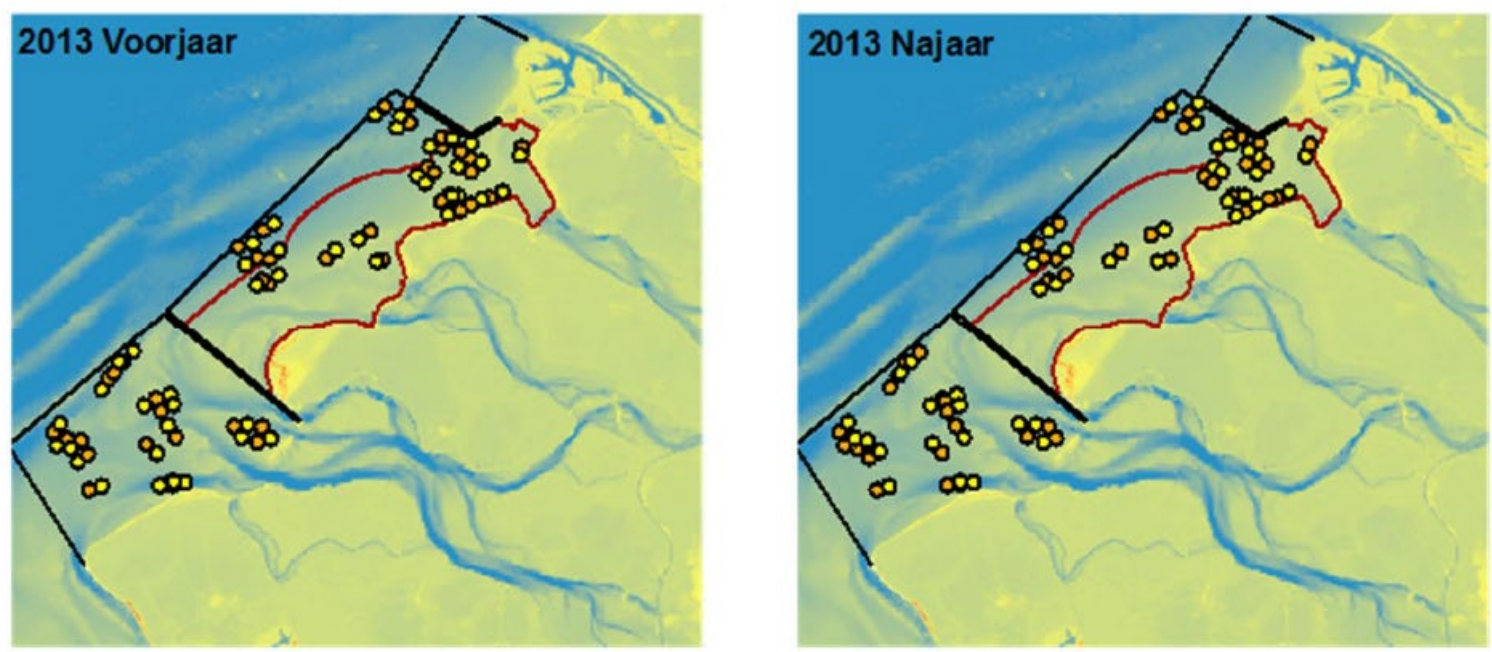

Figuur 2.2 Posities van de vistrekken met de garnalenkor met de 'Luctor' in voorjaar en najaar van 2013 (19 in bodembeschermingsgebied, 15 in zuidelijk referentiegebied, 6 in westelijk

referentiegebied) (representatief voor vismonitoring in andere jaren van de eerste fase). De rode lijn geeft het bodembeschermingsgebied aan, de oranje punten het begin en de gele punten het eind van een trek.

Voor de monitoring van de demersale vis is in 2015 aansluiting gezocht bij de Demersal Fish Survey (DFS) (DFS). Hierbij is de DFS in het gebied uitgebreid met 13 locaties (figuur 2.3). De locaties van de aanvullende trekken zijn geselecteerd uit het PMR visbemonsteringsprogramma. Het oorspronkelijke PMR visprogramma had als uitgangspunt de vergelijking tussen BBG en referentiegebied volgens de BACI aanpak waarbij alle dieptestrata bemonsterd werden. $\mathrm{Er}$ is voor dieptestrata $(<5 \mathrm{~m}, 5 \mathrm{~m}-10 \mathrm{~m}, 10$ $\mathrm{m}$ ) gekozen omdat de verspreiding van de verschillende bodemberoerende visserijen deels diepte gerelateerd is. Zo vissen boomkorkotters $>260$ pk vooral in de diepere geulen en is garnalenvisserij vooral

beperkt tot minder diepe gebieden. $\mathrm{Er}$ is voor deze aanpassing gekozen, omdat de visbemonstering met het vervallen van de BACI een ander accent heeft gekregen met als doel trends in de tijd te kunnen volgen in plaats van BACI. 


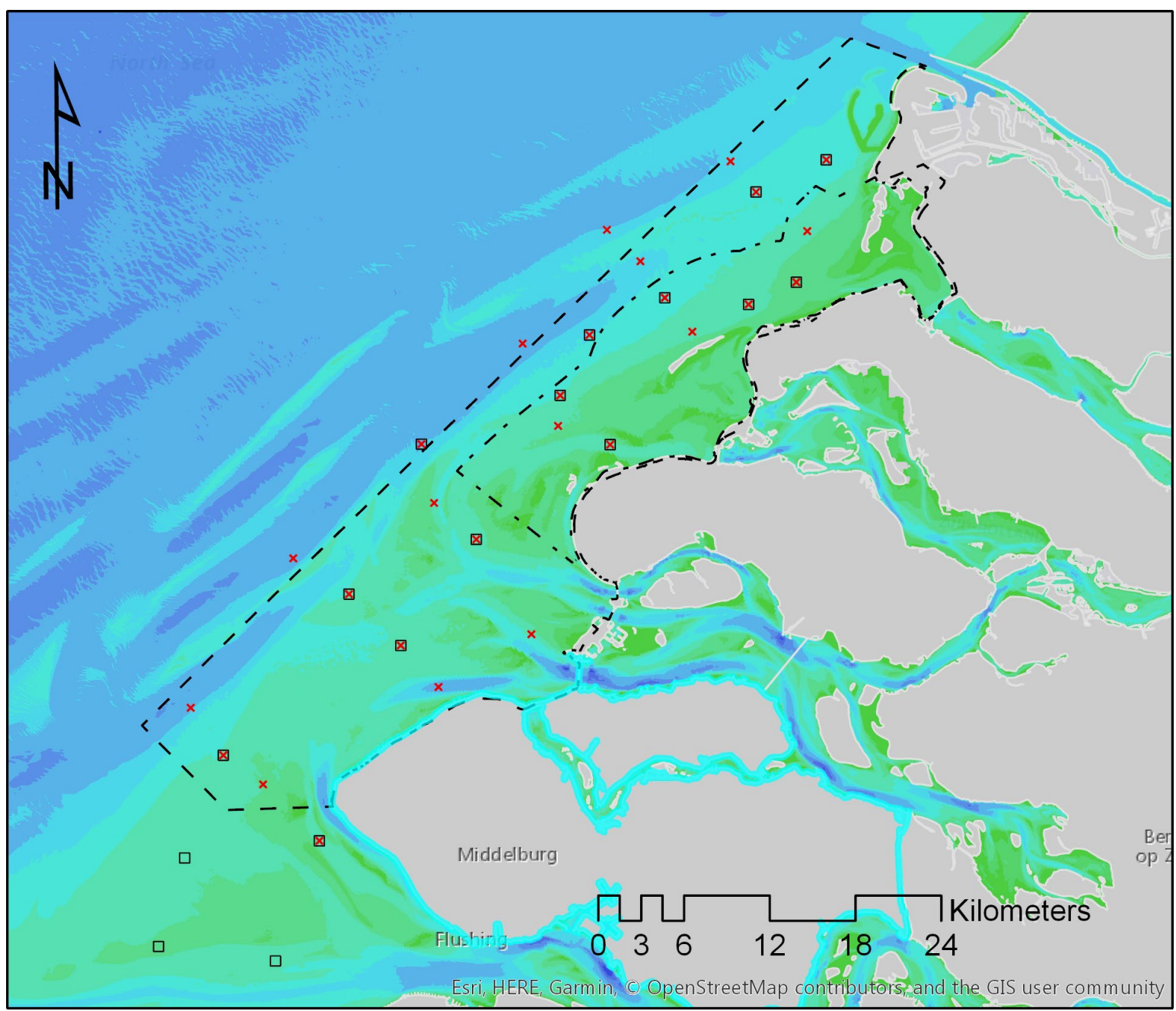

Figuur 2.3 De DFS ( $\square$ ) en PMR stations (x ) binnen de vismonitoring (Bolle 2016).

\section{Onderzoek en analyses}

In tabel 2.3 is een overzicht terug te vinden van al het onderzoek en de analyses die in de eerste en tweede fase van het Monitorings- en onderzoeksprogramma PMR-NCV binnen het perceel vis zijn uitgevoerd. Binnen het perceel vis zijn in de eerste fase de meeste analyses uitgevoerd in een opzet waarbij de ontwikkeling in de betreffende parameter is vergeleken tussen het Bodembeschermingsgebied en een referentiegebied (BACI analyse). De habitatmodellen zijn ook uitgevoerd zonder onderscheid tussen de gebieden. In de tweede fase is de BACI opzet niet meer gehanteerd: omdat de boomkorvisserij voorafgaand aan de instelling van het BBG al vrijwel verdwenen was uit de Voordelta, is er geen verschil in impact van de boomkorvisserij tussen het bodembeschermingsgebied en het referentiegebied.

Van de DFS zijn gegevens gebruikt vanaf 1970, waarbij tot 201413 locaties zijn bemonsterd en vanaf 201525 locaties. 


\section{Tabel 2.3}

Overzicht van alle onderzoek en analyses in de eerste en tweede fase van het Monitorings- en onderzoeksprogramma PMR-NCV binnen het perceel vis en de jaren waarvan onderzoeksgegevens in de analyse worden meegenomen

\begin{tabular}{|c|c|c|}
\hline analyse/figuur & Eerste fase & Tweede fase \\
\hline verspreidingskaarten & 2005 t/m 2013 & - \\
\hline frequentie van voorkomen & 2005 t/m $2013 \mathrm{BACl}$ & - \\
\hline lengte-frequentieverdelingen & 2005 t/m 2013 BACl & - \\
\hline gemiddelde lengte & 2005 t/m $2012 \mathrm{BACl}$ & $1970-2016$ \\
\hline lengte-leeftijdssleutels & 2005 t/m $2012 \mathrm{BACl}$ & $1970-2016$ \\
\hline leeftijdsopbouw & 2005 t/m $2012 \mathrm{BACl}$ & $1970-2016$ \\
\hline dichtheden op trekniveau vergeleken & 2005 t/m $2012 \mathrm{BACl}$ & \\
\hline $\begin{array}{l}\text { Habitatmodel soorten incl. abiotiek en } \\
\text { correlaties met lokale visserij inspanning }\end{array}$ & 2005 t/m $2012 \mathrm{BACl}$ & $2005-2016$ \\
\hline $\begin{array}{l}\text { Habitatmodel } 0 \text { en } 1 \text { jarigen incl. abiotiek en } \\
\text { correlaties met lokale visserij inspanning }\end{array}$ & 2005 t/m $2012 \mathrm{BACl}$ & $2005-2016$ \\
\hline $\begin{array}{l}\text { Habitatmodel gildes incl. abiotiek en } \\
\text { correlaties met lokale visserij inspanning }\end{array}$ & & $1970-2016$ \\
\hline $\begin{array}{l}\text { Habitatmodel zandspiering (perceel benthos) } \\
\text { incl. abiotiek en correlaties met lokale visserij } \\
\text { inspanning }\end{array}$ & 2009 t/m 2012 & 2009 t/m 2016 \\
\hline $\begin{array}{l}\text { analyse lange termijn serie binnen en buiten } \\
\text { Voordelta: DFS per soort }\end{array}$ & 1970 t/m 2011 & \\
\hline $\begin{array}{l}\text { analyse lange termijn serie binnen en buiten } \\
\text { Voordelta: DFS per gilde en covariaten incl. } \\
\text { correlaties met visserij inspanning }\end{array}$ & & 1970 t/m 2016 \\
\hline maagvulling in relatie tot tijd van de dag & 2005 t/m najaar 2012 & \\
\hline maagvulling & 2005 t/m najaar $2012 \mathrm{BACl}$ & \\
\hline dieetsamenstelling & 2005 t/m najaar $2013 \mathrm{BACl}$ & \\
\hline dieet diversiteit & 2005 t/m najaar $2012 \mathrm{BACl}$ & \\
\hline ontogenetische verschuiving in dieet & 2005 t/m $2013 \mathrm{BACl}$ & \\
\hline prooiselectie & 2005 t/m $2011 \mathrm{BACl}$ & \\
\hline groei & 2005 t/m $2011 \mathrm{BACl}$ & 1970 t/m 2016 \\
\hline conditie & 2005 t/m $2012 \mathrm{BACl}$ & 1970 t/m 2016 \\
\hline epibenthos uit visbemonstering & 2005 t/m $2011 \mathrm{BACl}$ & 1970 t/m 2016 \\
\hline leeftijdsopbouw & & 1970 t/m 2016 \\
\hline analyse visgemeenschap: lengte-biomassa & $2005 \mathrm{t} / \mathrm{m} 2013$ & 1970 t/m 2016 \\
\hline $\begin{array}{l}\text { analyse visgemeenschap: multivariaat } \\
\text { Voordelta + kust }\end{array}$ & 2005 t/m $2012 \mathrm{BACl}$ & 1970 t/m 2016 \\
\hline $\begin{array}{l}\text { analyse visgemeenschap: multivariaat met } \\
\text { abiotiek en covariaten Voordelta }\end{array}$ & & 2005 t/m 2016 \\
\hline
\end{tabular}

\subsubsection{Vogels}

Op basis van verschillende telmethodieken (vliegtuigtellingen, scheepstellingen en landtellingen) is tijdens de nulmetingen voor een aantal soorten vogels (roodkeelduiker, kuifduiker, fuut, zwarte zeeeend, eidereend, toppereend, kleine mantelmeeuw, visdief, grote stern) het aantal vogeldagen per seizoen in de Voordelta bepaald. Vogeldagen zijn een eenheid om het gebiedsgebruik door vogels weer te geven; dit is het product van het aantal vogels vermenigvuldigd met het aantal dagen dat zij in een gebied aanwezig zijn (RIKZ, 2007). 
In de jaren 2009-2012 is onderzoek uitgevoerd aan het gebiedsgebruik, foerageergedrag en de samenstelling van braakballen van aalscholvers uit de kolonie Breede Water op Voorne.

In de eerste en tweede fase heeft de vogelmonitoring zich toegespitst op de soorten grote stern, visdief en zwarte zee-eend.

\subsubsection{Zwarte zee-eend}

\section{Monitoring}

De ontwikkelingen (aantallen, gebiedsgebruik, verspreiding) in de populatie zwarte zee-eenden in de Voordelta werden in de eerste en tweede fase onderzocht door middel van vliegtuigtellingen en gedragsobservaties vanaf land (alleen in de eerste fase).

Onderzoek naar het dieet van zwarte zee-eenden is in de eerste fase uitgevoerd door veldwaarnemingen van foeragerende zee-eenden, en door de maaginhouden te analyseren van, op stranden aangespoelde, dode zee-eenden.

Om mogelijke verstoring van zwarte zee-eenden in kaart te brengen, is het gebiedsgebruik door mensen in en rond de ingestelde rustgebieden in de Voordelta bepaald door land- en luchtwaarnemingen. In de periode 2009- 2013 zijn iedere winterperiode (oktober-april) tien, en iedere zomerperiode vijftien waarnemingsvluchten uitgevoerd, waarbij voor de zwarte zee-eenden met name de verstoring in de winterperiode van belang is.

\section{Onderzoek en analyses}

In tabel 2.4 is een overzicht terug te vinden van al het onderzoek en de analyses die in de eerste en tweede fase van het Monitorings- en onderzoeksprogramma PMR-NCV binnen het perceel zwarte zeeeend zijn uitgevoerd.

In de eerste fase zijn verschillende factoren die de aanwezigheid van zwarte zee-eenden in de Voordelta kunnen bepalen in samenhang nader geanalyseerd in een uitgebreide statistische analyse. De factoren die in beschouwing zijn genomen zijn het voedselaanbod, de verstoring door scheepvaart, de stroomsnelheid bij de bodem en de diepte.

In de tweede fase is een energetisch model opgesteld voor de zwarte zee-eend, waarmee op basis van het aanwezige voedsel de draagkracht voor het aantal zwarte zee-eenden berekend kan worden.

\section{Tabel 2.4}

Overzicht van alle onderzoek en analyses in de eerste en tweede fase van het Monitorings- en onderzoeksprogramma PMR-NCV binnen het perceel zwarte zee-eend en de jaren waarvan onderzoeksgegevens in de analyse worden meegenomen.

\begin{tabular}{|l|l|l|}
\hline analyse/figuur & Eerste fase & Tweede fase \\
\hline Verspreidingskaarten & $2004-2006$ en 2009-2013 & 2004-2006 en 2009-2017 \\
\hline Maximale aantallen, aantal vogeldagen & $2004-2006$ en 2009-2013 & 2004-2006 en 2009-2017 \\
\hline $\begin{array}{l}\text { Midwinter- en voorjaars-aantal Nederlandse } \\
\text { kust }\end{array}$ & $2009-2013$ & 2008-2017 \\
\hline Gedragsobservaties zwarte zee-eend & $2009-2013$ & \\
\hline Dieet/maaginhouden & 2009 t/m 2012 & \\
\hline $\begin{array}{l}\text { Voedselaanbod } \\
\text { Brouwersdam }\end{array}$ & $2012-2013$ & $2004-2006$ en 2009-2017 \\
\hline Voedselaanbod Voordelta & $2004-2006$ en 2009-2013 & \\
\hline $\begin{array}{l}\text { Menselijk gebruik; ruimtelijke verspreiding en } \\
\text { intensiteit scheepvaart op basis van Als }\end{array}$ & $2009-2012$ & \\
\hline $\begin{array}{l}\text { Menselijk gebruik; ruimtelijke verspreiding op } \\
\text { basis van land- en vliegtuigwaarnemingen }\end{array}$ & $2005-2006$ en 2009-2013 & \\
\hline $\begin{array}{l}\text { Ruimtelijke correlatie tussen aantal zee- } \\
\text { eenden en voedselaanbod, stroomsnelheid, } \\
\text { diepte en scheepvaart-intensiteit }\end{array}$ & $2010-2013$ & \\
\hline $\begin{array}{l}\text { Draagkrachtmodellering potentiele aantal } \\
\text { eenden }\end{array}$ & & \\
\hline
\end{tabular}




\subsubsection{Sterns}

\section{Monitoring}

De ontwikkelingen (aantallen, gebiedsgebruik, verspreiding) van grote stern en visdief in de Voordelta zijn in de eerste en tweede fase onderzocht door middel van vliegtuigtellingen, waarnemingen aan gezenderde vogels en landwaarnemingen. Daarnaast is onderzoek uitgevoerd in broedkolonies van de grote stern, waarbij is vastgelegd wat er aan prooien werd meebracht voor de jongen en uit faeces is achterhaald wat de adulten gegeten hebben. Gedurende het onderzoek werden seizoensgebonden en jaarlijkse veranderingen in de samenstelling van het voedsel van zowel oudervogels (grote stern) als kuikens (grote stern, visdief) gemeten, en de effecten daarvan op de groei en overleving van de kuikens en het foerageergedrag van oudervogels. Het broedsucces van grote stern en visdief werd vastgesteld door onderzoek in een aantal kolonies aan de legselgrootte, de conditie van kuikens en het aantal vliegvlugge jongen, die indicatief kunnen zijn voor de relatie met voedselbeschikbaarheid. Gegevens van veldwaarnemingen (landwaarnemingen en luchtwaarnemingen) zijn gebruikt om het gebiedsgebruik rond de ingestelde rustgebieden in beeld te brengen.

\section{Onderzoek en analyses}

In tabel 2.5 is een overzicht terug te vinden van al het onderzoek en de analyses die in de eerste en tweede fase van het Monitorings- en onderzoeksprogramma PMR-NCV binnen het perceel sterns zijn uitgevoerd.

\section{Tabel 2.5}

Overzicht van alle onderzoek en analyses in de eerste en tweede fase van het Monitorings- en onderzoeksprogramma PMR-NCV binnen het perceel sterns en de jaren waarvan onderzoeksgegevens in de analyse worden meegenomen.

\section{Grote Stern}

\begin{tabular}{|c|c|c|c|c|c|}
\hline Monitoring & Scheelhoek & Slijkplaat & Markenje & $\begin{array}{l}\text { Natura } 2000- \\
\text { gebied } \\
\text { Voordelta }\end{array}$ & $\begin{array}{l}\text { Sternkolonies } \\
\text { in de Delta }\end{array}$ \\
\hline Vliegtuigtellingen & & & & '09- '17 & \\
\hline Kolonietellingen & & & & & '09- '17 \\
\hline $\begin{array}{l}\text { Broedsuccesbepaling } \\
\text { kolonies }\end{array}$ & & & & & '09 - '17 \\
\hline Broedsucces & $\begin{array}{l}\text { '09-'10,'12- } \\
\text { '13,'15-'17 }\end{array}$ & '14 & '11-'16 & & \\
\hline Kuikenconditie & $\begin{array}{l}\text { '09-'10, '12- } \\
\text { '13,'15-'17 }\end{array}$ & '14 & '11-'16 & & \\
\hline Adulte conditie & $\begin{array}{l}\text { '09-'10, '12- } \\
\text { '13,'15-'17 }\end{array}$ & '14 & & & \\
\hline Kuikendieet & $\begin{array}{c}\text { '09-'10, '12-'13, } \\
\text { '15-'17 }\end{array}$ & '14 & $\begin{array}{l}\text { '11-'13,'15- } \\
\text { '16 }\end{array}$ & & \\
\hline Adult dieet algemeen & $\begin{array}{l}\text { '09-'10, '12- } \\
\text { '13, '15-'17 }\end{array}$ & '14 & 10- '16 & & \\
\hline Adult dieet schalen & '13, '15-'17 & '14 & '13-'16 & & \\
\hline Gebiedsgebruik middels VHF & '09-'10 & & & & \\
\hline Gebiedsgebruik middels GPS & '12-'13, '15, '17 & '14 & & & \\
\hline $\begin{array}{l}\text { Gebiedsgebruik juveniele } \\
\text { sterns }\end{array}$ & & & & '09, '10, '17 & \\
\hline Gebruik rustgebieden & & & & '11, '17 & \\
\hline $\begin{array}{l}\text { Kleurringonderzoek (buiten } \\
\text { projecttijd) }\end{array}$ & $\begin{array}{l}\text { '10, '12-'13, } \\
\text { '15-'17 }\end{array}$ & '14 & $\begin{array}{l}\text { '10, '12-'13, } \\
\text { '15-'16 }\end{array}$ & & \\
\hline Verstoringsonderzoek & & & & '17 & \\
\hline
\end{tabular}


Visdief

\begin{tabular}{|c|c|c|c|c|c|c|c|}
\hline Monitoring & Scheelhoek & Slijkplaat & Markenje & Vogelvallei & Visdiefeiland & $\begin{array}{c}\text { Natura } \\
2000- \\
\text { gebied } \\
\text { Voordelta } \\
\end{array}$ & $\begin{array}{l}\text { Sternkolonies } \\
\text { in de Delta }\end{array}$ \\
\hline Vliegtuigtellingen & & & & '09 - '17 & & '09 - '17 & \\
\hline Kolonietellingen & & & & & '09-17 & & '09 - '17 \\
\hline $\begin{array}{l}\text { Broedsuccesbepaling } \\
\text { kolonies }\end{array}$ & & & & & '09-17 & & '09 - '17 \\
\hline Broedsucces & '09-'17 & '09 & '10-'13 & '10-'12 & '11-'12, '16-'17 & & \\
\hline Kuikenconditie & '09-'17 & '09 & '10-'13 & '10-'12 & '11-'12, '16-'17 & & \\
\hline Adulte conditie & '09-'17 & '09 & & '10-'12 & & & \\
\hline Kuikendieet & '09-'17 & '09 & & '10 & '16- '17 & & \\
\hline \multicolumn{8}{|l|}{ Adult dieet algemeen } \\
\hline \multicolumn{8}{|l|}{ Adult dieet schalen } \\
\hline $\begin{array}{l}\text { Gebiedsgebruik } \\
\text { middels VHF }\end{array}$ & '09-'10 & '09-'10 & & & & & \\
\hline Gebruik rustgebieden & & & & & & '11, '17 & \\
\hline $\begin{array}{l}\text { Kleurringonderzoek } \\
\text { (buiten projecttijd) }\end{array}$ & '10-'17 & & & & & & \\
\hline Verstoringsonderzoek & & & & & & '17 & \\
\hline
\end{tabular}

\begin{tabular}{|l|c|c|}
\hline Analyses/figuren & Eerste fase & $\begin{array}{c}\text { Tweede } \\
\text { fase }\end{array}$ \\
\hline Verspreidingskaarten & '09-'13 & '09-'17 \\
\hline Vogeldagenbepaling & '09-'13 & '09-'17 \\
\hline Gedragswaarnemingen offshore & '09-'13 & '09-'17 \\
\hline Koloniegroottes & '09-'13 & '09-'17 \\
\hline Kolonie-uitvliegsuccessen & '09-'13 & '09-'17 \\
\hline Gemiddelde legselgrootte & '09-'13 & '09-'17 \\
\hline Uitkomstsucces & '09-'13 & '09-'17 \\
\hline Uitvliegsucces & '09-'13 & '09-'17 \\
\hline Broedsucces & '09-'13 & '09-'17 \\
\hline $\begin{array}{l}\text { Gemiddelde kuikenconditie per } \\
\text { datum/leeftijd }\end{array}$ & '09-'13 & '09-'17 \\
\hline Gemiddelde adulte conditie per jaar & '09-'13 & '09-'17 \\
\hline Dieetsamenstelling kuiken & '09-'13 & '09-'17 \\
\hline Lengtefrequentie dieet kuiken & '09-'13 & '09-'17 \\
\hline $\begin{array}{l}\text { Prooilengte en -aanvoer per leeftijd } \\
\text { kuiken }\end{array}$ & '09-'13 & '09-'17 \\
\hline Foerageerduur per prooilengte/-soort & '09-'13 & '09-'17 \\
\hline Habitatgebruik gezenderde sterns & '09-'10, '12- & '14-'15, \\
\hline
\end{tabular}




\begin{tabular}{|c|c|c|}
\hline Analyses/figuren & Eerste fase & $\begin{array}{l}\text { Tweede } \\
\text { fase }\end{array}$ \\
\hline $\begin{array}{l}\text { Foerageerduur, triplengte, range, } \\
\text { homerange }\end{array}$ & '12- '13 & $\begin{array}{c}\text { '14-'15, } \\
\text { '17 }\end{array}$ \\
\hline Dispersie obv GPS & '12- '13 & $\begin{array}{c}\text { '14-'15, } \\
\text { '17 }\end{array}$ \\
\hline Habitatpreferentie & & '17 \\
\hline $\begin{array}{l}\text { Georeferenced prooidieren adhv } \\
\text { observaties van aangevoerde vis en GPS }\end{array}$ & & $\begin{array}{l}\text { '14-'15, } \\
\text { '17 }\end{array}$ \\
\hline Gebruik rustgebieden door het seizoen & '11 & '17 \\
\hline Overlap recreatie en sterns & & '17 \\
\hline $\begin{array}{l}\text { Dispersie/verblijftijd Delta obv } \\
\text { kleurringen }\end{array}$ & $\begin{array}{c}\text { '09- '10, '12- } \\
\text { '13 }\end{array}$ & $\begin{array}{c}\text { '14-'15, } \\
\text { '17 }\end{array}$ \\
\hline Trek obv kleurringen & $\begin{array}{l}\text { '09- '10, '12- } \\
\text { '13 }\end{array}$ & $\begin{array}{c}\text { '14-'15, } \\
\text { '17 } \\
\end{array}$ \\
\hline $\begin{array}{l}\text { Invloed beheer kolonies op uitkomst- } \\
\text { en uitvliegsucces }\end{array}$ & '09- '13 & '09-'17 \\
\hline $\begin{array}{l}\text { Invloed weersomstandigheden op } \\
\text { uitkomst- en uitvliegsucces }\end{array}$ & '09- '13 & '09-'17 \\
\hline $\begin{array}{l}\text { Invloed predatie op uitkomst- en } \\
\text { uitvliegsucces }\end{array}$ & '09- '13 & '09-'17 \\
\hline Vergelijking LF vissurveys en dieet GS & '09- '13 & \\
\hline $\begin{array}{l}\text { Afleiden proxy's } \\
\text { voedselbeschikbaarheid GS }\end{array}$ & & '09-'17 \\
\hline $\begin{array}{l}\text { Analyse broedsucces/kuikenconditie in } \\
\text { relatie tot } \\
\text { voedsel/weersomstandigheden }\end{array}$ & '09- '13 & '09-'17 \\
\hline $\begin{array}{l}\text { Energetische beperkingen } \\
\text { foeragerende GS }\end{array}$ & '09- '13 & \\
\hline $\begin{array}{l}\text { Analyse potentieel effect MVII op VD } \\
\text { (energetisch model) }\end{array}$ & & '17 \\
\hline $\begin{array}{l}\text { Analyse effect spuibeheer } \\
\text { Haringvliesluizen op VD Scheelhoek }\end{array}$ & & '09-'17 \\
\hline
\end{tabular}

\subsubsection{Abiotiek}

Onderzoek en analyses

In tabel 2.6 is een overzicht terug te vinden van de parameters die in de eerste en tweede fase van het Monitorings- en onderzoeksprogramma PMR-NCV binnen het perceel abiotiek zijn bepaald. Binnen het perceel abiotiek is gekeken naar de veranderingen in de abiotische condities in de Voordelta voor en na de aanleg van Maasvlakte 2. Metingen en modelschattingen zijn gebruikt om de relevante abiotische omstandigheden in de Voordelta te beschrijven.

De gegevens hebben betrekking op hydrodynamiek (o.a. stroomsnelheid, golfhoogte), morfologie (diepte), fysisch-chemische parameters (o.a. saliniteit, watertemperatuur) en meteorologische gegevens.

Deze gegevens zijn gegenereerd met behulp van numerieke waterbewegings- en golfvoortplantingsmodellen. 
Tabel 2.6

Overzicht van alle parameters die in de eerste en tweede fase van het Monitorings- en onderzoeksprogramma PMR-NCV binnen het perceel Abiotiek zijn bepaald en de jaren waarvoor

\begin{tabular}{|l|l|l|}
\hline analyse/figuur & Eerste fase & Tweede fase \\
\hline $\begin{array}{l}\text { Waterstand, golfhoogte, stroomsnelheid, } \\
\text { bodemschuifspanning }\end{array}$ & $2004-2012$ & $2004-2016$ \\
\hline Saliniteit, temperatuur & $2004-2012$ & $2004-2016$ \\
\hline Dieptekaart & 2004,2010 & $2004,2010,2015$ \\
\hline $\begin{array}{l}\text { Verbeterde berekening bodemschuifspanning } \\
\text { door golven }\end{array}$ & & $2004-2016$ \\
\hline $\begin{array}{l}\text { Weersomstandigheden } \\
\text { windsnelheid en -richting) }\end{array}$ & $2004-2012$ & $2004-2016$ \\
\hline Afvoer Haringvliet & $2004-2012$ & $2004-2016$ \\
\hline
\end{tabular}

\subsubsection{Gebruik}

\section{Monitoring}

In de eerste fase zijn zowel landwaarnemingen als luchtwaarnemingen gebruikt om het gebiedsgebruik rond de ingestelde rustgebieden in beeld te brengen. Iedere winterperiode is 10 keer, en iedere zomerperiode 15 keer gevlogen. In kaarten is het waargenomen gebruik ruimtelijk weergegeven, waarbij het onderscheid in gemotoriseerd en niet-gemotoriseerd gebruik belangrijk is.

\section{Onderzoek en Analyses}

In tabel 2.7 is een overzicht terug te vinden van al het onderzoek en de analyses die in de eerste en tweede fase van het Monitorings- en onderzoeksprogramma PMR-NCV binnen het perceel gebruik zijn uitgevoerd.

In de analyse van de land- en luchtwaarnemingen in de eerste fase, zijn de uitkomsten van de verschillende opnamedagen en van de verschillende meetmethoden met elkaar gecombineerd. Om meer informatie te achterhalen over de activiteiten van sportvissers (met name gericht op de bootjesvisserij en de opstapvisserij) en de aanwezigheid van staandwant in de Voordelta is de Federatie van Hengelsportverenigingen Zuidwest Nederland benaderd met een vragenlijst.

Voor de beschrijving van de bodemberoerende visserij in de Voordelta is gebruik gemaakt van VMSen AIS-data in combinatie met geanonimiseerde logboekgegevens (o.a. gegevens over gebruikt tuig en zeedagen), waarmee een schatting kan worden berekend van de visserij-activiteit (Hintzen et al. 2014).

\section{Tabel 2.7}

Overzicht van alle onderzoek en analyses in de eerste en tweede fase van het Monitorings- en onderzoeksprogramma PMR-NCV binnen het perceel Gebruik en de jaren waarvan onderzoeksgegevens in de analyse worden meegenomen.

\begin{tabular}{|l|l|l|}
\hline analyse/figuur & Eerste fase & Tweede fase \\
\hline $\begin{array}{l}\text { Verspreidingskaarten menselijke activiteiten } \\
\text { (land- en vliegtuigwaarnemingen) }\end{array}$ & 2005-2006, 2009-2012 & $\begin{array}{l}2005-2006, \\
2015\end{array}$ \\
\hline $\begin{array}{l}\text { Kaarten scheepvaartintensiteit op basis van } \\
\text { AIS }\end{array}$ & $2009-2012$ & - \\
\hline $\begin{array}{l}\text { Verstoringsindex rustgebieden Bollen van de } \\
\text { Ooster, Bollen van het Nieuwe Zand }\end{array}$ & 2005-2006, 2009-2013 & - \\
\hline
\end{tabular}




\title{
$3 \quad$ Beschrijving Voordelta
}

\author{
S.D. IJff ${ }^{1}$, J. Adema², T.C. Prins ${ }^{1}$ \\ ${ }^{1}$ Deltares, ${ }^{2}$ Arcadis
}

Dit hoofdstuk geeft een beschrijving van de kenmerken van de Voordelta en de natuurlijke factoren die van belang zijn voor de effecten van de natuurcompensatie. Kennis van de natuurlijke complexiteit en dynamiek van de Voordelta is van belang voor het interpreteren van de waarnemingen uit het monitoringprogramma.

\subsection{Morfologische ontwikkeling van de Voordelta}

De morfologie is mede sturend voor de natuurwaarden van de Voordelta. Morfologische veranderingen treden voortdurend op onder invloed van getij en golven en worden mede beïnvloed door menselijke ingrepen. De Voordelta in zijn huidige karakter is ontstaan door de uitvoering van de Deltawerken. Voor die tijd werd het gebied beschouwd als een onderdeel van de kustzone van de Noordzee, dat echter nog wel estuariene kenmerken had als getijgeulen en ondiepten, lagere saliniteit en hogere troebelheid dan de wateren verder van de kust en langs de Hollandse kust (Wolff 1973). De aanleg van de Deltawerken heeft grote effecten gehad op de processen in de buitendelta's van de (voormalige) estuaria, de gebieden van ondiepten en geulen aan de zeezijde van de mondingen. Die processen zijn veranderd door verminderde uitwisseling met de Deltawateren en door veranderingen in fysische processen, zoals stromingspatronen, golfwerking, zoetwaterafvoer en transport van zand en slib.

Vanaf 1970 ontstonden onder invloed van golfwerking de eerste zandbanken, die in hoogte groeiden en zich landwaarts verplaatsten, terwijl de oude getijdegeulen van Haringvliet en Grevelingen zich opvulden (figuur 3.1) (Kohsiek \& Mulder 1989, Wang et al. 2009, Elias \& Van der Spek 2014, Elias et al. 2016). Zo zijn na de aanleg van de Brouwersdam de Bollen van de Ooster in hoogte toegenomen en hebben ze één aaneengesloten plaat gevormd. Ook de Hinderplaat en Slikken van Voorne zijn in hoogte toegenomen. De zandbanken verplaatsten landwaarts met een afnemende snelheid totdat een min of meer stabilisatie optreedt (Mulder et al. 2010). De Middelplaat vertoont ten opzichte van de situatie in 1964 juist een afname in hoogte en veranderingen in de vorm. Daarnaast is de diepte van de geulen sterk afgenomen. De belangrijkste resterende geul is het Brouwershavensche Gat, die langzaam wordt opgevuld met sediment (Adema 2016). 


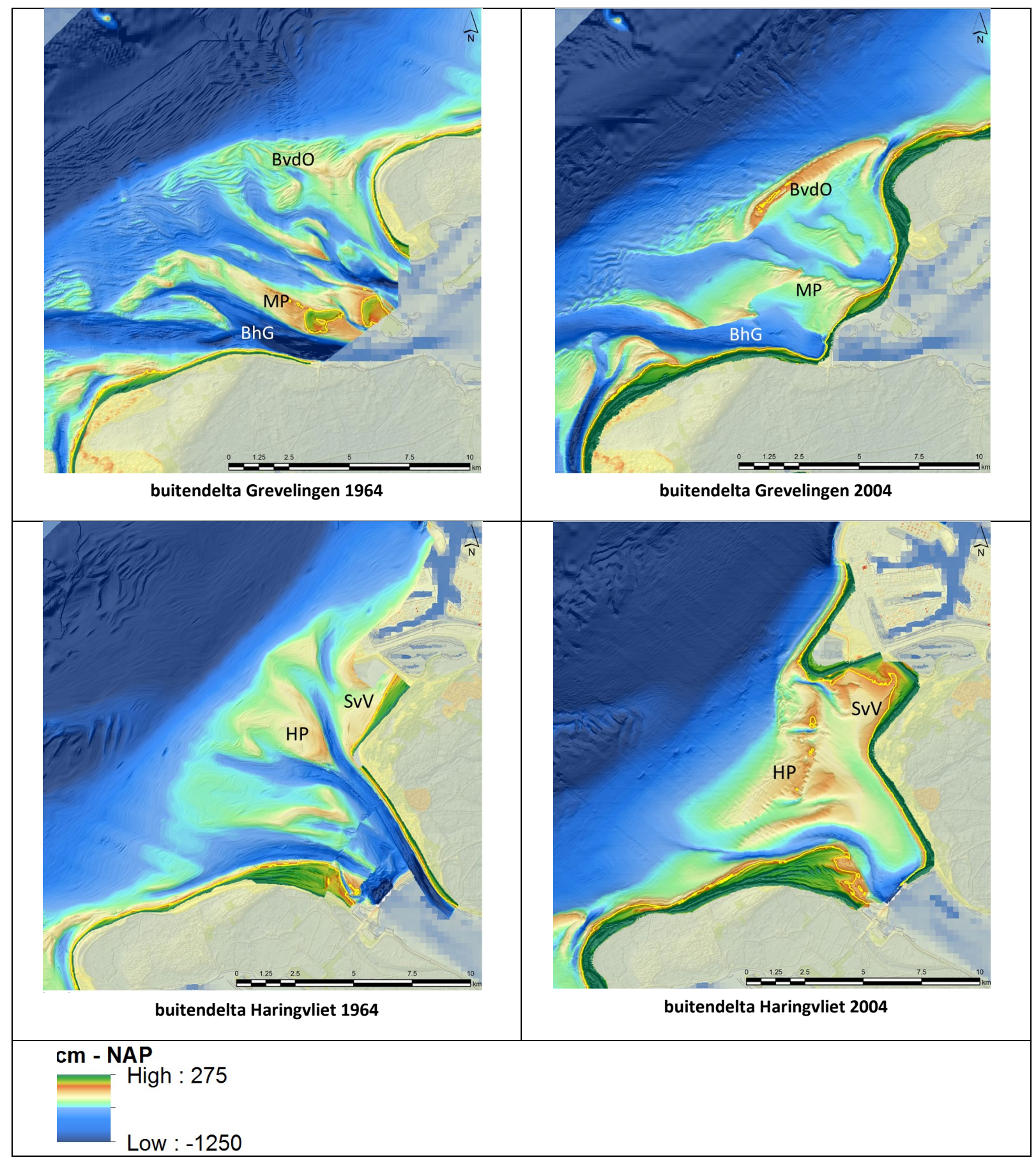

Figuur 3.1. Bodemligging in de buitendelta's van Grevelingen en Haringvliet in 1964 (links) en 2004 (rechts). De figuren laten zien dat de Bollen van de Ooster (BvdO), de Hinderplaat (HP) en Slikken van Voorne (SvV) sinds 1964 in hoogte zijn gegroeid en zich richting het land hebben verplaatst De Middelplaat (MP) is juist in hoogte afgenomen. De geulen worden langzaam opgevuld. De belangrijkste overgebleven geul is het Brouwerhavensche Gat (BhG) (Elias \& Van der Spek 2014).

Voor de grootschalige sedimentbalans van het gebied geldt dat netto vooral slib en ook zand vanuit het zuiden wordt aangevoerd. Een deel van het aangevoerde sediment blijft achter in de buitendelta van de Grevelingen. Ook in de buitendelta van het Haringvliet vindt netto sedimentatie plaats maar hier vindt de aanvoer van zand zowel vanuit het zuiden als vanuit het noorden plaats. Het netto transport langs de Maasmond naar de Hollandse kust is namelijk sterk gereduceerd, terwijl aanleg en onderhoud van het Slufterstrand resulteert in een zuidwaarts transport in de richting van de Haringvlietmonding (Alkyon 2006).

Vóór de aanleg van de Deltawerken was er in de Voordelta een dynamisch evenwicht tussen het zeewaarts getijgedreven zandtransport en het landwaarts gericht zandtransport door golven. De morfologische ontwikkeling van de Voordelta is de laatste decennia echter sterk beïnvloed door menselijke ingrepen, zoals de afsluiting van het Brielse gat (1950), de Haringvlietsluizen en -dam 
(1970), de Brouwersdam (1971) en de Oosterscheldekering (1986), en de aanleg van de eerste (1969) en Maasvlakte 2 (2009-2013). Figuur 3.2 laat een verschilkaart zien van de bodemhoogte tussen de perioden $2003 / 2004$ en $2012 / 2013$. Op deze kaart is zichtbaar dat een aantal gebieden in de Voordelta vooral erosie laten zien, en andere gebieden sedimentatie. Vaak is dit op de randen van geulen en platen.

Door de morfologische ontwikkelingen is het areaal boven gemiddeld laagwater sinds 1970 toegenomen. In totaal neemt hierdoor sinds 1990 het areaal beneden laagwater (habitattype H1110) met ongeveer $20 \mathrm{ha} / \mathrm{jaar}$ af. Dit is verwaarloosbaar ten opzichte van de bijna 90.000 ha $\mathrm{H} 1110$ in de Voordelta in 2007. Het areaal intergetijdengebied is in totaal met ongeveer 15 ha/jaar sinds 1990 toegenomen. Tussen 2007 en 2012 is het areaal van habitattype H1110 vooral afgenomen door de aanleg van Maasvlakte 2 (1.917 ha). Daarnaast is een klein deel (196 ha) als gevolg van opslibbing veranderd in habitattype H1140 (Van Oostveen \& Koolmees 2013).

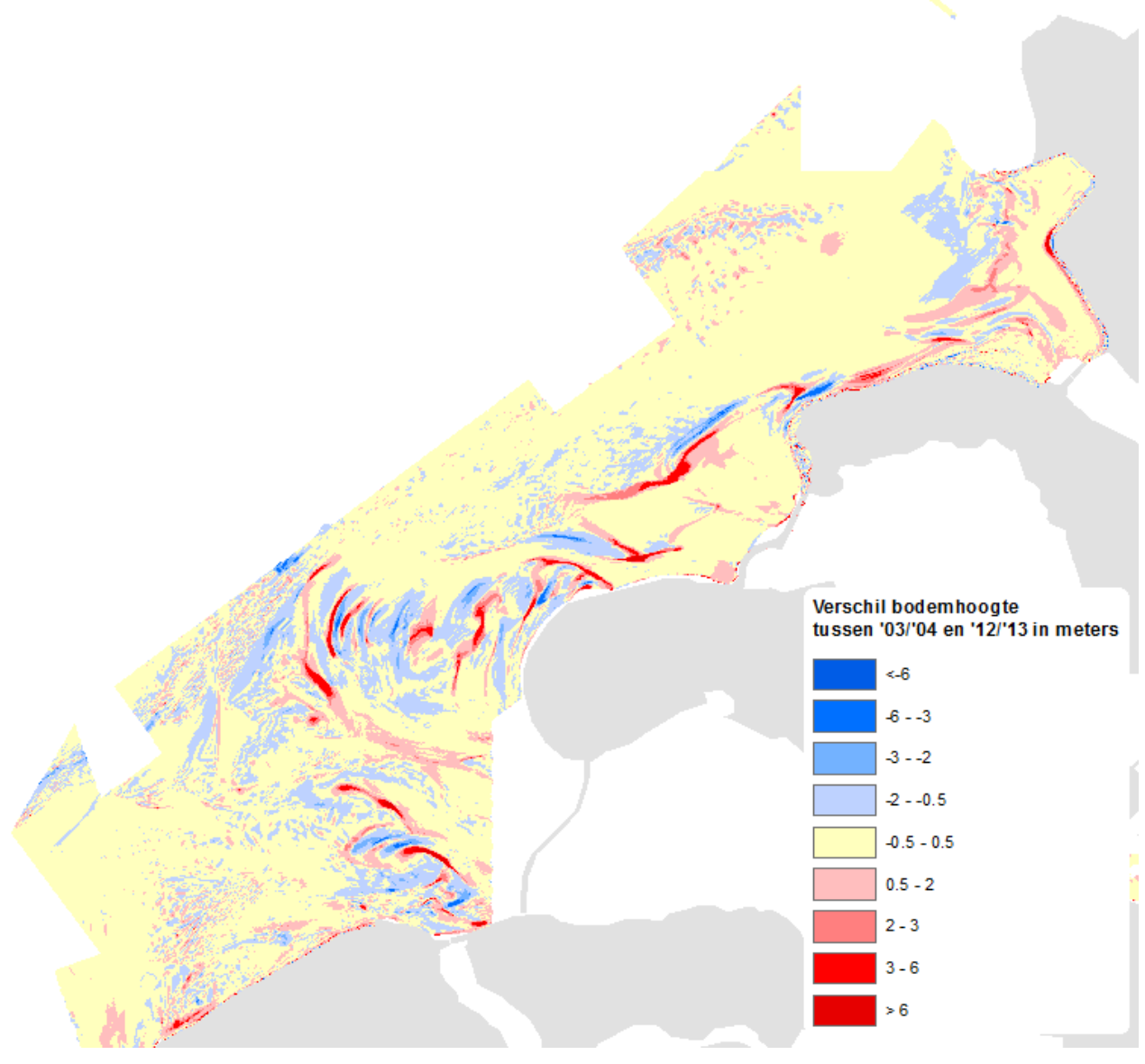

Figuur 3.2 Erosie en sedimentatie in de Voordelta tussen de perioden 2003-2004 en 2012-2013 (H. Meijer-Holzhauer, Deltares).

\subsection{Abiotische omgevingsfactoren}

De Voordelta wordt door de ondiepe ligging in de zuidwestelijke Delta gekarakteriseerd door een grote dynamiek in abiotische kenmerken zoals stroomsnelheid, sedimentsamenstelling en zoutgehalte.

Zandbanken ontstaan en bewegen zich langzaam door het gebied. Daarnaast kan de Voordelta worden gezien als een relatief ondiepe, warme en voedselrijke rand van de Noordzee. Deze factoren samen bepalen welke soorten in het gebied kunnen voorkomen, en zijn van groot belang voor het begrijpen van het systeem in zijn geheel en ook voor het effect van de compensatiemaatregelen. Hieronder worden de belangrijkste trends en bijzonderheden besproken. 


\subsubsection{Water- en luchttemperatuur}

Figuur 3.3 geeft de watertemperaturen (jaarrond, zomer en winter) bij Vlissingen, voor de periode 1959-2012. Er is een lichte stijging waar te nemen in de watertemperatuur. Deze trend is ook waargenomen bij andere meetstations langs de Nederlandse kust (Europlatform, Den Helder en K13A) (van Aken 2010, Adema 2016).

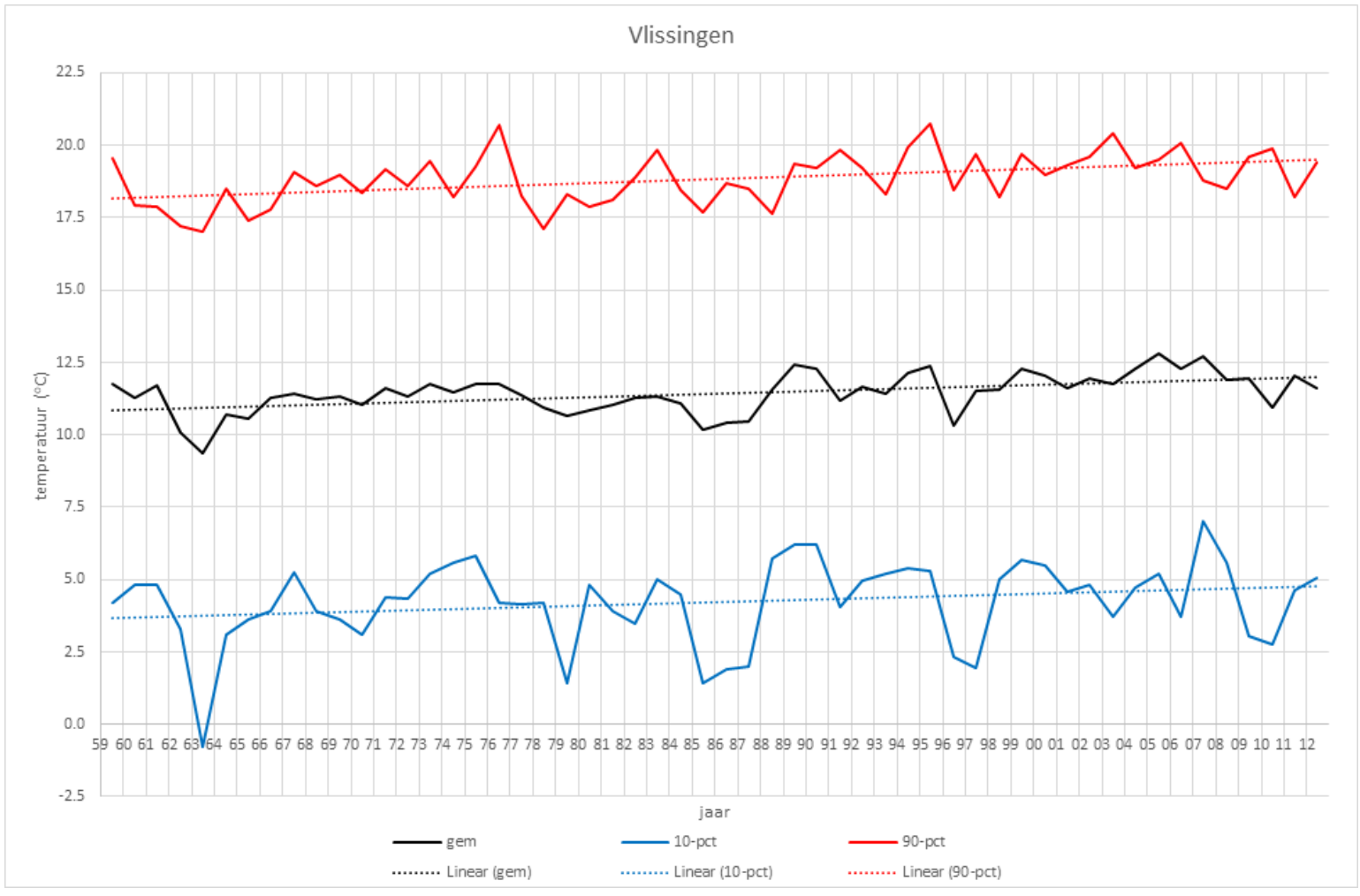

Figuur 3.3. Jaargemiddelde (gem), 10- en 90-percentiel watertemperatuur (resp. 10-pct en 90-pct) in Vlissingen, tezamen met de lineaire trends in elk van de parameters. De jaren zijn aangegeven op de $\mathrm{x}$-as, min de eerste twee cijfers (Adema 2016).

Het is bekend dat strenge winters kunnen leiden tot sterfte van bodemdieren en veranderingen in dichtheden en soortensamenstelling. Wintersterfte treedt op in het intergetijdengebied door vorst en ijsgang (Beukema 1979, Dekker \& Beukema 1999), maar ook in het sublitoraal door lage watertemperaturen (Reiss et al. 2006, Kröncke et al. 2013). Sinds 1990 zijn er slechts twee relatief koude winters geweest (1995/1996, 1996/1997), waarin het Hellmann-getal (een maat voor de kou in de maanden november-maart) boven de $100 \mathrm{kwam}$ (data KNMI). De winters in de monitoringjaren voor PMR-NCV (figuur 3.4) waren normaal (2009-2013) of zacht tot buitengewoon zacht (2004-2008, 2014-2017). 


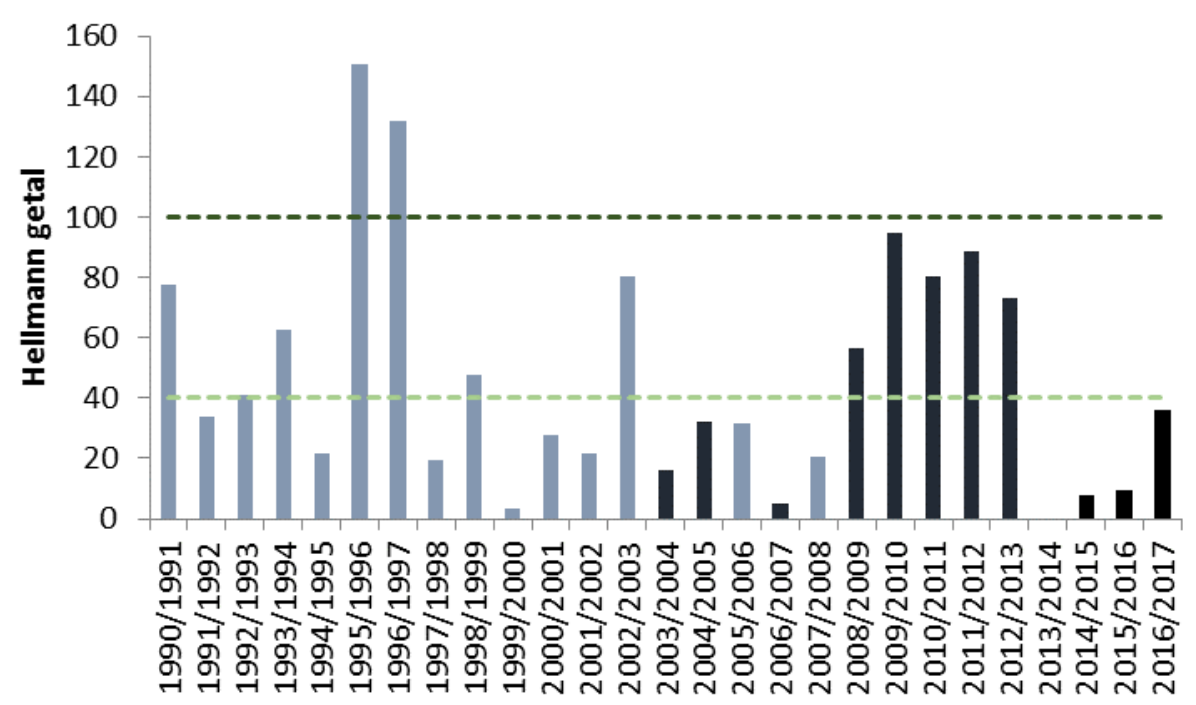

Figuur 3.4. Strengheid van de winter gemeten als Hellmann getal, voor de jaren 1990-2017. De classificatie is als volgt: $\mathrm{H}<10$ buitengewoon zacht; $\mathrm{H}<20$ zeer zacht; $\mathrm{H}<40$ zacht (lichtgroene stippellijn); $\mathrm{H}<100$ normaal; $\mathrm{H}>100$ koud (donkergroene stippellijn); $\mathrm{H}>160$ zeer koud; $\mathrm{H}>300$ streng (data: KNMI).

\subsubsection{Stormen en bodemschuifspanning}

De dominante windrichting in de Voordelta is ZW. Als gevolg hiervan is ook de dominante golfrichting ZW (figuur 3.5.

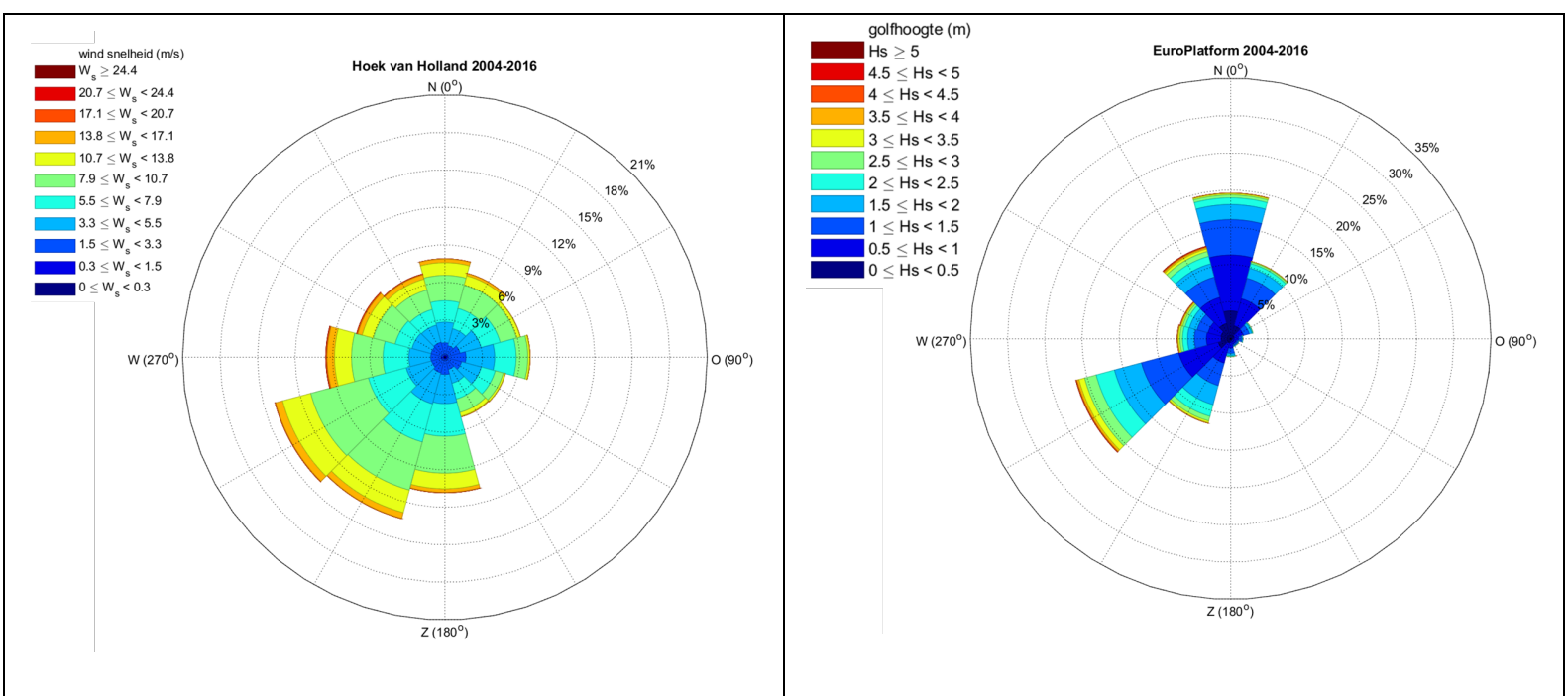

Figuur 3.5 Windrozen Hoek van Holland (links) en golfrozen Europlatform (rechts) voor de periode 2004-2016 (J. Adema, Arcadis).

\subsubsection{Stormen}

Voor de ecologie van de Voordelta is vooral het optreden van stormen van belang. Stormen zijn van invloed op stroomsnelheden en vooral golfhoogtes, en daarmee op de bodemschuifspanning die van invloed kan zijn op het bodemleven. Zware stormen kunnen leiden tot omwoeling van de bodem in ondiepe delen waardoor bodemdieren worden losgewoeld. Vooral bij lage watertemperaturen kunnen dan massaal (stervende of dode) schelpdieren aanspoelen op het strand (Cadée 2002, Dannheim \& Rumohr 2011)). In de PMR-NCV monitoringjaren is een zware storm (windsnelheid 10 Bft of hoger gemeten in Vlissingen of Hoek van Holland) alleen voorgekomen in januari 2007. In de periode 1990 t/m 2017 is een dergelijke storm in de Voordelta maar 5 keer voorgekomen (1990, 1993, tweemaal in 2002, 2007) (data KNMI). 


\subsubsection{Bodemschuifspanning}

De bodemschuifspanning door golven in de Voordelta is berekend op basis van gemeten golfhoogten en berekende waterstanden en stroomsnelheden (Adema 2018). Figuur 3.6 laat zien waar in de Voordelta hoge stroomsnelheden voorkomen (zowel op de bodem als aan het oppervlak).
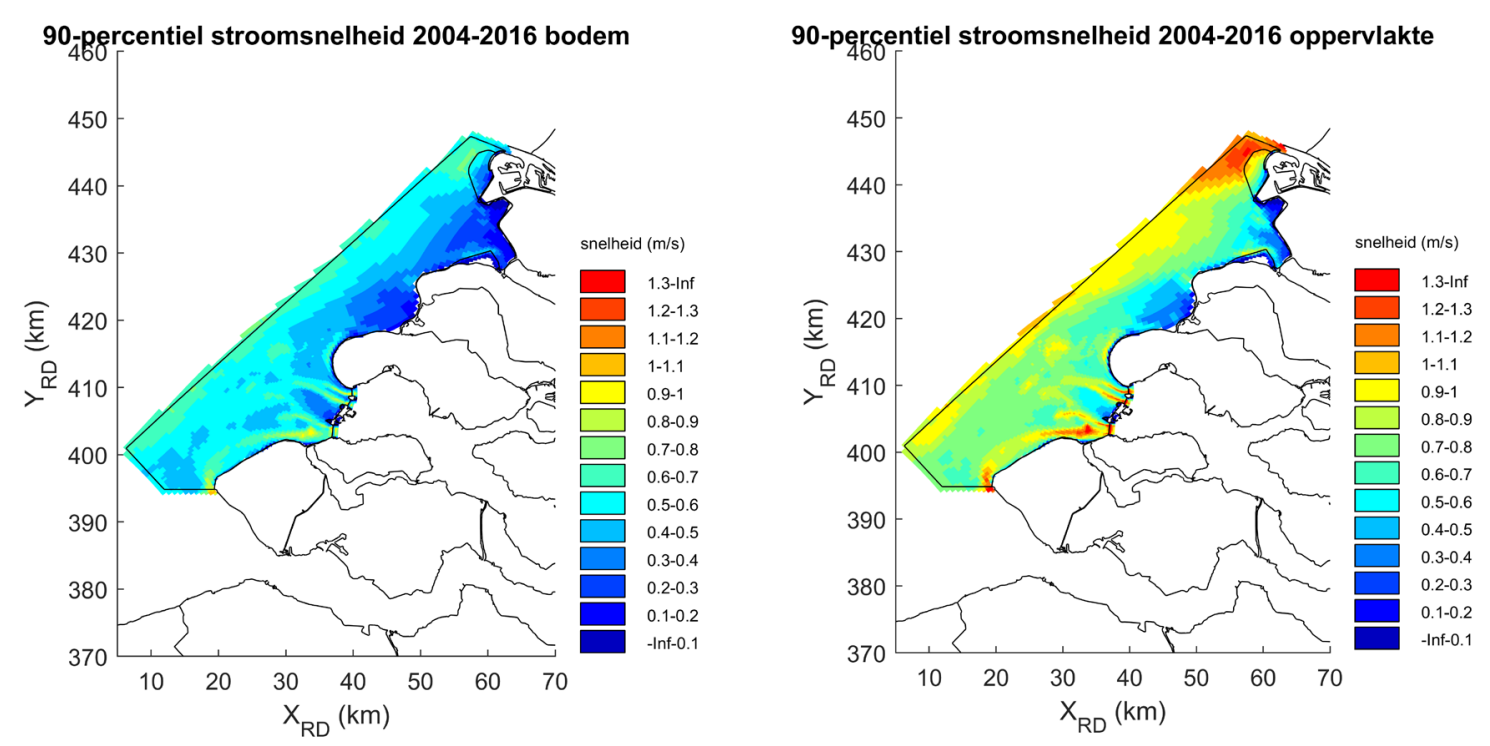

Figuur 3.690 percentiel stroomsnelheid op de bodem (links) en het oppervlak (rechts) in de Voordelta voor de periode 2004-2016.

Om een beeld te geven van de effecten van wind op de bodemschuifspanning in de Voordelta, wordt in figuur 3.7 aangegeven in welk bereik de 98-percentielwaarden van de bodemschuifspanning door golven vallen. De rode balken geven het percentage van de tijd per maand, waarin de 98-percentiel van de golfschuifspanning groter is dan $2.5 \mathrm{~N} / \mathrm{m}^{2}$ is. De rode en blauwe balk samen geven aan welk percentage van de tijd per maand de 98-percentiel van de bodemschuifspanning groter is dan $2 \mathrm{~N} / \mathrm{m}^{2}$. $\mathrm{Er}$ is een duidelijk seizoenspatroon met hogere bodemschuifspanning door golven in de wintermaanden. Hoge piekwaarden van de bodemschuifspanning waren in de winter van 2011/2012 het meest frequent. In december 2011 was in $23 \%$ van de tijd de piek-bodemschuifspanningen hoger dan $2 \mathrm{~N} / \mathrm{m}^{2}$. In figuur 3.6 is te zien dat het patroon in de Voordelta variabel is tussen jaren zonder duidelijke trend over de jaren 2007-2016. De ruimtelijke verdeling van de golfschuifspanning hangt samen met windsnelheid, diepte, waterstand en windrichting. Bij NW wind heeft de wind de langste strijklengte en het meeste effect op de golfhoogte.

Figuur 3.8 geeft de ruimtelijke verdeling van de golfschuifspanning op 29 augustus 2010 bij stormachtige wind (8 Bft uit NW richting). De hoogste bodemschuifspanning komt voor in de delen van de Voordelta waar de golven bij de zeewartse helling van de ondiepere banken komen. De hoogste waarden worden in dit geval gevonden westelijk van de geul van de Banjaard. Hier bevindt zich een steile geulhelling waar de golven tijdens een aanlandige storm als eerste zullen breken. Deze figuur is een illustratie van het algemene ruimtelijke patroon van de golfschuifspanning door golven in de Voordelta. 


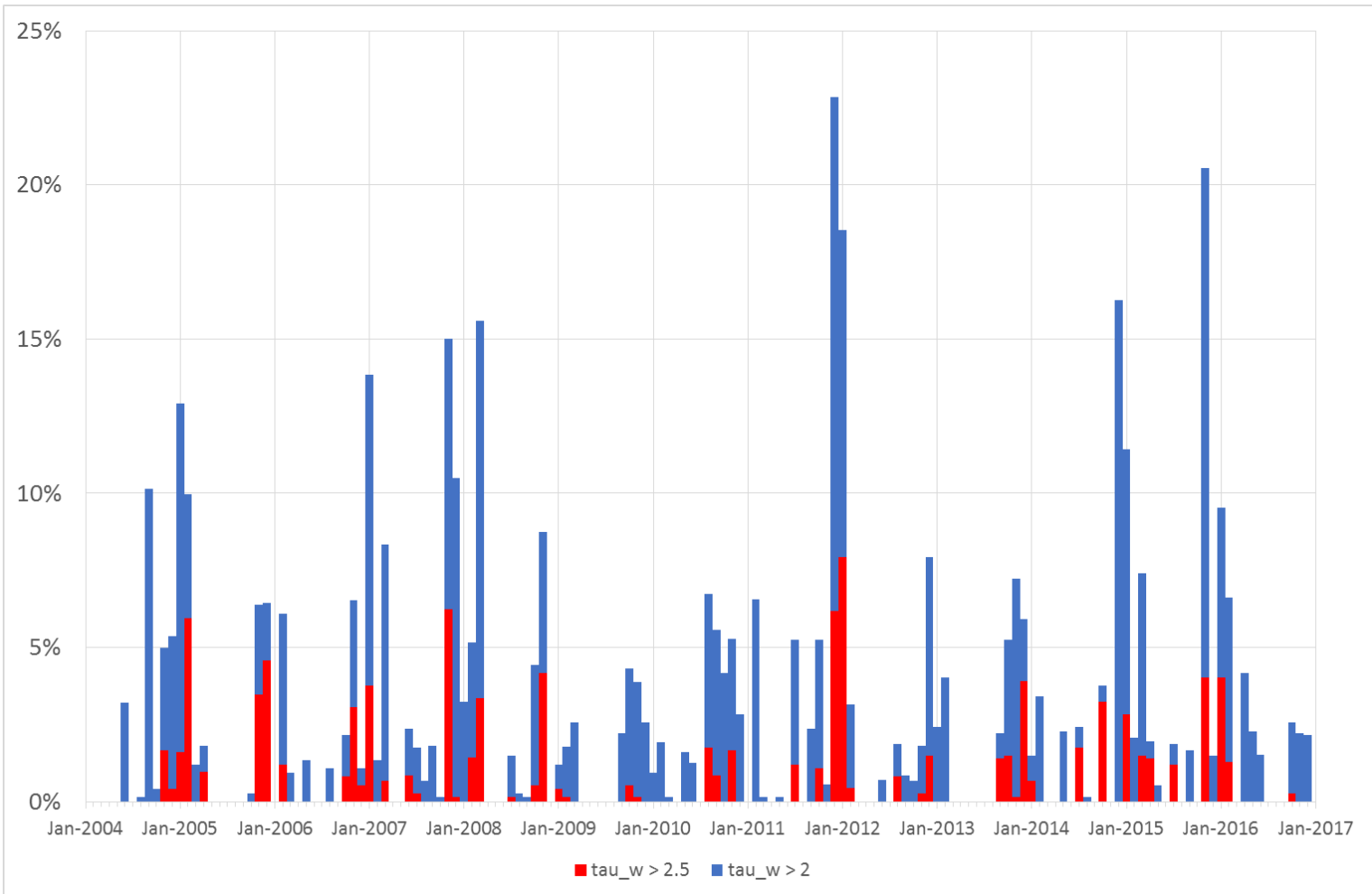

Figuur 3.7 Kans van voorkomen in \% van piek-bodemschuifspanning (98-percentiel) per maand. Gegevens zijn beschikbaar vanaf juni 2004 (Adema, 2018).

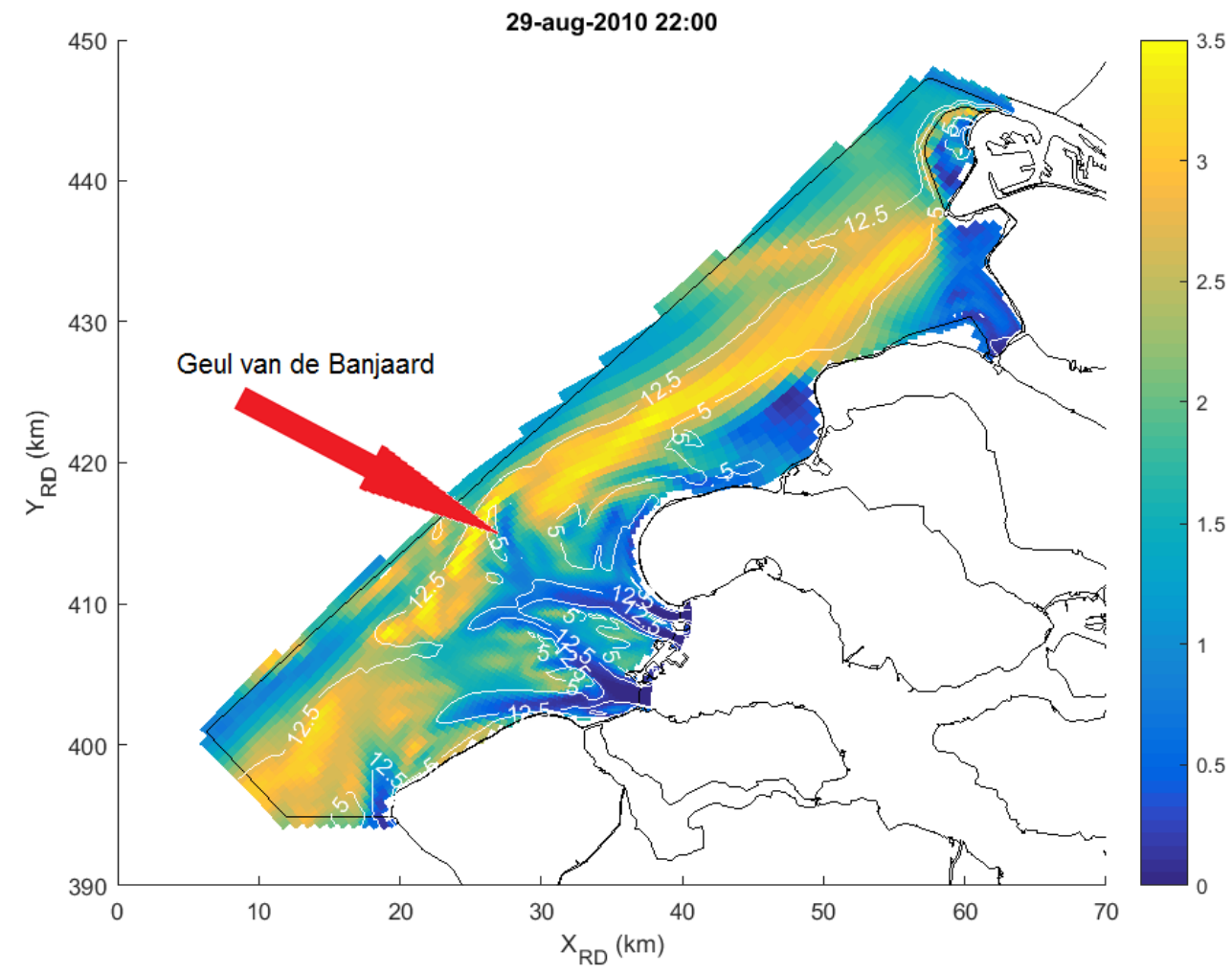

Figuur 3.8 Bodemschuifspanning door golven op 29 augustus 2010 om 22.00 uur, tijdens een storm (8 Bft, uit NW). De witte contouren geven de diepte weer (Adema, 2018). 


\subsubsection{Rivierafvoer en saliniteit}

\subsubsection{Rivierafvoer}

De waterkwaliteit en saliniteit van de Voordelta wordt beïnvloed door de afvoer van de rivieren Schelde, Maas en Rijn, waarbij de rivier de Rijn veruit de hoogste afvoer heeft. Als gevolg van de voltooiing van de Deltawerken heeft de uitstroom van rivierwater zich in de loop der tijd verplaatst. In de huidige situatie vindt de afvoer vooral via de Nieuwe Waterweg en het Haringvliet plaats. Door de sterke invloed van de rivieren is de Voordelta, evenals de rest van de Nederlandse kustwateren, een hoog productief gebied met relatief hoge concentraties voedingsstoffen en fytoplankton (BarettaBekker et al. 2009, Prins et al. 2012)) (figuur 3.9).

De afvoer van zoetwater via de Haringvlietsluizen is erg variabel, afhankelijk van de totale rivierafvoer (figuur 3.10 en 3.11). Tijdens hoge rivierafvoeren wordt veel rivierwater gespuid via het Haringvliet, terwijl bij lage rivierafvoeren er soms in het geheel geen water via de Haringvlietsluizen wordt afgevoerd.
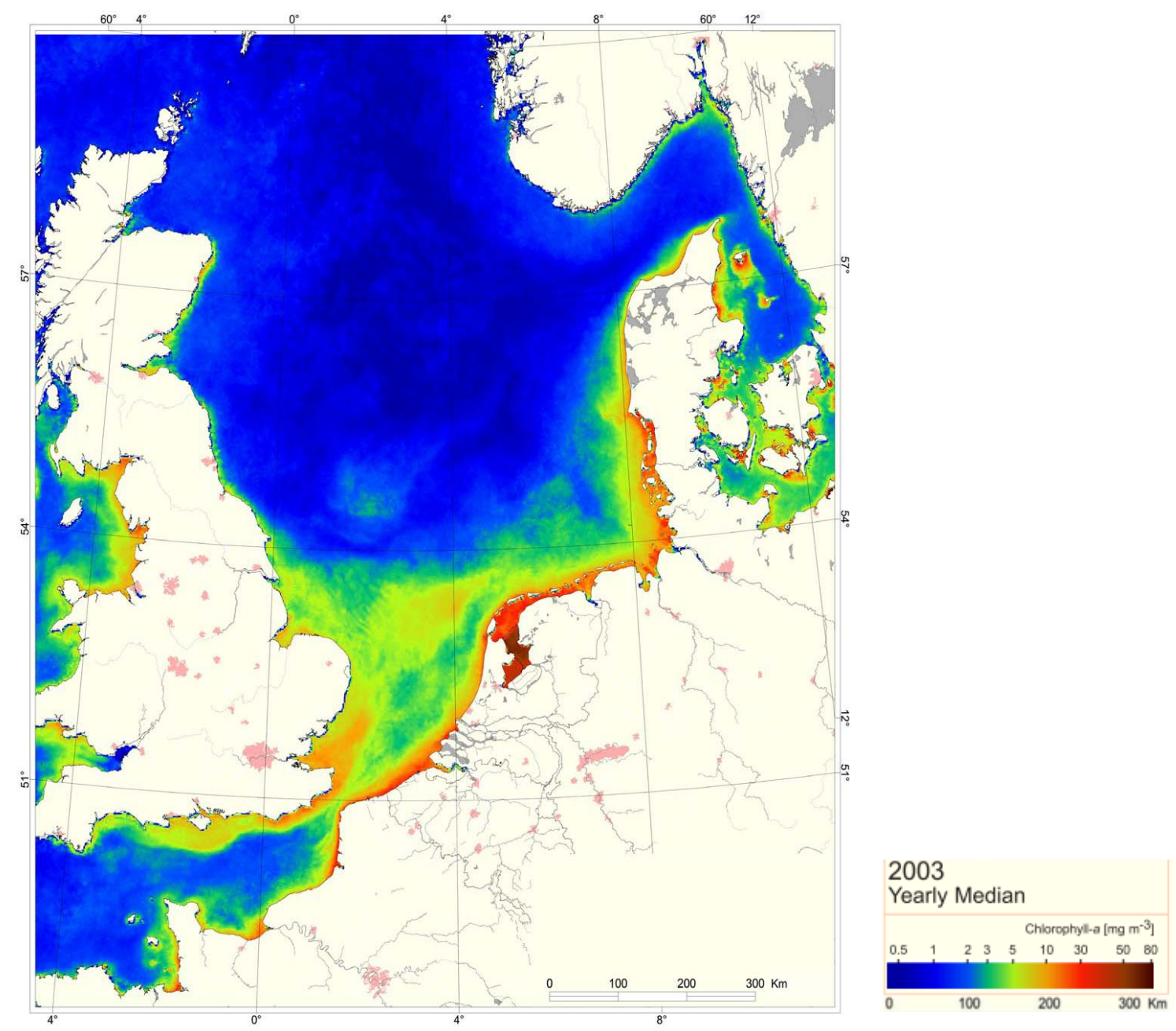

Figuur 3.9 Mediaan chlorophyl-a waarde uit 2003 (voorjaar, zomer en najaar), waarin te zien is dat de chlorofylwaarden hoog zijn langs de Nederlandse kust (onder andere in de Voordelta) (Peters et al., 2005) 


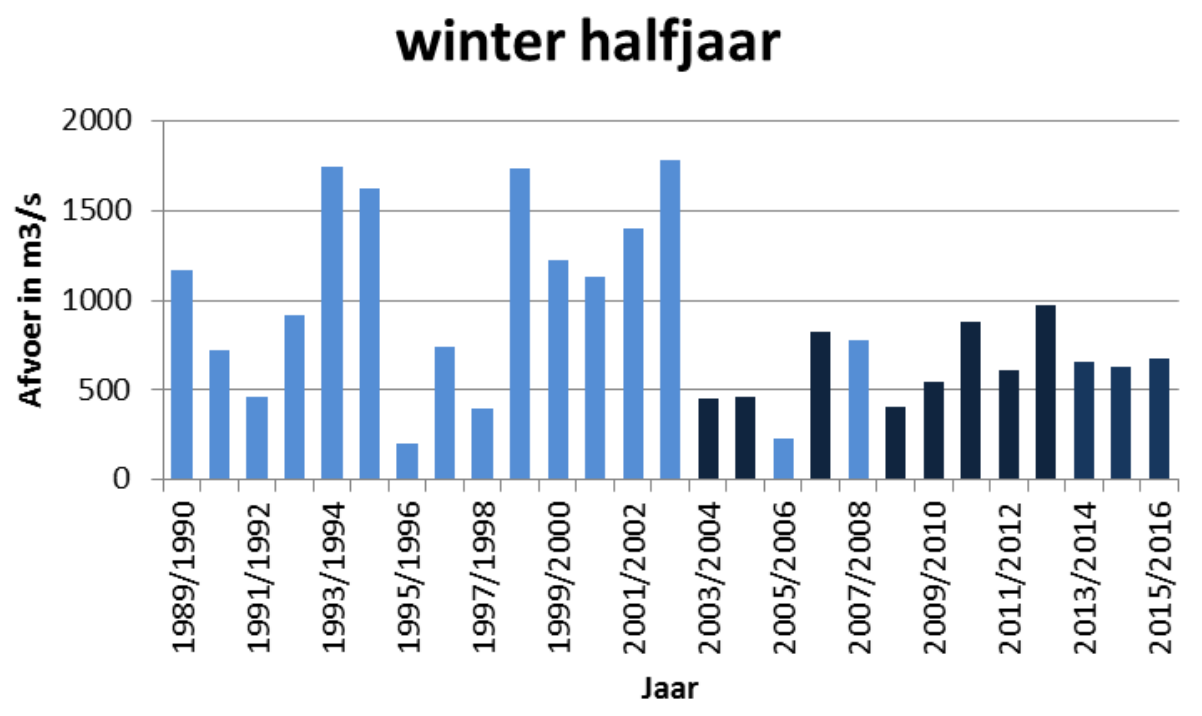

Figuur 3.10 Staafdiagram met gemiddeld spuidebiet van het Haringvliet in het winterhalfjaar voor 1989 - 2016 (data: RWS).

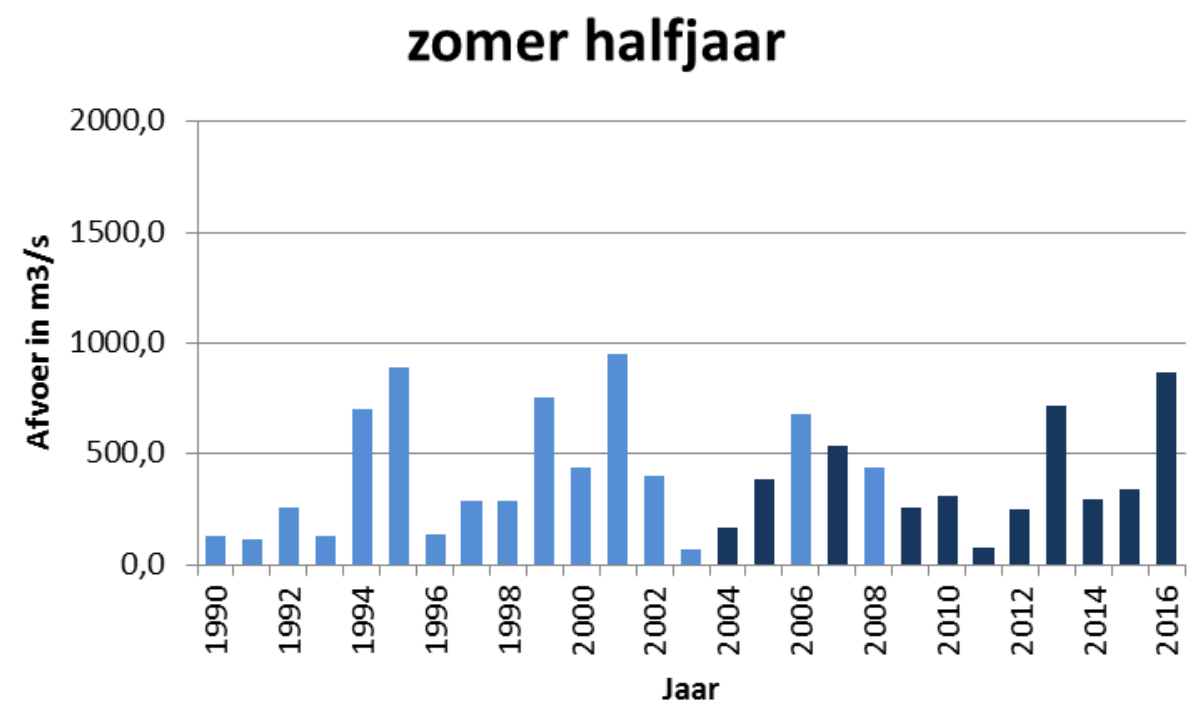

Figuur 3.11 Staafdiagram met gemiddeld spuidebiet van het Haringvliet in het zomerhalfjaar voor 1989 - 2016 (data:RWS).

\subsubsection{Saliniteit}

Het grootste deel van de Voordelta is zout (saliniteit $>30 \mathrm{psu}$ ). Alleen in het noordelijk deel van de Voordelta komen lagere zoutconcentraties voor door de uitstroom van het Haringvliet (figuur 3.12). De saliniteit in de Haringvlietmonding is als gevolg van de directe invloed van de afvoer van het Haringvliet zeer variabel. Bij hoge rivierafvoeren kan een groter deel van de Voordelta tijdelijk te maken hebben met verlaagde zoutgehaltes; in de Haringvlietmonding kunnen de zoutgehaltes zelfs tot beneden de 10 dalen, wat tot sterfte van bodemdieren kan leiden. In 1995 is sterfte van bodemdieren in de Voordelta vastgesteld bij saliniteit lager dan 5 (Craeymeersch et al. 1996). Het effect van het spuiwater op de saliniteit in de Voordelta is vooral te zien in de directe omgeving van de Haringvlietsluizen (figuur 3.13). Modelresultaten laten zien dat de veranderingen in saliniteit in de 
Haringvlietmonding als gevolg van de aanleg van Maasvlakte 2 aanmerkelijk kleiner zijn dan de natuurlijke variatie in saliniteit in dat gebied (Prins et al. 2014c).
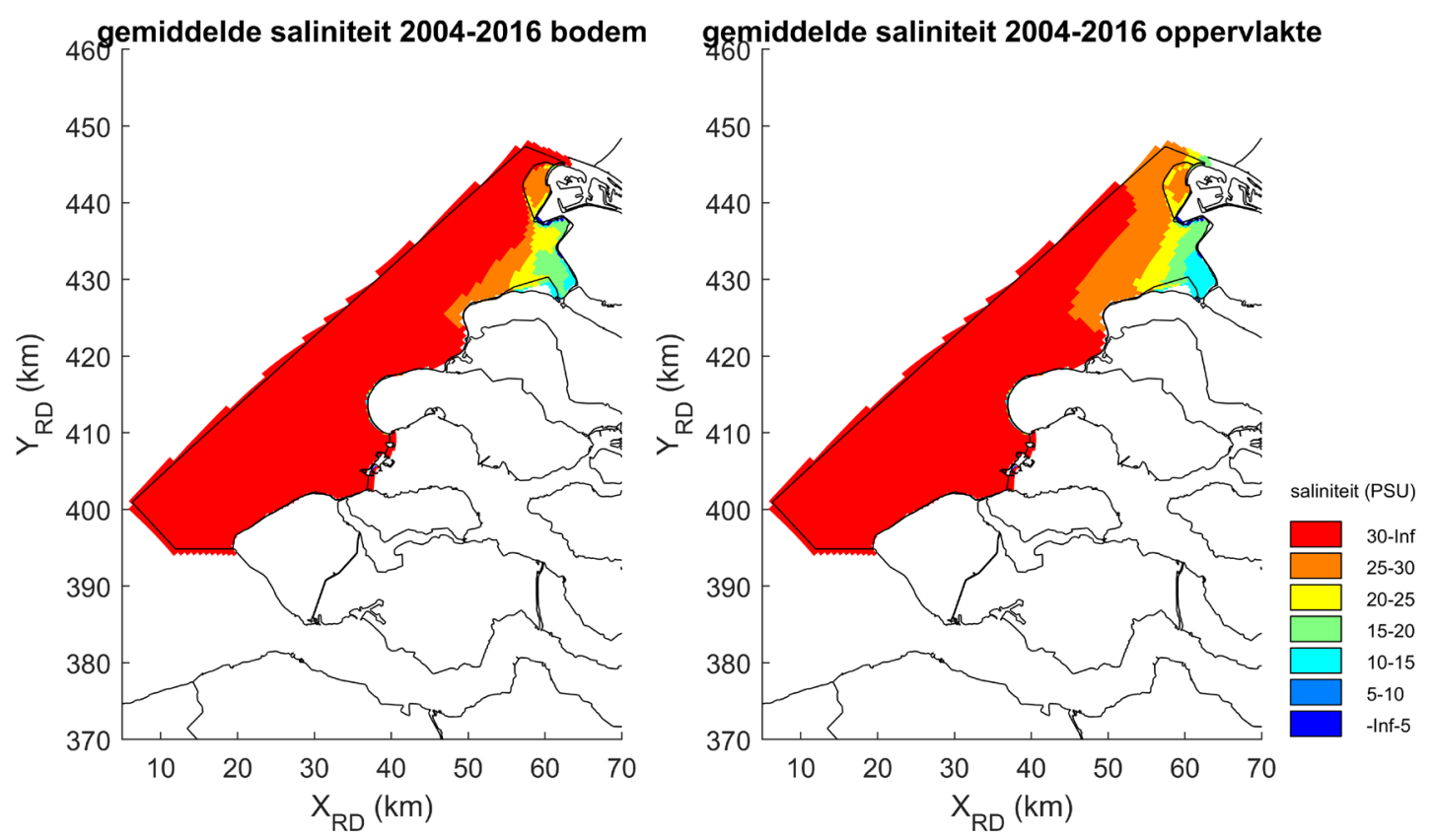

Figuur 3.12 Gemiddelde saliniteit op de bodem (links) en het oppervlak (rechts) van de Voordelta in de periode 2004-2016. Alleen in de Haringvlietmonding komt een lage saliniteit voor.

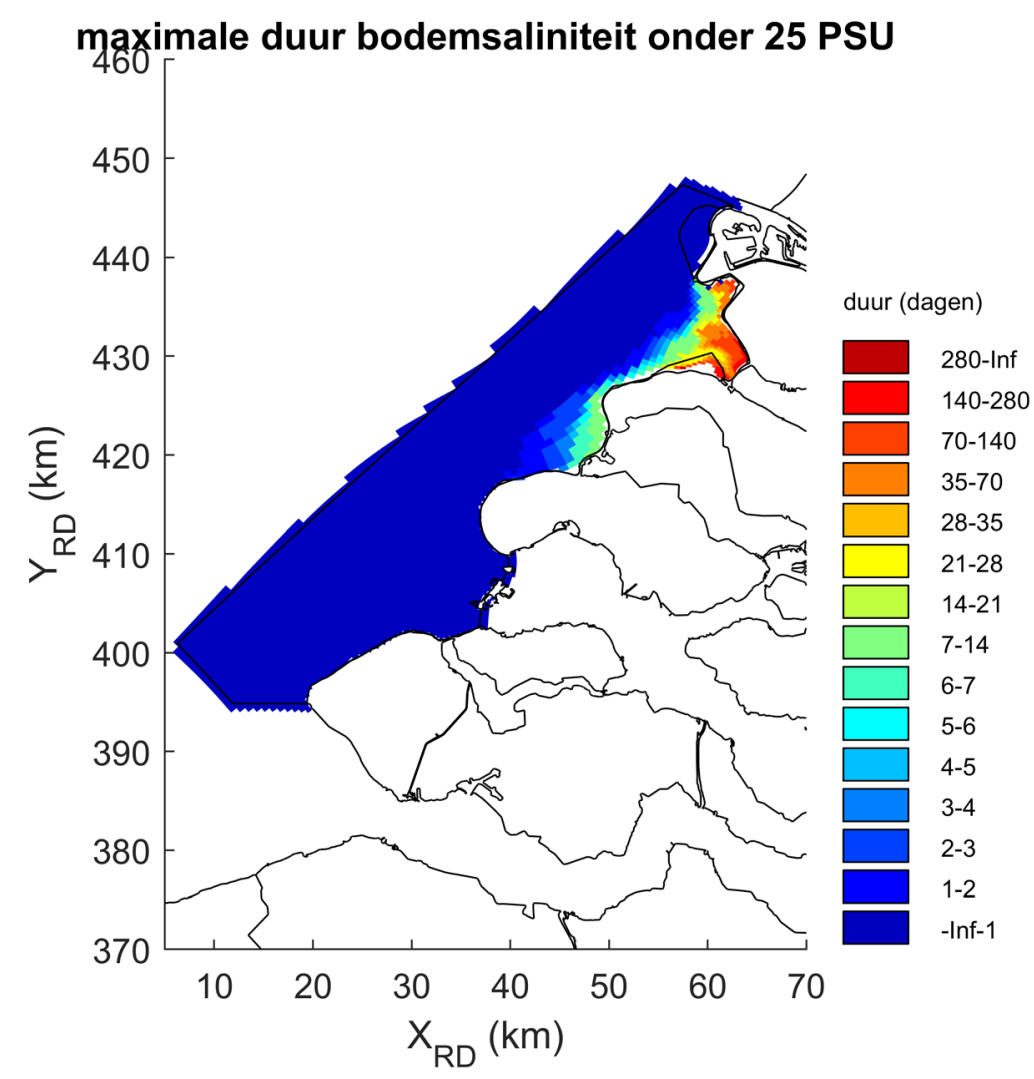

Figuur 3.13 Verlaagde zoutconcentraties in de Voordelta uitgedrukt in aantal dagen met een saliniteit lager dan 25 in de waterlaag bij de bodem, in de periode juni 2007 - mei 2008 waarin het Haringvliet een relatief hoge afvoer had. 


\subsection{Ecologie}

Zoals hiervoor beschreven is de Voordelta een zeer dynamisch gebied, met voortdurende wisseling en gradiënten in saliniteit, golfwerking, stroming en morfologie. Deze dynamiek is bepalend voor de soorten die in de Voordelta voorkomen. Op ondiepe zandbanken die blootgesteld zijn aan golfwerking, zal de bodemgemeenschap voor een groter deel bestaan uit soorten die in zekere mate aangepast zijn aan verstoring dan in de meer beschutte diepe delen van de Voordelta.

Het voorkomen van organismen in de Voordelta wordt echter niet uitsluitend bepaald door de aanwezigheid van een geschikte leefomgeving. Voedselbeschikbaarheid is een sterk sturende factor voor bijvoorbeeld Ensis (Van Duren et al. 2017). Zowel bodemdieren, vissen als vogels maken vaak deel uit van populaties waarvan het voorkomen is verspreid over een groter gebied. Bodemdieren van ondiepe, zandige habitats als de kustzone van de Noordzee zijn van nature sterk dynamische gemeenschappen, die grote fluctuaties in soortensamenstelling en dichtheden vertonen onder invloed van rekrutering en sterfte door abiotische factoren en predatie.

Het onderzoek in PMR-NCV richt zich vooral op de effecten van de natuurcompensatie op habitattype $\mathrm{H} 1110$ (bodemdieren en vis), en de vogelsoorten zwarte zee-eend, grote stern en visdief. In deze paragraaf wordt een toelichting gegeven op de langjarige ontwikkelingen van deze soortgroepen in de Voordelta.

\subsubsection{Bodemfauna}

De bodemdierengemeenschap in de Voordelta is veranderd door de effecten van de Deltawerken. In de noordelijke buitendelta van het Haringvliet is dat met name door de minder sterke wisselingen in saliniteit na de bouw van de Haringvlietdam. Na de aanleg van de Haringvlietdam is de invloed van de zoetwatertoevoer steeds meer gereduceerd. Als gevolg daarvan is na de jaren zestig de gemeenschap van een sterk dynamisch zout-brak milieu, die voorkwam in het mondingsgebied van het Haringvliet, grotendeels verdwenen en vervangen door een gemeenschap die voorkomt bij hoge saliniteit $(>30)$ maar ook bestand is tegen (tijdelijk) lagere zoutgehaltes. Vanaf de jaren tachtig is sprake van nieuw evenwicht met minder zoetwaterinvloed dan daarvoor. De Haringvlietmond staat sterker onder invloed van een zoetwater invoer en saliniteitverschillen, dan het zeewater gedomineerde westelijke deel (Wijnhoven \& Hummel 2008).

De Deltawerken hebben ook effect gehad op de bodemfauna door de geomorfologische veranderingen die de Deltawerken teweeg hebben gebracht. Dit geldt voor alle buitendelta's (Haringvliet, Grevelingen en, in mindere mate, de Oosterschelde). Uit onderzoek in de jaren 1984-1988 blijkt dat sedimentsamenstelling, diepte en hydrodynamiek hier de belangrijkste sturende factoren zijn voor de ecologie van bodemfauna (Craeymeersch et al. 1990a). Die factoren dragen bij aan de ruimtelijke variatie binnen de Voordelta, waarbij een aantal groepen (strata) van bodemdieren onderscheiden konden worden (op basis van soortensamenstelling en dichtheid) in een gradiënt van ondiep naar diep en van slibarm naar slibrijk. De strata zijn niet gelijk verdeeld over de verschillende buitendelta's; de buitendelta's van Haringvliet, Grevelingen en Oosterschelde verschillen van elkaar in soortensamenstelling, dichtheden en biomassa. De grootste soortenrijkdom en de hoogste dichtheden en biomassa worden aangetroffen op de overgangen van plaat naar geul en op de overgang naar diepere delen. De meest algemene soorten waren de halfgeknotte strandschelp (Spisula subtruncata), de schelpkokerworm (Lanice conchilega), de gewone hartegel (Echinocardium cordatum) en anemonen (soort niet beschreven). Zij vormden samen $60 \%$ van de totale biomassa in de jaren tachtig (Craeymeersch et al. 1990a).

Er kunnen grote jaarlijkse veranderingen optreden in aantallen en biomassa van bodemdieren (Craeymeersch 1999b). Voor schelpdieren, die een groot aandeel hebben in de totale biomassa van bodemdieren in de kustwateren, spelen een aantal factoren een rol, zoals groeisnelheid, sterfte en broedval (Beukema et al. 2010). Strenge winters kunnen van invloed zijn op de overleving van bodemdieren (Kröncke et al. 2013) en op de broedval (Beukema et al. 2010).

Een opvallende verandering in de schelpdierbestanden in de Voordelta, die van belang zijn voor schelpdier-etende vogels zoals de zwarte zee-eend, is het grotendeels verdwijnen van de halfgeknotte strandschelp Spisula subtruncata en de opkomst van de Amerikaanse zwaardschede Ensis directus. Al in de jaren negentig werd de zwaardschede in de Voordelta aangetroffen, maar vooral na 2000 zijn de dichtheden sterk toegenomen (Craeymeersch et al. 2006). In de jaren negentig was de halfgeknotte strandschelp nog de dominante soort (in biomassa). De laatste goede broedval van deze soort in de 
Voordelta was in 1994, en na 1998 zijn de bestanden sterk afgenomen (Craeymeersch et al., 2006). Sinds 2016 worden weer hogere dichtheden Spisula subtruncata waargenomen in de Voordelta en in andere delen van de Nederlandse kustwateren (Perdon et al. 2016, Troost et al. 2017). Dit is relevant voor de aantallen en verspreiding van zwarte zee-eenden, en in hoofdstuk 6 wordt hier verder op ingegaan.

\subsubsection{Vis}

De ondiepe kust, de Waddenzee en de Delta (waaronder de Voordelta) zijn kinderkamers voor jonge vis en garnalen uit de Noordzee. Door het relatief warmere zeewater, het rijke voedselaanbod en de mogelijkheid beschutting te zoeken voor roofdieren kan de jonge vis hier veilig opgroeien. Onderscheid kan gemaakt worden tussen groepen van vissen die op verschillende wijze gebruik maken van het deltagebied. De jongen van zowel bodemvissoorten (bijv. schol, tong, wijting), als pelagische soorten (die in de waterkolom leven, haring en sprot) groeien hier op. Deze groep wordt ook wel marien juvenielen genoemd. Naast de soorten die alleen hun juveniele levensfase in deze gebieden doorbrengen zijn er nog andere groepen: de doortrekkers, die alleen langskomen op weg naar de rivieren of terug naar zee (bijv. fint, aal en prikken); de seizoensgasten, die er een deel van het jaar verblijven om er te foerageren (bijv. haring, sprot, grauwe poon); de onregelmatige bezoekers die het gebied af en toe aandoen (bijv. kleine pieterman, dwergbolk, pitvis, dwergtong, schurftvis) en de residente soorten, die hun hele leven in deze gebieden blijven (bijv. vijfdradige meun, zeedonderpad, puitaal, grondels) (Elliott \& Hemingway 2002). De samenstelling en dichtheid van de visgemeenschap wordt niet alleen door lokale factoren bepaald, maar ook door de aanvoer van eieren en larven, die met de zeestroming worden getransporteerd vanuit paaigebieden elders, zoals de zuidelijke Noordzee of het Kanaal.

In het verleden is weinig onderzoek verricht dat gericht was op de visfauna in de Voordelta. Door De Jong (1997)) is een analyse van de gegevens van de Demersal Fish Survey over de jaren 1987-1995 uitgevoerd, voor Westerschelde, Oosterschelde en het zuidelijk deel van de Voordelta (de buitendelta van de Oosterschelde). Het noordelijk deel van de Voordelta maakte geen onderdeel uit van de analyse. Gekeken is naar de aantalsfluctuaties van tien niet-commerciële vissoorten, waarbij geconcludeerd werd dat er geen wezenlijke verschillen met de voorafgaande periode 1970- 1986 waren opgetreden.

De ruimtelijke structuur van de bodemvisgemeenschap wordt voornamelijk verklaard door het zoutgehalte, diepte en type substraat (Hamerlynck et al. 1993). Dichtheden van juveniele vissen in de Voordelta bleken dan ook te verschillen tussen de verschillende buitendelta's in de jaren ' 80 en ' 90 . De dichtheden waren het hoogst in de buitendelta van de Grevelingen, waarschijnlijk door de ondiepe en beschutte ligging die te danken is aan de bankengroei in dit gebied na de afsluiting in 1970. Het deel van de Voordelta in de voormalige Grevelingen monding fungeert daardoor sterker als sedimentatiegebied waar ook eieren en larven kunnen accumuleren (Hamerlynck \& Mees 1991, Hamerlynck et al. 1992, Beyst et al. 1999). De dichtheid van jonge platvissen is in de Haringvlietmond ook relatief hoog. De dichtheden zijn lager in de monding van de Oosterschelde, waar minder sedimentatie plaats vindt.

Jonge pelagische vis is belangrijk als stapelvoedsel voor grote stern en visdief, dit zijn in de Voordelta met name de soorten zandspiering, haring en sprot. Haring is een seizoensgast in de Voordelta. Haring paait in het westelijk deel van de Noordzee, de zuidelijke Noordzee en het Kanaal. De Nederlandse kust vormt een van de 'kraamkamers' voor de haring, waar de larven uitgroeien tot jonge haring van 10-13 cm lang. Deze jonge haring trekt aan het einde van de zomer naar open zee. Sprot is eveneens een seizoensgast. De paaigebieden liggen verspreid over een groot deel van de Noordzee. De larven worden vooral in de kustwateren aangetroffen, terwijl jonge sprot in de gehele zuidelijke Noordzee voorkomt.

Meer informatie over langetermijntrends van vis, en de invloed van de aanleg van Maasvlakte 2 en visserij in de Voordelta staat beschreven in Hoofdstuk 5 H1110. 


\subsubsection{Vogels}

De Voordelta is een belangrijk gebied voor een groot aantal soorten vogels. Voor de Natuurcompensatie zijn de zwarte zee-eend, grote stern en visdief van belang. Daarom worden voor deze vogelsoorten de algemene kenmerken en langjarige trends beschreven. De monitoringsresultaten uit de PMR-NCV monitoringsperiode worden beschreven in de hoofdstukken 6 Zwarte zee-eend en 7 Grote stern en visdief.

\subsubsection{Zwarte Zee-eend}

Het grootste deel van de populatie zwarte zee-eenden (Melanitta nigra) verblijft in de winter in de Oostzee (grootste concentratie in het NW Kattegat) en in de Noordzee voor de Deense kust. De winterpopulatie in Europa wordt geschat op 1,6 miljoen vogels (Delany \& Scott 2006), maar dat is mogelijk een overschatting (Brinkman et al. 2007). In de Nederlandse wateren worden de hoogste aantallen waargenomen in de wintermaanden (december-februari), en vooral het vroege voorjaar (maart-april). Vanaf april begint de trek naar de broedgebieden. De zwarte zee-eend broedt landinwaarts in Noord-Europa en Noord-Azië, in uiteenlopende biotopen zoals toendra's en langs overs van meren. In Nederland is de verspreiding beperkt tot de ondiepe kustwateren.

De zwarte zee-eend leeft van bodemdieren die in de ondiepe kustzone tot een diepte van ongeveer 20 meter kunnen worden opgedoken, en die in hoge dichtheden voorkomen. Zwarte zee-eenden foerageren op een breed scala aan tweekleppige schelpdieren. Daarnaast worden ook andere bodemdieren, zoals slakken, wormen, krabben, garnalen, vlokreeften, zee- en slangsterren en incidenteel vis of viseieren als mogelijke prooien genoemd (ICES 2005, Brinkman et al. 2007, Skov et al. 2008).

Zwarte zee-eenden zijn gevoelig voor verstoring. De verstoringsafstand is afhankelijk van de groepsgrootte, waarbij grotere groepen eerder vluchten dan kleinere groepen. Grotere groepen vluchten bij een langere afstand van 1.000-2.000 meter tot de verstoringsbron, terwijl kleinere groepen bij afstanden van $<1.000$ meter vluchten. Tijdens de rui verliezen de vogels het vliegvermogen en zijn ze extra kwetsbaar voor verstoring, met grotere verstoringsafstanden tot gevolg (Kersten et al. 2006).

Informatie over langjarige trends van de zwarte zee-eend staat beschreven in Hoofdstuk 6 Zwarte zee-eend.

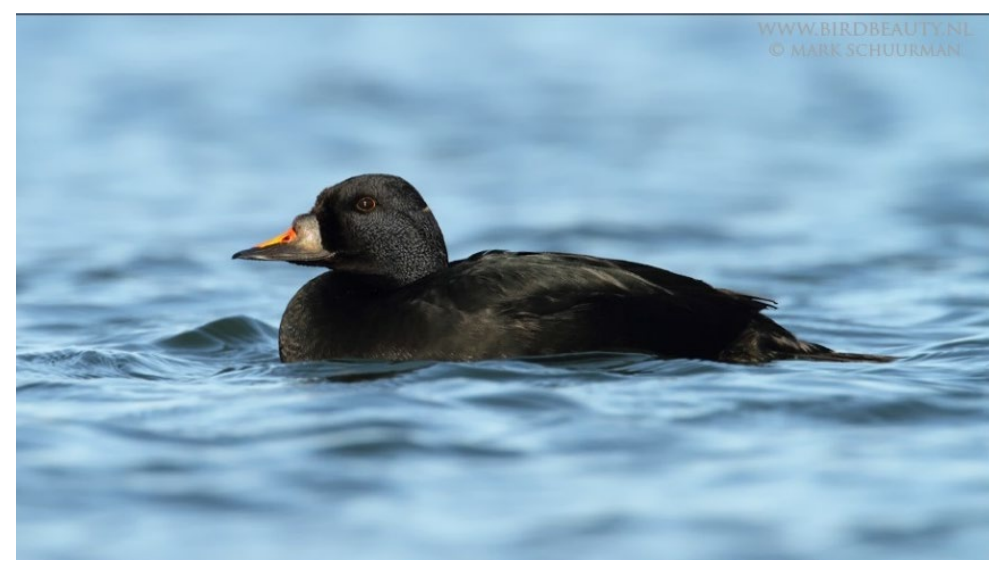

Zwarte zee-end (Foto: Mark Schuurman)

\subsubsection{Grote Stern}

De grote stern (Sterna sandvicensis) is een zomergast in Nederland die deel uitmaakt van de NW Europese populatie van ca. 55.000 broedparen. Het merendeel van de grote sterns komt eind aprilbegin mei aan in de broedgebieden. De broedgebieden in Nederland liggen langs de kust in het Deltagebied en de Waddenzee. De grote stern broedt op kwelders en in duinen, vaak in een klein aantal grote kolonies. 
De broedperiode is tussen eind april en begin juli. Het legsel bestaat meestal uit 1-2 eieren, die ongeveer 25 dagen bebroed worden. Enkele dagen na het uitkomen van de eieren verlaten de jongen het nest. De jongen kunnen na 25-35 dagen vliegen. Omdat de jonge sterns nog niet direct voor zichzelf kunnen zorgen, worden ze wekenlang gevoerd met visjes (zoals zandspiering). Na het uitvliegen vertrekken de jongen naar hetzelfde gebied als de oudervogels, om daar te leren foerageren. In juli en augustus trekken de grote sterns en hun jongen zowel richting het zuiden, vooral naar West-Afrika. In september-oktober vindt de trek plaats naar de overwinteringsgebieden in riviermondingen langs de West-Afrikaanse kust (Brenninkmeijer \& Stienen 1992), Vogelbescherming $\mathrm{NL}, 2018$ ).

De grote stern is een gespecialiseerde viseter, die zijn prooien vooral in de bovenste 1-2 meter van de waterkolom vangt. Het belangrijkste voedsel is kleine pelagische vis met een hoge voedselwaarde, zoals sprot, haring en zandspiering.

De grote sterns zijn in de Voordelta aangewezen op stranden, droogvallende platen en andere vlakke zandige gebieden om te rusten. Deze gebieden worden opgezocht als ze niet foerageren, zoals met slecht weer, en kunnen dienen als uitvalsbasis voor het foerageren door oudervogels en juvenielen (RIKZ 2007). Verstoring, bijvoorbeeld door recreanten, is mogelijk van invloed op het gebruik van stranden en droogvallende platen door grote sterns.

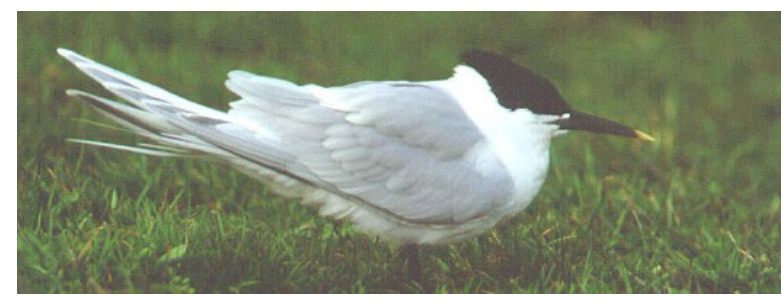

\section{Grote stern (J.B.H. Stok, soortenbank.nl)}

Kustbroedvogels, die in de nabijheid broeden en de Voordelta als foerageergebied gebruiken, zoals de grote stern, worden gekenmerkt door sterke veranderingen in plaats en omvang van broedkolonies. Grote sterns zijn zeer kritisch bij de keuze van een broedplaats, en belangrijke factoren zijn de afwezigheid van grondpredatoren en verstoring, het successiestadium van de vegetatie, de afstand tot de voedselgebieden en de aanwezigheid van kokmeeuwen en andere soorten sterns in de kolonie. Grote sterns zijn weinig agressief tegen predatoren zoals meeuwen en broeden graag onder de beschermende paraplu van fellere soorten zoals visdiefjes en kokmeeuwen (Brenninkmeijer \& Stienen 1992, Stienen 2006, Strucker et al. 2008).

Rond 1955 broedden er 35.000-40.000 paren van de grote stern in Nederland. In het Deltagebied was het aantal broedparen 8.000-10.000. De Nederlandse broedpopulatie kwam eind jaren vijftig in een snelle neerwaartse trend terecht, veroorzaakt door vergiftiging (gechloreerde koolwaterstoffen geloosd in de Nieuwe Waterweg). Een dal trad op rond 1965. Vanaf de jaren zeventig zijn de aantallen broedparen in het Deltagebied (incl. de kolonie in Zeebrugge) weer toegenomen tot 3.000-5.000 paren (Baptist \& Meininger 1996). De populatie heeft zich daarna verder hersteld tot aantallen tussen de 15.000-20.000 broedende individuen (figuur 3.14). 


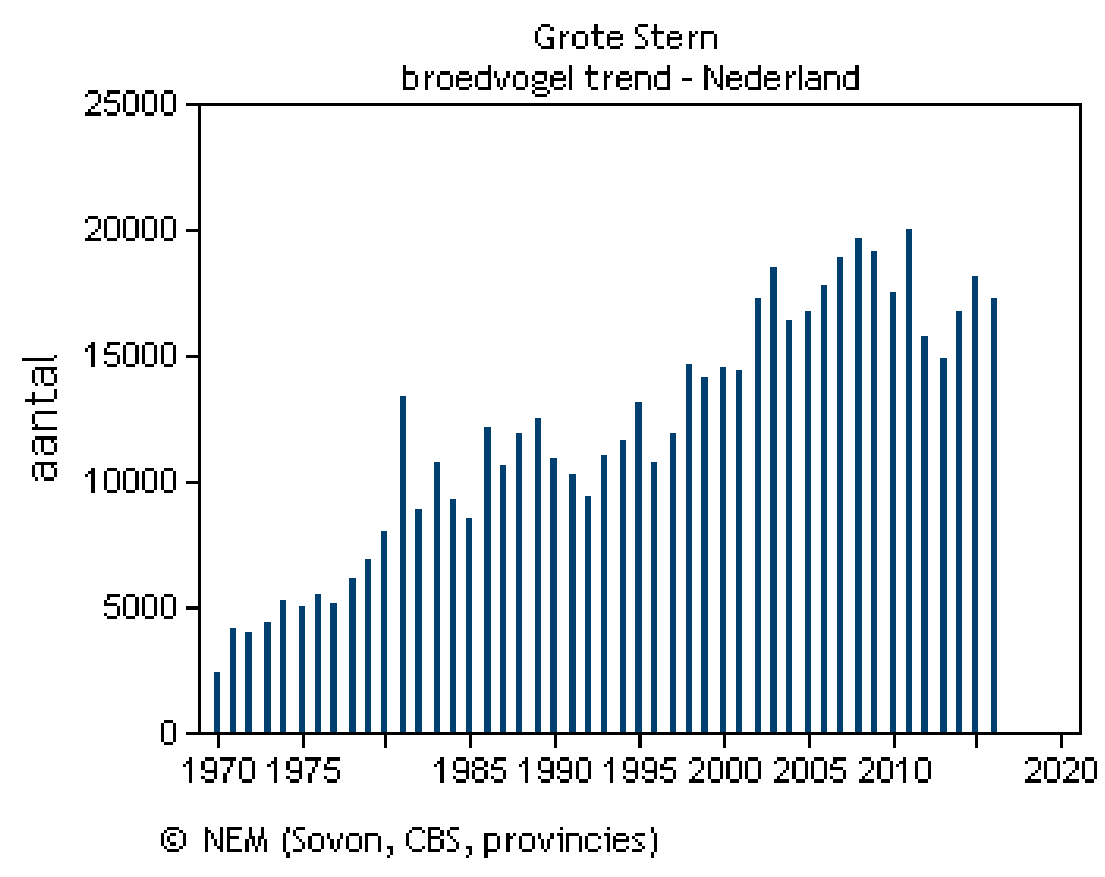

Figuur 3.14 Langjarige trend van het jaarlijks aantal broedende grote sterns in Nederland 1970-2015 (www.sovon.nl/nl/soort/6110)

De foerageergebieden van de grote stern bevinden zich in zoute wateren tot op enkele tientallen kilometers van de broedgebieden. De voedselbeschikbaarheid in de omgeving van hun broedgebied is bij sterns een belangrijke factor voor het broedsucces. Naast voedselbeschikbaarheid spelen ook predatie in de kolonie, kleptoparasitisme en weersinvloeden een grote rol in het broedsucces (Stienen 2006, Dänhardt \& Becker 2011).

\subsubsection{Visdief}

De visdief (Sterna hirundo) is een zomergast in Nederland die deel uitmaakt van de NW Europese populatie. De meest recente schattingen van de Europese populatie bedragen $270.000-570.000$ paar. De visdief komt van begin april tot en met oktober in Nederland voor. De broedgebieden in Nederland liggen vooral in het Delta-, het Wadden- en het IJsselmeergebied en bestaan uit kleine of grote kolonies in korte vegetatie, zoals duinen, kwelders, moerassen en weilanden (Stienen \& Brenninkmeijer 1992, Stienen et al. 2009).

De broedperiode is tussen juli en half augustus. Het legsel bestaat meestal uit 2-3 eieren, die ongeveer 23 dagen bebroed worden. Visdiefjes keren vaak terug naar kolonies waar ze in eerdere jaren hebben gebroed. Het broedseizoen is vanaf mei tot begin juni, en de broedduur is 21-24 dagen. De jongen kunnen na 23-27 dagen vliegen. Na het broedseizoen verlaten de jonge visdiefjes in familieverband de broedgebieden, om zich te verzamelen in voedselrijke gebieden (zowel zoete als zoute milieus) in de Voordelta en daarbuiten. In september-oktober vindt de trek plaats naar de overwinteringsgebieden in riviermondingen langs de West-Afrikaanse kust (Stienen \& Brenninkmeijer 1992, Stienen et al. 2009).

Visdiefjes foerageren tijdens het broedseizoen in gebieden tot op enkele kilometers van de broedgebieden. De visdief eet vooral vissen die in het bovenste deel van de waterkolom voorkomen, en daarnaast ook kreeftachtigen en in voedselrijk zoet water ook insecten of insectenlarven (Stienen \& Brenninkmeijer 1992). In de Voordelta foerageren visdiefjes in grote aantallen rond de zandplaten en voor de Haringvlietsluizen (RIKZ 2007).

Er is weinig bekend over de invloed van verstoring op foeragerende visdiefjes. Naar verwachting zijn visdiefjes niet erg gevoelig voor verstoring door scheepvaart, omdat ze vaak foeragerend achter schepen worden waargenomen. De platen in de Voordelta worden gebruikt om te rusten (RIKZ 2007). 


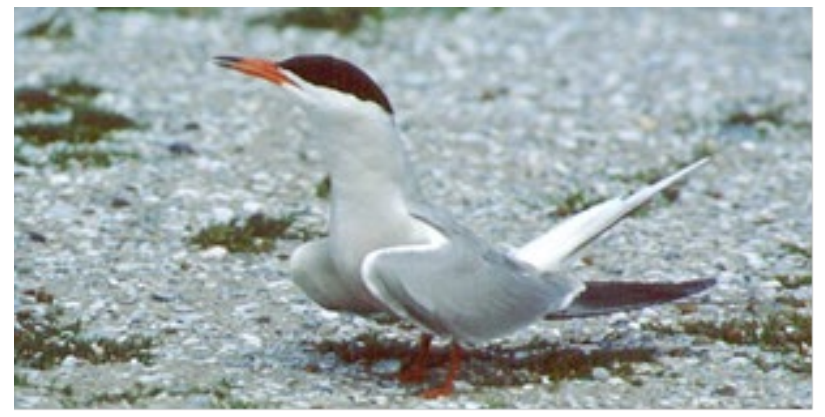

Visdief (J.B.H. Stok, soortenbank.nl)

Net zoals de grote stern, wordt het voorkomen van visdieven gekenmerkt door sterke veranderingen in plaats en omvang van broedkolonies. Visdiefjes broeden in kolonies van enkele tot soms duizenden paren, met een voorkeur voor de schaars begroeide delen van eilanden en geïsoleerde strandvlaktes, vaak in associatie met andere sterns of meeuwen (Stienen \& Brenninkmeijer 1992, Stienen et al. 2009). De soort is echter ook erg opportunistisch in de keuze van broedgebied, en wisselt gemakkelijk van broedgebied wanneer de omstandigheden veranderen (Strucker et al. 2012). Evenals bij de grote stern, wordt het uitkomstsucces bepaald door abiotische factoren zoals overspoeling van de kolonie en biotische factoren als predatie. Het uitvliegsucces wordt sterk bepaald door zaken als voedselvoorziening, predatie en weersomstandigheden (Stienen \& Brenninkmeijer 1992).

Rond 1930 bestond de Nederlandse populatie van visdiefjes uit ca. 26.000 broedparen, met kolonies die zich voornamelijk in het Deltagebied en het Waddengebied bevonden. Na een toename voor de oorlog, en afname tijdens de oorlog, herstelde de populatie zich tot meer dan 30.000 paren in 1948. Eind jaren vijftig is de populatie, net als die van de grote stern, als gevolg van vervuiling met gechloreerde koolwaterstoffen sterk gekrompen tot ongeveer 5.000 broedparen in 1965. Daarna heeft de populatie zich hersteld tot ongeveer 17.000-21.000 broedparen in 2012 (figuur 3.13) (Stienen \& Brenninkmeijer 1992). Het regiodoel van het Deltagebied is 6500 paar visdieven. De trends van het aantal visdieven in het gebied rond de Voordelta staat beschreven in Hoofdstuk 7 Grote stern en visdief.

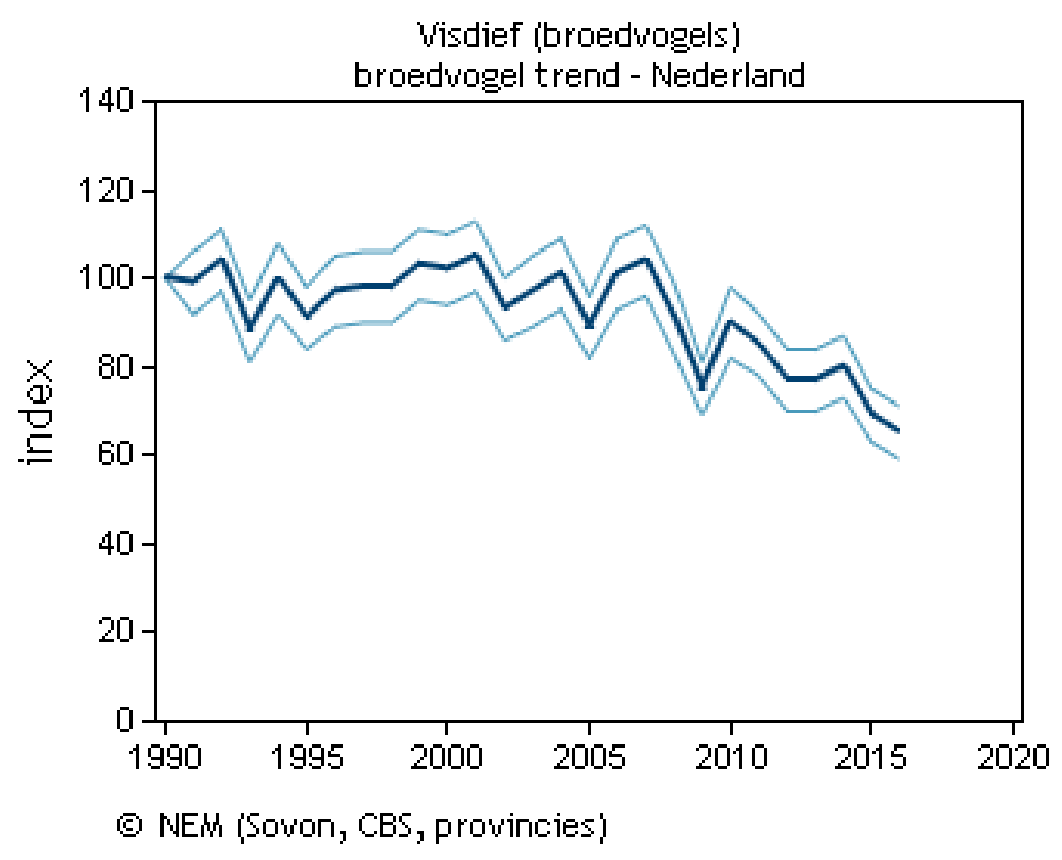

Figuur 3.15 Langjarige trend van jaarlijkse populatie-index visdieven in Nederland 1970-2016, gebaseerd op de gehele populatie of aantallen in de belangrijkste gebieden (www.sovon.nl/nl/soort/6150) 


\subsection{Menselijk gebruik}

De Voordelta wordt intensief gebruikt voor visserij, recreatie en scheepvaart. Het menselijk gebruik is intensiever in de zomermaanden dan in de wintermaanden. Figuur 3.14 geeft een cumulatief beeld van het waargenomen gebruik (zowel recreatie als beroepsscheepvaart) van de Voordelta in de periode 2005-2013.

\section{Recreatie}

Recreatie in de Voordelta vindt plaats in verschillende vormen, waaronder kitesurfen, windsurfen, kitebuggyen, recreatievaart met motorboten, zeilboten en zeiljachten, 'snelle' recreatievaart als waterskiën, waterscooters en vergelijkbare vormen, sportvisserij, duiken, kanoën, stand up paddling (SUP) en plaatbezoek (RWS 2016). Strandrecreatie vindt langs de gehele kust plaats. De Voordelta is populair als surfgebied. Vooral kitesurfen en in iets mindere mate windsurfen zijn populair, terwijl golfsurfen slechts in beperkte mate voorkomt. De kust van de Maasvlakte 2 wordt veel gebruikt door de recreanten. Kite- en windsurfen is kustgebonden en wordt vooral beoefend bij de Brouwersdam, Oostvoorne en de Maasvlakte en in mindere mate vanaf Goeree bij de Bollen van de Ooster en de Kwade Hoek. Windsurfen komt voor bij de Brouwersdam, Goeree en de Slufter. Plaatbezoek wordt het meest frequent waargenomen op de Verklikkerplaat. Plaatbezoek is afhankelijk van het getij en de droogvalduur van de platen en komt vooral voor in vakanties en weekenden in de periode mei $\mathrm{t} / \mathrm{m}$ september. Op de meeste dagen vindt geen plaatbezoek plaats (Prins et al. 2014c, Seegers et al. 2014).

Uit de evaluatie van het Beheerplan Voordelta in 2013 blijkt dat er veranderingen hebben plaats gevonden in het gebruik van de Voordelta (tabel 3.1). Zo heeft er o.a. een toename plaats gevonden in het aantal kitesurfers, zijn er SUP-activiteiten en strandslaaphuisjes bijgekomen (Van Oostveen \& Koolmees 2013).

\section{Scheepvaart}

Beroepsscheepvaart, maar ook recreatievaart, wordt vooral in de diepere delen van de Voordelta waargenomen, in de vaargeulen en de routes naar Westerschelde, Neeltje Jans en Stellendam. Zeiljachten met kajuit komen verspreid over de hele Voordelta veel voor. De vaargeul vanaf Stellendam is het drukst bevaren. De zeiljachten komen vrijwel nooit binnen de rustgebieden. Motorjachten komen weinig voor in de Voordelta (Prins et al. 2014c, Seegers et al. 2014).

In de Voordelta komen van oudsher verschillende vormen van visserij voor. Vanwege het belang van deze activiteit voor de natuurcompensatie, wordt de visserij apart besproken in hoofdstuk 4 Ontwikkeling in de visserij.

De menselijke activiteiten zijn van belang als mogelijke bron van verstoring voor zwarte zee-eend, grote stern en visdief. In de hoofdstukken 6 Zwarte zee-eend en 7 Grote stern en visdief wordt nader ingegaan op relevante verstoringsfactoren voor deze soorten. 


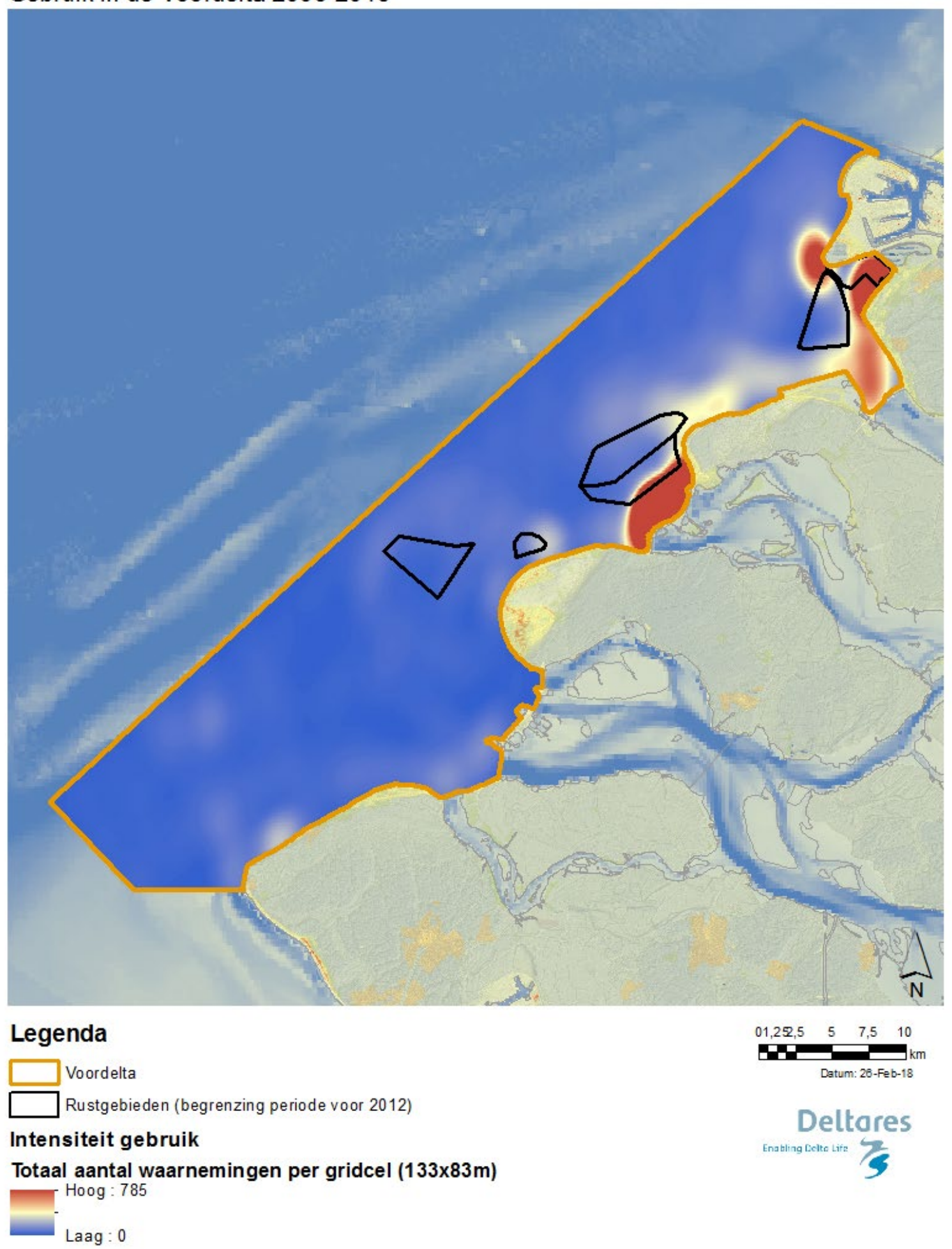

bron: Topografie (AHN1 - RWS DID, bathymetrie - RWS DID), Nederland (Rijkswaterstaat Noordzee),

Overige kaarten (Rijkswaterstaat Data en ICT Dienst (DID)) 
Tabel 3.1

Wijzigingen in activiteiten in de Voordelta ten opzichte van de eerste beheerplanperiode (Van Oostveen \& Koolmees 2013)

\begin{tabular}{|l|l|}
\hline Activiteit & Mate van wijziging t.o.v. $\mathbf{1}^{\text {ste }}$ beheerplan Voordelta \\
\hline Kitesurfen & Toename, nieuwe opstaplocatie \\
\hline SUP - stand up paddling & Nieuw \\
\hline Strandslaaphuisjes & Nieuw \\
\hline Strandschoonmaak & Intensiever, andere methode \\
\hline Zandsuppleties & Verandering in ruimte en tijd, nieuwe inzichten effecten \\
\hline Baggeractiviteiten (Slijkgat) & Toename \\
\hline Nb-wet vergund gebruik (Schelpdiervisserij) & Aanpassing \\
\hline $\begin{array}{l}\text { Nb-wet vergund gebruik (mosselzaadinvanginstallaties } \\
\text { (mzi's)) }\end{array}$ & Toename \\
\hline
\end{tabular}




\section{$4 \quad$ Ontwikkeling in de visserij}

N.T. Hintzen ${ }^{1}$, N.S.H. Tien ${ }^{1}$

${ }^{1}$ Wageningen Marine Research

Zoals in hoofdstuk 2 besproken was de boomkorvisserij voorafgaand aan de instelling van het BBG al vrijwel verdwenen uit de Voordelta, terwijl de garnalenvisserij juist sindsdien is toegenomen. Dit hoofdstuk geeft een overzicht van hoe de boomkorvisserij en de garnalenvisserij zich ontwikkeld hebben in de Voordelta. Hierbij wordt waar nodig ook naar een breder tijds- en ruimtekader gekeken.

Er worden twee onderzoeksvragen onderzocht:

1) Wat zijn de oorzaken van de verminderde boomkorvisserij in de Voordelta?

2) Hoe groot was de onttrekking van vis en andere (bij)vangsten in de periode T0 (2004-2008), T1 (2009-2013) en T2 (2014-2018)

Voor deze vragen is dezelfde informatie nodig, namelijk trends in de aanlandingen. Deze informatie wordt gegeven in hoofdstuk 4.3, waarna bovenstaande vragen worden beantwoord in hoofdstuk 4.4 en 4.5. Deze twee vragen worden uitgebreid besproken in Tien et al. (2017b)).

Daarnaast wordt een aanvullende vraag gesteld over de garnalenvisserij;

3 ) is de toename van de garnalenvisserij uniek voor de Voordelta, of is dit onderdeel van een toename langs de hele Nederlandse kust? Deze vraag wordt beantwoord in hoofdstuk 4.2 en uitgebreid besproken in Tien et al. (2017b)).

De basis van de analyses wat betreft de hoeveelheid visserij-inspanning en aanlandingen zijn de VMSen logboekgegevens van de schepen. Een uitleg van deze gegevens en de methodiek van opwerking is beschreven in Hintzen et al. (2014)) en uitgebreid beschreven in de eerste fase (Prins et al. 2014c). Het betreft een standaardmethodiek om VMS- en logboekgegevens op te werken naar aanlandingen per 'vissend VMS-ping'. Deze gegevens worden weer verder opgewerkt naar totale visserij-inspanning, waarbij de definitie van visserij-inspanning per vraag kan verschillen; bijvoorbeeld de hoeveelheid tijd die vissend in een bepaald gebied wordt doorgebracht, of het aandeel van het totale oppervlak dat per jaar wordt bevist.

Platviskotters: Van de boomkorvisserij in de Voordelta zijn platviskotters (boomkorschepen met 260-300 PK) verantwoordelijk voor 98.7\% van de gepleegde inspanning (tussen 2004 en 2007). Boomkorvisserij met kleiner motorvermogen komt vrijwel niet voor (1.3\%). Daarom is in de analyse gefocust op de platviskotters. De schepen trekken twee sleepnetten over de zeebodem waarbij de doelsoorten bestaan uit platvis. De netten worden opengehouden door een stalen balk, de boom. Aan de uiteinden van deze boom zitten zware stalen glijders (sloffen, een soort sleeën) die over de zeebodem glijden. Aan deze glijders zijn meerdere rijen kettingen (wekkerkettingen) bevestigd, die over de grond slepen en zo de platvis uit het zand op laten schrikken. De glijders en wekkerkettingen veroorzaken bodemberoering. De doelsoorten Noordzeebreed zijn schol en tong (ICES 2017). Garnalenkotters: Garnalenvisserij wordt uitgevoerd met garnalen(boom)korren. Net als bij de gewone boomkor wordt aan iedere kant van het schip een net voortgesleept over de bodem. Garnalenkorren zijn lichter in gewicht dan boomkorren. Bovendien zijn deze niet voorzien van wekkerkettingen, maar van klossenpezen die over de bodem rollen. Hierdoor is de bodemberoering minder groot dan bij boomkorren. Doelsoort is garnaal en er wordt weinig grote vis bijgevangen $(\sim 7 \%)$, door een verplichte zeeflap die vissen groter dan ca $10 \mathrm{~cm}$ weert (Prins et al. $2014 \mathrm{c}$ ).

\subsection{Ontwikkeling visserij-inspanning in de Voordelta}

De visserij door platviskotters in het gebied van het latere BBG was al vrijwel verdwenen (figuur 4.1), voordat het BBG in werking trad in 2008. De boomkorvisserij is grotendeels vertrokken uit de 
Voordelta en is de meest recente jaren alleen nog rondom de Oosterscheldemond en in de noordwestelijke hoek van de Voordelta aanwezig (figuur 4.2). De enige andere bodemberoerende visserij van betekenis in dit gebied, door garnalenkotters, is juist toegenomen sinds de instelling van het BBG (figuur 4.1). Ook binnen het BBG vindt een toename van garnalenvisserij plaats (figuur 4.3).

De ruimtelijke visserij-inspanning van de beide visserijen samen door de jaren heen is samengevat in figuur 4.4; hierbij is te zien welk aandeel van het gebied (voor het BBG en de rest van de Voordelta apart) intensief bevist is (donkerrood), niet bemonsterd is (wit) of op een tussenliggende mate van bevist is. Er is binnen het BBG een toename te zien van het oppervlak dat intensief bevist wordt, ten koste van oppervlak dat met een intermediaire mate wordt bevist. Dit gebeurt niet in de rest van de Voordelta. Echter, deze toename gaat niet ten koste van het oppervlak dat onbevist is: door de jaren heen blijft in beide gebieden het onbeviste gedeelte gelijk. Er zijn dus gebieden waar überhaupt niet gevist wordt, en binnen de beviste gebieden is de intensiteit van bevissing toegenomen.
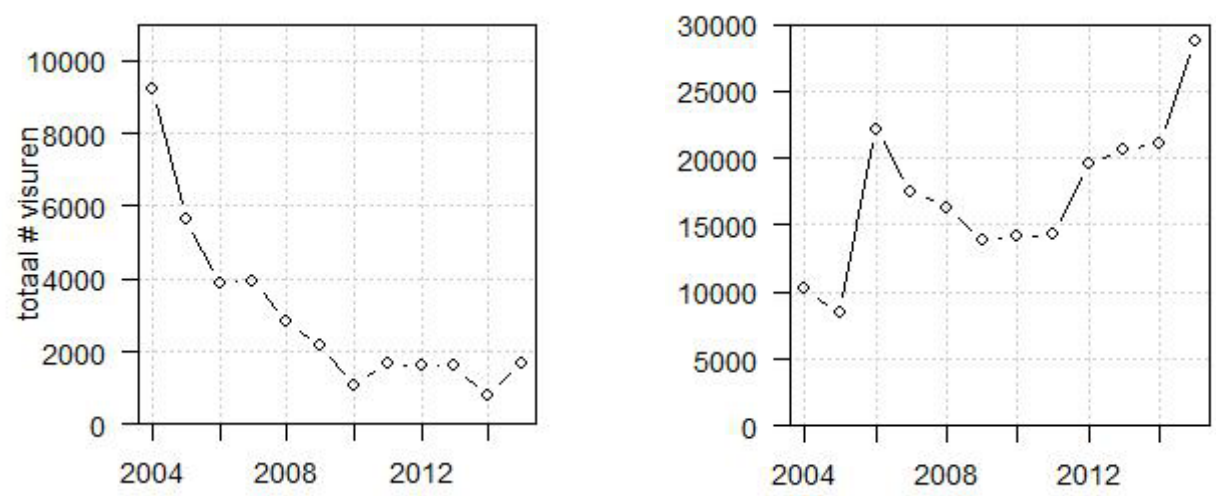

Figuur 4.1 Visserij- intensiteit per jaar van de platviskotters (links) en garnalenkotters (rechts) in de Voordelta tussen 2004-2015. Visserij- intensiteit is uitgedrukt in totaal aantal visuren. 


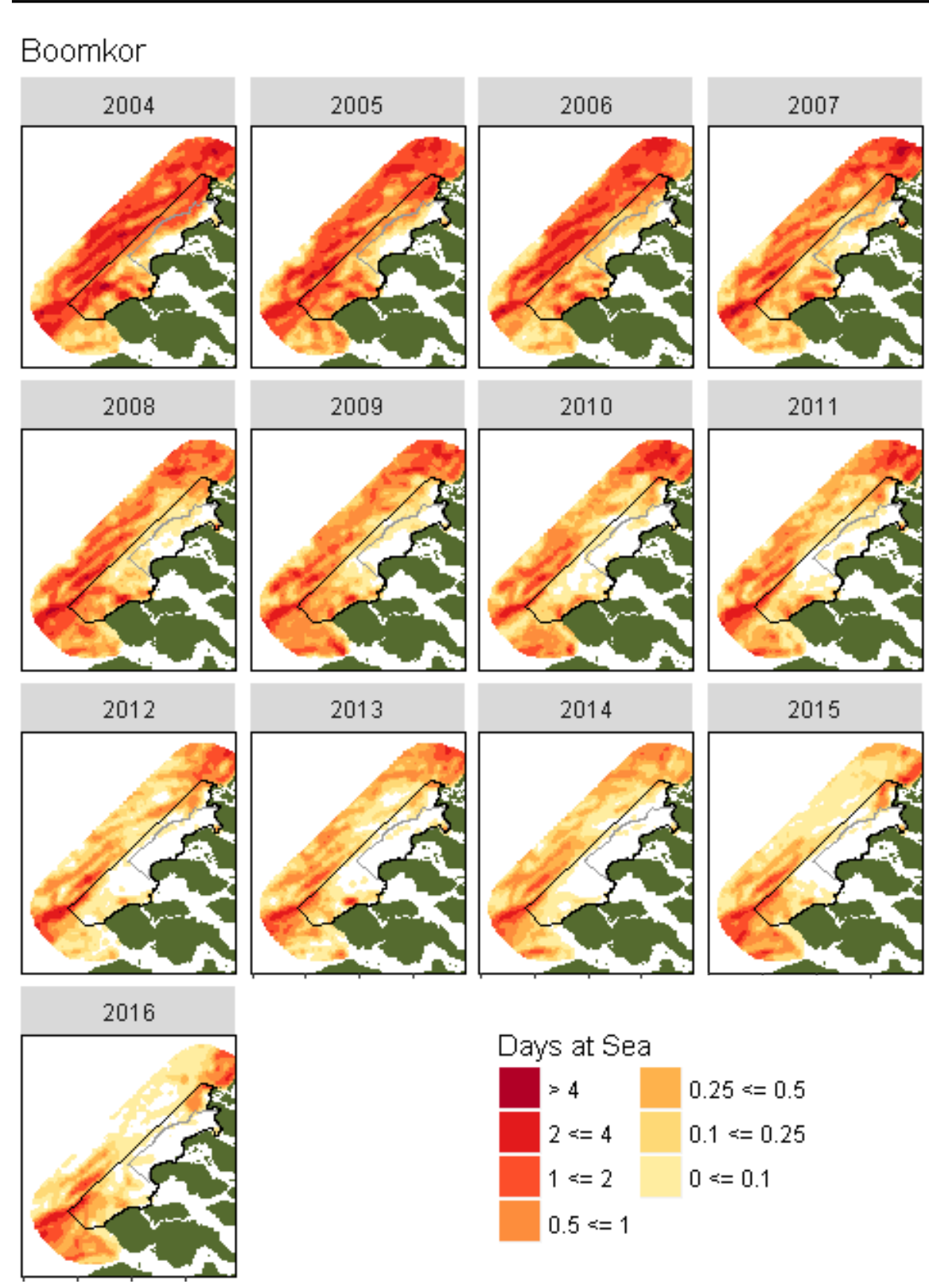

Figuur 4.2 Visserij- intensiteit van platviskotters in de Voordelta tussen 2004 en 2016. Visserijintensiteit is uitgedrukt in 'etmalen vissend op zee, per jaar' (days at sea) per vak van 0.5x0.5 km. Zwarte omlijning = Voordelta, grijze omlijning = BBG. Hoe roder, hoe intensiever de visserij is geweest. In het BBG zijn vanaf 2004 al geen intensief beviste plekken te zien. 


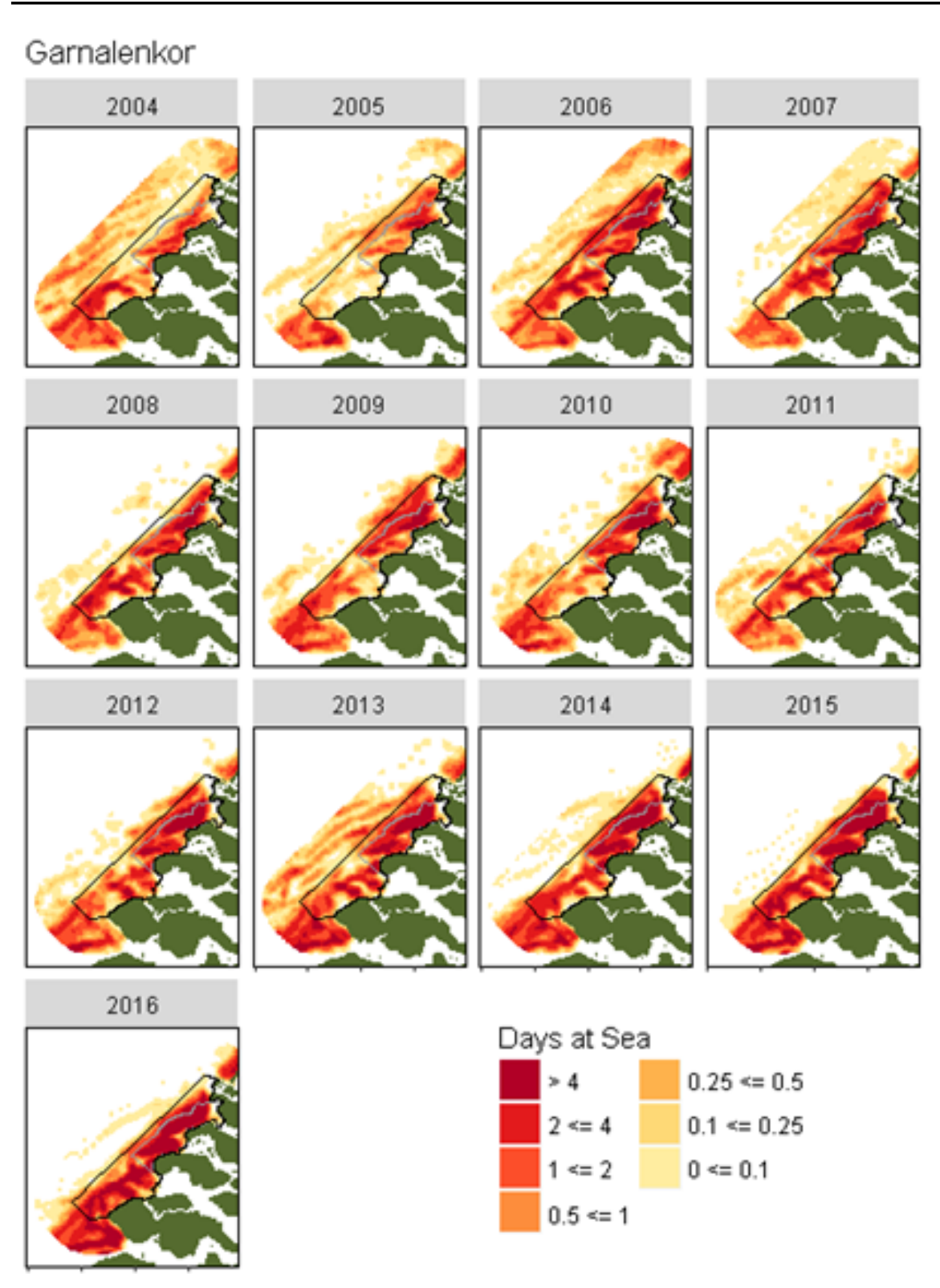

Figuur 4.3 Visserij-intensiteit van garnalenkotters in de Voordelta tussen 2004 en 2016. Visserijintensiteit is uitgedrukt in 'etmalen vissend op zee, per jaar' (days at sea) per vak van 0.5x0.5 km. Zwarte omlijning $=$ Voordelta, grijze omlijning $=$ BBG. 


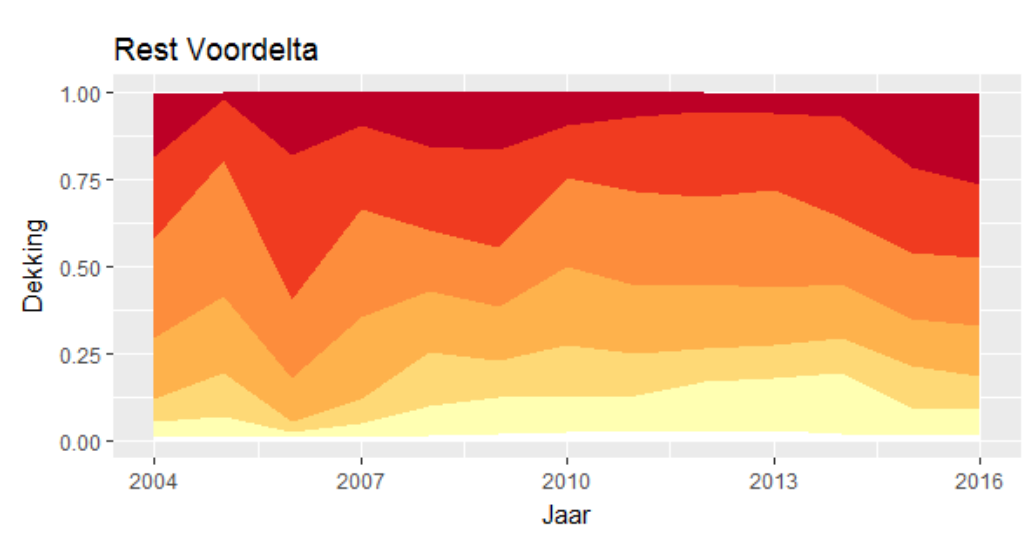

BodemBeschermingszone

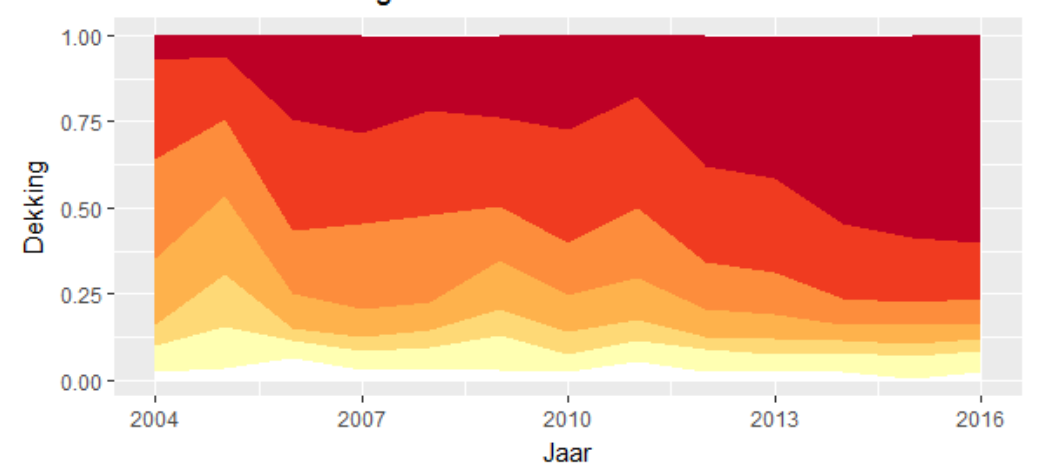

Figuur 4.4 Tijdserie van de gemiddelde visserij-intensiteit van de garnalenkotters en platviskotters samen. Bevist oppervlak is berekend per vak van $0.5 \times 0.5 \mathrm{~km}$, ingedeeld in dezelfde klassen als gebruikt in figuur 4.2 en 4.3, in het BBG en in de rest van de Voordelta, van 2004 tot en met 2016.

\subsection{Garnalenvisserij binnen en buiten de Voordelta}

Uit bovenstaande blijkt dat de garnalenvisserij over de periode 2004-2015 geïntensiveerd is in de Voordelta. De vraag die hieruit volgt, is of deze ontwikkeling uniek is voor de Voordelta of op een grotere ruimtelijke schaal speelt. Hierbij (zie (Tien et al. 2017b)) is de Nederlandse kust opgedeeld in 5 delen (figuur 4.5).

Voor ieder van de vijf gebieden is bepaald met welke visserij-intensiteit deze zijn bevist. Een visserijintensiteit van 1 betekent dat een afgebakend gebied gemiddeld in een jaar 1 maal volledig is bevist. Een grotere intensiteit betekent dus een hogere inspanning van de visserij. Hoewel in verschillende gebieden met andere intensiteiten wordt gevist, is de relatieve toename ongeveer overal gelijk (met uitzondering van het gebied tussen Hoek van Holland en IJmuiden (HVH - IJM). Oftewel, de ontwikkeling in de garnalenvisserij zoals we die gezien hebben in de Voordelta volgt nauw de ontwikkeling van de hele vloot in de andere kuststreken van Nederland en lijkt dus niet beïnvloed te zijn door de instelling van het Bodembeschermingsgebied. 
BBG

Voordelta+

$\square \mathrm{HVH}-\mathrm{IJM}$

IJM-DH

$\square$ DH-DUI

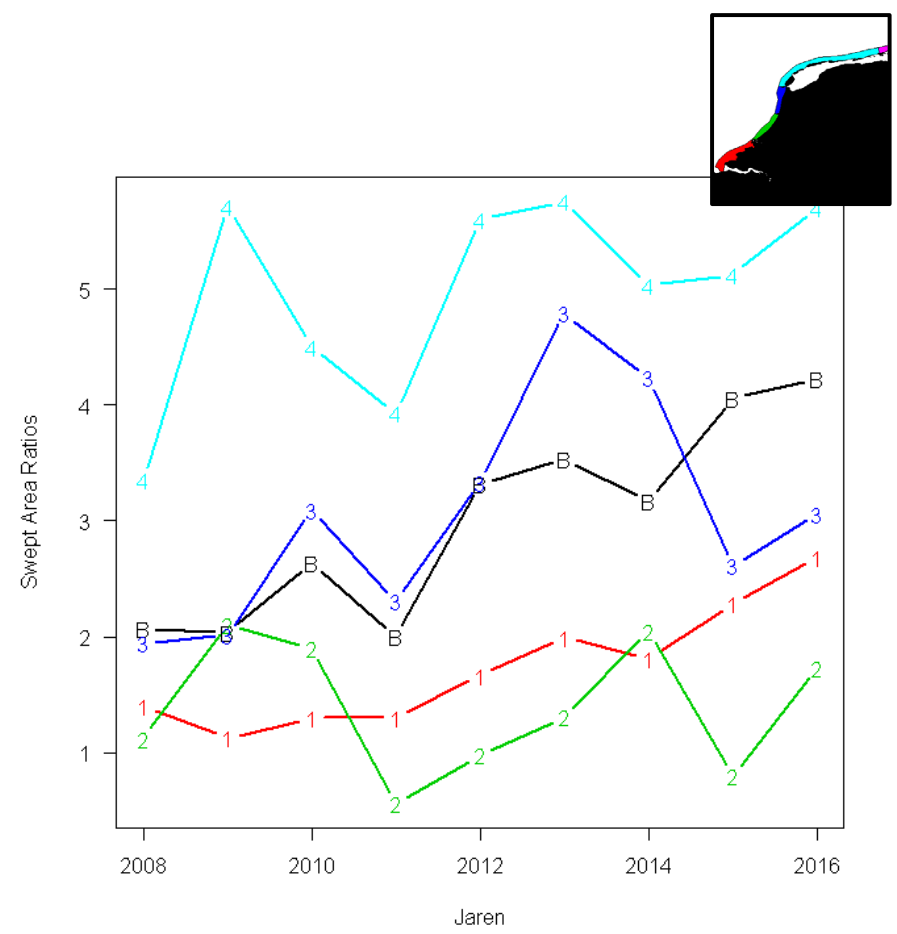

Fig. 4.5 De verandering in visserij-intensiteit (uitgedrukt als gemiddeld aantal keren bevist / 'Swept Area Ratios') door garnalenschepen in de Voordelta, het Bodembeschermingsgebied en andere gebieden langs de Nederlandse kust (HVH=Hoek van Holland, IJM=IJmuiden, DH=Den Helder, DUI=Duitsland). Zie ook het plaatje rechtsboven voor de definitie van gebieden.

\subsection{Langetermijntrends boomkorvisserij}

\subsubsection{Voordelta}

Goede logboekgegevens van de platviskotters zijn beschikbaar vanaf 1998 op het niveau van ICESkwadranten. De Voordelta is hoofdzakelijk onderdeel van ICES-kwadrant 32F3 (figuur 4.6). Deze logboekgegevens zijn gebruikt voor de analyse van langetermijntrends in aanlandingen in de Voordelta (Tien et al. 2017b). VMS-gegevens waarmee Voordelta-specifieke gegevens opgewerkt kunnen worden, zijn pas vanaf 2004 beschikbaar: het inschatten van trends over een langere termijn kan dus alleen op een hogere ruimtelijke schaal. De logboekinformatie is beschikbaar op het niveau van een visreis (en dus niet per vissende VMS-ping) en beschrijft per ICES-kwadrant hoeveel kilogram vis een schip per visreis gevangen heeft. 


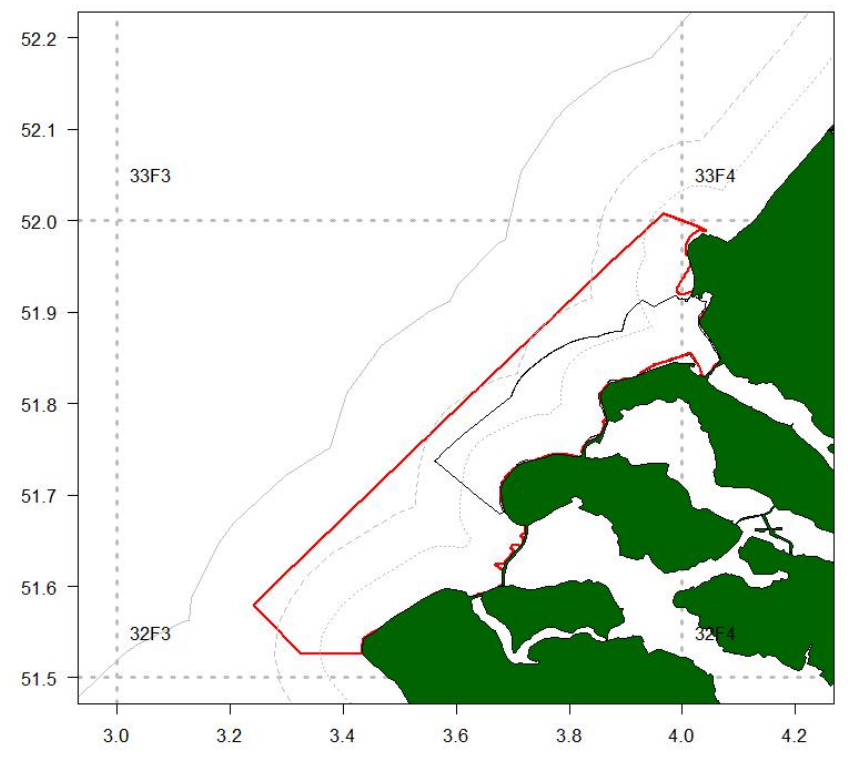

Figuur 4.6 De Voordelta (in rood) en het Bodembeschermingsgebied (in zwart), in relatie tot de ICES-kwadranten (de grote vierkanten in stippellijn). De Voordelta ligt hoofdzakelijk in ICES-kwadrant 32F3).

De belangrijkste aangelande soorten sinds 1998 zijn dezelfde in 32F3 als in de Voordelta; bot, tong, schar en schol. De sterke afname in aanlandingen in de Voordelta van 2004 (zwarte lijn in figuur 4.7) naar latere jaren is deel van een langere trend: vanaf 1998 is een sterke afname in aanlandingen uit $32 \mathrm{F3}$ te zien (grijze lijn in figuur 4.7). De aanlandingen uit de Voordelta nemen dus al ten minste sinds 1998 af.
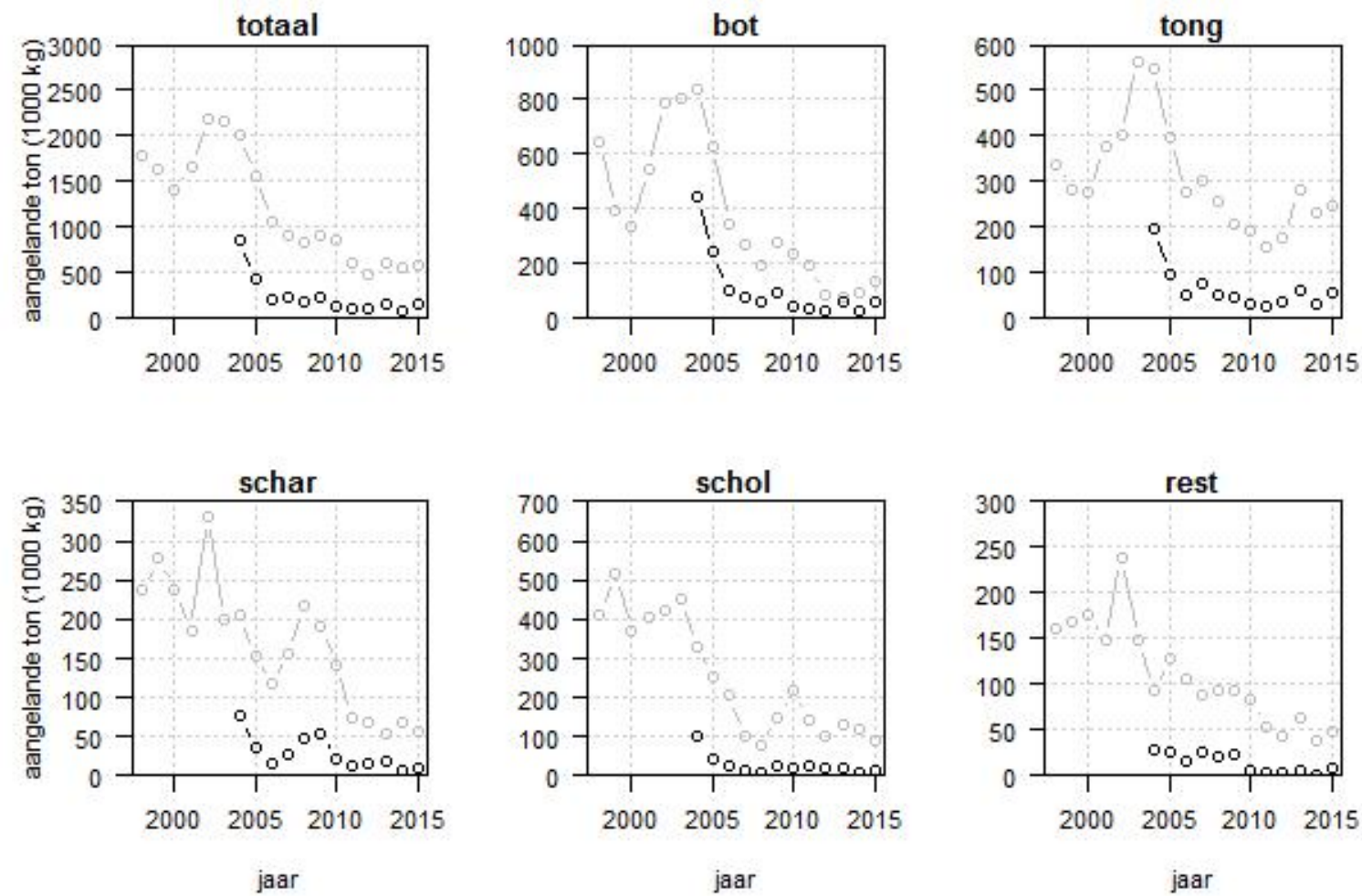

Figuur 4.7 De hoeveelheid aangelande vis van de 68 platviskotters die tussen 2004-2015 in de Voordelta actief zijn geweest: in de Voordelta (zwart) en in ICES-kwadrant 32F3 (grijs). ICESkwadrant 32F3 beslaat het grootste deel van de Voordelta, maar omvat een groter (en dieper) gebied. 


\subsubsection{Noordzeebreed}

Ook kan onderzocht worden, of voor de platviskotters het belang van de Voordelta, ten opzichte van de gehele, Noordzeebrede visserij, is veranderd door de tijd. Dit wordt op dezelfde manier onderzocht als in hoofdstuk 4.3.1, met de aanlandingen in de logboeken. Het aandeel van de aanlandingen (ten opzichte van alle aanlandingen van een schip dat zowel in als buiten de Voordelta viste) afkomstig uit ICES-kwadrant 32F3 liep tussen 2002 en 2012 sterk terug voor alle soorten en bleef daarna stabiel (figuur 4.8). Het belang van de Voordelta in de boomkorvisserij lijkt dus ook al een langere periode af te nemen.

In het begin van de tijdserie, in 1998, visten de vissers nog met regelmaat in de Voordelta; zo'n 35\% van de totale aanlandingen komen uit kwadrant 32F3. De vissers zijn in latere jaren een groter aandeel van hun tijd buiten de Voordelta gaan vissen wat terug te zien is aan de teruglopende fractie aanlandingen voor alle soorten weergegeven in figuur 4.6. De redenen hiervoor zijn niet eenduidig, maar dat dit is veroorzaakt door de aanleg van de Maasvlakte 2 en instelling van het Bodembeschermingsgebied wordt niet breed gedragen door de visserij.
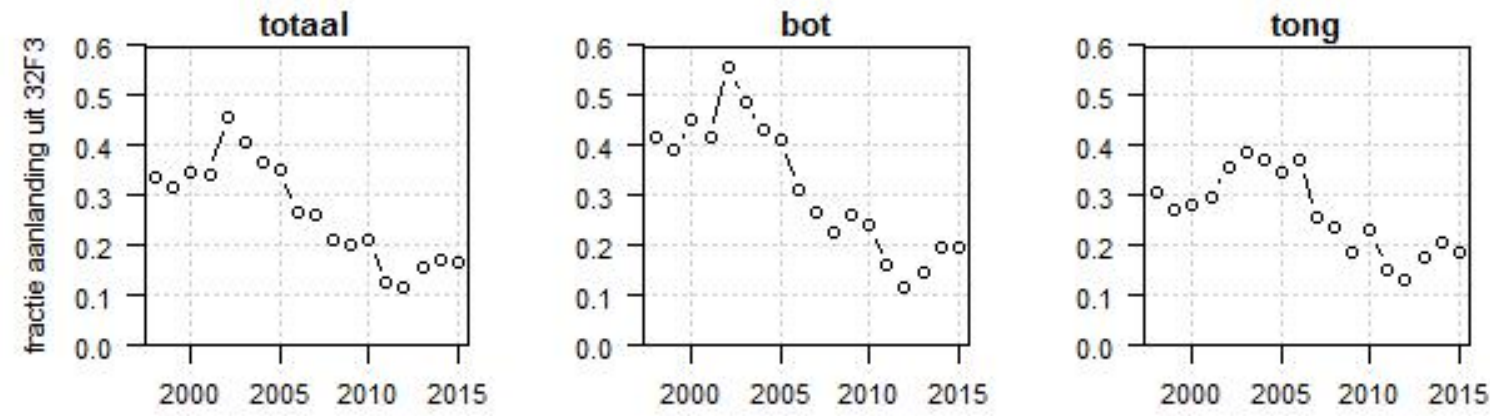

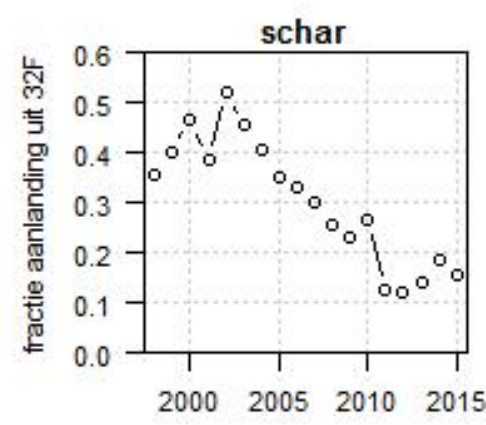

jaar

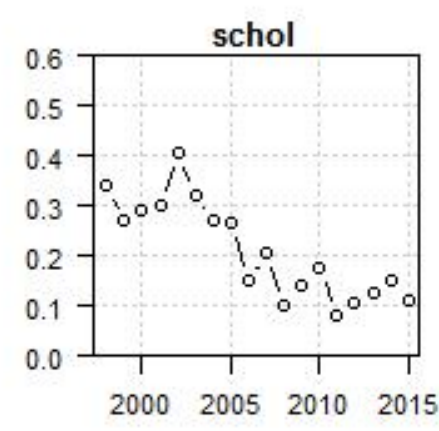

jaar

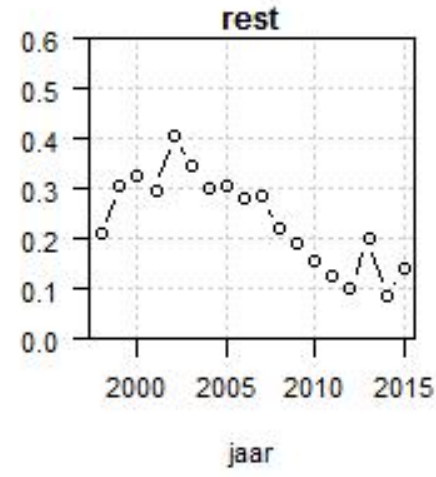

jaar

Figuur 4.8 Het aandeel vis aangeland vanuit ICES-kwadrant 32F3, van de gehele vangst van de 68 platviskotters die tussen 2004-2015 in de Voordelta actief waren. ICES-kwadrant 32F3 beslaat het grootste deel van de Voordelta, maar omvat een groter (en dieper) gebied.

\subsection{Beantwoording onderzoeksvragen}

\section{Vraag 1: Oorzaken van de verminderde boomkorvisserij in de Voordelta}

Met behulp van informatie uit logboeken, VMS-gegevens en interviews met vissers zijn de trends in de boomkorvisserij in detail geëvalueerd en afgezet tegen de Noordzeebrede trends (Tien et al. 2017b). In de boomkorvisserij in de Voordelta vissen schepen meestal met meerdere tuigen en op meerdere doelsoorten. Een groot deel van de kotters die op platvis vist in de Voordelta vist ook, en vooral, op garnaal in de Voordelta. Bovendien is geen van de kotters gespecialiseerd in de Voordelta maar is dit slechts een klein deel van hun visgebied. 
De afname in de boomkorvisserij lijkt Noordzeebreed plaats te vinden (figuur 4.9): de platviskotters zijn in hun hele visgebied minder gaan vissen in de periode 2004-2015. Binnen de Voordelta lijkt er wel een extra grote afname te zijn. Echter, het begin van deze Voordelta-specifieke afname lijkt eerder ingezet dan in de periode 2004-2015 (zie hoofdstuk 4.3) en heeft daardoor waarschijnlijk niet te maken met het instellen van het BBG in 2008. Wel stabiliseert de visserij-inspanning in de Voordelta rond 2008/2009 op een laag en basaal niveau. Het is mogelijk dat de komst van het BBG en de Maasvlakte 2 hier een rol bij hebben gespeeld door grotere fragmentatie en verlies aan visserijgrond. Het instellen van het Bodembeschermingsgebied kan dus een kleine, aanvullende rol hebben gespeeld in de afname van de bodemberoerende visserij in het gebied.

Ook uit de meeste interviews bleek dat de instelling van het BBG niet echt invloed lijkt te hebben gehad op de boomkorvisserij. In de voor boomkorvisserij gesloten gebieden visten de meeste vissers al niet meer voor 2008, hooguit om doorheen te vissen op weg naar de goede gronden. Verklaringen voor de achteruitgang zien vissers in andere factoren zoals bijvoorbeeld de Deltawerken, verandering in stromingen, klimaatverandering (Tien et al. 2017b).
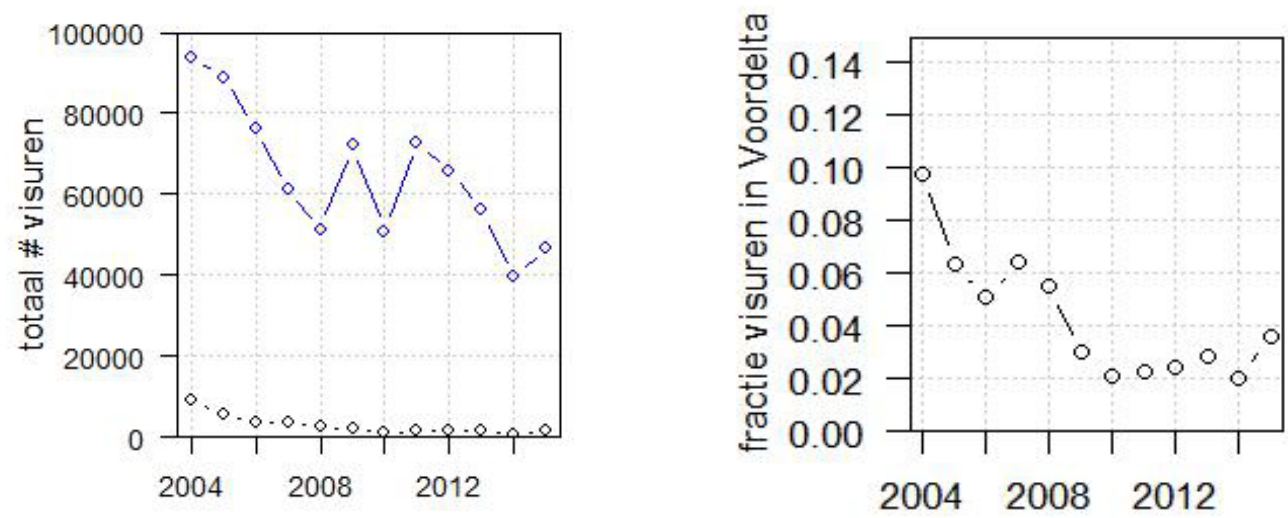

Figuur 4.9 Links: Ontwikkeling in aantal visuren van de platvisvisserij Noordzeebreed (blauw) en Voordelta (zwart). Rechts: De fractie visuren in de Voordelta van de 68 platviskotters die tussen 20042015 in de Voordelta actief zijn geweest, van de Noordzeebrede visserij van deze platviskotters.

\section{Vraag 2: Onttrekking van vis en andere bijvangsten}

Met behulp van informatie uit logboeken, VMS en discard-monitoringsprogramma's zijn schattingen gemaakt van de onttrekkingen (aanlandingen en discards) van vis en benthos ${ }^{1}$. Voor de onttrekking van benthos -anders dan garnaal- zijn de schattingen te onzeker om mee te nemen. De onttrekking van biomassa door de platviskotters is sterk afgenomen tussen 2004 en 2015 (tabel 4.1). Tussen de T0 (2006-2008) en de T1 (2009-2013) is de jaarlijkse onttrekking meer dan gehalveerd van 851 naar 322 ton biomassa en tussen T1 en T2 nog verder afgenomen naar 244 (2014-2015). De onttrekking door de garnalenvisserij is veel groter dan van de boomkorvisserij (tabel 4.1 en figuur 4.10). Ook is deze onttrekking juist toegenomen over de periode 2006-2015 (voor 2004-2005 zijn geen logboekgegevens beschikbaar). Tussen de T0 en T1 is de onttrekking door de garnalenkotters iets afgenomen van 1928 naar 1694 ton biomassa, maar in T2 sterk toegenomen naar 2682 ton. Opgeteld over beide typen visserij is de gemiddelde onttrekking van biomassa van T0 (2006-2008) naar T1 (2009-2012) afgenomen van 2779 ton naar 2016 ton maar in T2 (2014-2015) juist toegenomen naar 2926 ton (tabel 4.1 en figuur 4.10).

Het is ook interessant om te weten wat de ecologische impact van de visserij op bestanden is. Hiervoor is echter ook informatie over de bestandsgrootte nodig; het ecologische effect van visserij is niet alleen afhankelijk van de hoeveelheid onttrekking, maar ook van de grootte van het bestand. Er zijn drie bestanden waarvoor deze informatie beschikbaar is; schol, tong en garnaal (Tien et al.

\footnotetext{
${ }^{1}$ Let op; er zijn minder jaren binnen de drie periodes, dan zoals gedefinieerd in vraag 2. Dit komt doordat niet alle informatie voor alle jaren beschikbaar was.
} 
2017b). Het effect van de visserij op het schol- en tongbestand is afgenomen over de drie periodes (figuur 4.11). Voor de visbestanden is hierbij aangenomen dat de biomassaontwikkelingen in de Voordelta gelijk zijn aan die van het hele bestand (i.e., op Noordzeeschaal en hoger). Het effect op de garnaal in de Voordelta is afgenomen van T0 naar T1 maar toegenomen in T2.

De onttrekking van de Voordelta-visserij van schol en tong is verwaarloosbaar ten opzichte van de bestandsgrootte van deze soorten (figuur 4.11). Oftewel, de Voordelta visserij levert geen aantoonbare impact op de visstandontwikkeling van schol en tong. Voor garnaal ligt dat anders, waar de onttrekking juist substantieel is. Wel kan de visserij een substantiële impact hebben gehad op residente soorten, maar daarvoor ontbreken methoden en gegevens om te schatten of dit werkelijk het geval is.

\section{Tabel 4.1}

Gemiddelde onttrekking (aanlanding en discards, in ton biomassa) per jaar voor de drie periodes T0 (2006-2008), T1 (2009-2013) en T2 (2014-2015), voor de platviskotters en de garnalenkotters, opgedeeld in vis en benthos en onderverdeeld in aanlandingen en discards. Voor de garnalenkotters zijn in periode T0 alleen gegevens beschikbaar vanaf 2006. * Discards van benthos bestaat uit zowel ondermaatse garnaal, als andere benthossoorten. Van de benthosdiscards zijn alleen betrouwbare schattingen voor garnaal beschikbaar, niet van andere benthossoorten.

\begin{tabular}{|l|c|c|c|c|c|c|c|c|c|}
\hline & \multicolumn{3}{|c|}{ Platviskotters } & \multicolumn{3}{|c|}{ Garnalenkotters } & \multicolumn{3}{c|}{ Alle kotters } \\
\hline Vis & T0 & T1 & T2 & T0 & T1 & T2 & T0 & T1 & T2 \\
\hline Aanlanding & 772 & 302 & 229 & 76 & 68 & 70 & 848 & 370 & 299 \\
\hline Discards & 74 & 20 & 15 & 109 & 110 & 203 & 183 & 130 & 218 \\
\hline Totaal vis & 846 & 322 & 244 & 185 & 178 & 273 & 1031 & 500 & 517 \\
\hline & & & & & & & & & \\
\hline Benthos (incl garnaal) & & & & & & & & & \\
\hline Aanlanding & 5 & 0.3 & 0.2 & 860 & 863 & 1613 & 865 & 863 & 1613 \\
\hline Discards garnaal* & 0 & 0 & 0 & 883 & 653 & 796 & 883 & 653 & 796 \\
\hline Totaal benthos* & 5 & 0.3 & 0.2 & 1743 & 1516 & 2409 & 1748 & 1516 & 2409 \\
\hline & & & & & & & & \\
\hline Totaal vis en benthos & $\mathbf{8 5 1}$ & $\mathbf{3 2 2}$ & $\mathbf{2 4 4}$ & $\mathbf{1 9 2 8}$ & $\mathbf{1 6 9 4}$ & $\mathbf{2 6 8 2}$ & $\mathbf{2 7 7 9}$ & $\mathbf{2 0 1 6}$ & $\mathbf{2 9 2 6}$ \\
\hline
\end{tabular}




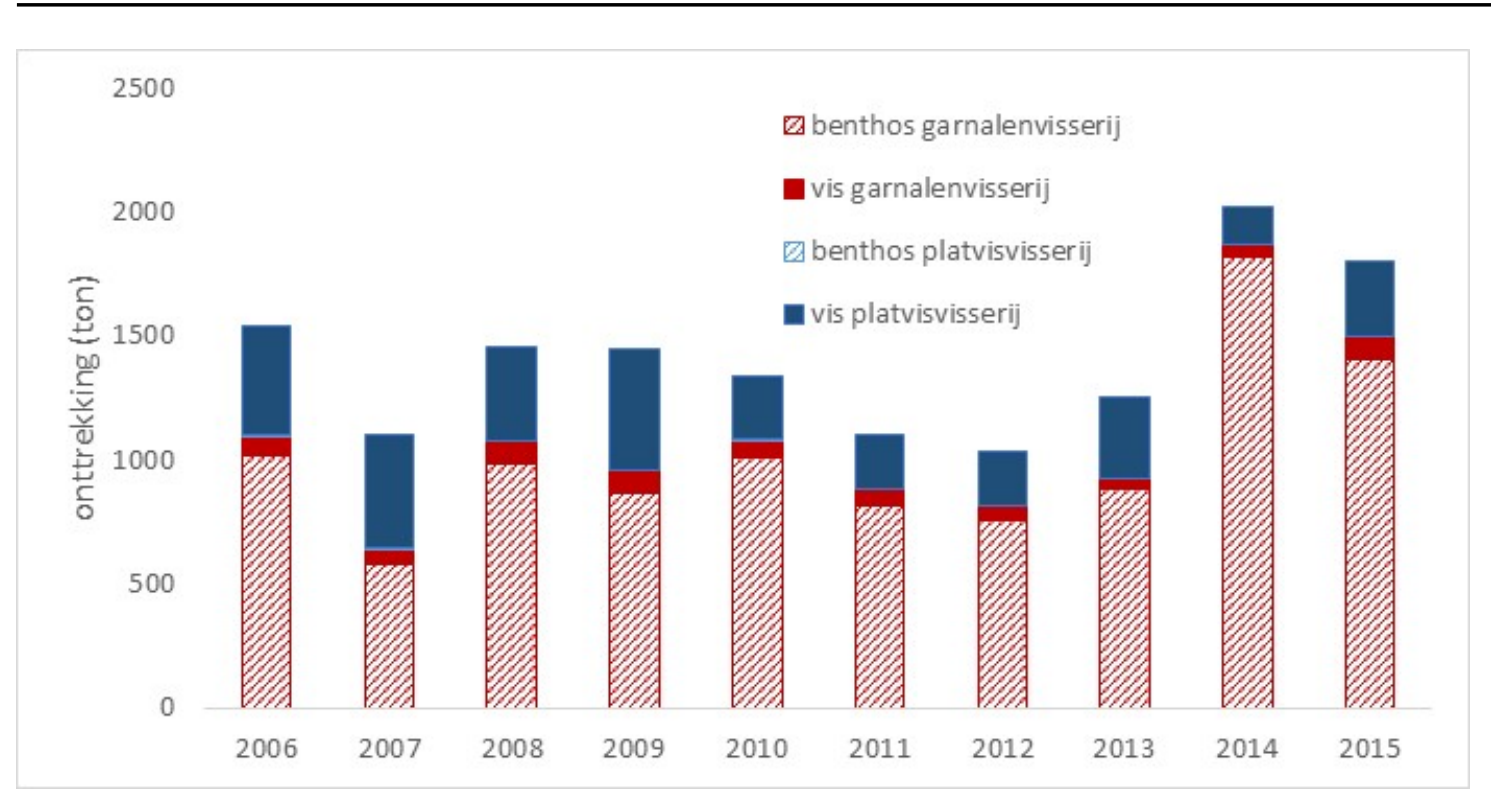

Figuur 4.10 Geschatte hoeveelheid onttrekking benthos (incl. garnaal) en vis door de garnalen- en boomkorvisserij, in ton biomassa per jaar.
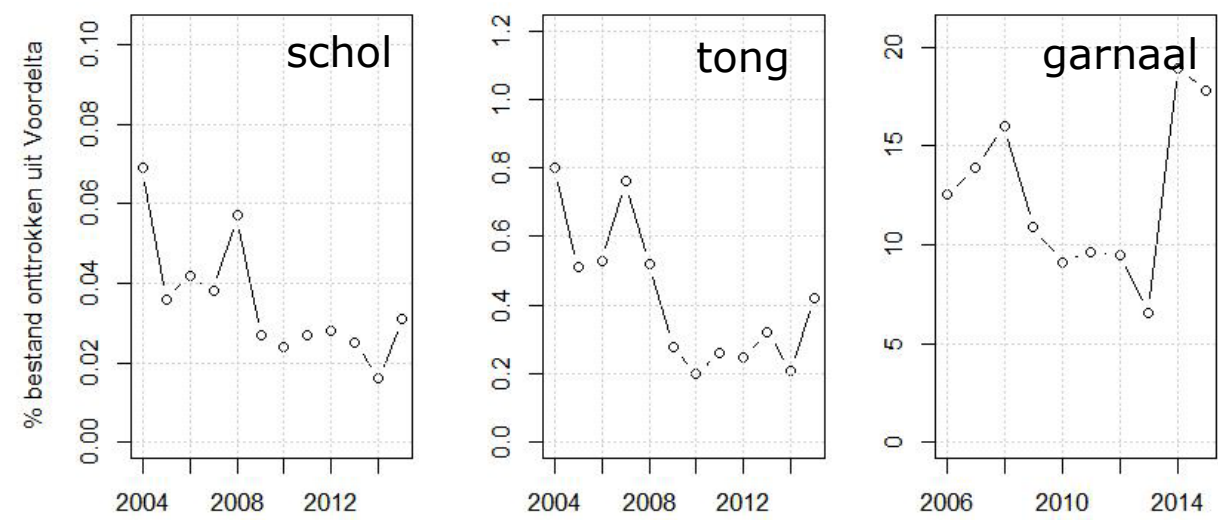

Figuur 4.11 Percentage van het bestand onttrokken door de platvis- en garnalenkotters in de Voordelta voor schol (links), tong (tweede figuur) en garnaal (derde figuur).

\subsubsection{Discussie}

De ontwikkeling in inspanning van de boomkorvissers is niet uniek voor de Voordelta. Noordzeebreed is deze sterk afgenomen, al neemt de inspanning in de Voordelta wel harder af. Zo is vooral de inspanning in de Voordelta per schip forser afgenomen, wat er op kan duiden dat vissers het gebied grotendeels overslaan in hun visserij .

Deze ontwikkeling is niet specifiek voor de periode rond de instelling van het bodembeschermingsgebied. Immers, al ruim voor 2004 vond de grootste afname plaats. Rond 20082009 lijkt de inspanning wel te stabiliseren. De verminderde inspanning lijkt niet terug te voeren te zijn op de ontwikkelingen in de doelsoorten van de visserij sinds 2004; sommige doelsoorten nemen juist toe in aantal (Tien et al. 2017b), al is de ruimtelijke verspreiding hiervan, en de abundantie in de Voordelta niet te schatten op basis van bestaande methoden.

Wel kan de fragmentatie in visgrond, door het instellen van rustgebieden en het BBG, een rol hebben gespeeld in de neergaande trend in boomkorvisserij inspanning.

De vangsten van schol en tong in de Voordelta zijn dusdanig klein van omvang dat deze een verwaarloosbaar effect hebben op de Noordzee-bestanden van de betreffende soorten. Dit is overigens 
alleen te bepalen voor soorten waarvoor bestandschattingen aanwezig zijn, en dat sluit lokale residente soorten uit.

Wel is er een forse toename in de garnalenvisserij in de Voordelta, die een grotere impact heeft op bodemberoering dan de platvissector. Als de inspanning van de twee visserijen worden samengenomen, blijkt dat het bevist oppervlak van het BBG toeneemt door de jaren, al blijft het onbevist deel stabiel (een kleine fractie van het totale gebied, $\sim 3 \%$ ). Dit kan duiden op het aanwezig zijn van onbevisbare gebieden in het BBG.

De aan het begin van dit hoofdstuk gestelde onderzoeksvragen met betrekking tot de visserij kunnen als volgt beantwoord worden:

1) Wat zijn de oorzaken van de verminderde boomkorvisserij in de Voordelta? De aangedragen redenen zijn niet Voordelta specifiek en wijzen vooral in de richting van een Noordzeebreed patroon. Mogelijk heeft fragmentatie van de visgrond een rol gespeeld. Het instellen van het BBG lijkt geen rol gespeeld te hebben.

2) Hoe groot was de onttrekking van vis en andere (bij)vangsten in de periode T0 (2004-2008), T1 (2009-2013) en T2 (2014-2018)

Deze onttrekking is samengevat in tabel 4.1. Wat betreft de impact van de onttrekking op de bestanden: Hoewel de onttrekking te kwantificeren is, heeft deze een verwaarloosbare impact op de bestanden waarvoor bestandschattingen beschikbaar zijn, met uitzondering van garnaal waar de impact substantieel is. De impact op het benthos en residente soorten waarvoor geen bestandschattingen beschikbaar zijn is niet te bepalen. 


\section{$5 \quad$ Habitat 1110}

J.A.M Craeymeersch ${ }^{1}$, I. Tulp ${ }^{1}$, L.J.Bolle ${ }^{1}$, V.L. Escaravage ${ }^{1}$, S.T. Glorius ${ }^{1}$, C. Chun ${ }^{1}$, N.S.H. Tien, A.F. Zuur $^{2}$

${ }^{1}$ Wageningen Marine Research, ${ }^{2}$ Highland Statistics Ltd.

\section{$5.1 \quad$ Benthos}

Bij de instelling van het bodembeschermingsgebied was de verwachting dat de beschermende maatregelen zouden leiden tot een lokale toename (10\%) van de biomassa van het benthos. Het onderzoek binnen Perceel Benthos is bedoeld om het effect van de compensatiemaatregelen in de Voordelta (de instelling van het bodembeschermingsgebied, BBG) op de benthosgemeenschap te bestuderen en om de vraag te beantwoorden of veranderingen in benthos gerelateerd kunnen worden aan het instellen van het bodembeschermingsgebied.

\subsubsection{Onderzoeksvragen}

Hieronder worden de MEP onderzoeksvragen uit het monitoringsplan (Tulp et al. 2015a) gegeven. Elke vraag wordt inhoudelijk behandeld aan de hand van de onderzoeksresultaten uit de periode 2004-

2016.

1) Wordt het verlies aan habitattype $\mathrm{H} 1110 \mathrm{~B}$ als gevolg van de aanleg van Maasvlakte 2 voldoende gecompenseerd? ${ }^{2}$

c) Zijn er positieve trends waar te nemen in kwaliteit van het Habitat 1110B (zoals deze wordt gedefinieerd in het profieldocument $\mathrm{H} 1110$ (versie 18 december 2008)) in de Voordelta sinds het begin van de afname van de boomkorvisserij uit de Voordelta rond de laatste eeuwwisseling?

a) d) Zijn de waargenomen trends toe te schrijven aan de afgenomen bodemberoering ten gevolge van de afname van de grote boomkorvisserij met wekkerkettingen in de gehele Voordelta of ook aan andere factoren?

b) e) Hoe groot was de onttrekking van vis en andere (bij)vangsten in de periode T0 (20042008), T1 (2009-2013) en T2 (2014-2018)?

In onderstaand schema zijn de belangrijkste relaties in de Voordelta op hoofdlijnen weergegeven.

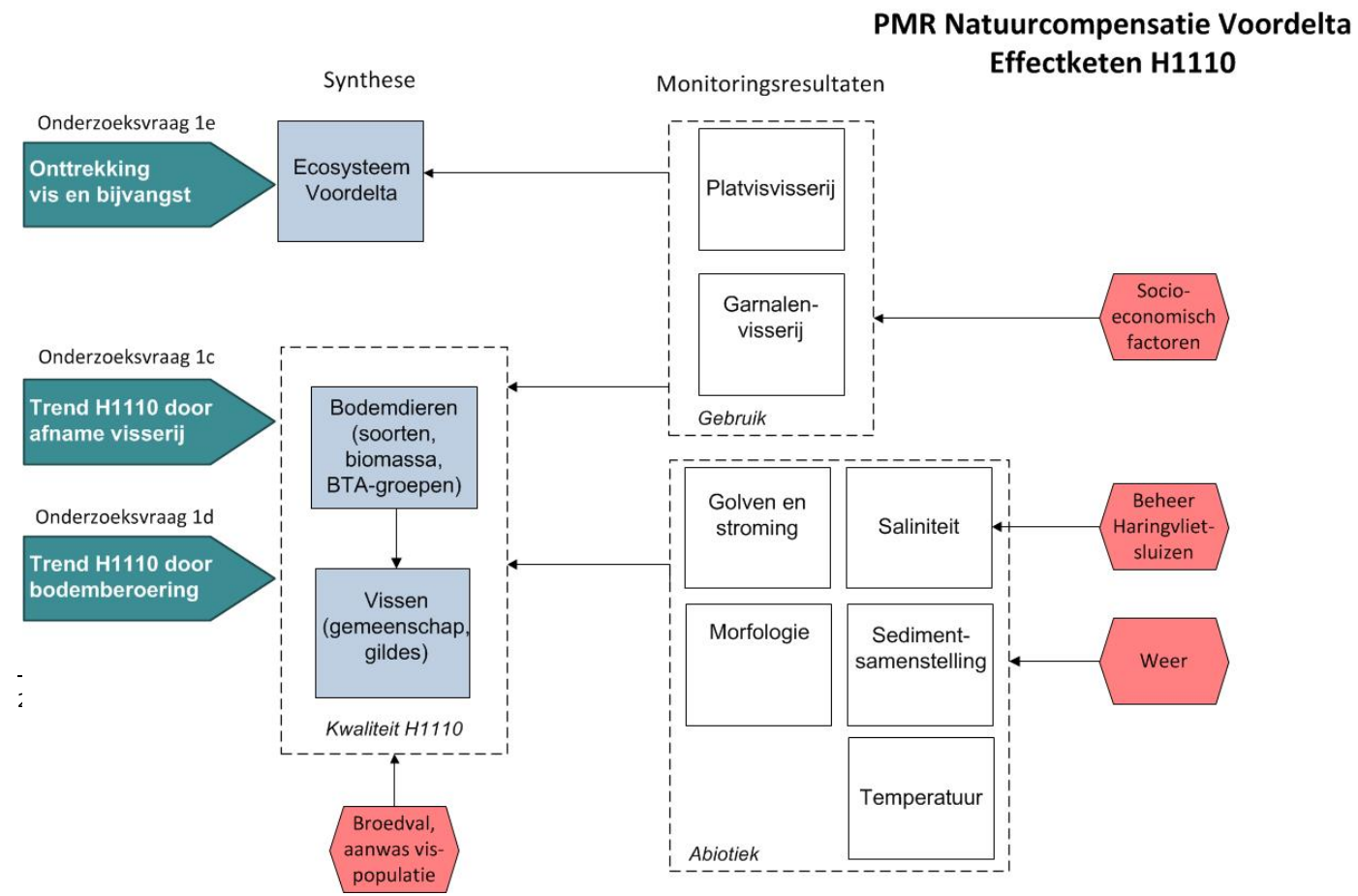




\subsubsection{Beantwoording van onderzoeksvragen: parameters}

Van de set geformuleerde MEP-vragen is voor benthos vooral MEP-vraag 1 (deel 1c en 1d) van belang Deelvraag 1 e) wordt behandeld in het hoofdstuk visserij.

In dit hoofdstuk zullen de verkorte termen boomkorvisserij en garnalenvisserij gehanteerd worden. Onder boomkorvisserij valt de visserij door boomkorschepen op platvis met een vermogen van 260-300pk. Onder garnalenvisserij door garnalenschepen met een vermogen <300 pk met een maaswijdte van 15-32mm; deze schepen vissen overigens ook met ook een (veel lichtere) boomkor.

Bodemdieren kunnen direct worden beïnvloed door de bodemberoerende visserij. Daarnaast is er een directe invloed van de visserij op abiotische omstandigheden, die direct of indirect kunnen doorwerken op benthos. Tevens kunnen externe factoren van invloed zijn, zoals het weer, economische ontwikkelingen binnen de visserij of ontwikkelingen buiten de Voordelta. Een voor het onderzoek complicerende factor is dat de garnalenvisserij in het bodembeschermingsgebied wel is toegestaan. In deze visserij wordt met fijnmazige netten gevist waardoor benthos onbedoeld bijgevangen wordt. Onttrekking van, en eventuele schade aan deze organismen kan een verandering, veroorzaakt door het wegvallen van de boomkorvisserij, maskeren. Daarnaast wordt alle bijvangst in de garnalenvisserij overboord gezet, en is daarmee voedsel dat beschikbaar komt voor aaseters. Ook dit kan een (onvoorzien) effect op het benthos hebben. Hieronder lichten we voor alle deelvragen toe welke analyses zijn uitgevoerd ter beantwoording ervan.

De onderzoeksvraag gaat om veranderingen in kwaliteit van H1110. De compensatie-opgave betrof een $10 \%$ verbetering in kwaliteit gemeten in totale bodemfauna biomassa. Daarom is deze parameter bij aanvang van het onderzoek aangewezen als de parameter op basis waarvan de evaluatie van de compensatie uitgevoerd zou worden. Vanwege de compensatie-opgave voor zwarte zee-eend is in de eerste fase daarnaast ook de verandering in de biomassa als voedsel voor vogels onderzocht. Naast deze twee parameters is nog een hele reeks andere parameters onderzocht. Belangrijk hierbij is te redeneren vanuit hypotheses over de verwachtte veranderingen als gevolg van de veranderingen in de bodemberoerende visserij. Hierbij is ook belangrijk dat het effect van beide bodemberoerende visserijen anders door kan werken op de bodemfauna.

De verwachting is dat het uitsluiten van de boomkorvisserij zou leiden tot een toename in totale biomassa en biomassa als voedsel voor vogels. Bij een afname in bodemberoerende visserij en sterfte als gevolg hiervan, verwachten we ook een verandering in de gemiddelde of maximale lengtes van schelpdieren, het gemiddeld individueel gewicht waarbij de verwachting is dat dieren ouder en dus ook groter en zwaarder kunnen worden als gevolg van uitsluiten van de boomkorvisserij. Ook kan het totaal aantal soorten veranderen of het aandeel grote soorten toenemen. Daarnaast kunnen ook taxonomische en/of functionele verschuivingen in de benthosgemeenschap duiden op een respons van de bodemfauna op het uitsluiten van de boomkorvisserij. De verwachting is dat een vermindering van visserijdruk resulteert in een verbeterde overleving van de voor visserij gevoelige soorten.

Deze responsparameters zijn allemaal gebruikt in de verschillende analyses en de resultaten hiervan worden in de volgende paragrafen beschreven.

Niet alle analyses die in de eerste fase zijn uitgevoerd zijn herhaald in de tweede fase. Veel details over methoden worden hier niet meer uitgebreid besproken. Hiervoor verwijzen we naar Craeymeersch en Escaravage (2014).

\subsubsection{Combineren bodemschaaf en box corer data}

Voor de bemonstering van de bodemfauna zijn twee verschillende tuigen gebruikt omdat niet elk bodemorganisme op dezelfde manier goed bemonsterd kan worden. De grotere organismen leven 
vaak wat meer verspreid dan de kleinere organismen. Om de grotere organismen representatief te bemonsteren moeten over een groter oppervlak bemonsterd worden. Voor de kleine organismen die vaak in hogere dichtheden voorkomen is een kleiner bemonsteringsoppervlak voldoende.

De bodemschaafmonsters worden verzameld over een lengte van $150 \mathrm{~m}$ met een $10 \mathrm{~cm}$ breed mes dat 7-9 cm diep steekt (totale oppervlakte $15 \mathrm{~m}^{2}$ ) en worden over een $5 \mathrm{~mm}$-zeef gespoeld. Deze bemonstering is daarmee vooral geschikt voor de wat grotere organismen. De box corer monsters, met een oppervlakte van $0.078 \mathrm{~m}^{2}$ en een diepte van ca $20 \mathrm{~cm}$, worden op een $1 \mathrm{~mm}$ zeef gespoeld. Vooral kleinere organismen worden daarom correct bemonsterd d.m.v. een box corer.

In de praktijk komt het er op neer dat voor een goede kwantitatieve inschatting van bodemdierenpopulaties er feitelijk een combinatie van beide methodes nodig is. Omdat de twee apparaten niet alle grootteklassen even efficiënt bemonsteren, zijn beide datasets samengevoegd om zo een beter beeld te krijgen van de totale biomassa, en van de populatieopbouw van een aantal soorten. Het voordeel daarvan is dat we voorkomen dat alle analyses in tweevoud worden uitgevoerd met bijbehorende interpretatieproblemen in het geval van tegengestelde resultaten.

De soorten van de box corer en bodemschaaf datasets zijn ingedeeld in drie hoofdcategorieën:

1. Soorten die alleen in de box corer voorkomen.

2. Soorten die alleen in de bodemschaaf voorkomen.

3. Soorten die gevonden zijn in beide monstertuigen.

De soorten uit de eerste twee groepen kunnen probleemloos in een dataset ingevoerd worden. Voor de soorten die in beide monstertuigen gevonden zijn is er een onderscheid gemaakt tussen twee groepen:

3a. Voor soorten die efficiënter (i.v.m. lengte en/of dichtheid) waargenomen worden met de bodemschaaf of de box corer wordt gebruik gemaakt van de gegevens van het meest efficiënt monstertuig.

3b. Voor soorten die met beide tuigen efficiënt bemonsterd worden, en waar door uitsluiting van deze soort vele waarnemingen verloren zouden gaan, wordt een gemiddelde bepaald van de bodemschaaf en de box corer waarnemingen (in dat geval wordt Fabulina fabula $<7.5 \mathrm{~mm}$ en Ensis directus $<21.5 \mathrm{~mm}$ uit de box corer geselecteerd).

Een gedetailleerdere beschrijving van de werkwijze is weergegeven in Craeymeersch \& Escaravage (2014)).

\subsubsection{Van BACI-experiment naar analyse van correlaties}

$\mathrm{Na}$ de eerste fase bleek dat de visserij in het bodembeschermingsgebied en erbuiten zich anders ontwikkeld heeft dan vooraf verwacht. Aanvankelijk was de opzet van het onderzoek met betrekking tot $\mathrm{H} 1110$ gestoeld op een vergelijking tussen het bodembeschermingsgebied (Impact) en een referentiegebied (Control) voor (Before) en na (After) de instelling van de maatregel. Het voordeel van een dergelijke BACI aanpak is dat hiermee conclusies over causale relaties getrokken kunnen worden. Naar aanleiding van de analyse van de visserijdruk bleek dat de boomkorvisserij na de instelling van de maatregel niet alleen in het bodembeschermingsgebied was afgenomen, maar feitelijk in de hele Voordelta en langs de hele Nederlandse kust. Tegelijkertijd is in dezelfde periode de garnalenvisserij sterk toegenomen. Deze ontwikkeling maakte het onmogelijk om aan de oorspronkelijke analyse vast te houden: immers er was geen contrast meer in behandeling tussen controle en impact gebied.

Daarom hebben we in de tweede fase de analyses anders ingestoken. In plaats van een vergelijking in ontwikkeling tussen twee gebieden, onderzoeken we nu direct de relatie tussen visserij inspanning en visdichtheden op de bemonsterde plekken, los van of deze plekken in het bodembeschermingsgebied liggen of niet. In deze rapportage betrekken we de resultaten uit beide fases. Voor de resultaten van de BACI analyses verwijzen we naar de eindrapportage van de eerste fase (Prins \& Van der Kolff 2014, Prins et al. 2014c.

In de uitgevoerde statistische analyses zijn telkens de effecten van abiotische omstandigheden en de verandering in visserijdruk op de bodemfauna onderzocht. Dat is op een aantal verschillende manieren gedaan die hieronder in aparte paragrafen besproken worden. 


\subsubsection{Leeswijzer analyses}

Allereerst beginnen we met een algemene beschrijving van de ontwikkelingen in de Voordelta in de periode vanaf 2004. Dit doen we door voor de onderzochte parameters de ruwe tijdseries te geven in de drie onderscheiden deelgebieden het zuidelijk referentiegebied (Zuid), de ondiepe zandbanken (Midden) en het noordelijker gelegen open wateren (Noord, figuur 2.1). Hierbij is nog niet gecorrigeerd voor variatie veroorzaakt door abiotische omstandigheden. Voor een aantal kenmerkende soorten geven we in deze paragraaf ook verspreidingskaartjes. Omdat we in dit hoofdstuk de relatie tussen visserij en ontwikkelingen in bodemfauna onderzoeken horen hier feitelijk ook de ontwikkelingen in ruimte en tijd in de visserij bij. Hiervoor verwijzen we naar hoofdstuk 4 Visserij.

In paragraaf 5.1.7 laten we de resultaten van de habitatmodellering zien: we onderzoeken de tijdreeksen waarbij de variatie in abiotiek gebruikt wordt om de ruis veroorzaakt door andere factoren dan door variatie in visserijdruk te verminderen. Hierbij wordt elk monsterpunt gekoppeld aan de daar geldende abiotische omstandigheden en visserijdruk. De habitatmodellering is met twee verschillende technieken uitgevoerd: enerzijds met linear mixed models waarbij gecorrigeerd is voor ruimtelijke correlatie (paragraaf 5.1.7.3) en anderzijds met de op dit moment meest geavanceerde methode op basis van Bayesiaanse statistiek met INLA ( Integrated nested Laplace approximation), wat met name geschikt in situaties waar we te maken hebben met data die zowel in ruimte als in tijd gecorreleerd zijn (paragraaf 5.1.7.4). Tot nu toe hebben we steeds univariate methodes gebruikt: er wordt telkens maar een responsvariabele tegelijkertijd bestudeerd (bv totale biomassa, biomassa als voedsel voor vogels, aantal soorten).

In paragraaf 5.1 .8 onderzoeken we de bodemfaunagemeenschap als geheel met behulp van multivariate analyses. Is de verhouding tussen de individuele soorten veranderd en welke rol hebben abiotische veranderingen en visserijdruk hierbij gespeeld?

In paragraaf 5.1.9 laten we de indeling in soorten los, maar werken we met vier groepen van soorten, die ingedeeld zijn volgens de Trait Based Approach (TBA), een recent ontwikkelde en veel toegepaste aanpak voor bodemfauna in Europese projecten (zie paragraaf 5.4). Aan de hand van hun life history kenmerken zijn bodemdieren ingedeeld in vier groepen die verschillen in de mate waarin ze aangepast zijn aan verstoring. We volgen de ontwikkeling van die vier groepen in de tijd.

In paragraaf 5.1.9.2 gaan we verder met de Trait based Approach en groeperen we de bodemfauna op basis van hun life history kenmerken: we analyseren het deel van de biomassa dat een bepaalde kenmerk gemeenschappelijk heeft: bijvoorbeeld langlevende soorten, of op het oppervlak levende soorten (epifauna), of soorten die leven van voedsel dat op het oppervlak ligt (depositfeeders) en toetsten dit aan de verwachtingen die we hierover hebben in relatie tot gevoeligheid voor bodemvisserij.

Uit de analyses van de veranderingen in visserij bleek dat het grootste deel van de boomkorvisserij al verdwenen was voor aanvang van het project en dat de visserijdruk van garnalenvisserij sinds de aanleg van Maasvlakte2 erg is toegenomen. Daarom zoomen we in paragraaf 5.1.10 in op die plekken in de Voordelta waar een duidelijk contrast is geweest in visserij. We hebben twee sets monsterpunten geselecteerd (uit de totale set) die bevist zijn (garnalenvisserij) of waren (boomkorvisserij), een set voor elke visserij. Daarnaast hebben we voor beide sets een controleset geselecteerd die qua abiotiek zoveel mogelijk lijkt op de beviste set, afgezien van de bevissing. In deze analyse gebruiken we zowel univariate als multivariate methoden.

Hierna zoomen we verder uit waarbij we ontwikkelingen buiten de Voordelta (langs de Zuid- en NoordHollandse kust) vergelijken met die in de Voordelta (paragraaf 5.1.11). Dit doen we op basis van de data uit de WOTscheldiersurvey die elk voorjaar jaarlijks is uitgevoerd sinds 1995 . Hierbij onderzoeken we of waargenomen veranderingen in een aantal bodemfaunasoorten te relateren zijn 
aan veranderingen in visserijdruk door boomkor- en of garnalenvisserij. Voor deze analyses zijn er geen gedetailleerde data over abiotiek beschikbaar.

In de discussie over het mogelijke effect van bodemberoerende visserij wordt vaak het argument gehanteerd dat natuurlijk verstoring door stormen en golven ook erg groot is in het dynamische kustgebied. Daarom geven we in paragraaf (5.1.12) een analyse van de natuurlijke verstoring in de Voordelta.

\subsubsection{Algemene beschrijving veranderingen in tijd en ruimte}

Voor een aantal soorten geven we de verspreiding in de jaren 2004-2015 (figuur 5.1-5.5). De soortkeuze is gebaseerd op dominante soorten (bv Ensis directus) of soorten die een opvallende ontwikkeling laten zien (Ophiura ophiura, Spio sp, Abra alba) of soorten met een typische ruimtelijke verspreiding (Mya arenaria). Andere soorten zijn te vinden via de visualisatietool (https://gammarus.shinyapps.io/H1110_app/) De abundantie van Ensis varieert sterk, waarbij 2009 er uitspringt met de hoogste dichtheden en grootste verspreiding (figuur 5.1). De verspreiding van Mya is beperkt tot de Haringvlietmond en enkele plekken dicht langs de kust en nam in de loop van de periode sterk af (figuur 5.2). Spio komt in de hoogste dichtheden voor in het Noordelijkste deel, maar laat vanaf 2010 ook een duidelijke toename in het zuidelijke deel zien. In 2015 waren de dichtheden weer veel lager en de verspreiding beperkter (figuur 5.3). Het voorkomen van Abra kenmerkt zich doordat de soort steeds op dezelfde plekken voorkomt, bv de zuidwestpunt voor Schouwen (figuur 5.4). Ophiura neemt toe over de periode en komt heel geclusterd voor, bijvoorbeeld in sommige jaren voor de Brouwersdam (figuur 5.5).

Het verloop van de zes geselecteerde parameters in de drie deelgebieden laat zien dat de dichtheid biomassa en het aantal taxa in het Noordelijk gebied in de hele periode hoger was dan in het Midden en Zuiden (figuur 5.6). Dat geldt niet voor biomassa als voedsel voor vogels. Voor de overige parameters zijn geen duidelijke consistente gebiedsverschillen. Het gemiddeld individueel gewicht vertoont een langzame daling over de periode. De toename in de tijd van aantal taxa heeft waarschijnlijk te maken met een verdere specialisatie in de determinatie. 


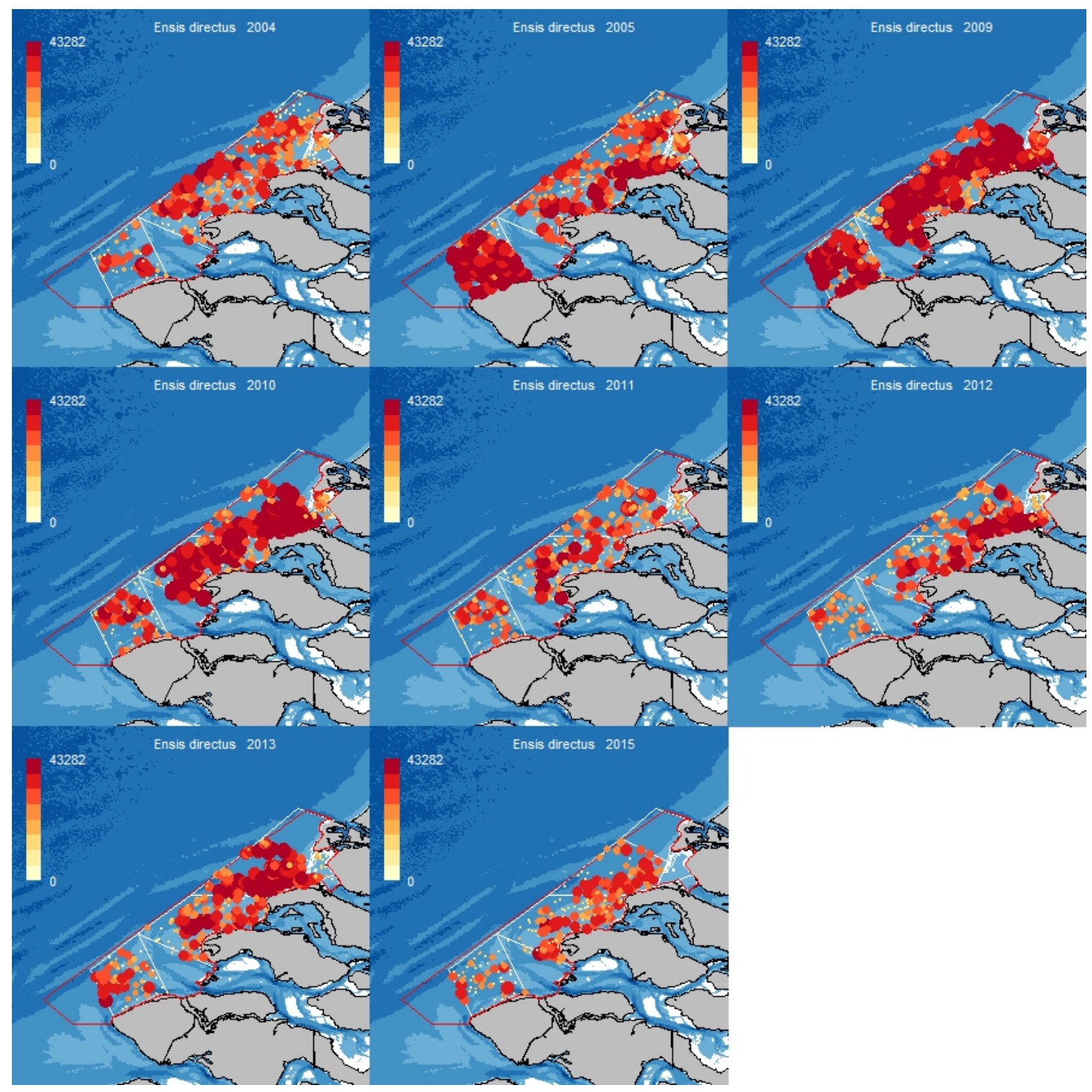

Figuur 5.1. Dichtheid van de Amerikaanse zwaardschede Ensis directus (ind $/ \mathrm{m}^{2}$ ). De kleurenschaal en de diameter van de cirkels is afhankelijk van de dichtheid. Bij de kleurenschaal is ook de minimale en maximale dichtheid weergegeven. 


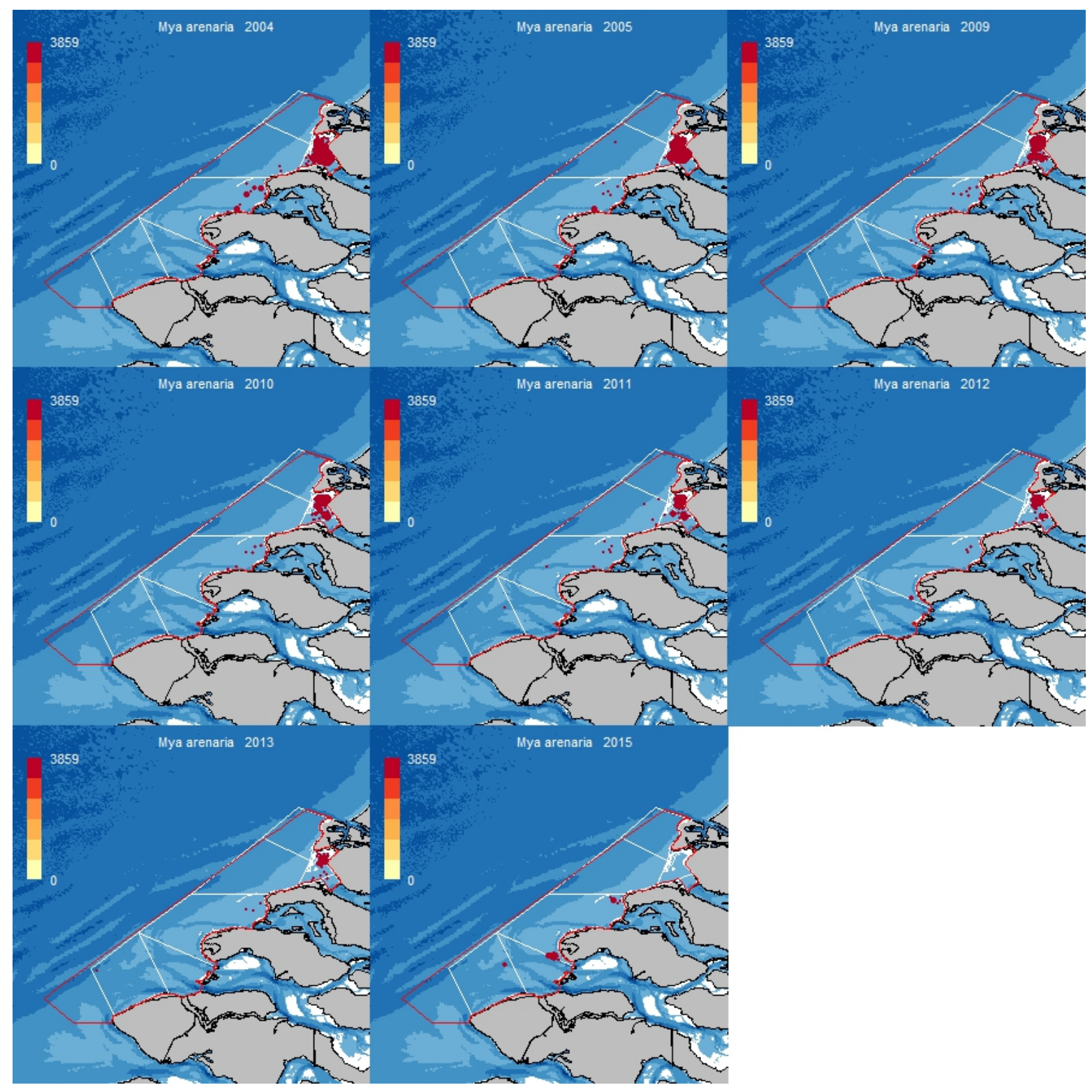

Figuur 5.2. Dichtheid van de strandgaper Mya arenaria (ind $/ \mathrm{m}^{2}$ ). De kleurenschaal en de diameter van de cirkels is afhankelijk van de dichtheid. Bij de kleurenschaal is ook de minimale en maximale dichtheid weergegeven. 


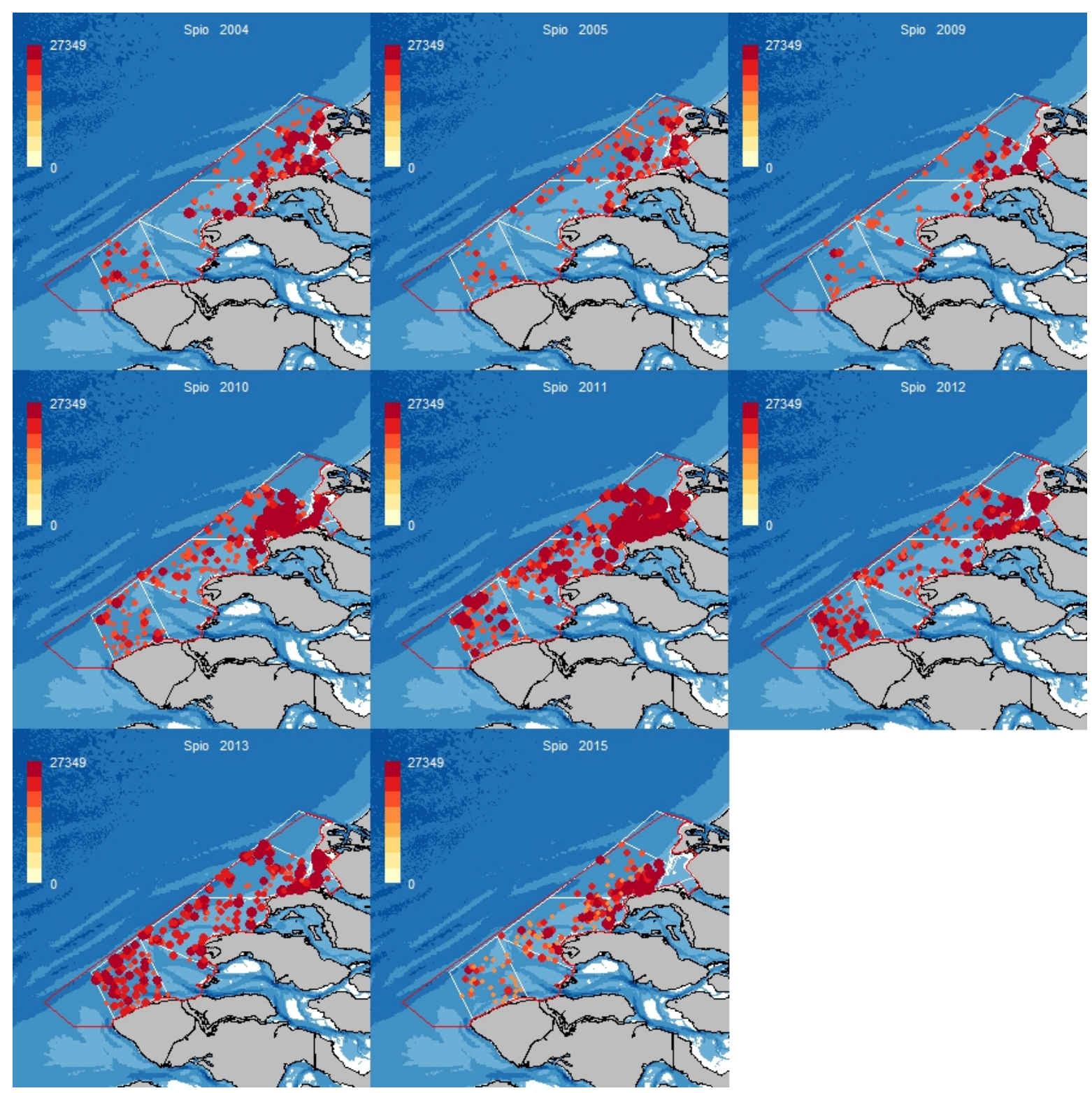

Figuur 5.3. Dichtheid van de borstelworrm Spio sp. (ind $/ \mathrm{m}^{2}$ ). De kleurenschaal en de diameter van de cirkels is afhankelijk van de dichtheid. Bij de kleurenschaal is ook de minimale en maximale dichtheid weergegeven. 


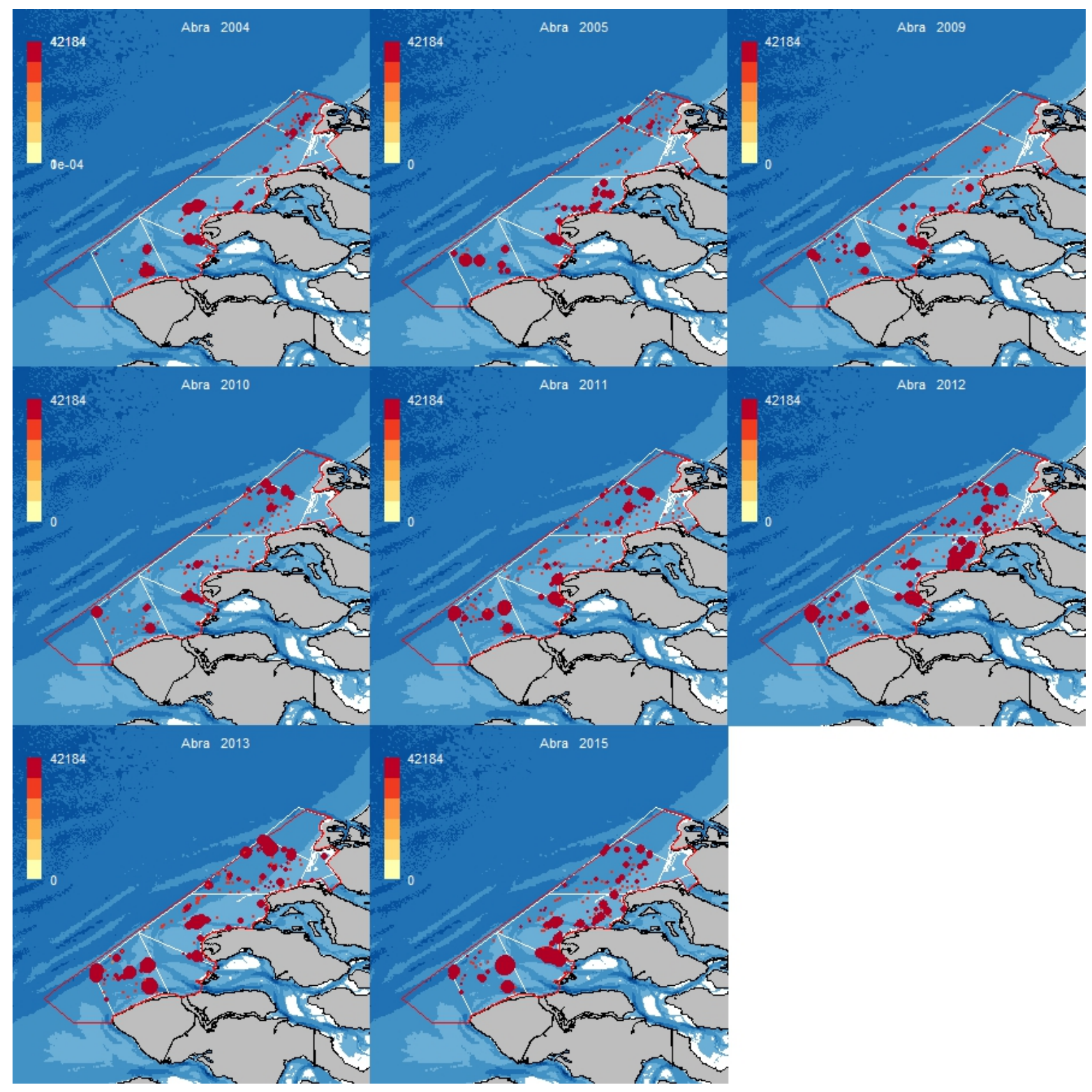

Figuur 5.4. Dichtheid van de witte dunschaal Abra alba (ind $/ \mathrm{m}^{2}$ ). De kleurenschaal en de diameter van de cirkels is afhankelijk van de dichtheid. Bij de kleurenschaal is ook de minimale en maximale dichtheid weergegeven. 


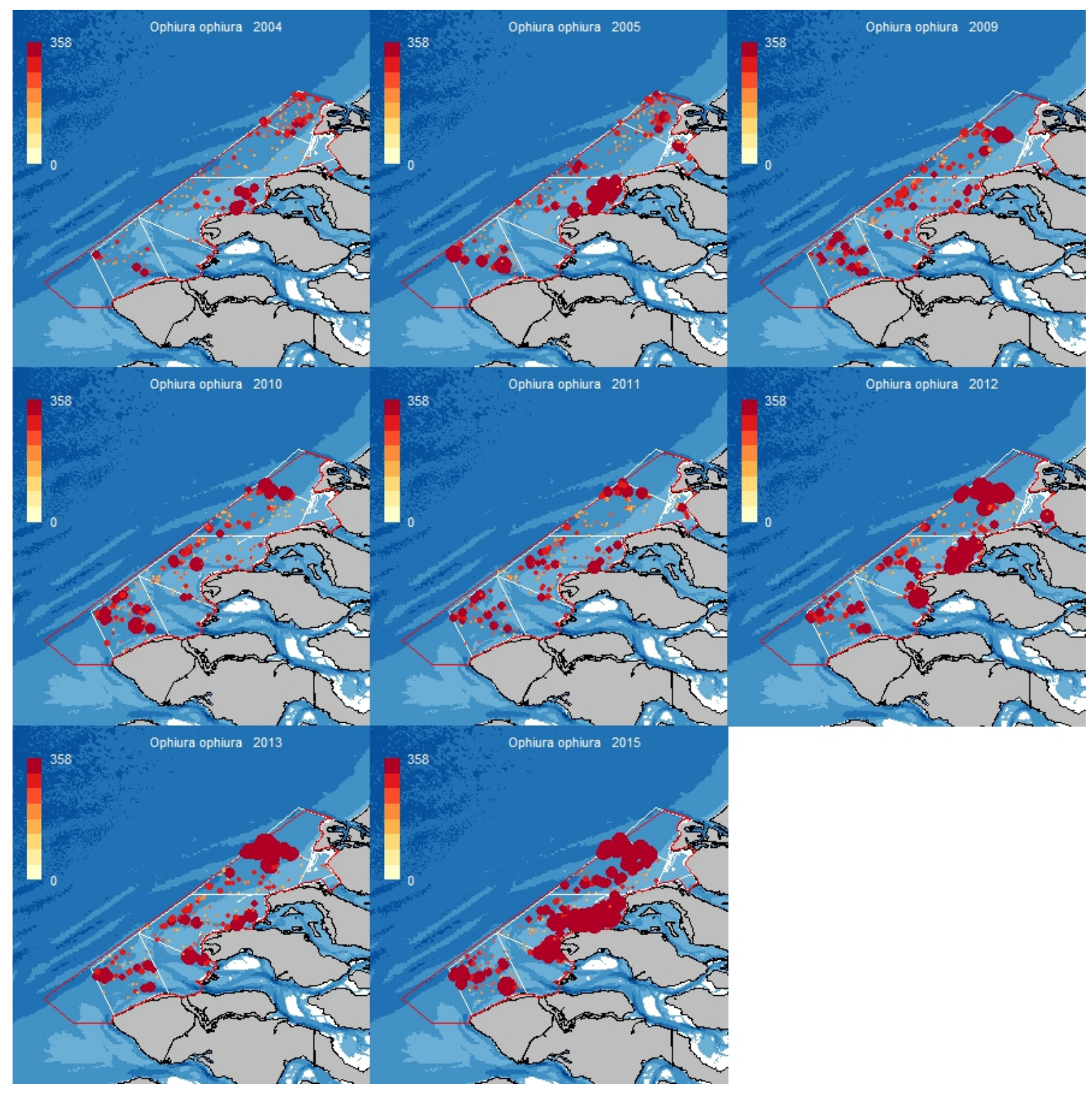

Figuur 5.5. Dichtheid van de gewone slangster Ophiura ophiura (ind $/ \mathrm{m}^{2}$ ). De kleurenschaal en de diameter van de cirkels is afhankelijk van de dichtheid. Bij de kleurenschaal is ook de minimale en maximale dichtheid weergegeven. 


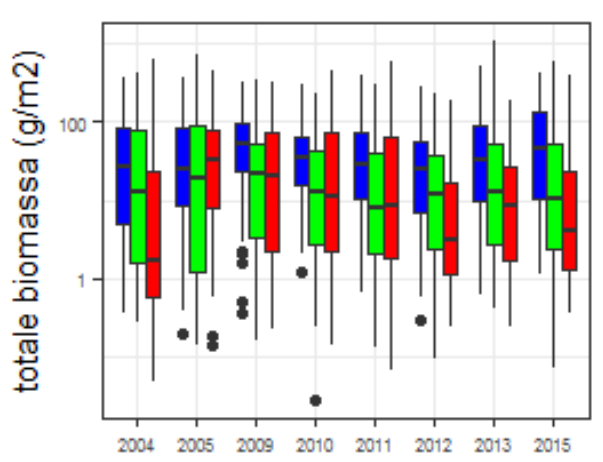

jaar
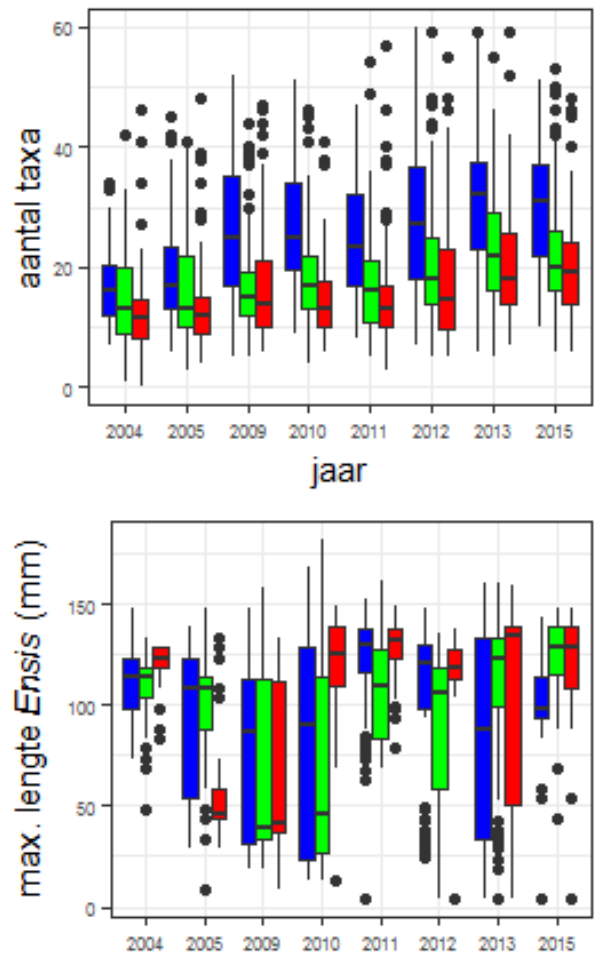

jaar

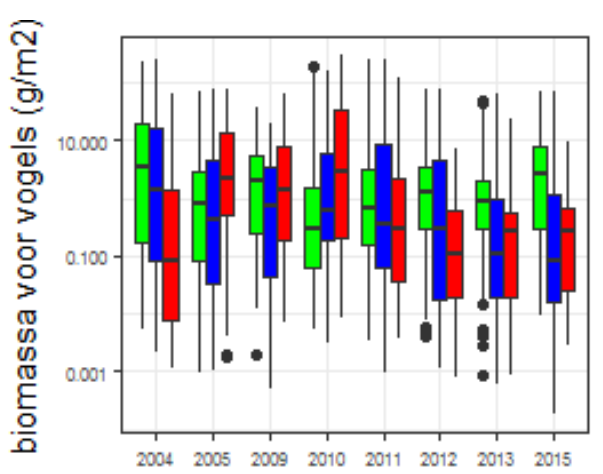

jaar

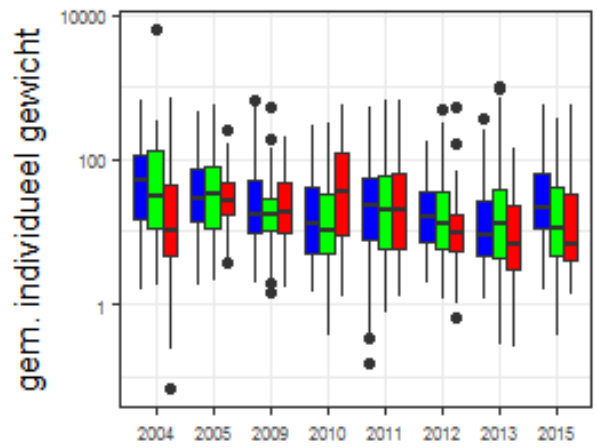

jaar
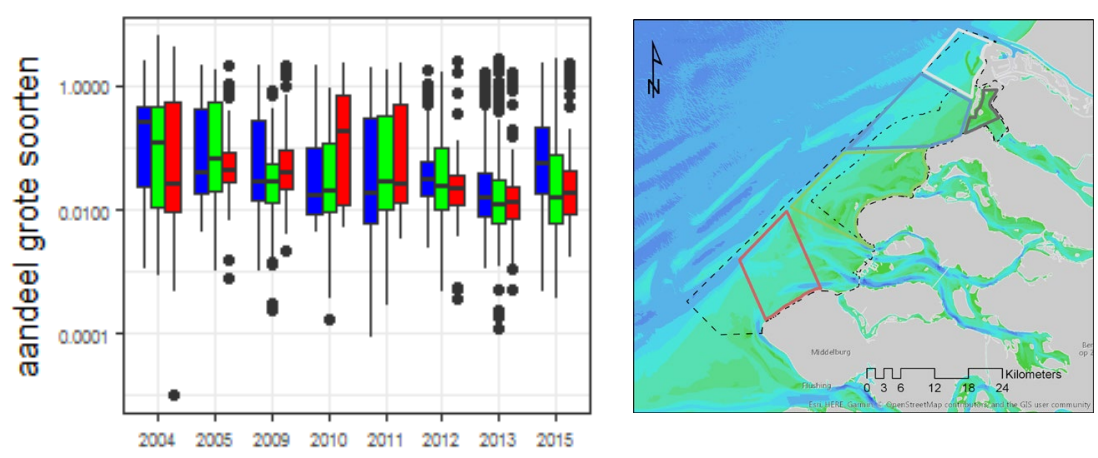

jaar

Figuur 5.6. Trend in de zes verschillende parameters in de drie deelgebieden Noord, Midden en Zuid.

\subsubsection{Veranderingen in bodemfauna in relatie tot abiotiek en visserij: habitatmodellering}

\subsubsection{Statistische analyse}

Eventuele ruimtelijke en temporele verschillen in abiotische karakteristieken zullen een effect hebben op de aanwezige bodemfauna. We hebben daarom geanalyseerd welke abiotische omstandigheden significant gecorreleerd zijn met de geselecteerde indicatoren voor de beschrijving van de toestand van de bodemdiergemeenschappen. Door het meenemen van zoveel mogelijk relevante abiotische factoren (temperatuur, diepte, stroomsnelheid, etc.) als verklarende factor kan de kracht van het model om een eventuele significante invloed van verandering in visserijdruk te detecteren, vergroot worden.

Niet alle mogelijk relevante omgevingsfactoren konden meegenomen worden in de statistische analyse. Uit recent modelwerk voor de MER Zandwinning is gebleken, dat op de schaal van de Nederlandse kustzone de ruimtelijke verdeling van biomassa van bodemdieren grotendeels verklaard kan worden door ruimtelijke patronen in voedselaanbod (primaire productie van fytoplankton) en slibconcentraties (van der Kaaij et al. 2017). Het is niet bekend of dit op de kleinere ruimtelijke schaal van de Voordelta ook van toepassing is. Het ontbreekt op dit moment aan gegevens die op de schaal 
van de bodemdierbemonstering informatie kan leveren over het voedselaanbod. In de toekomst is dit wellicht wel mogelijk op basis van satellietdata.

Bij de bemonstering van de bodemfauna wordt een groot aantal punten bemonsterd. Hierbij is de kans groot dat punten die dicht bij elkaar liggen meer op elkaar lijken dan punten die verder van elkaar verwijderd zijn. We noemen dat ruimtelijke autocorrelatie. Daarom mag je in een statistische analyse deze punten niet als onafhankelijke waarnemingen beschouwen. Hiermee is rekening gehouden door een ruimtelijke correlatiestructuur toe te voegen. Daarnaast is ook rekening gehouden met temporele autocorrelatie (metingen op hetzelfde punt in opeenvolgende jaren zullen meer op elkaar lijken dan metingen op hetzelfde punt verder uit elkaar in de tijd).

De habitatanalyse is met twee verschillende methoden uitgevoerd.

1. LME-(Linear Mixed Effects) modellen waarbij locatie als random factor is meegenomen volgens de methodiek beschreven in (Zuur et al. 2009). Voor verdere uitleg van de modellering verwijzen we naar Craeymeersch et al. (2015a)

2. Sinds de eerste fase van PMR-NCV is de statistiek weer verder ontwikkeld en de meest passende methode om dit soort habitatmodellering uit te voeren is met R-INLA (Integrated Nested Laplace Approximation). Hierbij hebben we de hulp ingeschakeld van Alain Zuur, die deze methode goed toegankelijk heeft gemaakt voor onderzoekers (Zuur et al. 2017).

Op basis van het Akaike Information Criterion (AIC) is per analyse het eenvoudigste model geselecteerd. Alle gefitte modellen zijn gevalideerd volgens de geijkte methoden (Zuur et al. 2009, Zuur et al. 2017).

De analyses zijn uitgevoerd voor drie selecties van data:

1) de totale set punten in de periode 2004-2015.

2) Omdat de boomkorvisserij in de Voordelta vooral in de diepere gebieden plaatsvindt, zijn alle analyses ook uitgevoerd voor alleen de punten die dieper dan $10 \mathrm{~m}$ liggen. Daarbij is de analyse beperkt tot de periode waarin nog wat hogere visserij-intensiteiten waargenomen zijn (2004-2005).

3) In een deel van de Voordelta (Noord) is vanaf 2009 ook sprake van een toename van de garnalenvisserij. Een derde analyse is daarom uitgevoerd met data uit dit gebied, minder dan $10 \mathrm{~m}$ diep en de periode 2009-2015, met de focus op de relatie tussen de benthische indicatoren en garnalenvisserij.

Voor deze drie selecties worden in figuur 5.7 de trends in de tijd gegeven, over de hele onderzoeksperiode. De totale biomassa fluctueert maar vertoont geen duidelijke trend. In alle gebieden is de totale biomassa van dezelfde grootteorde. Ook de biomassa als voedsel voor vogels verschilt jaarlijks, zonder duidelijke trend. De waardes zijn hoger in de diepere delen van de Voordelta (selectie 2). Het aantal taxa is lager in het ondiepe deel van het Noorden (selectie 3). In alle gebieden neemt het aantal taxa toe. Ook het gemiddelde individuele gewicht vertoont jaarlijkse fluctuaties. In selectie 3 zijn er de laatste 2 jaar $(2013,2015)$ hogere waardes gevonden. Hetzelfde geldt voor het aandeel grote soorten. De maximale lengte van Amerikaanse zwaardscheden fluctueert sterk over de jaren heen, met een grote variatie tussen de monsters. Ook zijn er met name verschillen tussen het selectie 3 en de overige gebieden. Dit is toe te schrijven aan ruimtelijke en temporele verschillen in broedval- en overlevingssucces. 


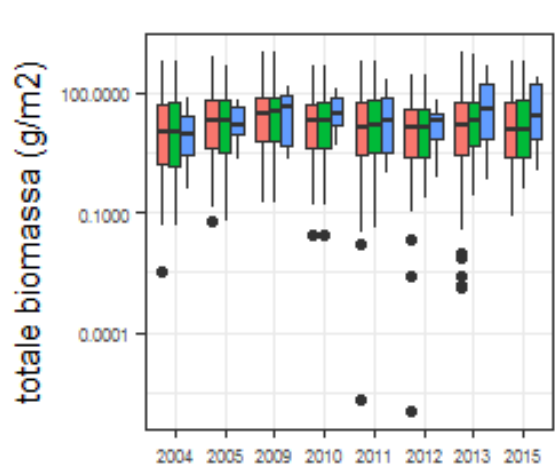

jaar

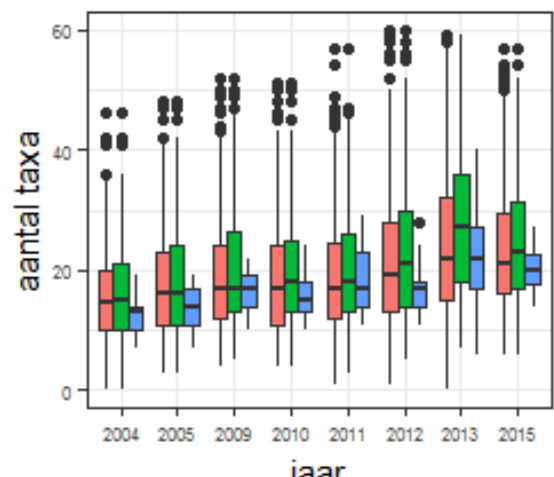

jaar

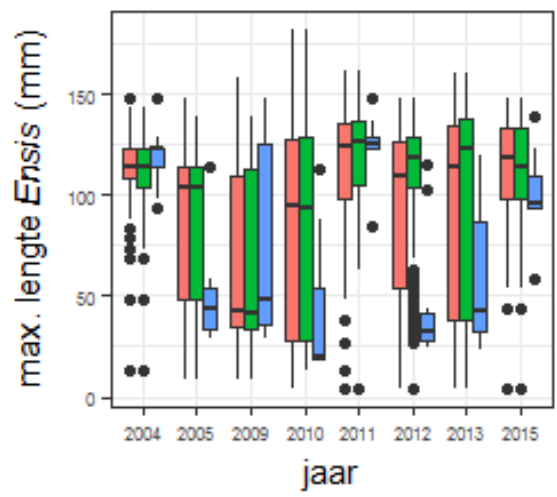

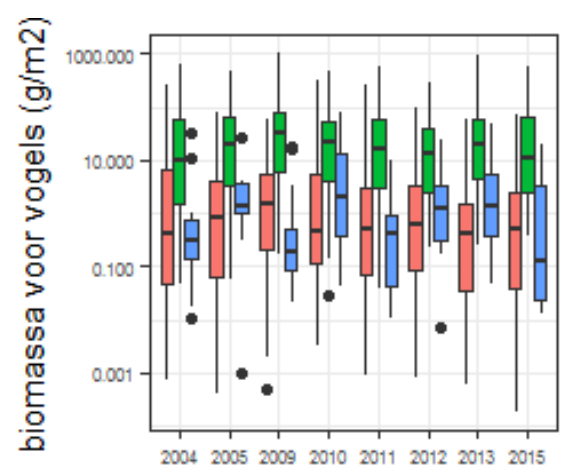

jaar

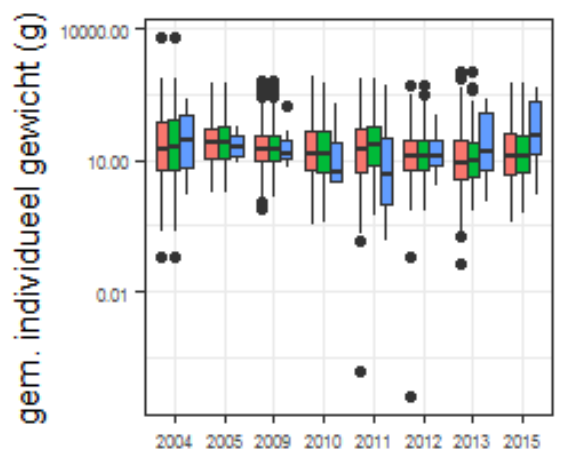

gebiedsselectie

宁alle punten

selectie boomkorvisserij

selectie garnalenvisserij

Figuur 5.7. Temporeel verloop van de totale biomassa ( $\mathrm{AFDW} / \mathrm{m} 2$ ), de totale biomassa als voedsel voor zwarte zee-eenden ( $\mathrm{g}$ AFDW/m2), het aantal taxa, het gemiddeld individueel gewicht, het aandeel grote soorten en de maximale lengte van Ensis directus in de drie gebieden waarvoor relatie met abiotiek en visserij-intensiteit gemodelleerd is (alle monsterpunten; monsterpunten dieper dan $10 \mathrm{~m}$, geselecteerd voor analyse boomkorvisserij; monsterpunten in Noord en ondieper dan 10m, geselecteerd voor analyse garnalenvisserij). 


\subsubsection{Verklarende variabelen}

In de habitatmodellering is gebruik gemaakt van de volgende gemeten of berekende waardes per locatie en enkele abiotische variabelen bepaald uit modelberekeningen (perceel Abiotiek, tabel 5.1)

Een deel van deze variabelen bleek onderling sterk gecorreleerd (collineair, zie ook Craeymeersch et al. (2015a)). Daarom is een selectie van deze variabelen in de uiteindelijke analyses gebruikt: VarSalSummer, MaxVel, MaxTauGolf, , naast diepte en mediane korrelgrootte.

De strengheid van de winter (bodemtemperatuur die in de voorafgaande winter 5 achtereenvolgende dagen onderschreden is (T5_winter)) kon niet meegenomen worden, omdat deze (gemodelleerde) data (uit perceel Abiotiek) niet beschikbaar zijn voor 2004. Bovendien was in deze factor niet significant in eerdere analyses (Craeymeersch en Escaravage (2014)).

Naast abiotische variabelen is de visserijdruk door boomkorvisserij (TBB) en garnalenvisserij (TBS) als verklarende variabele gebruikt. Hiervoor is de visserijdruk in het jaar voorafgaand aan de bemonstering gebruikt. De berekening hiervan is omschreven in Craeymeersch et al. (2015a). Indien nodig zijn abiotische data getransformeerd. Zie voor details Craeymeersch et al. (2015a).

Tabel 5.1

Variabelen gebruikt in de habitatmodellering.

\begin{tabular}{|c|c|c|}
\hline afkorting & omschrijving & herkomst \\
\hline Sed_med & mediane korrelgrootte & waarneming tijdens survey \\
\hline diepte & diepte t.o.v. NAP & waarneming tijdens survey \\
\hline AvgSalSpring & $\begin{array}{l}\text { De gemiddelde saliniteit aan de bodem in de } \\
\text { periode maart-mei }()\end{array}$ & model \\
\hline MinSal & $\begin{array}{l}\text { De minimale saliniteit aan de bodem in de } \\
\text { periode februari-juni (minimum van } \\
\text { maandelijks 5-percentiel) }\end{array}$ & model \\
\hline VarSalSpring & $\begin{array}{l}\text { De standaardeviatie (RMS) van de saliniteit } \\
\text { per seizoen als maat voor de schommelingen } \\
\text { (lengte: maart-mei, zomer: juni-augustus, } \\
\text { herfst: september-november, winter: } \\
\text { december-februari) }\end{array}$ & model \\
\hline S25_Winter & $\begin{array}{l}\text { Aantal dagen dat saliniteit in de voorafgaande } \\
\text { winter kleiner was dan } 25 \mathrm{ppt}\end{array}$ & model \\
\hline VelMax & $\begin{array}{l}\text { De maximale stroomsnelheid (maximum van } \\
\text { maandelijks 95-percentiel in de periode } \\
\text { januari-december) }\end{array}$ & model \\
\hline TauMaxVel & $\begin{array}{l}\text { De maximale bodemschuifspanning t.g.v. } \\
\text { stroming (maximum van maandelijks 95- } \\
\text { percentiel in de periode januari-december) }\end{array}$ & model \\
\hline MaxTauGolf & $\begin{array}{l}\text { De maximale bodemschuifspanning t.g.v. } \\
\text { golven (maximum van maandelijks 95- } \\
\text { percentiel in de periode januari-december) }\end{array}$ & model \\
\hline AvgTauGolf & $\begin{array}{l}\text { De gemiddelde bodemschuifspanning t.g.v. } \\
\text { golven (gemiddelde van maandelijks } \\
\text { gemiddelde waardes in de periode januari- } \\
\text { december; in } 2004 \text { vanaf juli) }\end{array}$ & model \\
\hline
\end{tabular}

\subsubsection{Resultaten Linear mixed models}

De uiteindelijk geselecteerde modellen laten voor diepte, mediane korrelgrootte, saliniteit, bodemschuifspanning en maximale stroomsnelheid significante effecten zien voor de meeste responsvariabelen (tabel 5.2). Biomassa en het aantal taxa is groter in diepere gebieden en ook het aandeel grote soorten en het gemiddeld individueel gewicht neemt toe met diepte. De biomassa parameters en het totaal aantal taxa nemen af in grover sediment. De gemiddelde lengte van Ensis neemt juist toe in grover sediment. Saliniteit is alleen significant voor aantal taxa en gemiddelde lengte van Ensis (beide negatief). Bodemschuifspanning laat negatieve effecten zien voor totale 
biomassa, aantal taxa en maximale lengte Ensis. Het aantal taxa was juist positief gecorreleerd met bodemschuifspanning. De meeste responsevariabelen nemen af met toenemende maximale stroomsnelheid, behalve het aantal taxa, dat neemt juist toe.

Voor alle responsvariabelen behalve de totale biomassa en het aandeel grote soorten zijn significante relaties met visserijdruk. Biomassa voor vogels en gemiddeld individueel gewicht zijn positief gecorreleerd met boomkorvisserij, maar aantal taxa en gemiddelde lengte van Ensis negatief. Voor de visserijdruk door garnalenvisserij zijn drie positieve relaties gevonden: zowel totale biomassa, biomassa voor vogels en aantal taxa nemen toe bij hogere visserijdruk.

Wanneer de analyse beperkt wordt tot alleen de punten die dieper dan $10 \mathrm{~m}$ liggen en alleen de punten uit de TO (2004-2005), veranderen de relaties in een aantal gevallen (tabel 5.3). Het effect van diepte verdwijnt (behalve voor het aandeel grote soorten: positief effect van diepte).

De relatie tussen de visserijdruk door boomkorvisserij en vijf van de zes responsvariabelen (behalve de gemiddelde lengte van Ensis) is positief.

Wanneer de analyse beperkt wordt tot de punten ondieper dan $10 \mathrm{~m}$ in deelgebied Noord, en periode vanaf 2009 (om in te zoomen op alleen het gebied en de periode waarin een toename in garnalenvisserij is geweest) dan wordt voor geen enkele indicator een relatie met visserijdruk gevonden, ook niet met garnalenvisserij (tabel 5.4).

Over het algemeen is het zo dat de random factoren (ruimtelijke en temporele correlatie, factoren die bijvoorbeeld met de dispersiemechanismen van soorten te maken hebben) veel meer van de variatie verklaren dan de fixed factoren (abiotiek, visserij, figuur 5.8).

\section{Tabel 5.2}

Overzicht van resultaten van de lineair mixed modellen. Alleen de uiteindelijk geselecteerde modellen (achterwaartse selectie) zijn gepresenteerd (op basis van Akaike Informatie Criterium). De analyse is uitgevoerd op alle monsterpunten in de periode 2004-2015 (zonder 2014), zonder de extra punten in de gesloten gebieden Bollen van de Ooster en Bollen van het Nieuwe Zand. Per responsvariabele (in kolommen) is aangegeven welke verklarende variabelen (fixed en random) significant zijn. De getallen geven de coëfficiënten aan, groen zijn significant positieve effecten, rood significant negatief effecten. De kruisjes geven aan of de betreffende variantiestructuur tot een beter model leidde.

\begin{tabular}{|c|c|c|c|c|c|c|c|c|}
\hline \multicolumn{3}{|c|}{ verklarende factoren } & \begin{tabular}{|c|} 
totale \\
biomassa \\
(Btot)
\end{tabular} & $\begin{array}{c}\text { biomassa } \\
\text { voor } \\
\text { vogels } \\
\text { (Bvogel) } \\
\end{array}$ & $\begin{array}{c}\text { aantal } \\
\operatorname{taxa}(\mathrm{S})\end{array}$ & $\begin{array}{c}\text { gem. ind. } \\
\text { gewicht } \\
\text { (indw) }\end{array}$ & $\begin{array}{c}\text { aandeel } \\
\text { grote } \\
\text { soorten } \\
\text { (W95) } \\
\end{array}$ & $\begin{array}{c}\text { max } \\
\text { lengte } \\
\text { Ensis } \\
\text { (L95) }\end{array}$ \\
\hline \multirow[t]{5}{*}{ fixed } & \multirow[t]{3}{*}{ abiotiek } & diepte & 0.0270 & 0.0512 & 0.0846 & 0.1280 & 20.06781 & - \\
\hline & & mediane korrelgrootte & -0.0012 & -0.0015 & -0.0020 & - & - & 0.0465 \\
\hline & & saliniteit & - & - & -0.2882 & - & - & -6.4646 \\
\hline & \multirow[t]{2}{*}{ visserijdruk } & boomkorvisserij & - & 0.3465 & -0.4780 & 0.3125 & - & -8.7858 \\
\hline & & garnalenvisserij & 0.1076 & 0.2462 & 0.6614 & - & - & - \\
\hline random & Iocatie & & $x$ & $x$ & $x$ & $\mathrm{x}$ & $x$ & $x$ \\
\hline $\begin{array}{l}\text { andere } \\
\text { variantiestructuur } \\
\text { per deelgebied }\end{array}$ & & & $\mathrm{x}$ & $x$ & $x$ & $x$ & $x$ & $x$ \\
\hline
\end{tabular}


Tabel 5.3

Zie omschrijving tabel 5.2, dezelfde analyses beperkt tot alle punten dieper dan $10 \mathrm{~m}$ in de periode 2004-2005.

\begin{tabular}{|c|c|c|c|c|c|c|c|c|}
\hline \multicolumn{3}{|c|}{ verklarende factoren } & \begin{tabular}{|c} 
totale \\
biomassa \\
(Btot)
\end{tabular} & \begin{tabular}{|c|} 
biomassa \\
voor \\
vogels \\
(Bvogel) \\
\end{tabular} & $\begin{array}{c}\text { aantal } \\
\operatorname{taxa}(\mathrm{S})\end{array}$ & $\begin{array}{l}\text { gem. ind. } \\
\text { gewicht } \\
\text { (indw) }\end{array}$ & \begin{tabular}{|c|} 
aandeel \\
grote \\
soorten \\
(W95) \\
\end{tabular} & $\begin{array}{c}\max \\
\text { lengte } \\
\text { Ensis } \\
\text { (L95) } \\
\end{array}$ \\
\hline \multirow[t]{6}{*}{ fixed } & \multirow[t]{5}{*}{ abiotiek } & diepte & - & - & - & - & 49.7154 & - \\
\hline & & mediane korrelgrootte & -0.0015 & - & -0.0078 & - & 0.8824 & - \\
\hline & & saliniteit & -0.3573 & - & 1.4842 & -0.9762 & - & -0.976 \\
\hline & & bodemschuifspanning golven & -0.9109 & -1.8269 & -2.6392 & - & - & - \\
\hline & & max stroomsnelheid & -2.4826 & -3.8062 & -4.5899 & -4.2555 & -1334.88 & - \\
\hline & visserijdruk & boomkorvisserij & 0.3998 & 0.3393 & 0.9074 & 0.9880 & 194.5929 & - \\
\hline random & locatie & & $x$ & $x$ & $x$ & $\mathrm{x}$ & - & $x$ \\
\hline \multicolumn{3}{|c|}{$\begin{array}{l}\text { andere } \\
\text { variantiestructuur } \\
\text { per deelgebied }\end{array}$} & $\mathrm{x}$ & $\mathrm{x}$ & $\mathrm{x}$ & - & $\mathrm{x}$ & - \\
\hline \multirow[t]{2}{*}{ autocorrelatie } & ruimte & & - & - & - & - & - & - \\
\hline & tijd & & - & $\mathrm{x}$ & - & - & - & - \\
\hline
\end{tabular}

\section{Tabel 5.4}

Zie omschrijving Tabel 5.2, dezelfde analyses beperkt tot periode 2009-2015, alle punten ondieper dan $10 \mathrm{~m}$ gelegen in deelgebied Noord Voordelta.

\begin{tabular}{|c|c|c|c|c|c|c|c|c|}
\hline \multicolumn{3}{|c|}{ verklarende factoren } & $\begin{array}{c}\text { totale } \\
\text { biomassa } \\
\text { (Btot) }\end{array}$ & \begin{tabular}{|c|} 
biomassa \\
voor \\
vogels \\
(Bvogel) \\
\end{tabular} & $\begin{array}{c}\text { aantal } \\
\operatorname{taxa}(\mathrm{S})\end{array}$ & $\begin{array}{c}\text { gem. ind. } \\
\text { gewicht } \\
\text { (indw) }\end{array}$ & \begin{tabular}{|c|} 
aandeel \\
grote \\
soorten \\
(W95) \\
\end{tabular} & $\begin{array}{c}\text { max } \\
\text { lengte } \\
\text { Ensis } \\
\text { (L95) } \\
\end{array}$ \\
\hline \multirow[t]{6}{*}{ fixed } & \multirow[t]{5}{*}{ abiotiek } & diepte & - & - & - & - & - & 7.5788 \\
\hline & & mediane korrelgrootte & - & - & -0.0037 & 0.0095 & - & - \\
\hline & & \begin{tabular}{|l} 
saliniteit \\
\end{tabular} & - & - & -2.9892 & 1.7284 & - & - \\
\hline & & bodemschuifspanning golven & - & - & - & & 2162.534 & - \\
\hline & & max stroomsnelheid & 1.0687 & 1.0754 & 0.8568 & 2.6012 & 1161.394 & -118.007 \\
\hline & visserijdruk & garnalenvisserij & - & - & - & - & - & - \\
\hline random & locatie & & $x$ & $x$ & - & $x$ & $x$ & - \\
\hline \multirow[t]{2}{*}{ autocorrelatie } & \multicolumn{2}{|l|}{ ruimte } & - & - & - & $x$ & $x$ & - \\
\hline & \multicolumn{2}{|l|}{ tijd } & - & - & - & - & - & - \\
\hline
\end{tabular}

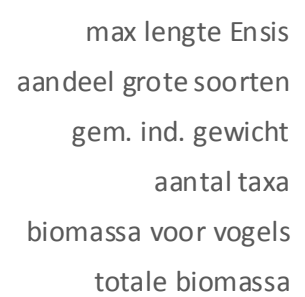

totale biomassa
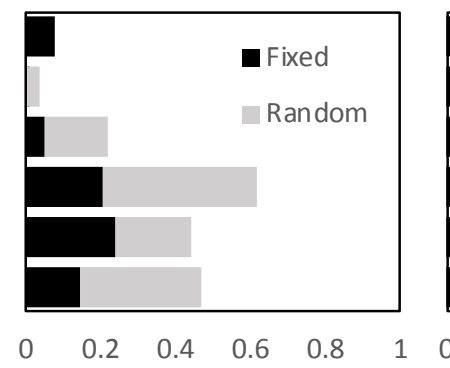
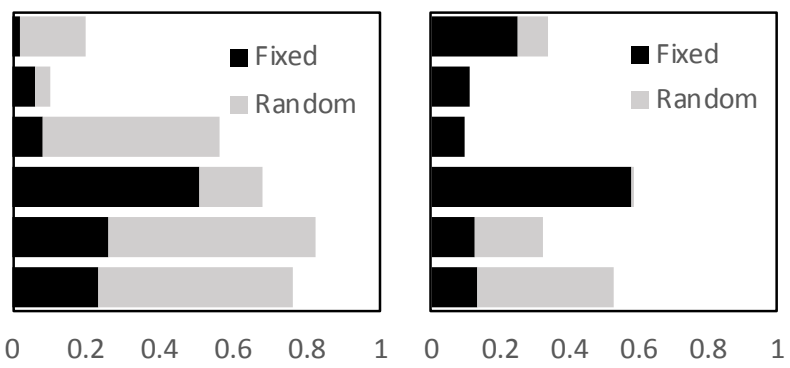

Figuur 5.8 Verdeling verklarende kracht van fixed (abiotiek, visserij) en random (ruimtelijke en temporele correlatie) variabelen gebaseerd op pseudo- $\mathrm{R}^{2}$ waardes uit de Linear Mixed modellen (links voor modellen gebaseerd op alle punten, midden voor T0 en alleen punten $>10 \mathrm{~m}$, rechts voor periode 2009-2015, alleen punten $<10 \mathrm{~m}$ gelegen in deelgebied Noord. 


\subsubsection{Resultaten R-INLA}

Voor de twee respons parameters totale biomassa en biomassa als voedsel voor vogels, is deze relatie opnieuw onderzocht (Alain Zuur, Highland Statistics) met de meest geavanceerde statistische technieken bedoeld voor analyses waarbij waarnemingen in de ruimte en in de tijd gecorreleerd zijn (met andere woorden punten die dicht bij elkaar liggen lijken meer op elkaar dan punten die verder uit elkaar liggen en waarnemingen uit opeenvolgende jaren lijken meer op elkaar dan waarnemingen met grotere tussenpozen). In deze analyse zijn in beginsel dezelfde selectie aan verklarende variabelen meegenomen als in de LME's (vorige paragraaf), met die kanttekening dat er strenger geselecteerd is op collineariteit. Dit is gedaan omdat de R-INLA modellen anders computertechnisch te moeilijk worden en teveel rekentijd vergen. Daarom is de selectie aan covariabelen beperkt tot: diepte, mediane korrelgrootte, visserijdruk door de boomkorvisserij en garnalenvisserij.

In Zuur en Ieno (2017a) worden de analyses uitgebreid beschreven. De analyse van de totale biomassa is uitgevoerd met een Gamma GAM (General Additive Model). Kenmerk van een dergelijke analyse is dat het effect van covariaten niet beschreven wordt door een lineaire relatie maar door een smoother: een flexibele (niet-lineaire) relatie tussen predictor en response variabele.

Uit de analyse van de totale biomassa (figuur 5.9) bleek dat de effecten van de covariaten (abiotische factoren, visserij) erg klein zijn vergeleken met de ruimtelijke variatie die niet door een van de covariaten verklaard wordt (tabel 5.5). Een informele vergelijking van de verklarende kracht (op basis van het Deviance Information Criterion (: DIC)) van modellen met en zonder covariaten en ruimtelijke correlatie leidt tot deze conclusie. Het verschil in DIC tussen het model met en zonder covariaten is aanzienlijk kleiner dan het verschil tussen een model met en zonder ruimtelijke correlatie (verschil in DIC tussen model 3 en 4 is erg klein, Tabel 5.5). Uit de analyse wordt duidelijk dat punten tot $3 \mathrm{~km}$ afstand zijn gecorreleerd, met een sterke correlatie in de afstand tot $1 \mathrm{~km}$. Wat betreft de effecten van beide visserijen geldt dat het betrouwbaarheidsinterval van de smoother voor boomkorvisserij over bijna de hele range 0 omvat, wat betekent dat die factor nauwelijks iets verklaart. Daarentegen laten de diepte en sediment smoother wel duidelijke patronen zien: een toename met diepte en een optimum bij 100-200 $\mu \mathrm{m}$ mediane korrelgrootte. Ook het effect van garnalenvisserij is duidelijk: een toename in biomassa bij een toenemende visserijdruk.

\section{Tabel 5.5}

Vergelijking van de verschillende modellen voor totale biomassa. Het model met de laagste DIC waarde is het best passende model.

\begin{tabular}{|l|r|r|}
\hline response variabele & $\begin{array}{l}\text { totale } \\
\text { biomassa }\end{array}$ & $\begin{array}{l}\text { biomassa als } \\
\text { voedsel voor } \\
\text { vogels }\end{array}$ \\
\hline model & $\begin{array}{l}\text { Deviance } \\
\text { Information } \\
\text { Criterion (DIC) }\end{array}$ & $\begin{array}{l}\text { Deviance } \\
\text { Information } \\
\text { Criterion (DIC) }\end{array}$ \\
\hline $\begin{array}{l}\text { GAM zonder covariaten zonder ruimtelijke/temporele } \\
\text { correlatie }\end{array}$ & 11433,62 & \\
\hline GAM met covariaten & 10248,45 & 8318,50 \\
\hline GAM met covariaten en ruimtelijke/temporele correlatie & 8712,09 & 6088,96 \\
\hline $\begin{array}{l}\text { GAM met ruimtelijke/temporele correlatie zonder } \\
\text { covariaten }\end{array}$ & 9095,21 & 6182,57 \\
\hline
\end{tabular}

De analyse van biomassa voor vogels (figuur 5.10) is ingewikkelder omdat er veel nullen in voorkomen (locaties waar de biomassa in een jaar nul was). Daarvoor is een Zero Altered Gamma Model (ZAG) model gebruikt: eerst wordt de aan-/afwezigheid gemodelleerd (met een Bernouillie GAM) en daarna voor de punten met positieve waarnemingen de dichtheid (met een Gamma GAM, zie Zuur \& Ieno (2017b). Ook hier is de conclusie met betrekking tot de verhouding tussen het belang van de ruimtelijke correlatie en de covariaten dat de verklaring door de ruimtelijke correlatie veel sterker is dan door de covariaten. Dat geldt zowel voor de aan-afwezigheid als voor de dichtheid. 

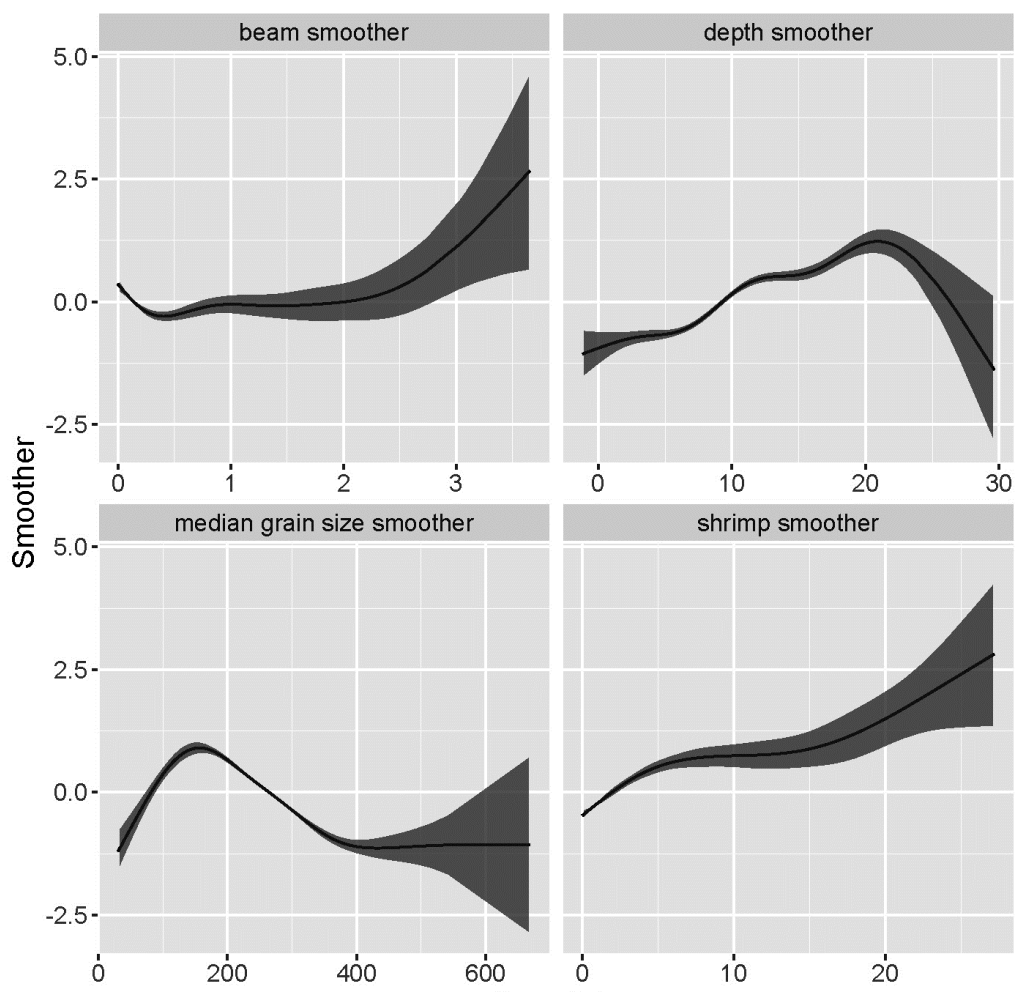

Figuur 5.9. Smoothers met $95 \%$ betrouwbaarheidsintervallen voor de smoothers uit het GAM model. met ruimtelijke/temporele autocorrelatie voor de analyse van totale biomassa.

(beam=boomkorvisserij en shrimp=garnalenvisserij in aantal trawlminuten per $50 \times 50 \mathrm{~m}$ gridcel in voorafgaande jaar; depth=diepte $(\mathrm{m})$; median grain size=mediane korrelgrootte $(\mu \mathrm{m})$.
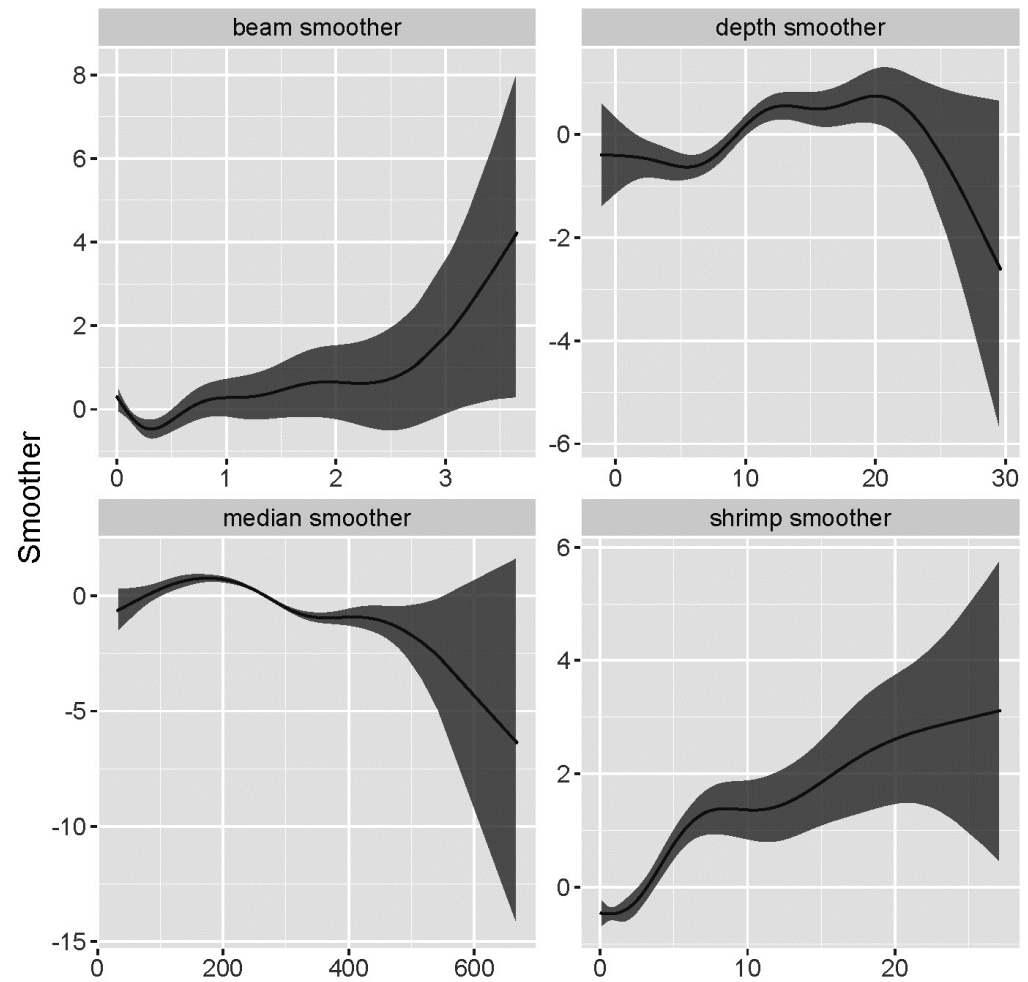

Figuur 5.10. Smoothers met $95 \%$ betrouwbaarheidsintervallen voor de smoothers uit het Gamma GAM deel van het ZAG model met ruimtelijke/temporele autocorrelatie voor de analyse van biomassa als voedsel voor vogels. (beam=boomkorvisserij en shrimp=garnalenvisserij in aantal trawlminuten per $50 \times 50$ m gridcel in voorafgaande jaar; depth=diepte $(\mathrm{m})$; median grain size=mediane korrelgrootte $(\mu \mathrm{m})$. 


\section{Deelconclusie}

- Abiotiek, visserijdruk (beide visserijen) en de correlatie in ruimte en tijd verklaren samen 40-80\% van de variatie in biomassa bodemdieren, maar slechts $<20 \%$ voor het aandeel grote soorten en de gemiddelde lengte van Ensis.

- Abiotiek en visserijdruk (beide visserijen) verklaren samen veel minder variatie dan de correlatie in ruimte en tijd.

- In de totale set vertonen twee van de zes onderzochte responsvariabelen een positieve relatie met visserijdruk door boomkorvisserij (biomassa voor vogels en gemiddeld individueel gewicht), twee een negatieve (aantal taxa, gemiddelde lengte Ensis), en de overige geen. De deelset laat voor alle parameters (behalve gem. lengte Ensis) een positief verband met boomkorvisserij zien.

- In de totale set vertonen drie van de zes onderzochte responsvariabelen (totale biomassa, biomassa voor vogels en aantal taxa) een positieve relatie met visserijdruk door garnalenvisserij en de overige drie geen. De deelset laat voor geen enkele parameter een verband met garnalenvisserij zien.

- $\quad$ De R-INLA analyses laten zien dat de verklarende kracht van abiotiek en visserijdruk gering zijn in verhouding tot de ruimtelijke correlatie. Van de covariaten laten alleen mediane korrelgrootte, diepte en de garnalenvisserij een duidelijk verband zien met totale biomassa en biomassa als voedsel voor vogels. Het verband met garnalenvisserij is positief: er is een hogere biomassa bij hogere visserijdruk.

\subsubsection{Veranderingen in bodemfaunagemeenschap: multivariate analyses}

\subsubsection{Statistische analyses}

In multivariate analyses wordt niet één enkele variabele in de analyses meegenomen (zoals bijv. in de habitatmodelleringen gepresenteerd in paragraaf 5.1.7.) maar wordt de bodemdiergemeenschap als geheel bekeken. Meerdere soorten worden in de analyse meegenomen, rekening houdend met de onderlinge samenhang (Legendre \& Legendre 1998).

We hebben multivariate analyses uitgevoerd via zogenoemde ordinatietechnieken. Daarbij wordt elk monster in een plot weergegeven als een punt in een multidimensionele ruimte met de dichtheden per soort als coördinaten. Het aantal dimensies is gelijk aan het aantal soorten. Vervolgens kan de dimensionaliteit gereduceerd worden door een nieuwe as te trekken zodanig dat deze de aanwezige variatie maximaal representeert. Een tweede, orthogonale, as kan getrokken worden om de overblijvende variatie maximaal te representeren, etc. voor verdere assen. Aldus laten de assen van dit plot -ook ordinatiediagram genoemd - de voornaamste trends in de data zien, in afnemende volgorde. In de ecologische praktijk volstaan meestal twee of drie assen. Hierbij is de eigenwaarde per as een maat voor de door deze as verklaarde variantie. In zo'n ordinatiediagram kunnen zowel de monsters als de soorten weergegeven worden, in aparte diagrammen of samen in een zogenaamd biplot. Op grond van de spreiding in de diagrammen kunnen conclusies getrokken worden over verschillen en overeenkomsten in de monsters, in soortensamenstelling en -dichtheid (Jongman et al. 1987, Borcard et al. 2011).

We hebben vier ordinatietechnieken gebruikt:

- Detrended Correspondentie Analyse (DCA),

- Redundantie Analyse (RDA),

- Canonische Correspondentie Analyse (CCA), en

- Partiële Canonische Correspondentie Analyse (pCCA).

Bij een DCA hebben de variabelen die potentieel een invloed hebben op het voorkomen van soorten (zoals bijvoorbeeld mediane korrelgrootte), en de dichtheden, geen invloed op de ordening van de monsters in het multidimensionale vlak. In deze studie hebben we getracht de assen te interpreteren in functie van de geomorfologische ligging, door deelgebieden in het ordinatiediagram te projecteren. Hierbij hebben we de deelgebieden zoals onderscheiden in figuur 2.1 gehanteerd: MV2 gebied, Haringvlietmond, Noord, Midden en Zuid, waarbij er duidelijke geomorfologische verschillen zijn. 
Noord omvat vooral open wateren, Midden vooral de ondiepe zandbanken en Zuid het referentiegebied voor de kust van Walcheren (zie figuur 2.1).

Ook hebben we een aantal abiotische variabelen (zie paragraaf 5.1.7.2) achteraf als vectoren in het ordinatiediagram geprojecteerd. Daarbij wordt bij projectie van de monsters op de vectoren de maximale correlatie met de overeenkomstige variabelen gerealiseerd, tenminste als deze variabelen het grootste deel van de variantie kunnen verklaren. De DCA-analyse is uitgevoerd met alle data van de jaren 2004-2015. Soorten/taxa die in minder dan 10 monsters gevonden werden, zijn niet meegenomen in de analyses. Ook zijn meerdere taxa samengevoegd, o.a. wegens verandering in taxonomisch inzicht en determinatiesleutels tijdens de onderzoeksperiode. Voor details zie Craeymeersch et al. (2015a).

Een op deze manier vastgestelde relatie tussen de resultaten van DCA en mogelijk verklarende variabelen is puur beschrijvend, zonder enige statistische test om de significantie vast te stellen. Zo'n test kan wel via een directe gradiëntanalyse (CCA).

De significantie van de relatie met een aantal abiotische variabelen hebben we onderzocht met een CCA. In eerste instantie zijn dezelfde abiotische variabelen gebruikt als bij de DCA-analyse en de habitatmodellen (paragraaf 5.1.7). Later zijn nog de volgende variabelen toegevoegd: hellingshoek en -richting, uitgedrukt t.o.v. het noorden en t.o.v. het zuiden. De analyses zijn uitgevoerd met data van de jaren 2004-2015 en met uitsluiting van de monsters genomen in de Haringvlietmond en in het noordelijke deel gelegen voor de kust van Maasvlakte 2 dat alleen tijdens de nulmetingen bemonsterd is.

De relatie met visserijdruk door boomkorvisserij en garnalenvisserij is onderzocht met een partiële ordinatie (pCCA). Hierbij is vooraf gecorrigeerd voor het effect van abiotische variabelen, evenals voor jaarlijkse fluctuaties. Zo kunnen we de relatie van soorten direct in verband brengen met visserijdruk. De analyses zijn uitgevoerd met verschillende dataselecties:

- data van de jaren 2004-2015 en met uitsluiting van de monsters genomen in de Haringvlietmond en in het noordelijke deel gelegen voor Maasvlakte 2 dat alleen tijdens de nulmetingen bemonsterd is. Daarbij is in afzonderlijke analyses de relatie met beide type visserijen onderzocht.

- data van de jaren 2004 en 2005, en bemonsterde locaties die dieper dan 10m waren. Deze selectie is gebruikt omdat dat de enige periode is dat er nog enige variatie in visserijdruk door boomkorvisserij binnen het gebied was. In deze subset is alleen relatie met boomkorvisserij onderzocht.

- Data vanaf 2009, locaties in deelgebied Noord en ondieper dan $10 \mathrm{~m}$. Deze selectie is gebruikt omdat hier de grootste variatie in visserijdruk door de garnalenvisserij voorkwam en is daarom gebruikt om de relatie met garnalenvisserij te onderzoeken.

De keuze om niet alle jaren mee te nemen komt voort uit de sterke correlatie tussen visserij en jaar. Als alle jaren meegenomen worden kan er niet meer gecorrigeerd worden voor jaarlijkse verschillen die te wijten zijn aan bijvoorbeeld temporele verschillen in broedval. Bij de eerste analyses bleek dat veel soorten met de sterkste positieve of negatieve relatie met visserij-intensiteit slechts op een gering aantal stations gevonden waren, zoals eerder vastgesteld (Craeymeersch et al. 2016a). Daarom zijn uiteindelijk alleen die taxa meegenomen die in meer dan $10 \%$ van de monsters aangetroffen waren.

DCA en CCA gaan ervan uit dat de soorten bij benadering volgens een Gauss-kromme op de omgevingsvariabelen reageren. In een aantal gevallen is echter een lineaire respons eerder te verwachten, bijv. als de gradiënten vrij kort zijn.

Voor een gerichte analyse naar veranderingen in de tijd en verschillen tussen deelgebieden is een RDA gebruikt. De analyse is uitgevoerd met data van de jaren 2004-2015 en met uitsluiting van de monsters genomen in de Haringvlietmond en in het noordelijke deel gelegen voor Maasvlakte 2 dat alleen tijdens de nulmetingen bemonsterd is.

De analyses zijn uitgevoerd met de dichtheden per soort na vierdemachtsworteltransformatie (om het relatieve grote gewicht van kwantitatief dominante soorten te verkleinen; (Field et al. 1982). Een deel van de abiotische variabelen is op dezelfde wijze getransformeerd als in Craeymeersch et al (2014): 
log10 (VarSalSummer), Diepte^0.75, sqrt (AvgTauGolf). Omdat de variabelen op schalen met een verschillend bereik gemeten worden, zijn ze verder gestandaardiseerd tot data met een gemiddelde van 0 en een variantie van 1 . De globale significantie van de relatie met alle variabelen samen is getest met een Monte-Carlo-permutatietest (999 permutaties). Op dezelfde manier is de significantie van iedere variabele afzonderlijk getest, alsook de significantie van de canonische assen, dit zijn de assen geconstrueerd als lineaire combinatie van de omgevingsvariabelen.

Collineariteit (als twee verklarende factoren sterk gecorreleerd zijn, bijv. diepte en temperatuur) is opgespoord door berekening van de zogenaamde Variation Inflation Factors (VIF). In dat geval bevat deze variabele weinig unieke informatie en is er sprake van overtollige verklarende variabelen. In dat geval is een van de collineaire variabelen verwijderd.

Alle analyses zijn uitgevoerd met de gecombineerde dataset (zie 5.3) en uitgevoerd met R ( $R$ Core Team 2013) en de bibliotheek vegan (Oksanen et al. 2016). Verder is ook gebruikt gemaakt van de bibliotheken RODBC (Ripley \& Lapsley 2015), rmarkdown (Allaire et al. 2017), sp (Pebesma et al. 2009), maptools (Bivand \& Lewin-Koh 2015) en raster (Hijmans 2016).

\subsubsection{Ruimtelijke verschillen in soortensamenstelling}

De eerste twee ordinatie-assen van de DCA-analyse verklaren $8.4 \%$ van de variantie in de dataset. figuur 5.11 geeft de ordening van de monsters in het eerste ordinatievlak. Daarin liggen monsters met eenzelfde soortensamenstelling dus dicht bij elkaar, monsters die sterk verschillen in soortensamenstelling ver uit elkaar. Duidelijk is dat er geen sprake is van echt aparte gemeenschappen, maar van gradiënten in soortensamenstelling en -dichtheid, gelieerd aan de geografische ligging: er zijn geen monsters die als het ware in groep afgesplitst in het diagram voorkomen. Wel overlappen vooral de monsterpunten in het mondingsgebied van het Haringvliet weinig met deze in de andere deelgebieden (zie inzet in figuur 5.11). Soorten met een hoge score langs de eerste as (soorten niet weergegeven) zijn dan ook typische soorten voor dit deel van de Voordelta: de gewone kokkel Cerastoderma edule, de strandgaper Mya arenaria (zie ook figuur 5.2), de veelkleurige zeeduizendpoot Hediste diversicolor, de gewone groenworm Marenzelleria viridis. Linksonder in het diagram bevinden zich de kniksprietkreeftjes van het geslacht Bathyporeia en de gemshoornworm Scolelepis squamata, soorten kenmerkend voor de dynamische condities van ondiepe zandbanken. De structuur van de bodemdiergemeenschappen is dus erg gelijkend op wat op basis van de data in de jaren tachtig is vastgesteld (Craeymeersch et al. 1990a), en de basis vormde voor het PMR-NCV benthosmonitoringsprogramma. 


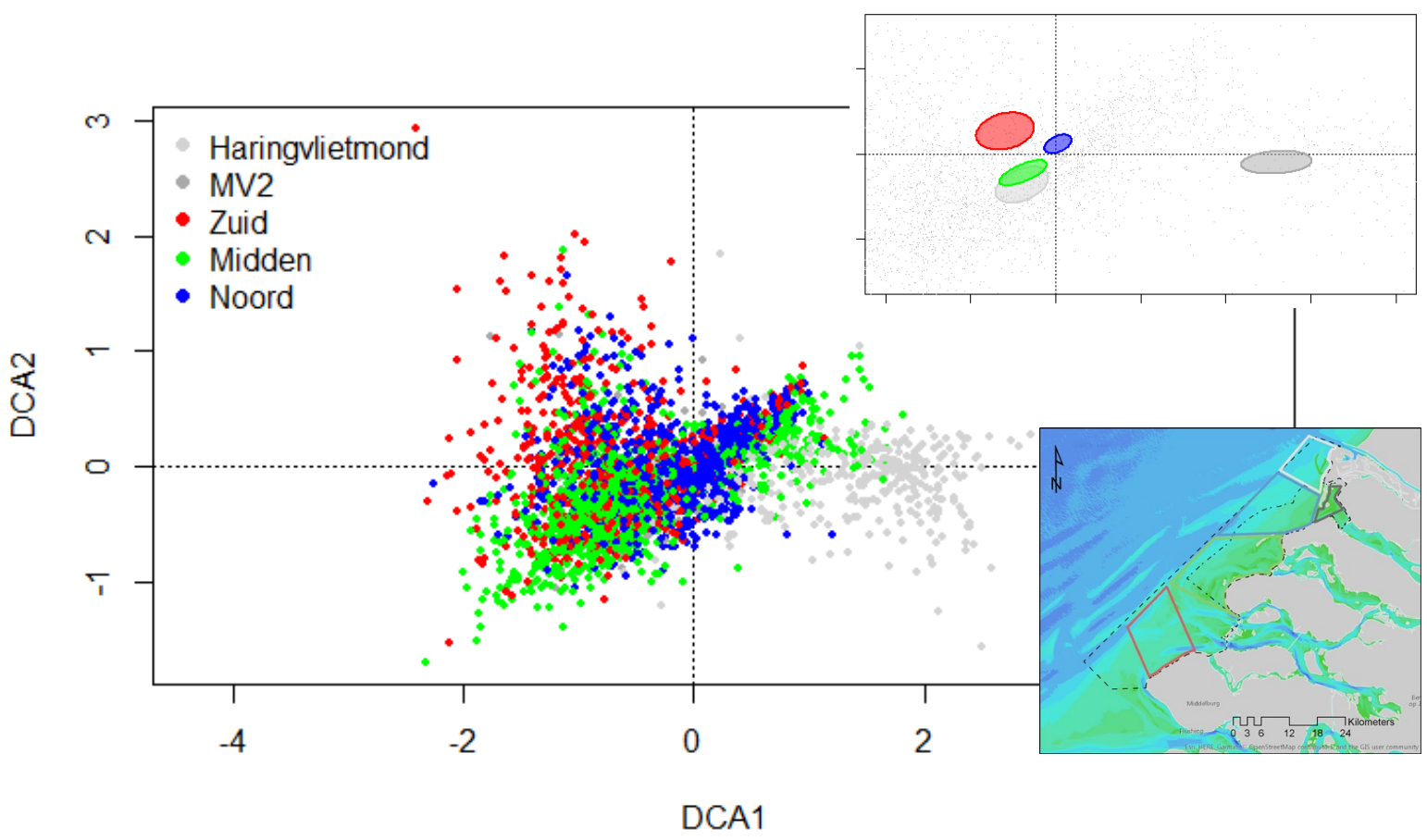

Figuur 5 11. Ordening van de monsters in het eerste vlak van een DCA-analyse. De monsters zijn gemarkeerd met een andere kleurcode per deelgebied (zie inzet kaartje). De inzet rechtsboven geeft de $99 \%$ confidentie-ellipsen van de monsters van elke deelgebied. Percentages verklaarde varianties zijn resp. 4.7 en 3.7\% voor resp. de eerste en de tweede as (data 2004-2015). De donkergrijze punten van MV2 liggen onder de andere punten.

\subsubsection{Temporele veranderingen in soortensamenstelling}

Duidelijk is dat het mondingsgebied van het Haringvliet, en met name het deel ten oosten van de Hinderplaat, een andere soortensamenstelling heeft dan de rest van de Voordelta onder invloed van de omgevingsvariabelen. We kunnen dan ook verwachten dat juist hier veranderingen in de tijd anders zullen zijn (andere soorten en/of andere trend) dan elders in het onderzoeksgebied. Dat is ook al eerder gebleken bij analyse van data verzameld om de eventuele invloed van de aanleg van het baggerspeciedepot in de Slufter na te gaan. Daarbij is dit gebied vanaf 2015 niet meer bemonsterd, juist vanwege het afwijkende karakter.

Omdat het meest noordelijk deel van het onderzoeksgebied (MV2) alleen de eerste jaren bemonsterd is, hebben we de analyse zonder de monsters van dit deelgebied uitgevoerd, alleen met monsters genomen in het zuidelijk referentiegebied (Zuid), de ondiepe zandbanken (Midden) en het noordelijker gelegen open wateren (Noord).

De drie gebieden laten ongeveer eenzelfde trend in de tijd zien (figuur 5.12). De laatste vier jaar liggen de ellipsen lager in het $1^{\text {ste }}$ ordinatievlak dan de eerste jaren. De verschillen langs de eerste ordinatie-as wijzen op verschillen tussen respectievelijk Noord en Midden/Zuid. Dat komt overeen met de verwachting: een iets andere soortensamenstelling in de diepere wateren (Noord) dan in de ondiepe zandbanken (Midden en Zuid).

De soorten die het meest bijdragen aan de verandering (niet getoond in figuren, maar duidelijk als figuur 5.12 met soorten geplot wordt, deze soorten liggen dan ver buiten de wolk) in de tijd zijn: de Amerikaanse zwaardschede Ensis directus, de wapenworm Scoloplos armiger, borstelwormen van het geslacht Spio (verschillende soorten samengevoegd op genus-niveau wegens veranderingen in determinatiesleutels) en het kniksprietkreeftje Bathyporeia elegans. De trend van deze soorten is weergegeven in figuur 5.13. De temporele en ruimtelijke verspreiding van $E$. directus en Spio sp. zijn gegeven in figuren 5.1 en 5.3. E. directus kent in alle deelgebieden toe- en afnames in de tijd. De andere soorten zijn in de tijd toegenomen (figuur 5.13). 

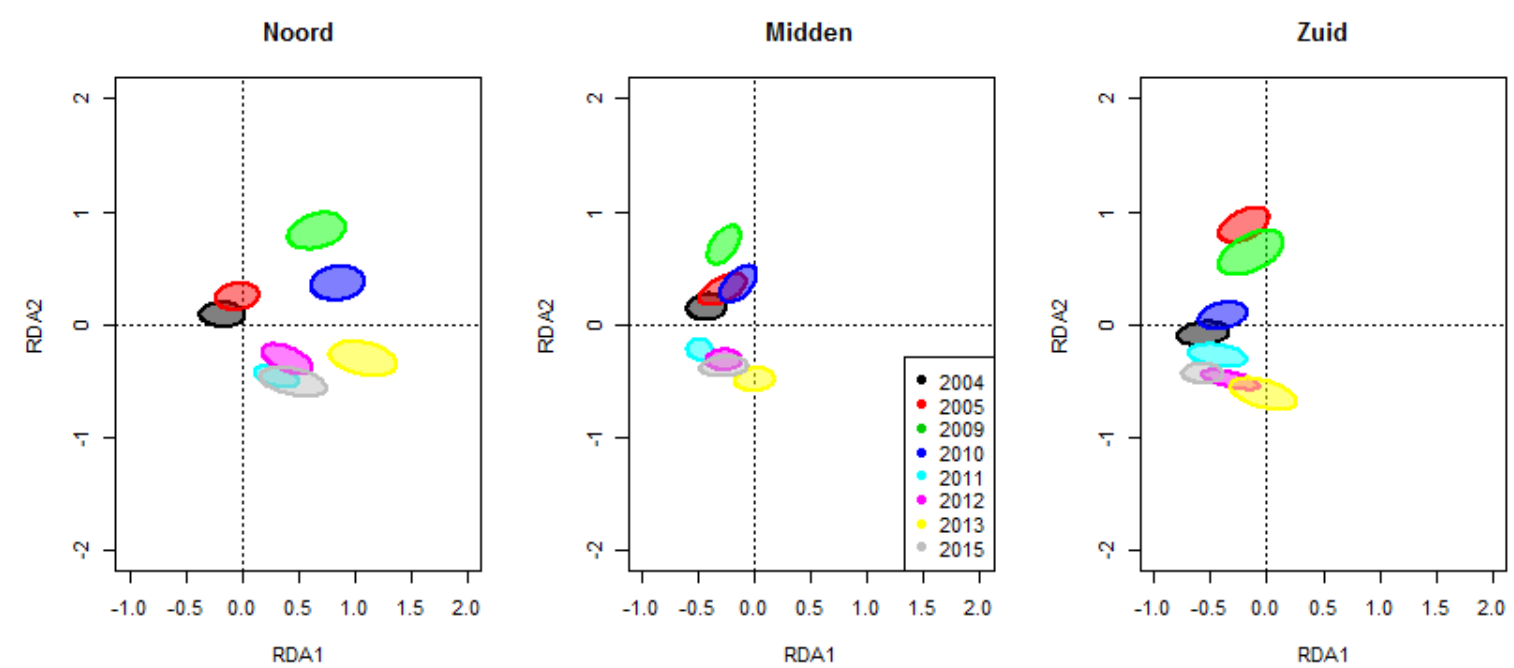

Figuur 5.12. RDA-analyse met gebied (Noord, Midden, Zuid) en jaar (als normale variabele): per jaar zijn de confidentie-intervallen van de monsters in de drie gebieden gegeven. Voor de duidelijkheid zijn de drie gebieden in aparte figuren weergegeven (data 2004-2015, excl. MV2 en mondingsgebied Haringvliet).
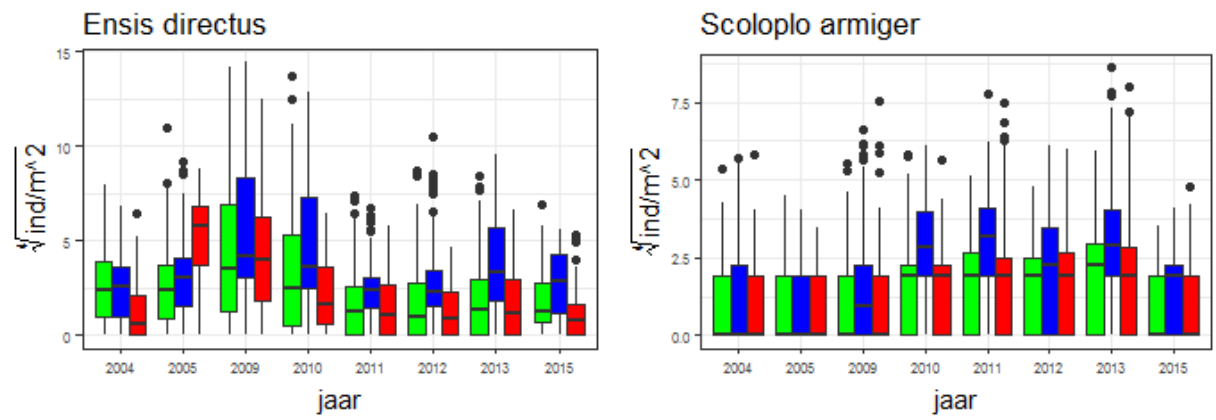

Bathyporeia elegans
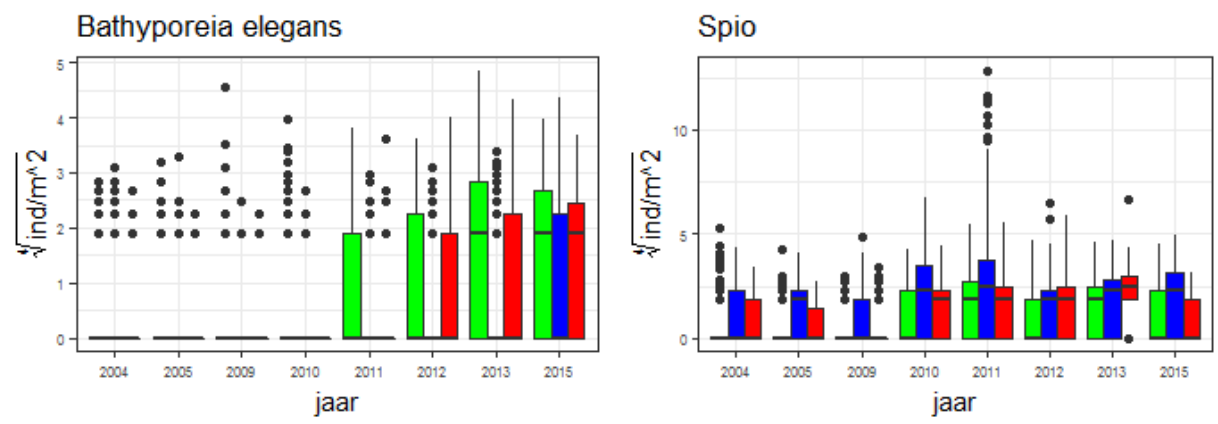

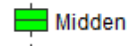

Noord

Zuid

Figuur 5.13. Temporele trends in dichtheden van vier soorten die het meest bijdragen aan verandering in de tijd, weergegeven als box-and-whisker pots. 


\subsubsection{Relatie soortensamenstelling en omgevingsvariabelen}

Uit een directe gradiëntanalyse (CCA) blijkt dat de abiotische variabelen een significant deel van de variantie verklaren $(p=0.001)$, gezamenlijk $6.4 \%$. Ze zijn ook ieder afzonderlijk significant (Tabel 5.6), al is de bijdrage van de hellingshoek en -richting beperkt. Jaarlijkse verschillen verklaren $2.6 \%$ van de variantie (zie ook 5.1.8.3) en jaar (nominaal) is daarom als conditional variabele in de analyse meegenomen. De vif-waardes per jaar varieerden tussen 1.9 en 2.7.

\section{Tabel 5.6}

Significantie en percentage verklaarde variantie van abiotische variabelen in een pCCA-model (met jaar als co-variabele)

\begin{tabular}{|l|l|l|l|}
\hline Variabele & omschrijving & P waarde & \% verklaarde variantie \\
\hline VarSalSummer & saliniteit & 0.001 & $1.9 \%$ \\
\hline AvgTauGolf & bodemschuifspanning & 0.001 & $1.6 \%$ \\
\hline Mediaan & mediane korrelgrootte & 0.001 & $1.2 \%$ \\
\hline Diepte & diepte & 0.001 & $1.4 \%$ \\
\hline MaxVel & stroomsnelheid & 0.001 & $2.5 \%$ \\
\hline slope_d & hellingshoek & 0.001 & $0.2 \%$ \\
\hline Northerness & $\begin{array}{l}\text { hellingsrichting tov } \\
\text { Noorden }\end{array}$ & 0.012 & $0.05 \%$ \\
\hline Easterness & $\begin{array}{l}\text { hellingsrichting tov } \\
\text { Oosten }\end{array}$ & 0.010 & $0.07 \%$ \\
\hline
\end{tabular}

figuur 5.14 geeft de ligging van de monsters, en de richting en grootte van de gradiënten in omgevingsvariabelen weer in het ordinatievlak van de eerste twee canonische assen (assen verkregen als lineaire combinatie van abiotische variabelen). De omgevingsvariabelen zijn met een pijl weergegeven. De lengte van de pijl is een maat voor de mate waarin de verspreiding van de soorten (en dus de monsters) verschilt langs die variabele, en aldus een maat voor het belang van die variabele (in het gekozen ordinatievlak).

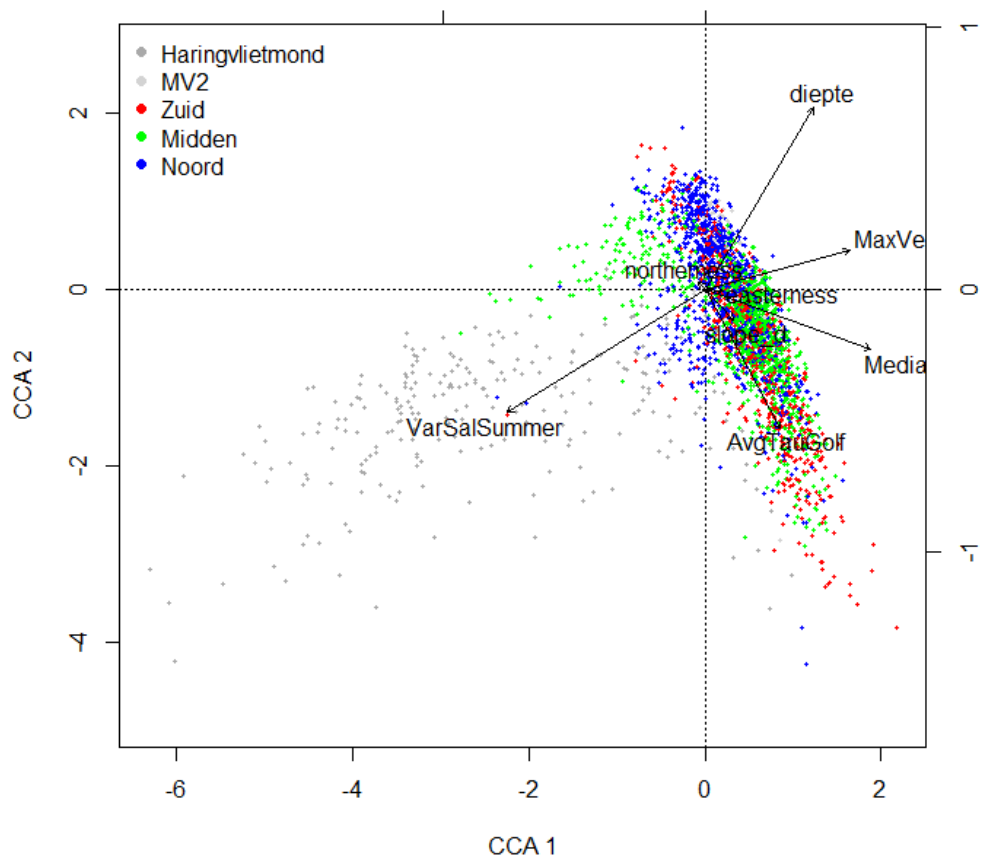

Figuur 514 Ordinatie van monsters en abiotische variabelen in het eerste ordinatievlak van een partiële CCA (met jaar als co-variabele) (data 2004-2015). Voor verklaring afkortingen variabelen zie tabel 5.6 
Geconcludeerd kan worden dat deze analyses de sterke relatie bevestigen tussen de verschillen in soortensamenstelling en -dichtheid en natuurlijke gradiënten in abiotische omgevingsvariabelen, zoals al eerder beschreven (Craeymeersch et al. 1990b, Craeymeersch 1999a, Prins et al. 2014a).

\subsubsection{Relatie soortensamenstelling en visserijdruk}

Eerst is een analyse uitgevoerd met data van de jaren 2004-2015 en met uitsluiting van de monsters genomen in de Haringvlietmond en in het noordelijke deel gelegen voor Maasvlakte 2 die alleen tijdens de nulmetingen bemonsterd zijn. Daarbij is in een pCCA-analyse de relatie met beide type visserijen onderzocht. Hieruit blijkt dat boomkorvisserij een significant deel van de variantie verklaart $(p=0.001)$, al is het aandeel erg klein: $0.7 \%$. De covariabelen (abiotiek en tijd) verklaren $7.7 \%$ van de totale variantie in de dataset. De abiotische variabelen verklaren dus veel meer van de variantie dan boomkorvisserij. Ook garnalenvisserij verklaart een significant deel van de variantie $(p=0.001)$, en verklaart een groter aandeel van de totale variantie: $4.5 \%$.

In figuur 5.15 zijn voor beide type visserijen de soorten weergegeven die de hoogste en laagste correlatie hebben met visserijdruk. Taxa als fuikhorens Tritia sp. (beide soorten samengevoegd, nog onder naam Nassarius in figuur) en de glanzende tepelhoren Euspira nitida zijn positief gecorreleerd met boomkorvisserij, taxa als Oligochaeta en Bathyporeia negatief. Taxa als het zaagje Donax vittatus, de rechtsgestreepte platschelp Fabulina fabula en de halfgeknotte strandschelp Spisula substruncata zijn positief gecorreleerd met garnalenvisserij, taxa als de borstelwormen Aphelochaeta marioni en Mediomastus fragilis negatief. Van aasetende soorten zoals Tritia sp., de kleine heremietkreeft Diogenes pugilator, en de strandkrab Carcinus maenas zou verwacht kunnen worden dat ze in hogere dichtheden voorkomen bij visserij-activiteiten (tot een bepaalde intensiteit). Bij de gewone zeester Asterias rubens is vastgesteld dat er een optimum is bij een bepaalde visserijintensiteit, en bij hogere visserijdruk opnieuw een afname (Ramsay et al. 2000). Mogelijk dat dit ook speelt bij Carcinus maenas. Tritia sp. (nog onder naam Nassarius in figuur) laat een sterke tijdtrend zien. Tijdens de WOT-schelpdiersurvey, gestart in de Voordelta in 1993, werd tot 2000 slechts een enkele individu gevonden (in 1999). Sindsdien is de soort enorm toegenomen, in aantal vindplaatsen en dichtheden (Craeymeersch \& Rietveld 2005). Hoogstwaarschijnlijk gaat het vooral om de gevlochten fuikhoren Tritia reticulata. Veel auteurs beschrijven als noordelijke limiet voor deze soort de Britse eilanden, en de recente toename zou dus om een noordwaartse verspreiding kunnen gaan. Andere auteurs beschouwen de noordelijke limiet van Tritia reticulata echter als het noorden van Noorwegen.
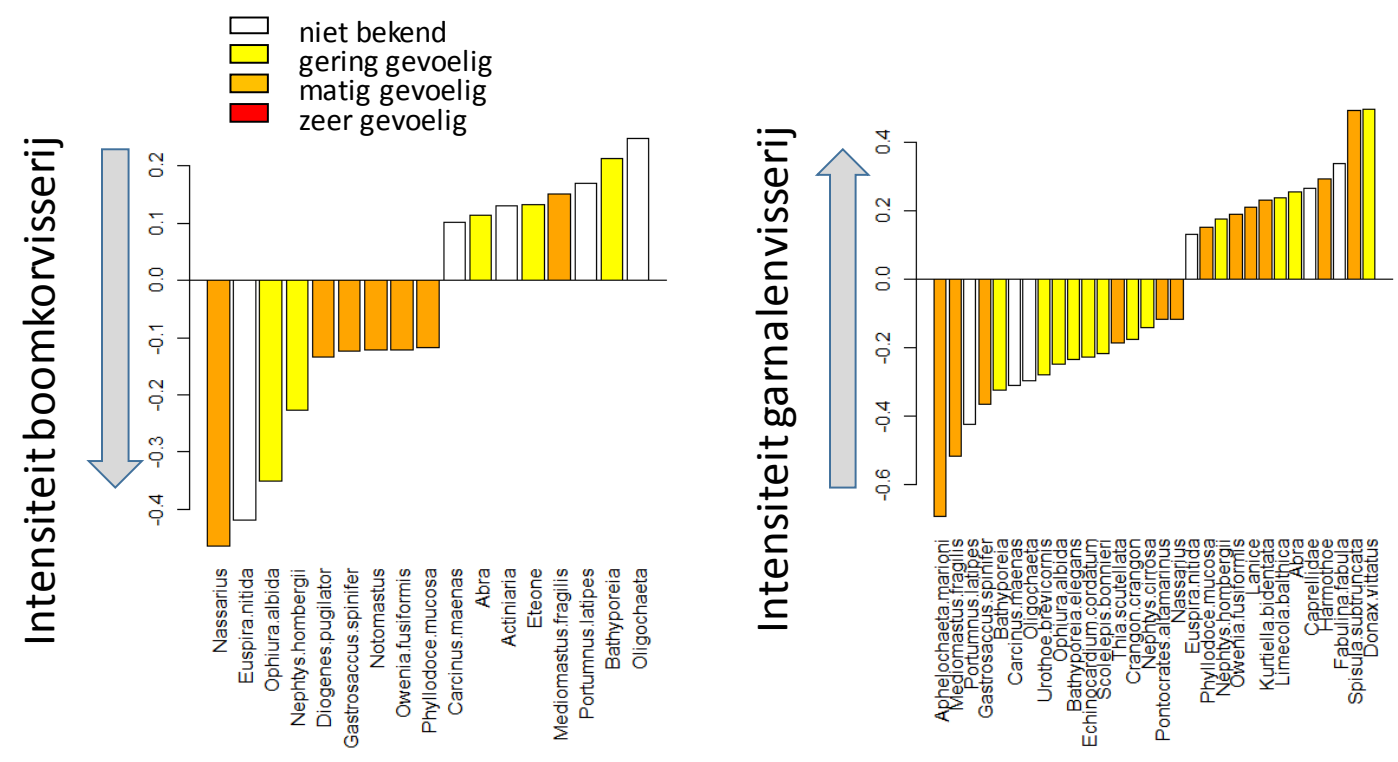

Figuur 5.15 Score van soorten langs canonische as gerelateerd aan boomkorvisserij (links) en garnalenvisserij (rechts). Alleen soorten met een absolute score groter dan 0.1 zijn weergegeven (data 2004-2015, zonder Haringvlietmond en MV2). Kleuren geven gevoeligheid weer (berekeningen volgens Bolam et al. (2014)); score<35: gevoeligheid laag, score 35-50: gevoeligheid matig, score > 50: gevoeligheid hoog).

Opvallend is dat meerdere taxa een andere relatie lijken te hebben met boomkorvisserij dan met garnalenvisserij: Tritia sp., de kleine slangster Ophiura albida, de aasgarnaal Gastrosaccus spinifer, de 
witte dunschaal Abra alba, Oligochaeta. Dus zelfs onder de meest positief of negatief gecorreleerde soorten verschilt de respons op boomkorvisserij en garnalenvisserij. Ondanks dat we nu, in tegenstelling tot een eerdere studie (Craeymeersch et al. 2016a), zeldzamere soorten niet bij de analyse meegenomen hebben en extra geomorfologische variabelen (hellingshoek en -richting) bepaald hebben, komen we tot dezelfde conclusie: aangezien er ruimtelijk weinig overlap is tussen de boomkorvisserij en de garnalenvisserij wijzen de tegengestelde relaties wellicht op ruimtelijke verschillen die niet gedekt worden door de gebruikte abiotische variabelen die de verschillen in omstandigheden beschrijven.

Geen enkele soort heeft een hoge gevoeligheidscore. En, tegengesteld aan de verwachting, zijn er bij beide type visserijen meer matig gevoelige soorten dan weinig gevoelige soorten positief gecorreleerd met de visserij-intensiteit, terwijl de soorten die negatief correleerden met visserij inspanning juist soorten betrof met een lage gevoeligheid.

Daarom hebben we ook analyses uitgevoerd met een selectie van de data, met de focus op respectievelijk boomkorvisserij en garnalenvisserij.

Een gerichte analyse op de relatie met visserij-intensiteit van boomkorvisserij is uitgevoerd met data van 2004 en 2005 (periode met nog relatief hoge visserij-intensiteiten in het zuidelijk referentiegebied en in het gebied gelegen voor de Maasvlakte (MV2)). Taxa die positief gerelateerd zijn met visserijintensiteit zijn o.a. de borstelwormen behorend tot de geslachten Capitella en Notomastus, de rechtsgestreepte platschelp Fabulina fabula en de halfgeknotte strandschelp Spisula subtruncata. Negatief gerelateerd zijn o.a. de otterschelp Lutraria lutraria, de borstelworm Scolelepis bonnieri, het zaagje Donax vittatus en de zeeklit Echinocardium cordatum (figuur 5.16)

Een gerichte analyse op de relatie met de intensiteit van garnalenvisserij is uitgevoerd met data vanaf 2009 in de open wateren (Noord, blauw in figuur 5.17), waar de visserij-intensiteit het meest is toegenomen tijdens de onderzoeksperiode. Positief gecorreleerd zijn o.a. de taxa de kokkel Cerastoderma edule, de witte dunschaal Abra alba, de wadpier Arenicola en de gewone slangster Ophiura ophiura, negatief gecorreleerd zijn o.a. de breedpootkrab Portumnus latipes, het kniksprietkreeftje Bathyporeia, de gewone garnaal Crangon crangon en de borstelworm Phyllodoce mucosa (figuur 5.17).

Meerdere taxa tonen in beide analyses een uniforme positieve of negatieve relatie met visserijintensiteit. Fabulina fabula, Spisula subtruncata, de kokerworm Owenia fusiformis en Actiniaria (zeeanemonen) zijn positief gecorreleerd met visserijdruk, Bathyporeia elegans, Spio en Echinocardium cordatum negatief. Slechts 2 taxa hebben een tegengestelde relatie (neemt toe met de ene visserij en af met de andere): het tweetandschelpje Kurtiella bidentata en het zaagje Donax vittatus.

Voor veel taxa is de gevonden relatie echter tegen de verwachting in. Veel soorten met een matige gevoeligheid voor verstoring door visserij hebben hogere dichtheden bij hogere bevissingsdruk. En juist vooral soorten met een lage gevoeligheid zijn negatief gecorreleerd. Bij garnalenvisserij komen zowel soorten met een geringe gevoeligheid als soorten met een matige gevoeligheid in hogere dichtheden voor bij zowel een lage als een hogere visserijdruk.

Kortom, ook na meer detaillering in de analyses: meenemen van extra abiotische variabelen, selecteren van gebieden, en een beperking van het aantal taxa (geen al te zeldzame taxa) t.o.v. eerdere analyses (Craeymeersch et al. 2016a) leidden de multivariate analyses niet tot duidelijke, eenduidige, relaties met visserijdruk. 

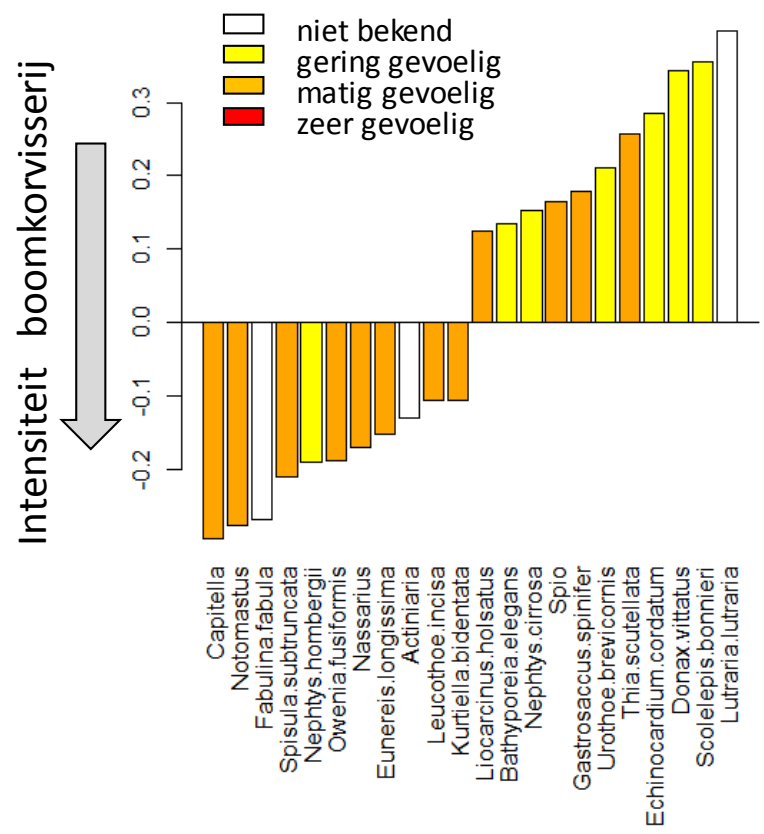

Figuur 5.16 Score van soorten langs canonische as gerelateerd aan boomkorvisserij. Alleen soorten met een absolute score groter dan 0.1 zijn weergegeven (data 2004-2005, diepte>10m). Kleuren geven gevoeligheid weer (berekeningen volgens Bolam et al. (2014)); score<35: gevoeligheid laag, score 35-50: gevoeligheid matig, score > 50: gevoeligheid hoog).
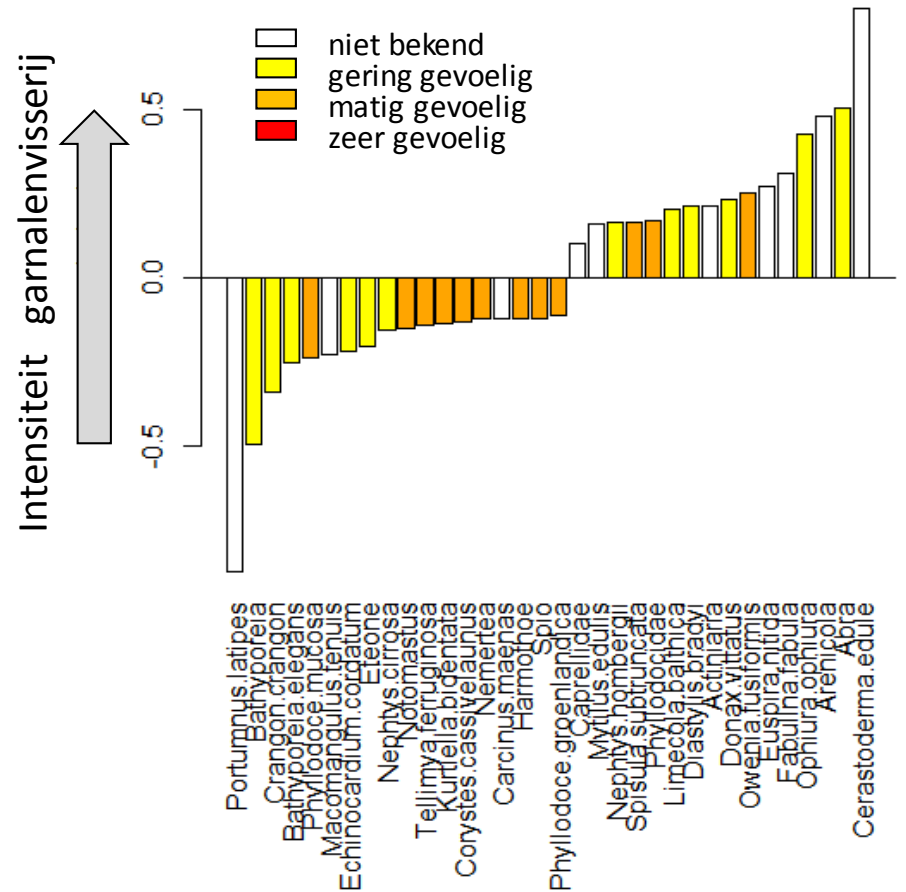

Figuur 5-17 Score van soorten langs canonische as gerelateerd aan garnalenvisserij. Alleen soorten met een absolute score groter dan 0.1 zijn weergegeven (data 2009-2015, open wateren Voordelta, diepte < 10m). Kleuren geven gevoeligheid weer (berekeningen volgens Bolam et al. (2014)); score<35: gevoeligheid laag, score 35-50: gevoeligheid matig, score > 50: gevoeligheid hoog). 


\section{Deelconclusie}

- Ruimtelijk is de bodemgemeenschapsstructuur sterk gerelateerd aan verschillen in saliniteit, mediane korrelgrootte, diepte, en hydrodynamiek. De Haringvlietmonding kenmerkt zich door een andere faunagemeenschap dan de rest van de Voordelta, waar vooral gradiënten te zien zijn gerelateerd aan verschillen in diepte, mediane korrelgrootte en hydrodynamiek. Dit was de basis van de bemonsteringsopzet, gebaseerd op data van de jaren tachtig.

- In de onderzoeksperiode zijn er Voordelta-brede temporele veranderingen in de soortensamenstelling en -dominantie.

- In verhouding tot de verklaarde variantie door abiotiek is de verklaarde variantie door visserijdruk (en met name door boomkorvisserij) erg gering.

- $\quad \mathrm{Er}$ is geen duidelijke, eenduidige, relatie tussen de soortensamenstelling en visserij-intensiteit, zowel voor boomkorvisserij als voor garnalenvisserij.

\subsubsection{Trait based approach}

We zijn geïnteresseerd in veranderingen in de bodemfaunagemeenschap als gevolg van de verandering in visserijdruk. Tot nu toe hebben we dat geanalyseerd aan de hand van parameters op basis van veranderingen in individuele soorten. Sinds de start van PMR-NCV zijn er in diverse Europese projecten (DEVOTES Olivier Beauchard, BENTHIS Adriaan Rijnsdorp) aanpakken ontwikkeld om dit soort vragen op een meer mechanistische manier te onderzoeken. In plaats van individuele soorten wordt de bodemfauna gegroepeerd op basis van hun life history kenmerken die meer of minder gevoelig zijn voor verstoring (Biological Trait Analysis, BTA). Bijvoorbeeld, bodemdiersoorten met verschillende eigenschappen zullen de passage van een boomkor op verschillende manieren ervaren als functie van de penetratiediepte en van de frequentie, van lichte verstoring tot chronische stress.

De verwachting is dat ecologische indicatoren die afgeleid zijn van die biologische eigenschappen geschikt zijn voor het kwantificeren van de gevoeligheid/weerbaarheid van bodemdieren voor bodemberoering en daardoor gebruikt kunnen worden in de voorspelling van de effecten van visserij op het zeebodemleven.

Deze aanpak hebben we op twee manieren gebruikt: allereerst hebben we de soorten ingedeeld in 4 groepen die gebaseerd zijn op de eigenschappen die de gevoeligheid voor verstoring bepalen en de ontwikkeling in ruimte en tijd van die soort gevolgd (paragraaf 5.1.9.1). Daarnaast is op basis van de individuele eigenschappen de totale biomassa verdeeld over verschillende kenmerken die meer of minder gevoelig zijn voor verstoring, en is de relatie van deze categorieën met visserijdruk geanalyseerd (paragraaf 5.1.9.2).

\subsubsection{Ontwikkeling van BTA groepen in tijd en ruimte}

Al in de jaren 70 en 80 zijn theorieën waarbij life-history strategieën in verband zijn gebracht met de ruimtelijke-temporele heterogeniteit van de omgeving (Habitat Templet Concept (Southwood 1977, Greenslade 1983, Southwood 1988)

Op basis van een uitgebreid literatuur onderzoek (>200 referenties) uitgevoerd in het kader van het DEVOTES project (O. Beauchard, pers. com.) zijn 13 biologische eigenschappen m.b.t. de leef-modus, de voedselvergaring en de reproductie gedocumenteerd voor 172 bodemdiertaxa waargenomen voor het MWTL-Noordzee project. Door middel van een multivariate analyse op basis van die 13 biologische eigenschappen onderscheidden zich vier groepen van soorten als functie van de gevoeligheid van die soorten voor de intensiteit en de periodiciteit van de veranderingen in de omgevingsfactoren (figuur 5.18). Hoewel de gevoeligheid voor verstoring met onderscheid van intensiteit en frequentie geen deel uitmaakte van de geselecteerde biologische eigenschappen, komen de gradiënten waargenomen in de 
multivariate analyse goed overeen met de theoretische voorspellingen volgens het 'Habitat Templet' Concept.

K-strategen zijn typerend voor een omgeving met weinig verandering (groot, langlevend, trage groei, late maturiteit). Langs de verticale as in figuur 5.18 neemt de intensiteit in de variatie van de omgevingsfactoren toe met een verschuiving van soorten tussen groepen $\mathrm{K} 2-$, $\mathrm{K} 1$ - en $\mathrm{r}$-strategen. $\mathrm{K} 2-$ strategen zijn daarbij meer gevoelig dan K1-strategen. De r-strategen (kortlevend, vroege geslachtsrijpheid) zijn wel afhankelijk van de periodes van luwte tussen de pieken van verstoring om zich in stand te houden. Bij een hoge frequentie van de verstoringen vinden we zeer tolerante soorten (klein, kortlevend, continu en grootschalige voortplanting), verzameld onder de noemer van Astrategen.

De indeling is ook toegepast op de Voordelta data en deze analyse is uitgebreid beschreven in Craeymeersch et al. 2014. In deze analyse is gerekend met biomassa productie in plaats van met biomassa (zie voor details Craeymeersch et al. 2014). De verwachting is dat een toename in bevissingsintensiteit zou moeten leiden tot een verschuiving van $\mathrm{K} 2$ - naar $\mathrm{r}$ - of A-gedomineerde bodemdiergemeenschappen. A-strategen komen relatief erg weinig voor en op weinig plekken (figuur 5.19). K2-strategen zijn met name in het Haringvlietmondingsgebied vaak de dominante groep. In het bodembeschermingsgebied domineren op veel locaties in het ene jaar r-strategen, in het andere jaar K1-strategen. Over de tijd laten geen van de groepen duidelijke veranderingen zijn, er zijn wel gebiedsverschillen (Figuur 5.20)

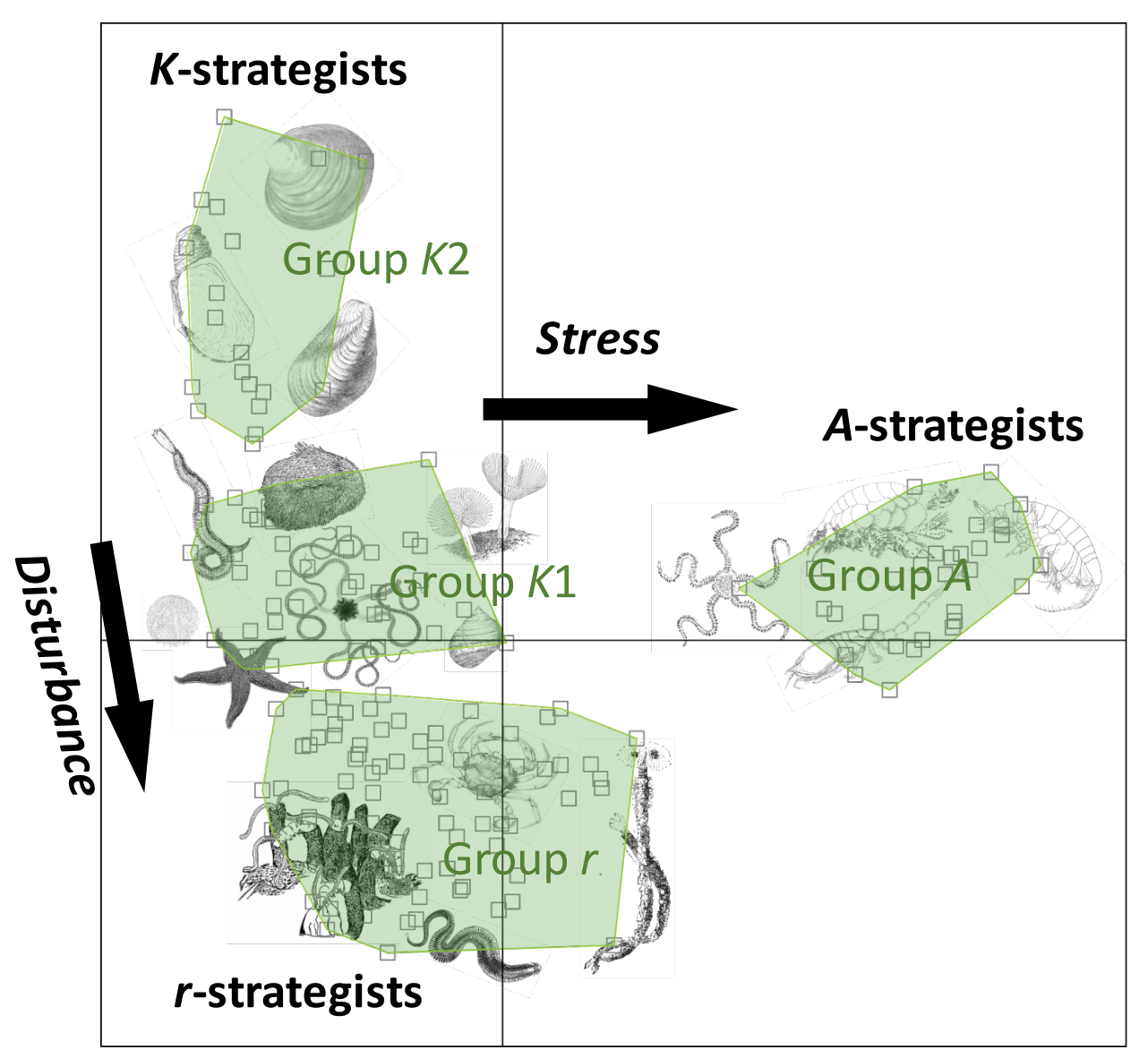

Figuur 5.18. Weergave en interpretatie van de multivariate analyse uitgevoerd op basis van de 13 biologische eigenschappen voor 172 bodemdieren taxa verzameld in het MWTL-Noordzee project (Beauchard \& Herman in prep). Bij toenemende verstoring treedt een verschuiving op van $\mathrm{K}$ naar $\mathrm{r}$ strategen, bij toenemende stress (frequentie van verstoring) van $\mathrm{K}$ naar $\mathrm{A}$ strategen. 


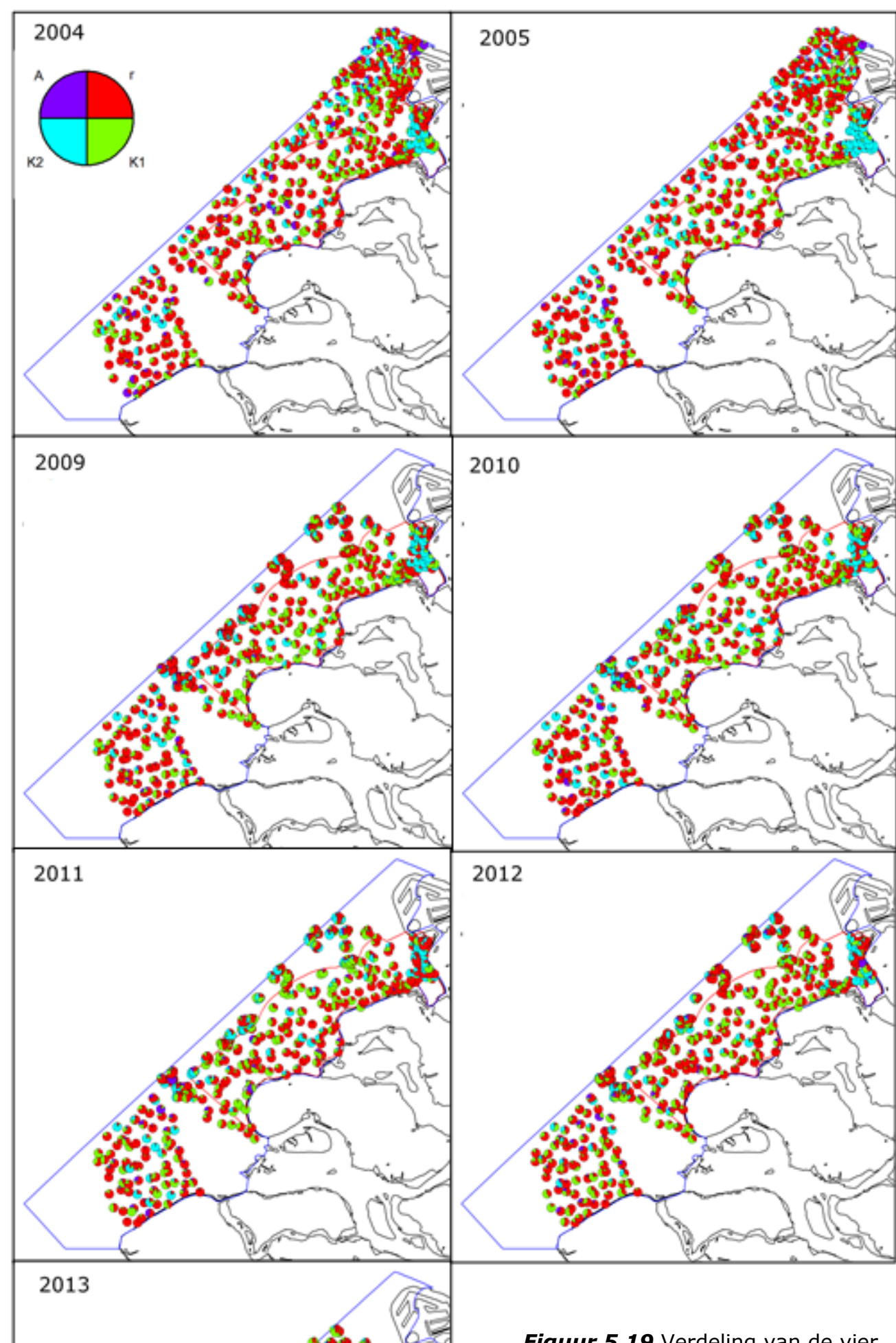

groepen per monsterpunt (productie per jaar zonder Ensis) in de verschillende jaren. 

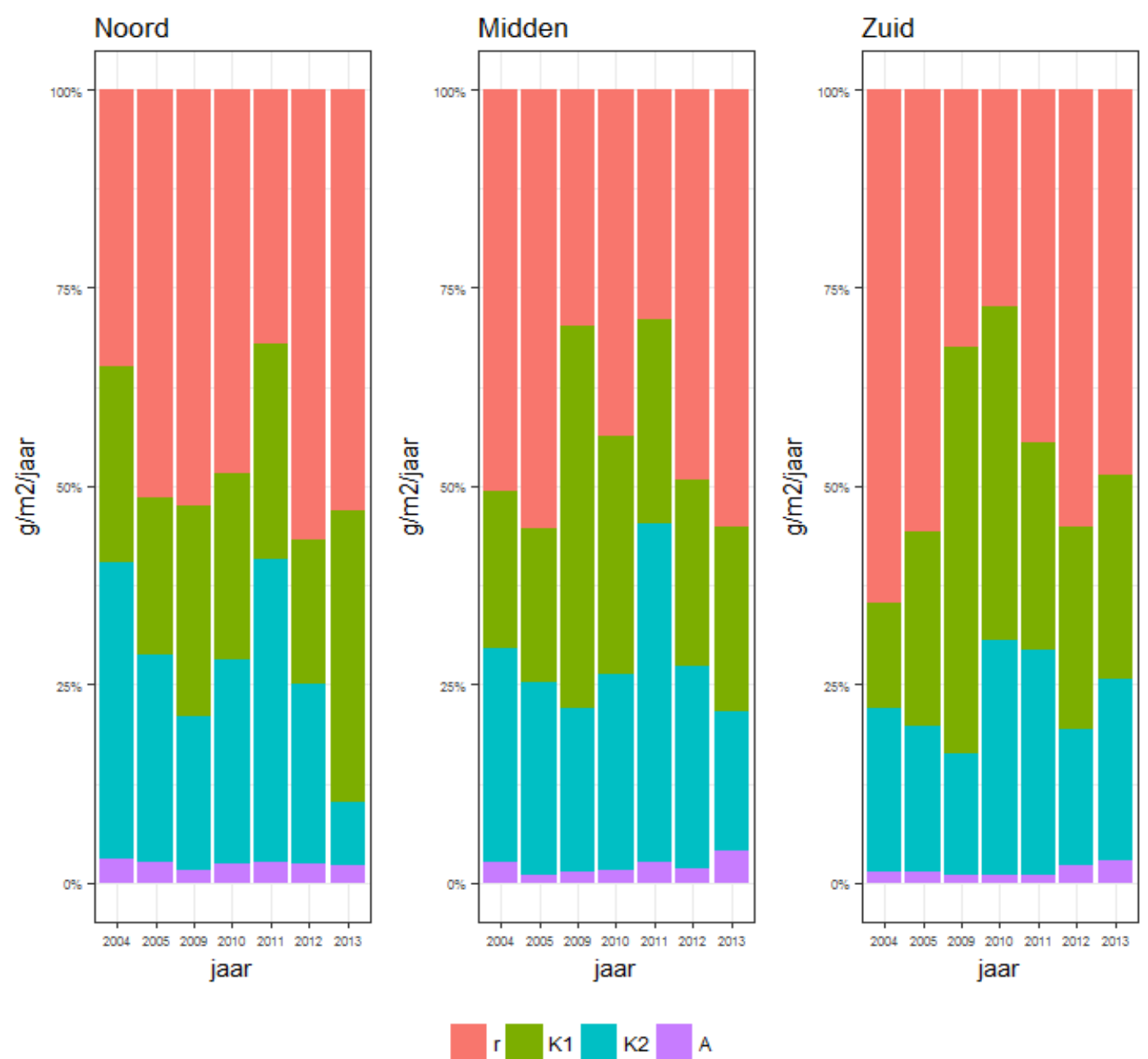

Figuur 5.20 Trend in de verhouding tussen de productie door r, A, K1 en K2 strategen (productie zonder Ensis directus) in de Voordelta.

\section{Deelconclusies}

- In de Voordelta komt de voor verstoring meest gevoelige groepen bodemdieren (K1 en K2) relatief weinig voor

- In de Voordelta komen soorten die aangepast zijn aan een hoge frequentie van verstoring (A strategen) weinig voor

- De productie door bodemfauna in de Voordelta wordt gedomineerd door $r$-strategen

- De verhouding tussen de drie groepen vertoont geen duidelijke trend over de tijd: de verschuiving van $\mathrm{r}$ naar $\mathrm{K}$ strategen zoals verwacht bij uitsluiten visserij is niet waargenomen. 


\subsubsection{Veranderingen in soortgroepen: biological trait analyses}

Tot nu toe zijn parameters op basis van de verschillende soorten geanalyseerd. Een andere aanpak is om niet de individuele soorten (of de hele gemeenschap) te analyseren, maar het aandeel van de bodemfauna dat een bepaalde kenmerk gemeenschappelijk heeft bijvoorbeeld: het aandeel van de biomassa dat langlevend is, of het aandeel dat ingegraven leeft, of het aandeel met een exoskelet. Het voordeel van deze aanpak (Biological Trait Analysis) is dat we op basis van eigenschappen (traits) die meer of minder gevoelig zijn voor visserij kunnen analyseren of visserij invloed heeft gehad op het deel van de biomassa met een visserijgevoelige eigenschap.

In deze aanpak worden alle taxa beschreven in termen van hun vorm en functie. In dit geval wordt gebruik gemaakt van acht eigenschappen van soorten die de levenswijze, het gedrag en de morfologie beschrijven (tabel 5.7). De modaliteiten, categorieën binnen eigenschappen, werden door Bolam et al. (2014)) geclassificeerd op relatieve gevoeligheid voor (ottertrawl)visserij. De relatieve score kon hierbij variëren van 1 (lage gevoeligheid voor visserij) tot 10 (hoge gevoeligheid). De methodiek wordt uitgebreid beschreven in Bolam et al. (2014). Voor deze studie is een database gebruikt die binnen het EU project 'BENTHIS' is ontwikkeld, met als doel effecten van visserijdruk op het functioneren van het benthisch ecosysteem inzichtelijk te maken Bolam et al. (2014)). Deze database bevat informatie voor meer dan 850 taxa (op genus niveau) voor tien verschillende eigenschappen zoals bijvoorbeeld levensverwachting, mobiliteit en voedselvoorkeur. Door het combineren van alle eigenschappen van alle soorten op één monsterlocatie wordt het ecosysteem van deze locatie beschreven als een set van functies en eigenschappen (modaliteiten), i.p.v. als een set van soortenabundantie. Dit maakt het mogelijk veranderingen en verschillen in ecosysteem functioneren te onderzoeken. Hierbij is de verwachting dat voor visserijgevoelige modaliteiten (bijvoorbeeld langlevende soorten, soorten zonder exoskelet, op de oppervlakte levend of zelfs sessiel) afnemen met toenemende visserijdruk.

Voor de analyse zijn dezelfde selecties van data gebruikt als in paragraaf 5.1.8. De reden hiervoor is dat we gebieden/perioden selecteren waarin er 1 ) een duidelijk contrast is in visserijdruk en 2 ) er zo weinig mogelijk collineariteit is tussen jaar en visserijdruk.

Om het effect van de boomkorvisserij te onderzoeken is de set uit 2004-2005 gebruikt voor het gebied dieper dan 10m. Voor het effect van garnalenvisserij is de periode 2009-2015 gebruikt voor het gebied ondieper dan 10m. De biomassa's per trait modaliteit zijn voor de analyses vierdemachtswortel getransformeerd. In de analyse zijn alle soorten (dus inclusief heel talrijke soorten, zoals Ensis directus, en zeldzame soorten) meegenomen. Voor de analyses is gebruik gemaakt van een partial CCA (zie voor uitleg paragraaf 5.1.8), waarbij de covariaten (abiotiek) als conditional variabelen meegenomen worden en de visserijdruk als constrained variabele. 
Tabel 5.7

Gevoeligheid van modaliteiten per trait voor bodemvisserij (aangepast aan (Bolam et al. 2014)). Tussen haakjes staan de afkortingen zoals gebruikt in de figuren 5.21 en 5.22)

\begin{tabular}{|c|c|c|c|c|c|}
\hline \multirow[b]{3}{*}{ score } & \multicolumn{5}{|c|}{ relatieve gevoeligheid voor visserij } \\
\hline & \multicolumn{2}{|l|}{ lage gevoeligheid } & \multicolumn{2}{|c|}{ gemiddelde gevoeligheid } & \multirow{2}{*}{\begin{tabular}{|l|} 
hoge gevoeligheid \\
$9-10$
\end{tabular}} \\
\hline & $1-2$ & 3-4 & 5-6 & 6-7 & \\
\hline lengte $(\mathrm{mm})$ & $\begin{array}{l}\leq 10(\mathrm{SR} 10) \\
11-20(\mathrm{SR} 11-20)\end{array}$ & & $\begin{array}{l}21-100 \\
(\text { SR21-100) }\end{array}$ & $\begin{array}{l}101-200 \\
\text { (SR101-200) }\end{array}$ & $>200(S R>200)$ \\
\hline morfologie & $\begin{array}{l}\text { exoskelet } \\
\text { hard/korstvormig } \\
\text { (MP_chitin/crustose) }\end{array}$ & $\begin{array}{l}\text { kussen- } \\
\text { /mantelvorm } \\
\text { (MP_cushion/tunic) }\end{array}$ & & Zacht (MP_soft) & $\begin{array}{l}\text { Naaldvormig } \\
\text { (MP_stalked) }\end{array}$ \\
\hline habitat & $\begin{array}{l}\text { vrij levend (LH_free) } \\
\text { in hol/onder steen } \\
(\text { LH_crev) }\end{array}$ & $\begin{array}{l}\text { ingegraven } \\
\text { (LH_burrow) } \\
\text { in sediment } \\
\text { in buis (LH_tube) }\end{array}$ & & $\begin{array}{l}\text { op de bodem } \\
\text { (LH_epi) }\end{array}$ & $\begin{array}{l}\text { vastgehecht aan } \\
\text { substraat (LH_att) }\end{array}$ \\
\hline sed. positie & $\begin{array}{l}\operatorname{diep}(>10 \mathrm{~cm}) \\
\left(\mathrm{Sp}_{-}>10\right)\end{array}$ & $\begin{array}{l}\text { gemiddeld diep (5- } \\
10 \mathrm{~cm})\left(\mathrm{Sp} \_6-10\right)\end{array}$ & & $\begin{array}{l}\text { ondiep }(0-5 \mathrm{~cm}) \\
\left(\mathrm{Sp} \_0-5\right)\end{array}$ & $\begin{array}{l}\text { op de oppervlakte } \\
\text { (Sp_surf) }\end{array}$ \\
\hline mobiliteit & $\begin{array}{l}\text { Zwemmend } \\
\text { (MB_swim) }\end{array}$ & & & $\begin{array}{l}\text { Ondergegraven } \\
\text { (MB_burrow) }\end{array}$ & Sessiel (MB_ses) \\
\hline $\begin{array}{l}\text { levensduur } \\
\text { (jaren) }\end{array}$ & $\begin{array}{l}<1 \text { (Long }<1) \\
1-2 \text { (Long1-2) }\end{array}$ & & & 3-10 (long3-10) & $>10$ (Long $>10)$ \\
\hline \begin{tabular}{|l} 
strategie \\
ontwikkeling \\
larven
\end{tabular} & $\begin{array}{l}\text { planktonisch etend } \\
\text { (LD_pk) }\end{array}$ & & $\begin{array}{l}\text { afhankelijk van } \\
\text { dooierzak } \\
\text { (LD_IC) }\end{array}$ & & Direct (LD_direct) \\
\hline $\begin{array}{l}\text { locatie } \\
\text { ontwikkeling } \\
\text { eieren }\end{array}$ & $\begin{array}{l}\text { uitgescheiden in } \\
\text { water (Egg_pel) } \\
\text { aseksueel } \\
\text { (Egg_asex) }\end{array}$ & & $\begin{array}{l}\text { vastgezet aan } \\
\text { bodem } \\
\text { (Egg_ben) }\end{array}$ & & $\begin{array}{l}\text { uitgebroed door } \\
\text { volwassenen (Egg_bro) }\end{array}$ \\
\hline bioturbatie & omwoeler (BT_diff) & & \begin{tabular}{|l} 
naar beneden \\
(BT_down) \\
geen (BT_none) \\
naar boven \\
(BT_up)
\end{tabular} & & oppervlakte(BT_surf) \\
\hline voedsel & $\begin{array}{l}\text { predator (F_pred) } \\
\text { aaseter (F_scav) } \\
\text { deposit (F_dep) }\end{array}$ & & \begin{tabular}{|l|} 
subsurface \\
deposit \\
(F_subdep) \\
parasiet (F_par)
\end{tabular} & & suspensie (F_susp) \\
\hline
\end{tabular}

\section{Effect boomkorvisserij}

In de pCCA wordt $22.3 \%$ van de variatie verklaard door de conditional variabelen gebied, jaar, mediane korrelgrootte, bodemschuifspanning en stroomsnelheid en $1.4 \%$ van de variatie wordt door visserijdruk bepaald (significant), $76.3 \%$ van de variatie kan niet verklaard worden door het model. De gradiënt in boomkorvisserij is niet gecorreleerd met gradiënten in omgevingsvariabelen waardoor het boomkor-effect goed van de effecten van abiotische variabelen onderscheiden kan worden. Meer modaliteiten nemen af dan toe bij hoge visserijdruk (Figuur 5.21). De modaliteiten die toenemen met hogere visserijdruk zijn: grotere, langlevende, diep ingegraven, filterfeeding sessiele soorten (Tabel 5.8). De modaliteiten die afnemen met toenemende visserijdruk zijn kleinere, kortlevende, ondiep ingegraven op de bodem levende soorten (Tabel 5.8). Dit is dus tegengesteld aan de verwachting. Als reden hiervoor zou gedacht kunnen worden aan Ensis die een heel groot deel van de biomassa uitmaakt. Die soort classificeert als grotere, langlevende, diep ingegraven soort en juist die modaliteiten hebben een positieve relatie met bodemberoering door visserij. Maar ook wanneer de analyse zonder Ensis wordt uitgevoerd, blijft het algemene beeld hetzelfde, met langerlevende, diep 
ingegraven soorten die een positieve relatie met visserij laten zien. Als we inzoomen op welke soorten er nu veel bijdragen aan de modaliteiten die positief met boomkorvisserij geassocieerd zijn, is inderdaad opvallend vaak Ensis directus belangrijk. Geleedpotigen en wormen maken vaak en voor een groot deel de meest negatief geassocieerde modaliteiten uit. In de classificatie van Bolam et al. (2014)) is diep ingegraven geclassificeerd als ongevoelig voor visserij, maar groot en langlevend als gevoelig. Ensis directus heeft deze combinatie van modaliteiten. Doordat Ensis directus zich diep kan ingraven is deze soort wellicht toch niet zo gevoelig voor visserij. Bovendien is gevoeligheid voor visserij ook nog eens leeftijdsafhankelijk (Bergman \& van Santbrink 2000). Mogelijk dient de toewijzing van modaliteiten en gevoeligheid van modaliteiten die is gebaseerd op Bolam et al. (2014)) herzien worden.

\section{Effect boomkor op trait-modaliteiten}

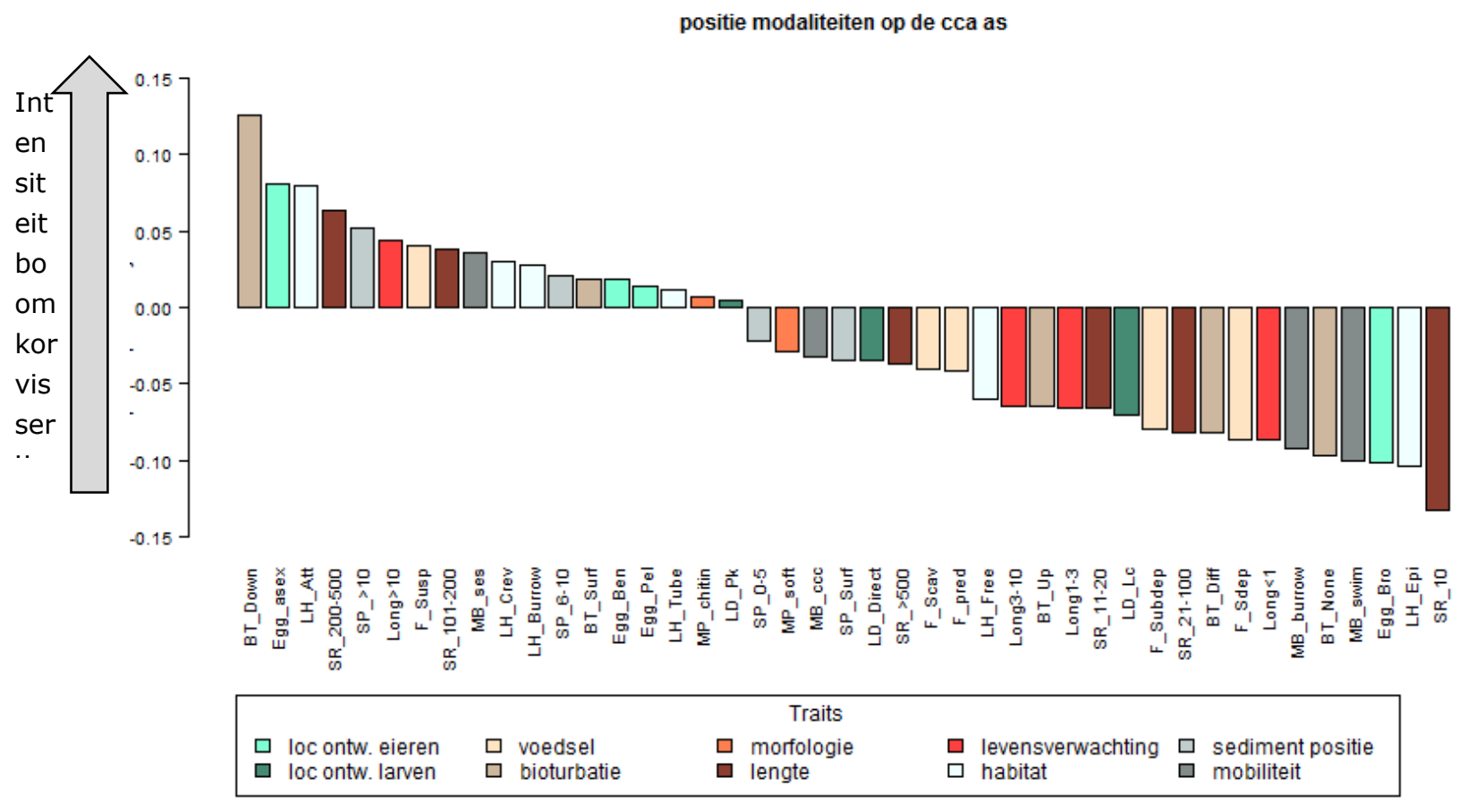

Figuur 5.21 Positie van de trait-modaliteiten op de boomkorvisserijvector in CCA model.

\section{Tabel 5.8}

Meest positief- en meest negatief met boomkorvisserij geassocieerde modaliteiten per trait categorie.

\begin{tabular}{|c|c|c|c|}
\hline nr & trait & positieve modaliteiten & negatieve modaliteiten \\
\hline 1 & mobiliteit & Sessiel (MB_ses) & Zwemmend (MB_swim) \\
\hline 2 & habitat & $\begin{array}{l}\text { Vastgehecht aan substraat } \\
\text { (LH_att) }\end{array}$ & Op de bodem (LH_epi) \\
\hline 3 & levensduur & >10 jaar (Long>10) & $<1$ jaar (Long<1) \\
\hline 4 & lengte & $200-500 \mathrm{~mm}(\mathrm{SR} 200-500)$ & $\leq 10 \mathrm{~mm}(\mathrm{SR} 10)$ \\
\hline 5 & sediment positie & $\operatorname{diep}(>10 \mathrm{~cm})$ & Op de oppervlakte (SP_surf) \\
\hline 6 & voedsel & Suspension feeder (F_susp) & Deposit feeder (F_dep) \\
\hline 7 & $\begin{array}{l}\text { locatie ontwikkeling } \\
\text { eieren }\end{array}$ & Aseksueel (Egg_asex) & $\begin{array}{l}\text { Uitgebroed door volwassen dieren } \\
\text { (Egg_bro) }\end{array}$ \\
\hline 8 & $\begin{array}{l}\text { strategie ontwikkeling } \\
\text { larven }\end{array}$ & Planktonisch etend (LD_pk) & Afhankelijk van dooierzak (LD_Ic) \\
\hline 9 & bioturbatie & Naar beneden (BT_down) & Geen (BT_none) \\
\hline 10 & morfologie & $\begin{array}{l}\text { Exoskelet hard/korstvormig } \\
\text { (MP_chitin) }\end{array}$ & Zacht (MP_soft) \\
\hline
\end{tabular}




\section{Effect garnalenvisserij}

In de pCCA wordt $24.1 \%$ van de variatie verklaard door de conditional variabelen jaar, bodemschuifspanning, stroomsnelheid, saliniteit en $2.7 \%$ van de varatie wordt door visserijdruk bepaald (significant), 73.2\% van de variatie kan niet verklaard worden door het model. Meer modaliteiten nemen af dan toe bij hoge visserijdruk (figuur 5.22). De modaliteiten die toenemen bij hogere visserijdruk zijn: middelmatig grote-, langlevende-, diep ingegraven-, filterfeeding sessiele soorten (tabel 5.9). Modaliteiten die afnemen bij hogere visserijdruk zijn: klein en grotere-, kortlevende, ondiep ingegraven, epifauna soorten (tabel 5.9). In de modaliteiten die positief met garnalenvisserij geassocieerd zijn, is opvallend vaak de zwaardschede (Ensis directus) en halfgeknotte strandschelp (Spisula subtruncata) belangrijk. Net als bij boomkorvisserij, heeft Ensis een belangrijk aandeel naar leidt verwijdering van Ensis nauwelijks tot andere rangschikking. Geleedpotigen (Arthropoda) en wormen (Annelida) maken vaak en voor een groot deel de meest negatief geassocieerde modaliteiten uit. De positieve relatie van de modaliteit 'sessiel' is niet volgens verwachting. Zoals ook bij boomkorvisserij zijn de sessiele soorten ook soorten die diep ingegraven zitten waardoor ze mogelijk ontsnappen aan beschadiging/mortaliteit veroorzaakt door visserij.

Effect garnalenvisserij op trait-modaliteiten

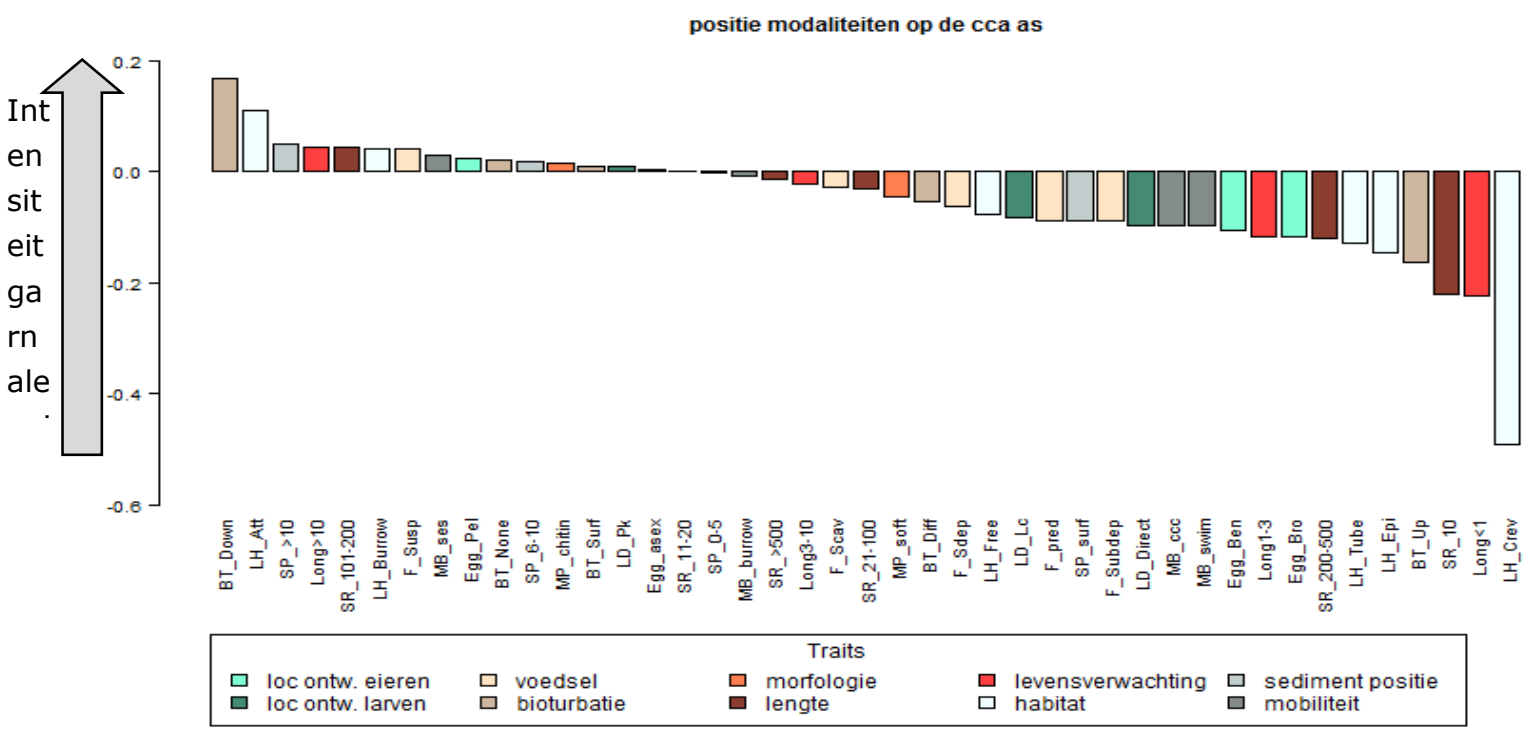

Figuur 5. 22 Positie van de trait-modaliteiten op de garnalenvisserijvector in CCA model.

\section{Tabel 5.9}

Meest positief- en meest negatief met garnalenvisserij geassocieerde modaliteiten per trait categorie.

\begin{tabular}{|c|c|c|c|}
\hline nr & trait & positieve modaliteiten & negatieve modaliteiten \\
\hline 1 & mobiliteit & sessiel (MB_ses) & zwemmend (MB_swim) \\
\hline 2 & habitat & vastgehecht aan substraat (LH_att) & $\begin{array}{l}\text { in hol/onder steen (LH_crev) op de } \\
\text { bodem (LH_epi) }\end{array}$ \\
\hline 3 & levensduur & $>10$ jaar Long $>10$ & $<1$ jaar $($ Long < 1$)$ \\
\hline 4 & lengte & $101-200$ mm (SR_101-200) & $<10$ mm (S_10) \\
\hline 5 & sediment positie & diep >10 cm $(\mathrm{SP}>10)$ & op de oppervlakte (SP_surf) \\
\hline 6 & voedsel & suspensie (F_susp) & subsurface deposit (F_subdep) \\
\hline 7 & $\begin{array}{l}\text { locatie } \\
\text { ontwikkeling } \\
\text { eieren }\end{array}$ & uitgescheiden in water (Egg_pel) & $\begin{array}{l}\text { uitgebroed door volwassene } \\
\text { (Egg_bro) }\end{array}$ \\
\hline 8 & $\begin{array}{l}\text { Strategie } \\
\text { ontwikkeling } \\
\text { larven }\end{array}$ & planktonisch etend (LD_pk) & direct (LD_direct) \\
\hline 9 & bioturbatie & naar beneden (BT_down) & naar boven (BT_up) \\
\hline 10 & morfologie & $\begin{array}{l}\text { exoskelet hard/korstvormig } \\
\text { (MP_chitin) }\end{array}$ & zacht (MP_soft) \\
\hline
\end{tabular}




\section{Deelconclusies}

- Het grootste deel van de variatie in de multivariate analyses op basis van traits wordt verklaard door abiotiek.

- De relatie van modaliteiten met de intensiteit van boomkorvisserij en garnalenvisserij is statistisch significant, maar gezien het lage percentage verklaarde variantie is dit biologisch niet relevant.

- Het verband tussen modaliteiten en visserijdruk door boomkor is tegengesteld aan de verwachting: De modaliteiten die toenemen met hogere visserijdruk zijn: grotere, langlevende, diep ingegraven, filterfeeding sessiele soorten. De modaliteiten die afnemen met toenemende visserijdruk zijn kleinere, kortlevende, ondiep ingegraven op de bodem levende soorten.

- De modaliteiten die toenemen bij hogere visserijdruk door garnalenvisserij zijn: middelmatig grote-, langlevende-, diep ingegraven-, filterfeeding sessiele soorten. Het grootste deel van deze biomassa wordt bepaald door Ensis directus. Dit is mogelijk een aanwijzing dat Ensis directus profiteert van verstoring door bodemvisserij. Ook in analyses zonder Ensis directus is er een positief verband tussen deze modaliteiten en visserijdruk.

\subsubsection{Vergelijking veranderingen in bodemfauna eigenschappen tussen locaties met een contrast in visserijdruk}

In voorgaande analyses is telkens de bodemfaunabemonstering in de gehele Voordelta (uitgezonderd Haringvlietmond en MV2) meegenomen. Omdat de boomkorvisserij al sterk was afgenomen bij aanvang van de nulmetingen, zowel binnen als buiten het bodembeschermingsgebied, is er weinig contrast in visserijdruk tussen het bodembeschermingsgebied en de omliggende gebieden en in het hele gebied door de jaren heen. De hoge boomkorvisserij intensiteiten tijdens de nulmeting-jaren (2004-2005) kwamen bovendien slechts voor in geografisch zeer beperkte gebieden. Daarom zoomen we in deze paragraaf in op die geografische schaal waarin wel contrast voorkomt in bevissingsintensiteit. Selecties van gebieden en perioden worden gebruikt waarin het contrast in visserijdruk gemaximaliseerd wordt. Voor de twee verschillende visserijen zijn verschillende selecties van monsterpunten gemaakt.

\subsubsection{Analytische opzet}

Voor beide types van visserij is er gezocht naar PMR-monsterlocaties met een significante veranderingen in visserijdruk door de jaren heen (beviste locaties): afname in boomkorvisserij of toename in garnalenvisserij. Vervolgens zijn er nabije locaties geselecteerd om als referentie (controle locaties) te dienen voor de autonome ontwikkelingen die synchroon gaan met de veranderingen in visserijdruk op de beviste locaties (figuur 5.23).

Niveaus en verloop in bodemdieren gemeenschappen tussen 2004-2015 in die twee groepen van beviste en controle locaties zijn geanalyseerd in relatie tot het verschil in visserijdruk (zowel boomkorvisserij als garnalenvisserij) tussen beide groepen.

\subsubsection{Analyse van de bodemdieren eigenschappen}

De vergelijking tussen beviste en controle locaties is aanvankelijk gemaakt op het niveau van de gemeenschappen d.m.v. een multivariate analyse (RDA) waar de relatie tussen verschillen in visserijdruk en bodemdierendichtheden (na dubbel wortel transformatie) onderzocht is. Hierbij is rekening gehouden met de invloed van de omgevingsvariabelen door deze mee te nemen als conditional variabele in de analyse. Om het verstorende effect van zeldzame soorten op de analyse te voorkomen is er een selectie gemaakt van soorten die in minimaal $5 \%$ van de monsters getroffen zijn. Van de soorten die een significant verband tonen met de RDA assen zijn boxplot grafieken gemaakt om de verschillen in niveaus en verloop tussen beviste en controle locaties te schetsen.

Naast de multivariate en univariate analyse is er ook een aantal geaggregeerde indicatoren (dezelfde als in paragraaf 5.1.7.3: gemiddeld individueel gewicht, 95ste percentielen voor individuele gewicht, 95ste percentielen voor Ensis lengte, aantal soorten, totale biomassa en biomassa geoormerkt als voedsel voor vogels) geanalyseerd. De niveaus en het verloop van die indicatoren tussen beviste en controle locaties worden d.m.v. boxplots grafieken geïllustreerd. 


\subsubsection{Locaties}

De beviste locaties zijn geselecteerd op basis van de correlatie met de intensiteiten in Boomkor (TBB)en Garnaal(TBS)-visserij vs het jaartal. Dit levert 18 beviste locaties voor elke type van visserij met een significante toename (Garnalenvisserij) dan wel afname (Boomkorvisserij) in visserijdruk over de jaren 2004-2015. De controle locaties zijn vervolgens geselecteerd op basis van de volgende criteria: - Maximum $5000 \mathrm{~m}$ van de vislocaties (arbitraire voorwaarde om voldoende locaties te houden) - Visserij intensiteit (per visserij) maximaal een derde van die bij de vislocaties (t.g.v. het contrast tussen groepen).

Uiteindelijk blijven er 28 beviste locaties (17 boomkorvisserij, 11 garnalenvisserij) en 74 controle locaties (44 boomkorvisserij, 30 garnalenvisserij) over voor de analyse (figuur 5.23).

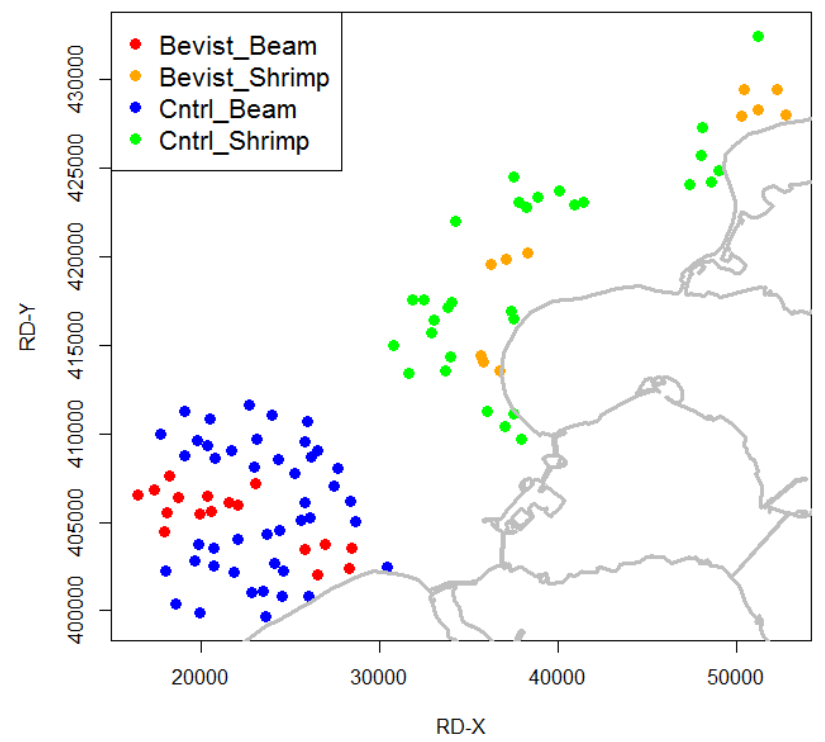

Figuur 5.23 Geografische posities van de Garnaallocaties ("Bevist_Shrimp", "Cntrl_Shrimp") en van de Boomkorlocaties ("Bevist_Beam", "Cntrl_Beam") met weergave van de codekleur gebruikt in het huidige hoofdstuk

De garnalenvisserijlocaties' ("Bevist_Shrimp", "Cntrl_Shrimp") liggen bij de koppen van Goeree en Schouwen en de boomkorvisserijlocaties ("Bevist_Beam", "Cntrl_Beam") voor de kust (Noord) van Walcheren.

De intensiteit van de boomkorvisserij nam sterk af op de beviste locaties tussen 2004 en 2010 en bleef op relatieve lage waardes tussen 2010 en 2015 (figuur 5.24). Op de controle locaties was de boomkorvisserij intensiteit in 2004-2005 een ordegrootte tot een vijfde lager dan in de beviste locaties in dezelfde periode en nam verder af na 2015. Tussen 2010 en 2015 is de intensiteit van de boomkorvisserij in dezelfde ordegrootte in beide groepen van beviste en controle locaties. 

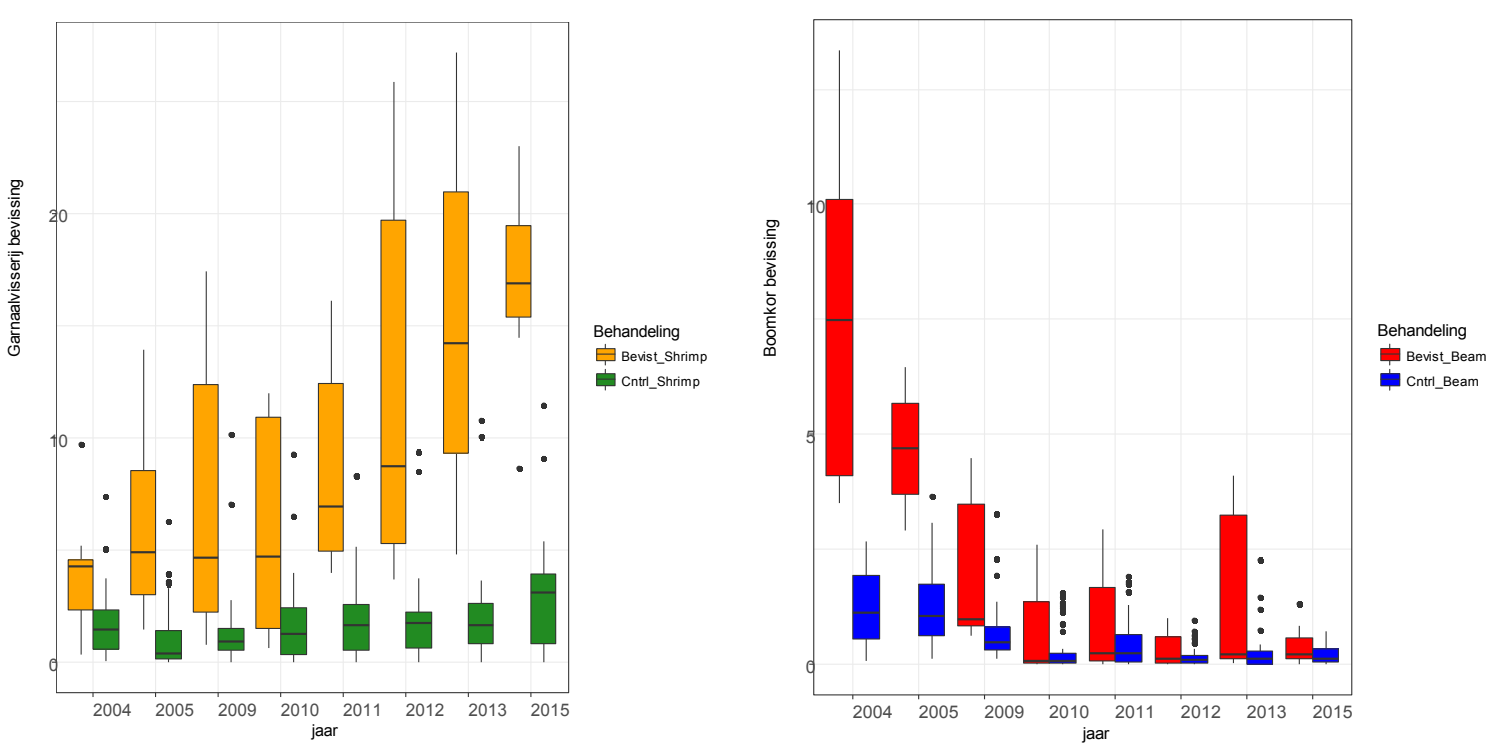

Figuur 5.24 Verandering in visserij intensiteit (Links: garnalenvisserij, Rechts: boomkorvisserij in minuten per $50 \times 50 \mathrm{~m}$ gridcel) op een selectie van 28 beviste locaties (17 boomkoorvisserij, 11 garnalenvisserij) vergeleken met 74 controle locaties (44 boomkorvisserij, 30 garnalenvisserij).

De intensiteit van de garnalenvisserij was hoger op de beviste dan op de controle locaties tussen 2004 en 2010 en nam vervolgens sterk toe tussen 2011 en 2015. In de controle locaties bleef de intensiteit van garnalenvisserij redelijk constant over de hele studieperiode.

Op beviste locaties door de boomkorvisserij vindt ook een matige garnalenvisserij plaats vergelijkbaar met de niveaus waargenomen op de door de garnalenvisserij beviste locaties in 2004-2005. De intensiteit van garnalenvisserij op de controle locaties voor de boomkorvisserij zijn op dezelfde niveau als op de controle locaties voor de garnalenvisserij. Op alle locaties geselecteerd voor de studie naar de garnalenvisserij (zo wel beviste als controle) is de intensiteit van de boomkorvisserij extreem laag.

\subsubsection{Omgevingsfactoren op de locaties}

Bij de analyse is er getracht om te corrigeren voor het effect van de, voor de bodemdieren, meest bepalend omgevingsfactoren (zie habitat model) in de analyse (partiële RDA). Dergelijke informatie kan wel nuttig zijn voor een correcte interpretatie van de waarnemingen.
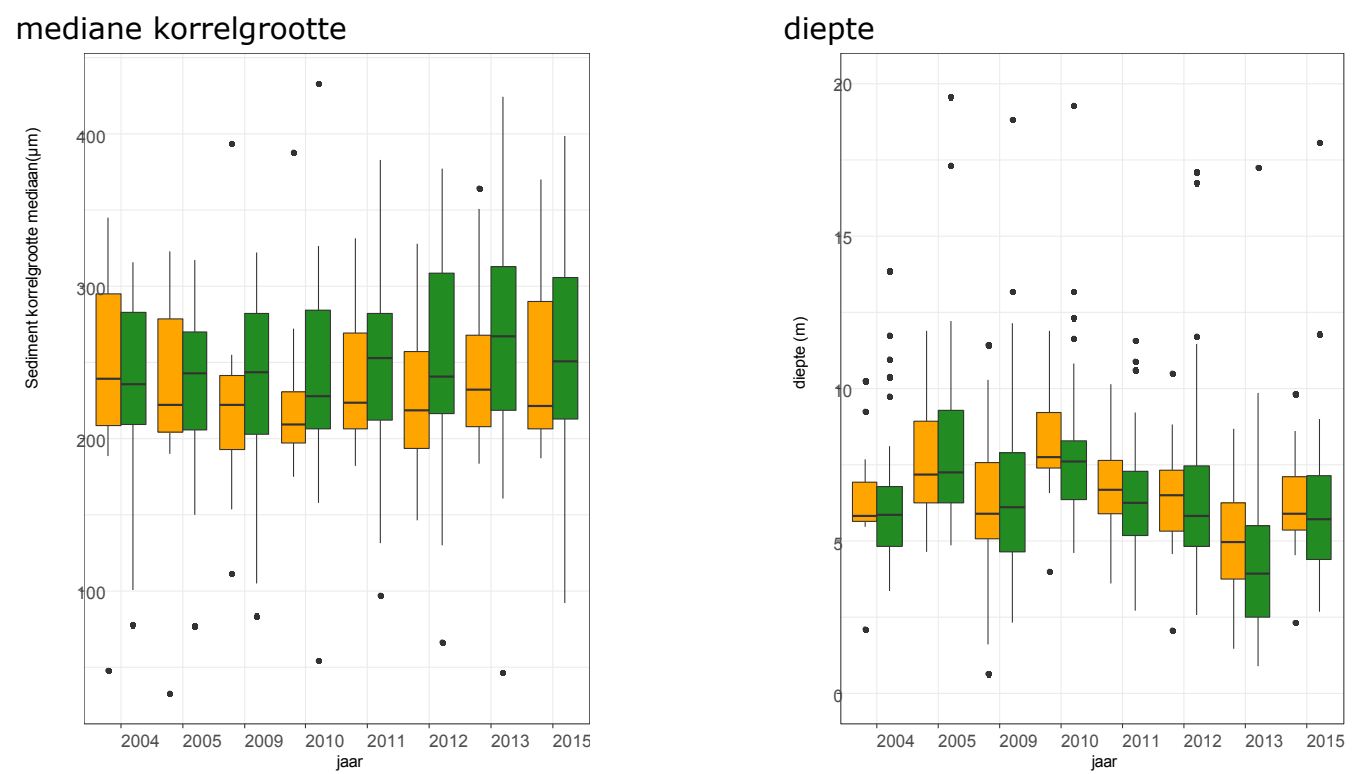

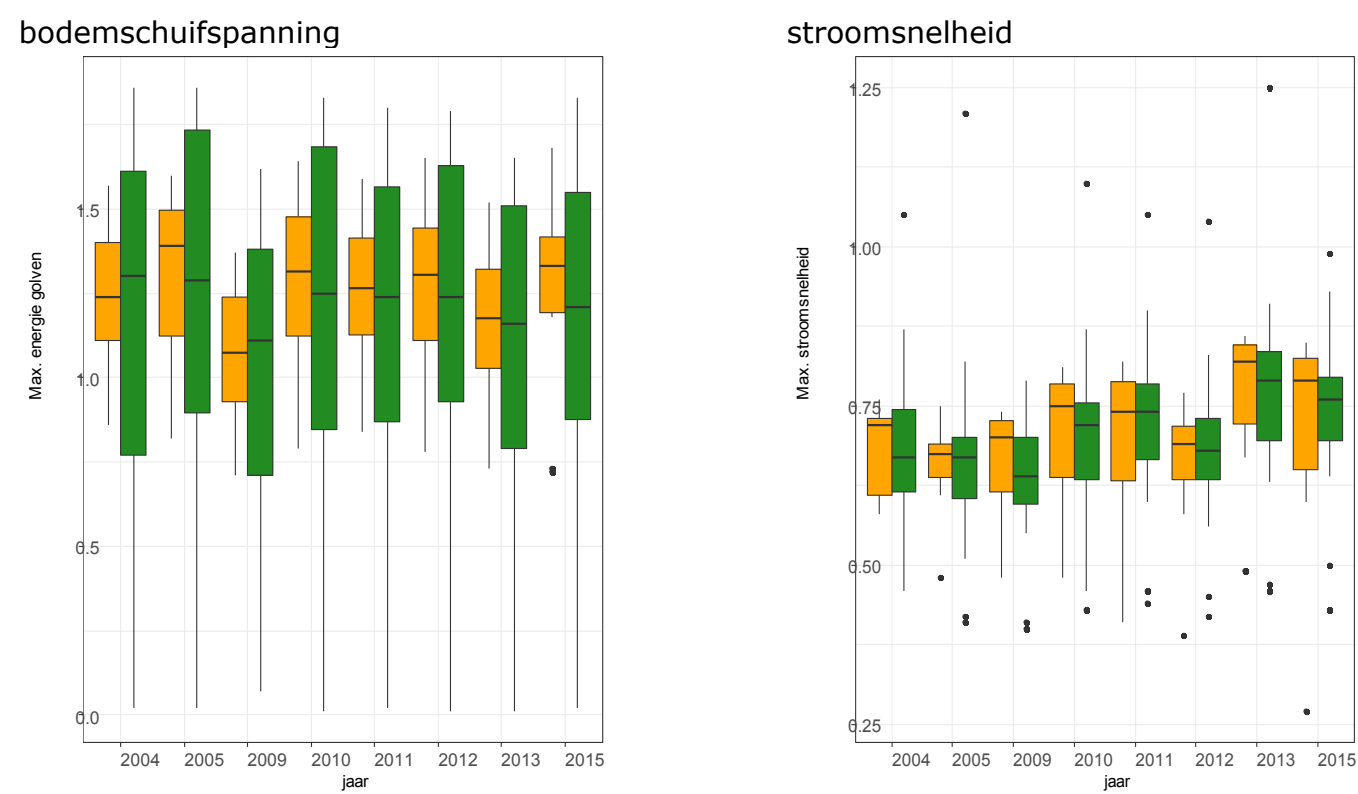

Figuur 5.25 mediane korrelgrootte, diepte, bodemschuifspanning door golven en stroomsnelheid op de garnalenvisserij locaties (oranje: beviste locaties, groen: controle locaties).

Over het algemeen komen de omgevingsfactoren goed overeen op de geselecteerde beviste en controle locaties voor de garnalenvisserij (figuur 5.25).
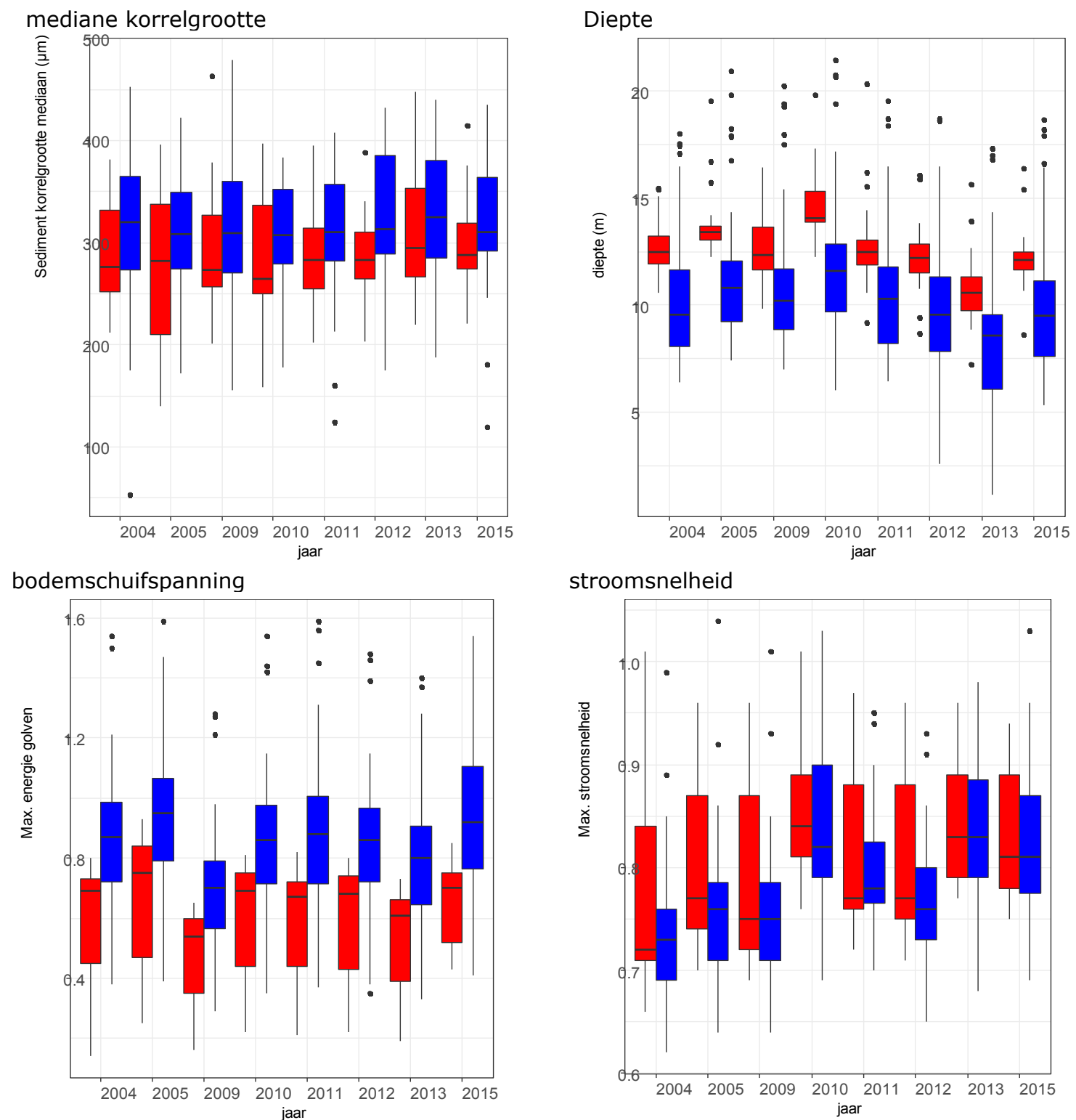
Figuur 5.26 mediane korrelgrootte, diepte, bodemschuifspanning door golven en stroomsnelheid op de bodem waargenomen op de boomkorvisserij locaties (rood: beviste locaties, blauw: controle locaties).

De mediane korrelgrootte is de meeste jaren wat hoger (grover sediment) in de controle dan in de beviste locaties voor de boomkorvisserij (figuur 5.26). De beviste locaties zijn in alle jaren gemiddeld 2 tot 3 meter ondieper dan de controle locaties.

Zoals bij de garnalenvisserij dataset is de onnauwkeurigheid in de positie van de monsterlocaties en de scherpe gradiënten (randplaten, geulen, zandgolven) aanwezig in het monstergebied vermoedelijk verantwoordelijk voor de jaar tot jaar variatie binnen beide groepen van waarnemingen. Als gevolg van het verschil in diepte tussen de twee groepen van locaties (beviste locaties dieper dan de controle locaties) is de bodemschuifspanning door golven op de beviste locaties lager dan op de controle locaties. Zoals bij de garnalenvisserij dataset kenmerken de jaren 2010, 2013 en 2015 zich door hogere maximale stroomsnelheden dan de overige jaren. Vooral in de jaren met lagere stroomsnelheden (2004-2009 en 2011-2012) zijn de maximale stroomsnelheden hoger in de beviste dan in de controle locaties.

De waarnemingen tonen duidelijke verschillen aan in abiotische factoren tussen de beviste en controlelocaties voor de boomkorvisserij. De beviste locaties zijn dieper, hebben een grover sediment, lagere bodemschuifspanning door golven (wel hogere stroomsnelheden) dan de controle locaties.

Idealiter wordt de vergelijking tussen beviste en onbeviste locaties gedaan op locaties die niet in abiotiek verschillen, maar wel in visserijdruk. Dit is helaas niet mogelijk omdat de enige boomkorvisserij die er tijdens de metingen plaatvond zich afspeelde in de diepere geulen in het zuiden van het gebied en er geen vergelijkbare gebieden voorhanden zijn waar geen visserij plaatsvond. Door de abiotiek in de analyse mee te nemen, proberen we wel voor de geconstateerde gebiedsverschillen in abiotiek te corrigeren.

\subsubsection{Waarnemingen op de garnalenvisserij locaties}

\section{RDA dichtheden van soorten}

Bij de eerste run op de hele dataset bleek Ensis directus Amerikaanse zwaardschede van grote invloed te zijn op de resultaten van de RDA met een hoge score op de eerste as van de RDA (figuur 5.27). De dichtheden van Ensis directus zijn van dezelfde ordegrootte in beide behandelingen in alle monsterjaren m.u.v. 2012 en 2013 met veel hogere waardes in de beviste- ( $\left.\mathrm{gem}=1940 \mathrm{~N} / \mathrm{m}^{2}\right)$ dan in de controle locaties $\left(\right.$ gem $\left.=345 \mathrm{~N} / \mathrm{m}^{2}\right)$.

Naast Ensis zijn ook de taxa Spio sp. (borstelworm) en Eteone sp. (borstelworm) uitgesloten van de analyse vanwege een onevenredige invloed op de projectie ten opzicht van de overige soorten: Spio $\mathrm{sp}$. is gekenmerkt door een enorme aanwas in 2011 in de beviste locaties en Eteone sp. komt met hoge dichtheden voor in zowel de beviste als de controle locaties tussen 2010 en 2012.

Na de uitsluiting van Ensis directus, Eteone sp. en Spio sp. is de RDA herhaald op de overige soorten. Van de totale variatie in de dataset werd ca $13 \%$ toegeschreven aan de omgevingsfactoren en $10 \%$ aan de groepsindeling tussen beviste en controlelocaties, en de interactie ermee met tijd (figuur 5.28). 

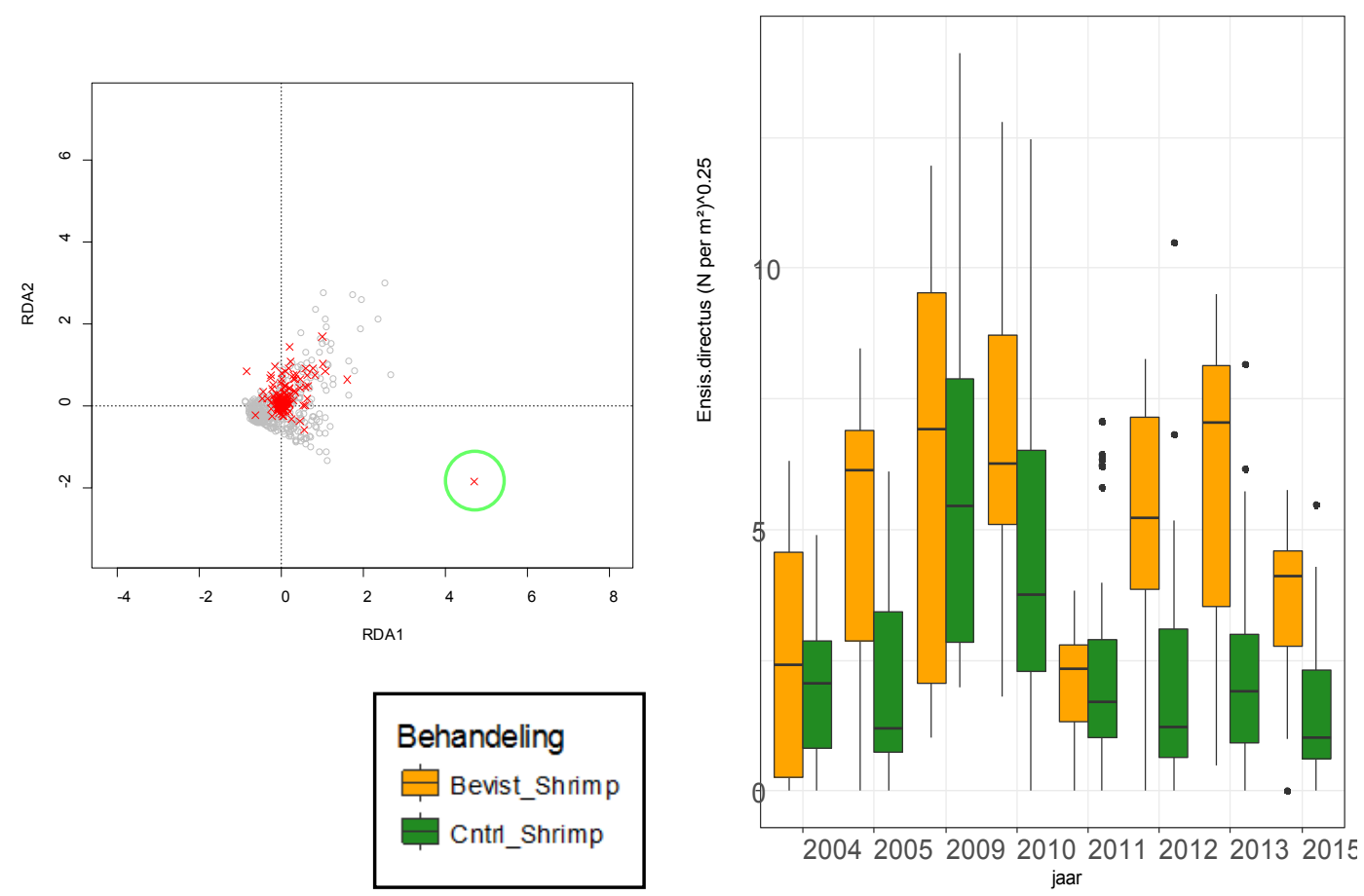

Figuur 5.27 RDA op de hele dataset(grijze cirkels: monsterlocaties, rode kruisjes: taxa) met Ensis als uitschieter (omcirkeld) op de eerste as van de RDA (links). Rechts: Ensis dichtheden (N/m²^0.25) in beviste en controle locaties.

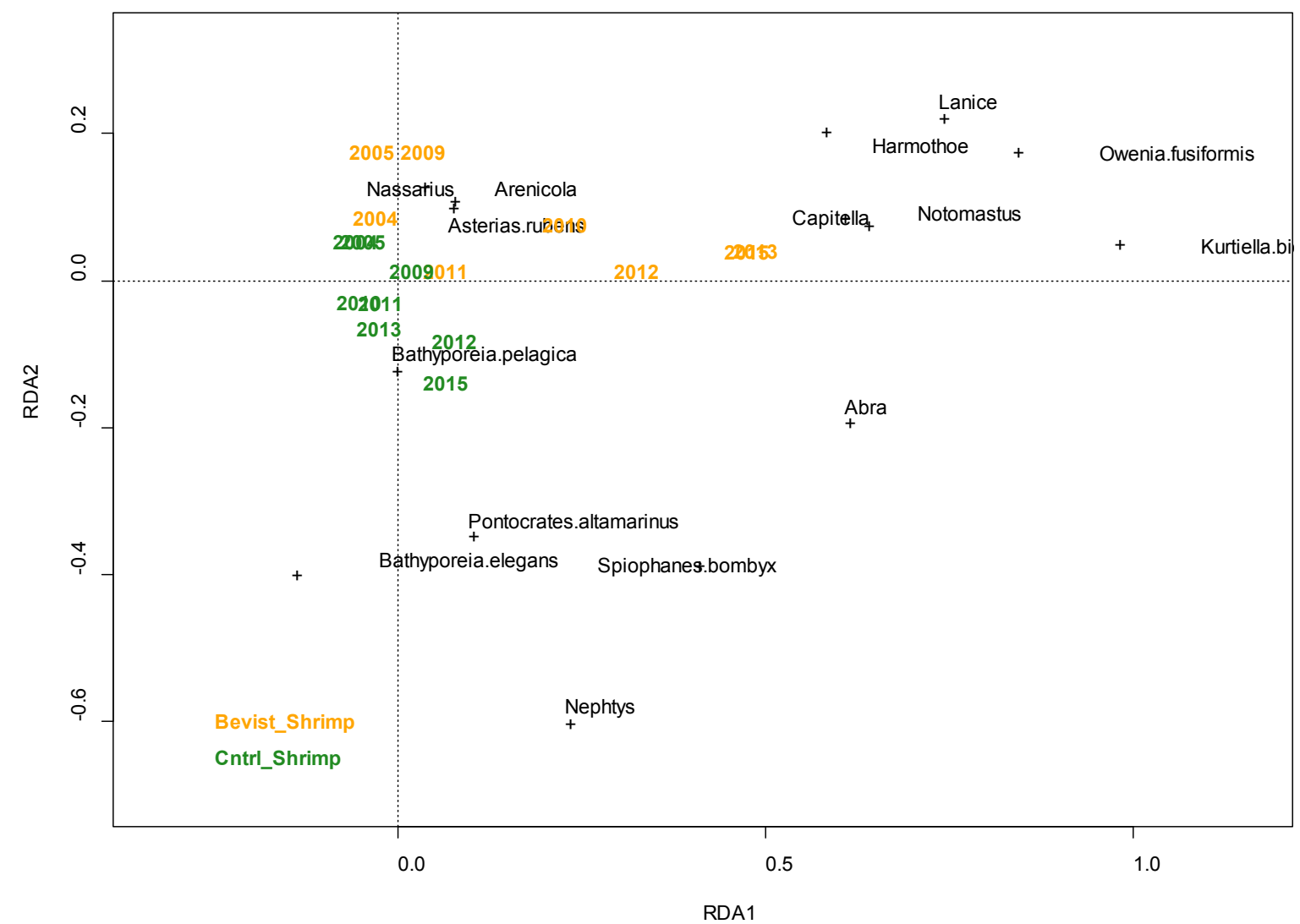

Figuur 5.28 Projectie van de 15 soorten met een hoge affiniteit met de RDA assen samen met de jaar centroïden berekend op basis van locaties scores op de RDA assen met onderscheid van de groepsindeling tussen beviste en controle locaties m.b.t .de garnalenvisserij.

In de begin jaren 2004-2009 liggen de locaties in de beviste en controlelocaties dicht bij elkaar in het RDA vlak (figuur 5.28); de beviste locaties hebben in die jaren wel hogere waardes op de tweede as van de RDA dan de controle locaties. Vooral in 2010, 2012, 2013 en 2015 lopen de gemeenschappen 
uit elkaar (vooral langs de eerste RDA as), samen met intensivering van de garnalenvisserij (Figuur $x 2)$.

Er zijn 15 soorten met een hoge affiniteit met de RDA assen en die dus goed gecorreleerd zijn met de groepsindeling (beviste vs controle locaties) en de interactie ervan met het jaar. Alle soorten met hoge scores op de eerste as van de RDA zijn gekenmerkt door verhoogde dichtheden op de beviste locaties in de jaren met hoge visserijdruk. Die soorten komen overigens slechts sporadisch voor en/of in lagere dichtheden in de controle- dan in de beviste locaties (figuur 5.29).

Opvallend zijn de toenemende dichtheden aan Abra alba witte dunschaal en Capitella sp.(borstelworm) en overige slib-minnende soorten (Lanice sp. zandkokerworm, Owenia fusiformis vertakte kokerworm) behorend tot de Abra alba gemeenschap (Degraer et al., 2004), in de jaren van hoge visserijintensiteit vergeleken met de controle locaties (figuur 5.24). Een dergelijke toename in dichtheid in de jaren 2012-2013 in de beviste locaties werd ook getoond door Ensis directus (figuur 5.27) uitgesloten van de multivariate analyse.
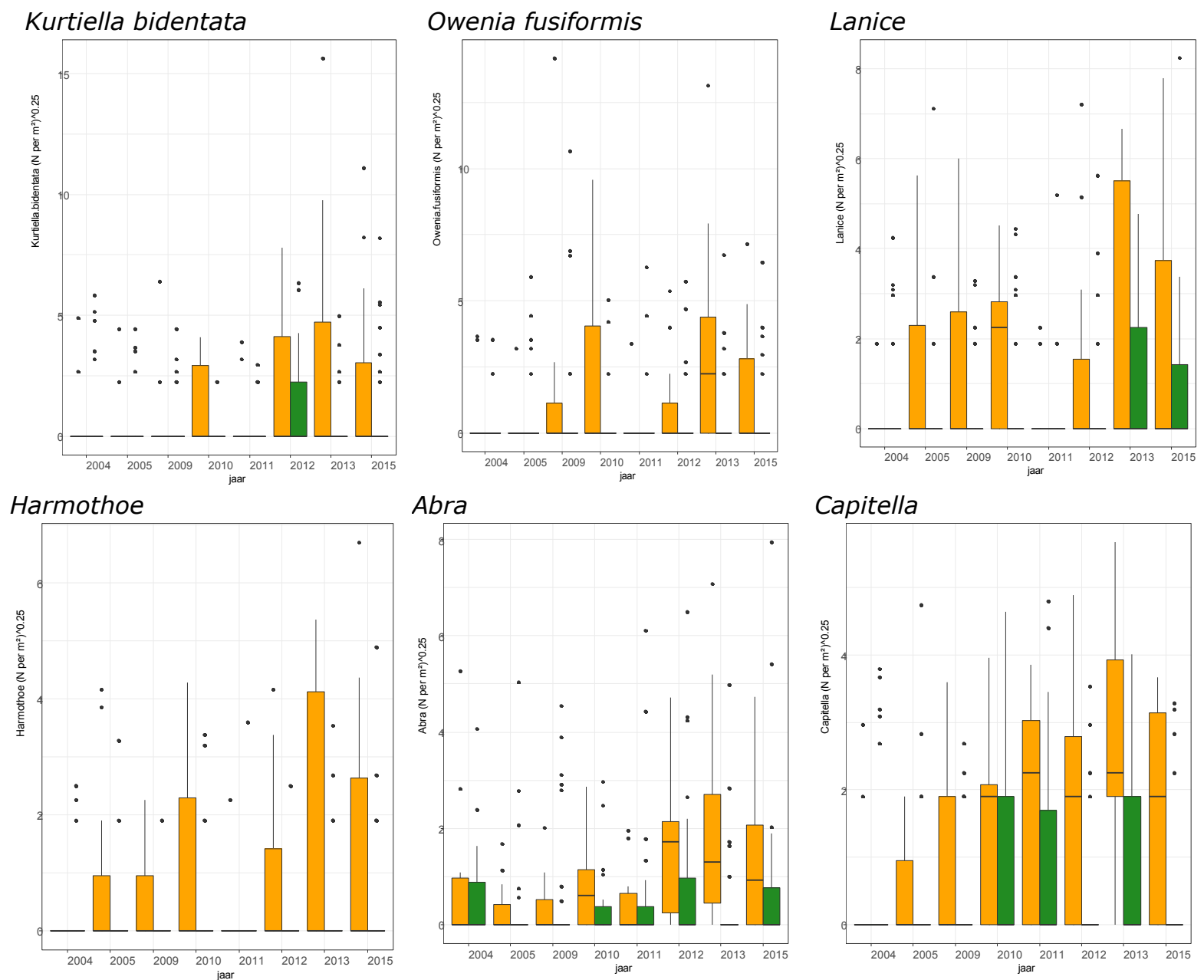

\section{Capitella}

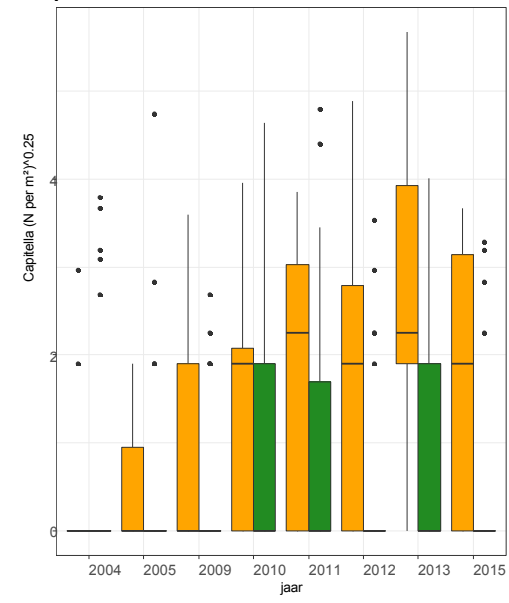

\section{Notomastus}

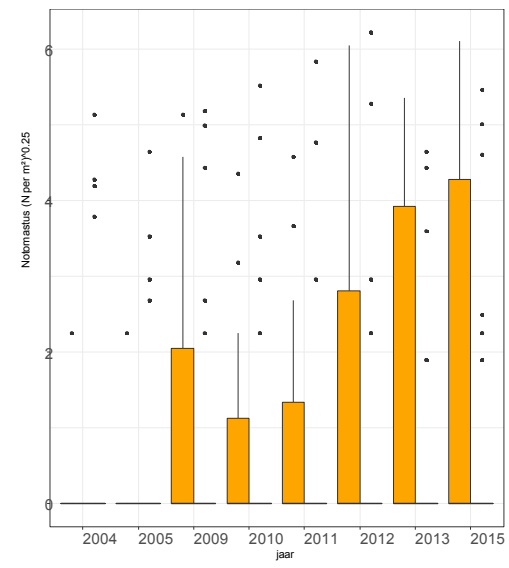

\section{Behandeling}

E Bevist_Shrimp

Cntrl_Shrimp

Figuur 5.29 Dichtheden $\left(\left[\mathrm{N} / \mathrm{m}^{2}\right]^{0.25}\right.$ ) van soorten met hoge (positieve scores) op de eerste as van de RDA uitgevoerd op de garnalenvisserij dataset. 
Univariate bodemdieren indicatoren (garnalenvisserij dataset)

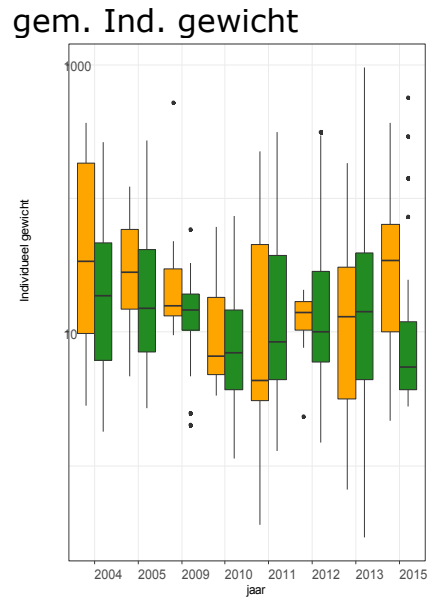

Aantal soorten

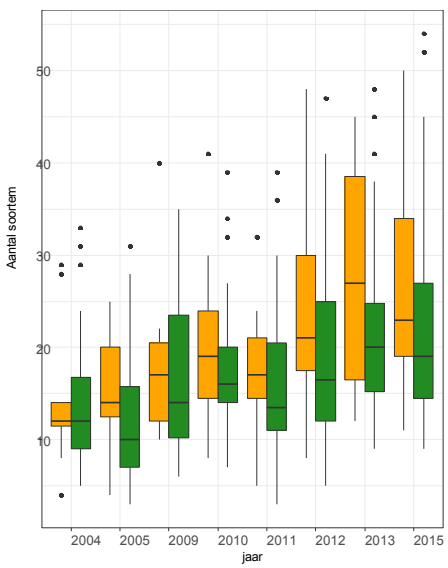

Max. lengte Ensis (L95)

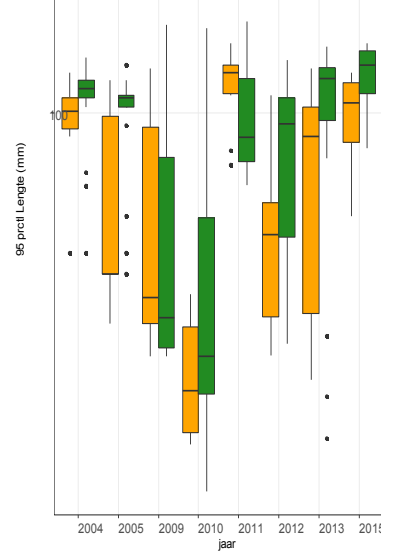

Totale biomassa

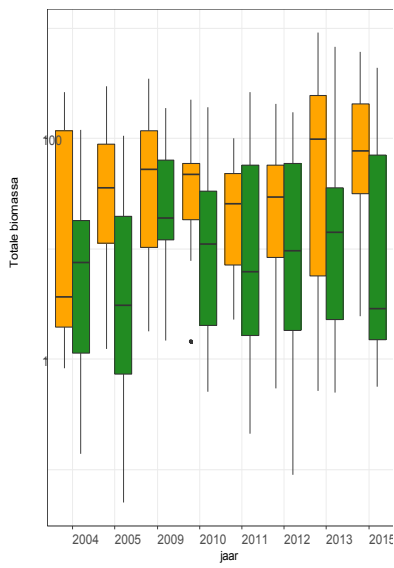

Aandeel grote soorten (W95)

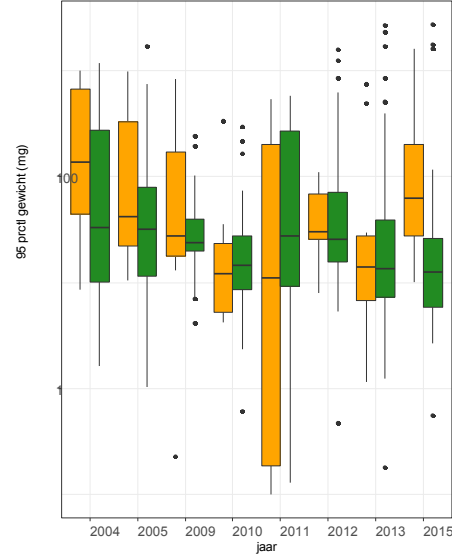

Biomassa voor vogels

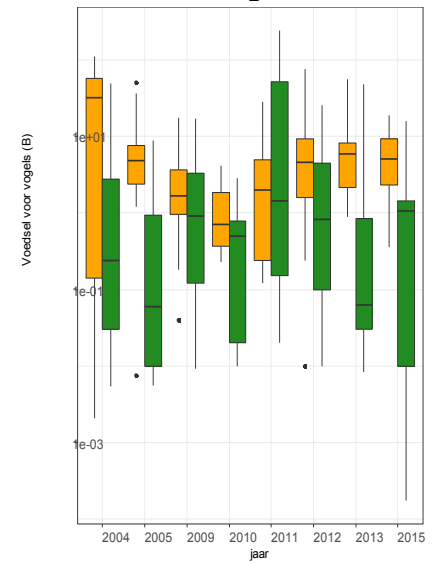

Figuur 5.30 Individuele parameters tussen 2004 en 2015 in de monsters uit de "Garnalenvisserijl" dataset met onderscheid tussen beviste (oranje) en controle (groen) locaties.

De veranderingen in individuele descriptoren door de jaren heen en tussen de behandelingen komen goed overeen: relatieve afname van grote individuen tussen 2004 en 2010 gevolgd door een kortstondige toename tussen 2010 en 2011 en tweede afname tussen 2011 en 2012, vooral in de beviste locaties (figuur 5.30).

De patronen in de individuele indicatoren zijn tegengesteld aan die in de Ensis directus dichtheid (zie figuur 5.27). De relatieve afname in grote individuen valt samen met een toename in Ensis directus dichtheid en andersom zorgen afnemende Ensis directus dichtheden voor een relatieve toename in grote individuen. Dit heeft vooral te maken met de sterke bijdrage van kleine individuen uit de nieuwe cohorten die verantwoordelijk zijn voor de toenamen in dichtheid.

Het aantal soorten neemt toe zowel in de beviste als in de controle locaties. Na 2011, samen met de intensivering van de garnalenvisserij zijn hogere aantal soorten waargenomen in de beviste dan in de controle locaties. De totale biomassa is in vier uit de acht monsterjaren (2005, 2010, 2013 en 2015) hoger in de beviste dan in de controle locaties (figuur 5.30). In de andere jaren is er een grote overlap tussen de biomassa in beide groepen van locaties. Ook de biomassa als voedsel voor vogels is regelmatig hoger (2005, 2013 en 2015) in de beviste dan in de controle locaties (figuur 5.30). 


\subsubsection{Waarnemingen op de "Boomkorvisserij" locaties}

\section{RDA op soorten dichtheden}

Zoals bij de analyse van de garnalenvisserij dataset, blijkt Ensis directus van onevenredige invloed te zijn op de RDA vergeleken met de overige soorten (figuur 5.31).

In alle jaren toont Ensis directus hogere dichtheden in de beviste dan in de controle locaties. In beide groepen van locaties volgen de dichtheden van Ensis directus een parallelle ontwikkeling. Om zicht te krijgen op de response van de andere soorten op de RDA factoren (jaartal en behandeling) is Ensis directus uitgesloten van de analyse. Na het verwijderen van Ensis directus, bleek Nephtys (borstelworm) de projectie "scheef" te trekken langs de tweede as van de RDA. Na inspectie blijkt Nephtys alle jaren aanwezig te zijn in beide groepen van locaties zonder noemenswaardig patroon. Na het verwijderen van beide soorten levert de analyse een wat meer gelijkmatig projectie van de monsterlocaties en van de soorten op het vlak gevormd door de twee eerste assen van de RDA (figuur 5.32).

Van de totale variatie in de dataset werd ca $14 \%$ toegeschreven aan de omgevingsfactoren en $10 \%$ aan de groepsindeling tussen beviste en controlelocaties en de interactie ervan met het jaartal
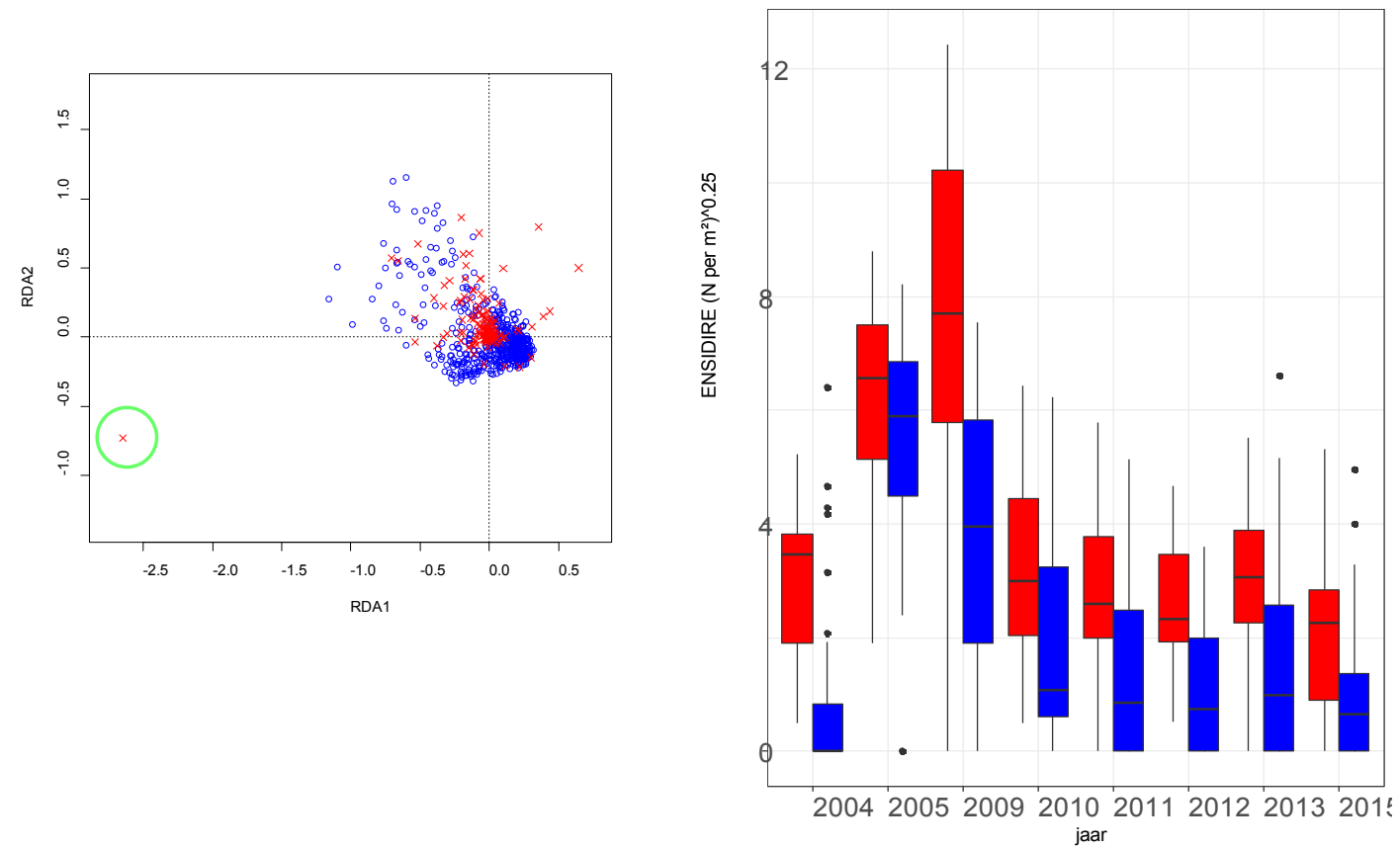

Figuur 5.31 RDA op de hele dataset met Ensis directus als uitschieter (omcirkeld) op de eerste as van de RDA (links). Rechts: Ensis directus dichtheden $\left(\left[\mathrm{N} / \mathrm{m}^{2}\right]^{0.25}\right)$ in beviste en controle locaties. (rood: beviste locaties, blauw: controle locaties) 


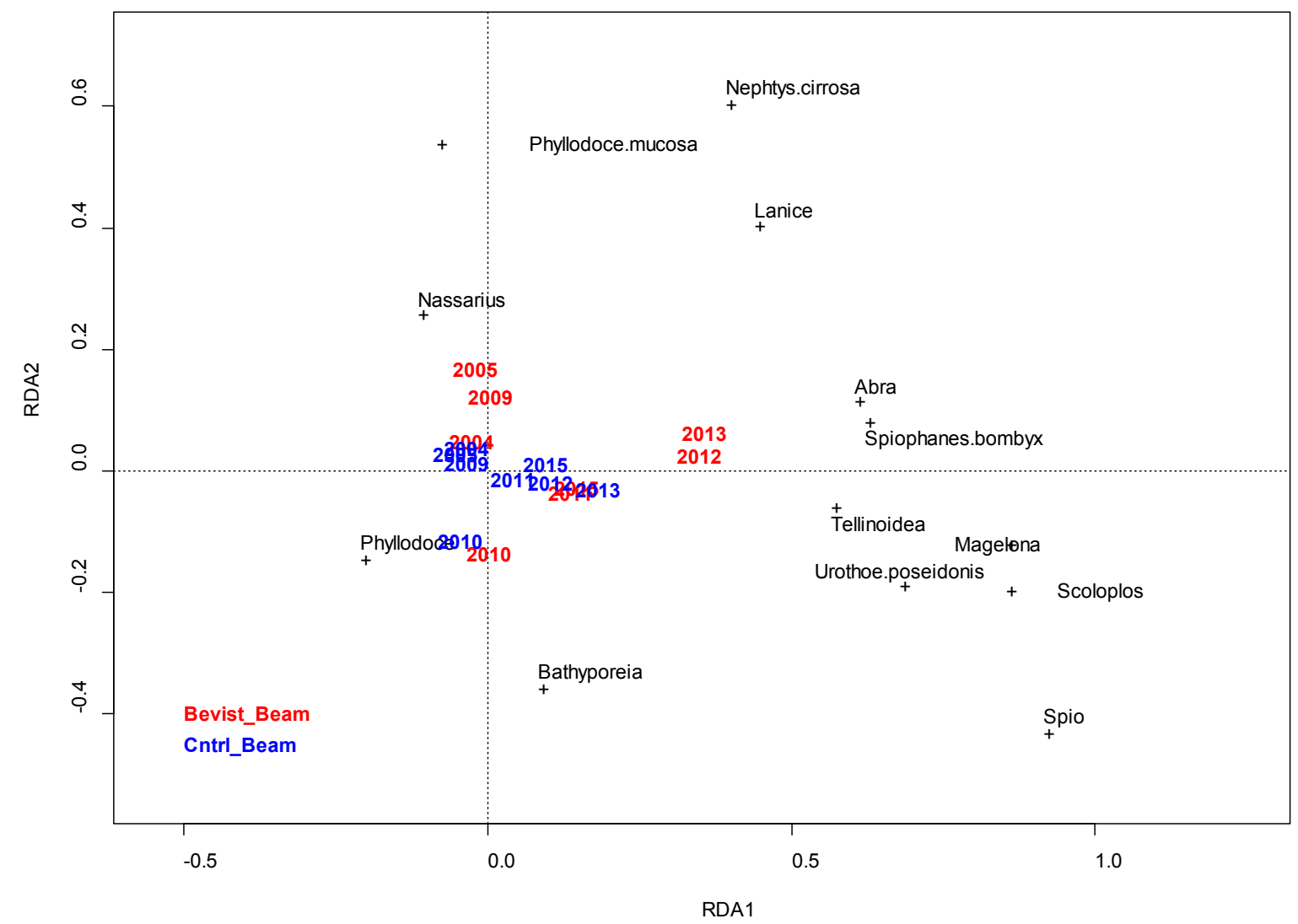

Figuur 5.32 Projectie van de 13 soorten met een hoge affiniteit met de RDA assen samen met de jaar centroïden berekend op basis van locatiescores op het RDA vlak met onderscheid van de groepsindeling tussen beviste en controle locaties m.b.t. de boomkorvisserij. (rood: beviste locaties, blauw: controle locaties)

Juist in het jaar 2004 met het hoogste verschil in de intensiteit van boomkorvisserij tussen de beviste en de controle locaties vallen de projecties voor de twee groepen zeer dicht bij elkaar. Die nabijheid duidt op overeenkomsten tussen de bodemdieren gemeenschappen in deze twee groepen van locaties. Dit geldt ook in zekere mate voor de jaren 2010, 2011 en 2015 waar de RDA projecties voor die jaren naar elkaar schuiven. Daar tegenover kenmerken de jaren 2005, 2009, 2012 en 2013 zich door een relatief grote afstand tussen de centroïden van de beviste en controlelocaties. In die jaren wijken de bodemfaunagemeenschappen dus af tussen de beviste en onbeviste locaties.

Dertien soorten werden geselecteerd op basis van hun relatieve scores op de RDA. De soorten met hoge scoren op de eerste as van de RDA zoals Spiophanes bombyx, Abra of Spio zijn gekenmerkt door hoge dichtheden in 2012-2013 in de beviste locaties (figuur 5.33).
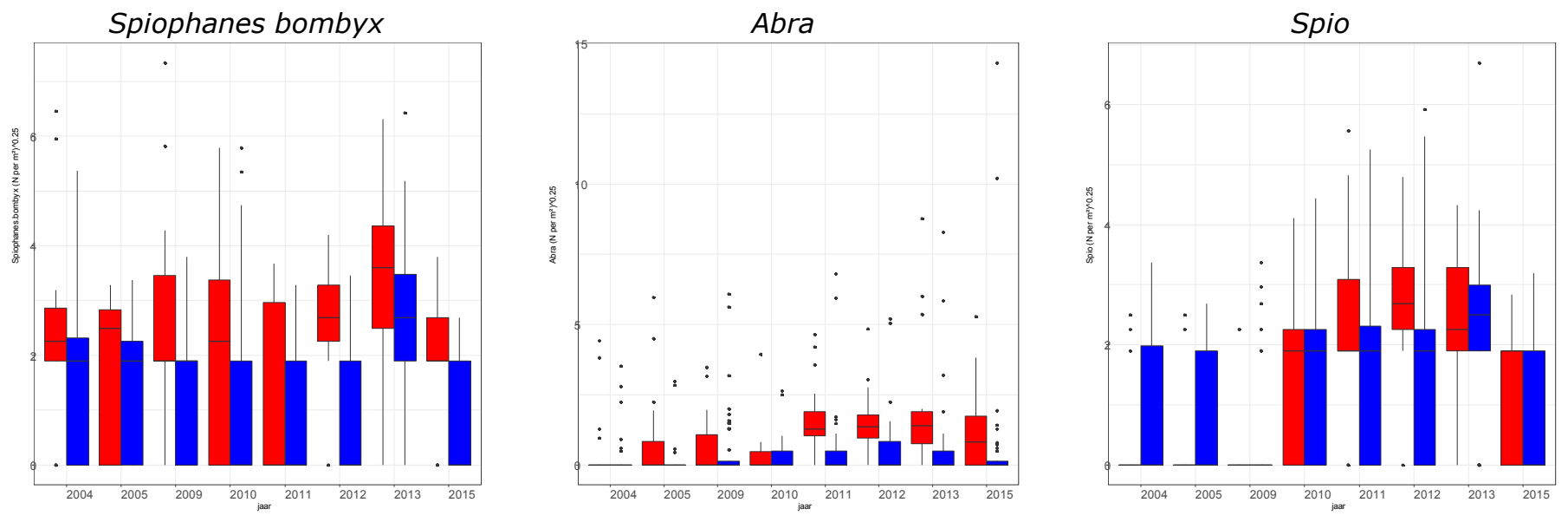

Figuur 5.33 Dichtheden van soorten met hoge score op de eerste as van RDA (boomkorvisserij) (rood: beviste locaties, blauw: controle locaties) 

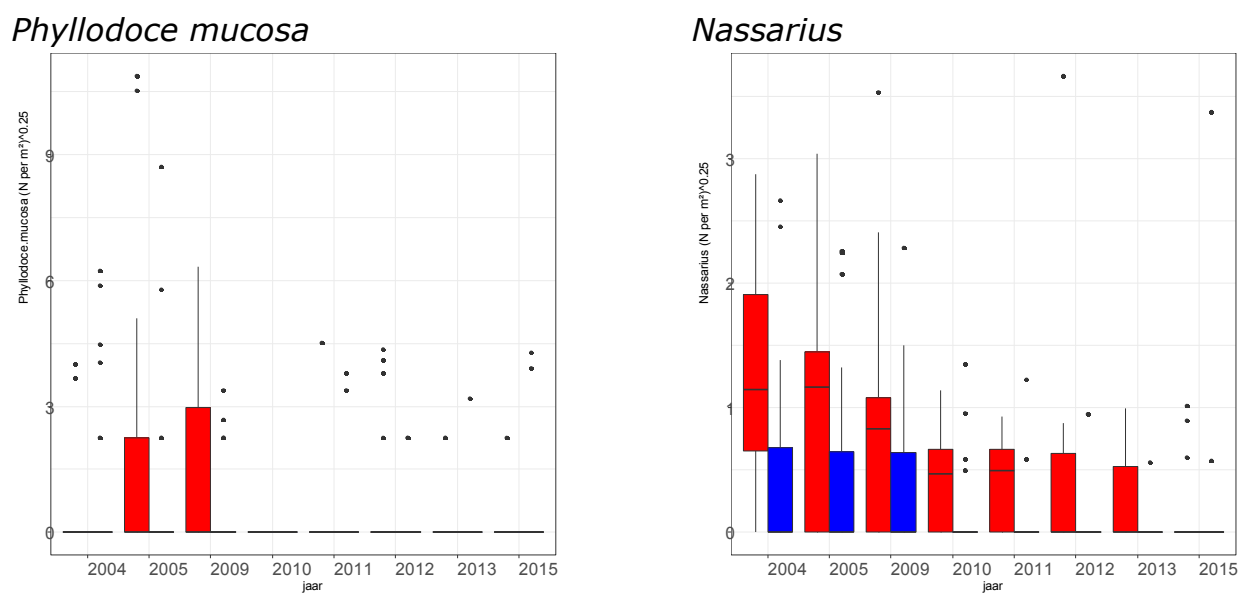

Figuur 5.34 Dichtheden van soorten met hoge scores op de tweede as van RDA (boomkorvisserij). (rood: beviste locaties, blauw: controle locaties).
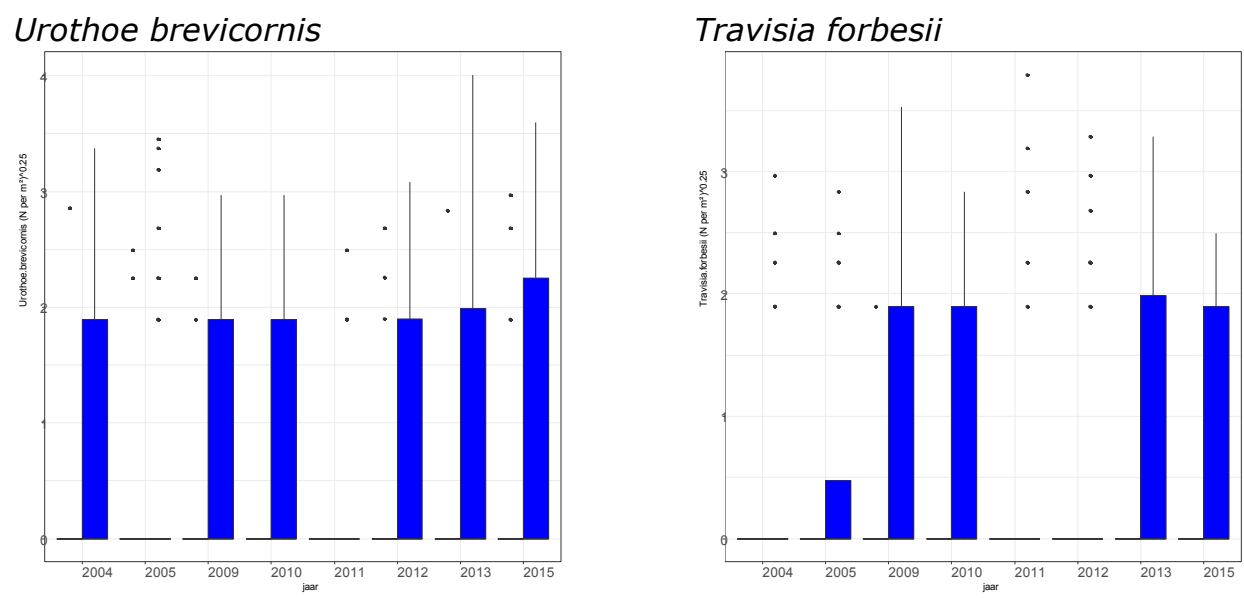

Figuur 5.35 Dichtheden van soorten met lage scores op de tweede as van RDA en negatieve scores op de eerste as (boomkorvisserij, rood: beviste locaties, blauw: controle locaties)

Soorten zoals Phyllodoce mucosa en Tritia sp. met hoge scores op de tweede as van de RDA zijn gekenmerkt door hoge dichtheden in de jaren 2005-2009 en daar ook vooral in de beviste locaties (figuur 5.34).

Soorten die kenmerkend zijn voor de controle locaties met lage scores op de tweede as van RDA en negatieve scores op de eerste as zijn bijvoorbeeld Urothoe brevicornis of Travisia forbesii die vooral waargenomen zijn op die controle locaties. (figuur 5.35). 


\section{Univariate bodemdieren indicatoren ("Boomkor dataset")}
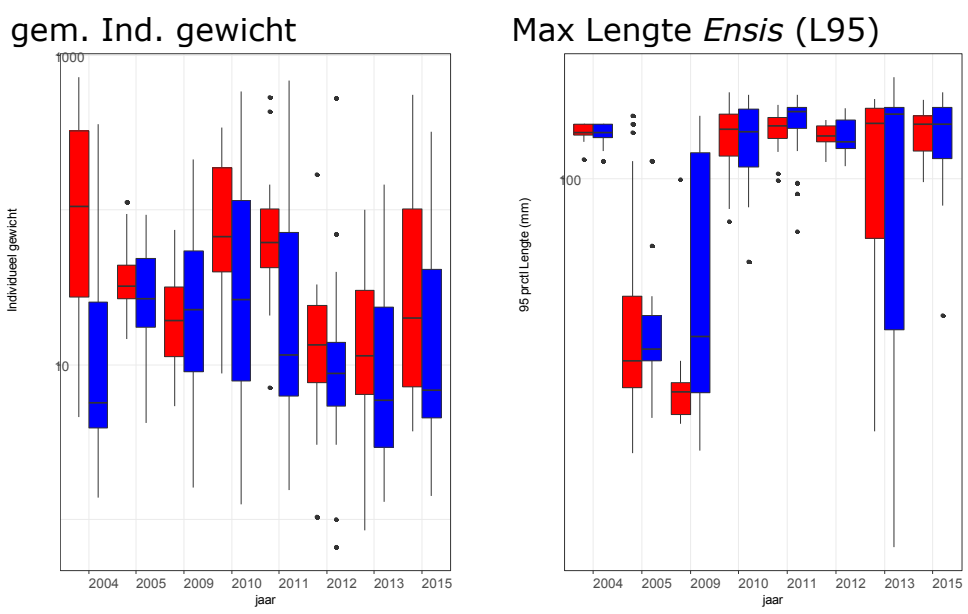

Aandeel grootte soorten (W95)
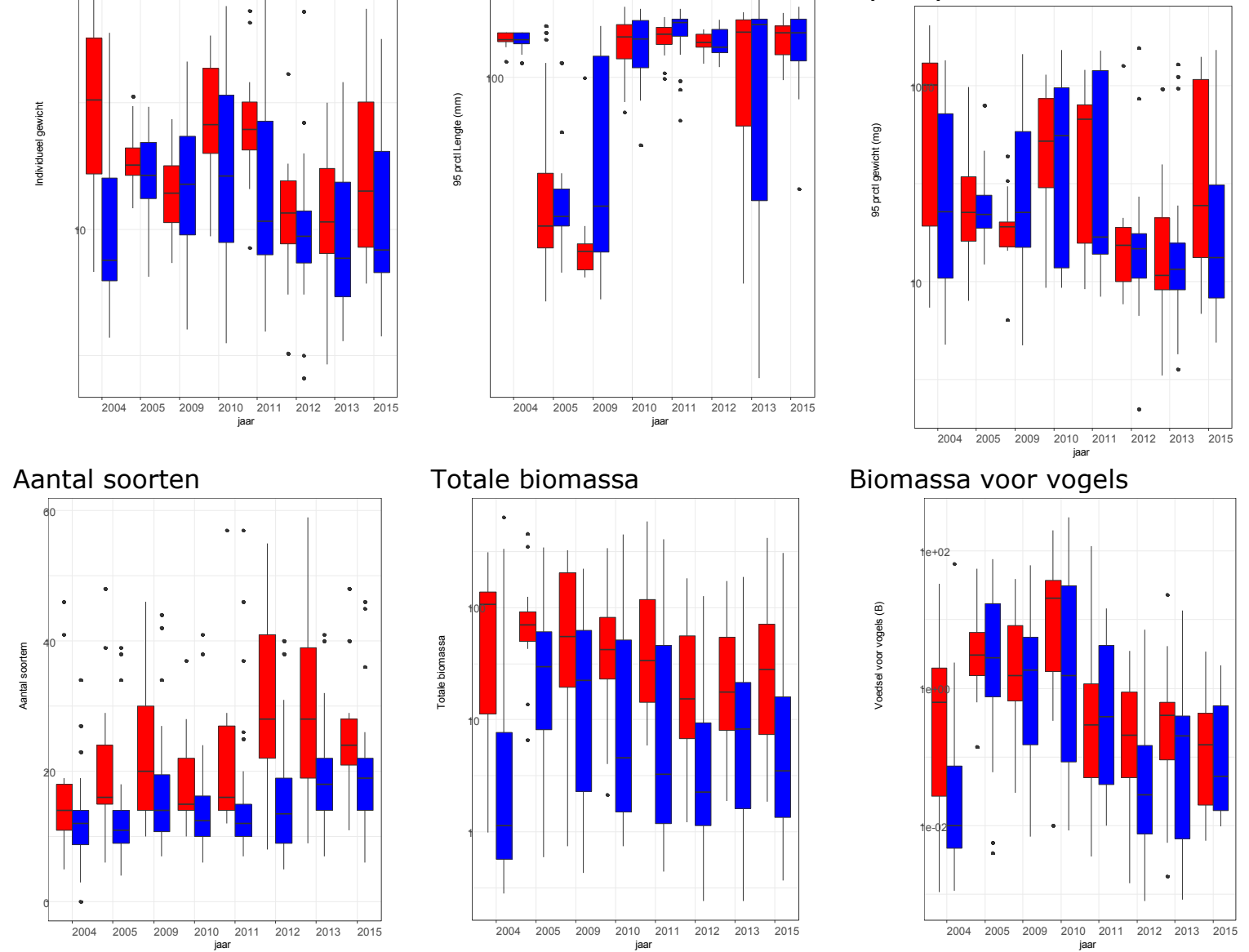

Figuur 5.36 Individuele parameters tussen 2004 en 2015 in de monsters uit de "Boomkorvisserij" dataset met onderscheid tussen beviste (rood) en controle (blauw) locaties.

Net zoals in de analyse van de garnalenvisserij dataset, blijkt de populatiedynamiek van Ensis directus zeer bepalend te zijn voor de individuele eigenschappen van de bodemdierengemeenschap. De pieken in Ensis directus dichtheden (zie figuur 5.31) in de jaren 2005-2009 en (in mindere mate) in 20122013) vertalen zich in een afname in de gewichten van de bodemdieren individuen. Met uitzondering van de periode van verhoogde Ensis directus dichtheden in 2005-2009 zijn de gemiddelde individuele gewichten meestal hoger in de beviste dan in de controle locaties.

De soortenaantallen zijn in alle jaren hoger in de beviste dan in de controle locaties, in het bijzonder in de jaren 2012 en 2013, terwijl de visserijdruk in die periode op vergelijkbare niveaus stond in beide groepen van locaties (figuur 5.36).

In alle jaren zijn de waardes van totale biomassa en van gemiddeld individueel gewicht hoger in de beviste dan in de controle locaties. Dit was vooral het geval in 2004, juist het jaar met de hoogste intensiteit aan boomkorvisserij, waar de mediane waarde twee orde van grootte groter was in de beviste dan in de controle locaties. De biomassa als voedsel voor vogels komt beter overeen tussen beide groepen locaties, met uitzondering van 2004 waar de waardes beduidend lager waren in de controle dan in de beviste locaties. 


\section{Deelconclusie}

- De geselecteerde monsterpunten leveren het sterkste contrast in visserijdruk tussen bevist en onbeviste locaties op in het studiegebied. Het kan dus verondersteld worden dat deze selectie geschikt is voor het detecteren van de effecten van visserij op het benthos.

- beviste en controle locaties verschillen enigszins van elkaar m.b.t. de omgevingsfactoren (vooral de boomkorvisserij locaties). De effecten van die verschillen op de bodemdieren gemeenschappen blijken (na correctie) wel van ondergeschikte belang te zijn vergeleken met de jaar tot jaar veranderingen.

- De jaren van intense garnalenvisserij zijn gekenmerkt door een verhoging in dichtheden aan Ensis en aan Abra alba, Capitella en overige slib-minnende soorten (Lanice sp., Owenia fusiformis) op de beviste locaties vergeleken met de controle locaties.

- De positieve relatie beschreven in hoofdstuk 5.1.10.5. tussen het aantal soorten en de intensiteit van garnalenvisserij is ook waargenomen in de huidige dataset.

- In het jaar 2004, waarin de boomkorvisserij het hoogste was, was de overeenkomst in bodemdierengemeenschappen tussen de beviste en de controle locaties tegen de verwachting in het grootst.

- $\quad$ Met uitzondering van Tritia sp. die de hoogste dichtheid bereikte op de beviste locaties tijdens de laatste jaren (2004-2005) van intense boomkorvisserij, worden de meeste verschillen in dichtheden van soorten tussen beviste en controle locaties waargenomen na 2010 en dus zonder verband met de boomkorvisserij.

- De populatiedynamiek van Ensis directus is van grote invloed op de univariate benthos parameters door de dominantie van die soort.

\subsubsection{Lange termijn veranderingen in bodemfauna in de Voordelta en langs de Hollandse kust in relatie tot visserij}

De visserijdruk is niet alleen in de Voordelta sterk afgenomen sinds begin van deze eeuw. Dit is een patroon dat overal langs de kust waargenomen is. Het moment waarop en het tempo waarin de visserijdruk is afgenomen verschilt wel tussen gebieden langs de kust (Craeymeersch et al. 2015a). In de eerste fase hebben we de lange termijn veranderingen van een aantal soorten uit de WOT schelpdiersurvey die uitgevoerd wordt vanaf 1995 binnen en buiten de Voordelta geanalyseerd en op het oog vergeleken met de ontwikkelingen in de visserijdruk. Hier gaan we nog een slag verder en onderzoeken we of ook kwantitatief of de veranderingen in de bodemfauna gecorreleerd zijn met de verandering in de visserijdruk. Voor al de onderzochte schelpdiersoorten geldt dat ze relatief langlevend zijn en gevoelig voor bodemberoerende bevissing. Naast de twee schelpdiersoorten zijn ook slangsterren en heremietkreeften geanalyseerd, die beide ook geclassificeerd zijn als gevoelig voor bodemberoerende visserij.

Bij de aanpak van deze analyse was er de mogelijkheid voor twee routes, die beide zijn toegepast:

1. De visserijdata worden berekend op basis van VMS (Vessel Monitoring System, zie hoofdstuk visserij) data. Die zijn echter pas beschikbaar vanaf 2004 (en voor garnalenvisserij vanaf 2006). Het voordeel van deze data is dat de ruimtelijke indeling zelf gekozen kan worden.

2. De visserijdata worden afgeleid uit de logboekdata op het niveau van ICES-kwadranten (figuur 5.37). Deze data zijn beschikbaar vanaf 1995, maar bieden afgezien van de kwadranten geen ruimtelijke resolutie. Bovendien is deze informatie alleen voor de

3. boomkorvisserij beschikbaar. 

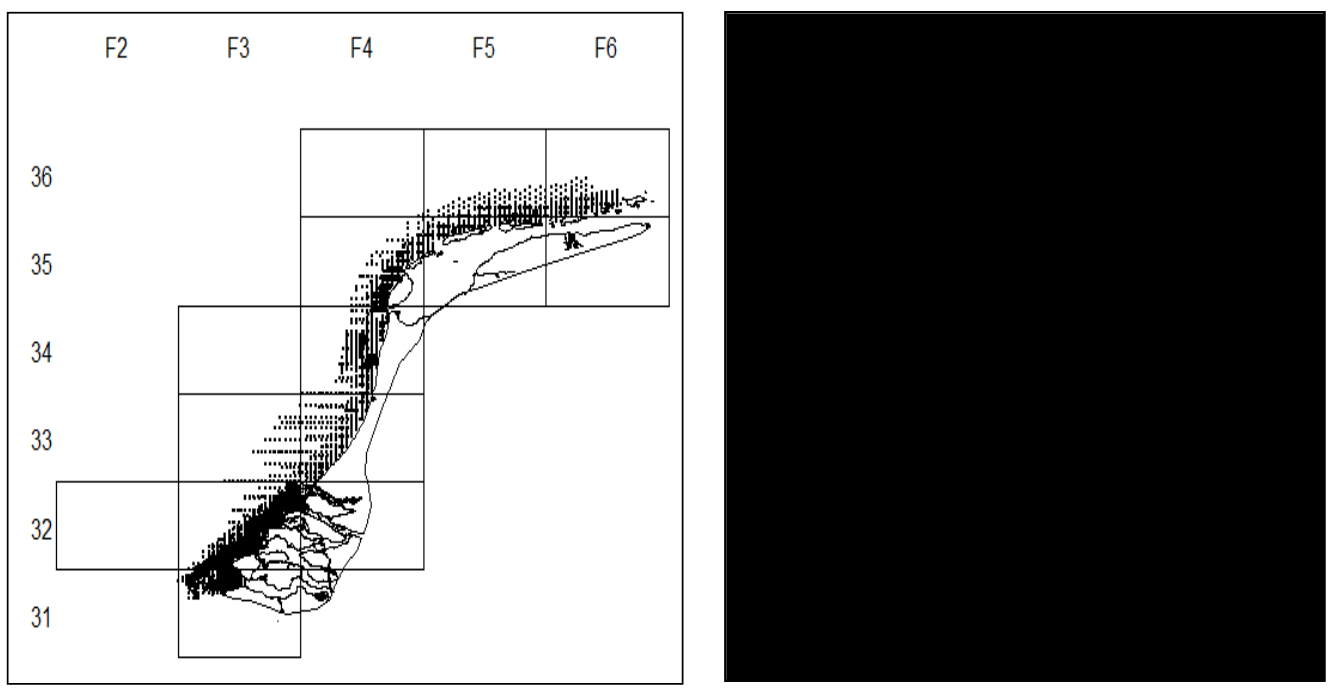

Figuur 5.37 Indeling kustzone in ICES kwadranten (links) of DFS gebieden (rechts).

De trendanalyses zijn in twee stappen uitgevoerd

1. Met behulp van een GAM (General Additive Model) hurdle model met een Gamma distributie zijn op basis van de individuele monsterpunten de aan- of afwezigheid en de dichtheden geanalyseerd. Vanwege het grote aantal nulwaarnemingen is een tweetraps aanpak nodig Eerst wordt met een GAM op basis van een Bernouilli verdeling de aan- of afwezigheid geschat. Vervolgens wordt voor de positieve waarnemingen de dichtheid geschat op basis van een Gamma verdeling. De verklarende factoren die hierbij zijn gehanteerd zijn waterdiepte, jaar en de positie van het monsterpunt (lengte- en breedtegraad).

2. Vervolgens worden de jaarindexen per deelgebied die hieruit verkregen worden gebruikt voor het berekenen van een tijdtrend met behulp van een Bayesiaans tijdseriemodel (Harvey 1989, Ghosh \& Clyde 2011), waarbij onderzocht wordt of de visserij-inspanning hiervoor een verklarende factor zou kunnen zijn. De kans hierop wordt uitgedrukt in een inclusion probability: dit kan vergeleken worden met de p-waarde in niet Bayesiaanse (frequentistic) statistiek. Het geeft het aantal keren van de 1000 MCMC (Markov Chain Monte Carlo) iteraties aan waarbij de covariaat in het model terecht komt. Hoe hoger de inclusion probability, hoe sterker de indicatie van een correlatie tussen visserijdruk en de dichtheid. Een waarde van $>0.1$ geeft aan dat de covariaat in >100 van de 1000 interacties in het model opgenomen wordt.

3. Deze analyses zijn dus op twee ruimtelijke manieren uitgevoerd: op basis van ICESkwadranten en logboekgegevens voor de visserijdruk (vanaf 1995) en op basis van de DFS gebieden op basis van VMS data voor de visserijdruk (vanaf 2004). In totaal zijn op deze manier 13 soorten geanalyseerd waarvan 8 schelpdieren (tabel 5.10). 
Tabel 5.10

Overzicht van soorten uit de WOT schelpdiersurvey die geanalyseerd zijn. De laatste drie soorten zijn aaseters en komen in de volgende paragraaf aan bod.

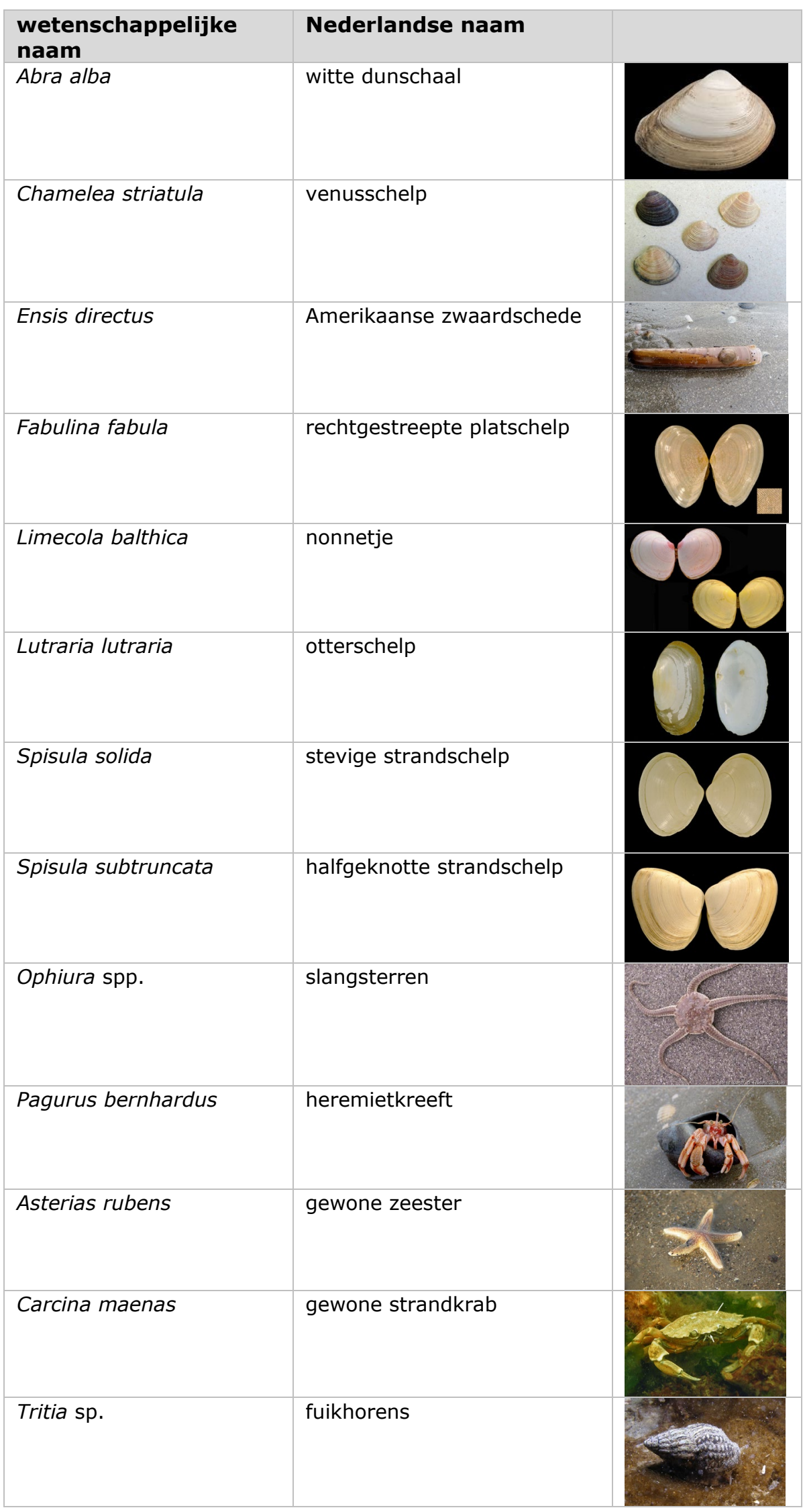




\subsubsection{Lange termijn ontwikkelingen in relatie tot visserijdruk op basis van VMS}

De lange termijnontwikkelingen laten voor veel soorten vergelijkbare ontwikkelingen zien tussen de gebieden langs de Nederlandse kust (figuur 5.38). Veel soorten zijn toegenomen over de afgelopen 10 jaar. Op het oog lijken er weinig grote verschillen in de deelgebieden te zijn, maar sommige soorten komen wel veel in een gebied voor en minder in de andere gebieden: bv witte dunschaal en otterschelp (let op: de absolute niveaus kunnen in deze figuren niet vergeleken worden omdat het modelvoorspellingen betreft op basis van de mediane diepte per gebied).
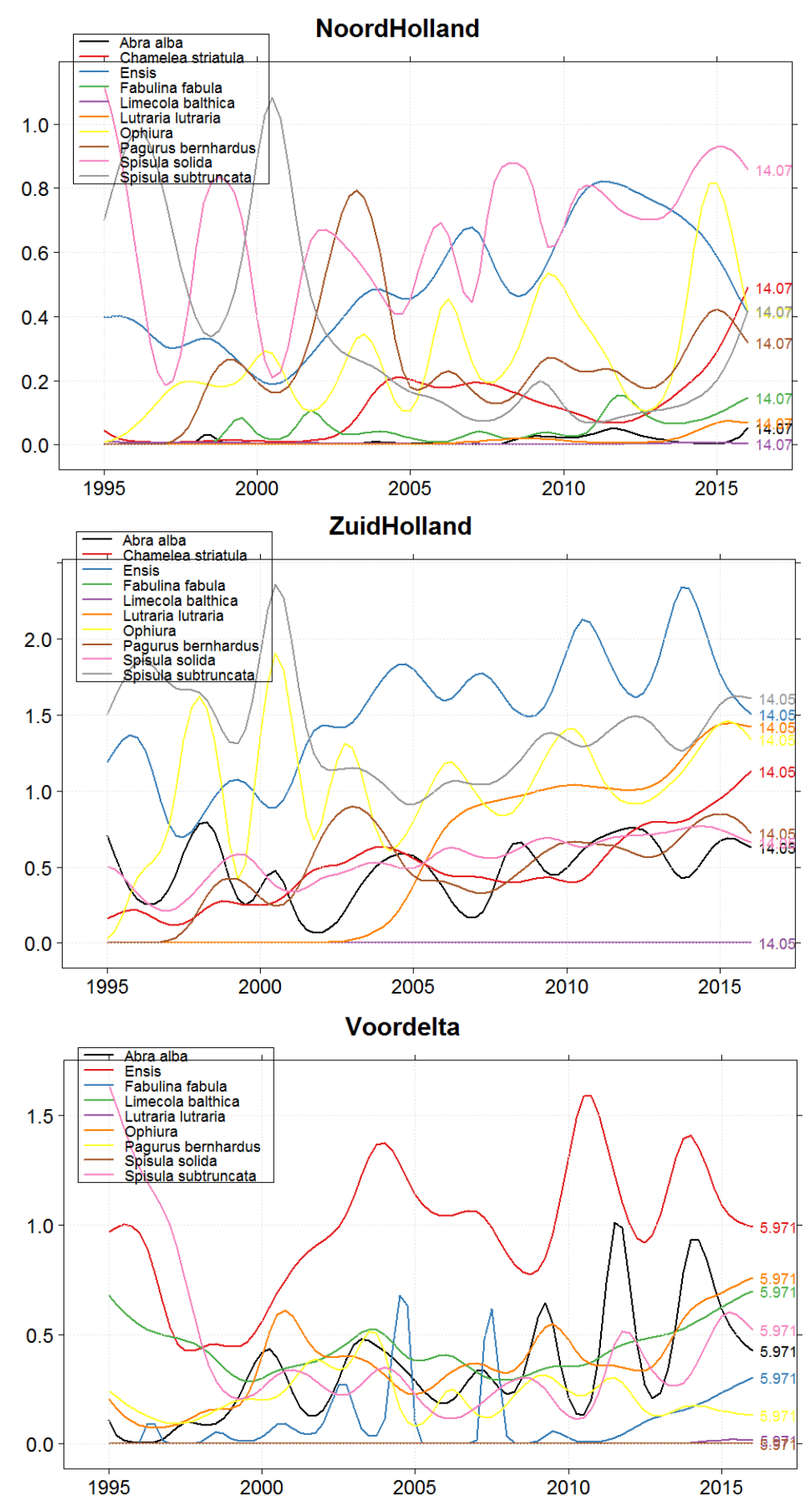

Figuur 5.38 De resultaten van het hurdle model waarbij per jaar de dichtheid geschat is op basis van waterdiepte, jaar en geografische positie. De cijfers geven de mediane diepte weer per locatie (die is dus niet soortspecifiek) waarvoor de modelvoorspelling gegeven is. Chamelea striulata (venusschelp) komt bijna niet voor in de Voordelta. Verticale as: dichtheid $(\mathrm{n} / \mathrm{m} 2)$ op mediane diepte en mediane locatie 
De VMS data geven de mogelijkheid om de ontwikkelingen in de bodemfauna te analyseren over de periode 2006-2016 (figuur 5.39). In deze periode is voor geen van de onderzochte soorten en gebieden een relatie gevonden met de visserijdruk door boomkorvisserij of garnalenvisserij. De reden hiervoor kan heel goed liggen in de lengte van de serie: 10 jaar is erg weinig voor een dergelijke analyse. Daarom hebben we ook dezelfde analyse op het niveau van ICES kwadranten uitgevoerd, op basis van logboekdata (volgende paragraaf). Die tijdserie is aanzienlijk langer: 1995-2016 (22 jaar).
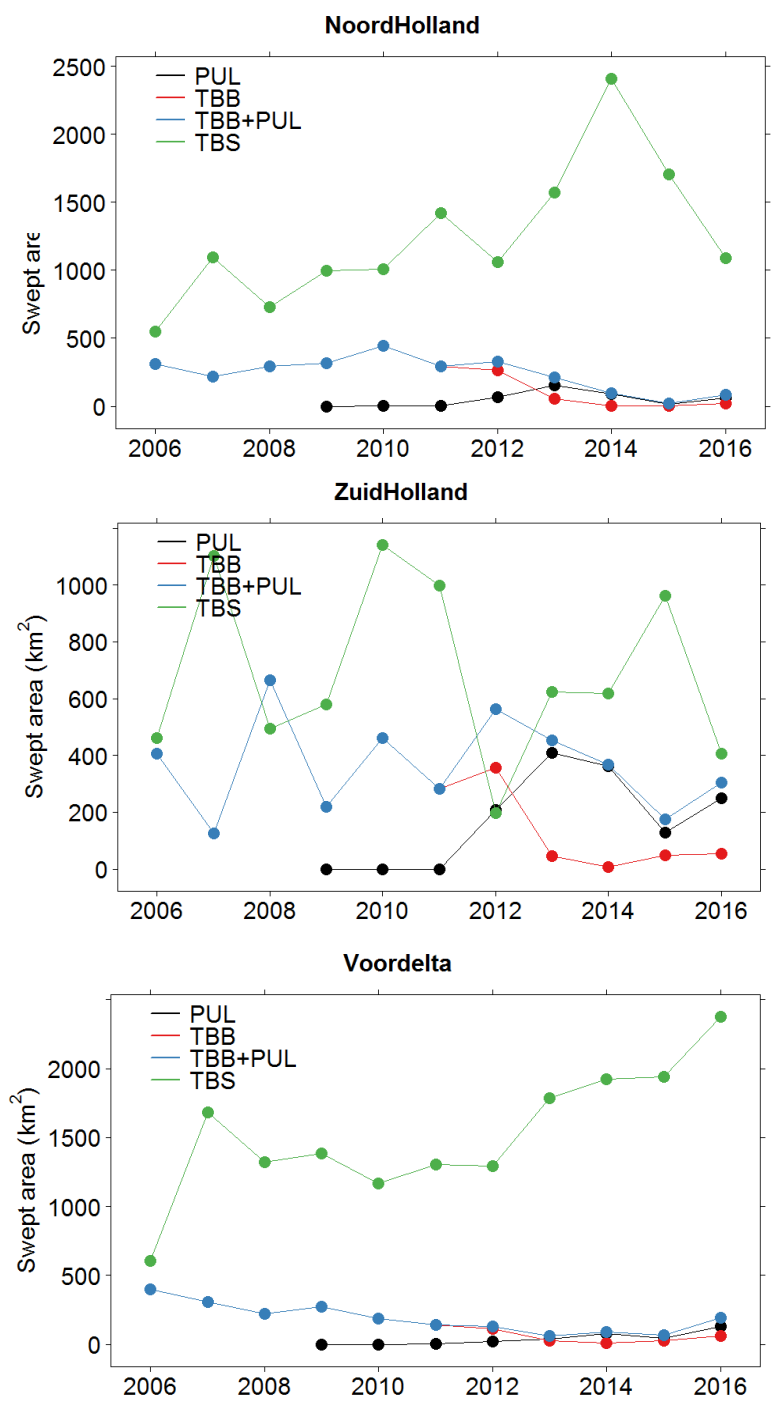

Figuur 5.39 Ontwikkeling visserij inspanning (bevist oppervlak) in de periode 2006-2016.PUL= pulsvisserij, TBB=boomkorvisserij, TBS=garnalenvisserij. In de analyse is voor boomkorvisserij de categorie TBB+PUL gebruikt (analoog aan alle andere analyses). Verticale as: bevist oppervlak $\left(\mathrm{km}^{2}\right)$ 


\subsubsection{Lange termijn ontwikkelingen in relatie tot visserijdruk op basis van logboekdata}

We beperken de grafische weergave van de analyse tot de ICES kwadranten die het meest overeenkomen met de gebieden Voordelta, Zuid-Holland en Noord-Holland (32F3, 33F4, 34F4, figuur 5.40)). De lange termijn ontwikkelingen laten ook op basis van deze gebiedsindeling toenames zien voor veel soorten in de laatste 10 jaar. De otterschelp komt vrijwel niet voor in de Voordelta (32F3) en de Voordelta wijkt daarmee af van de overige kustgebieden. Daarentegen komt de witte dunschaal juist vooral in de Voordelta voor en is daar over de hele periode toegenomen. Slangsterren zijn vooral in de Voordelta toegenomen en veel minder langs de Hollandse kust.
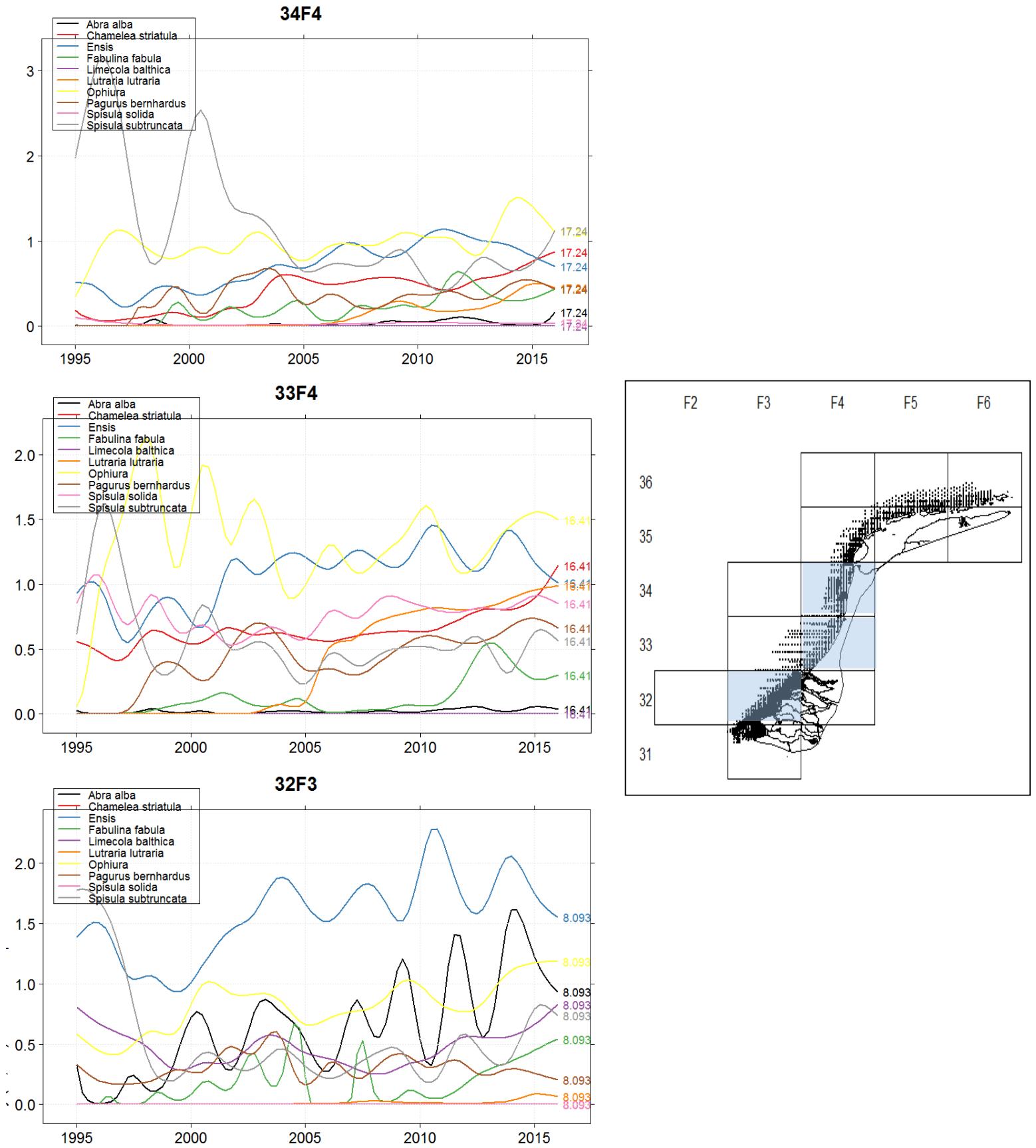

Figuur 5.40 De resultaten van het hurdle model waarbij per jaar de dichtheid geschat is op basis van waterdiepte, jaar en geografische positie voor drie ICES kwadranten (zie kaartje). De cijfers geven de mediane diepte weer per locatie (die is dus niet soortspecifiek) waarvoor de modelvoorspelling gegeven is. Verticale as: dichtheid $(\mathrm{n} / \mathrm{m} 2)$ op mediane diepte en mediane locatie 

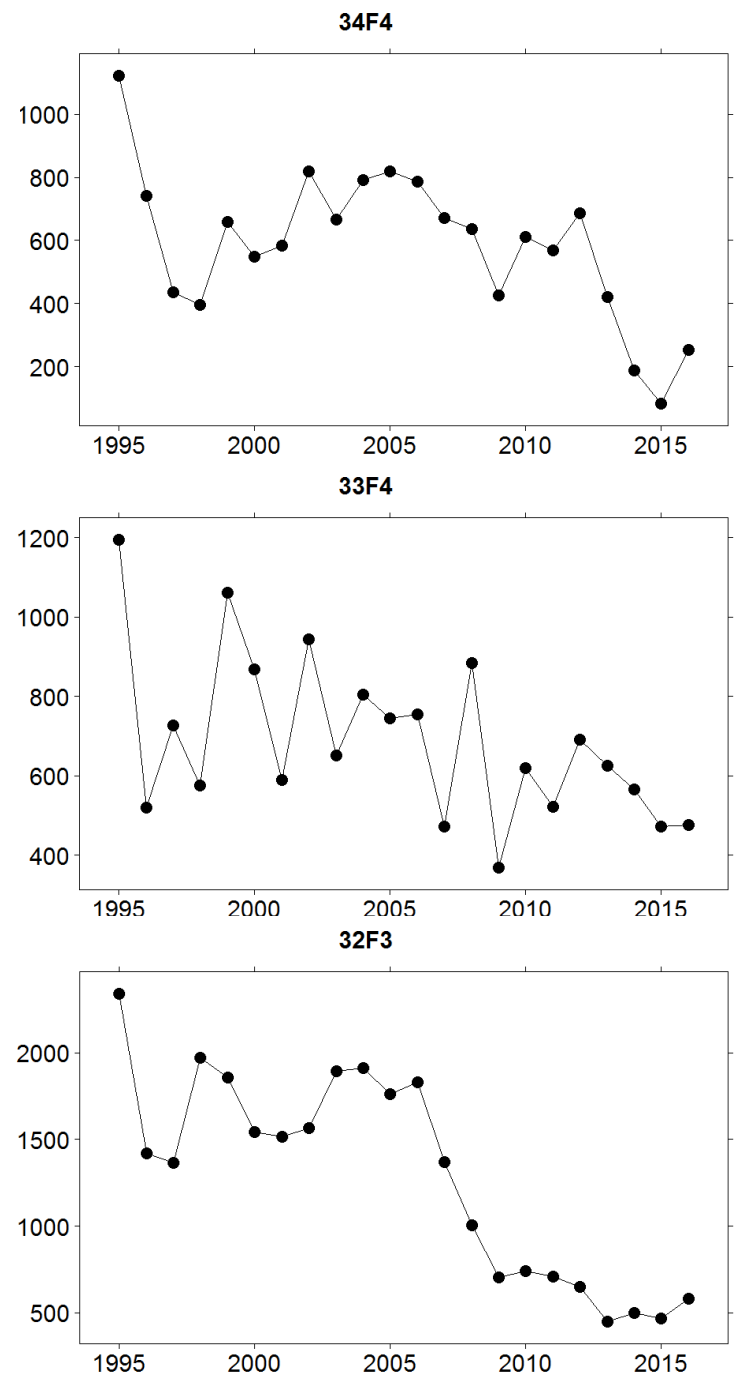

Figuur 5.41 Ontwikkeling inspanning boomkorvisserij in de drie ICES-kwadranten. Verticale as: aantal zeedagen per $\mathrm{km}^{2}$ per jaar

In deze langere serie op ICES kwadrantniveau zijn wel significante correlaties met de visserij intensiteit door de boomkorvisserij (figuur 5.41) gevonden (tabel 5.11). Voor kwadrant 32F3 ( Voordelta) is voor de rechtsgestreepte platschelp, het nonnetje, slangsterren en stevige strandschelp een matig tot sterk (stevige strandschelp) positieve relatie gevonden met visserijdruk. Voor halfgeknotte strandschelp was de relatie sterk negatief. In kwadrant 33F4 ( Zuid-Holland) is alleen voor slangsterren een sterk negatief verband gevonden met visserijdruk. In kwadrant 34F4 ( Noord-Holland) is voor Amerikaanse zwaardschede een sterk positief, voor otterschelp een sterk negatief en voor stevige strandschelp een matig positief verband met visserijdruk gevonden.

\subsubsection{Lange termijn ontwikkelingen in aasetende soorten in relatie tot visserijdruk op basis van VMS en logboekdata}

Een aantal soorten dat bemonsterd is in de WOT schelpdiersurvey betreft aasetende soorten. Dergelijke soorten kunnen profiteren van de discards die bij boomkorvisserij overboord gezet worden. Wanneer de visserijdruk afneemt zou dat zichtbaar kunnen zijn in de dichtheden van dergelijke aasetende soorten. Aan de andere kant produceert de garnalenvisserij ook discards. Gezien de toename in de druk van deze visserij, kan een eventuele afname in aaseters door afname van de boomkorvisserij gemaskeerd worden door de toename in discards als gevolg van garnalenvisserij. Garnalenvisserij kan ook een direct negatief effect hebben op deze soorten via verhoogde mortaliteit 
door het tuig. We hebben de bovenstaande analyse ook uitgevoerd voor de drie aaseters die goed bemonsterd worden in de survey: gewone strandkrab, de gewone zeester en fuikhorens.

Opvallend is dat fuikhorens en gewone zeester samen lijken te fluctueren. Gewone strandkrab komt langs de kust veel minder voor dan in de Voordelta en fluctueert daar ook mee met de andere twee soorten. Opvallend is de piek in aantallen van de drie soorten tussen 1995 en 2000 . Langs de Noorden Zuid-Hollandse kust nemen het laatste decennium Tritia fuikhorens toe. In de Voordelta is een duidelijke piek te zien rond 2008, die niet duidelijk is in de andere gebieden (figuur 5.42).

Op basis van de VMS data (de serie vanaf 2006) en de logboekdata (de serie vanaf 1995) zijn er voor de Voordelta en de Hollandse kust geen significante relaties met de boomkorvisserij gevonden.
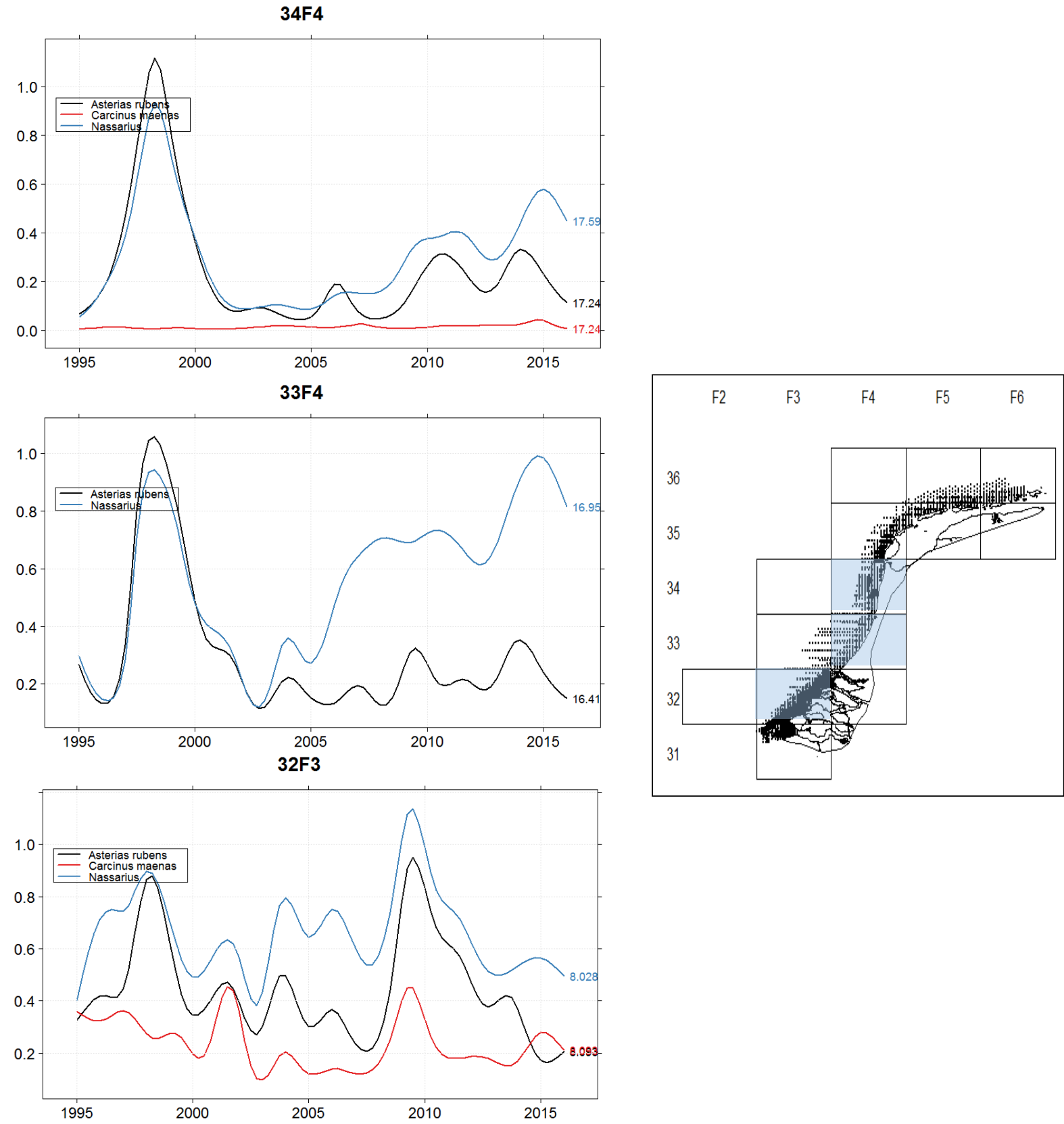

Figuur 5.42 De resultaten van het hurdle model waarbij per jaar de dichtheid geschat is op basis van waterdiepte, jaar en geografische positie voor drie ICES kwadranten (zie kaartje). De cijfers geven de mediane diepte weer per locatie (die is dus niet soortspecifiek) waarvoor de modelvoorspelling gegeven is. Verticale as: dichtheid $(\mathrm{n} / \mathrm{m} 2)$ op mediane diepte en mediane locatie 
Tabel 5.11

Resultaten van de tijdserie analyses in relatie tot visserijdruk door boomkorvisserij op basis van logboekdata. De inclusion probability geeft aan in hoeveel van de MCMC iteraties visserij als verklarende factor geselecteerd wordt.

\begin{tabular}{|c|c|c|c|c|}
\hline Soort & gebied & $\begin{array}{l}\text { Inclusion } \\
\text { probability }\end{array}$ & $\begin{array}{l}\text { Effect van } \\
\text { boomkorvisserij }\end{array}$ & coefficient \\
\hline Abra alba & alle gebieden & $<0.1$ & - & \\
\hline Chamelea striatula & alle gebieden & $>0.1$ & - & \\
\hline \multirow[t]{3}{*}{ Ensis directus } & $34 \mathrm{~F} 4$ & $>0.7$ & sterk & positief \\
\hline & $36 \mathrm{~F} 5$ & $>0.9$ & sterk & positief \\
\hline & overige gebieden & $>0.1$ & - & \\
\hline \multirow[t]{2}{*}{ Fabulina fabula } & $32 \mathrm{~F} 3$ & $>0.4$ & matig & positief \\
\hline & overige gebieden & $>0.1$ & - & \\
\hline \multirow[t]{2}{*}{ Limecola balthica } & $32 \mathrm{~F} 3$ & $>0.6$ & matig & positief \\
\hline & overige gebieden & $>0.1$ & - & \\
\hline \multirow[t]{3}{*}{ Lutraria lutraria } & $34 \mathrm{~F} 4$ & $>0.9$ & sterk & negatief \\
\hline & $36 \mathrm{~F} 5$ & $>0.3$ & matig & positief \\
\hline & overige gebieden & $>0.1$ & - & \\
\hline \multirow[t]{3}{*}{ Ophiura } & $32 \mathrm{~F} 3$ & $>0.3$ & matig & positief \\
\hline & $33 F 4,34 F 4$ & $>0.8$ & sterk & negatief \\
\hline & overige gebieden & $>0.1$ & - & \\
\hline Pagurus bernhardus & alle gebieden & $>0.1$ & - & \\
\hline \multirow[t]{3}{*}{ Spisula solida } & $32 \mathrm{~F} 3$ & $>0.9$ & sterk & positief \\
\hline & $34 \mathrm{~F} 4$ & $>0.5$ & matig & positief \\
\hline & overige gebieden & $>0.1$ & - & \\
\hline \multirow[t]{3}{*}{ Spisula subtruncata } & $32 \mathrm{~F} 3$ & $>0.8$ & sterk & negatief \\
\hline & $36 \mathrm{~F} 5$ & $>0.8$ & sterk & positief \\
\hline & overige gebieden & $>0.1$ & - & \\
\hline Asterias rubens & alle gebieden & $<0.1$ & - & \\
\hline Carcinus maenas & alle gebieden & $<0.1$ & - & \\
\hline \multirow[t]{2}{*}{ Tritia sp. } & $36 \mathrm{~F} 5$ & $>0.9$ & sterk & positief \\
\hline & overige gebieden & $<0.1$ & - & \\
\hline
\end{tabular}

\section{Deelconclusie}

- Veel soorten uit de WOTschelpdiersurvey laten de laatste 10 jaar een toename zien. Dat geldt niet alleen voor de Voordelta maar ook voor de Hollandse kust

- Op basis van de VMS data (vanaf 2006) worden geen significante relaties met boomkor of garnalenvisserij gevonden. De serie is echter erg kort voor deze analyse en de power waarschijnlijk te laag.

- Voor een aantal soorten worden op basis van de logboekdata (boomkorvisserij) significante correlaties met de visserijdruk gevonden, maar de verbanden zijn zowel positief als negatief: vier soorten (Amerikaanse zwaardschede, rechtsgestreepte platschelp, nonnetje, stevige strandschelp) positief, drie soorten (otterschelp, slangsterren, halfgeknotte strandschelp) in sommige gebieden positief, in andere negatief.

- Voor drie soorten (witte dunschaal, venusschelp, heremietkreeft) is geen verband met visserijdruk door boomkorvisserij gevonden.

- De aasetende soorten lijken samen te fluctueren. In de Voordelta is er geen duidelijke lange termijntrend. Langs de Noord- en Zuid-Hollandse kust nemen fuikhorens de laatste tien jaar sterk toe.

- Voor geen van de aasetende soorten zijn significante relaties met de boomkorvisserij gevonden.

- Om de power van de analyse op basis van VMS data te vergroten kan in een vervolganalyse in plaats van een gebiedsgemiddelde inspanning, de inspanning per monsterpunt meegenomen worden (vergelijkbaar met zoals in de habitatmodellering Voordelta gedaan is) 


\subsubsection{Vergelijking natuurlijke versus visserijverstoring}

De Voordelta is een dynamisch gebied, en natuurlijke verstoring door golven en stroming overal of in grote delen van de Voordelta zou een grote invloed op het bodemleven kunnen hebben in verhouding tot de verstoring door bodemberoerende visserij. Daardoor zou de kans op het vaststellen van effecten van visserij - of het verdwijnen ervan - kleiner kunnen zijn dan in gebieden met geringe natuurlijke verstoring. Daarom is in 2015 (Craeymeersch et al. 2015b) ook een schatting gemaakt van de natuurlijke verstoring.

Recente studies in het Kanaal en de Engelse Noordzee (Bolam et al. 2014) duiden op een grote ruimtelijke variatie in totale productie, maar ook op een ruimtelijk verschil in de gevoeligheid van totale productie voor bodemberoerende visserij, met de grootste gevoeligheid in gebieden met weinig of geen natuurlijke verstoring. Op basis van biologische eigenschappen hebben we de gevonden soorten onderverdeeld in groepen in relatie tot hun gevoeligheid voor bodemberoering, een benadering ontwikkeld in het kader van het EU-project DEVOTES (http://www.devotes-project.eu/). De inschatting van de bodemberoering door natuurlijke fenomenen (golven en stroming) is gebeurd op basis van de gemeten en gemodelleerde data in het kader van het onderzoek naar de natuurcompensatie (PMR-NCV). Het voornaamste doel was om op deze manier na te gaan of er gebieden zijn waar de potentiële verstoring door visserij hoger is (geweest) dan de natuurlijke verstoring.

\section{Natuurlijke bodemberoering}

Globaal hebben we voor het bepalen van de gevoeligheid voor natuurlijke verstoring, de methodiek van Diesing et al. (2013)) en Aldridge et al. (2015)) gevolgd. Daarbij wordt aangenomen dat de hoogte van de ribbels die onder invloed van getijstroming en golven ontstaan, een maat is voor de natuurlijke bodemberoering. Hierbij wordt aangenomen dat de verstoringsdiepte van dit soort ribbels gelijk is aan de helft van de ribbelhoogte. De berekeningen zijn gebaseerd op de beschikbare abiotische gegevens zoals die in de Voordelta zijn gemeten of berekend (Craeymeersch et al. 2015). In de studie van Diesing et al (2013) worden de ribbelhoogtes vertaald naar verstoringsdiepten en wordt de kans berekend dat deze meer is dan 1 of $4 \mathrm{~cm}$. Hierbij wordt gekwantificeerd hoe vaak de verstoringsdiepte die grens overschrijdt, waarbij een dag waarop een dergelijk moment voorkomt, meteen als een hele dag telt.

De kans op verstoring is het grootst dichtbij de kust (figuren 5.43 en 5.44). Verder van de kust af loopt het aantal dagen per jaar met verstoring snel terug. In de zuidelijke helft van de Voordelta worden de grenswaardes minder vaak overschreden dan in de noordelijke helft. In de zuidelijke helft zijn de condities in het algemeen gunstiger voor mega-ribbels, en minder gunstig voor de kleinere ribbels. Eenzelfde analyse voor een verstoringsdiepte van $3 \mathrm{~cm}$ laat zien dat dit in alle locaties minder dan 1 dag per jaar voorkomt. 

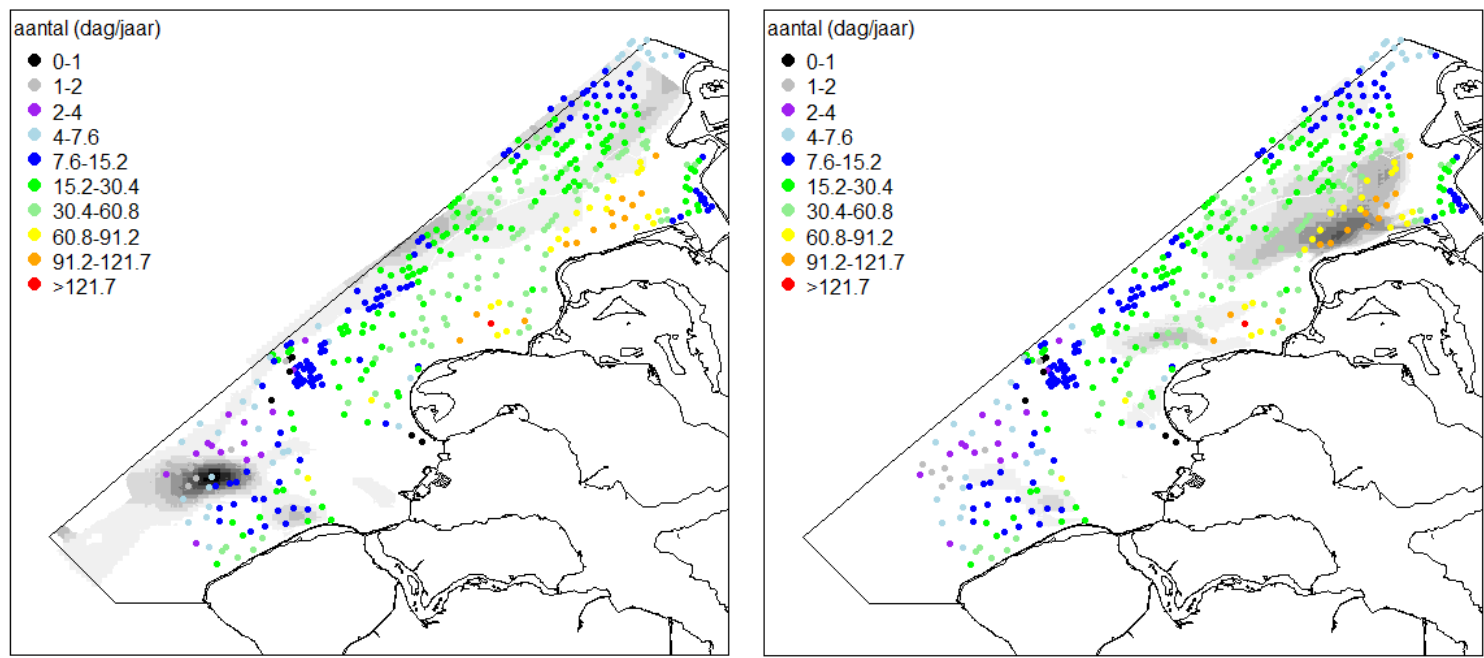

Figuur 5.43 Aantal dagen per jaar, gemiddeld over de jaren 2005 tot en met 2013, dat de verstoringsdiepte meer dan $1 \mathrm{~cm}$ bedraagt en verspreiding van de boomkorvisserij in 2004/2005 en garnalenvisserij in 2012/2013 (grijstinten).

Voor ribbelhoogtes tussen 1 en $5 \mathrm{~cm}$ verandert de overschrijdingskans heel snel. Het hierboven beschreven ruimtelijke patroon geldt ook voor individuele jaren (tabel 5.12).

Daarin is per jaar aangegeven op hoeveel locaties met welke frequentie de beroeringsdiepte meer dan $1 \mathrm{~cm}$ bedraagt. Let op: het totaal aantal locaties verschilt, omdat in deze periode Maasvlakte 2 is aangelegd, waardoor een aantal locaties is komen te vervallen. 


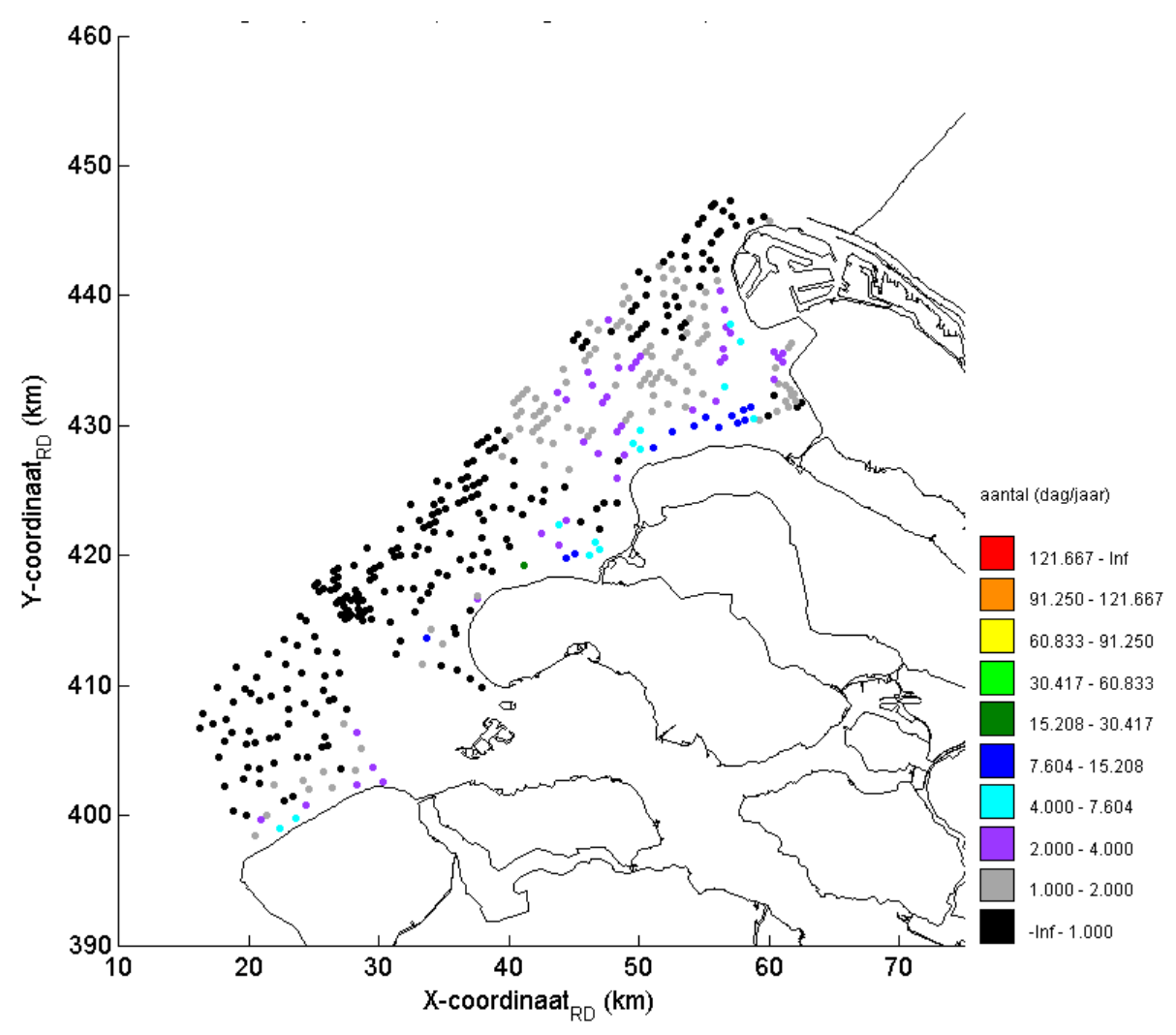

Figuur 5.44 Aantal dagen per jaar, gemiddeld over de jaren 2005 tot en met 2013, dat de verstoringsdiepte meer dan $2 \mathrm{~cm}$ bedraagt.

Tabel 5.12

Over de Voordelta ruimtelijk gemiddeld aantal dagen dat de verstoring door natuurlijke processen de gegeven grenswaarde in een jaar overschrijdt.

\begin{tabular}{|l|c|c|c|c|}
\hline \multirow{2}{*}{ Jaar } & \multicolumn{4}{|c|}{ grenswaarde } \\
\cline { 2 - 5 } & $\mathbf{1} \mathbf{~ c m}$ & $\mathbf{2} \mathbf{~ c m}$ & $\mathbf{3} \mathbf{~ c m}$ & $\mathbf{4} \mathbf{~ c m}$ \\
\hline 2005 & 31.35 & 2.05 & 0.06 & 0.00 \\
\hline 2006 & 24.99 & 1.32 & 0.04 & 0.00 \\
\hline 2007 & 31.44 & 2.35 & 0.08 & 0.00 \\
\hline 2008 & 27.13 & 1.85 & 0.06 & 0.00 \\
\hline 2009 & 28.40 & 1.38 & 0.05 & 0.00 \\
\hline 2010 & 31.15 & 1.72 & 0.04 & 0.00 \\
\hline 2011 & 23.55 & 1.44 & 0.04 & 0.00 \\
\hline 2012 & 27.30 & 1.51 & 0.05 & 0.00 \\
\hline 2013 & 23.98 & 1.02 & 0.02 & 0.00 \\
\hline
\end{tabular}

Om een directe vergelijking mogelijk te maken tussen absolute natuurlijke verstoring en visserijverstoring moeten beide bronnen van beroering op dezelfde schalen van intensiteit en frequentie uitgedrukt worden. Dat kan vooralsnog niet. Onder meer omdat de keuzes bij het berekenen van de ribbelhoogte niet geverifieerd kunnen worden door gebrek aan metingen van ribbels in de Voordelta. De frequentie van voorkomen van een bepaalde bodemberoering hangt heel sterk samen met wat als criterium gehanteerd wordt voor de verstoringsdiepte. Dat de onzekerheid in het voorspellen van de ribbelhoogte leidt tot een grote spreiding in de voorspelde frequentie van natuurlijke bodemberoering, wordt ook door Aldridge et al. (2015)) onderkend.

Een ander probleem is dat beide type verstoringen waarschijnlijk op een verschillende manier doorwerken op organismen die in de bodem leven. De directe impact van visserij is waarschijnlijk niet direct te vergelijken met de impact van een mobilisatie van het sediment door stroming of golven. Een harde schelp die een organisme kan beschermen bij natuurlijke verstoring, is niet per se geschikt om het dier tegen het contact met een wekkerketting van een boomkor te beschermen. Andere 
kenmerken zijn waarschijnlijk belangrijker in het laatste geval, zoals ontwijking of een vlugge rekolonisatie. Bij het vergelijken van door visserij veroorzaakte bodemberoering met natuurlijke verstoring dient aan dit aspect meer aandacht besteed te worden (Aldridge et al. 2015).

We kunnen wel de ruimtelijke verdeling van de plekken met grote natuurlijke verstoring vergelijken met de verdeling van beide bodemberoerende visserijen. Dan blijkt dat in het

bodembeschermingsgebied de gebieden met de hoogste natuurlijke verstoring en gebieden met de meeste garnalenvisserij samenvallen. Hoe deze twee manieren van verstoring zich kwantitatief tot elkaar verhouden is echter niet te concluderen.

\section{1 .13 Discussie}

Op basis van de bemonsteringen uitgevoerd in de periode 2004-2015 is een brede range aan analyses uitgevoerd waarbij we het mogelijke effect van de verandering in visserijdruk onderzocht hebben, rekening houdend met de variatie die inherent is aan een dynamisch kustgebied.

\subsubsection{Bodemfauna in de Voordelta in relatie tot visserij}

De effecten van boomkorvisserij op het benthos in relatie tot abiotische variabelen, zoals dat onderzocht is in de diverse analyses (univariaat en multivariaat), laten een vrij uniform beeld zien. Vergeleken met de variatie die door ruimte en tijd wordt veroorzaakt (ruimtelijk en temporele autocorrelatie), is de bijdrage van de abiotische factoren en visserijdruk gering. Dat is de conclusie uit de LME's, maar die conclusie wordt nog sterker als we de berekening met R-INLA uitvoeren. De biomassa als voedsel voor vogels is hoger, en het aantal taxa en de maximale lengte van Ensis is lager op punten met een hogere visserijdruk door boomkorvisserij. Het grote belang van ruimtelijke en temporele autocorrelatie kan verschillende oorzaken hebben. De ruimtelijke autocorrelatie wordt mogelijk veroorzaakt door factoren die we niet goed kennen of kunnen uitdrukken in beschrijvende parameters. Verschillen binnen de Voordelta in voedselaanbod kunnen een rol spelen, maar mogelijk ook verschillen in aanvoer en vestiging tussen bodemdiersoorten. De temporele autocorrelatie wordt waarschijnlijk deels veroorzaakt doordat broedval en vestiging van soorten op bepaalde locaties in een jaar, in de volgende jaren nog doorwerkt op de soortensamenstelling.

Ingezoomd op de voor de boomkorvisserij relevante gebieden en periodes laat voor alle parameters (behalve max. lengte Ensis directus) een positief verband met boomkorvisserij zien. Drie van de zes onderzochte responsvariabelen (totale biomassa, biomassa voor vogels en aantal taxa) laten een positieve relatie zien met visserijdruk door garnalenvisserij en de overige drie vertonen geen verband. De deelselectie van punten gericht op garnalenvisserij laat voor geen enkele parameter een verband met garnalenvisserij zien.

Concluderend leveren de habitatmodellen een beeld dat op plekken met veel visserij een hogere benthosbiomassa voorkomt. De vraag is natuurlijk of hier sprake van een causaal verband is. Ofwel de biomassa neemt toe als gevolg van visserij, ofwel de visserij concentreert zich op plekken met veel bodemdierenbiomassa. De belangrijkste component van de biomassa is Ensis directus (soms wel tot $60 \%$ ). Om te begrijpen hoe bovenstaande werkt is het noodzakelijk om iets meer van het gedrag van Ensis te weten (zie volgende paragraaf).

De analyse waarbij gepoogd is gebieden met een verschil in bevissing te contrasteren (paragraaf 5.1.11) liet zien dat bij aanvang de beviste en onbeviste garnalenlocaties erg vergelijkbaar waren, maar dat de beviste en onbeviste plots uit elkaar gingen lopen vanaf het moment van de intensivering van de garnalenvisserij in 2009. Dit bleek zowel uit de veranderingen in de soortengemeenschap als uit de zes parameters. De jaren van intense garnalenvisserij zijn gekenmerkt door een verhoging in dichtheden aan Ensis directus en aan Abra alba, Capitella sp. en overige slib-minnende soorten (Lanice sp., Owenia fusiformis) op de beviste locaties vergeleken met de controle locaties.

De beviste en onbeviste boomkorlocaties lieten geen verschil in ontwikkeling zien in de gemeenschap, maar wel met betrekking tot het gemiddelde individuele gewicht en de totale bodemdieren biomassa, met hogere waardes in de beviste locaties in het jaar 2004 (het jaar met maximale boomkorvisserij intensiteit). Ook in deze analyse bleek weer dat de populatiedynamiek van Ensis directus van grote invloed is op de univariate benthosparameters door de dominantie van die soort. 
De trait-based approach liet zien dat in de Voordelta de voor verstoring meest gevoelige groep bodemdieren (K2) en de groep van soorten die aangepast zijn aan een hoge frequentie van verstoring (A strategen) weinig voorkomen. De bodemfauna in de Voordelta wordt gedomineerd door $r$ strategen. De verwachting is dat bij een afname in bodemberoerende visserij er een verschuiving optreedt van $\mathrm{r}$ en $\mathrm{A}$ naar $\mathrm{K}$ strategen. In de onderzochte tijdserie zien we dit niet.

Ook het grootste deel van de variatie in de multivariate analyses op basis van traits werd verklaard door abiotiek. De relaties met de intensiteit van boomkorvisserij en garnalenvisserij waren statistisch significant, maar gezien het lage percentage verklaarde variantie waarschijnlijk biologisch niet relevant. Het gevonden verband tussen modaliteiten en visserijdruk door boomkor en garnalenvisserij waren tegengesteld aan de verwachting: De modaliteiten die toenamen met hogere visserijdruk waren: grotere, langlevende, diep ingegraven, filterende sessiele soorten. Dit wordt waarschijnlijk vooral veroorzaakt door Ensis directus: weliswaar groot en langlevend, maar ook diep ingegraven, waardoor ze toch bestand zijn tegen bodemberoering. Ook hier komt dus weer de belangrijke rol van Ensis directus naar voren.

Uit de analyse van de natuurlijke verstoring in de Voordelta bleek verder dat de gebieden met de meeste natuurlijk verstoring sterk overlappen met de gebieden die het intensiefst bevist worden door de garnalenvisserij.

\subsubsection{Lange termijn ontwikkelingen binnen en buiten de Voordelta}

Veel soorten uit de WOT schelpdiersurvey laten de laatste 10 jaar een toename zien zowel in de Voordelta als langs de Hollandse kust. Op basis van de VMS data (vanaf 2006) hebben we geen significante relaties met boomkor of garnalenvisserij gevonden. De serie is echter erg kort voor deze analyse en de statistische power waarschijnlijk te laag. Voor een aantal soorten worden op basis van de wat langere serie (vanaf 1995) op basis van logboekdata significante correlaties met de visserijdruk door de boomkorvisserij gevonden, maar de verbanden zijn zowel positief als negatief: vier soorten (Amerikaanse zwaardschede, rechtsgestreepte platschelp, nonnetje, stevige strandschelp) positief, drie soorten (otterschelp, slangsterren, halfgeknotte strandschelp) in sommige gebieden positief, in andere negatief. De aasetende soorten lijken samen te fluctueren maar voor geen van de aasetende soorten zijn significante relaties met de boomkorvisserij gevonden.

Gezien de hersteltijd die verwacht wordt voor veel bodemfaunasoorten (Kaiser et al. 2006) is met name de serie op basis van de VMS data nog erg kort. Bovendien hebben we in de analyse telkens het verband onderzocht van de bodemfauna met de visserij in het voorgaande jaar. Wanneer veranderingen zich echter pas over een termijn van meerdere jaren voordoen, zou ook verschillende intervallen onderzocht moeten worden (bv visserijdruk over afgelopen 5 jaar). Voor een dergelijke analyse is de tijdserie echter te kort.

\subsubsection{De rol van Ensis in het kustgebied}

Uit vrijwel alle analyses komt de dominante rol van Ensis directus naar voren. Ensis directus lijkt geen last te hebben van boomkor- en garnalenvisserij, sterker nog, er is vaak een positief verband gevonden met visserijdruk. De dieren leven rechtstandig in zelf gegraven, decimeters diepe gangen (tot wel $90 \mathrm{~cm}$, Drew 1907) in de bodem. Ze zitten in ongestoorde toestand vlak onder het bodemoppervlak, met alleen de korte sifonen boven de bodem. Bij verstoring kunnen ze zich razendsnel in hun gang terug trekken doordat ze het sediment vloeibaar en beter doordringbaar kunnen maken door water in het sediment te spuiten (Drew 1907). Ensis directus leeft in medium en grof zand, maar ook in fijn substraat en slibrijke gebieden en komt aan voedsel door water te filteren. De individuen groeien snel en worden gemiddeld 3-4 jaar tot 8 jaar (Witbaard et al. 2015). De soort is heel mobiel en in staat om zich snel te verplaatsen en zelfs te zwemmen door zich af te zetten met de voet (Drew 1907), en is ook in staat om zijn leefomgeving aan te passen door het invangen van sediment.

Deze eigenschappen maken de soort uitstekend toegerust voor het leven in de dynamische kustomgeving onder invloed van natuurlijke en visserijverstoring. De ingraafdiepte en snelle reactievermogen zorgen er waarschijnlijk voor dat ze geen last hebben van de visserij, en de snelle manier van verplaatsen geeft ze de mogelijkheid om nieuwe (open gevallen) plekken te koloniseren. Dit mogelijk mechanisme waardoor ze geen last en misschien zelfs wel voordeel van visserijverstoring 
hebben, is ook al in andere studies gevonden (Tulp et al. submitted). Daarnaast is de soort ook niet heel kieskeurig met betrekking tot het sediment. In groeiexperimenten bleek de algenconcentratie veel belangrijker dan sediment voor de groei (Kamermans et al. 2013). Er lijkt wel een leeftijdsafhankelijke sedimentsvoorkeur te zijn, waarbij de jongere individuen slibrijke sediment prefereren (Witbaard et al. 2017).

\subsubsection{Conclusies}

1) Wordt het verlies aan habitattype $\mathrm{H} 1110 \mathrm{~B}$ als gevolg van de aanleg van Maasvlakte 2 voldoende gecompenseerd? ${ }^{3}$

c) Zijn er positieve trends waar te nemen in kwaliteit van het Habitat 1110B (zoals deze wordt gedefinieerd in het profieldocument $\mathrm{H} 1110$ (versie 18 december 2008)) in de Voordelta sinds het begin van de afname van de boomkorvisserij uit de Voordelta rond de laatste eeuwwisseling?

Uit de resultaten blijkt dat er veranderingen in de tijd zijn in verschillende variabelen die de bodemdiergemeenschap beschrijven. Deze veranderingen duiden echter niet eenduidig op een ontwikkeling die verwacht zou kunnen worden bij vermindering van de boomkorvisserij.

d) Zijn de waargenomen trends toe te schrijven aan de afgenomen bodemberoering ten gevolge van de afname van de grote boomkorvisserij met wekkerkettingen in de gehele Voordelta of ook aan andere factoren?

Er is geen eenduidig verband met de afname van de boomkorvisserij. Op de veranderingen in de inzichten over de effecten van boomkorvisserij wordt nader ingegaan in paragraaf 5.4.

e) Hoe groot was de onttrekking van vis en andere (bij)vangsten in de periode T0 (2004-2008), T1 (2009-2013) en T2 (2014-2018)?

Deze vraag is behandeld in hoofdstuk 4 .

\subsection{Vis}

Bij de instelling van het BBG was de verwachting dat de beschermende maatregelen zouden leiden tot een lokale toename (10\%) van de biomassa van het benthos. Deze $10 \%$ toename in benthos zou kunnen doorwerken op de hoeveelheid vis als voedsel voor vis en vogels en als onderdeel van Habitat 1110, de zogenaamde typische soorten van Habitat 1110 B (LNV 2008, Bijlage 3). Het onderzoek binnen Perceel Vis is bedoeld om het effect van de compensatiemaatregelen in de Voordelta (de instelling van het $B B G$ ) op vis en de visgemeenschap te bestuderen en om de vraag te beantwoorden of veranderingen in vis en de visgemeenschap gerelateerd kunnen worden aan het instellen van het BBG.

\subsubsection{Onderzoeksvragen}

Van de set geformuleerde MEP-vragen is voor vis vooral MEP-vraag 1 van belang en MEP-vraag 3 \& 4, daar waar het voedsel voor visdief/grote stern betreft (zandspiering en haring). Dat onderdeel wordt behandeld in het hoofdstuk sterns (hoofdstuk 7). MEP-vraag 1 is onderverdeeld in vijf deelvragen:

1) Wordt het verlies aan habitattype $\mathrm{H} 1110 \mathrm{~B}$ als gevolg van de aanleg van Maasvlakte 2 voldoende gecompenseerd?

\footnotetext{
${ }^{3}$ Deelvragen a en b zijn behandeld in MEP-aanleg
} 
c) Zijn er positieve trends waar te nemen in kwaliteit van het Habitat 1110B ( zoals deze wordt gedefinieerd in het profieldocument $\mathrm{H} 1110$ (versie 18 december 2008)), in de Voordelta sinds het begin van de afname van de boomkorvisserij uit de Voordelta rond de laatste eeuwwisseling?

d) Zijn de waargenomen trends toe te schrijven aan de afgenomen bodemberoering ten gevolge van de afname van de grote boomkorvisserij met wekkerkettingen in de gehele Voordelta of ook aan andere factoren?

e) Hoe groot was de onttrekking van vis en andere (bij)vangsten in de periode T0 (2004-2008), T1 (2009-2013) en T2 (2014-2018)?

Van deze deelvragen is voor vis vooral deelvraag 1c en 1d van belang. Deelvraag 1e wordt behandeld in het hoofdstuk visserij (hoofdstuk 4). Vraag 1a en 1b zijn beantwoord in het onderzoeksprogramma van MEP Aanleg (WVL 2013), en vallen niet onder het MEP-NCV programma. In deze rapportage wordt niet verder op die vragen ingegaan.

\subsubsection{Beantwoording van onderzoeksvragen: parameters}

De biomassa van bodemdieren, en daarmee de hoeveelheid voedsel voor beschermde/typische soorten, kan direct worden beïnvloed door de bodemberoerende visserij. Ook vis zelf kan door de veranderde visserijdruk worden beïnvloed. Daarnaast heeft de visserij mogelijk invloed op abiotische omstandigheden, die direct of indirect kunnen doorwerken op benthos en vis. Een voor het onderzoek complicerende factor is dat de garnalenvisserij in het bodembeschermingsgebied is toegestaan. In deze visserij wordt met fijnmazige netten gevist waardoor jonge vis en benthos onbedoeld bijgevangen wordt. Onttrekking van, en eventuele schade aan deze organismen kan een verandering, veroorzaakt door het wegvallen van de boomkorvisserij, maskeren. Daarnaast wordt alle bijvangst in de garnalenvisserij overboord gezet, en is daarmee voedsel dat beschikbaar komt voor aaseters. Ook dit kan een onvoorzien effect op de bodemvis hebben.

Hieronder lichten we voor alle deelvragen toe welke analyses zijn uitgevoerd ter beantwoording ervan. De onderzoeksvragen 1c \& d richten zich op het vaststellen van veranderingen in kwaliteit van $\mathrm{H} 1110$ als gevolg van de compensatiemaatregel. Vooraf is niet vastgesteld welke parameter gebruikt wordt voor het kwantificeren van kwaliteit voor vis. Ook het profieldocument (LNV 2008, EZ 2014) geeft hiervoor geen uitsluitsel. Daarom hanteren we hier een set van parameters waarvan de verwachting is dat die veranderingen in de visfauna laten zien als gevolg van de verandering in de bodemberoerende visserij.

- $\quad$ Effect op dichtheid en soortensamenstelling. Naast een verandering in dichtheden (paragraaf 5.2.7) kunnen ook verschuivingen in de vis/epibenthosgemeenschap (paragraaf 5.2.8) duiden op een verandering in de bodemfauna.

- $\quad$ Effect op leeftijdsopbouw. Bij een afname in bodemberoerende visserij en sterfte als gevolg hiervan, verwachten we ook een verandering in de leeftijdsopbouw (paragraaf 5.2.10): een verschuiving van een gemeenschap oververtegenwoordigd door kleine en jonge vissen naar een gemeenschap met een evenwichtiger leeftijdsverdeling, waarin ook oudere dieren aanwezig zijn. Door vermindering van visserijdruk is de verwachting dat dit resulteert in een verbeterde overleving van de residente soorten en een toename van de oudere leeftijdsgroepen. Dit zou dan met name verwacht worden voor soorten die hun hele leven in het gebied blijven (residente soorten), niet voor kinderkamersoorten, die de Voordelta voornamelijk voor de juveniele stadia gebruiken.

- Effect via voedselaanbod. Als het prooiaanbod (door veranderingen in het benthos) verandert kunnen sommige soorten daarvan meer profiteren dan andere soorten. In welke richting een dergelijke soortenverschuiving plaats vindt is niet op voorhand te voorspellen. Wanneer biomassa, dichtheid, productie en/of samenstelling van benthos verandert als gevolg van de verminderde bodemberoering, zou dat mogelijk kunnen doorwerken in het dieet van vissen (paragraaf 5.2.9), de groei (paragraaf 5.2.11) en/of conditie (paragraaf 5.2.12). Een overzicht van alle metingen en analyses is gegeven in hoofdstuk 2 . 


\subsubsection{Van BACI experiment naar analyse van correlaties}

Vanwege dezelfde reden als genoemd bij benthos (paragraaf 5.1.4) hebben we in de tweede fase de analyses anders ingestoken. In plaats van een vergelijking in ontwikkeling tussen twee gebieden, onderzoeken we nu direct de relatie tussen visserijinspanning en visdichtheden op de bemonsterde plekken, los van of deze plekken in het BBG liggen of niet. In deze rapportage betrekken we de resultaten uit beide fases. De resultaten van de analyses die alleen in de eerste fase zijn uitgevoerd (Tulp et al 2013) worden ook besproken, maar alleen daar waar het veranderingen door de tijd betreft. Voor de resultaten van de BACI analyses verwijzen we naar de eindrapportage van de eerste fase (Tulp et al 2013).

Tijdens de nulmetingen in 2005 en 2007 en in de eerste fase van PMR-NCV zijn de ontwikkelingen in de demersale visgemeenschap onderzocht door bemonsteringen in voor- en najaar met behulp van een garnalenkor op 53 plekken. De bemonsteringsopzet was diepte gestratificeerd en gericht op het onderzoeken van gebiedsverschillen tussen BBG en referentiegebied. In 2011 is geen najaarsbemonstering uitgevoerd (zie Tulp et al 2014 voor details).

In de tweede fase is de visbemonstering anders ingestoken: in plaats van een uitgebreid programma waarbij twee maal per jaar (voor- en najaar) een relatief groot aantal trekken (53) werd uitgevoerd, is overgegaan op een bemonstering alleen in het najaar, met een veel lagere intensiteit. In plaats van onderzoek naar gebiedsverschillen heeft de bemonstering nu veel meer een 'vinger aan de pols' karakter en ligt de focus meer op ontwikkelingen in de Voordelta als geheel ten opzichte van buiten de Voordelta. In de tweede fase van PMR-NCV is in de nazomer/ het vroege najaar de jaarlijkse vissurvey voor PMR-NCV uitgevoerd als onderdeel van de Demersal Fish Survey (DFS). Voor PMR-NCV zijn naast de 11-14 locaties in de Voordelta van de DFS survey, 13 extra locaties bemonsterd die gelegen zijn tussen de standaard DFS locaties (zie hoofdstuk 2 en Figuur 5.45).

Het grote verschil tussen fase 1 en fase 2 is dus dat we in fase 1 vooral ontwikkelingen in deelgebieden in de Voordelta onderzocht hebben en in fase 2 vooral een vergelijking maken tussen ontwikkelingen in de Voordelta en langs de Hollandse kust (DFS gebieden 402 en 403, zie figuur 5.45).

Met het gebruikte tuig worden naast vissen ook epibenthossoorten zoals krabben en zeesterren gevangen. In een aantal analyses in dit hoofdstuk worden ook de gegevens van het epibenthos gebruikt.

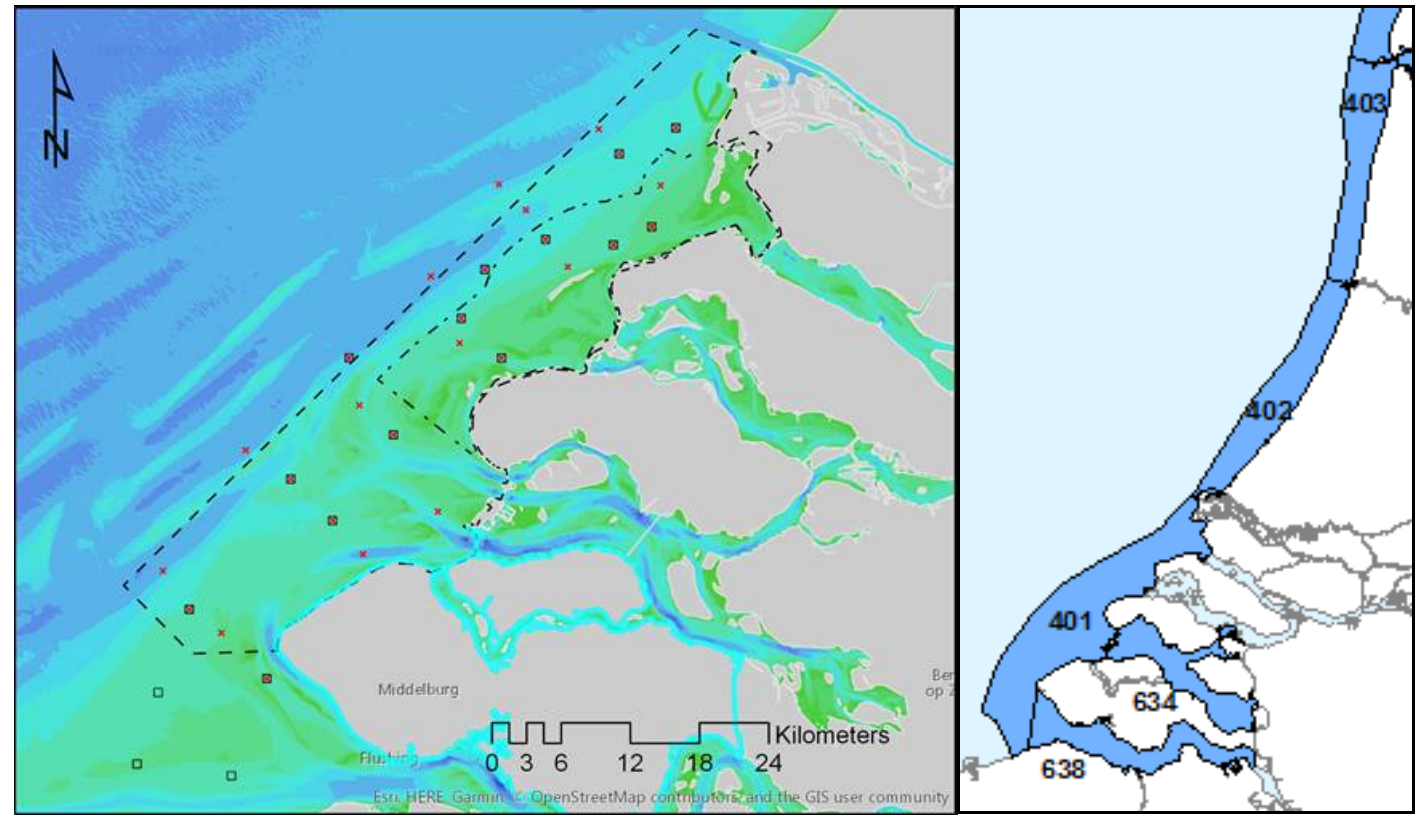

Figuur 5.45 Links: De DFS ( $\square$ ) en PMR stations (x ) binnen de vismonitoring (Bolle 2016). Rechts: De drie DFS gebieden die zijn meegenomen in de analyses: Voordelta (401), Zuid-Hollandse kust (402) en Noord-Hollandse kust( 403). 


\subsubsection{Ecologie van vis in de Voordelta}

Voor estuaria is een duidelijk indeling in zogenaamde gildes beschikbaar. Bij de indeling in gildes wordt onderscheid gemaakt tussen vissoorten aan de hand van wanneer en waarvoor de estuaria door deze soort gebruikt worden Elliott \& Hemingway 2002b. De Voordelta valt niet echt onder de estuaria, maar de indeling in gildes is hier ook (deels) bruikbaar. Vissen hebben een complexe levenscyclus waarbij de verschillende levensstadia vaak in verschillende, ruimtelijk gescheiden, gebieden leven (Petitgas et al. 2013). De ondiepe kust, de Waddenzee en de Delta zijn kinderkamers voor jonge vis en garnalen uit de Noordzee. Door het relatief warmere zeewater, het rijke voedselaanbod en de mogelijkheid beschutting te zoeken voor roofdieren, kunnen ze hier veilig opgroeien. De jongen van zowel bodemvissoorten (bijv. schol, tong, wijting), als pelagische soorten (die in de waterkolom leven, haring en sprot) groeien hier op. Deze groep wordt ook wel marien juvenielen genoemd. Er zijn ook nog andere gildes: de doortrekkers, die alleen langskomen op weg naar de rivieren of terug naar zee (bijv. fint, aal en prikken); de seizoensgasten, die er een deel van het jaar verblijven om er te foerageren (bijv. sprot, grauwe poon); de onregelmatige bezoekers die het gebied af en toe aandoen (bijv. kleine pieterman, dwergbolk) en de residente soorten, die hun hele leven in deze gebieden blijven (bijv. vijfdradige meun, zeedonderpad, puitaal, grondels, dwergtong, schurftvis, pitvis) (Elliott \& Hemingway 2002b). De onregelmatige bezoekers (of dwaalgasten) volgens deze classificatie zijn echt specifiek voor de echte estuaria, in de kustzone komen ze veel algemener voor.

\subsubsection{Algemene schets ontwikkeling vis en epibenthos in de Voordelta en langs de Hollandse kust}

Om de grote veranderingen in de visfauna langs de kust en in de Voordelta te beschrijven maken we gebruik van lengte-biomassa verdelingen (figuur 5.46). Deze manier van weergave geeft een indruk van de verandering in 1) de verdeling van de soorten, 2) de totale visbiomassa en 3) de lengteverdeling. Over het algemeen zijn de ontwikkelingen in Voordelta en Hollandse kust erg vergelijkbaar. Een aantal ontwikkelingen vallen op:

- De grotere vis $(>40 \mathrm{~cm}$ ) verdwijnt gaandeweg de decennia uit het spectrum, ook vanaf 2010 neemt dit nog verder af.

- De rol van schol is veranderd: dichtheden zijn veel lager en de grotere schol is verdwenen

- De dominante rol van schol is met name in de laatste periode overgenomen door schar

- Zandspieringachtigen en dwergtong komen op in de laatste periodes 


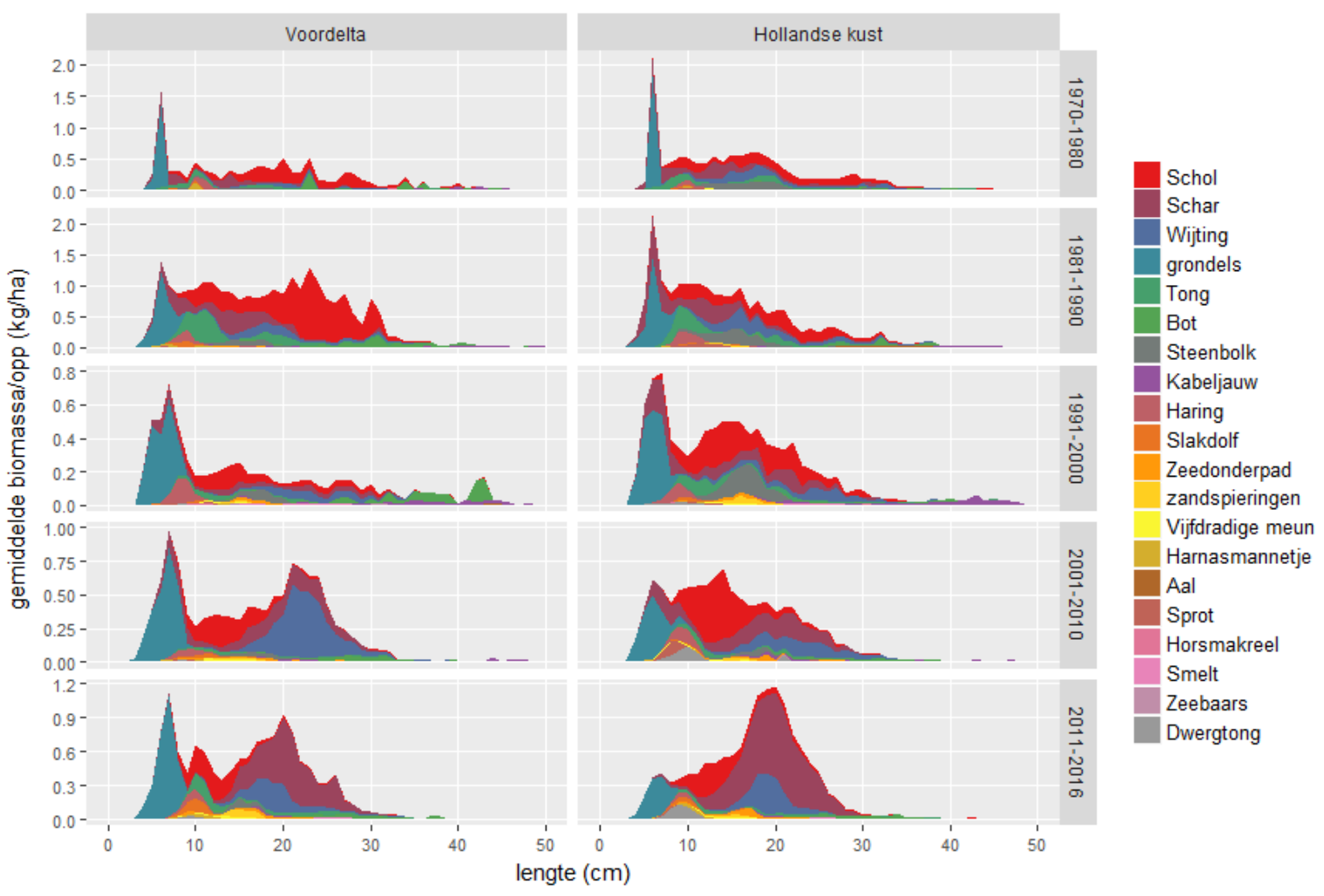

Figuur 5.46 Ontwikkeling van de visgemeenschap (in biomassa/oppervlakte van de 20 meest voorkomende soorten) gemiddeld per 10 jaar periode in de Voordelta en langs de Hollandse kust. Let op verschillen in y-assen.

Een groot aandeel van de vangst in de visbemonsteringen bestaat uit epibenthos. Omdat bodemvis en epibenthossoorten samen een gemeenschap vormen hebben we de ontwikkeling van de verhouding tussen aantallen vis en de aantallen van de zes meest voorkomende epibenthossoort(-groep)en op een rij gezet voor de Voordelta en de Zuid- en Noord-Hollandse kust (figuur 5.47). Met name voor de Voordelta valt de enorme toename in slangsterren vanaf 2009 op. Ook in de jaren tussen 1970 en 1990 kwamen af en toe pieken voor, maar recentelijk is dit een jaarlijks fenomeen dat veel minder prominent is langs de Noord- en Zuid-Hollandse kust. Ook zeesterren vertonen af en toe pieken, bijvoorbeeld tussen 1985 en 1989 en in 2010 en 2011. Dezelfde signalen zijn zichtbaar in de PMR benthosbemonstering (paragraaf 5.1.11.3). 


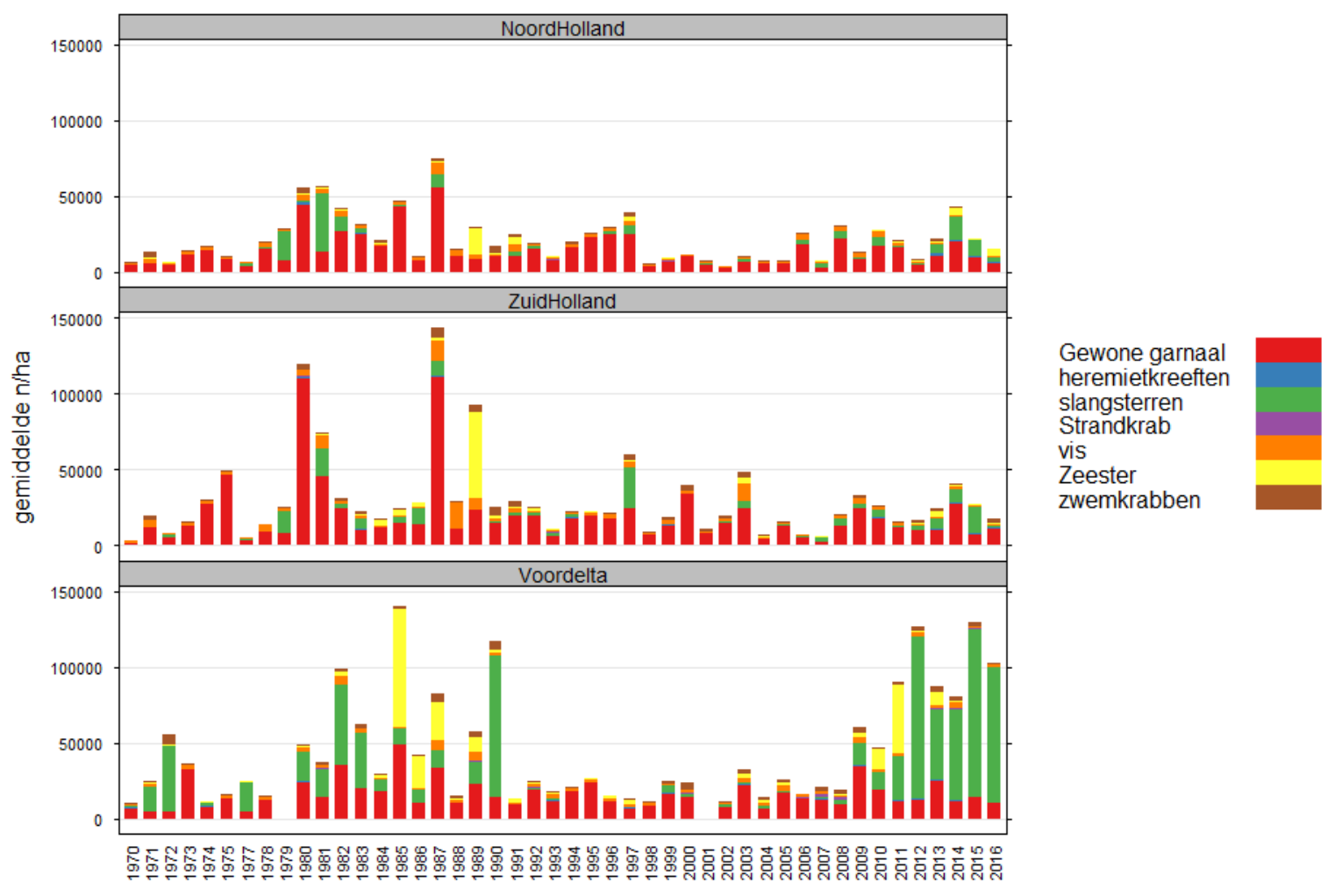

Figuur 5.47 Ontwikkeling in dichtheden (gemiddelde aantallen/ha) gevangen vis en 6 epibenthossoort(-groep)en.

\section{Deelconclusies}

- $\quad$ Sinds 1970 hebben zich grote veranderingen voorgedaan in de visgemeenschap van Voordelta en de Hollandse kust: verschuiving naar kleinere soorten/exemplaren.

- De dominante rol van schol is vanaf 2000 overgenomen door schar.

- $\quad$ Ontwikkelingen zijn sterk vergelijkbaar tussen Voordelta en aangrenzende kustgebied.

- In de Voordelta zijn slangsterren sterk toegenomen sinds 2009, deze toename is niet zichtbaar in overige kustgebieden.
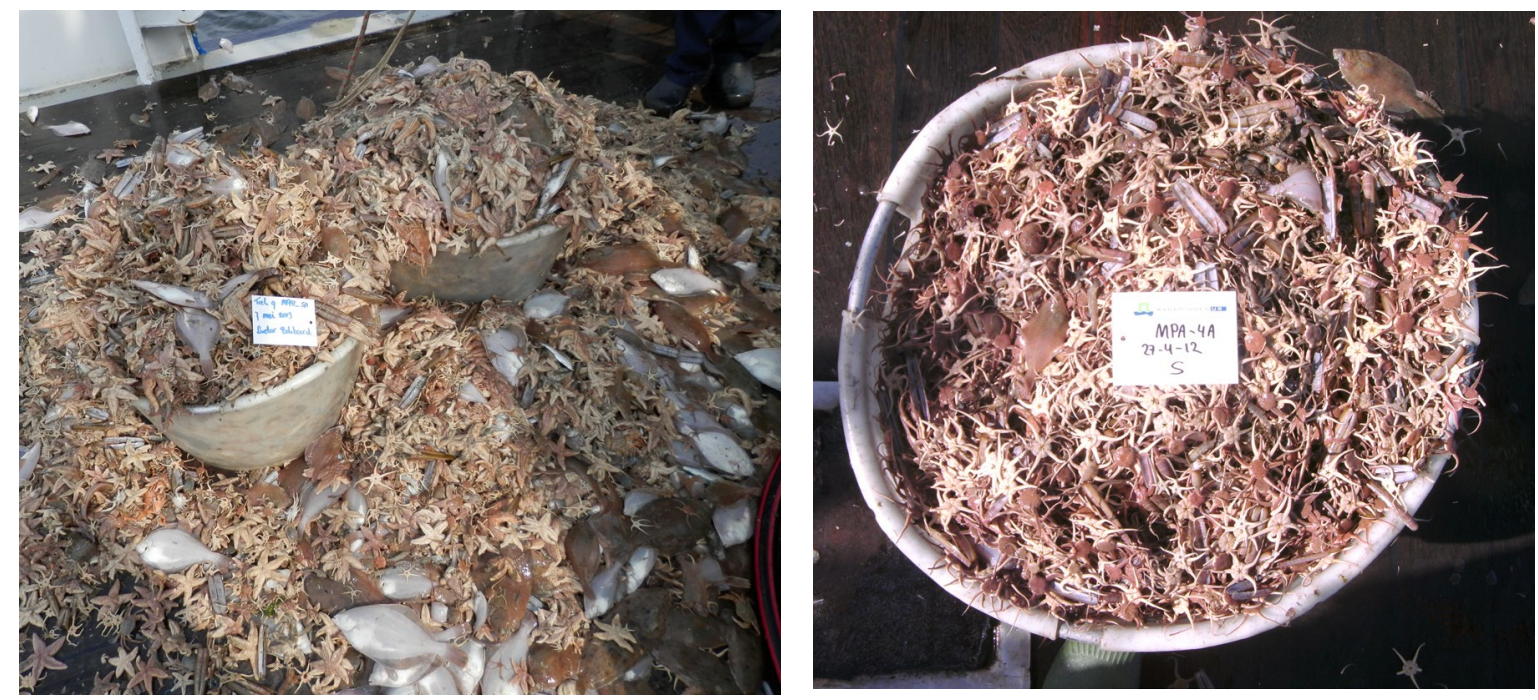

voorbeeld van vangsten met veel slangsterren en zeesterren 


\subsubsection{Veranderingen in dichtheden in relatie tot abiotiek en visserij}

\subsubsection{Habitatmodellering}

\section{$1^{\text {e }}$ fase}

In fase 1 zijn de relaties tussen het voorkomen van 16 individuele soort(-groep)en in de vissurvey van de $1^{\mathrm{e}}$ fase en de lokale visserij-inspanning geanalyseerd (Tulp et al. 2014). Hierbij is alleen voor zandspiering een negatieve relatie gevonden met visserij-inspanning (door zowel boomkor- als garnalenvisserij, tabel 5.13). Voor garnaal, bot, grondel en de totale hoeveelheid vis werd een positieve relatie gevonden met de inspanning van een van de twee visserijen. Voor een uitgebreide beschrijving van de analyse, zie hoofdstuk 3.6.3 van Tulp et al. (2014). (Voor de analyse van de zandspiering gevangen in de benthossurvey, zie hoofdstuk 7).

\section{Tabel 5.13}

Samenvatting significante relaties in de habitatmodellen voor individuele soorten met diepte, doorzicht, factor jaar en de inspanning van beide soorten visserij als verklarende variabelen uitgevoerd in de eerste fase. Per soort zijn de significante factoren (na Bonferroni correctie) en hun relatie (positief + of negatief -, of voor jaar: * als minimaal 2 jaren significant van elkaar verschillen) per soort gegeven. Meegenomen surveyjaren: 2005, 2007, 2009-2012.

\begin{tabular}{|l|l|l|l|l|l|}
\hline & Diepte & doorzicht & factor(jaar) & $\begin{array}{c}\text { inspanning } \\
\text { platvisvloot }\end{array}$ & $\begin{array}{c}\text { inspanning } \\
\text { garnalenvloot }\end{array}$ \\
\hline haring en sprot & - & - & $*$ & & \\
\hline wijting & + & - & $*$ & & \\
\hline zeedonderpad & + & & $*$ & & \\
\hline harnasmannetje & + & & & $*$ & - \\
\hline zandspieringen & - & & & & \\
\hline kleine pieterman & & + & $*$ & & \\
\hline pitvis & + & & $*$ & + & \\
\hline grondels & - & & $*$ & & \\
\hline schurftvis & + & & $*$ & & \\
\hline schol & - & & $*$ & & \\
\hline schar & + & & $*$ & & \\
\hline bot & - & & $*$ & & + \\
\hline tong & + & & & $*$ & \\
\hline dwergtong & + & - & & & \\
\hline garnaal & & & & \\
\hline totaal vis & & & & \\
\hline
\end{tabular}

\section{$2^{\mathbf{e}}$ fase}

In de tweede fase zijn in tegenstelling tot de eerste fase niet individuele soorten geanalyseerd, maar zijn in plaats daarvan ecologische groepen vis geanalyseerd. Van sommige ecologische groepen wordt verwacht dat ze direct beïnvloed zullen worden door boomkorvisserij. Zo kan een groter effect van boomkorvisserij verwacht worden op vis die zich op de bodem ophoudt (demersale vis), dan op vis in de waterkolom (pelagische vis). Het voordeel van deze aanpak is dat de analyse niet zo gevoelig is voor stochastische veranderingen in individuele soorten door bijvoorbeeld een sterke jaarklasse. De aanpak sluit in feite goed aan bij de Trait Based Approach die binnen Perceel benthos gehanteerd wordt (zie paragraaf 5.1.9) : in plaats van individuele soorten, analyseren we groepen van soorten die een bepaalde eigenschap gemeenschappelijk hebben, met de nadruk op eigenschappen waarvan we verwachten dat visserij daar een effect op heeft. Zo maken we onderscheid in de volgende groepen: 
1. Verticaal habitat: Soorten die veel tijd op de bodem doorbrengen (demersale soorten) hebben waarschijnlijk meer last van bodemberoerende visserij dan soorten die zich hoger in de waterkolom ophouden (pelagische soorten)

2. Voedselgroep: Soorten wiens eten (gedeeltelijk) uit benthos bestaat, hebben waarschijnlijk meer last van bodemberoerende visserij dan soorten die met name leven van vis en plankton.

3. Gilde: Residente soorten brengen hun hele leven in het gebied door en worden daarom waarschijnlijk disproportioneel veel beïnvloed door de lokale bodemberoerende visserij. Van marien juveniele soorten leven alleen de jonge stadia in het ondiepe kustgebied. Ook van marien juveniele soorten is de verwachting dat ze negatief beïnvloed zullen worden door de visserij, waarbij het mechanisme waarop beide visserijen doorwerken naar verwachting verschilt. Garnalenvisserij is sinds 2013 verplicht gebruik te maken van een zeeflap om vis groter dan $10 \mathrm{~cm}$ te laten ontsnappen. Het grootste deel van deze groep vissen is kleiner dan $10 \mathrm{~cm}$ en zal naar verwachting meer beïnvloed worden door garnalenvisserij dan grotere vissen.

4. Lengte van de vis. Ook hierbij speelt bovengenoemde kans op bijvangst in de garnalenvisserij een rol.

Een bijkomend voordeel van deze benadering met ecologische groepen is dat het aantal vissen per trek hoger is dan bij analyse van individuele soorten, aangezien elke groep uit meerdere soorten bestaat. Hierdoor zijn de dichtheden in vrijwel alle trekken groter dan nul, waardoor de dichtheid geanalyseerd kan worden in plaats van alleen de aan-/afwezigheid.

Habitatmodellen worden gebruikt om de grote natuurlijke variatie veroorzaakt door abiotiek weg te filteren, waardoor we in de overgebleven variatie op zoek kunnen gaan naar signalen die gerelateerd zijn aan visserijverstoring. Zo kunnen we onderzoeken of er een verband bestaat tussen de visdichtheden en de bodemberoerende visserij. Vanwege het beperkt aantal beschikbare trekken in de dataset (158 trekken in 12 jaar) is ook het aantal verklarende factoren dat gebruikt kan worden beperkt. Van alle beschikbare factoren uit het perceel abiotiek en de abiotische gegevens geregistreerd tijdens de bemonstering is een selectie gemaakt op basis van de verklarende kracht. Bij onderling sterk gecorreleerde variabelen (collineariteit) is een van de twee gekozen. In de habitatmodellen per soortgroep zijn de volgende parameters gebruikt: visserij-inspanning van de platvisvloot (TBB) en van de garnalenvloot (TBS) in de maand voorafgaand aan de trek, diepte en windsterkte ten tijde van de trek, jaar, station en saliniteit, stroomsnelheid, bodemschuifspanning van de golven (BSPG) en temperatuur. Van deze laatste vier abiotische factoren zijn in aparte habitatmodellen zowel de waardes in week voorafgaand aan de trek als ten tijde van de trek geanalyseerd. Voor details over de statistische analyses wordt verwezen naar Tulp et al. (2014).

Uit de habitatmodellen blijkt dat visdichtheid van geen enkele ecologische groep een negatieve relatie met de visserij-inspanning vertoont. Van beide sets modellen (abiotiek ten tijde van de trek, en in de week voorafgaand aan de trek) bleek -als er een significante relatie was - de richting van de relatie tussen abiotiek en visdichtheid (positief of negatief) op beide tijdschalen gelijk. Wel zijn er meer significante effecten van abiotische variabelen gevonden in de waardes ten tijde van de trek. Daarom worden hier alleen de resultaten van deze modellen gepresenteerd (tabel 5.14). De enige significante relatie met visserij was positief: de dichtheid van de residente vis nam toe met de visserij-intensiteit van de garnalenvloot (en alleen in de analyse met de abiotiek ten tijde van de trek).

Vergeleken met de soortsspecifieke habitatmodellen (zie uitkomsten $1^{\mathrm{e}}$ fase) valt het op dat er minder significante relaties zijn met de abiotische variabelen. Dat wordt deels veroorzaakt doordat het totaal aantal trekken de helft is van wat het in de eerste fase was en deels doordat verschillende soorten (met wellicht verschillende habitatvoorkeuren) nu samengevoegd zijn.

Het effect van visserij is gevisualiseerd door de residuen van een model met abiotiek -maar zonder visserij - te plotten tegen visserij (voor twee voorbeelden zie figuur 5.48). Hieruit wordt duidelijk dat er geen duidelijke relaties tussen visserij en visdichtheid zijn. 

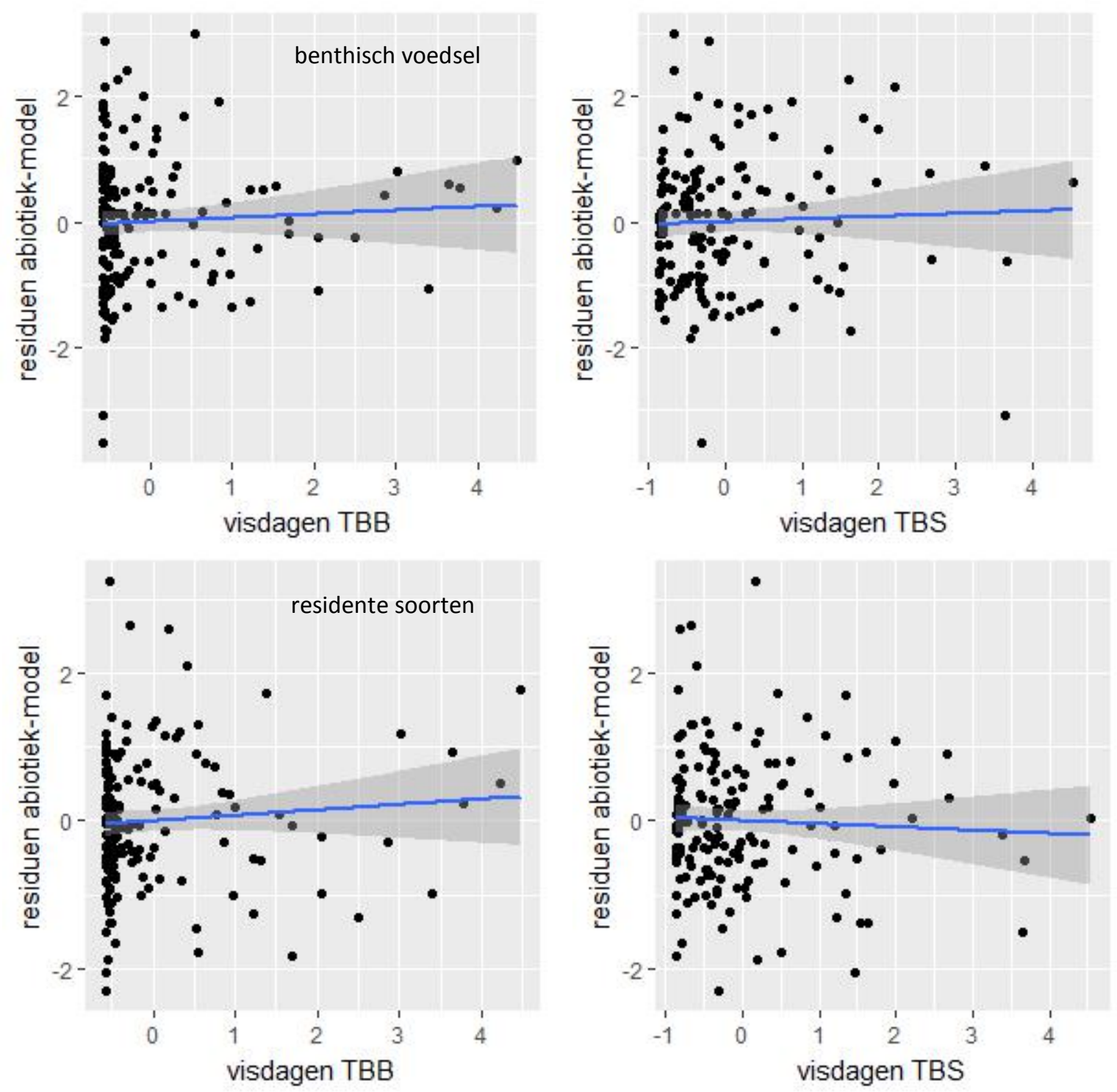

Figuur 5.48. Twee voorbeelden van de relatie tussen visdichtheden en visserij-inspanning. Residuen van het abiotiekmodel in relatie tot visserij inspanning (TBB boomkorvisserij) en TBS

(garnalenvisserij) voor soorten die van benthisch voedsel leven (bovenste figuren) en residente soorten (onderste figuren).

\section{Tabel 5.14}

Samenvatting significante relaties in de habitatmodellen met abiotische waardes ten tijde van de trek voor de periode 2004-2015. In de modellen voor non-benthisch voedsel, marien juvenielen en grote vis is station meegenomen als random factor. Per soort zijn de significante factoren (na Bonferroni correctie) en hun relatie (positief + of negatief -, of voor jaar: * als minimaal 2 jaren significant van elkaar verschillen) met de soort gegeven.

\begin{tabular}{|c|c|c|c|c|c|c|c|}
\hline & \multirow{2}{*}{$\begin{array}{c}\text { verticaal } \\
\text { habitat }\end{array}$} & \multicolumn{2}{|c|}{ voedsel } & \multicolumn{2}{|c|}{ gilde } & \multicolumn{2}{|c|}{ lengte vis } \\
\hline & & benthos & anders & $\begin{array}{l}\text { marien } \\
\text { juveniel }\end{array}$ & resident & klein & groot \\
\hline \multicolumn{8}{|l|}{ factor(jaar) } \\
\hline diepte & & & & & & & + \\
\hline windkracht & & & & + & & & \\
\hline
\end{tabular}




\begin{tabular}{|l|c|c|c|c|c|c|c|}
\hline $\begin{array}{l}\text { bodemschuifspanning } \\
\text { golven }\end{array}$ & - & - & & - & & & \\
\hline stroomsnelheid & & & & & & & \\
\hline saliniteit & - & - & & & & - & \\
\hline temperatuur & & & & & & & \\
\hline Inspanning platvisvloot & & & & & & & \\
\hline Inspanning garnalenvloot & & & & & + & & \\
\hline
\end{tabular}

\section{Deelconclusie}

- De dichtheden per ecologische groep - waarvan verwacht werd dat ze negatief beïnvloed worden door visserij - vertonen, rekening houdend met variatie veroorzaakt door abiotiek, geen relatie met de lokale visserij-inspanning.

- Door ecologische groepen te analyseren (in plaats van individuele soorten) was de dichtheid vis per trek veel hoger, waardoor de hoeveelheid vis geanalyseerd kon worden, in plaats van alleen aan-/afwezigheid. Een probleem bij de analyses is het lagere aantal trekken in de PMRsurvey van de $2^{\mathrm{e}}$ fase. Bovendien is de abiotische invloed waarschijnlijk vooral soortspecifiek. Hierdoor is het aantal significante verklarende factoren lager dan bij de analyse van de visdata in de $1^{\mathrm{e}}$ fase.

\subsubsection{Trendanalyses binnen en buiten de Voordelta}

In 2015 zijn de trends in visdichtheid binnen de Voordelta en daarbuiten (Zuid-Hollandse en NoordHollandse kust) op een rij gezet op basis van de Demersal Fish Survey voor de periode 1970-2014 (Tulp 2015a). In de tweede fase hebben we dit herhaald met een iets andere aanpak; met een GAM (General Additive Model) in plaats van het programma Trendspotter.

De trendanalyses zijn uitgevoerd per gilde: estuarien residente soorten, marien juveniele soorten, seizoensgasten, trekvissen en dwaalgasten. Van deze groepen komen de laatste drie relatief weinig voor en hier worden alleen de trends van de residente en marien juveniele soorten gepresenteerd.

Onder de marien juveniele soorten vallen: schol, tong, schar, griet, tarbot, rode poon, haring, kabeljauw, wijting, zeebaars, koornaarvis, smelt, steenbolk. Onder de estuariene soorten vallen: grondels, zeenaalden, harnasmannetje, puitaal, bot, zeedonderpad, zandspieringen, vijfdradige meun, slakdolf, botervis, zwarte grondel, pitvis.

Naast deze gildes zijn nog twee soorten apart geanalyseerd omdat deze een speciaal belang hebben in het PMR programma: zandspieringachtigen en garnaal.

Er zijn twee verschillende analyses uitgevoerd:

1. Lange termijn trends: 1970-2016. Voor alle gildes is een generalised additive mixed model (GAMM) gebruikt om de dichtheid te schatten op basis van een Gamma verdeling. Hierbij zijn datum van bemonstering, diepte, jaar en de positie van het monsterpunt (lengte- en breedtegraad) als verklarende variabelen meegenomen. De zandspieringachtigen worden te weinig gevangen (er zijn teveel nulwaarnemingen) om bovenstaande model toe te passen. Daarom is voor deze soorten met behulp van een GAM hurdle model met een Gamma distributie de aan- of afwezigheid en de dichtheden geanalyseerd. Eerst wordt met een GAM op basis van een Bernouilli verdeling de aan- of afwezigheid geschat. Vervolgens wordt voor de positieve waarnemingen de dichtheid geschat op basis van een Gamma verdeling. De verklarende factoren die hierbij zijn onderzocht zijn dezelfde als hierboven genoemd.

2. De trendberekening over de periode 2006-2016 in relatie tot visserij. Naast datum van bemonstering, diepte en jaar zijn vanaf 2006 ook de inspanning door de garnalenvisserij en boomkorvisserij als verklarende variabelen meegenomen. Hiermee kan dus de trend in dichtheid gerelateerd worden aan de visserij. Verder waren de modellen gelijk aan hierboven.

\section{Lange termijn trends binnen en buiten de Voordelta}


De trends in estuariene soorten in alle drie gebieden laten de laatste decennia geen duidelijke toe- of afnames zien (figuur 5.49). Langs de Noord-Hollandse kust stijgt de trend wel geleidelijk vanaf eind jaren 1990. Voor de Zuid-Hollandse en Noord-Hollandse kust zit er een dip in de periode 1970-1980, gevolgd door een sterke toename. Uit deze trends valt niet op te maken dat de ontwikkelingen in de Voordelta de laatste decennia verschillen van die langs de Zuid-Hollandse kust. De toename in residente soorten langs de Noord-Hollandse kust is niet zichtbaar in de overige gebieden.

Marien juvenielen vertonen in alle gebieden relatief hoge dichtheden in de periode 1980-1990 gevolgd door een afname die zich langer voortzet langs de Noord-Hollandse kust dan in de andere gebieden. De trend van garnaal laat in alle gebieden schommelingen zien met wat hogere waardes in de periode 1980-1990 (Figuur 5.50). Zandspieringachtigen nemen in alle gebieden sterk toe vanaf ca. 1990 (figuur 5.50).
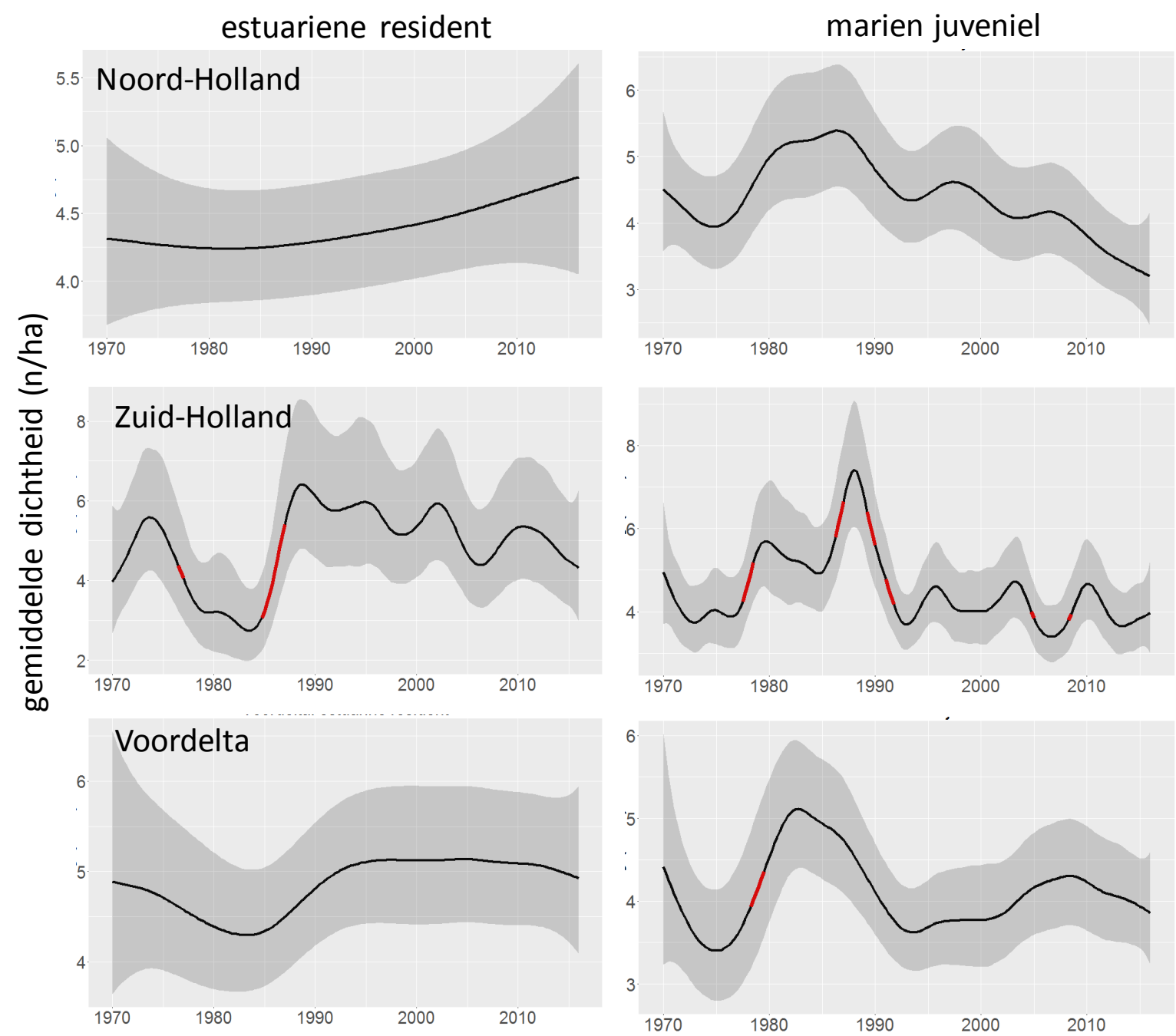

Figuur 5.49 Trends (Generalised additive mixed model, met dag van het jaar, diepte en jaar als smoothers) van de dichtheid van mariene juveniele en residente soorten (met $95 \%$ betrouwbaarheidsintervallen), in de Voordelta, langs de Zuid-Hollandse en Noord-Hollandse kust in de periode 1970-2016. De rode lijnen geven periodes aan met significante veranderingen. Het model verklaarde 23, 34 en $16 \%$ van de variatie voor marien juvenielen voor respectievelijk Noord-Holland, Zuid-Holland en Voordelta. Voor de residente soorten was dat minder: (2, 22, en 6\%). 

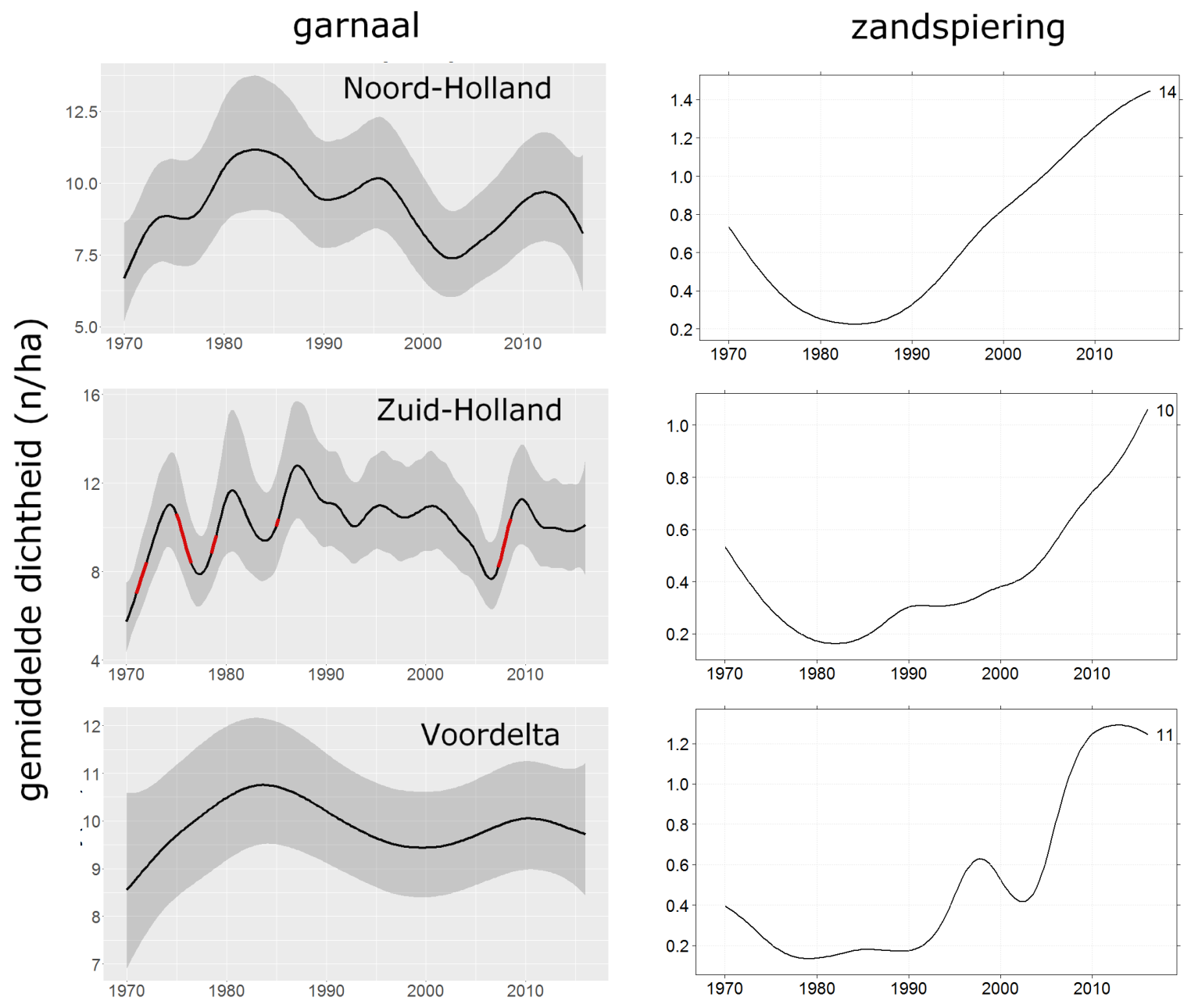

Figuur 5.50 Trends (met 95\% betrouwbaarheidsintervallen) van de dichtheid van garnaal (GAMM, met diepte en jaar als smoothers) en van de dichtheid op de gemiddelde diepte van zandspieringachtigen (hurdle model, getal bij de lijn geeft de gemiddelde diepte) in de Voordelta, langs de Zuid-Hollandse en Noord-Hollandse kust in de periode 1970-2016. De rode lijnen (links) geven periodes aan met significante veranderingen.

\section{Trends over de periode 2006-2016 in relatie tot visserij}

In 2015 zijn de trends in vis binnen de Voordelta en daarbuiten (Zuid-Hollandse en Noord-Hollandse kust) visueel vergeleken met de trends in visserij inspanning (Tulp 2015a). Dat is toen uitgevoerd op basis van de visserij inspanning per ICES kwadrant (alleen boomkorvisserij). In deze fase nemen we de visserij-inspanning mee als verklarende variabele in de trendberekening. Omdat de inspanning door de garnalenvisserij pas vanaf 2006 beschikbaar is, kunnen we deze analyse alleen uitvoeren voor de periode vanaf 2006. We hebben eerst de trend berekend, zoals in de vorige paragraaf. De resulterende jaarindexen zijn vervolgens gebruikt in een tijdseriemodel met visserij-inspanning als verklarende variabele (Figuur 5.51). Op die manier kan getoetst worden of visserij een significante verklarende factor van de trend is. 

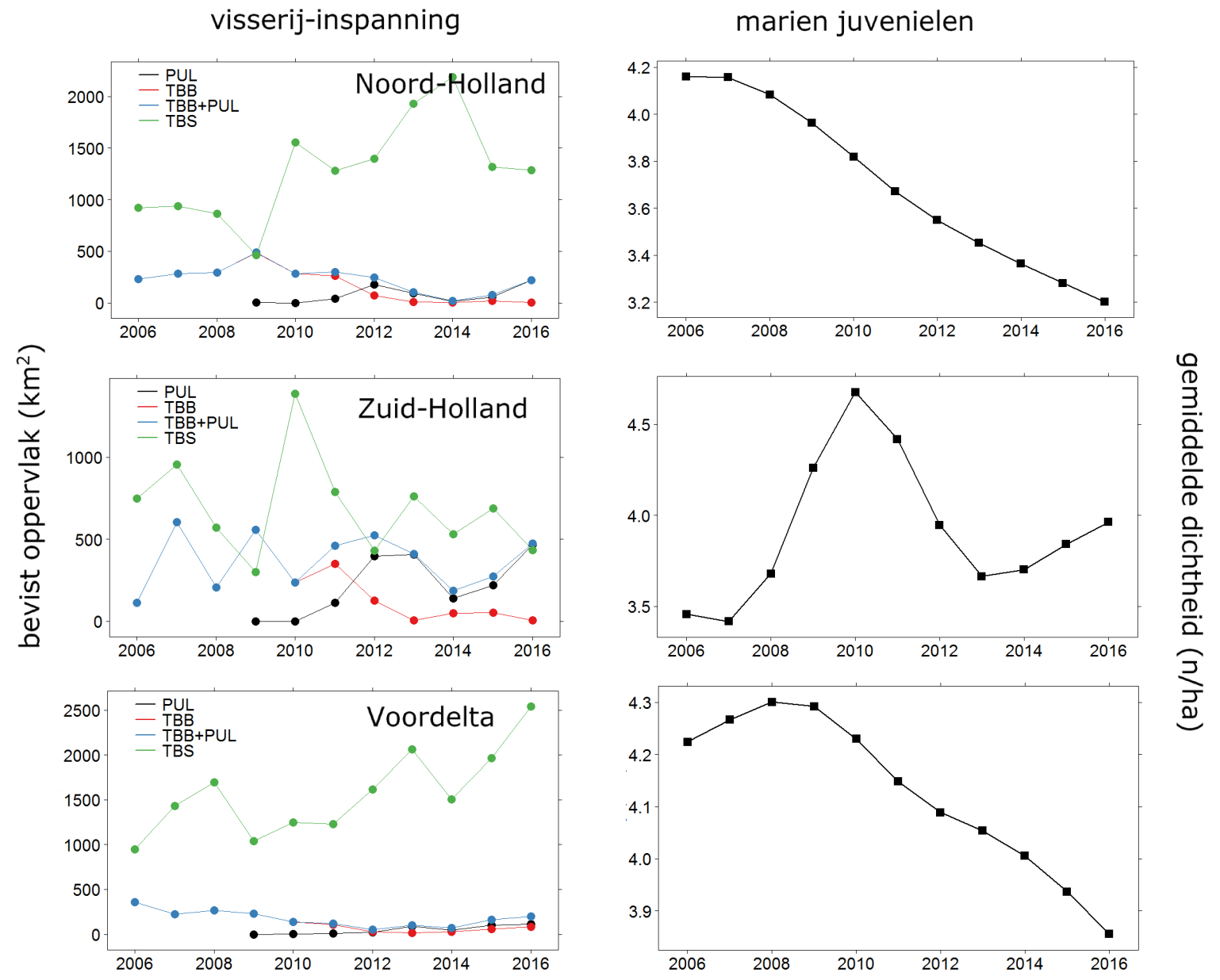

Figuur 5.51 Tijdserie van de ontwikkeling in bodemberoerende visserij (links) en het tijdseriemodel voor marien juvenielen (rechts). PUL = pulsvisserij, TBB = boomkorvisserij, TBS = garnalenvisserij. In de analyse zijn TBB en PUL samengenomen (net zoals in alle andere analyses).

De analyses zijn uitgevoerd voor de gilde marien juvenielen en residenten. In geen van de gildes en gebieden bleek de inspanning door boomkorvisserij of garnalenvisserij een significante verklarende factor te zijn voor de trend. Gezien de korte tijdserie waarover deze analyse mogelijk was, is dit ook niet zo'n onverwachte uitkomst. We zullen voor de synthese 2020 deze analyse herhalen op basis van informatie (zowel vis gegevens als visserij-inspanning) op trekniveau in plaats van op basis van het gemiddelde jaarsignaal. Naar verwachting is de resolutie dan beter en kan het effect van visserij op de diverse gebieden beter onderzocht worden. Feitelijk wordt de analyse dan vergelijkbaar met het habitatmodel (zie vorige paragraaf), waarbij het verschil is dat er behalve diepte geen andere abiotische variabelen meegenomen kunnen worden, omdat die niet beschikbaar zijn in de juiste resolutie.

\section{Deelconclusie}

Langetermijn trends (1970-2016)

- Over het algemeen komen trends in de Voordelta goed overeen met die langs de Zuid-Hollandse kust. Trends langs de Noord-Hollandse kust wijken daar iets van af.

- Marien juvenielen vertoonden in alle gebieden relatief hoge dichtheden in de periode 1980-1990 gevolgd door een afname die zich langer voortzet langs de Noord-Hollandse kust dan in de andere gebieden.

- De trend van garnaal laat in alle gebieden schommelingen zien met wat hogere waardes in de periode 1980-1990.

- Zandspieringachtigen namen in alle gebieden sterk toe vanaf ca. 1990.

Trends in relatie tot visserij (2006-2016)

- Voor geen van de onderzochte groepen is er een relatie gevonden tussen de trend in aantalsontwikkeling en visserij-inspanning. 
- De serie voor een dergelijke analyse is erg kort en is uitgevoerd op geaggregeerde jaargemiddelden voor visserij-inspanning. Een analyse op trekniveau heeft waarschijnlijk een grotere power.

\subsubsection{Veranderingen in vis/epibenthos gemeenschap}

Naast veranderingen in individuele soorten of gildes zoals in voorgaande paragrafen besproken, kan ook de samenstelling van de visgemeenschap veranderen. Dit facet onderzoeken we met behulp van multivariate analyses. We onderzoeken hier hoe alle soorten in samenhang met elkaar veranderen in samenhang met abiotische variabelen en visserijdruk. De analyse is beperkt tot de soorten die in minimaal $5 \%$ van de trekken voorkomen. Hierbij nemen we ook een aantal epibenthossoorten (zeester, brokkelster, slangsterren, zwemkrabben, garnaal, heremietkreeften) mee, omdat die dezelfde leefomgeving delen als bodemvis en ook veel gevangen worden in de survey. De abiotische factoren die gebruikt zijn, zijn dezelfde als gebruikt in de habitatmodellering (paragraaf 5.2.6.1).

De vragen die we hierbij proberen te beantwoorden zijn:

- Zijn er verschillen in ontwikkelingen door de tijd in de visgemeenschappen in de drie deelgebieden (figuur 5.45)?

- Kunnen de ontwikkelingen in de visgemeenschap in de Voordelta verklaard worden door ontwikkelingen in abiotische variabelen of visserijdruk?

Deze analyse is uitgevoerd op basis van twee tijdseries:

1. Lange tijdserie: ontwikkeling in de tijd

Een Detrended Correspondence Analysis (DCA analyse, zie voor uitleg paragraaf 5.1.8) op basis van de DFS serie in de Voordelta en de Zuid- en Noord-Hollandse kust in de periode 1986-2016 (vanaf 1986 is de bemonstering met hetzelfde schip uitgevoerd en is het aantal monsterpunten gelijk gebleven); uit deze periode/gebieden zijn geen abiotische en visserij-gegevens beschikbaar. De analyse laat zien dat alle drie gebieden een duidelijke ontwikkeling in de tijd vertonen (figuur 5.52), waarbij de richting in de tijd overeenkomt tussen de drie gebieden.
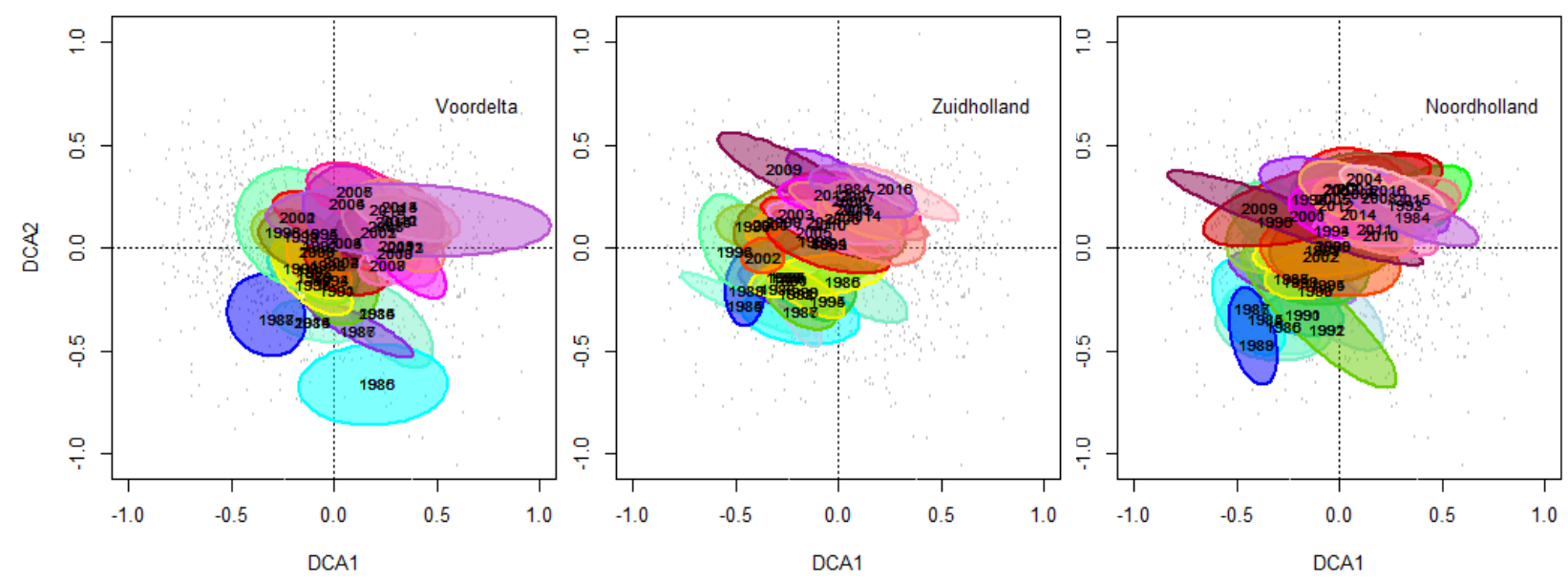

Figuur 5.52 DCA analyse van de DFS data 1986-2016 voor drie deelgebieden Voordelta, Zuid- en Noord-Holland (gebieden 401, 402 en 403 in figuur 5.45) met de centroïden per jaar. De analyse is uitgevoerd voor de drie gebieden samen. De volgorde van jaren volgt de kleuren van de regenboog: blauw, groen, geel, violet (van linksonder naar rechtsboven).

2. Korte tijdserie: ontwikkeling in de tijd, met verklarende factoren Op basis van de DFS serie met PMR-uitbreiding voor de Voordelta in de periode 2005-2016, waarbij ook abiotische gegevens en gegevens over de visserijdruk zijn meegenomen (voor eerdere jaren en de andere gebieden zijn deze gegevens niet beschikbaar). Allereerst is voor deze set een DCA uitgevoerd waarin de ontwikkeling in de tijd zichtbaar wordt, gevolgd door een Canonical Correspondence Analysis (CCA analyse) waarbij abiotische variabelen meegenomen worden als conditional factoren 
(factoren die wel effect hebben, dat verdisconteerd wordt in de analyse) en constrained factoren (factor jaar en visserijdruk), waarvan we toetsen of ze significant bijdragen aan het model. Het mogelijke effect van visserijdruk op de verschuiving is in twee analyses voor de boomkorvisserij en garnalenvisserij apart getoetst.

Deze analyse van alleen de Voordelta data uit de periode 2005-2015 laat ook een duidelijke verschuiving over de jaren zien (figuur 5.53); de samenstelling verschilt markant tussen de eerdere en latere jaren van de tijdreeks. De biplots laten de verdeling van de soorten zien in relatie tot de jaren en de visserijdruk, na correctie voor abiotische factoren. Soorten die aan de randen vallen van de biplot zijn soorten die 'hard trekken' aan de verdeling. Dat kunnen invloedrijke soorten zijn die sterke veranderingen laten zien in een bepaalde periode, maar ook de wat zeldzamere soorten (zoals bv botervis, puitaal, mul, kabeljauw, kleine pieterman).

In beide analyses (met garnalenvisserij en boomkorvisserij), is de visserijdruk significant (boomkorvisserij $\mathrm{p}=0.001$, garnalenvisserij $\mathrm{p}=0.004$ ). De bijdrage aan de totaal verklaarde inertia (de term voor variantie in multivariate analyses) is echter gering: $0.7 \%$ voor de boomkorvisserij en $6.9 \%$ voor de garnalenvisserij (tabel 5.15). In deze analyses is het jaareffect sterk gecorreleerd met het visserij effect: de boomkorvisserij is sterk afgenomen door de tijd, de garnalenvisserij is juist sterk toegenomen. Daardoor kan statistisch niet goed onderscheid worden gemaakt tussen het jaareffect en het visserij-effect.
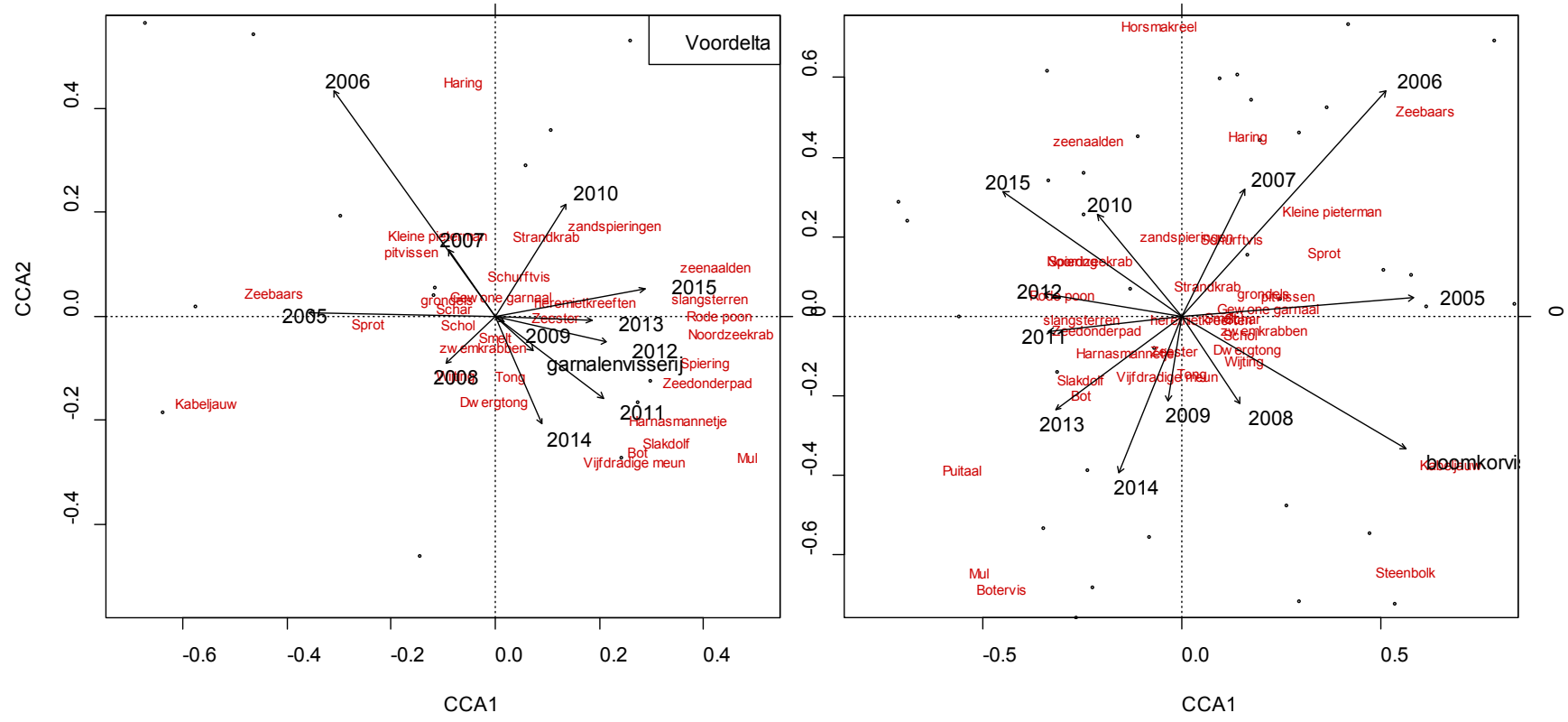

Figuur 5.53 CCA analyse van de DFS Voordelta data 2004-2015. Abiotische variabelen zijn meegenomen als conditional factoren (windsnelheid, diepte, stroomsnelheid, saliniteit, temperatuur, bodemschuifspanning, zie tabel 5.1), factor jaar en visserijdruk door garnalenvisserij (links) en boomkorvisserij (rechts als constrained factoren). 
Tabel 5.15

Verklaarde inertia door abiotische variabelen, jaar en visserijdruk voor de CCA analyses.

\begin{tabular}{|c|c|c|c|c|}
\hline visserijdruk & $\begin{array}{l}\text { inertia } \\
\text { verklaard (\%) }\end{array}$ & & & \\
\hline & $\begin{array}{l}\text { conditional } \\
\text { (abiotiek) }\end{array}$ & $\begin{array}{l}\text { constrained } \\
\text { (factor jaar + } \\
\text { visserijdruk }\end{array}$ & $\begin{array}{l}\text { constrained } \\
\text { (alleen } \\
\text { visserijdruk) }\end{array}$ & unconstrained \\
\hline boomkor & 10.8 & 11.9 & 0.7 & 46.1 \\
\hline garnalen & 22.0 & 11.9 & 6.9 & 46.2 \\
\hline
\end{tabular}

\section{Deelconclusie}

- De bodemgemeenschap (vis en epibenthos) is veranderd in de periode 1986-2016, maar de ontwikkelingen in Voordelta, Zuid-Hollandse en Noord-Hollandse kust zijn in dezelfde richting.

- In de Voordelta zijn diverse abiotische factoren en de inspanning door boomkorvisserij en garnalenvisserij significante voorspellende variabelen voor de verandering in de gemeenschap in de periode 2005-2016, maar de abiotische variabelen verklaren een veel groter deel van de variantie.

- Het effect van jaar en visserij-inspanning zijn collineair en statistisch niet van elkaar te onderscheiden: mogelijk wordt variatie veroorzaakt door jaar verdisconteerd met variatie veroorzaakt door de trend in visserijdruk of andersom.

\subsubsection{Veranderingen in prooikeuze}

Alleen in de eerste fase is onderzoek uitgevoerd aan het dieet en de prooikeuze van vissoorten over de periode 2005-2011. Voor details betreffende de analyse verwijzen we naar Tulp et al (2014). In de tweede fase is gekozen voor een 'vinger-aan-de-pols' bemonstering waarbinnen geen ruimte was voor de arbeidsintensieve maaganalyses. Daarom wordt hier volstaan met een korte beschrijving van de belangrijkste resultaten uit de eerste fase.

Wanneer biomassa, dichtheid, productie en/of samenstelling van benthos verandert als gevolg van de verminderde bodemberoering, zou dat mogelijk kunnen doorwerken in het voedselaanbod en de voedselkeuze van vissen. Zo zou de maagvulling of het dieet van een soort kunnen veranderen (Tulp et al. 2014). Daarnaast geldt dat, als een vissoort voorkeur heeft voor prooisoorten die gevoelig of juist ongevoelig zijn voor visserijdruk, een verminderde visserijdruk hierdoor ook een positief of juist een negatief effect zou kunnen hebben op deze vissoort. Daarom is ook onderzocht of er een voorkeur is voor prooisoorten die gevoelig zijn voor visserij (Tulp et al. 2014). Voor deze laatste analyse is een koppeling gemaakt tussen de prooikeuze van vis en de bodemfaunabemonstering in de directe omgeving van de plek waar de vis gevangen is.

\section{Is de maagvulling van vis in de Voordelta veranderd door de jaren heen?}

De mate waarin de maag gevuld is, is bij veel soorten gerelateerd aan het moment van de dag (veel soorten hebben een dag-nachtritme en eten meest overdag of juist 's nachts), maar daarnaast kan het ook iets zeggen over voedselbeschikbaarheid (en daarmee over veranderingen in het aanwezige benthos). De maagvulling van negen vissoorten is geanalyseerd. Na correctie voor dagpatroon waren er significante verschillen in het percentage lege magen tussen de seizoenen; er werden lagere percentages lege magen in het najaar gevonden voor grondels, schurftvis en schol en hogere percentages voor tong. Daarnaast waren de percentages lege magen lager in de periode na 2008 voor kleine pieterman, schurftvis en schol en hoger voor grondels en tong.

\section{Is de diversiteit van de prooikeuze van vis in de Voordelta veranderd door de jaren heen?}

Een mogelijk effect van de afname in bodemberoerende visserij is een toename van soortdiversiteit in het benthos. Een dergelijk veranderd voedselaanbod zou tot uiting kunnen komen in een verandering van de diversiteit van gekozen prooien (mits een prooisoort niet door een andere vervangen wordt). 
Daarom hebben we de Shannon-Wiener index van het dieet berekend. Deze index geeft een indicatie van de diversiteit van het dieet: hoe hoger de index, hoe meer groepen er gegeten worden.

Het dieet van tien vissoorten is onderzocht. Bij veel vissoorten bleek dat het dieet wordt gedomineerd door een of twee prooigroepen. De meest voorkomende prooisoorten zijn Ensis sp., wormen en garnalen. Voor bijna alle soorten zijn Ensis sp. en wormen een belangrijke voedselbron. Typische garnaleneters zijn wijting, kleine pieterman, grondel en schurftvis. De overige platvissen eten wel eens garnaal, maar dit vormt niet de hoofdmoot van het dieet. Vis als prooi is alleen belangrijk voor kleine pieterman en schurftvis en soms voor wijting. De soorten met gemiddeld het meest diverse dieet zijn kleine pieterman, grondels, schar en pitvis. Wijting, schol en bot hebben het minst diverse dieet. Voor grondel, schurftvis en schol lijkt er in het voorjaar wel een afname in diversiteit te zijn. Binnen soorten zijn er weinig opvallende verschuivingen in het dieet tussen jaren te zien. Veel soorten laten een lengte gestructureerd (=ontogenetische ontwikkeling) patroon in hun dieetkeuze zien: de prooikeuze verandert met de leeftijd/lengte van de vis.

De diversiteitsindex liet geen duidelijke veranderingen over de jaren zien en we vonden ook geen verschillen in diversiteit in prooikeuze tussen voor- en najaar.

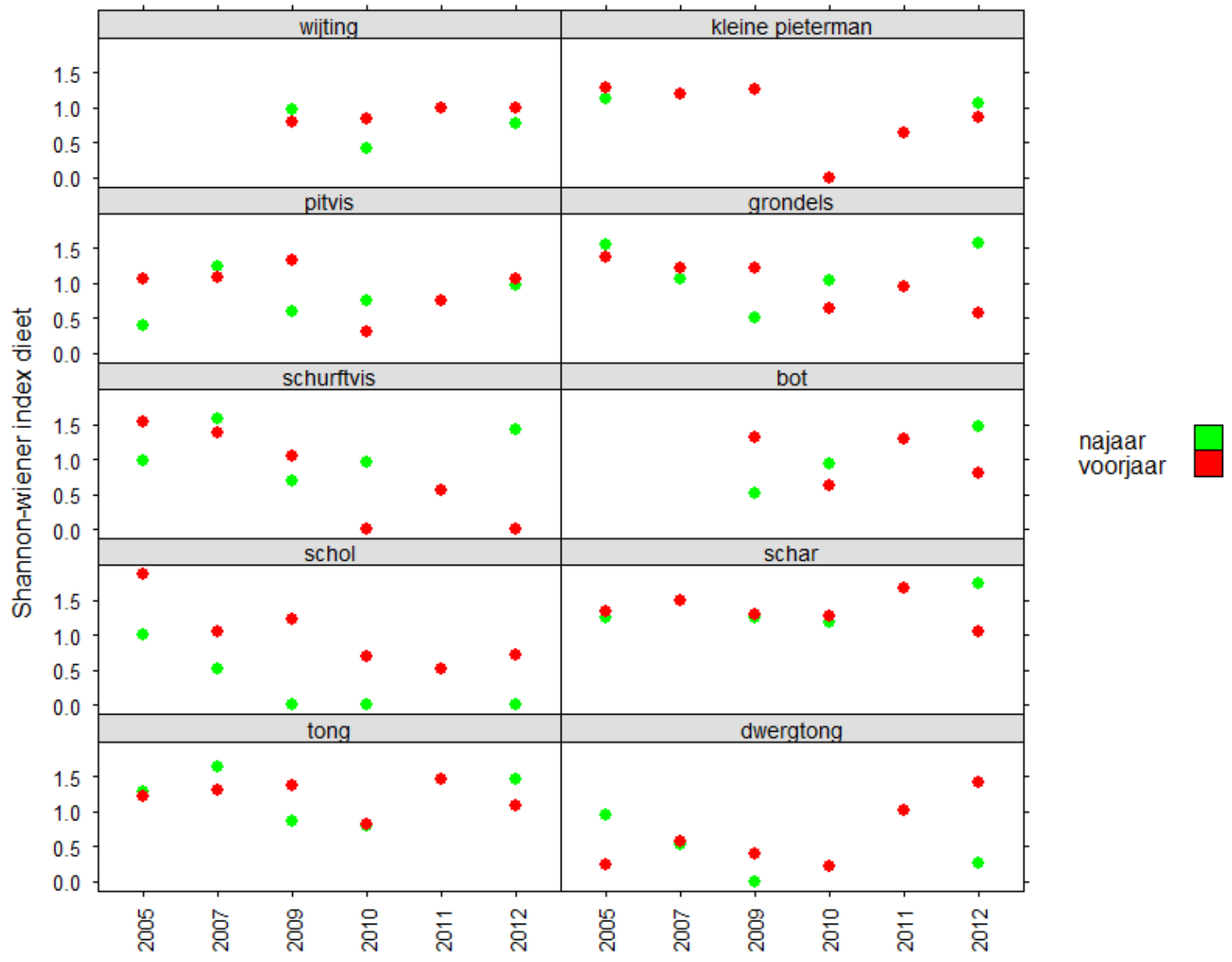

Figuur 5.54 Diversiteitsindex voor het dieet van tien vissoorten in de eerste fase in voor- en najaar.

\section{Selecteren vissen bepaalde prooien en is er een eventuele voorkeur voor bepaalde prooien gerelateerd aan hun gevoeligheid voor visserij?}

Selecteren vissen bepaalde prooien, of gaan ze opportunistisch te werk en eten ze wat er voorhanden is? En als er een prooivoorkeur bestaat, is deze voorkeur voor visserij-gevoelige of voor visserijongevoelige benthos? Een analyse is uitgevoerd op de maaginhoud van zeven vissoorten waarvoor voldoende data voorhanden waren (figuur 5.54). De benthos-inhoud van deze magen is geclassificeerd op visserij-gevoeligheid, aan de hand van de ten tijde van de eerste fase best beschikbare indeling (Bolam et al. 2014). Wat hierbij opviel is dat de voor visserij sensitieve benthossoorten maar weinig voorkomen in het gebied (lage waardes voor sensitieve soorten vergeleken met de overige categorieën) en dat deze bovendien niet worden geprefereerd door vissen. 
De onderzochte zeven vissoorten selecteren inderdaad actief specifieke prooien. Dat wordt duidelijk als we het aanbod vergelijken met het dieet: de verdeling tussen de drie categorieën benthos op de bodem is anders dan in de magen (figuur 5.55). Echter, de voorkeur gaat met name uit naar prooisoorten die resistent zijn voor visserij: het aandeel resistente prooisoorten in de omgeving is veel lager dan het aandeel in de magen.
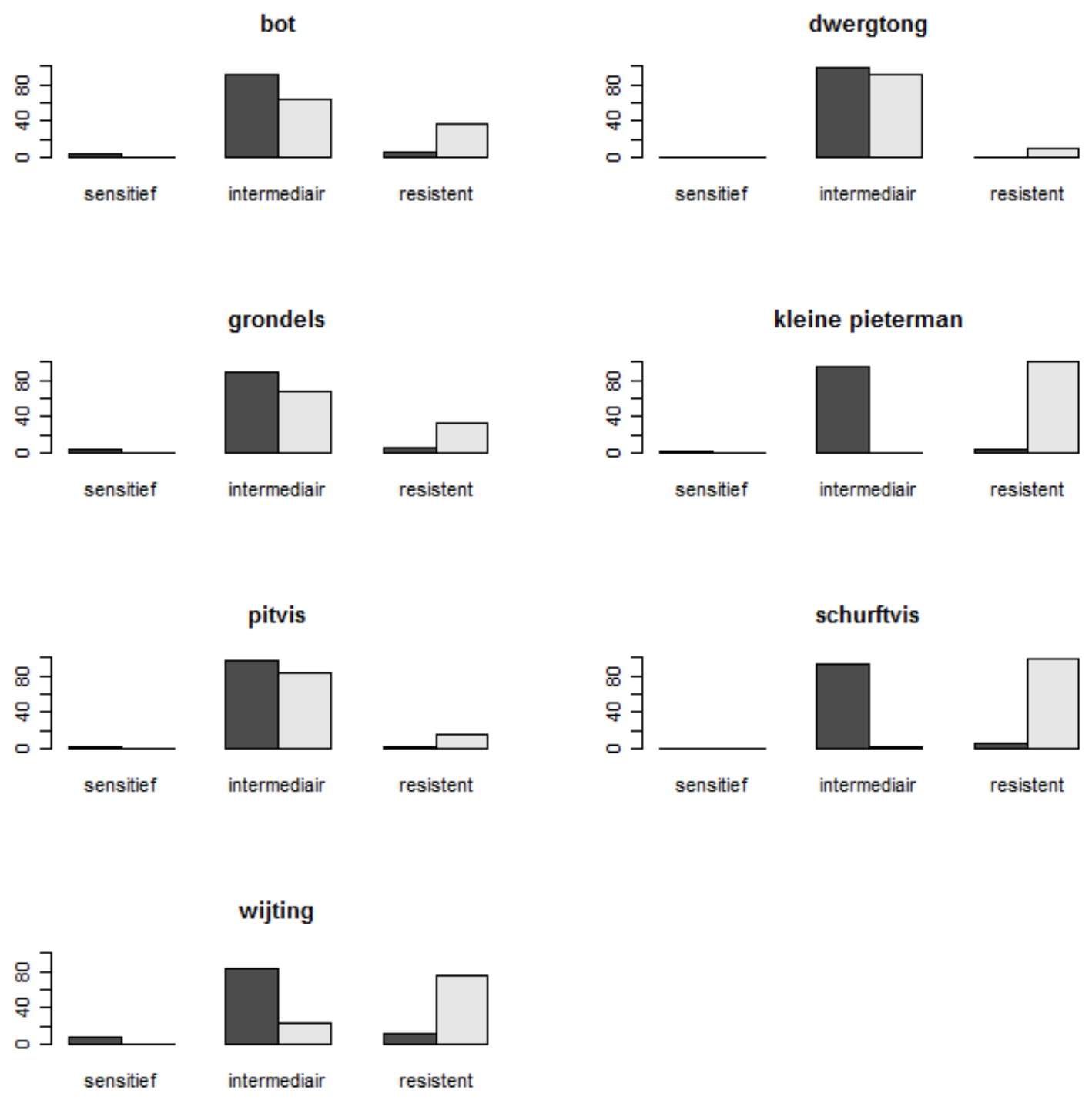

Figuur 5.55 Het gemiddelde percentage biomassa (asvrij drooggewicht) in de magen (licht grijs) en in de directe omgeving van de plek waar de vis gevangen is (donker grijs) van bodemfauna die sensitief/intermediair/resistent is met betrekking tot visserijdruk. Wanneer de grijze balk (gegeten) groter is dan de donkere balk (aanwezig) is dan is er sprake van selectie.

\section{Deelconclusie}

- De maagvulling van vissen vertoonde wel veranderingen in de periode 2005-2011, bij een aantal soorten nam de maagvulling toe, bij een aantal af.

- De diversiteit van de prooikeuze is niet veranderd in de periode 2005-2011.

- Vissen selecteerden prooisoorten die resistent zijn voor visserij (meer dan soorten die intermediair gevoelig zijn).

- $\quad$ Prooisoorten die gevoelig zijn voor visserij kwamen relatief weinig voor in het gebied. 


\subsubsection{Veranderingen in leeftijdsopbouw}

Wanneer het wegvallen van de bodemvisserij gunstig uitgewerkt heeft voor vis, wordt verwacht dat dit terug te zien is in de leeftijdsopbouw van de visgemeenschap. Bij lagere visserijsterfte krijgen vissen langer de tijd om door te groeien en ouder te worden.

Ontwikkelingen in de leeftijdsopbouw over de jaren 2002-2016 zijn vergeleken tussen de Voordelta en de Hollandse kust voor twee commerciële soorten: schol en tong. Voor de commerciële soorten bot en schar is de serie iets korter: 2008-2016. Dit zijn de soorten waarvoor in de hele DFS otolieten verzameld worden. Voor schol, tong en bot is geen verandering in leeftijdsstructuur waarneembaar (figuur 5.56). Voor schar is met name vanaf 2010 meer oudere vis waargenomen. De leeftijdsopbouw in Voordelta en Hollandse kust is voor alle vier soorten erg vergelijkbaar.

Voor dwergtong, schurftvis, kleine pieterman en pitvis zijn er alleen voor de Voordelta en voor een beperkt aantal jaren uit de periode 2005-2016 gegevens beschikbaar (2009, 2010, 2012, 2013, 2015, 2016). Bij kleine pieterman en dwergtong nam het aandeel oudere vis juist af (figuur 5.57). In pitvis en schurftvis is geen duidelijke ontwikkeling waarneembaar (figuur 5.57).

De waargenomen patronen zouden te maken kunnen hebben met een toename van de garnalenvisserij. Deze visserij vindt plaats vlak onder de kust en vissen in de categorie $<10 \mathrm{~cm}$ zijn gevoelig voor bijvangst in de garnalenvisserij. Klein blijvende soorten zoals dwergtong en kleine pieterman zullen in alle lengte- en leeftijdsklassen bijgevangen worden door deze vorm van visserij. Bij schol, tong, bot en schar worden vooral de kleiner (jongere) exemplaren bijgevangen in de garnalenvisserij, de grotere vis worden uit de garnalennetten geweerd door de zeeflap. Het patroon in schar is opvallend anders dan dat in de andere drie commerciële soorten. De ruimtelijke verspreiding van schar wijkt af van die van schol, bot en tong. Settlement van net gemetamorfoseerde larven vindt plaats in dieper water, pas daarna trekt jonge schar naar ondiepe wateren. Waar oudere schol en tong naar dieper water trekt, blijkt sinds ongeveer 2010 oudere schar juist dicht bij de kust te blijven. De reden daarvoor is onbekend. Terwijl de klein blijvende soorten (zoals dwergtong en kleine pieterman) mogelijk juist last hebben gehad van de toename in de garnalenvisserij, komt kleine schar relatief minder voor in het verspreidingsgebied van de garnalenvisserij. Oudere schar heeft vanwege de toepassing van de zeeflap geen grote kans bijgevangen te worden in de garnalenvisserij, ook al overlapt hun verspreiding met die van de garnalenvisserij.

Er kan niet gesteld worden dat de waargenomen veranderingen in leeftijdsopbouw het gevolg is van veranderingen in de visserij. De veranderingen bij dwergtong en kleine pieterman zijn niet heel uitgesproken en zijn mogelijk toevallige fluctuaties. Voor deze soorten zijn ook relatief weinig leeftijdsgegevens beschikbaar, wat de interpretatie niet eenvoudiger maakt. De veranderingen bij schar lijken duidelijker maar zouden ook andere oorzaken kunnen hebben, zoals veranderingen in zeewatertemperatuur. 


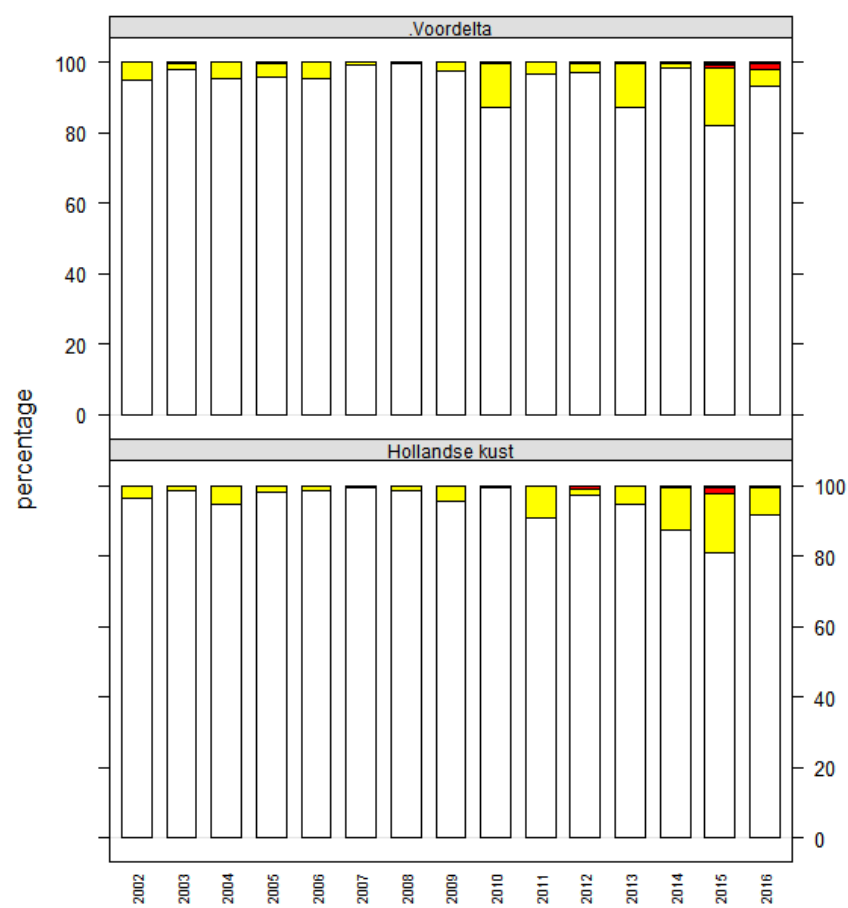

bot

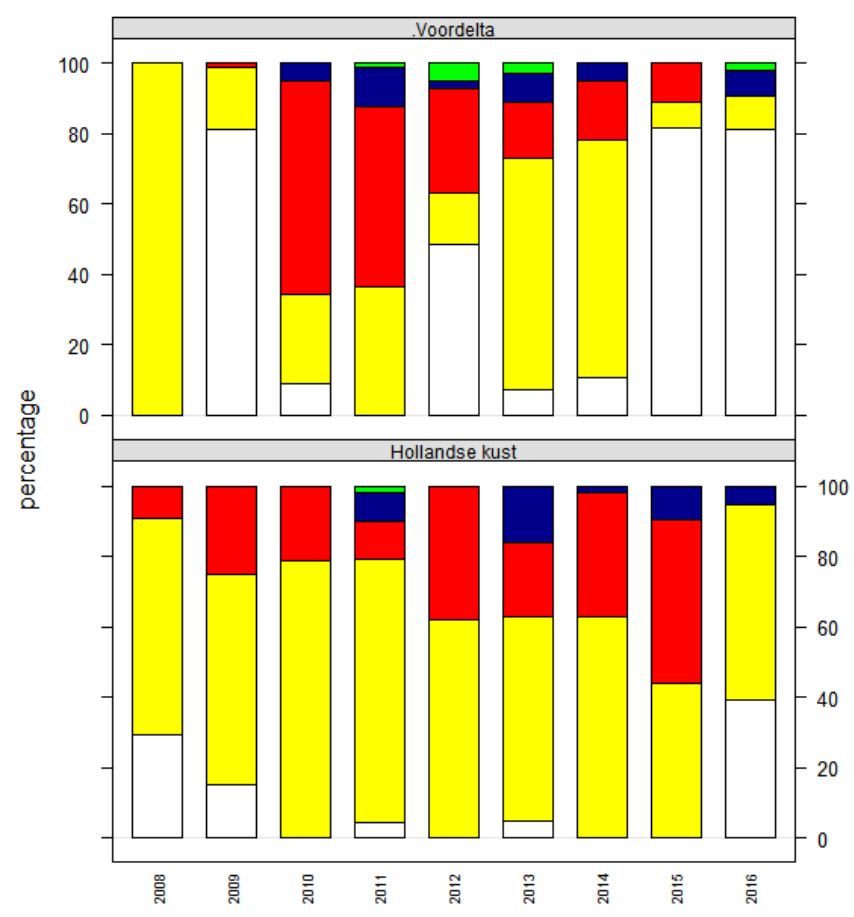

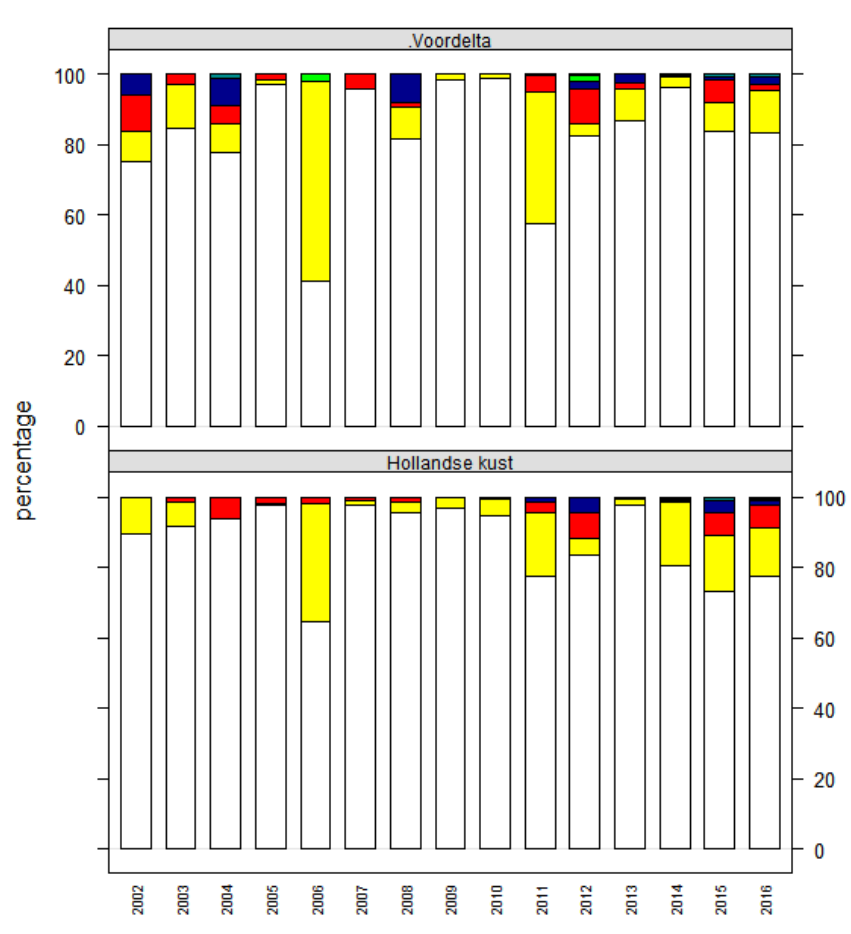

schar

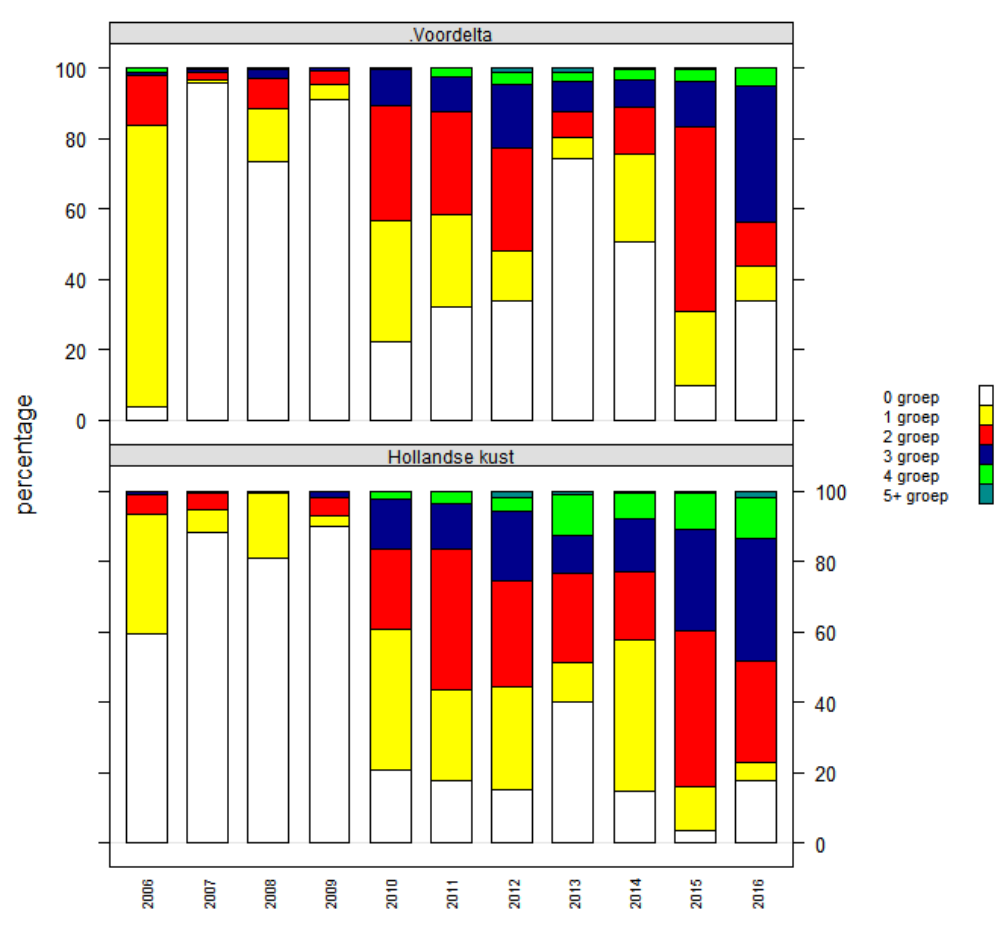

Figuur 5.56 Leeftijdverdeling in de periode 2006-2016 van schol, tong, bot en schar in de Voordelta en langs de Hollandse kust (Noord- en Zuid-Holland). 


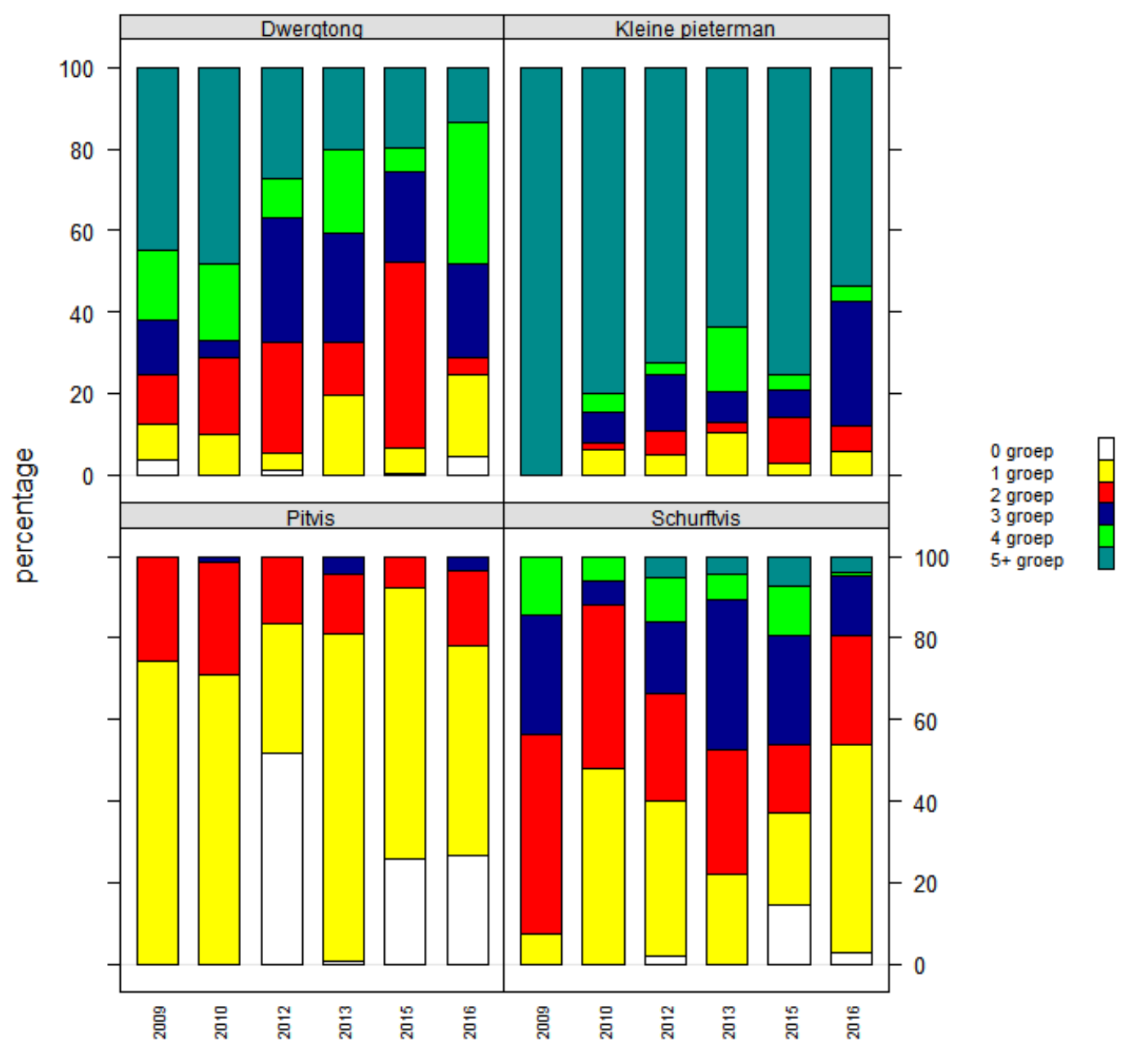

Figuur 5.57 Leeftijdverdeling in de periode 2009-2016 van dwergtong, kleine pieterman, pitvis en schurftvis in de Voordelta.

\section{Deelconclusie}

- Drie (schol, tong, bot) van de vier commercieel beviste soorten lieten geen verandering in leeftijdsstructuur zien in de periode 2002/2008-2016.

- Bij schar nam het aandeel oudere vis duidelijk toe, zowel in de Voordelta als langs de Hollandse kust.

- Van twee van de vier klein blijvende niet-commerciële vissoorten (kleine pieterman en dwergtong) nam het aandeel oudere vis juist af in de periode 2009-2016. De andere twee (pitvis, schurftvis) vertonen geen veranderingen.

- De waargenomen patronen zouden te maken kunnen hebben met de veranderingen in de visserij in het kustgebied: de toename in de garnalenvisserij en de afname in de boomkorvisserij, maar kunnen ook door andere factoren (zoals een trend in watertemperatuur) veroorzaakt zijn.

\subsubsection{Veranderingen in groei}

De Voordelta en Hollandse kustzone worden gebruikt als kinderkamergebied. Verbeteringen in de voedselsituatie (door verandering in visserijdruk) zouden zichtbaar kunnen worden in de groei van vis. Daarom worden hier de ontwikkelingen in groeisnelheid onderzocht voor 0-, 1- en 2-jarige schol, schar en tong en vergeleken tussen de Voordelta en Hollandse kust. Voor de meeste leeftijd/gebiedcombinaties van schol, schar en tong lijkt de gemiddelde lengte per leeftijd af te nemen door de jaren heen (figuur 5.58, 5.59). Dit effect is sterker voor oudere vissen. Het patroon doet zich voor zowel in de Voordelta als langs de kust en is een fenomeen dat ook Noordzeebreed waargenomen is (Bolle et al. in prep, Schuijer (2015)). 

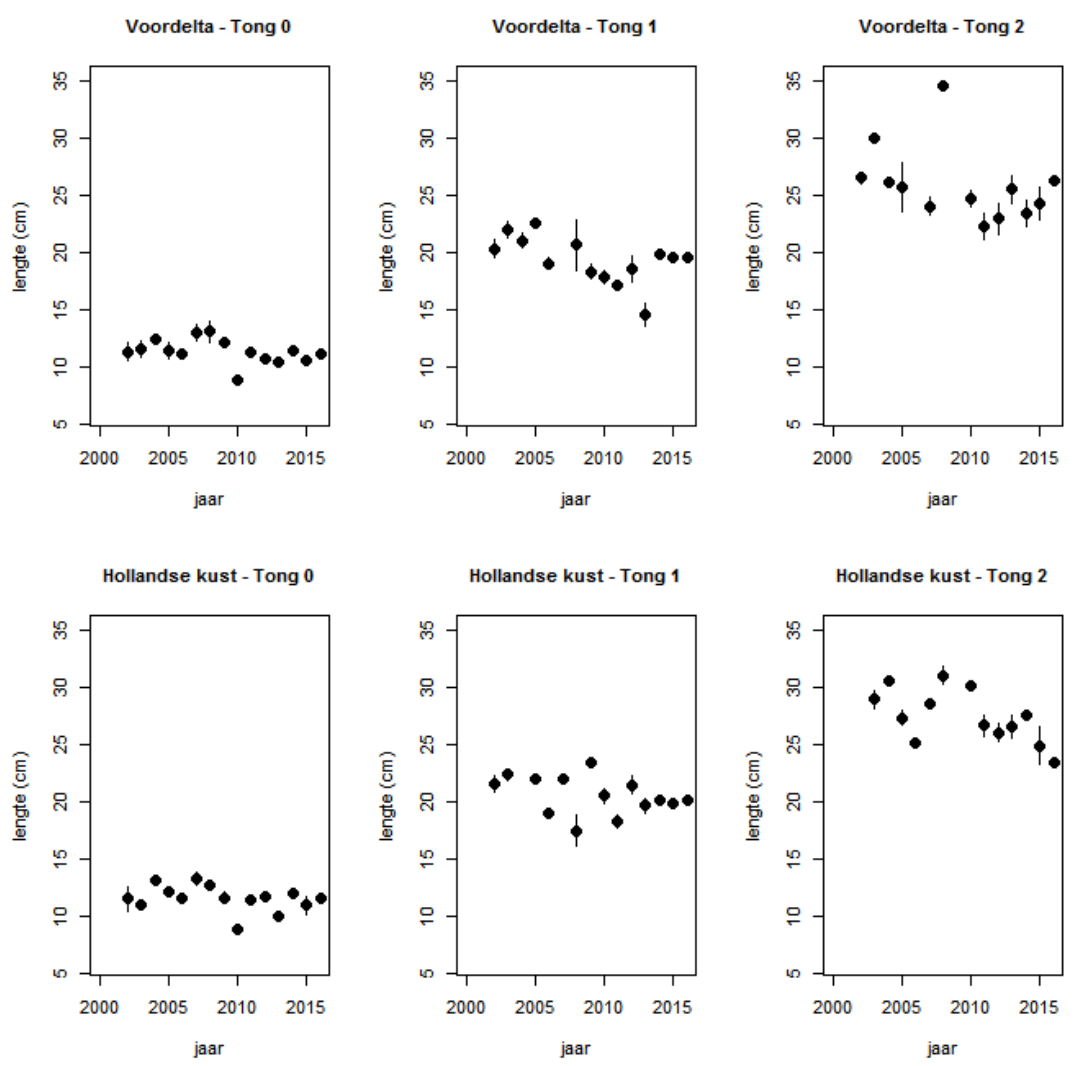

Figuur 5.58 Gemiddelde lengte en standaard deviatie van 0-, 1- en 2-jarige tong in de Voordelta en langs de Hollandse kust.
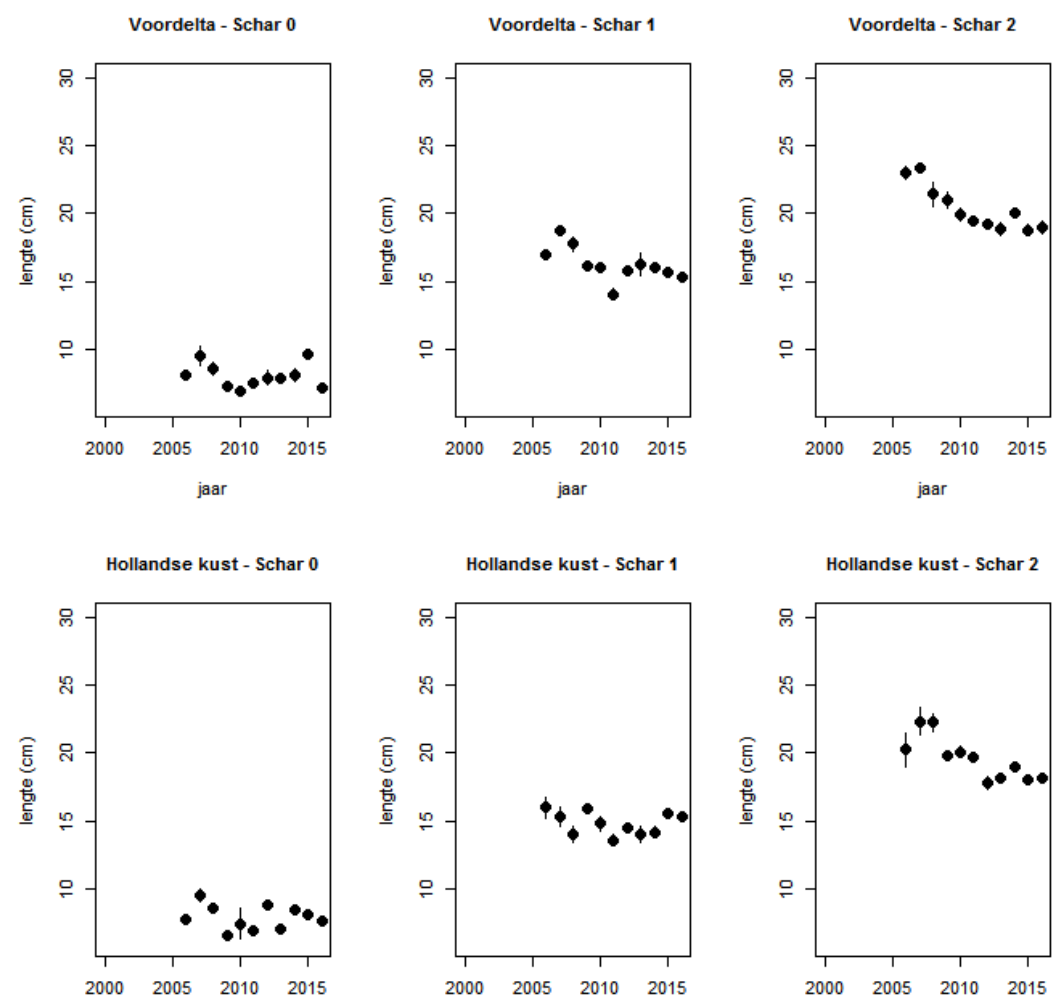

jaar

jaar

Figuur 5.59 Gemiddelde lengte en standaard deviatie van 0-, 1- en 2-jarige schar in de Voordelta en langs de Hollandse kust. 


\section{Deelconclusie}

- Schol, tong en schar vertoonden een afname in lengtegroei. Dit is een fenomeen dat zich op grote (Noordzeebrede) schaal voordoet. Hiervoor zijn een viertal hypothese (zie discussie).

\subsubsection{Veranderingen in conditie}

Veranderingen in voedselbeschikbaarheid (door veranderingen in visserijdruk) kunnen ook doorwerken op de conditie van vis. Bij verbetering van de voedselsituatie zou dit gereflecteerd kunnen worden in een betere conditie.

Lange termijn trends in de conditie zijn vergeleken tussen de Voordelta en de Hollandse kust. Hiervoor was een DFS tijdreeks vanaf 1995 beschikbaar voor schol, tong en schar en een tijdreeks vanaf 2004 voor bot. Conditie is uitgedrukt als Fulton's conditie factor (K-factor, (Nash et al. 2006)), waarbij geldt: hoe hoger de $\mathrm{K}$-factor, hoe beter de conditie van de vis.

De conditie van een soort varieerde van jaar op jaar, maar opvallend is dat de trend in de Voordelta en de Hollandse kust wel dezelfde jaar op jaar schommelingen vertoont (figuur 5.60). Er is geen duidelijke toe- of afname over de jaren heen.
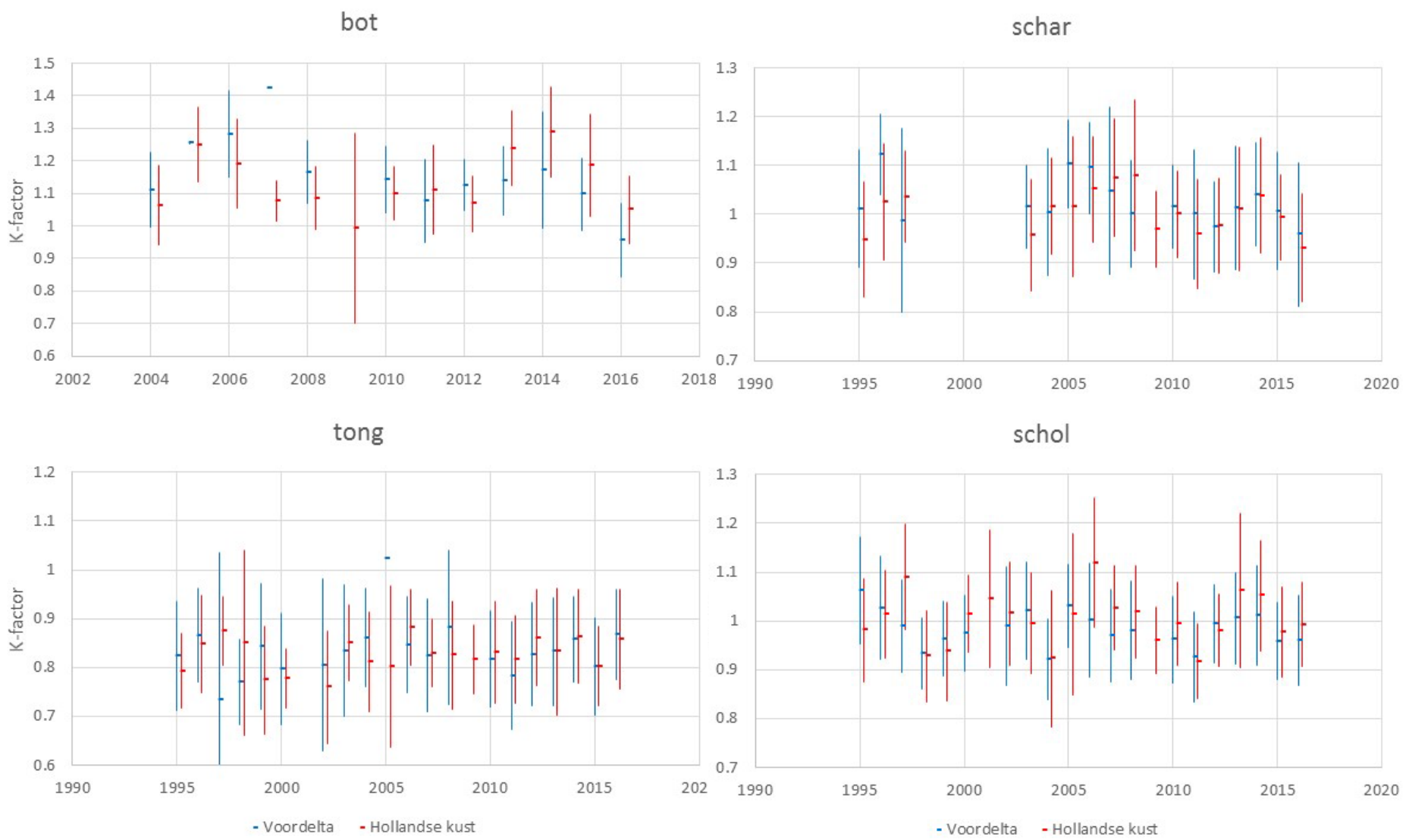

Figuur 5.60 De k-factor (Fulton's conditie factor) van bot, tong, schol en schar in de DFS-tijdreeks, in de gebieden Voordelta (blauw) en de Hollandse kust (rood). Gemiddelden en standaard deviatie(balken).

\section{Deelconclusie}

- De conditie van de soorten schol, tong, schar en bot laat geen duidelijke toe- of afname zien in de periode 1995/2004-2016. 
- Er zit wel een duidelijk jaarsignaal in de conditie, dat parallel loopt tussen Voordelta en Hollandse kust.

\subsubsection{Discussie}

We hebben in de diverse analyses onderzocht of er veranderingen te zien zijn in de visfauna die gerelateerd kunnen zijn aan een verandering in visserijdruk. Hierbij is onderzocht of er veranderingen in dichtheid, soortensamenstelling, prooikeuze, leeftijdsopbouw, groei en conditie zijn opgetreden.

Daarvoor hebben we middels habitatmodellen onderzocht of de dichtheden van ecologische groepen veranderd zijn. Ook hebben we de visgemeenschap als geheel geanalyseerd samen met kwantitatief belangrijke groepen epibenthos. Relaties met mogelijke veranderingen in het prooiaanbod zijn onderzocht in dieetanalyses. Veranderingen in leeftijdsopbouw zijn onderzocht aan de hand van otolieten. De verwachting was dat de leeftijdsopbouw reageert op een veranderde visserijdruk, waarbij we een verschuiving verwachtten van een gemeenschap oververtegenwoordigd door kleine en jonge vissen naar een gemeenschap met een evenwichtiger leeftijdsverdeling, waarbij ook oudere dieren gevangen worden. Onze verwachting was dat we dit met name zouden zien in residente soorten: soorten die hun hele leven in het gebied blijven. Wanneer het prooiaanbod verbeterd zou zijn, verwachten we ook een verandering in groei (lengte bij een bepaalde leeftijd) en of conditie van vis.

Door aansluiting bij de DFS in de tweede fase zijn er veel meer mogelijkheden ontstaan voor analyses van lange termijnveranderingen. Sinds 1970 hebben zich grote veranderingen voorgedaan in de visgemeenschap in de Voordelta en langs de hele Nederlandse kust. Ten eerste is het groottespectrum veranderd naar gemiddeld kleinere vissen. Dat komt deels door het verdwijnen van grote exemplaren, maar ook de opkomst van klein blijvende soorten zoals dwergtong en schurftvis. De dominante rol van schol is overgenomen door schar. Zandspieringen vertonen een opvallende toename in de laatste decennia. Gezien de sterke relatie van zandspieringen met de bodem en hun sterke voorkeur voor een bepaalde sedimentsamenstelling (Tien et al. 2017a) zijn hiervoor een aantal mogelijke verklaringen. De twee meest voor de hand liggende hiervan zijn de zandsuppleties die al decennia worden uitgevoerd langs de hele Nederlandse kust (Herman et al. 2016) en het verdwijnen van de boomkorvisserij. Een opvallende ontwikkeling is de sterke toename van slangsterren in de Voordelta sinds 2009. Ook in de benthosbemonstering zien we deze ontwikkeling (Figuur 5.5), maar minder prominent. Deze toename is niet zichtbaar langs de Hollandse kust. Slangsterren kunnen in dichte tapijten voorkomen. Ze filteren eetbaar materiaal uit de bodem, alhoewel ze ook beschreven worden als actief jagende predatoren (Boos et al. 2010). Uit experimenteel werk (Hendrick et al. 2016) is duidelijk dat slangsterren last hebben van bedekking door sediment (door storm of bodemomwoeling), maar dat ze ook in staat zijn (afhankelijk van de sediment-diepte en -type) om daar onder uit te kruipen. Uit diverse studies blijkt dat slangsterren gevoelig zijn voor bodemberoerende visserij (Hinz et al. 2012), hoewel ze beschadigde armen kunnen regenereren. In een verwante soort is in Patagonië een sterke dichtheidstoename gevonden na het sluiten van een gebied voor bodemberoerende visserij.

De habitatmodellen op basis van de ecologische groepen (de gildes) laten zien dat de dichtheden, rekening houdend met variatie veroorzaakt door abiotiek, geen relatie met de lokale visserijinspanning (zowel boomkor- als garnalenvisserij) in de Voordelta vertonen. Uit de statistische trendberekeningen van de ecologische groepen blijkt dat de trends in de Voordelta over het algemeen goed overeenkomen met die langs de Zuid-Hollandse kust. Trends langs de Noord-Hollandse kust wijken daar iets van af. Marien juvenielen vertonen in alle gebieden relatief hoge dichtheden in de periode 1980-1990 gevolgd door een afname die zich langer voort heeft gezet langs de NoordHollandse kust dan in de andere gebieden. Voor geen van de onderzochte groepen is er een statistische relatie gevonden tussen de trend in aantalsontwikkeling en visserij-inspanning. De relatief korte tijdserie (alleen data over visserij-inspanning voor 2006-2016) kan hier een oorzaak van zijn.

Ook de multivariate analyses laten zien dat de bodemgemeenschap (vis en epibenthos) in de loop van de periode is veranderd, maar de ontwikkelingen in Voordelta, Zuid-Hollandse en Noord-Hollandse kust gaan in dezelfde richting. In de Voordelta zijn diverse abiotische factoren en de inspanning door boomkorvisserij en garnalenvisserij significante voorspellende variabelen voor de verandering in de gemeenschap, maar de abiotische variabelen verklaren een veel groter deel van de variantie. 
Uit de analyse van de magen (alleen uitgevoerd in de eerste fase van het onderzoek) bleek geen eenduidig signaal uit de verandering in maagvulling. De diversiteit van de prooikeuze was niet veranderd in de periode 2005-2011. Uit de combinatie van maaganalyses en het beschikbare benthos op de plekken waar de vissen gevangen waren, bleek dat vissen actief prooisoorten selecteren (dus meer dan op basis van het voorkomen verwacht zou worden) die resistent zijn voor visserij. Bodemfaunasoorten die gevoelig zijn voor visserij bleken ook relatief weinig voor te komen in het gebied.

Voor een aantal soorten kon de verandering in leeftijdsstructuur bestudeerd worden. Hierbij bleek dat drie van de vier commercieel beviste soorten (schol, tong, bot) geen verandering in leeftijdsstructuur lieten zien in de periode 2002/2008-2016. Bij schar nam het aandeel oudere vis duidelijk toe zowel in de Voordelta als langs de Hollandse kust. Schol, tong en bot zijn alle marien juvenielen, waarbij recentelijk grote verschuivingen in leefgebied naar dieper water gerapporteerd is voor met name de oudere jaarklassen (van Keeken et al. 2007, Teal et al. 2015). Van twee van de vier klein blijvende niet-commerciële vissoorten (kleine pieterman en dwergtong) nam het aandeel oudere vis juist af in de periode 2009-2016. De andere twee (pitvis, schurftvis) vertoonden geen veranderingen. De waargenomen patronen zouden te maken kunnen hebben met de veranderingen in de visserij in het kustgebied: de toename in de garnalenvisserij en de afname in de boomkorvisserij, maar zouden ook andere oorzaken kunnen hebben, zoals bijvoorbeeld veranderingen in zeewatertemperatuur. In de garnalenvisserij lopen met name de kleinere soorten een groot risico lopen bijgevangen te worden (< $10 \mathrm{~cm}$ (Catchpole et al. 2008)).

Een fenomeen dat zich op grote (Noordzeebrede) schaal voordoet is de afname in lengte op een bepaalde leeftijd (Schuijer 2015). Dit zagen we ook terug bij schol, tong en schar in de Voordelta en langs de Hollandse kust. Diverse hypothesen zijn voorgesteld over de mogelijke oorzaken hiervan. Mogelijke sturende factoren zijn: toenemende temperatuur, afnemende nutriënten, visserij-effect, dichtheidsafhankelijke effecten (bij huidige hoge aantallen platvis neemt concurrentie om voedsel toe). De conditie van de soorten schol, tong, schar en bot laat geen duidelijke toe- of afname zien in de periode 1995/2004-2016. Er zit wel een duidelijk jaarsignaal in, dat parallel loopt tussen Voordelta en Hollandse kust. Dit suggereert dat de voedselsituatie, temperatuur of andere groeibepalende factoren wel variëren tussen jaren, maar dat dat op een vrij brede ruimtelijke schaal gesynchroniseerd is.

\subsubsection{Conclusies}

De dichtheden van de diverse ecologische groepen in de Voordelta lieten geen veranderingen zien die verband houden met de veranderingen in visserijdruk. Ook de lange termijn veranderingen in visdichtheden zowel binnen als buiten de Voordelta lieten geen relatie met visserijdruk zien. Uit de multivariate analyses bleek dat de samenstelling van de visgemeenschap veranderd is, maar vergelijkbaar in de Voordelta en de rest van de kust. De verandering in zowel boomkorvisserij als garnalenvisserij is een significante verklarende factor hiervoor, maar de bijdrage aan de totale variantie is veel kleiner dan het deel dat verklaard wordt door abiotiek. Aangezien jaar en visserijdruk collineair zijn kan de invloed van visserijdruk eigenlijk groter (of juist kleiner) zijn, omdat variatie veroorzaakt door visserijdruk in de factor jaar kan gaan zitten en andersom.

Van de vier onderzochte grote soorten (drie marien juveniele en een residente soort) lieten een (marien juveniele) soort een verandering zien naar een leeftijdsverdeling met meer oudere vis, de andere drie soorten lieten geen verandering zien. Van twee van de vier kleine soorten (alle residente soorten), verschoof de leeftijdsverdeling juist op naar minder oude dieren, de overige twee soorten lieten geen verandering zien. Dit geeft dus geen eenduidig beeld van een verschuiving naar een gemeenschap met meer oudere dieren. Het dieet van vis in de Voordelta werd gekenmerkt door een selectie van bodemfaunasoorten die resistent zijn tegen bodemberoerende visserij. Dergelijke soorten blijken, vergeleken met andere bodemfaunasoorten, een onevenredig groot aandeel in het dieet van de vissen te vormen. 


\subsection{Huidige stand van zaken kennis effecten garnalenvisserij}

\subsubsection{Achtergrond}

De garnalenvisserij is economisch en in aantallen schepen één van de belangrijkste visserijen in Nederland. De inspanning en aanlandingen van de (internationale) garnalenvisserij heeft een sterke groei doorgemaakt vanaf 1970 tot nu (ICES 2016). Van de internationale vloot maken Duitsland en Nederland een vergelijkbaar deel uit en zijn samen verantwoordelijk voor ca. $70 \%$ van de aanlandingen. De visserijdruk in de Nederlandse Waddenzee en Noordzeekustzone beperkt zich tot de geulen en loopt op tot 50 keer bevissing per jaar. Garnalenvisserij opereert vooral in de zone tot $20 \mathrm{~m}$ diep en het verspreidingsgebied overlapt daarmee sterk met Natura 2000 gebieden. Voor zowel de Noordzeekustzone als de Waddenzee is voor deze Natura 2000 gebieden een verbeterdoelstelling geformuleerd voor Habitat 1110. Het effect van het garnalentuig op het ecosysteem is echter niet goed bekend. Er zijn in de afgelopen jaren diverse studies geweest (waarvan een deel nu nog bezig is) waarbij de mogelijke effecten van de garnalenvisserij onderzocht zijn en worden. Deze studies worden hier op een rij gezet. De vraag hierbij is: wat is het effect van garnalenvisserij op het bodemecosysteem?

De vraag kan op verschillende niveaus beantwoord worden. Het is van belang daarbij onderscheid te maken tussen effecten op de korte en lange termijn, effecten in een zwaar bevist gebied of een relatief onberoerd gebied. Verder is er een verschil in directe effecten op de bodem door passage van het tuig, bijvoorbeeld sterfte of beschadiging en indirecte effecten die via terugkoppelingen in het voedselweb lopen. Door (herhaald) contact met het tuig kan de ontwikkeling van kwetsbare of structuurvormende organismen (anemonen, kokerwormen, zeemos) beperkt worden en kan de vestiging van schelpdierlarven op de bodem belemmerd worden. Ook is het denkbaar dat het regelmatig 'aanvegen' van de zeebodem een effect heeft op de bovenste (slib) laag van het sediment. Of en de mate waarin deze effecten optreden kunnen verschillen tussen gebieden met verschillende sediment en bodemstructuur. In de tot nu toe uitgevoerde onderzoeken is met name het directe (korte termijn) effect van bevissing onderzocht, in gebieden die al decennialang bevist zijn.

\subsubsection{Effecten garnalenvisserij Natura2000 gebieden}

Looptijd 2012-2014, Glorius et al. (2015)), http://edepot.wur.nl/332091, Tulp et al. (submitted)), Onderwerpen: (i) korte termijn effecten garnalenvisserij op het bodemecosysteem (BACI), (ii) dosiseffectrelatie tussen visserijinspanning en effecten op het bodemecosysteem In 2012 is een experiment uitgevoerd in 15 vakken verdeeld over 5 gebieden langs de NL kust en in de Waddenzee waarbij de benthosontwikkeling in een bevist en een onbevist plot zijn vergeleken voor en na de bevissing. De vissers zijn via diverse kanalen wel verzocht om de gebieden te mijden ivm het experiment, maar 13 van de 15 'onbeviste' vakken bleken toch bevist door garnalenvissers. De oorspronkelijke BACI-opzet kon daardoor in de analyse niet meer gebruikt worden. Uiteindelijk is alleen de correlatie berekend tussen de daadwerkelijk opgetreden visserijinspanning (berekend op basis van VMS data) en de ontwikkeling van het benthos. Het tweede deel, het Molenrak experiment, bestond uit 5 vakken die met verschillende intensiteit bevist werden $(0,1,2,3,4 x)$. Uit dit experiment bleek dat er geen effect was op totale dichtheid van bodemfauna maar dat de bevissing wel een effect had op de dichtheid van de verschillende soorten. In het $3 x$ en $4 x$ beviste vak nam de soortdiversiteit en de evenredige verdeling over de soorten af door een toename van met name Ensis en garnaal. Onze interpretatie hiervan is dat deze zich snel verplaatsende en koloniserende soorten de verstoorde plekken in namen. Op de T2 (na de volgende winter) was dit effect nog steeds zichtbaar 
maar niet meer significant. Verder bleek ook dat fragiele soorten (anemonen, poliepen en hydrozoa) afnamen na bevissing.

Voor beide experimenten is de ontwikkeling in de bodemfauna ook geanalyseerd met de zogenaamde Trait Based Approach (TBA). Daarin worden niet individuele soorten bekeken maar groepen van soorten die dezelfde kenmerken delen (traits, zie ook paragraaf 5.1.9), bijvoorbeeld of ze ingegraven leven of op het oppervlak, en naar levensduur (lang of kort). Uit deze analyse bleek dat, alhoewel het effect van visserij niet statistisch significant was, eigenschappen die gevoelig zijn voor visserij wel een negatieve relatie vertoonden met visserij.

\subsubsection{Experiment Voordelta}

2010-2012, Schellekens et al. (2014), Onderwerp: korte termijn effecten garnalenvisserij op het bodemecosysteem (BACI).

In zes proefvakken in het BBG is visserij gecontroleerd uitgevoerd; in de helft van elk proefvak is door een garnalenvisser gevist (beviste deel), zesmaal per jaar in de periode mei - november. In de andere helft van het proefvak is in het kader van het experiment niet gevist (controle deel). Ieder jaar is voorafgaand aan de bevissing en in de herfstperiode de bodemfauna bemonsterd met bodemschaaf en box corer. Ook in dit experiment werd in de meeste jaren in de meeste controlegebieden gevist door beroepsvissers. De resultaten laten geen duidelijk effect van de garnalenvisserij op de bodemfauna zien, maar het experiment is sterk gehinderd door de onbedoelde visserij. Er kon wel onderscheid gemaakt worden tussen iets meer en minder beviste gebieden, maar geen vergelijking met helemaal niet beviste gebieden. In de gevallen dat alsnog een effect gemeten had kunnen worden (power hoog genoeg was), is voor geen van de onderzochte indicatoren een significant verschil gevonden.

\subsubsection{BENTHIS}

2013-2017, output www.benthis.eu, Onderwerp: ontwikkeling mechanistische systematiek voor beoordeling visserij-impact op bodemecosysteem

De methode maakt gebruik van het principe dat de levensduur van soorten en de gemiddelde tijd tussen twee bevissingen in dezelfde eenheid (jaren) worden uitgedrukt. Op die manier is te bepalen welke fractie van het benthos naar verwachting met een vistuig in aanraking komt, voordat zijn natuurlijke levensduur is bereikt. Daarnaast is levensduur een goede voorspeller voor de snelheid waarmee een soort zich kan herstellen nadat sterfte door bevissing is opgetreden. Uitgebreid onderzoek laat verder zien dat de mate van sterfte sterk afhangt van de penetratiediepte van een vistuig in het sediment. Met name het meten van de penetratiediepte is iets dat tuig-specifiek veldwerk vereist. Dit is voor garnalenvisserij binnen Benthis niet gebeurd. Daardoor kan de methode op dit moment alleen worden toegepast voor garnalenvisserij op basis van aannames. Het meten van de penetratiediepte van garnalentuigen zou leiden tot een veel betere inschatting van de effecten, met minder onzekerheid.

\subsubsection{VIBEG}

2013-, onderwerp: relatie garnalenvisserij en leeftijdsopbouw benthosgemeenschap in NZKZ en veranderingen na sluiting gebieden voor garnalenvisserij

In de Noordzeekustzone en Vlakte van de Raan zijn een aantal gebieden gesloten voor garnalenvisserij. Voor (2013) en na (2015) de sluiting is een uitgebreide benthosmonitoring uitgevoerd. Ook hier bleek na sluiting dat de bevissing in deze gebieden niet afgenomen was en effecten van sluiting niet beoordeeld konden worden. Naast het veldwerk is een deskstudie uitgevoerd, met de data van met name de MWTL en WOT-schelpdiersurvey data. De uitkomst van deze analyses is in het algemeen dat er een effect meetbaar is van garnalenvisserij, maar dat dit effect alleen in jaren met relatief weinig stormen te zien is. In andere jaren wordt de samenstelling van het benthos volledig bepaald door de natuurlijke dynamiek van het ecosysteem. 


\subsubsection{KBWOT RIBS}

2015-2016, output Powerpoint presentatie (Analyse wordt vervolgd en afgemaakt in kader van PMR compensatiemonitoring), Onderwerp: relatie tussen garnalenvisserij en vestigingskans schelpdieren Wordt het recruitment van kokkels en mossels beïnvloed door het regelmatig aanvegen van de zeebodem door de garnalenvisserij? In de analyse vonden we van de drie jaren met broedval voor 2010 en 2013 een negatief verband tussen de aan/afwezigheid van eenjarige mosselen en de intensiteit van de garnalenvisserij en voor 2014 een positief verband. In 2018 zal deze analyse uitgebreid worden naar meer jaren.

\subsubsection{Ontwikkeling bodemfauna in referentiegebied Rottum}

2002-2017, output Fey et al. 2013; Fey-Hofstede et al. (2014), Glorius et al in prep, Onderwerp: veranderingen na sluiting gebieden voor menselijke activiteiten (waaronder garnalenvisserij) (BACI) De ontwikkeling van de bodemfauna in een voor menselijke activiteiten gesloten gebied (referentiegebied: Schild en Boschwad) is vergeleken met een gebied waar zulke activiteiten wel toegestaan zijn (controlegebied: Zuidoost Lauwers en Spruit). Vóór de instelling van het referentiegebied is in drie jaar het benthos bemonsterd (2002, 2003 en 2005). Na de instelling van het referentiegebied zijn jaarlijks bemonsteringen uitgevoerd, met het karakter van 'vinger aan de pols'. Deze bemonstering is niet intensief genoeg om (statistisch) betrouwbare verschillen aan te kunnen tonen. De laatste jaren lijkt een andere ontwikkeling op te treden in de bodemfauna (totale dichtheden en soortenrijkdom) in de gesloten geulen ten opzichte van de open geulen. De rapportage over een uitgebreidere bemonstering in 2016, waarbij ook statistische hardere uitspraken gedaan kunnen worden is nog niet gereed.

\subsubsection{Monitoring Viswad gebieden Waddenzee}

2015-2017, output Powerpoint presentatie, rapportage in prep, Onderwerp: veranderingen na sluiting gebieden voor garnalenvisserij (BACI)

Op een aantal plekken in de westelijke Waddenzee wordt de ontwikkeling van de bodemfauna vergeleken tussen gebieden die gesloten zijn voor alleen de garnalenvisserij, voor alleen de mosselzaadvisserij, voor beide visserijen en voor gebieden toegankelijk voor beide visserijen. De focus ligt primair op mosselbanken en geassocieerde fauna, maar er wordt ook aandacht besteed aan overige soorten die mogelijk kwetsbaar zijn voor bodemberoering. In dit onderzoek wordt niet gecontroleerd wat de werkelijk uitgevoerde visserijdruk is geweest. In 2015 en 2016 zijn metingen uitgevoerd in voorjaar en zomer. Tot nu toe zijn er nog geen eenduidige ontwikkelingen zichtbaar. Dit programma wordt in 2017 en 2018 voortgezet.

\subsection{9 overige literatuur}

In de literatuur is een handvol studies beschreven waarin het effect van garnalentuig op de bodem is onderzocht. Die studies concentreerden zich op beschadiging van biogene structuren zoals Sabellaria spinulosa riffen, kokerwormvelden Lanice conchilega en zeemosvelden Sertularia cupressina (Riesen \& Reise 1982, Buhs \& Reise 1997, Berghahn \& Vorberg 1998, Vorberg 2000). Riesen \& Reise (1982)) beargumenteren dat garnalen en boomkorvissers met opzet Sabellaria riffen verwoestten om er beter te kunnen vissen en om schade aan de netten te voorkomen. Vorberg (2000)) voerde experimenten uit en concludeerde dat het effect op Sabellaria riffen met name door contact met de sloffen veroorzaakt wordt. Na experimentele visserij konden de tracks van de sloffen onderscheiden worden in gebieden met kokerwormvelden, maar de klossenpees leek hier geen schade te hebben veroorzaakt (Berghahn \& Vorberg 1998). De afname van zeemosvelden Sertularia cupressina die eens algemeen waren in de Waddenzee (Lavaleije \& Dankers 1993), wordt ook geweten aan garnalenvisserij. Sinds begin jaren '70 zijn de velden sterk achteruit gegaan en uiteindelijk verdwenen, alhoewel de soort nog steeds voorkomt in de Waddenzee. Berghahn \& Vorberg (1998)) beargumenteren dat de garnalenvisserij hier niet de oorzaak van is geweest omdat $S$. cupressina een flexibele structuur heeft 


\subsection{Voortschrijdend inzicht effecten van sleepnetvisserij op de zeebodem en het benthische ecosysteem}

\subsubsection{Uitgangspunt}

De compensatieopgave voor de aanleg van de Maasvlakte-2 was gebaseerd op een inschatting van de negatieve effecten van de bodemtrawlvisserij op de natuurwaarden van de Voordelta. De redenering was dat bodemvisserij de natuurwaarde vermindert en dat de instelling van een bodembeschermingsgebied zonder visserijverstoring tot een kwaliteitsverbetering zou leiden. Onder de aanname dat de toenmalige visserij de natuurwaarde met $10 \%$ zou reduceren zou een bodembeschermingsgebied van 10 maal de oppervlakte van de MV2 voldoende zijn om het verlies van habitat 1110 te compenseren. De kwaliteiten die verloren gaan en die dus moeten worden gecompenseerd zijn (Rijnsdorp et al. 2006): (i) de biomassa (330-550 ton ADW bodemdieren) en diversiteit van bodemdieren (als voedsel voor vissen en vogels); (ii) 1960 ha potentieel leefgebied voor schelpdieren (als voedsel voor Zwarte zee-eenden); (iii) 32 ton vis (als voedsel voor vogels en zeehonden); (iv) aantallen van aandachtssoorten vissen waarvan kan worden verwacht dat ze effecten ondervinden van dit verlies aan leefgebied; (v) vogeldagen van (aandachts-) soorten waarvan kan worden verwacht dat ze meer of minder effecten ondervinden van dit verlies aan foerageergebied (met name zwarte zee-eend). Uiteindelijk is de compensatieopgave algemener geformuleerd: verbeteren van de kwaliteit van $\mathrm{H} 1110$, in termen van de beschikbaarheid van voedsel voor beschermde en typische soorten, zodanig dat voor het oppervlakteverlies wordt gecompenseerd. In dit hoofdstuk richten we ons op de compensatieopgave (i) en (ii) en analyseren hoe de wetenschappelijke kennis over de effecten van sleepnetvisserij (alle visserijen met een gesleept tuig, dus ook boomkorvisserij) zich sinds 2005 heeft ontwikkeld. Het doel hiervan is om de uitgangspunten uit 2005 te staven aan de nieuwe kennis die sindsdien is ontwikkeld over de effecten van bodemtrawlvisserij op de zeebodem. Dit hoofdstuk behandelt dus de vraag: als we opnieuw voor een dergelijke opgave zouden staan: wat zouden dan de verwachtingen dan zijn?

\subsubsection{De stand van kennis in 2005}

De nadelige effecten van bodemtrawls zijn in de jaren 90 intensief bestudeerd onder andere in een reeks BEON-projecten (Beleidsgericht Ecologisch Onderzoek Noordzee) en twee door de EU gefinancierde onderzoeken, IMPACT-1 en IMPACT-2. Deze studies waren vooral gericht op het schatten van de directe sterfte, die door de passage van een vistuig werd veroorzaakt, en de hersteltijd. Deze studies hebben overtuigend aangetoond dat bodemvisserij de biomassa en talrijkheid van bodemdieren en de soortenrijkdom reduceert. De beschikbare gegevens zijn samengevat in twee review papers die een schatting hebben gemaakt van de visserijsterfte van verschillende vistuig habitat combinaties en de hersteltijd van verschillende groepen bodemdieren (Collie et al. 2000, Kaiser et al. 2006). Niet alle vistuig-habitat combinaties waren vertegenwoordigd. Voor de garnalenvisserij bijvoorbeeld, was geen informatie beschikbaar. De aanname dat de toenmalige visserij de natuurwaarde met $10 \%$ zou reduceren is gebaseerd op een expert beoordeling van deze informatie.

Om de ecosysteemeffecten van bodemvisserij te kwantificeren was een grootte-gestructureerd ecosysteem model beschikbaar (Duplisea et al. 2002). Dit model is verder verfijnd door (Hiddink et al. 2006). De grootteklassen van bodemdieren concurreerden om voedsel en werden gekenmerkt door een maximale biomassa (draagkracht) en een specifieke groeisnelheid. De interactie tussen het habitattype en de visserijeffecten werd gemodelleerd door relaties tussen groei en omgevingsfactoren en tussen sterfte en omgevingsfactoren op te nemen. Het model is gebruikt om de effecten van bodemvisserij op de biomassa, productiviteit en biodiversiteit van het benthische ecosysteem te onderzoeken. Het model was gevalideerd met veldwaarnemingen over een gradiënt van 
visserijintensiteit in een aantal zandige gebieden in de diepere delen van de zuidelijke Noordzee. Zowel het model als de veldgegevens toonden aan dat bodemvisserij de biomassa, productie en soortenrijkdom verminderde. De effecten waren het grootst in gebieden met een lage natuurlijke verstoring. De effecten waren gering in gebieden met een hoge natuurlijke verstoring. De auteurs waarschuwden dat de resultaten afhankelijk zijn van de vele aannames en simplificaties en dat verder onderzoek nodig is om het model te verfijnen en de toepasbaarheid in andere habitats te evalueren. Ook hield het model geen rekening met de rol van predatie door vis en de mogelijke effecten van visserij op de rekrutering van bodemdieren.

Omdat er geen informatie beschikbaar was over de directe effecten (visserij sterfte) van de garnalenvisserij op het benthos is bij de afweging welke bodemtrawlvisserij uit het bodembeschermingsgebied moest worden uitgesloten aangenomen dat de sterfte door het garnalentuig 15\% was van de sterfte veroorzaakt door de boomkor (Rijnsdorp et al., 2006).

Conclusie. De compensatieopgave is gebaseerd op de toenmalige stand van de wetenschappelijke kennis en een arbitraire inschatting dat de bodemtrawlvisserij de natuurwaarde met $10 \%$ zou reduceren. De verwachting over het effect van de compensatiemaatregel is noodzakelijkerwijs geformuleerd in globale termen (toename biomassa van bodemdieren; toename areaal schelpdieren).

\subsubsection{Kennisontwikkeling sinds 2005}

Het onderzoek naar de effecten van bodemvisserij is sinds 2010 sterk gestimuleerd door het FP7project BENTHIS (2012-2017) en het Trawling Best Practice (TBP) project. Het BENTHIS project had o.a. tot doel een methodiek te ontwikkelen om de effecten van bodemvisserij te kwantificeren en indicatoren te ontwikkelingen voor de Kaderrichtlijn Mariene Strategie. Een andere belangrijke ontwikkeling is de 'biological trait analyse' en de toepassing daarvan op macrobenthos (Bremner et al. 2006b; a, Bremner 2008).

\subsubsection{Biological trait analyse}

Het benthische ecosysteem wordt gekenmerkt door een zeer groot aantal soorten. Om de enorme diversiteit tot praktischer proporties te reduceren is een 'biological trait analyse' ontwikkeld die de individuele soorten in een aantal groepen classificeert aan de hand van kenmerken, zoals bijvoorbeeld leefwijze (in/op het sediment), morfologie en life history (zoals lichaamsgrootte, levensduur manier van voedselvergaring, grootte bij volwassenheid, manier van voortplanten, enz.). Benthische habitats verschillen in de samenstelling van de gemeenschap en daarmee ook in de samenstelling van biologische kenmerken. Zo liet (Bolam et al. 2017) zien dat de combinatie van sediment en waterdiepte bepaalt welke typen voedselvergaring voorkomen. (Beauchard et al. 2017) en Beauchard et al. (in prep) toonde het belang aan van life history kenmerken (zoals grootte bij volwassenheid, manier van voortplanten) om de samenstelling van de benthosgemeenschap te verklaren in relatie tot de natuurlijke verstoring en de mate van voorspelbaarheid in het voedselaanbod.

De levensduur van een organisme is een van de sleutelkenmerken die de life history van een soort typeren en is gerelateerd aan zowel lichaamsgrootte, leeftijd bij geslachtsrijpheid en voortplantingsinspanning. Ieder habitat wordt gekenmerkt door een typische levensduuropbouw van het benthos (Rijnsdorp et al. 2018). Het aandeel langlevende soorten neemt toe met het aandeel gravel (grof sediment) en neemt af met het aandeel slib (zeer fijn sediment). Het aandeel langlevende soorten neemt af met de mate van natuurlijke verstoring van de zeebodem door stroming en golven (de zogenaamde bodemschuifspanning).

Biologische traits kunnen ook gebruikt worden om de eigenschappen van dieren te groeperen die mogelijk hun kwetsbaarheid voor sleepnetvisserij beïnvloeden. Zo zullen diepgravende of robuuste benthos soorten minder gevoelig zijn dan soorten die op de zeebodem leven of een fragiele bouw hebben. 


\subsubsection{Visserij impact van verschillende vistuigen}

Binnen de Europese Unie wordt met veel verschillende vistuigen op bodemvis gevist. Het Europese onderzoeksprogramma BENTHIS heeft een benadering ontwikkeld waarbij een vistuig in haar componenten wordt ontleed en waarbij de dimensies (lengte $x$ breedte $x$ hoogte en gewicht) van de componenten worden bepaald. Op deze manier kan niet alleen de voetafdruk - het oppervlakte van de zeebodem dat per uur wordt bevist - van een vistuig worden bepaald, maar kan ook het penetratieprofiel van het vistuig worden berekend (Eigaard et al. 2016). Door deze gegevens te combineren met de gedetailleerde vispositie registraties (VMS) kon voor het eerst de verspreiding en intensiteit van het totaal aan bodemvisserijactiviteiten (gecombineerd voor alle verschillende tuigen) in Europa worden bepaald (Eigaard et al. 2017).

De toepassing van de BENTHIS-benadering wordt nog belemmerd door de beperkte informatie die beschikbaar is voor validatie van de penetratiediepte. De beschikbare veldmetingen zijn beperkt tot een klein aantal typen vistuig en een beperkt aantal habitats. De penetratiediepte van een vistuig is mede afhankelijk van de korrelgrootte en de mate van compactheid van het sediment. Het verder ontwikkelen en toepassen van fysische modellen waarmee de penetratiediepte kan worden berekend is een veelbelovende benadering om de kennisleemte te dichten (O'Neill \& Ivanović 2016).

\subsubsection{Meta-analyse van benthos sterfte en herstel}

Binnen BENTHIS en het internationale onderzoeksproject 'Trawling Best Practices' project is een literatuur review uitgevoerd van het effect van bodemvisserij op de sterfte en het herstel van bodemdieren. Omdat de resultaten van individuele studies een grote variatie in uitkomsten laat zien is een meta-analyse uitgevoerd volgens het systematisch review protocol (Hughes et al. 2014). De meta-analyse geeft een schatting van het gemiddelde effect dat is gebaseerd op de uitkomsten van alle publicaties. In totaal werden 62 publicaties (122 experimenten) geselecteerd van 'control-impact', 'before-after' of gecombineerde BACI studies, waarin zowel het gemiddelde als de variantie of monstergrootte waren gerapporteerd (Sciberras et al. 2018). De resultaten van 34 andere publicaties konden niet worden meegenomen omdat informatie over variantie of monstergrootte ontbrak.

Gemiddeld reduceerde een passage van een sleepnet het aantal bodemdieren met $26 \%$ en de soortenrijkdom met $19 \%$. De reductie was afhankelijk van het vistuig. Vistuigen die dieper in de zeebodem doordringen hadden een groter effect. Ook nam het effect toe in fijner sediment (silt), in biogene habitats en in gebieden die in de voorafgaande 10 jaar niet waren bevist.

De herstelsnelheid verschilde tussen soortgroepen. Sessiele en langlevende soorten zoals sponzen, zachte koralen en schelpdieren, hadden een lagere herstelsnelheid dan kortlevende en mobiele soorten zoals borstelwormen en garnaalachtigen (malacostracaea). Gradiëntstudies, die de veranderingen in benthosgemeenschap van onbeviste (of licht beviste) gebieden tot zwaar beviste gebieden onderzoeken, geven een betere en lagere schatting van de herstelsnelheid dan BACI studies omdat de gradiëntstudies op een grotere ruimtelijke schaal zijn uitgevoerd die een reëler beeld geven dan de vaak kleine studiegebieden in de CI, BA en BACI studies (Sciberras et al. 2018); (Hiddink et al. 2017).

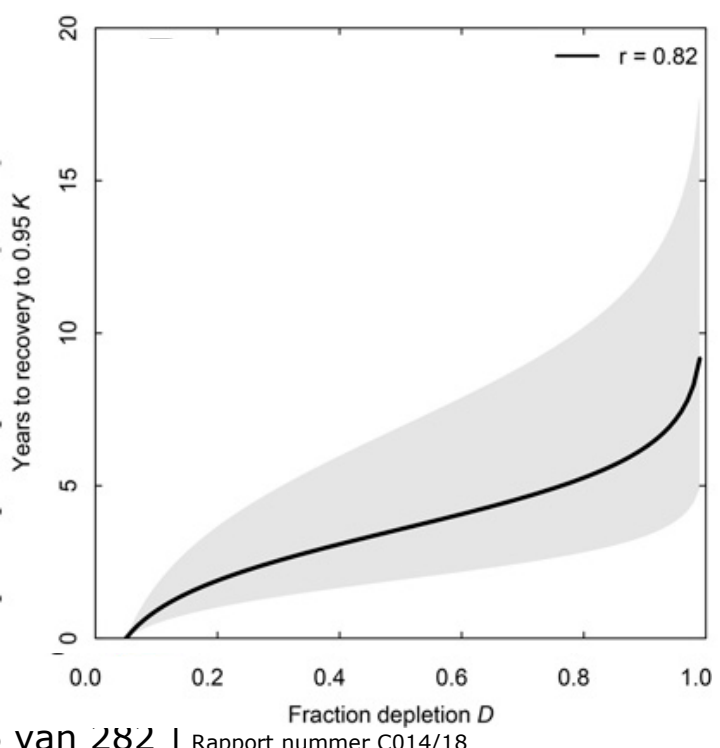

| 166 van 282 | Rapport nummer c014/18 
Figuur 5. 61 De relatie tussen de mediane hersteltijd (jaar) tot $95 \%$ van de draagkracht voor een bodemdiergemeenschap en de fractie van de biomassa (D) die na bevissing is overgebleven. De grijze enveloppe geeft het $95 \%$ betrouwbaarheidsinterval (uit Hiddink et al., 2017).

Figuur 5.61 geeft een schatting van de hersteltijd van de benthos biomassa tot 95\% van de draagkracht in afhankelijkheid van de mate waarin de biomassa is gereduceerd. Bij een reductie van de biomassa met 50\% ligt de verwachtte hersteltijd tussen de 2 en 7 jaar. Bij een reductie met $20 \%$ is dit 1 tot 3 jaar. Bij een (extreme) reductie van 99\% ligt de voorspelde hersteltijd tussen de 5 en 17 jaar als het benthos met $99 \%$ is gereduceerd. Verwacht wordt dat het herstel (veel) trager zal verlopen als er geen bronpopulatie in de buurt aanwezig is, of indien de aanwezige larven zich niet succesvol kunnen vestigen.

Een probleem in de beschikbare studies is dat slechts voor een beperkt aantal vistuigen experimentele gegevens beschikbaar zijn over het effect op de benthische gemeenschap. Ook zijn niet alle vistuighabitat combinaties bestudeerd. De gevonden relatie tussen de directe sterfte van bodemdieren ten gevolge van de passage van een sleepnet en de diepte waarin het vistuig in de zeebodem doordringt maakt het mogelijk de penetratiediepte van het vistuig als proxy te gebruiken voor de reductie in aantallen of biomassa van bodemdieren. Als we het penetratieprofiel van een vistuig kunnen bepalen is het mogelijk om de door Hiddink et al (2017) gevonden relatie te gebruiken om de sterfte te bepalen.

\subsubsection{Studies op het Nederlands Continentaal Plat}

De uitkomsten van de meta-analyse worden ondersteund door de resultaten van de analyse van benthosgegevens van het NCP (MWTL data) in relatie tot visserij. De gevoeligheid van het benthos voor bodemvisserij verschilde tussen habitats. In de relatief ondiepe zuidelijke Noordzee bleek er geen significant visserijeffect aantoonbaar op zowel de biomassa als de soortenrijkdom van het benthos, terwijl in de diepere delen van het Friese front en Oestergronden de soortenrijkdom afnam met een toename in de visserij-intensiteit (van Denderen et al. 2014). Analyse van de MWTL data plus de data van acht visserijgradiënt studies in de Noordzee en Ierse Zee laat zien dat visserij en natuurlijke verstoring tot vergelijkbare veranderingen in de benthosgemeenschap leiden, en dat deze verandering wordt gekenmerkt door een afname van langlevende soorten, soorten met een exoskelet en soorten die hun voedsel uit het water filtreren. In gebieden die waren blootgesteld aan hoge natuurlijke verstoring werd geen additioneel effect van visserij op de functionele samenstelling van het benthos gevonden (van Denderen et al. 2015).

Visserij verlaagt de gemiddelde levensduur van de soorten in de benthosgemeenschap. Dit visserijeffect nam echter af bij toenemende natuurlijke verstoring (hogere bodemschuifspanning; (Rijnsdorp et al. 2018). Ook in de MWTL kon in gebieden met een hoge bodemschuifspanning geen visserij effect worden vastgesteld (van Denderen et al. 2015).

De statistische modellen die gebruikt zijn in bovengenoemde studies geven geen uitsluitsel over het mechanisme dat het benthos meer of minder gevoelig maakt voor visserijverstoring. Echter, op basis van algemene ecologische theorie is de verwachting dat een gemeenschap bestaande uit kortlevende soorten zich sneller kan herstellen na een verstoring. Of de soorten ook andere kenmerken hebben (bijvoorbeeld de ingraafdiepte, mate van mobiliteit) die hun gevoeligheid voor visserijverstoring beïnvloeden, is nog onduidelijk.

\subsubsection{Voedselweb effecten}

In een modelstudie onderzochten Van Denderen et al (2013) hoe de voedselrelatie tussen benthos en vis de effecten van bodemvisserij op het benthos beïnvloedt, en de weerslag daarvan op de visserijopbrengst. Bodemvisserij verschuift de concurrentieverhoudingen binnen het benthos. Soorten die relatief ongevoelig zijn voor bodemvisserij kunnen profiteren wanneer zij om voedsel concurreren met gevoelige soorten.

De invloed van visserij is afhankelijk van welk reguleringsproces in het ecosysteem bepalend is voor de aanwezige hoeveelheid benthos. Het kan zijn dat voedselbeschikbaarheid de groei van benthos 
beperkt ('bottom-up regulering'), maar ook dat predatoren de hoeveelheid benthos in toom houden ('top-down regulering'). In een ecosysteem waarin sprake is van bottom-up regulering neemt het gevoelige benthos ( $\mathrm{S}$ in Figuur 5.62) snel af terwijl het relatief ongevoelige benthos ( $\mathrm{R}$ ) sterk toeneemt. De grootste veranderingen vinden plaats bij een zeer lage visserij intensiteit en zijn daardoor niet zichtbaar in Figuur 5.62b. Bij verdere toename van de visserij-intensiteit neemt het relatief ongevoelige benthos geleidelijk af. De afnamesnelheid is afhankelijk van de visserijsterfte die het vistuig veroorzaakt.

Als het benthos gereguleerd wordt door de predatie door vis (figuur 5.62e en $\mathrm{h}$ ) hangt het effect van een toenemende visserijintensiteit af van de balans tussen het negatieve effect van het vistuig op benthos en het positieve effect van minder predatie op het benthos, door een lagere visstand. Bij een klein predatie-effect klein overheerst de visserijsterfte en neemt de biomassa van relatief gevoelig benthos af met een toenemende visserijintensiteit (Figuur xe). Als het effect van predatie hoger is dan zien we dat, bij toenemende visserij-intensiteit, het predatiegevoelige benthos eerst toeneemt (visserij reduceert de visbiomassa en daarmee de predatiedruk op het benthos). Bij een bepaalde visserijintensiteit slaat de balans om en overheerst de visserijsterfte op het benthos (Figuur $\mathrm{xh}$ ), met name omdat daar verdere afname van de visstand met meer visserij nauwelijks mogelijk is.

(b)

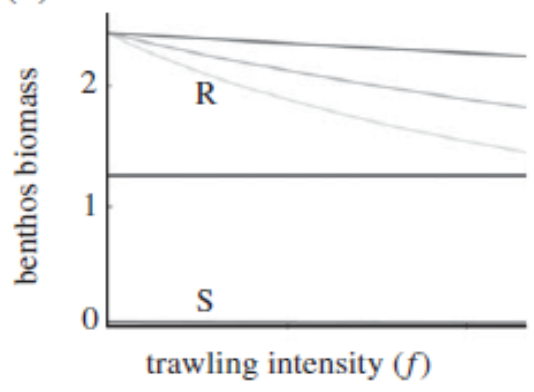

(e)

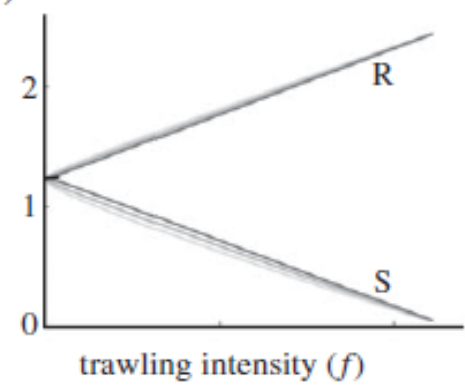

(h)

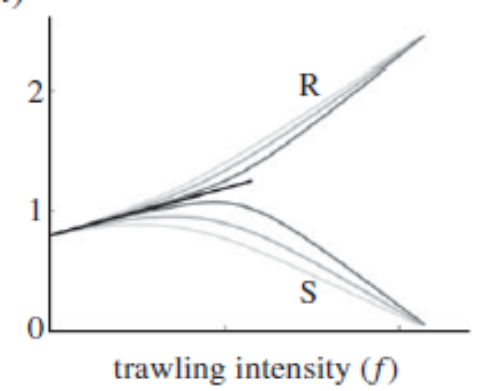

Figuur 5.62 Het effect van visserijintensiteit op de biomassa van relatief ongevoelig $(R)$ en relatief gevoelig (S) benthos in een systeem dat door voedsel (bottom-up) wordt gereguleerd (b) of door predatie (top-down) wordt gereguleerd ( $\mathrm{e}=$ licht predatie effect, $\mathrm{h}=$ matig predatie effect). De zwarte lijn geeft de biomassa aan van benthos dat volledig ongevoelig is voor visserij (gebaseerd op van Denderen et al, 2013)

\subsubsection{Impact assessment methode}

Binnen BENTHIS en TBP zijn methodes ontwikkeld om de impact van sleepnetvisserij op de zeebodem te kwantificeren. De visserij impact wordt geschat als de vermindering van de benthosbiomassa (B) ten opzichte van de draagkracht (K) (Pitcher et al. 2017). Deze kan worden berekend uit de visserijsterfte, visserijintensiteit en de herstelsnelheid van het benthos.

Een tweede methode schat het effect van de visserij op de levensduuropbouw van het benthos. Beide methodes zijn door ICES gebruikt als basis voor de berekening van indicatoren voor trawling impact en status van de zeebodem (ICES 2017).

\subsubsection{Discussie}

Het doel van dit hoofdstuk was om de oorspronkelijke verwachtingen over de bijdrage van het instellen van het bodembeschermingsgebied aan de natuurcompensatie te evalueren aan de hand van de voortschrijdende wetenschappelijke kennis.

Het inzicht in hoe sleepnetvisserij het benthos beïnvloedt is niet wezenlijk veranderd. Het is zeker dat sleepnetvisserij een deel van het benthos in het pad van het sleepnet doodt en zodoende de biomassa van het benthos reduceert. De mate waarin de biomassa wordt gereduceerd hangt af van de visserijsterfte en de herstelsnelheid. Recent onderzoek geeft schattingen voor deze parameters. 
Langlevende dieren hebben in het algemeen een lagere herstelsnelheid zodat visserij de samenstelling van de benthosgemeenschap verschuift naar korter levende soorten.

Het recente onderzoek heeft aangetoond dat het benthos in habitats met een hoge natuurlijke verstoring relatief ongevoelig is voor visserijverstoring, maar het is nog niet duidelijk waarom dit zo is. Het is mogelijk dat de variabiliteit in het benthos het moeilijk maakt om statistisch significante effecten aan te tonen. Anderzijds is het mogelijk dat de benthosgemeenschap in habitats met een hoge natuurlijke verstoring gekenmerkt wordt door soorten die relatief ongevoelig zijn voor visserij (lage visserijsterfte en/of hoge herstelsnelheid). Recent onderzoek heeft inderdaad laten zien dat deze habitats een lager aandeel van langlevende soorten heeft en dus gekenmerkt wordt door een gemeenschap met een hogere herstelsnelheid. Het is nog niet onderzocht of het benthos in het kustgebied mogelijk uit robuustere soorten bestaat die minder kwetsbaar zijn voor visserijsterfte. Het kan niet worden uitgesloten dat specifieke kwetsbare soorten door de jarenlange chronische bevissing van het kustgebied en door andere factoren al lang geleden zijn verdwenen. Mogelijk is het herstel afhankelijk van het succesvol vestigen van jonge levensstadia. Dit is een mechanisme dat we tot nu toe nog niet bestudeerd hebben. Het is ook mogelijk dat de tijd tot herstel langer is dan van tevoren verwacht. Zo liet het benthos 5 jaar na sluiting van de sleepnetvisserij in het windmolenpark voor de Hollandse kust geen herstel van het benthos zien, mogelijk veroorzaakt door de predatie van kleine benthivore vis (Bergman et al. 2015). De rekrutering kan mogelijk ook belemmerd worden door de voortdurende visserijactiviteiten van de garnalenvisserij. Alhoewel deze visserij waarschijnlijk geen grote visserijsterfte veroorzaakt op de volwassen bodemdieren, kan de regelmatige oppervlakte verstoring van de zeebodem de bodemstructuur ongeschikt maken voor het vestigen van bodemdieren, of sterfte veroorzaken onder de recent gevestigde bodemdieren.

Betekent dit dat de aanname waarop de compensatieopgave is gebaseerd hiermee wordt verworpen? Deze vraag kan niet met zekerheid worden beantwoord omdat het onduidelijk is waarom het benthos in de kustzone minder gevoelig zou zijn voor visserijverstoring. Anderzijds zijn er geen aanwijzingen dat het benthos in de Voordelta eigenschappen heeft die hen minder kwetsbaar maken voor visserijsterfte. Er zijn vier mogelijke verklaringen voor het uitblijven van een duidelijk herstel van het benthos in het bodembeschermingsgebied die allen even waarschijnlijk zijn: (i) de natuurlijke variabiliteit is te groot (of het contrast in visserij-intensiteit binnen het gebied is te klein) om een statistisch verband aan te kunnen tonen; (ii) natuurlijke verstoring is te groot waardoor herstel kwetsbare soorten vertraagt; (iii) de continue verstoring door de garnalenvisserij heeft teveel invloed op vestigingskans; (iv) voedselweb interacties tussen vis en benthos compliceren het verband tussen bevissing en de biomassa en samenstelling van het benthos ( $v$ ) de dominantie van Ensis die goed bestand lijkt tegen verstoring.

\subsubsection{Conclusie}

1) Wordt het verlies aan habitattype $\mathrm{H} 1110 \mathrm{~B}$ als gevolg van de aanleg van Maasvlakte 2 voldoende gecompenseerd?

a. Zijn er positieve trends waar te nemen in kwaliteit van het Habitat 1110B (zoals deze wordt gedefinieerd in het profieldocument $\mathrm{H} 1110$ (versie 18 december 2008)) in de Voordelta sinds het begin van de afname van de boomkorvisserij uit de Voordelta rond de laatste eeuwwisseling?

b. Zijn de waargenomen trends toe te schrijven aan de afgenomen bodemberoering ten gevolge van de afname van de grote boomkorvisserij met wekkerkettingen in de gehele Voordelta of ook aan andere factoren?

c. Hoe groot was de onttrekking van vis en andere (bij)vangsten in de periode T0 (2004-2008), T1 (2009-2013) en T2 (2014-2018)?

Op basis van de voortschrijdende kennis kunnen we de verwachtingen over het effect van het instellen van het bodembeschermingsgebied bijstellen. Op basis van de huidige kennis over de mechanismen waarmee sleepnetten het benthos beïnvloeden verwachten we dat sterke afname in intensiteit van boomkorvisserij (in het bodembeschermingsgebied of daarbuiten) zal resulteren in een toename van het benthos dat kwetsbaar is voor sleepnetvisserij, met name in gebieden met lage dynamiek en daarmee een lagere natuurlijke verstoring. We verwachten dus een verandering in de benthos samenstelling (meer kwetsbare soorten) en toename van de soortenrijkdom in de meer beschutte 
gebieden van de Voordelta. Of de totale biomassa van bodemdieren zal toenemen is afhankelijk van de processen in het voedselweb (predatie door vis en competitie om voedsel) die het benthos reguleren. In hoog-dynamische delen van de Voordelta waar de zeebodem regelmatig wordt verstoord door natuurlijke processen is het onzeker of de biomassa en soortenrijkdom van het benthos zal herstellen omdat het onzeker is of de boomkorvisserij hier een negatief effect heeft op het benthos dat in deze delen van de Voordelta bestaat uit soorten die minder gevoelig zijn voor verstoring door natuurlijke dynamiek of visserij.

Voor het feit dat de bovengenoemde bijgestelde verwachtingen niet te zien zijn in de waargenomen veranderingen in het benthos is een aantal mogelijke verklaringen:

- Het deel van de Voordelta waar, met name in de T0 jaren, nog boomkorvisserij met relatief hoge intensiteit voorkwam, is klein. Er zijn daarom maar weinig monitoringpunten met hoge visserijintensiteit, waardoor de er weinig contrast is in visserijdruk en de meetbaarheid van het effect van visserij op de bodemdierengemeenschap klein is.

- Echter, vanwege het grotendeels verdwijnen van de boomkorvisserij uit de Voordelta zou een verandering in het benthos (in de richting zoals boven beschreven: meer kwetsbare soorten) sinds de T0 verwacht kunnen worden. Dat deze verandering over de periode 2004-2016 niet waarneembaar is, kan door verscheidene factoren veroorzaakt zijn:

- de grote natuurlijke jaarlijkse variatie in het benthos beperkt de meetbaarheid van een trend

- de verstoring door natuurlijke processen is zo groot dat er geen verandering in het benthos naar meer kwetsbare soorten optreedt

- door de dominantie van Ensis directus, die mogelijk minder gevoelig is voor verstoring door visserij en natuurlijke dynamiek, treedt er geen verandering op of is de meetbaarheid gering

- continue verstoring door garnalenvisserij heeft tot gevolg dat er geen verandering optreedt

- voedselweb interacties tussen vis en benthos compliceren het verband tussen bevissing en de biomassa en samenstelling van het benthos.

Waarschijnlijk spelen al deze factoren een rol. Het is niet mogelijk om, op basis van de beschikbare gegevens en analyses, een uitspraak te doen over welke van deze verklaringen het meest effect heeft. 


\section{$6 \quad$ Zwarte zee-eend}

S. Dirksen ${ }^{1,2}$, P.W. van Horssen ${ }^{1,3}$, E. van der Zee ${ }^{1}$, K. van de Wolfshaar ${ }^{4}$, T.C. Prins ${ }^{5}$

${ }^{1}$ Altenburg \& Wymenga, ${ }^{2}$ Sjoerd Dirksen Ecology, ${ }^{3}$ GreenStat, ${ }^{4}$ Wageningen Marine Research,

${ }^{5}$ Deltares

\subsection{Onderzoeksvragen}

Hieronder worden de MEP onderzoeksvragen uit het monitoringsplan (Tulp et al. 2015b) weergegeven. Elke (deel)vraag zal inhoudelijk behandeld worden aan de hand van de onderzoeksresultaten uit de periode 2005-2017.

De vraag die centraal staat is MEP-vraag:

3) Wordt het verlies aan foerageergebied van de zwarte zee-eend als gevolg van de aanleg en het gebruik van Maasvlakte 2 voldoende gecompenseerd?

Bij deze vraag zijn vier deelvragen geformuleerd:

e) Hoeveel potentieel foerageergebied is er daadwerkelijk verloren gegaan a.g.v. het ruimtebeslag van MV2, de ontwikkeling van de erosiekuil en het gebruik van MV2?

f) Leidt het instellen van het bodembeschermingsgebied tot een gelijkblijvende potentiële functie van de Voordelta voor de zwarte zee-eend in termen van voedselbeschikbaarheid?

g) Draagt het instellen van rustgebieden, specifiek voor de zwarte zee-eend, bij aan een gelijkblijvende potentiële functie van de Voordelta als foerageer- en rustgebied?

h) Is de aangepaste begrenzing van de extra rustgebieden vanuit PMR-NCV juist gekozen om bij te dragen aan het instandhoudingsdoel?

Elk van deze deelvragen wordt hieronder in een aparte paragraaf behandeld, waarbij de relevante resultaten en conclusies worden gepresenteerd. Afsluitend worden alle resultaten in samenhang besproken en in een bredere context geplaatst.

In onderstaand schema zijn de belangrijkste relaties in de Voordelta op hoofdlijnen weergegeven.

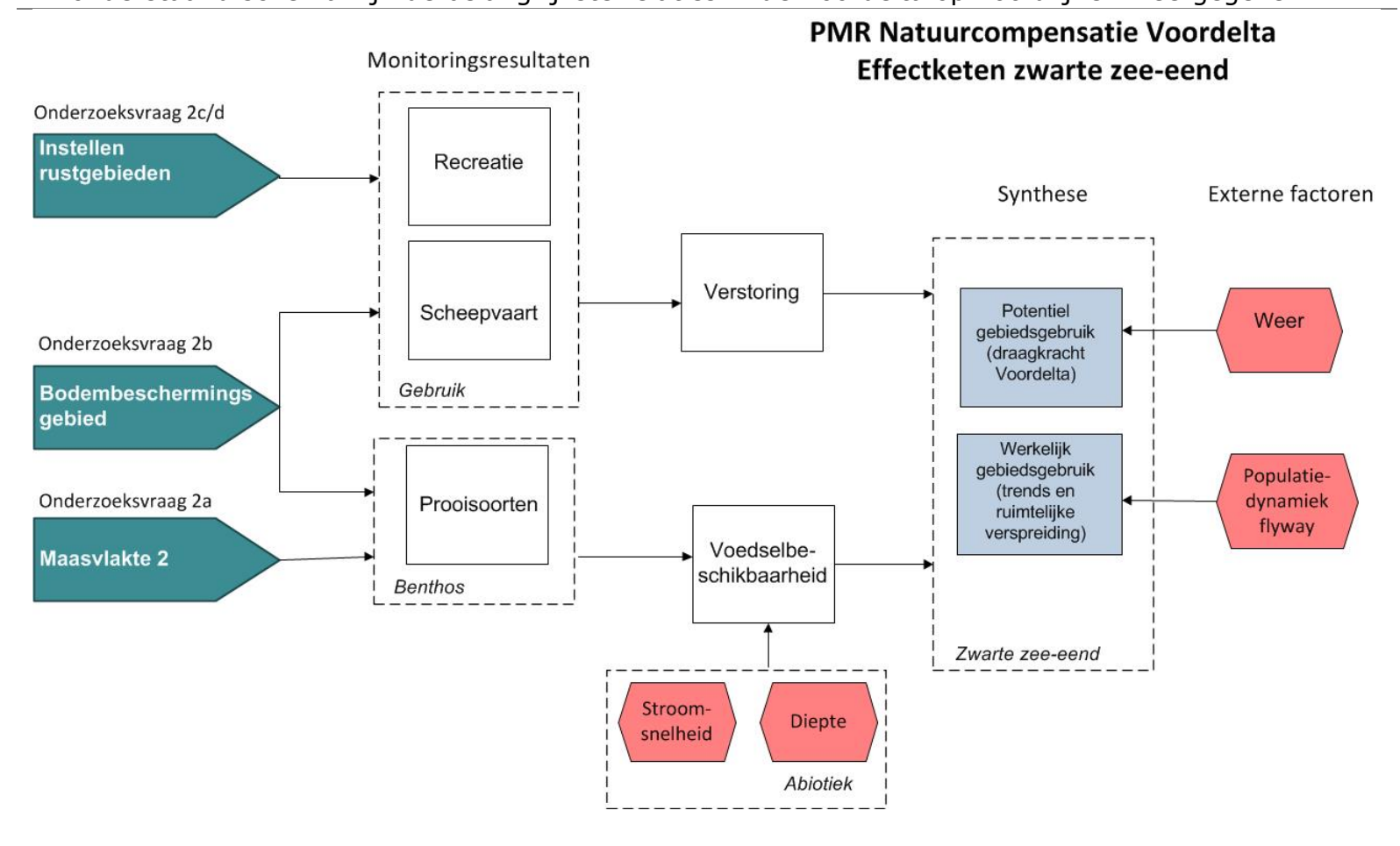




\subsection{Korte beschrijving van de uitgevoerde monitoring en onderzoek}

Voor de beantwoording van de MEP-vraag en onderzoeksvragen zijn twee lijnen gevolgd in het PMRNCV programma: via tellingen en observaties enerzijds en scenarioberekeningen met een energetisch model anderzijds. Evenals in de T0, is monitoring uitgevoerd waarbij de aantallen en de verspreiding van de zwarte zee-eend in de Voordelta is vastgelegd, aanvullend op de al lopende MWTL metingen. Dit is aangevuld met een aantal waarnemingen van zwarte zee-eenden langs andere delen van de Nederlandse kust. Deze waarnemingen geven een goed beeld van de aanwezigheid van zwarte zeeeenden in de Voordelta. In de T1 is vastgesteld dat het aantal zwarte zee-eenden in de Voordelta veel lager was dan de maximale aantallen die tussen 1975-2000 zijn waargenomen, en maar een klein deel van het aantal eenden in de Nederlandse kustwateren. Of zwarte zee-eenden in de Voordelta verblijven is niet alleen afhankelijk van de situatie in de Voordelta maar ook van de situatie in alternatieve overwinteringsgebieden. Om toch te kunnen evalueren of de potentiële functie van de Voordelta voor zwarte zee-eenden in stand is gebleven, is daarom een draagkrachtmodel ontwikkeld. Hiermee kunnen op grond van gegevens over voedsel en verstoring, de potentiële aantallen zwarte zee-eenden waarvoor in de Voordelta voldoende voedsel en rust is, berekend worden. Daarmee krijgen we meer inzicht in de potentiële functie van de Voordelta als foerageer- en rustgebied voor zwarte zee-eenden, los van het feit of de eenden daadwerkelijk overwinteren in het gebied.

\subsubsection{Monitoring}

\section{Tellingen}

De ontwikkelingen (aantallen, gebiedsgebruik, verspreiding) in de populatie zwarte zee-eenden in de Voordelta worden onderzocht door middel van vliegtuigtellingen en (in de T1) gedragsobservaties vanaf land (voor een gedetailleerde beschrijving zie Hoofdstuk 4 in (Prins et al. 2014c)). Voor deze synthese t/m 2017 zijn gegevens uit de T0 periode beschikbaar, en gegevens over de periode van april $2009 \mathrm{t} / \mathrm{m}$ mei 2017 (tabel 6.1). De resultaten van het T0 onderzoek hebben betrekking op de monitorings-jaren ${ }^{4}$ van 2004/2005 en 2005/2006 (Poot et al. 2006).

Tevens is kennis over de ontwikkelingen in aantal zwarte zee-eenden in andere kustgebieden van belang om de ontwikkelingen in de Voordelta te kunnen relateren aan ontwikkelingen in andere deelpopulaties. Voor die vergelijking zijn monitoringresultaten van de Belgische kust en de kustwateren in het noorden van Nederland beschikbaar.

\section{Tabel 6.1}

Overzicht van aantallen uitgevoerde tellingen van zwarte zee-eenden vanuit een vliegtuig, in de Voordelta en langs de kust van Holland en de Waddeneilanden, in verschillende periodes en monitorings-jaren (PMR-NCV en MWTL).

\begin{tabular}{|l|c|c|c|}
\hline Fase & \multicolumn{1}{|c|}{$\begin{array}{l}\text { T0 } \\
\text { Jaren }\end{array}$} & $\begin{array}{l}\text { T1 } \\
2004 / 2005-2005 / 2006\end{array}$ \\
\hline $\begin{array}{l}\text { Aantal monitorings-jaren } \\
\text { Voordelta } \\
\text { oktober-mei }\end{array}$ & 2 & 5 & 60 \\
\hline $\begin{array}{l}\text { Voordelta } \\
\text { juni-september }\end{array}$ & 33 & 41 & 22 \\
\hline $\begin{array}{l}\text { Hollandse kust, Wadden } \\
\text { november-januari }\end{array}$ & 0 & 7 & 7 \\
\hline $\begin{array}{l}\text { Hollandse kust, Wadden } \\
\text { maart-april }\end{array}$ & 0 & 10 & 7 \\
\hline
\end{tabular}

\footnotetext{
${ }^{4}$ Een monitorings-jaar is een jaar dat loopt van juli $t / m$ juni in het jaar erna.
} 
Dieet

In de $\mathrm{T} 1$ is onderzoek naar het dieet van zwarte zee-eenden uitgevoerd door veldwaarnemingen van foeragerende zee-eenden, en door de maaginhouden te analyseren van, op stranden aangespoelde, dode zee-eenden. In de winters van 2009-2013 zijn 35 zwarte zee-eenden verzameld langs de Nederlandse kust. Tien vogels hadden schelpresten van de Amerikaanse zwaardschede in de maag; vier daarvan waren uit de Voordelta afkomstig. Van die tien vogels waren er slechts twee met een groot aantal schelpresten van de zwaardschede ( $>100)$ in de maag.

Ook de beschikbaarheid van het geprefereerde dieet is van belang. Om dit te bepalen zijn bemonsteringen van bodemdieren uitgevoerd in de Voordelta (zie Hoofdstuk 5). Gegevens over de dichtheden, afmetingen en biomassa van schelpdieren waren beschikbaar voor 2009-2013 en 2015. Op basis van kennis over het dieet van de zwarte zee-eend, afkomstig uit de veldwaarnemingen, het maagonderzoek en literatuur (ICES 2005, Brinkman et al. 2007, Skov et al. 2008), zie ook §2.5.3 in Prins et al. (2014c)), is het voor de zwarte zee-eend geschikte hoofdvoedsel in de Voordelta beschreven aan de hand van de grootte en vorm van de schelpen. Zes soorten schelpdieren zijn beschouwd als de belangrijkste potentiële voedselbron voor zwarte zee-eenden in de Voordelta: de Amerikaanse zwaardschede (Ensis leei, voorheen Ensis directus) met een schelplengte tussen 40 en $90 \mathrm{~mm}$, en daarnaast soorten met een schelplengte tussen 15 en 35 mm: witte dunschaal (Abra alba), zaagje (Donax vittatus), nonnetje (Limecola balthica, voorheen Macoma balthica), halfgeknotte strandschelp (Spisula subtruncata), rechtsgestreepte platschelp (Tellina fabula). Aangenomen is dat met de beschrijving van de biomassa van deze soorten het grootste deel van de profijtelijke prooien van zwarte zee-eenden wordt beschreven, en voor deze rapportage is dezelfde selectie aangehouden. Naast deze soorten zijn de mossel (Mytilus edulis) en de kokkel (Cerastoderma edule) mogelijk bruikbare prooien, maar deze twee soorten kwamen in hogere dichtheden alleen voor in het mondingsgebied van het Haringvliet bij de Slikken van Voorne, waar al meer dan 20 jaar geen zwarte zee-eenden zijn waargenomen (figuur 2.18 in (Prins et al. 2014c)).

\section{Verstoring}

Om mogelijke verstoring van zwarte zee-eenden in kaart te brengen, is het gebiedsgebruik door menselijke activiteiten in en rond de ingestelde rustgebieden in de Voordelta bepaald door land- en luchtwaarnemingen (tabel 6.2). Uit veldwaarnemingen blijkt dat de zwarte zee-eend voornamelijk wordt verstoord door gemotoriseerde scheepvaart. De verstoringsafstand hiervan is ongeveer $1 \mathrm{~km}$ (Krijgsveld et al. 2008, Schwemmer et al. 2011). Daarom is het gebiedsgebruik in een bufferzone van $1 \mathrm{~km}$ rondom de rustgebieden ook meegenomen in de analyse. Voor de T0 periode zijn gegevens over menselijke activiteiten beschikbaar over het jaar 2005 en begin 2006 (Seegers et al. 2006) In de periode 2009- 2013 zijn volgens de planning iedere winterperiode (oktober-april) tien, en iedere zomerperiode vijftien waarnemingsvluchten uitgevoerd, waarbij voor de zwarte zee-eend met name de verstoring in de winterperiode van belang is. Deze waarnemingen zijn na de T1 niet voortgezet. Voor de winterhalfjaren in 2009-2013 zijn AIS-data (Automatic Identification System) verkregen (2009/10 t/m 2012/13) en opgewerkt om de intensiteit van de beroepsscheepvaart te kwantificeren. Met AIS wordt o.a. de positie van schepen met hoge frequentie vastgelegd. Het systeem is gefaseerd ingevoerd, pas in de jaren 2011-2014 is gestart met de invoering van AIS-plicht voor vissersschepen <15 meter, vóór die tijd waren alleen koopvaardijschepen en grotere vissersschepen verplicht uitgerust met AIS (Hintzen et al. 2014). Kleinere schepen (o.a. recreatievaart) hebben vaak geen AIS. Aangenomen is dat met de AIS data het grootste deel van de scheepvaart in de voor de zwarte zeeeenden relevante periode beschreven wordt.

Deze opgewerkte AIS data zijn gebruikt in een statistische analyse en in het draagkrachtmodel.

\section{Tabel 6.2}

Overzicht van het aantal waarnemingsdagen van menselijk gebruik (vliegtuig- en landwaarnemingen) in de Voordelta (Seegers et al. 2006, Seegers et al. 2014).

\begin{tabular}{|l|l|l|l|}
\hline Fase & $\begin{array}{l}\text { T0 } \\
\text { Jaren }\end{array}$ & $\begin{array}{l}\text { T1 } \\
2004 / 2005-2005 / 2006\end{array}$ & $\begin{array}{l}\text { T1-T2 } \\
2013 / 2014-2016 / 2017\end{array}$ \\
\hline Aantal monitorings-jaren & 1 & 7 & - \\
\hline winterhalfjaar & 19 & 141 & - \\
\hline zomerhalfjaar & 16 & 119 & - \\
\hline
\end{tabular}




\subsubsection{Modellering van potentiële aantallen zwarte zee-eenden}

De afgelopen jaren is gewerkt aan het ontwikkelen van een draagkrachtmodel voor de zwarte zeeeend, waarmee berekend kan worden hoeveel eenden gedurende een bepaalde periode in een gebied kunnen verblijven en overleven. Dit aantal wordt berekend op basis van gegevens over het beschikbare voedsel en andere omgevingsfactoren. Bij die analyse wordt gebruik gemaakt van een energiemodel dat berekent hoeveel energie de eenden binnen krijgen via het voedsel en hoeveel energie de eenden verbruiken tijdens het verblijf in het gebied. De ontwikkeling en de opzet van het model is uitgebreid beschreven in achtergrondrapporten (Brinkman 2015, van de Wolfshaar et al. 2018).

In de toepassing van het draagkrachtmodel in de Voordelta, is de Voordelta verdeeld in gridcellen die gelijk zijn aan de gridcellen die gebruikt zijn voor de bodemdierbemonstering (zie Hoofdstuk 5). Deze gridcellen zijn ongeveer $1,2 \mathrm{~km}^{2}$ groot. Voor iedere gridcel wordt berekend hoeveel zwarte zee-eenden er gedurende de maanden september tot en met april kunnen verblijven en overleven.

Het model maakt berekeningen voor een individuele eend, gebaseerd op een aantal algemene kenmerken specifiek voor de zwarte zee-eend, zoals het energieverbruik bij zwemmen, vliegen, duiken en het verteren van voedsel. Daarnaast maakt het model gebruik van gegevens die specifiek zijn voor iedere gridcel. Dit betreft het lokale voedselaanbod bepaald op grond van de dichtheid van verschillende lengteklassen van de schelpdieren die als voedsel dienen en diepte, stroomsnelheid en de frequentie van verstoring door scheepvaart. Ook andere omgevingsomstandigheden zoals lucht- en watertemperatuur worden gebruikt, maar die zijn gelijk voor alle gridcellen.

Voor voedselaanbod zijn de resultaten van het voorafgaande najaar gebruikt, die afkomstig zijn uit de bemonstering van bodemdieren (Hoofdstuk 5). In 2014 is geen bodemdierbemonstering uitgevoerd.

Vanwege het ontbreken van deze gegevens is daarom voor 2014/2015 geen berekening gemaakt van het potentiële aantal zwarte zee-eenden (tabel 6.3).

Voor verstoring is gebruik gemaakt van AIS data. Voor scheepvaart in de T0 zijn AIS data van 2009/2010 gebruikt. Voor de jaren na 2012/2013 zijn de gegevens van 2012 gebruikt omdat de data van latere jaren ten tijde van de modellering nog niet beschikbaar waren. De verstoring is uitgedrukt in een gemiddelde verstoring voor elke gemodelleerde winter/voorjaar periode. Uit een eerdere analyse is gebleken dat de verschillende jaren grotendeels hetzelfde patroon in de ruimtelijke verdeling van scheepvaart hebben, al zijn er wel verschillen in intensiteit in bepaalde delen van de Voordelta. Echter, de gebieden waar zwarte zee-eenden het meest zijn waargenomen, vertonen weinig verschillen in scheepvaart tussen jaren (zie ook §6.5.2).

Voor de overige omgevingsfactoren (klimatologie, stroomsnelheid, diepte) zijn data van perceel Abiotiek gebruikt.

\section{Tabel 6.3}

Overzicht van de gebruikte gegevens in de modelberekeningen.

\begin{tabular}{|l|l|l|l|}
\hline $\begin{array}{l}\text { Periode } \\
\text { modelberekening } \\
\text { (september- } \\
\text { april) }\end{array}$ & $\begin{array}{l}\text { Bodemdier- } \\
\text { data } \\
\text { (najaar) }\end{array}$ & $\begin{array}{l}\text { Diepte, } \\
\text { stroomsnelheid, } \\
\text { temperaturen } \\
\text { water en lucht } \\
\text { (september- } \\
\text { april) }\end{array}$ & $\begin{array}{l}\text { Scheepvaart } \\
\text { (september- } \\
\text { april) }\end{array}$ \\
\hline $2004 / 2005$ & 2004 & $2004 / 2005$ & $2009 / 2010$ \\
\hline $2005 / 2006$ & 2005 & $2005 / 2006$ & $2009 / 2010$ \\
\hline $2009 / 2010$ & 2009 & $2009 / 2010$ & $2009 / 2010$ \\
\hline $2010 / 2011$ & 2010 & $2010 / 2011$ & $2010 / 2011$ \\
\hline $2011 / 2012$ & 2011 & $2011 / 2012$ & $2011 / 2012$ \\
\hline $2012 / 2013$ & 2012 & $2012 / 2013$ & $2012 / 2013$ \\
\hline $2013 / 2014$ & 2013 & $2013 / 2014$ & $2012 / 2013$ \\
\hline $2015 / 2016$ & 2015 & $2015 / 2016$ & $2012 / 2013$ \\
\hline
\end{tabular}


Een aantal aannames in de toepassing van het model (Brinkman 2015, van de Wolfshaar et al. 2018) is van belang bij de interpretatie van de resultaten:

- Het model berekent de draagkracht per gridcel, uitgedrukt in het aantal eenden dat gedurende de gehele periode september-april in die cel kan verblijven en foerageren. Indien de omstandigheden in een gridcel dusdanig zijn dat een eend onvoldoende voedsel binnen kan krijgen om de dagelijkse energiebehoefte te dekken (door onvoldoende voedsel, diepte, stroomsnelheid, verstoring, enz.) en dus niet gedurende de hele periode september-april in die gridcel kan overleven, is de draagkracht voor eenden in die cel nul

- De berekeningen zijn gebaseerd op gebruik van één schelpdiersoort als prooi. Voor de Amerikaanse zwaardschede (Ensis leei, tot 2016 Ensis directus) is de aanname dat de eenden per duik één prooi eten. Bij de halfgeknotte strandschelp (Spisula subtruncata) is de aanname dat er 5 prooien per duik worden gegeten.

- De energie die het voedsel oplevert verschilt per soort, afhankelijk van de schelplengte van een individu en daarmee de beschikbare hoeveelheid vlees, de kosten voor het kraken van de schelp, enz.

- De eenden besteden standaard 2 uur per dag aan zwemmen.

- De eenden moeten terug vliegen als ze als gevolg van de stroomsnelheid ter plekke teveel afdrijven. De stroomsnelheid ter plaatse bepaalt dus hoeveel energie de eenden aan vliegen moeten besteden

- Scheepvaart verstoort eenden tot op een afstand van $1 \mathrm{~km}$, en iedere verstoring heeft als effect dat de eenden wegvliegen en gedurende een uur niet foerageren. Scheepvaartverstoring is afgeleid van AIS-data, en uitgedrukt in een gemiddelde frequentie van verstoring per gridcel die gelijk is gedurende de hele periode oktober-maart.

- $\quad$ De tijd die de eenden aan foerageren kunnen besteden is afhankelijk van de tijd die verloren gaat door afdrijven en verstoring. De foerageertijd verandert in de loop van de winter als gevolg van de afname in de hoeveelheid beschikbaar voedsel door gewichtsverlies van de schelpdieren en door predatie door de eenden, maar ook door veranderingen in de energie-vraag van de eenden door abiotische omstandigheden zoals temperatuur. Uit modelresultaten blijkt dat in gridcellen waar de omstandigheden zodanig zijn dat er eenden kunnen overwinteren, de foerageertijd gedurende het seizoen kan variëren tussen 2-5 uur per dag met een enkele uitschieter tot 7 uur per dag.

- De duiktijd is afhankelijk van de diepte maar niet van de dichtheid van het voedsel. Er wordt met een vaste zoektijd bij de bodem gerekend.

- Per gridcel is uitgerekend hoeveel eenden er potentieel gedurende de gehele periode septemberapril kunnen verblijven. Omdat zwarte zee-eenden in groepen leven, is een ondergrens van 100 eenden per gridcel gebruikt. Als het berekende potentiële aantal in een gridcel kleiner dan 100 was, is het aantal op nul gesteld.

- Aspecten van het gedrag, zoals onderlinge interacties, worden niet in het model meegenomen

Met deze uitgangspunten geeft het model een schatting van het potentiële aantal zwarte zee-eenden dat gedurende het winterhalfjaar in de Voordelta kan verblijven op grond van het voedselaanbod, de mate van verstoring door scheepvaart en andere omgevingsfactoren zoals diepte, stroomsnelheid en temperatuur.

\subsection{Het effect van het verdwijnen van het Maasvlakte 2 gebied}

De eerste deelvraag van de MEP vraag richt zich op de betekenis van het kustgebied dat door aanleg van Maasvlakte 2 is verdwenen, als foerageergebied voor de zwarte zee-eend:

a) Hoeveel potentieel foerageergebied is er daadwerkelijk verloren gegaan a.g.v. het ruimtebeslag van MV2, de ontwikkeling van de erosiekuil en het gebruik van MV2?

i. Wat is op basis van voortschrijdend inzicht de betekenis van het gebied dat verloren is gegaan voor de zwarte zee-eend in termen van voedselbeschikbaarheid en rust?

ii. Hoe is, op basis van voortschrijdend inzicht, het effect van de aanleg en het gebruik van Maasvlakte 2 op het instandhoudingsdoel voor deze soort te beoordelen? 


\subsubsection{Historische waarnemingen}

In 1973 werden bij grootschalige vogeltellingen in het Deltagebied in januari/februari 15.000 zwarte zee-eenden in de Voordelta geteld. Vliegtuigtellingen in de Voordelta zijn sinds de winter 1975/1976 regelmatig uitgevoerd (Baptist \& Meininger 1996). Tussen 1975-1980 werden gemiddelde wintermaxima geteld van zo'n 15.000, en maximale aantallen tot 28.000 zwarte zee-eenden in de maanden december-maart (Baptist \& Meininger 1996). In de jaren tachtig en begin jaren negentig waren de aantallen lager met maxima tussen 2.000-10.000, met uitzonderlijk hoge aantallen in de koude winters van 1986/1987 (20.000) en 1987/1988 (16.000) (Baptist \& Meininger 1996).

Baptist \& Meininger (1996)) presenteren een overzicht van gebieden in de Voordelta die voor de zwarte zee-eend van betekenis waren in de periode 1975-1995. Op basis van figuur 4.5 in hun publicatie is figuur 6.1 in dit rapport samengesteld. Uit deze figuur wordt duidelijk dat in die periode het gebied dat later Maasvlakte 2 zou worden, geen betekenis had voor zwarte zee-eenden.

In de periode tussen 1975-1985 werd ruim 75\% van de vogels aangetroffen in de Haringvlietmonding, in het Slijkgat en ten oosten van de Hinderplaat. Nadien verschoven de concentraties eenden naar de Grevelingenmonding, de Banjaard voor de kust van Schouwen en de Oosterschelde-monding (Baptist \& Meininger 1996).

De aantallen tijdens midwintertellingen in de Voordelta tussen 1990-2006 waren sterk wisselend met maximaal zo'n 9.000 vogels (2003). In het vroege voorjaar werden gemiddeld de hoogste aantallen waargenomen, met maxima tot 25.000 in april 2002 (Berrevoets et al. 2002, Berrevoets \& Arts 2003, Hoekstein \& Lilipaly 2003), (Berrevoets et al. 2005).

Ook in de winters van 2000-2004 (vóór het begin van de PMR-NCV monitoring) zijn de grootste concentraties zwarte zee-eenden waargenomen bij de Brouwersdam en in de Oosterschelde-monding bij de Bollen van het Nieuwe Zand (Berrevoets et al. 2005). In het MWTL-gegevensbestand voor 1994/1995 - 2004/2005 zijn gegevens opgenomen van tellingen uit een vliegtuig en vanaf de kust. In die tellingen zijn in het gebied dat nu Maasvlakte 2 is geen zwarte zee-eenden waargenomen. Dat geldt ook voor het water ten westen van de huidige Maasvlakte 2 . In tabel 6.4 zijn deze gegevens samengevat.

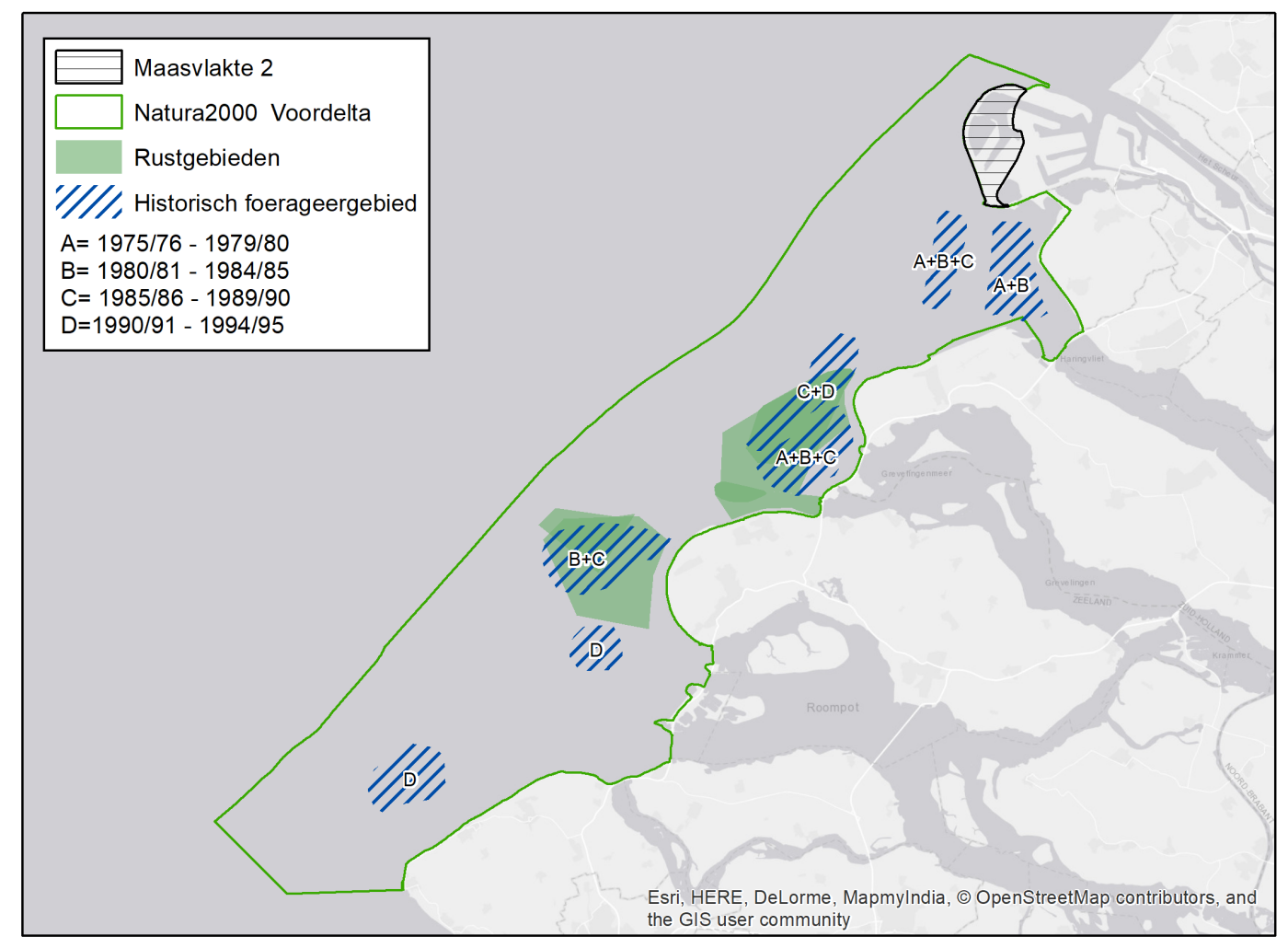

Figuur 6.1. Belangrijke gebieden voor zwarte zee-eenden in de Voordelta in de periode 1975-1995 (gebaseerd op figuur 4.5 van (Baptist \& Meininger 1996)). Aangegeven zijn de huidige begrenzing van het Natura 2000-gebied Voordelta en het daarvan afgehaalde deel voor Maasvlakte 2, alsmede de voor zee-eenden relevante rustgebieden. 
Tabel 6.4

Zwarte zee-eenden in de Voordelta 1994/1995 - 2004/2005 (gegevens Rijkswaterstaat MWTL): het gemiddelde (per monitorings-jaar juli - juni) en het minimum en maximum van het gemiddelde gedurende de 12 monitorings-jaren.

\begin{tabular}{|c|c|c|c|c|}
\hline & \multicolumn{4}{|c|}{ Gemiddelde per monitorings-jaar } \\
\hline & gemiddeld & $\begin{array}{c}\text { Aantal } \\
\text { monitorings- } \\
\text { jaren }\end{array}$ & minimum & maximum \\
\hline Huidige Maas vlakte 2 & 0 & 12 & 0 & 0 \\
\hline W van Maasvlakte 2 & 0 & 12 & 0 & 0 \\
\hline Overig Voordelta & 1854 & 12 & 217 & 4255 \\
\hline
\end{tabular}

\subsubsection{Waarnemingen in de TO}

Tijdens de T0 metingen in 2004/2005 en 2005/2006 waren maximaal ca. 10.000 zwarte zee-eenden (dagmaximum) aanwezig in de Voordelta. In figuur 6.2 zijn deze waarnemingen samengevat voor het voorjaar en het winterhalfjaar. In de T0 jaren werden in de zomermaanden (juni-augustus) ook zwarte zee-eenden in de Voordelta waargenomen (maximaal 2.000-6.000 eenden).

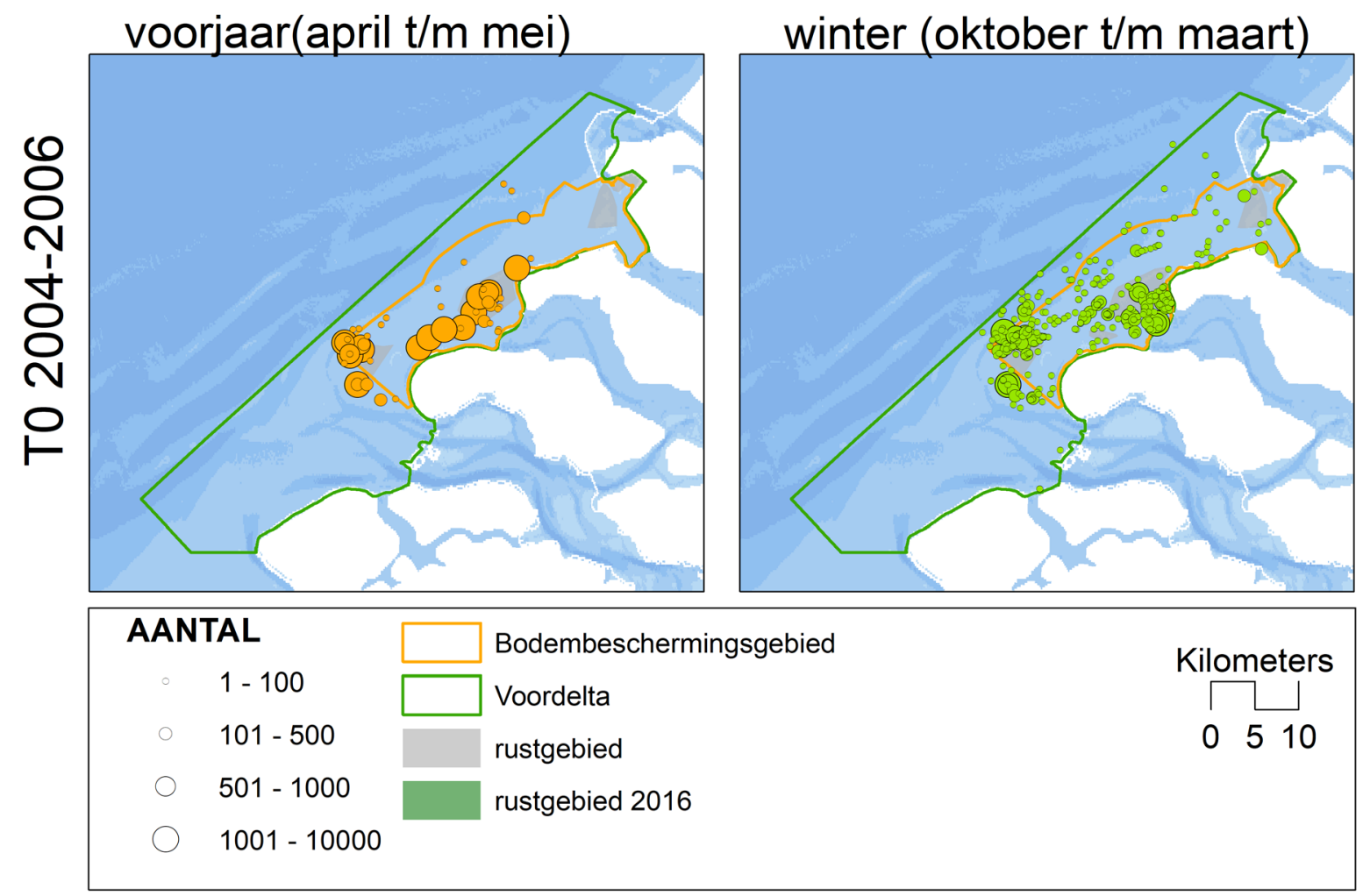

Figuur 6.2. Verspreiding zwarte zee-eenden in voorjaar (april t/m mei) en winterhalfjaar ( oktober $\mathrm{t} / \mathrm{m}$ maart) gedurende de TO periode.

\subsubsection{Voedselaanbod in de T0}

Een schatting van het voedselaanbod voor zwarte zee-eenden in het gebied dat verloren is gegaan als gevolg van de aanleg van Maasvlakte 2, is gebaseerd op de resultaten van het onderzoek aan bodemdieren in 2004 en 2005 . Het voedselaanbod is bepaald door de totale biomassa van de prooisoorten van zwarte zee-eenden te schatten. Ongeveer de helft van het gebied lag dieper dan ca. $15 \mathrm{~m}$. Deze diepte is aangehouden als de maximale diepte tot waar zwarte zee-eenden succesvol kunnen foerageren. Het totale voedselaanbod in het gebied tot die diepte is geschat voor zowel het Maasvlakte 2 gebied als het bodembeschermingsgebied en de gehele Voordelta. 
De schatting van het aandeel van het Maasvlakte 2 gebied in het totale voedselaanbod voor zwarte zee-eenden in de Voordelta, in de delen tot ca. $15 \mathrm{~m}$ diep, is zowel in 2004 als in $2005<0.5 \%$. Het potentiële foerageergebied voor zwarte zee-eenden dat zou verdwijnen als gevolg van de aanleg van Maasvlakte 2 is in de Passende beoordeling (Heinis et al. 2007) geschat op 3.1\%, gebaseerd op het aandeel van het geschatte oppervlak van Maasvlakte 2 en de ontgrondingskuil in het totale oppervlak van het Natura 2000 gebied.

\subsubsection{Modelberekening potentiële aantal zwarte zee-eenden in het Maasvlakte2 gebied}

Met het draagkrachtmodel is berekend hoeveel zwarte zee-eenden konden verblijven en overleven in het kustgebied waar Maasvlakte 2 is aangelegd. Die berekening is uitgevoerd op basis van de beschikbare hoeveelheid voedsel uit de bodemdierbemonstering van het najaar van 2004 en 2005. Het resultaat van de berekening was dat er geen eenden in het gebied konden verblijven en overleven. Dit was zowel het geval met de Amerikaanse zwaardschede als voedsel, als met de halfgeknotte strandschelp als voedsel. Ook wanneer het effect van verstoring buiten beschouwing werd gelaten leverde het model dit resultaat.

\subsubsection{Conclusies}

\section{Deelconclusies}

- Er zijn geen aanwijzingen dat het Maasvlakte 2-gebied in het verleden gebruikt werd als foerageer- of verblijfgebied door zwarte zee-eenden

- Op basis van het voedselaanbod in 2004 en 2005 is het potentiële aantal zwarte zee-eenden dat in het Maasvlakte 2-gebied kon overwinteren, nul.

\subsection{De potentiële functie van de Voordelta en het instellen van het bodembeschermingsgebied}

De tweede deelvraag richt zich op de bijdrage van het bodembeschermingsgebied aan het voedselaanbod voor de zwarte zee-eend:

b) Leidt het instellen van het bodembeschermingsgebied tot een gelijkblijvende potentiële functie van de Voordelta voor de zwarte zee-eend in termen van voedselbeschikbaarheid?

i. Is de potentiële draagkracht van het gebied toegenomen door de ingestelde maatregelen n.l. het beperken van de grote boomkorvisserij? Het gaat hier om de potentiële draagkracht met betrekking tot de voedselvoorziening van deze soort in relatie tot het instandhoudingsdoel; dit betekent niet de jaarlijkse aanwezigheid van de zwarte zee-eend in het gebied volgens het instandhoudingsdoel.

ii. Zijn andere factoren dan voedselbeschikbaarheid binnen en buiten de Voordelta bepalend voor het al dan niet aanwezig zijn van deze soort in de Voordelta?

iii. Is er voldoende oogstbaar voedsel in de totale Voordelta voor het aantal vogels volgens het instandhoudingsdoel

\subsubsection{Waarnemingen van zwarte zee-eenden in de Voordelta}

Na de aanleg van Maasvlakte 2 zijn vanaf 2009/2010 de zwarte zee-eenden jaarlijks geteld. In tabel 6.5 zijn de maxima per jaar weergegeven. Het totale gebruik van het gebied door zee-eenden is in vogeldagen uitgedrukt (aantal getelde vogels vermenigvuldigd met het aantal dagen die ze in het gebied verblijven). Figuur 6.3 geeft het aantal vogeldagen opgesplitst voor de twee rustgebieden en het overige deel van de Voordelta (figuur 6.3). Deze gegevens zijn op kaarten weergegeven in figuur 6.4 . 
Tabel 6.5

Het maximum aantal zwarte zee-eenden in de Voordelta tijdens de T0, T1 en T2 op basis van vliegtuigtellingen (monitorings-jaar loopt van juli tot en met juni het volgende jaar). Gegevens $\mathrm{t} / \mathrm{m}$ 2014-2015 uit Fijn et al. (2016)), in 2008/2009 is alleen in het voorjaar geteld.

\begin{tabular}{lll}
\hline monitorings-jaar & maximum & maand waarin maximum geteld is \\
\hline $\mathbf{2 0 0 4 - 2 0 0 5}$ & & \\
\hline $\mathbf{2 0 0 5 - 2 0 0 6}$ & 9.078 & april \\
\hline T1 & 10.244 & mei \\
\hline $\mathbf{2 0 0 8 - 2 0 0 9}$ & & \\
\hline $\mathbf{2 0 0 9 - 2 0 1 0}$ & 2.225 & april \\
\hline $\mathbf{2 0 1 0 - 2 0 1 1}$ & 3.400 & december \\
\hline $\mathbf{2 0 1 1 - 2 0 1 2}$ & 3.205 & februari \\
\hline $\mathbf{2 0 1 2 - 2 0 1 3}$ & 7.780 & april \\
\hline $\mathbf{2 0 1 3 - 2 0 1 4}$ & 1.152 & maart \\
\hline $\mathbf{2 0 1 4 - 2 0 1 5}$ & 1.760 & november \\
\hline T2 & & \\
\hline $\mathbf{2 0 1 5 - 2 0 1 6}$ & 530 & december \\
\hline $\mathbf{2 0 1 6 - 2 0 1 7}$ & 1.485 & Januari \\
\hline
\end{tabular}

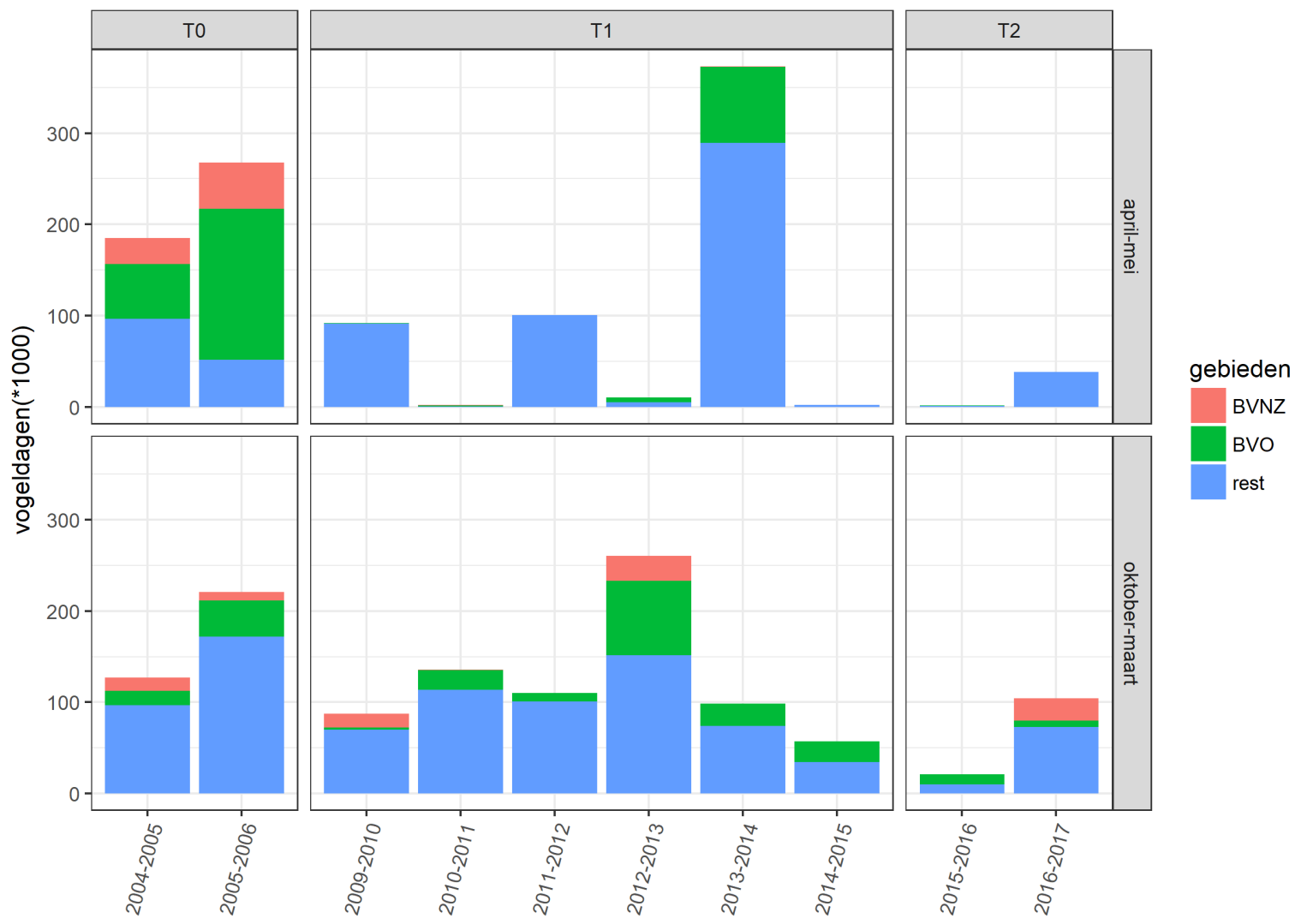

Figuur 6.3. Totaal aantal vogeldagen van de zwarte zee-eend in verschillende deelgebieden van de Voordelta tijdens het voorjaar (boven) en het winterhalfjaar (onder). BVNZ=rustgebied Bollen van het Nieuwe Zand; BVO=rustgebied Bollen van de Ooster; rest=overige delen Voordelta 

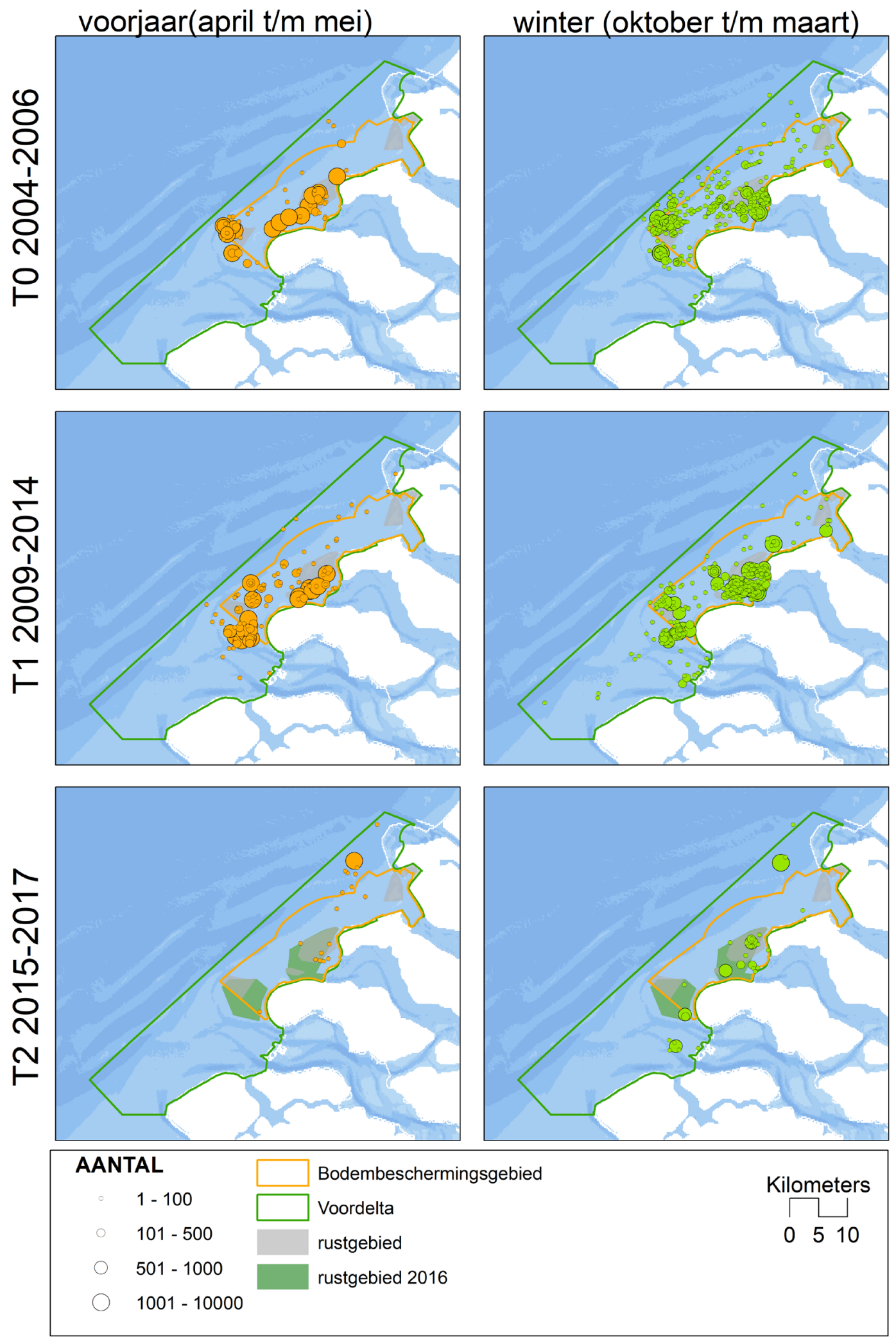

Figuur 6.4 Verspreiding van zwarte zee-eenden in voorjaar (april/mei) en winterhalfjaar (oktober $\mathrm{t} / \mathrm{m}$ maart) in T0, T1 en T2.

De maxima van de zwarte zee-eend in de Voordelta lijken in de loop van de onderzoeksperiode afgenomen (tabel 6.5). Het gebruik van het gebied uitgedrukt in aantal vogeldagen (apart voor winterhalfjaar en voorjaar) vertoont echter een minder duidelijke trend (figuur 6.3). Na de T0 lijken de aantallen vogeldagen in de winter wel lager, maar de aantallen in 2012/13 zijn duidelijk hoger. Het beeld voor het voorjaar is nog gevarieerder: er zijn van jaar op jaar grote verschillen in de mate waarin het gebied door zwarte zee-eenden als verblijfgebied gebruikt wordt gedurende de voorjaarstrek. 
Door de grote variabiliteit is er geen sprake van een trend of duidelijk verschil in aantal vogeldagen tussen de T0 jaren en de T1 jaren. Gedurende het winterhalfjaar zijn de twee rustgebieden Bollen van het Nieuwe Zand en Bollen van de Ooster gesloten voor menselijke activiteiten. Het aandeel van de rustgebieden in het totaal aantal vogeldagen varieert in de T1 tussen $10 \%$ en $50 \%$ (gemiddeld $23 \%$ ). Het aandeel van die gebieden in de T0 (toen het nog geen rustgebieden waren) was niet significant anders.

Het totaal aantal vogeldagen over een heel jaar (gerekend over de periode oktober-september, niet in de grafiek) is ook verreweg het hoogste in 2006 en 2013. Ook voor de jaartotalen vogeldagen geldt dat er geen significante trend is of een verschil tussen T0 en T1.

\subsubsection{Voedselaanbod voor zwarte zee-eenden in de Voordelta}

Hier wordt een beschrijving gegeven van het voedselaanbod voor de hierboven beschreven selectie van zes soorten prooien (Ensis spp., Abra alba, Donax vittatus, Tellina fabula, Limecola balthica, Spisula subtruncata).

Voor de vier soorten met de hoogste biomassa-dichtheden (te weten Ensis leei, Abra alba, Limecola balthica, Spisula subtruncata) is in figuur 6.5 de gemiddelde biomassa-dichtheid in de loop van de jaren sinds 2004 gegeven. In figuur 6.6 zijn deze vier soorten gestapeld weergegeven en wordt de totale biomassa voor twee zones van diepteligging in het gebied weergegeven (tot $15 \mathrm{~m}$ en dieper dan $15 \mathrm{~m}$ ). Zwarte zee-eenden kunnen duiken tot 20 meter, maar hebben een voorkeur voor ondieper gelegen voedsel en worden in de Voordelta vrijwel alleen waargenomen in de ondiepere delen tot 15 m (Prins et al. 2014c).

Het voorkomen van voor zee-eenden geschikte prooien varieert tussen jaren. Er is voor het gebied als geheel geen duidelijke trend. De opsplitsing naar diepte laat echter zien, dat dieper dan $15 \mathrm{~m}$ een gestage daling van de biomassa van schelpdieren optreedt. In de ondiepere delen tot $15 \mathrm{~m}$ diepte varieert het aanbod tussen jaren, met 2009/2010 met het laagste aanbod. Ook is het aanbod in de laatste drie monitorings-jaren relatief laag. Het gaat steeds met name om Ensis leei, de andere soorten dragen eigenlijk nauwelijks bij aan de hoeveelheid geschikt voedsel. Inmiddels is bekend dat na 2015 de halfgeknotte strandschelp in de Voordelta, maar ook elders in de Nederlandse kustzone, sterk is toegenomen in aantallen en biomassa (Troost et al. 2017). Deze toename is zichtbaar voor 2015/2016 in Figuur 6.6.

In 2016-2018 is een bank met hogere dichtheden van de halfgeknotte strandschelp opgekomen in het gebied ten zuidwesten van Maasvlakte2 buiten het bodembeschermingsgebied (Perdon et al. 2016, Troost et al. 2017)). Op die plek zijn ook concentraties zwarte zee-eenden zijn waargenomen (Dirksen et al. 2017). In figuur 6.7 is voor alle monitorings-jaren de verspreiding van waargenomen groepen zwarte zee-eenden zichtbaar gemaakt in combinatie met de dichtheden van Ensis op de monsterpunten. In die figuur is te zien dat de verspreiding van eenden in het algemeen overlapt met het voorkomen van concentraties van de Amerikaanse zwaardschede. Voor 2016/2017 zijn nog geen definitieve bodemdiergegevens uit de PMR-NCV monitoring beschikbaar. Wel is duidelijk uit voorlopige gegevens en uit resultaten van de schelpdiersurvey (Troost et al. 2017) dat een relatief groot deel van de zwarte zee-eenden (1485 eenden in januari 2017) in dat jaar is waargenomen bij de bank van Spisula subtruncata ten westen van Maasvlakte 2. Overigens vormde ook in deze latere jaren de Amerikaanse zwaardschede het grootste deel ( $>70 \%$ ) van de biomassa van schelpdieren (op basis van natgewicht) in de Voordelta (Perdon et al. 2016, Troost et al. 2017). 


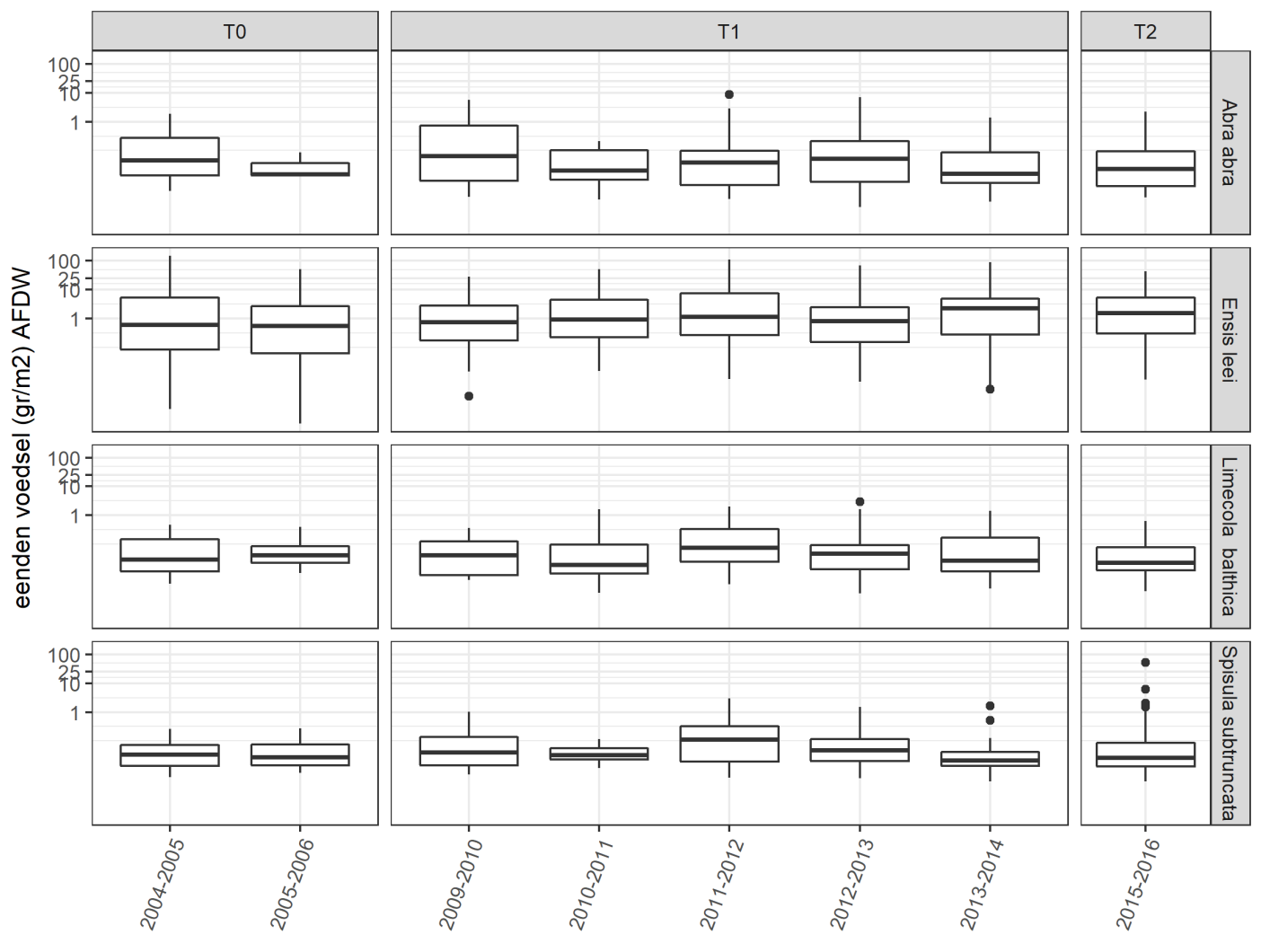

Figuur 6.5 Boxplots van biomassa ( $\mathrm{g}$ asvrij drooggewicht $/ \mathrm{m}^{2}$ ) per gridcel voor 4 verschillende soorten schelpdieren (in maten die voor zwarte zee-eenden eetbaar zijn) voor de jaren met bemonsteringen in de herfst in de periode 2004 - 2015. Voor iedere gridcel van de benthos-bemonsteringen zijn de gegevens van alle beschikbare locaties gemiddeld alvorens het gemiddelde per gridcel te berekenen.

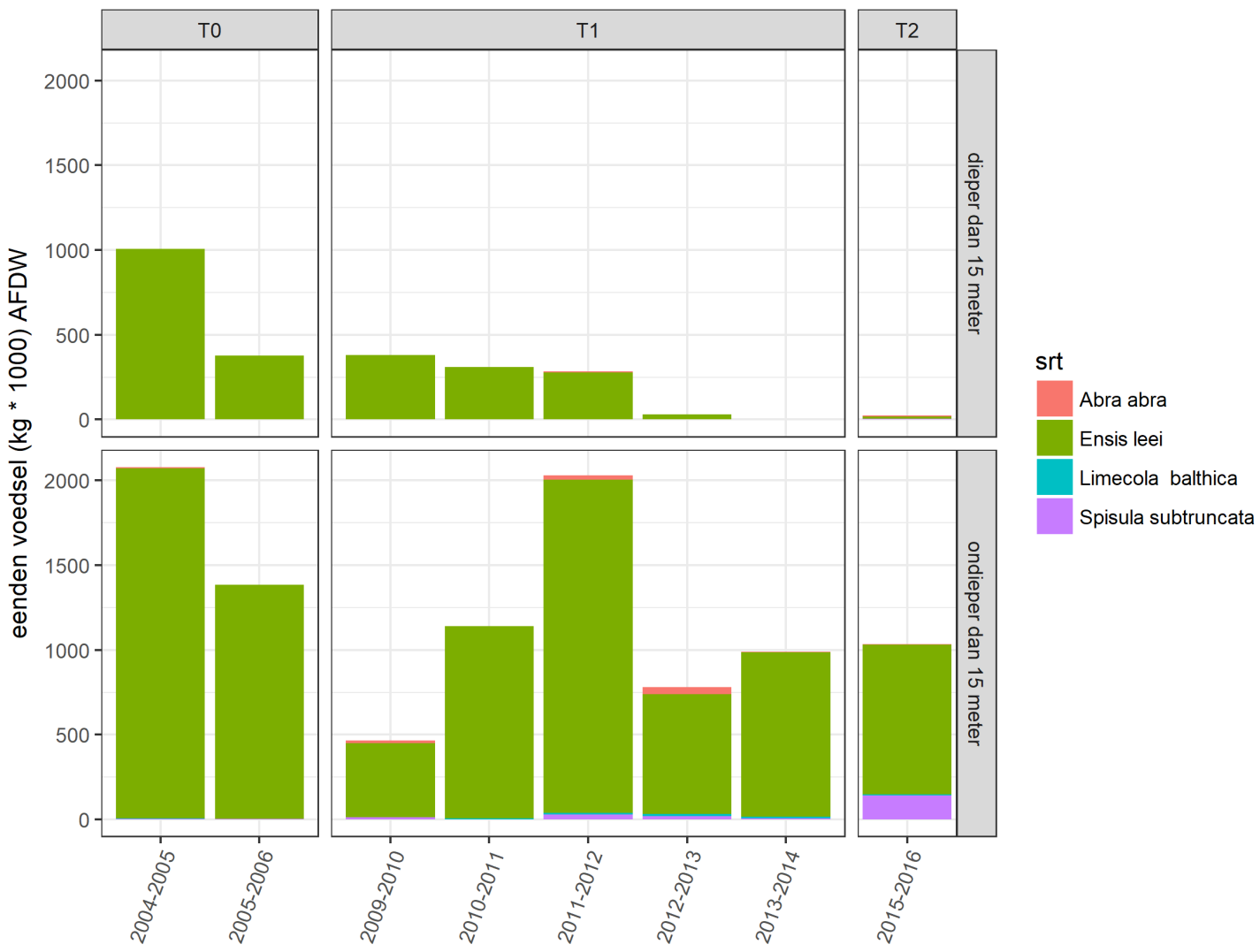

Figuur 6.6 Totale biomassa voor de gehele Voordelta voor 4 verschillende soorten schelpdieren (in maten die voor zwarte zee-eenden eetbaar zijn) voor de jaren met bemonsteringen in de herfst in de periode 2004 - 2015, opgesplitst naar bodemdiepte: tot $15 \mathrm{~m}$ en dieper dan $15 \mathrm{~m}$. 

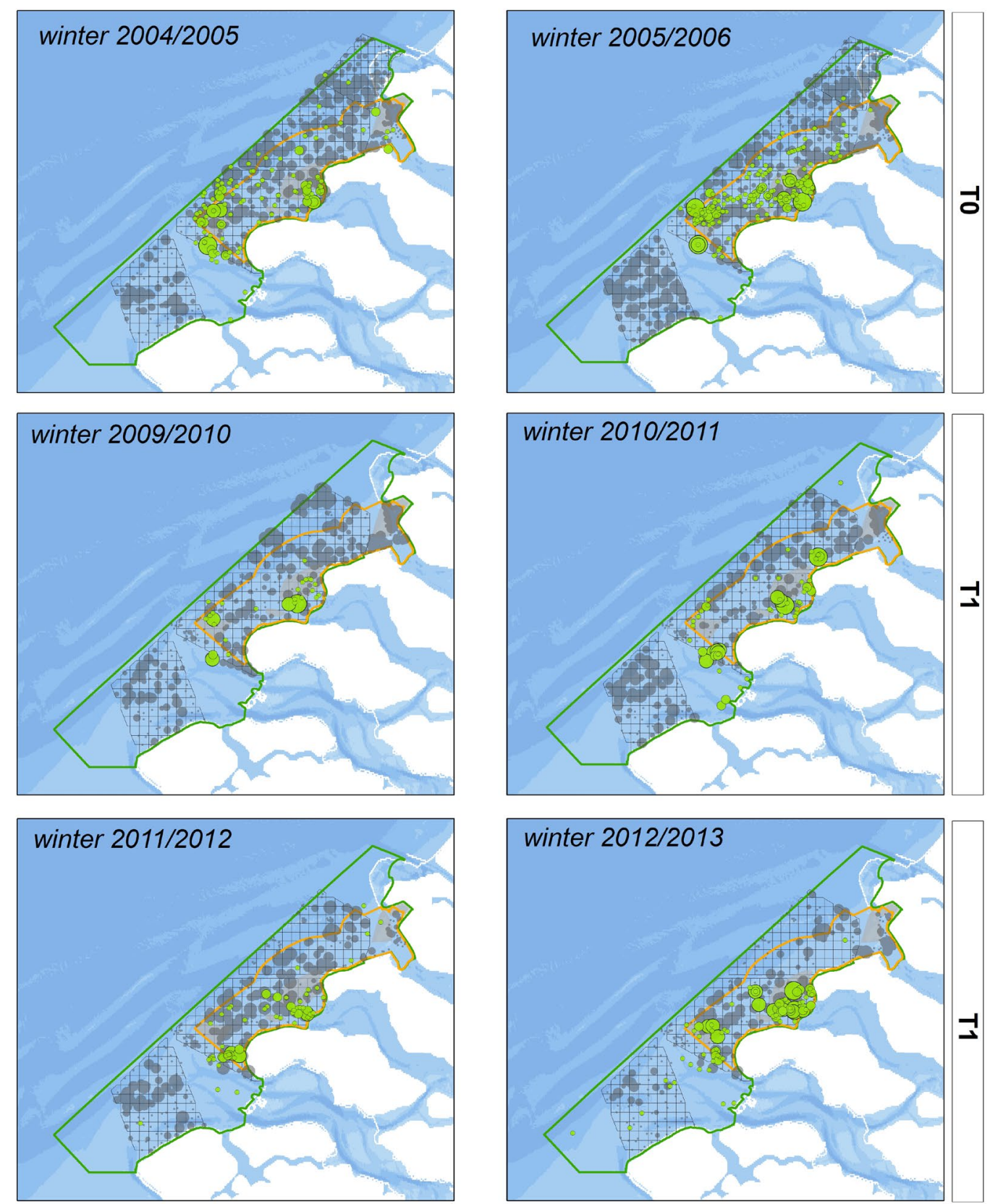

Figuur 6.7a Biomassa van Ensis leei van 4-10 cm (grijze bollen) in het voorafgaande najaar en de cumulatieve verspreiding van zwarte zee-eenden in oktober-maart (groene bollen). Voor 2014/2015 zijn geen bodemdiergegevens verzameld. Voor 2016/2017 is de analyse van bodemdiergegevens nog niet gereed. 

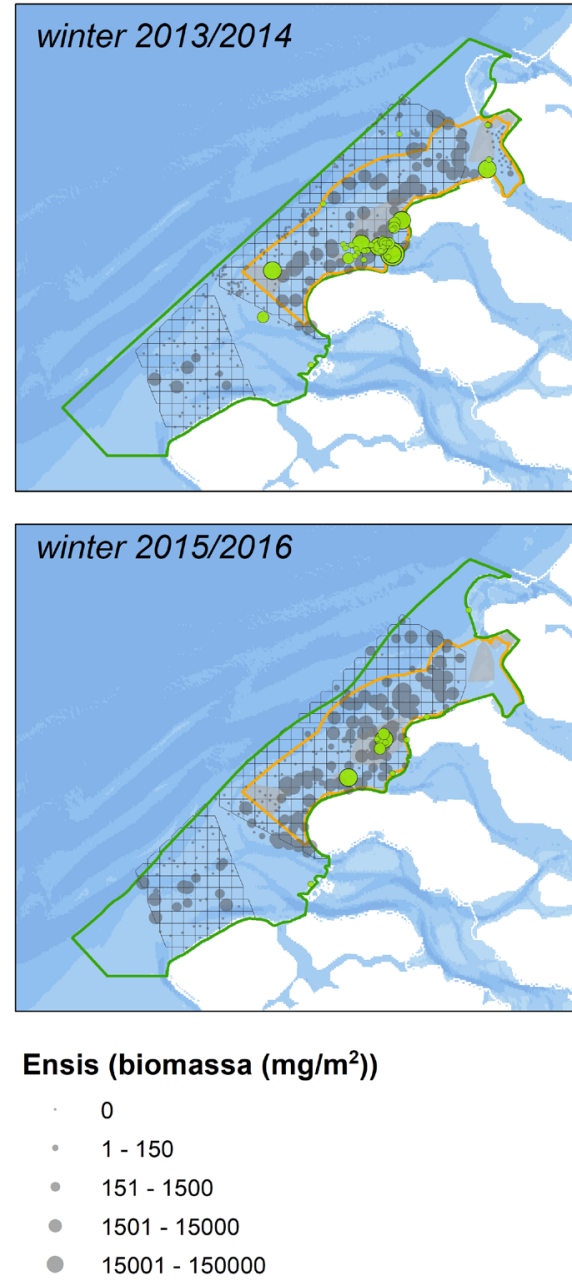
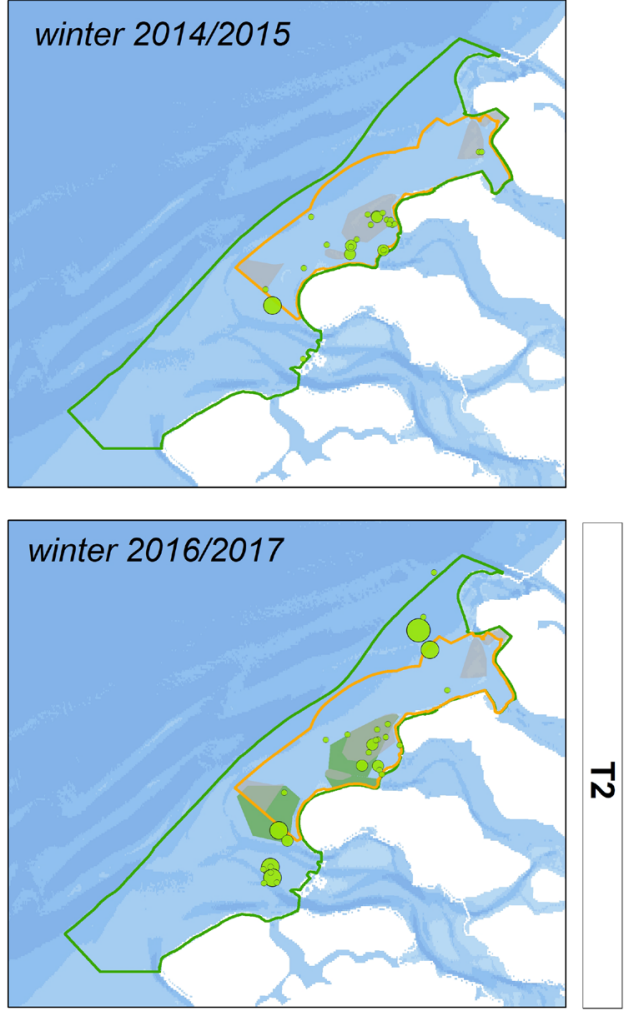

\section{Zwarte Zee-eenden Status}

\begin{tabular}{l|l}
$1-100$ & $\begin{array}{l}\square \\
101-500\end{array}$ \\
$\begin{array}{l}\square \\
501-1000\end{array}$ & N2000 Voordelta \\
$1001-10000$ & rustgebied \\
rustgebied 2016
\end{tabular}

Figuur 6.7b Biomassa van Ensis leei van 4-10 cm (grijze bollen) in het voorafgaande najaar en de cumulatieve verspreiding van zwarte zee-eenden in oktober-maart (groene bollen). Voor 2014/2015 zijn geen bodemdiergegevens verzameld. Voor 2016/2017 is de analyse van bodemdiergegevens nog niet gereed.

\subsubsection{Het effect van verstoring}

In 2013 zijn de verspreiding en aantallen zwarte zee-eenden statistisch gemodelleerd met behulp van R-INLA (zie (Prins et al. 2014c); (Zuur et al. 2014)). In deze aanpak is de verspreiding van de zwarte zee-eenden in het Voordelta gebied (uitgedrukt in som per monitorings-jaar en per rastercel) voorspeld met een statistisch model als functie van diepte, bodemstroomsnelheid van water, voedselbeschikbaarheid en gemiddelde verstoring door scheepvaart, rekening houdend met ruimtelijke correlatie.

Dit levert per monitorings-jaar een statistische schatting van de aantallen zwarte zee-eenden op, die kan worden vergeleken met de waargenomen aantallen. Voor de T1 zijn deze statistische voorspellingen gebaseerd op de variatie in voedsel en verstoring in 2009 tot en met 2012. Uit deze analyse is gebleken dat rust, c.q. verstoring, een belangrijke verklarende factor is voor de uiteindelijk gemodelleerde aantallen.

Om dit te illustreren wordt in figuur 6.8 voor vier variabelen het relatieve aandeel van die variabele op de voorspelling weergegeven. De helling van deze lijnen geeft de gevoeligheid van de voorspellingen van het model voor de betreffende variabele weer. In de grafiek valt te lezen dat het model meer zeeeenden voorspelt in ondieper water, met meer voedsel, bij lage bodemstroomsnelheid en met weinig

\footnotetext{
${ }^{5}$ http://www.r-inla.org/
} 
verstoring. De aantallen voorspelde zee-eenden zijn vooral gevoelig voor de variabele (verstoring) en met name in het lage bereik ( $<5 \%$, en in iets mindere mate $5-10 \%)$.

Ook met het draagkracht-model is het effect van verstoring op het potentiële aantal eenden in de Voordelta onderzocht. Deze resultaten worden besproken in §6.4.5.

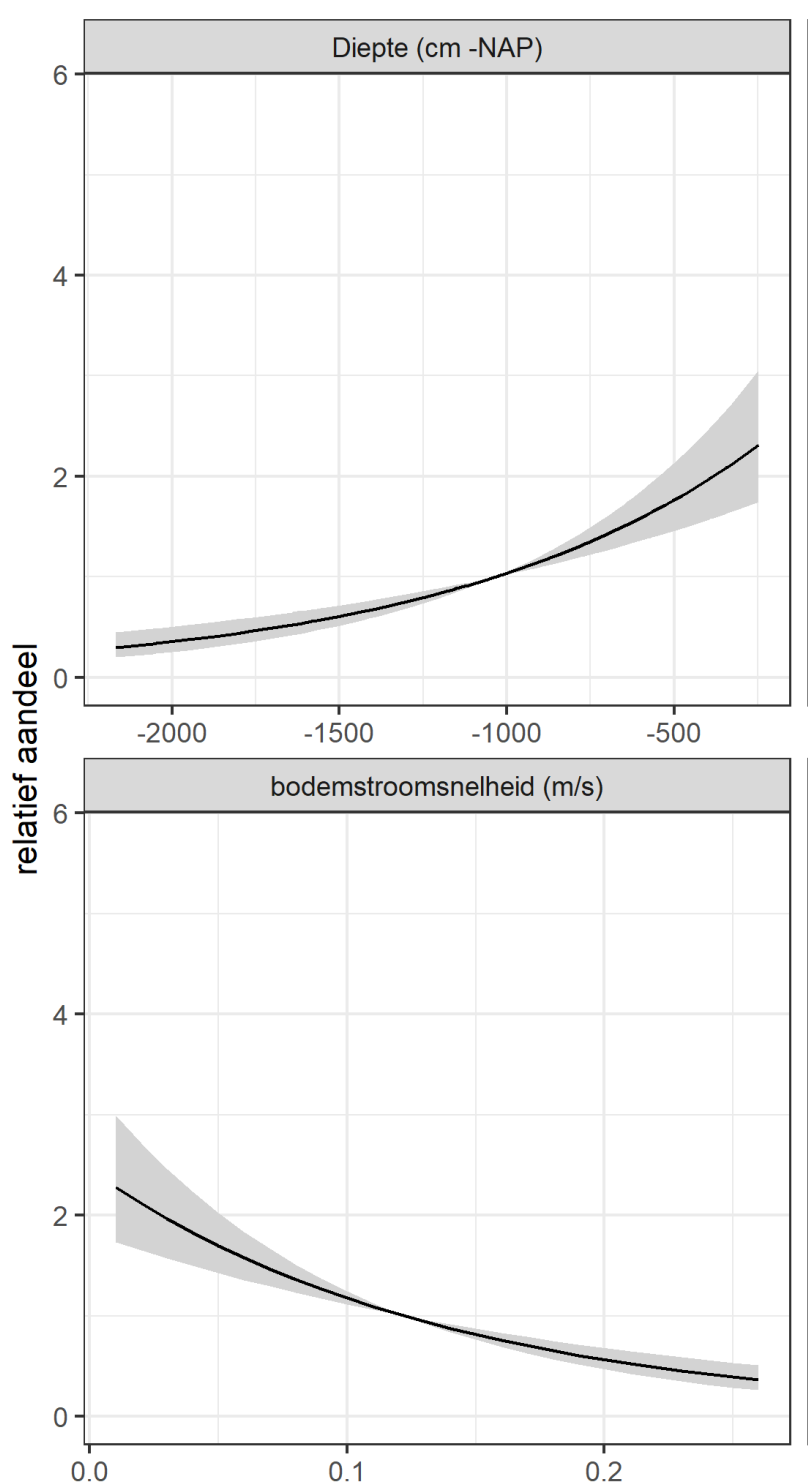

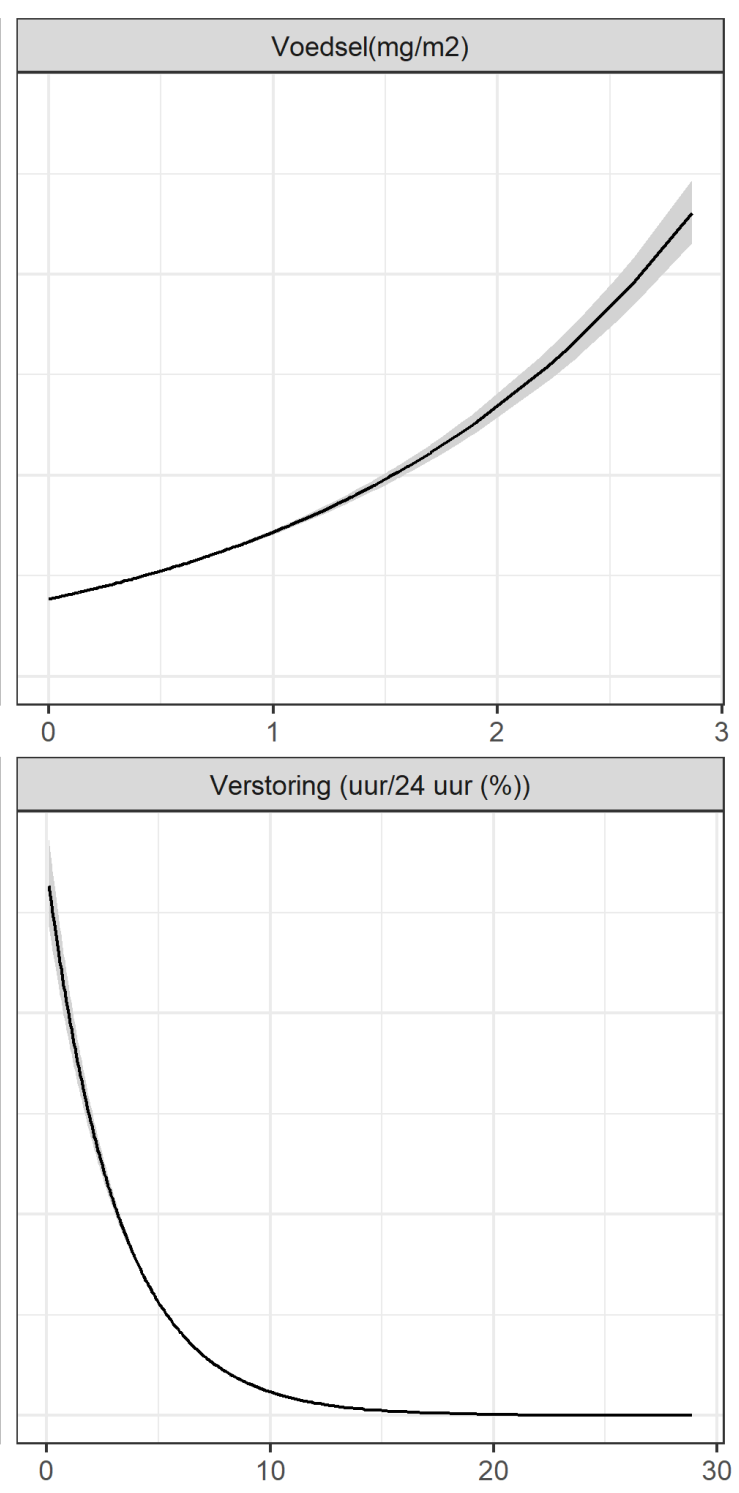

Figuur 6.8 Relatieve effect van vier variabelen op de voorspelling van een statistisch model dat de aanwezigheid van zwarte zee-eenden voorspelt op basis van omgevingsfactoren. Het relatieve effect is berekend door de waardes van de overige variabelen constant te houden (op het gemiddelde) en de waardes van de beschouwde variabele te variëren (zie (Zuur et al. 2014) voor meer details)

\subsubsection{Het effect van schelpdier-soortensamenstelling}

In de Nederlandse kustzone waren zwarte zee-eenden tot het begin van deze eeuw nadrukkelijk verbonden aan het eten van halfgeknotte strandschelp (Spisula subtruncata), die in dichte 'banken' voorkwam (Leopold et al. 1995, Leopold 1996). Begin deze eeuw verdween de halfgeknotte strandschelp grotendeels, en kwam de Amerikaanse zwaardschede sterk op.

Sinds deze afname in dichtheden van de halfgeknotte strandschelp en de sterke opkomst van de Amerikaanse zwaardschede, is de zwaardschede de belangrijkste prooisoort voor zwarte zee-eenden (Tulp et al. 2010). De sterke afname van het bestand halfgeknotte strandschelpen valt samen met een afname in aantallen zwarte zee-eenden in de Nederlandse wateren, en wordt genoemd als een van de oorzaken van de verminderde aantallen zee-eenden (ICES 2005, Leopold et al. 2011). Door de langwerpige vorm is de Amerikaanse zwaardschede mogelijk een minder geschikte prooi voor zwarte zee-eenden dan kleinere en rondere schelpen, doordat er meer handelingstijd nodig is om de lange 
schelpen in te slikken. Zwarte zee-eenden eten vooral kleine zwaardschede van 5-9 cm, omdat grotere schelpen niet meer ingeslikt kunnen worden (Brinkman et al. 2007, Skov et al. 2008). Mogelijk is de zwaardschede geen voorkeursprooi voor de zwarte zee-eenden (Smit et al. 2011). Uit veldonderzoek, onder andere in de Voordelta, bleek dat zwarte zee-eenden op Ensis waren overgestapt (Poot et al. 2014). Ook waarnemingen bij de Deense Noordzeekust (Horns Rev) laten zien dat zwarte zee-eenden foerageren op zowel de Amerikaanse zwaardschede als op de halfgeknotte strandschelp, zonder dat er duidelijke aanwijzingen zijn dat de beschikbaarheid of biomassa van de laatste soort te laag is geworden (Skov et al. 2008).

In recente jaren nemen aantallen en biomassa van Spisula subtruncata weer toe in de Nederlandse kustwateren (Perdon et al. 2016, Troost et al. 2017). In de laatst beschikbare bemonstering in het kader van PMR-NCV is hier al iets van te zien (figuur 6.5). In de winter van 2016/17 was er voor de kust van Bergen-Camperduin een concentratie van vele tienduizenden tot waarschijnlijk 100.000 zwarte zee-eenden, die naar alle waarschijnlijkheid afkwamen op lokale hoge dichtheden van Spisula subtruncata en (in mindere hoge dichtheden) enkele andere kleinere schelpdiersoorten (Fijn et al. 2017a). Dichtheid van geschikte bodemdieren alleen is dus zeker niet de enige factor die de aanwezigheid van zee-eenden bepaalt: het soort schelpdier en het optreden van dichte banken is een belangrijke factor.

\subsubsection{Potentiële aantallen zwarte zee-eenden in de Voordelta}

Met het zwarte zee-eend model (van de Wolfshaar et al. 2018) is het aantal eenden berekend dat in de Voordelta kan verblijven, voor alle jaren waarvoor gegevens over schelpdieren beschikbaar waren. In aanvulling daarop zijn voor die jaren gegevens gebruikt over diepte, stroomsnelheid en weersomstandigheden. Berekeningen zijn uitgevoerd voor jaren uit de $T_{0}(2004 / 2005,2005 / 2006)$ en voor 2009/2010 t/m 2015/2016, met uitzondering van 2014/2015 waarvoor geen bodemdiergegevens beschikbaar waren (tabel 6.3).

De berekeningen, uitgevoerd met de Amerikaanse zwaardschede als voedsel, laten zien dat er in alle jaren ruim voldoende voedsel in de Voordelta aanwezig was om meer dan 9700 zwarte zee-eenden gedurende de periode september-april in de Voordelta te laten verblijven (figuur 6.9). Het aantal van 9700 zwarte zee-eenden is afgeleid van het instandhoudingsdoel voor de zwarte zee-eend in de Voordelta dat is gedefinieerd als een midwinter-aantal van 9700 eenden (van Oostveen et al. 2014). Het resultaat van de modelberekening (aantal eenden gedurende de gehele periode september-april) is niet helemaal vergelijkbaar met het instandhoudingsdoel (midwinter-aantal), maar voor een eenvoudige vergelijking is in figuur 6.9, 6.10 en 6.13 het berekende potentiële aantal gerelateerd aan het instandhoudingsdoel van 9700 eenden.

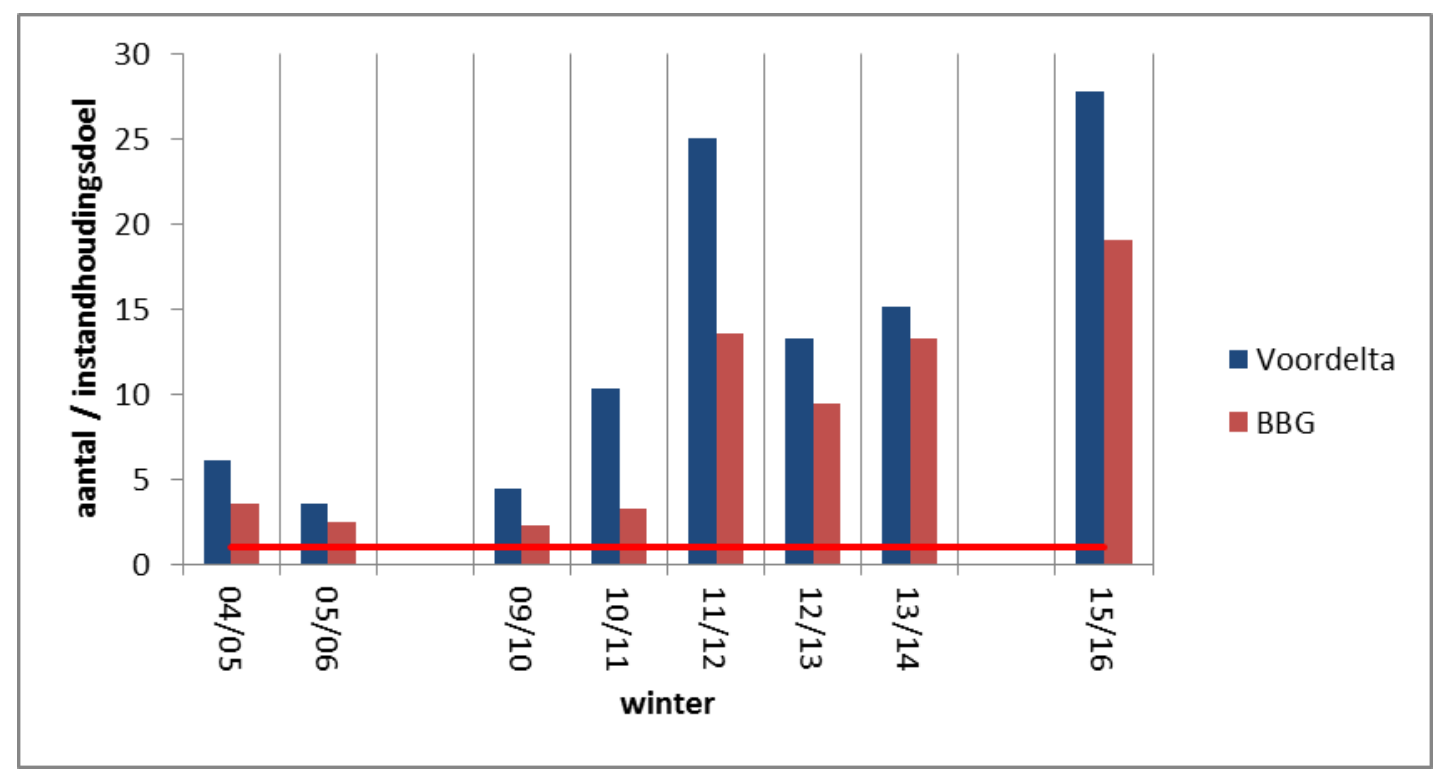

Figuur 6.9. Het potentiële aantal zwarte zee-eenden in de periode september-april in de hele Voordelta en in het bodembeschermingsgebied (BBG) met de Amerikaanse zwaardschede als voedsel en zonder verstoring door scheepvaart, in verhouding tot het instandhoudingsdoel van 9700 eenden (rode lijn). 
De aantallen berekende eenden per gridcel van $1,2 \mathrm{~km}^{2}$ variëren in de meeste gevallen tussen 0 en 4000, met een paar uitschieters tot ca. 7000. Voor de gehele Voordelta laten de modelresultaten zien dat er in de jaren 2004-2016 voldoende voedsel lag voor ca. 30.000 tot meer dan 200.000 eenden. Het totaal aantal zwarte zee-eenden dat in de Voordelta kan verblijven is het hoogst in de winterhalfjaren van 2011/2012 en 2015/2016, en het laagst in de winterhalfjaren van 2005/2006 en 2009/2010. De verschillen tussen jaren worden veroorzaakt door verschillen in de hoeveelheid voedsel, maar ook de plek en de diepte waarop de schelpdieren voorkomen. Daarbij speelt naast de biomassa van de Amerikaanse zwaardschede ook de lengte van de schelpen een rol. Te kleine schelpen bevatten weinig voedsel en leveren relatief weinig energie op ten opzichte van de energiekosten om het voedsel te vergaren. Te grote schelpen zijn niet meer geschikt als voedsel voor de eenden, omdat de schelpen te groot zijn om in te slikken. Uit het onderzoek aan maaginhouden van aangespoelde zwarte zee-eenden dat al eerder gerapporteerd is (Prins et al. 2014c) is gebleken dat de eenden voornamelijk schelpen van de Amerikaanse zwaardschede met een lengte tot $10 \mathrm{~cm}$ eten. In de modelberekeningen is deze lengte daarom voor de Amerikaanse zwaardschede als maximale prooilengte aangehouden.

Wanneer alleen naar het bodembeschermingsgebied wordt gekeken, geldt nog steeds dat in alle jaren het instandhoudingsdoel ruimschoots (minimaal een factor 2,5) gehaald wordt (figuur 6.9). Het potentiële aantal eenden in het bodembeschermingsgebied is gemiddeld $61 \%$ van het berekende totale aantal in de Voordelta. Ook in de waarnemingen wordt een wezenlijk deel van de eenden in of nabij het bodembeschermingsgebied waargenomen (figuur 6.7). In de Voordelta wordt de zwarte zeeeend vrijwel alleen waargenomen op locaties met een diepte tot $15 \mathrm{~m}$, waarbij het grootste deel $(>80 \%)$ van de eenden voorkomt in gebieden tot een diepte van 8 meter (Prins et al. 2014c). Ook in de modelresultaten worden de hoogste potentiële aantallen eenden gevonden in gridcellen met een diepte tot 10 meter, en het overgrote deel in gridcellen met een diepte tot 15 meter (van de Wolfshaar et al. 2018). Van het totale areaal tot $15 \mathrm{~m}$ in de Voordelta, ligt ca. $40 \%$ in het bodembeschermingsgebied. Dit wijst op het relatief grote belang van het bodembeschermingsgebied (ca. $27 \%$ van het oppervlak van de Voordelta) voor de zwarte zee-eend.

Een zelfde soort berekening als voor de Amerikaanse zwaardschede is ook uitgevoerd met de halfgeknotte strandschelp als voedsel. Het potentiële aantal eenden dat uit de modelresulaten volgt is in dat geval nul. De bank met hogere dichtheden van de halfgeknotte strandschelp in het gebied ten zuidwesten van Maasvlakte2 uit 2016/2017 is in de huidige modelberekeningen (die gaan tot 2015/2016) nog niet meegenomen.

Wanneer in de modelberekeningen rekening wordt gehouden met de verstoring door scheepvaart, zijn de potentiële aantallen zwarte zee-eenden lager dan zonder verstoring (figuur 6.10). Voor de hele Voordelta berekent het model een afname van gemiddeld $13 \%$ in het potentiële aantal eenden als gevolg van verstoring door scheepvaart. Voor alleen het bodembeschermingsgebied is die afname gemiddeld $5 \%$. Dit verschil wordt veroorzaakt door het voorkomen van relatief grotere delen zonder verstoring binnen het bodembeschermingsgebied, zoals de aangewezen rustgebieden Bollen van het Nieuwe Zand en Bollen van de Ooster.

De modelberekeningen voorspellen dat zwarte zee-eenden potentieel in grote delen van de Voordelta zouden kunnen verblijven. Wanneer rekening gehouden wordt met de huidige verstoring door scheepvaart, worden de potentiële aantallen vooral waargenomen in het bodembeschermingsgebied en in enkele jaren in delen van het gebied voor de kust van Walcheren (figuur 6.11). Er is een groot verschil tussen jaren in de effecten van verstoring door scheepvaart. Het effect hangt vooral af van waar de verstoring optreedt en waar het geschikte voedsel ligt. Verstoring die met dezelfde intensiteit voorkomt op dezelfde locatie, kan in het ene jaar daardoor meer effect hebben dan in het andere jaar. Daarnaast moet worden vastgesteld dat verschillen tussen jaren vooral beïnvloed worden door verschillen in het voedselaanbod, terwijl de huidige mate van verstoring door scheepvaart een relatief gering effect heeft in vergelijking met de jaarlijkse verschillen in voedselaanbod. 


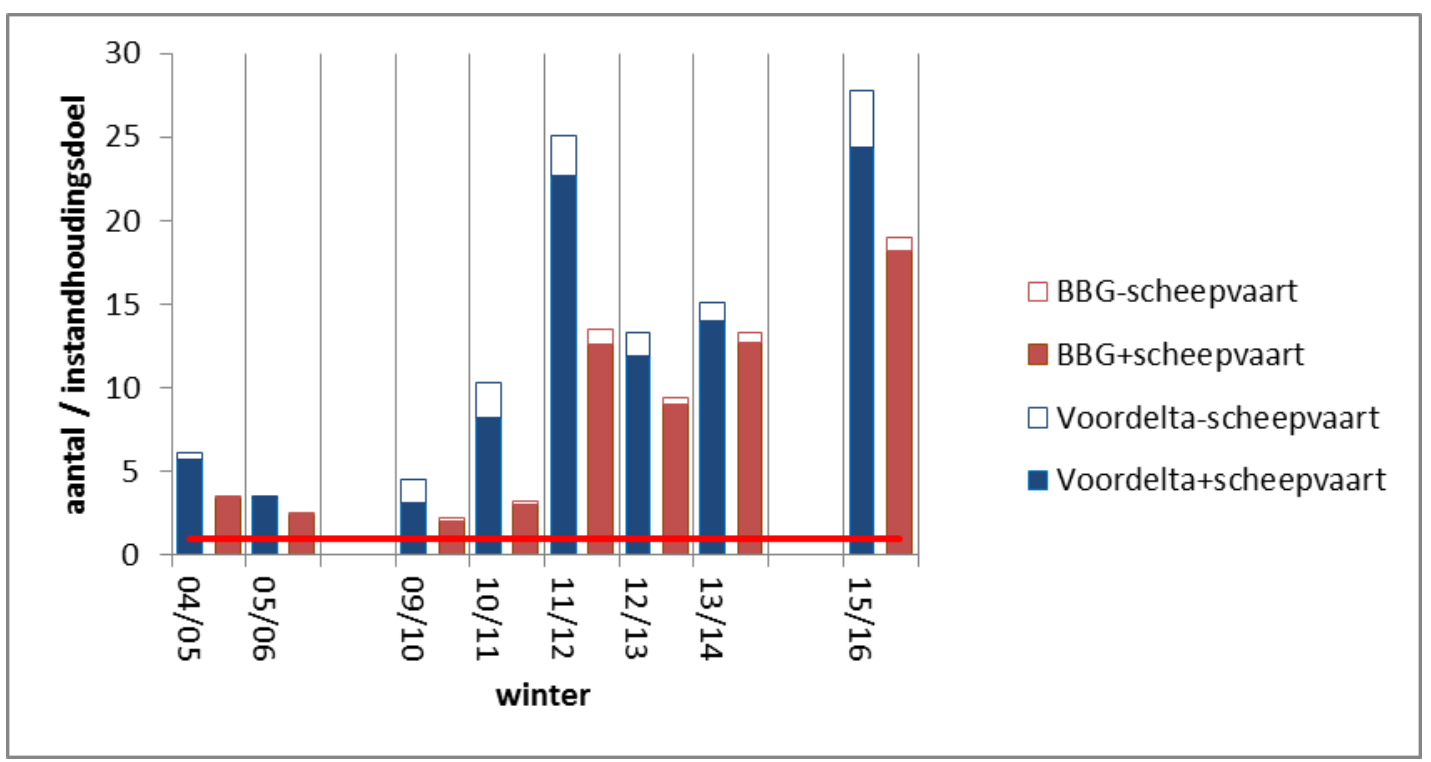

Figuur 6.10. Het potentiële aantal zwarte zee-eenden in de periode september-april in de hele Voordelta en in het bodembeschermingsgebied (BBG) met de Amerikaanse zwaardschede als voedsel, in verhouding tot het instandhoudingsdoel van 9700 eenden (rode lijn). De gevulde kolommen geven het potentiële aantal eenden met aanwezigheid van verstoring door scheepvaart. De open kolommen geven het potentiële extra aantal eenden zonder verstoring. Het totaal van de open en gevulde kolommen geeft dezelfde aantallen als in figuur 6.8 .

Het ruimtelijke patroon dat uit de modelberekening komt, komt uiteraard redelijk goed overeen met de biomassa van de Amerikaanse zwaardschede in figuur 6.7. Er zijn wel wat verschillen, veroorzaakt doordat niet alleen de totale biomassa maar ook de dichtheid en de grootteverdeling van de schelpen van belang is voor het energiebudget van de eenden.

Om een beter beeld te krijgen van de belangrijkste potentiële concentratiegebieden van zwarte zeeeenden, is een vervolganalyse op de modelresultaten toegepast, waarbij steeds voor een groep van 9 gridcellen (een groep van 3 cellen horizontaal en 3 cellen verticaal) berekend is of in die groep van 9 cellen minimaal $50 \%$ van het instandhoudingsdoel wordt behaald. Op die manier komt in beeld in welke delen van de Voordelta het zwaartepunt van het potentiële aantal eenden ligt. Deze clustering is ook een manier om invulling te geven aan het feit, dat zwarte zee-eenden in sterke mate gegroepeerd voorkomen langs de kust. De 'clusters' die op deze manier berekend worden, geven weer in welke deelgebieden van ca. $11 \mathrm{~km}^{2}$ de omstandigheden dusdanig gunstig zijn dat hier grote groepen zwarte zee-eenden zouden kunnen verblijven. Het resultaat (figuur 6.12) laat zien dat de potentieel belangrijkste concentratiegebieden vooral voorkomen bij de Brouwersdam en voor de kust van Schouwen (o.a. bij de Bollen van het Nieuwe Zand), en in sommige jaren ten noordwesten van Walcheren en bij de monding van het Haringvliet. Dit komt op hoofdlijnen overeen met gebieden waar recent of langer geleden zwarte zee-eenden zijn waargenomen. Overigens is het niet zo dat er buiten de clusters geen zwarte zee-eenden worden voorspeld door het model, zoals al getoond in figuur 6.10. De keuze voor een groep van 9 cellen is willekeurig. Wanneer een groter aantal aaneengesloten cellen wordt gekozen (bijvoorbeeld $5 * 5$ cellen) verandert het beeld enigszins doordat het gestelde potentiële aantal over een groter gebied gehaald kan worden. De gebieden worden groter, maar de ligging van de belangrijkste concentratiegebieden blijft grotendeels gelijk. 


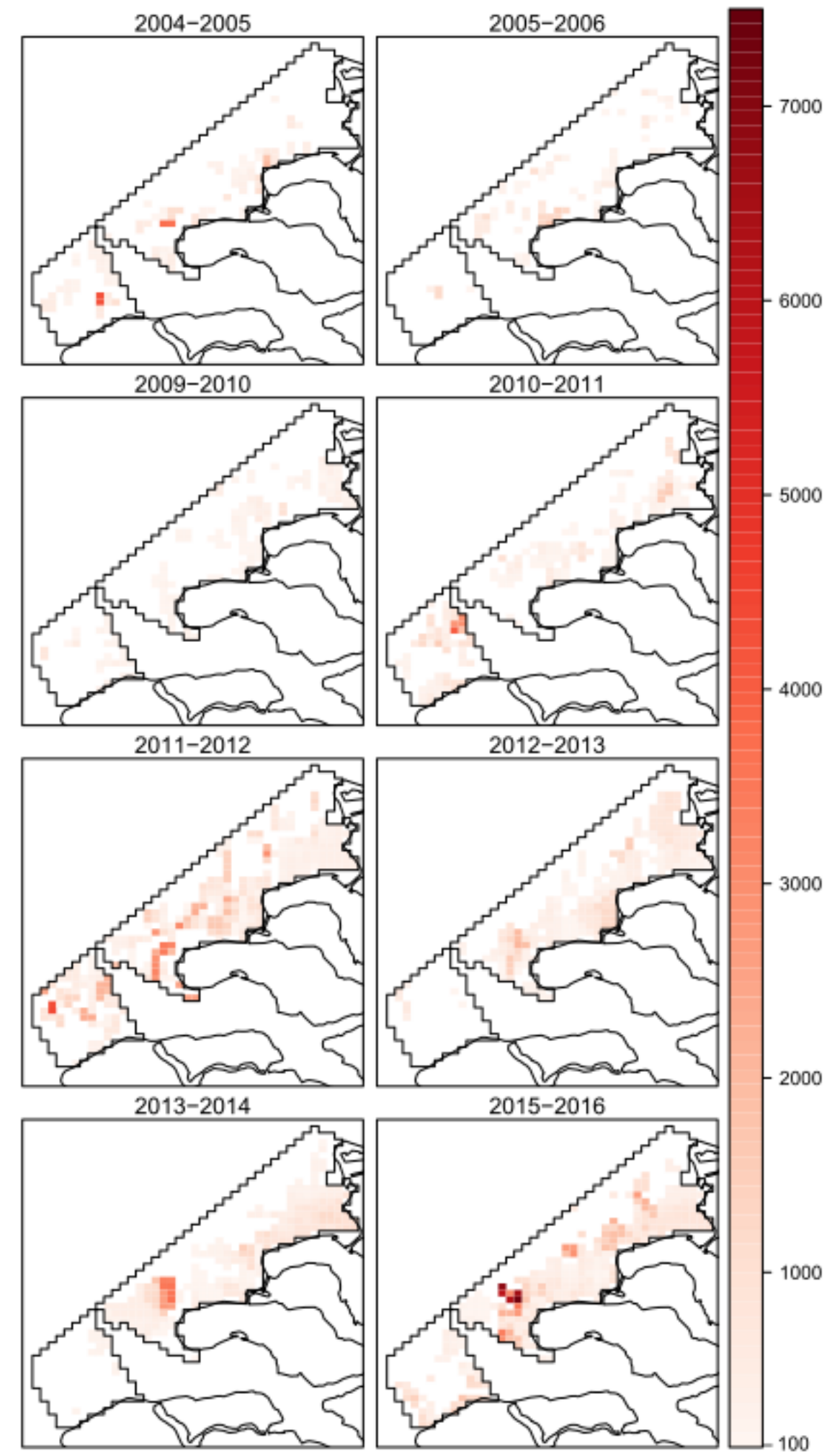

Figuur 6.11. Ruimtelijke verspreiding van de potentiële aantallen zwarte zee-eenden in de Voordelta, met de Amerikaanse zwaardschede als voedsel en de waargenomen scheepvaart. De kleurcodering geeft de potentiële aantallen per gridcel weer. 

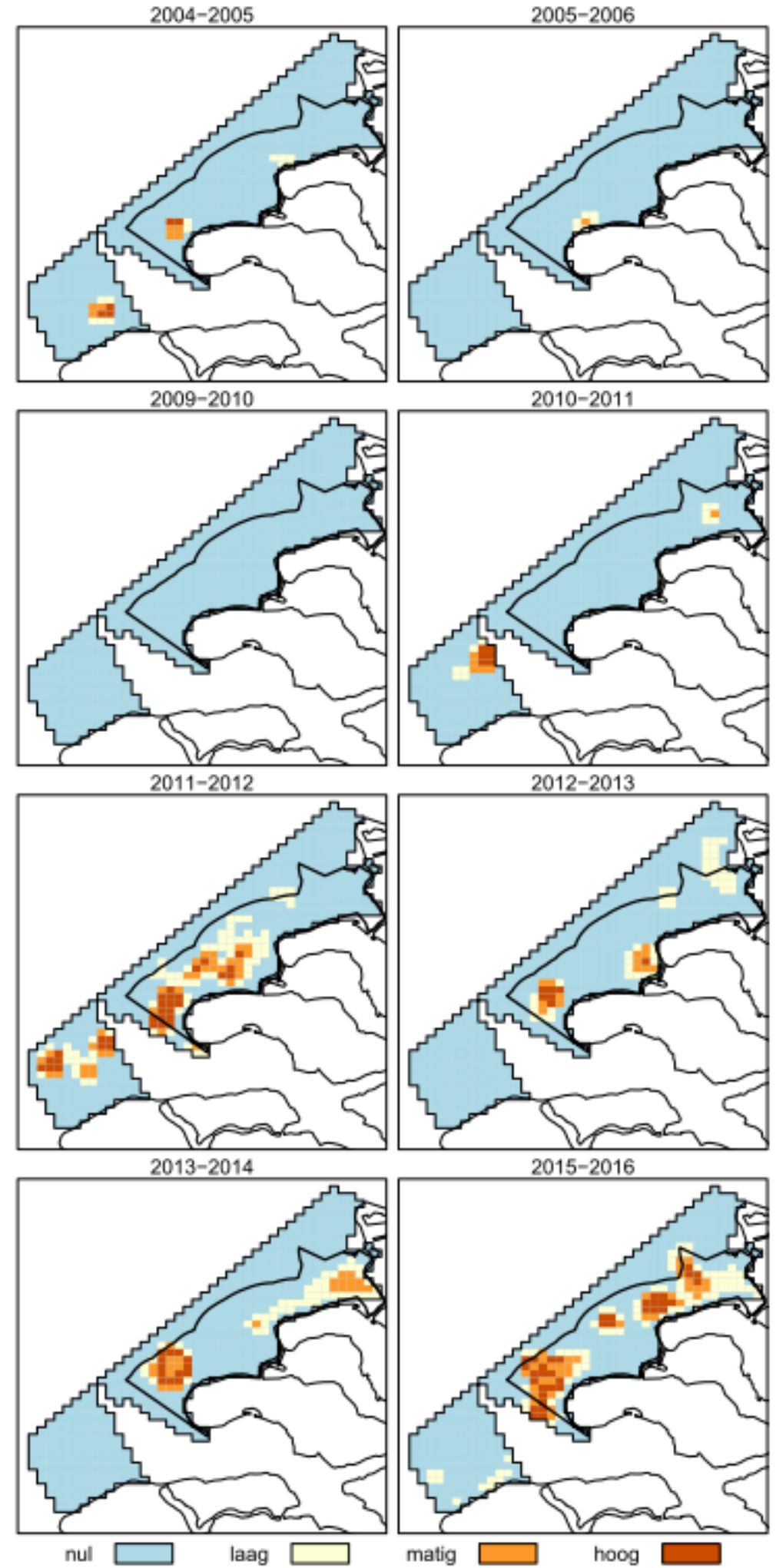

Figuur 6.12. Resultaten van de 'clustering' per winterhalfjaar. Weergegeven zijn de gridcellen geclassificeerd als: 'nul' $=$ tot $50 \%$ van het instandhoudingsdoel per cluster; 'laag' $=50-75 \%$ van het instandhoudingsdoel per cluster; 'matig' = 75-99\% van het instandhoudingsdoel; 'hoog' = het instandhoudingsdoel wordt gehaald per cluster. 


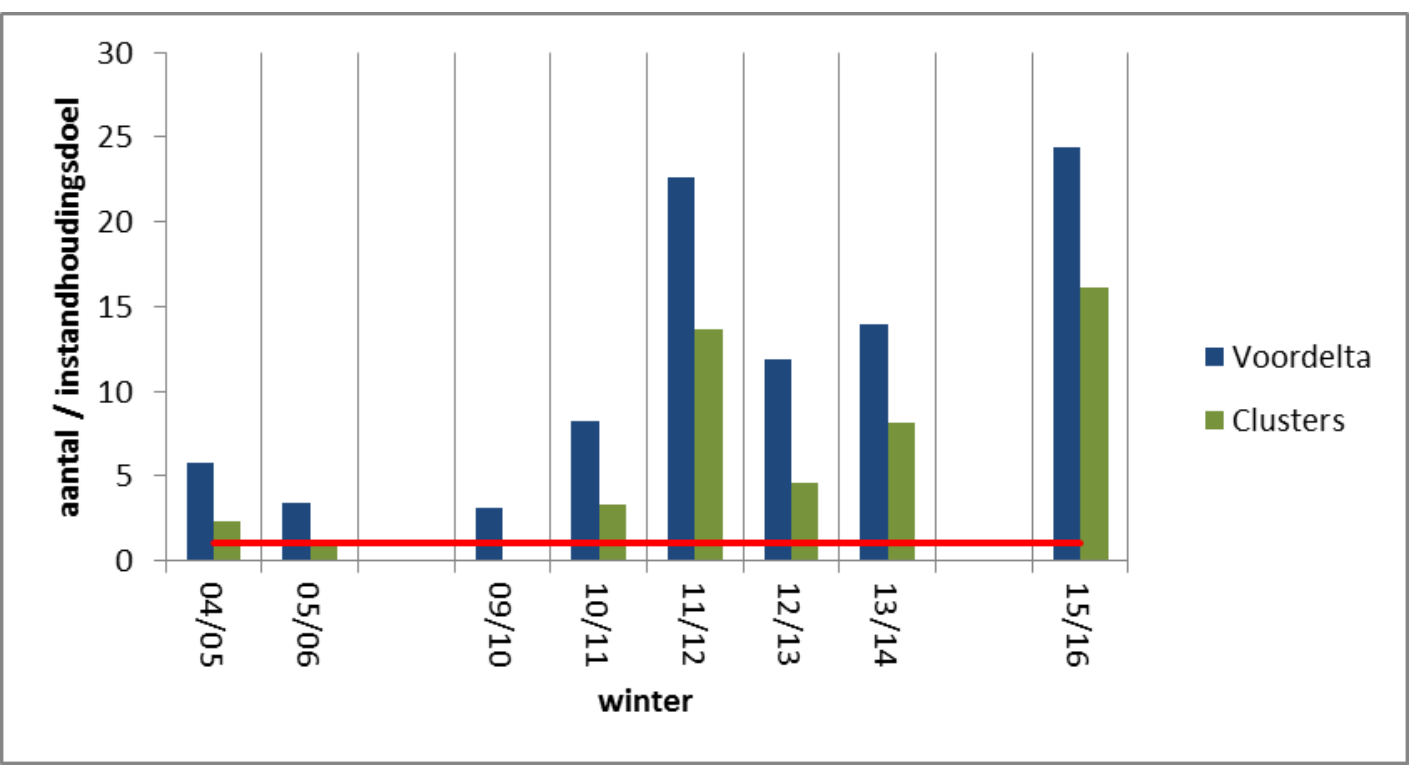

Figuur 6.13. Het potentiële aantal zwarte zee-eenden in de periode september-april in de hele Voordelta (blauw) en binnen de clusters van 9 cellen (groen) met de Amerikaanse zwaardschede als voedsel, in verhouding tot het instandhoudingsdoel van 9700 eenden (rode lijn). De getallen voor de hele Voordelta zijn dezelfde als in Figuur 6.9. De getallen voor de clusters geven het potentiële aantal eenden binnen de gebieden aangeduid met 'matig' en 'hoog' in figuur 6.12.

$\mathrm{Er}$ is ook gerekend met de potentiële aantallen zwarte zee-eenden binnen de clusters van 9 cellen waar minimaal $75 \%$ van het instandhoudingsdoel gehaald wordt; dit zijn de gebieden aangeduid met 'matig' en 'hoog' in Figuur 6.12. In die berekening blijkt uiteraard dat het potentiële aantal zwarte zee-eenden lager is dan wanneer de aantallen voor de gehele Voordelta berekend worden (figuur 6.13).

De modelresultaten in figuren 6.9, 6.10 en 6.13 laten zien, dat de grootste jaarlijkse verschillen in potentiële aantallen eenden worden veroorzaakt door verschillen in het voedselaanbod. Daarbij gaat het niet alleen om de absolute hoeveelheid biomassa, maar (in mindere mate) ook om de locatie (diepte, stroomsnelheid) en grootteverdeling van de schelpen. Verstoring door scheepvaart zoals die nu in het model is meegenomen heeft eveneens een effect, maar dit is beperkt ten opzichte van het effect van het voedselaanbod.

Op grond van de modelresultaten en de daarbij gemaakte aannames kan geconcludeerd worden dat er geen verandering in de potentiële aantallen zwarte zee-eenden is opgetreden die samenhangt met de aanleg en aanwezigheid van Maasvlakte 2. Uit de modelresultaten blijkt ook, dat met alleen de Amerikaanse zwaardschede als voedsel, er in alle jaren voldoende voedsel in de Voordelta aanwezig lijkt voor een potentieel aantal zwarte zee-eenden van minimaal 9700. Wanneer de aanvullende eis wordt gesteld dat de aantallen in geclusterde groepen gehaald moeten kunnen worden, wordt in $2009 / 2010$ het potentiële instandhoudingsdoel van 9700 niet gehaald. Dit is te verklaren uit de lage biomassa van voedsel in de ondiepe delen $(<15 \mathrm{~m}$ ) van de Voordelta (figuur 6.6).

\subsubsection{Ontwikkelingen in gebieden buiten de Voordelta; Nederland}

Om de ontwikkelingen in de Voordelta te kunnen vergelijken met de overige delen van het Nederlandse kustgebied worden de telgegevens uit die gebieden hieronder gepresenteerd samen met de informatie over de Voordelta. In Figuur 6.14 is te zien dat de aantallen langs de Nederlandse kust variëren. Ook is duidelijk dat de aantallen in de Voordelta altijd maar een klein deel van het totaal langs de Nederlandse kust zijn. In deze figuur zijn de telgegevens uit alle beschikbare maanden gegeven. In Figuur 6.15 zijn de januaritellingen vanaf 1987 weergegeven. Hoewel met flinke aantalsvariaties van jaar op jaar, is er een geleidelijke afname van de aantallen te zien. Hoewel minder duidelijk, lijkt die er in de Voordelta ook te zijn - in ieder geval zijn de recente aantallen het laagst in zowel de hele Nederlandse kustzone als in de Voordelta. 


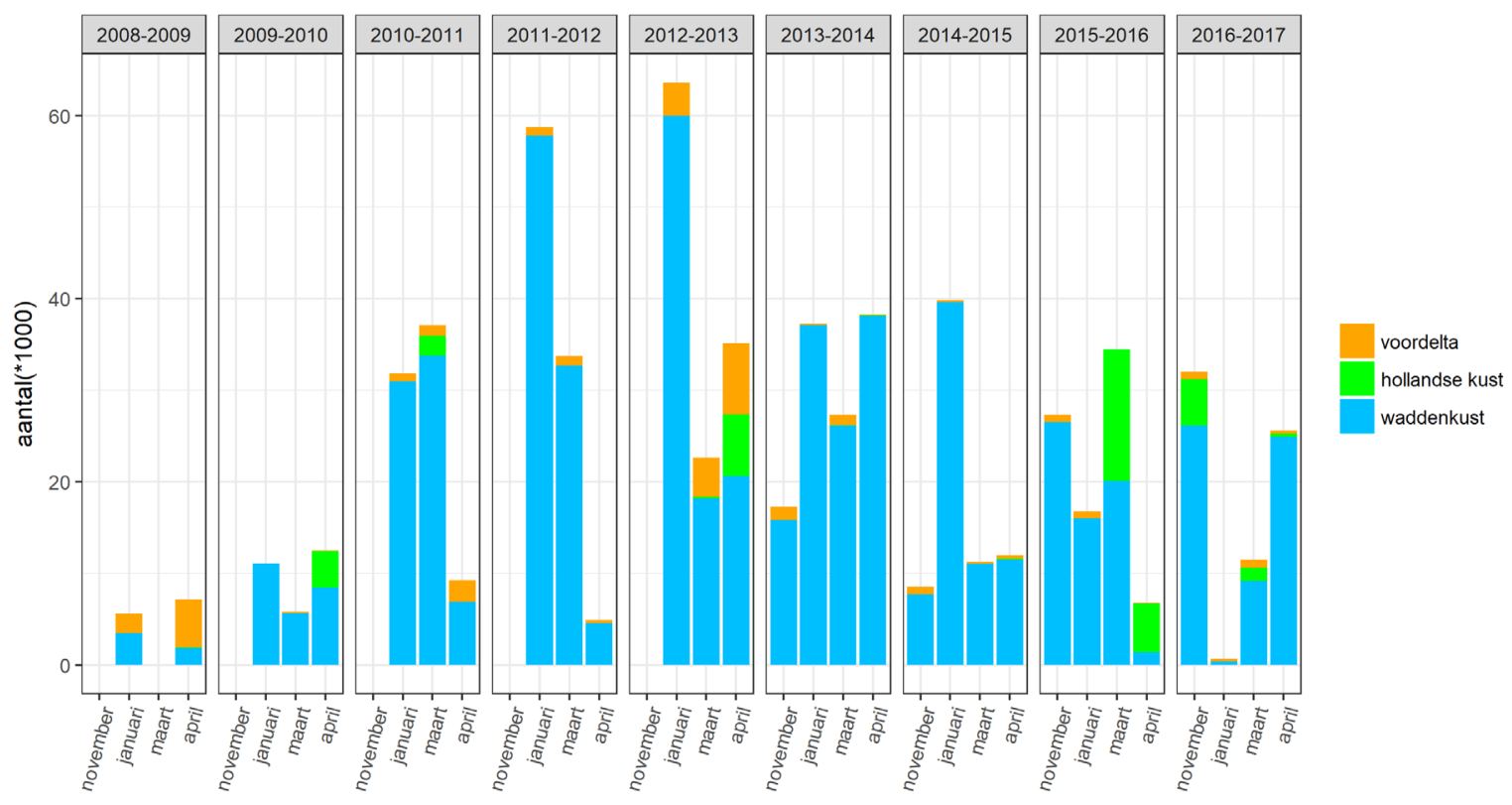

Figuur 6.14 Aantallen zwarte zee-eenden in de Nederlandse kustwateren in het winterhalfjaar van 2008-2017. NB in maanden zonder data zijn geen tellingen uitgevoerd.

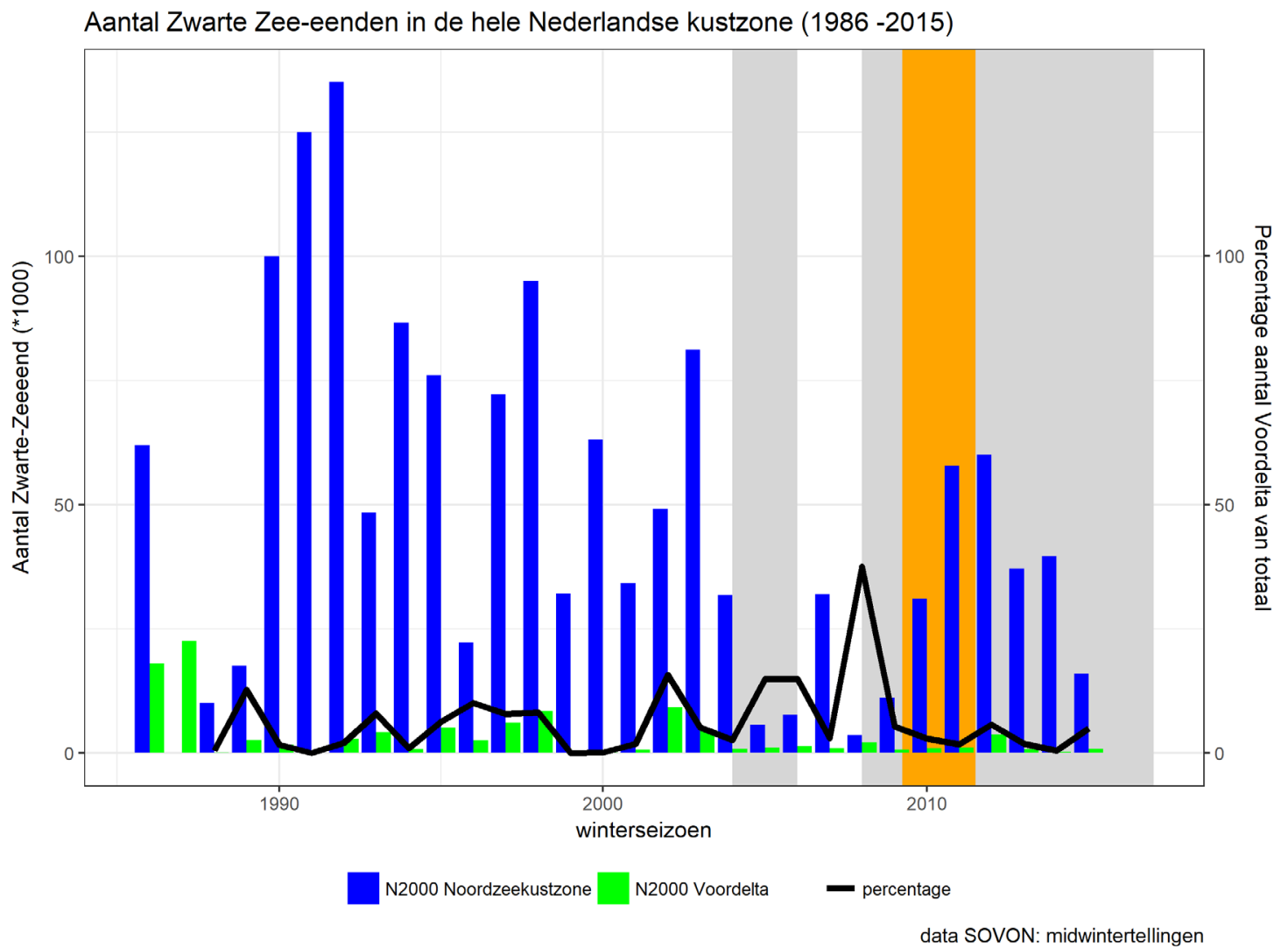

Figuur 6.15 Aantallen zwarte zee-eenden in de Nederlandse kustwateren in de midwintertelling van 1987-2017: aantallen in N2000-gebied Noordzeekustzone (blauwe kolom), N2000-gebied Voordelta (groen kolom) en het aandeel van de Voordelta in procent van het totaal (zwarte lijn). Grijs gearceerd: jaren van monitoring PMR-NCV. Oranje gearceerd: periode van aanleg van Maasvlakte 2 


\subsubsection{Ontwikkelingen in gebieden buiten de Voordelta; NW Europa}

Hieronder wordt een korte schets gegeven van wat er voor zwarte zee-eenden bekend is van aantallen, verspreiding en andere ontwikkelingen in de landen om ons heen. Dit is bedoeld als context bij de ontwikkelingen die in de Voordelta worden vastgesteld. Zwarte zee-eenden in Nederland zijn deel van de 'W Siberia \& N Europe/W Europe \& NW Africa' - populatie. De meest recente schatting van het aantal vogels in deze populatie is bij gebrek aan goede gegevens bepaald op $600.000-1.200 .000$ vogels (Wetlands International 2016). Ontwikkelingen in de belangrijkste overwinteringsgebieden ten noorden en zuiden van Nederland worden hier als referentie kort samengevat.

\section{Denemarken}

Informatie voor Denemarken is verkregen van Ib Krag Petersen (Aarhus University). De meest recente schatting van het aantal zwarte zee-eenden in Denemarken stamt uit 2008 en bedraagt ca. 600.000 vogels: ca. 400.000 in het Oostzeegebied van Denemarken en rond 200.000 near-shore op de Noordzee (Petersen \& Nielsen 2011). Er zijn ook tellingen gedaan in 2013 en 2016, maar men is nog niet klaar met het uitwerken en ruimtelijk modelleren van de beschikbare gegevens. Voor het Oostzeegebied was de telling in 2016 onderdeel van een gezamenlijke inspanning met Duitsland, Polen, Litouwen, Letland, Estland, Finland en Zweden. Het is de bedoeling deze gegevens te combineren voor een gezamenlijk ruimtelijk model voor onder andere zwarte zee-eend in het gebied, maar dit zal nog enige tijd vergen.

\section{Duitsland}

Informatie voor Duitsland is verkregen van Nele Markones (FTZ-Westküste, Chistian-AlbrechtsUniversität, Kiel). Op de Noordzee voor de kust van Schleswig-Holstein werden in februari 2016 c. 45.000 zwarte zee-eenden geteld, op minder dan 50\% van het totale oppervlak (Borkenhagen et al. 2016). Op grond hiervan concluderen de auteurs dat in het gebied afgelopen winter meer zwarte zeeeenden herbergde dan het gemiddelde winteraantal van 80.000 dat Garthe et al. (2007)) voor dit gebied berekenden voor de periode 1993-2006.

In het Nedersaksische deel van de Noordzee werden in februari 20164.100 zwarte zee-eenden geteld (N. Markones in e-mail). Dit is aanzienlijk lager dan het gemiddelde winteraantal van 52.000 dat Garthe et al. (2007) berekenden voor dit deel.

\section{België}

Informatie voor België is verkregen van Eric Stienen en Nicolas Vanermen (Instituut voor Natuur- en Bosonderzoek). Er zijn tellingen beschikbaar vanaf 1986. In de vorige eeuw werden geregeld maxima boven 10.000 zwarte zee-eenden geteld. In Tabel 6.6 zijn de maxima uit de periode waarin ook de monitoring voor PMR-NCV is uitgevoerd weergegeven. Hoewel de aantallen lijken te schommelen is er een langjarige afname zichtbaar. Het lijkt er in ieder geval niet op dat vogels die met name het laatste jaar niet in de Voordelta zaten naar België zijn uitgeweken. Wel worden tijdens scheepstellingen in de laatste jaren steeds vaker grotere groepen zee-eenden in het late voorjaar en de vroege zomer gezien (E. Stienen in e-mail). In het voorjaar van 2015 waren dat maximaal 2.000 (gegevens Koninklijk Belgisch Instituut voor Natuurwetenschappen, zie Fijn et al. (2016))), in 2017 werden in april bijna 6.000 en in mei bijna 7.000 zwarte zee-eenden geteld. 
Tabel 6.6

Maximaal getelde aantallen zwarte zee-eenden langs de Belgische kust vanaf 2005 (gegevens Instituut voor Natuur- en Bosonderzoek via Eric Stienen en Nicolas Vanermen).

\begin{tabular}{|l|l|}
\hline jaar & maximaal aantal \\
\hline $\mathbf{2 0 0 5}$ & 1018 \\
\hline $\mathbf{2 0 0 6}$ & 2517 \\
\hline $\mathbf{2 0 0 7}$ & 896 \\
\hline $\mathbf{2 0 0 8}$ & 2140 \\
\hline $\mathbf{2 0 1 0}$ & 351 \\
\hline $\mathbf{2 0 1 1}$ & 210 \\
\hline $\mathbf{2 0 1 2}$ & 184 \\
\hline $\mathbf{2 0 1 3}$ & 1905 \\
\hline $\mathbf{2 0 1 4}$ & 394 \\
\hline $\mathbf{2 0 1 5}$ & 444 \\
\hline $\mathbf{2 0 1 6}$ & 627 \\
\hline $\mathbf{2 0 1 7}$ & 6685 \\
\hline
\end{tabular}

Frankrijk

Voor Frankrijk zijn recente gegevens te vinden in jaarlijkse monitoringrapporten (Deceuninck et al. 2016, Gaudard et al. 2017). Zwarte zee-eenden worden verspreid langs de Franse kust aangetroffen, maar nauwelijks ten zuiden van de monding van de Gironde. In januari 2016 werden er 12.664 geteld, in januari 2015 was het totaal 17.312. Dit is nog ongeveer een kwart tot een derde van de aantallen rond 1990. In recente jaren wisselden de aantallen sterk: 2009: 21.750, 2010: 16.292, 2011: 24.780, 2012: 36.940, 2013: 27.225 en 2014: 31.932. Over een tijdschaal van de laatste decennia is er in Frankrijk een afname, maar vanaf 2009 is niet een duidelijke trend zichtbaar.

Samenvattend lijken de aantallen in andere landen op de flyway stabiel te zijn of licht af te nemen, waarbij steeds sterke fluctuaties tussen jaren zichtbaar zijn. Internationaal wordt gewerkt aan betere monitoring van de populatie als geheel. Daarbij is het verbeteren van modelberekeningen, waarbij met in achtneming van omgevingsvariabelen getelde aantallen worden geëxtrapoleerd naar gebiedstotalen, van groot belang.

\subsubsection{Conclusies}

\section{Deelconclusies}

- De maximale aantallen eenden zijn waargenomen in het voorjaar (apr/mei) van de T0; in de T1 zijn de maximale aantallen $19-95 \%$ (gemiddeld $70 \%$ ) lager.

- $E r$ is geen trendmatige verandering in het aantal vogeldagen over de periode 2004-2017, maar er zijn wel aanzienlijke verschillen tussen jaren.

- Het potentiële aantal eenden in de Voordelta (op basis van werkelijk beschikbaar voedsel) en rekening houdend met verstoring door scheepvaart, vertoont geen trendmatige verandering die samenhangt met de aanleg en aanwezigheid van Maasvlakte 2

- De Voordelta heeft een beperkt aandeel in de totale aantallen zwarte zee-eenden in Nederland. De aantalsontwikkeling in de Voordelta is niet afwijkend in vergelijking met overige gebieden in de Nederlandse kustzone

\subsection{De potentiële functie van de Voordelta en het instellen van de rustgebieden}

De derde deelvraag richt zich op het belang van de rustgebieden:

c) Draagt het instellen van rustgebieden, specifiek voor de zwarte zee-eend, bij aan een gelijkblijvende potentiële functie van de Voordelta als foerageer- en rustgebied?

i. Is de potentiële draagkracht van de Voordelta gelijk gebleven door het instellen van de rustgebieden? 
ii. Is er voldoende rust in de Voordelta om de draagkracht voor het gestelde aantal vogels in het instandhoudingsdoel te kunnen waarborgen?

De vierde deelvraag gaat over het effect van de aanpassing in de begrenzing van de rustgebieden (zie Hoofdstuk 1).

d) Is de aangepaste begrenzing van de extra rustgebieden vanuit PMR-NCV juist gekozen om bij te dragen aan het instandhoudingsdoel?

i. Worden de aangepaste rustgebieden gebruikt door de aanwezige zwarte zee-eenden? In welke periode houden zij zich hier op en welke ecologische functies vervullen de rustgebieden voor deze soort?

ii. Hoe is de verspreiding van de zwarte zee-eend in de Voordelta in de wintermaanden (oktobermaart) en daarbuiten (april-september) ${ }^{6}$ ?

\subsubsection{Gebruik rustgebieden}

In tabel 6.7 zijn de aantallen vogeldagen voor winterhalfjaar en voorjaar weergegeven voor de verschillende aangewezen rustgebieden en het overige gebied. In figuur 6.16 is het aantal vogeldagen in en buiten de rustgebieden weergegeven.

De rustgebieden zijn (mede) aangewezen op grond van de aanwezigheid van zee-eenden in de jaren vóór de aanwijzing. Dit is in tabel 6.7 te zien in de aantallen vogeldagen die in de T0 in de toen nog toekomstige rustgebieden werden vastgesteld (zie ook figuur 6.3). Figuur 6.17 maakt duidelijk dat een wezenlijk, maar tussen jaren sterk wisselend aantal en aandeel van de doorgebrachte vogeldagen in de rustgebieden is vastgesteld. Echter, gebieden buiten de rustgebieden zijn ook van grote betekenis voor de zwarte zee-eend: in de meeste jaren wordt meer dan $50 \%$ van de vogeldagen buiten de rustgebieden doorgebracht. Over het effect van de veranderde begrenzing van de rustgebieden in 2016 kunnen nog geen conclusies getrokken worden, omdat er pas van één monitorings-jaar na dat besluit gegevens zijn.

\footnotetext{
${ }^{6}$ De monitoring heeft in de meeste jaren plaats gevonden in de maanden oktober-mei. De verspreiding in de zomermaanden (juni-september) wordt daarom in dit rapport niet behandeld.
} 
Tabel 6.7

Totaal aantal vogeldagen in het winterhalfjaar en voorjaar voor de zwarte zee-eend in de Voordelta tijdens de T0 (2004-2006), de T1 (2009-2014) en de T2 (2015-2017). De rustgebieden 'Bollen van de Ooster' (BVO), 'Bollen van het Nieuwe Zand' (BVNZ), de 'Hinderplaat' (HIN), de 'Slikken van Voorne' (SV) en de 'Verklikkerplaat' (VK) worden onderscheiden. Alleen BVO en BVNZ zijn (mede) ingesteld als rustgebied voor de zwarte zee-eend, sinds 2008. Voor 2016-2017 zijn de veranderde begrenzingen van de rustgebieden aangehouden. Gegevens t/m 2014-2015 uit Fijn et al. (2016)).

\begin{tabular}{|c|c|c|c|c|c|c|c|c|}
\hline & oktober-maart & BVO & BVNZ & HIN & SV & VK & rest & Totaal \\
\hline \multirow[t]{2}{*}{ TO } & 2004-2005 & 15.463 & 14.644 & 1.135 & 0 & 0 & 96.850 & 128.092 \\
\hline & 2005-2006 & 39.366 & 9.381 & 10 & 0 & 0 & 171.956 & 220.713 \\
\hline \multirow[t]{6}{*}{ T1 } & 2009-2010 & 2.301 & 14.738 & 0 & 0 & 0 & 70.186 & 87.224 \\
\hline & 2010-2011 & 21.597 & 526 & 0 & 0 & 0 & 113.522 & 135.645 \\
\hline & 2011-2012 & 9.148 & 189 & 28 & 0 & 0 & 100.802 & 110.167 \\
\hline & 2012-2013 & 82.043 & 27.047 & 0 & 0 & 0 & 151.244 & 260.334 \\
\hline & 2013-2014 & 24.400 & 0 & 440 & 0 & 0 & 74.137 & 98.977 \\
\hline & 2014-2015 & 22.731 & 43 & 2.044 & 0 & 0 & 34.583 & 59.401 \\
\hline \multirow[t]{3}{*}{ T2 } & $2015 / 2016$ & 10.850 & 0 & 0 & 0 & 0 & 10.120 & 20.970 \\
\hline & $2016 / 2017$ & 6.941 & 24.510 & 0 & 0 & 0 & 72.814 & 104.265 \\
\hline & april-mei & BVo & BVNZ & HIN & sV & VK & rest & Totaal \\
\hline \multirow[t]{2}{*}{ TO } & 2004-2005 & 59.995 & 28.575 & 0 & 0 & 0 & 96.480 & 185.050 \\
\hline & 2005-2006 & 165.373 & 50.794 & 0 & 0 & 40.300 & 51.762 & 308.228 \\
\hline \multirow[t]{6}{*}{ T1 } & 2009-2010 & 568 & 0 & 0 & 0 & 0 & 91.014 & 91.582 \\
\hline & 2010-2011 & 1.256 & 770 & 0 & 0 & 0 & 172 & 2.198 \\
\hline & 2011-2012 & 0 & 0 & 0 & 0 & 0 & 100.538 & 100.538 \\
\hline & $2012-2013$ & 4.900 & 81 & 0 & 0 & 0 & 5.080 & 10.061 \\
\hline & 2013-2014 & 83.629 & 300 & 0 & 0 & 0 & 289.284 & 373.212 \\
\hline & 2014-2015 & 0 & 0 & 0 & 0 & 0 & 2.057 & 2.057 \\
\hline \multirow[t]{2}{*}{ T2 } & $2015 / 2016$ & 522 & 0 & 0 & 0 & 0 & 748 & 1.270 \\
\hline & $2016 / 2017$ & 38 & 30 & 0 & 0 & 0 & 38.234 & 38.301 \\
\hline
\end{tabular}




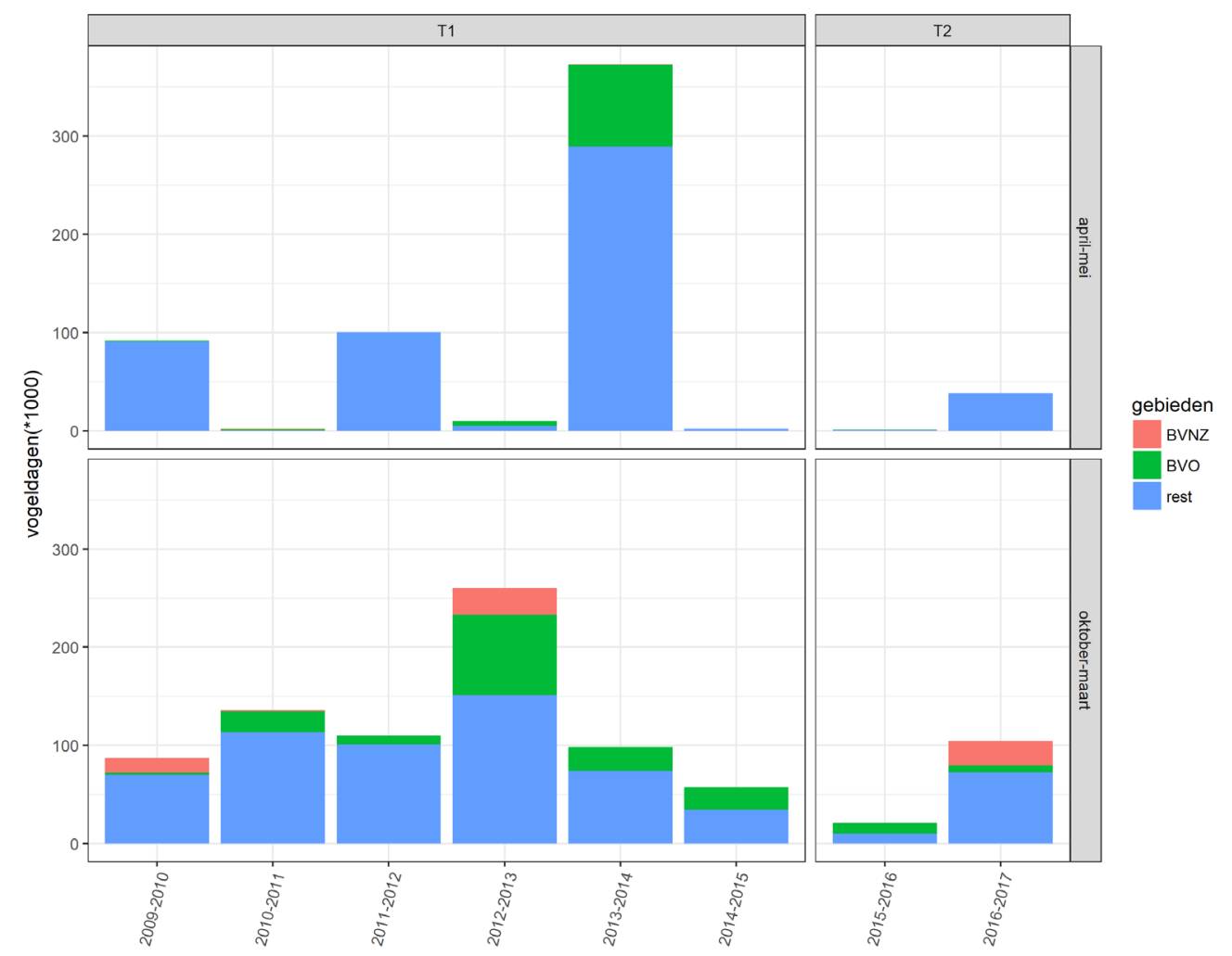

Figuur 6.16 Aantal vogeldagen binnen de rustgebieden Bollen van het Nieuwe Zand (BVNZ) en Bollen van de Ooster (BVO) en in de rest van de Voordelta, in het winterhalfjaar oktober-maart en in het voorjaar april-mei, in absolute aantallen. NB In de $\mathrm{T}_{0}$ waren er nog geen rustgebieden.

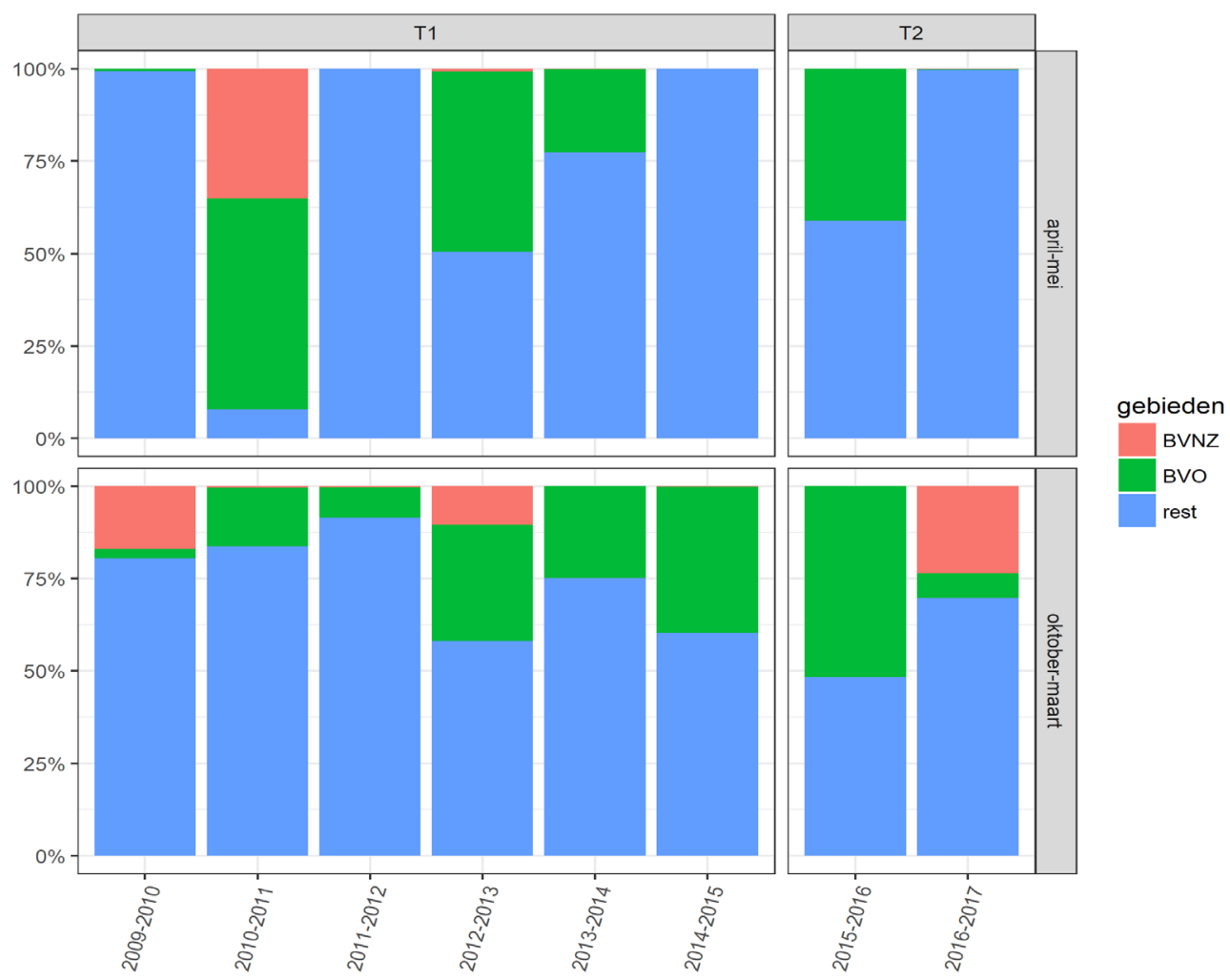

Figuur 6.17 Procentuele verdeling van de vogeldagen binnen de rustgebieden Bollen van het Nieuwe Zand (BVNZ) en Bollen van de Ooster (BVO) en in de rest van de Voordelta, in het winterhalfjaar oktober-maart en in het voorjaar april-mei. NB In de TO waren er nog geen rustgebieden. 

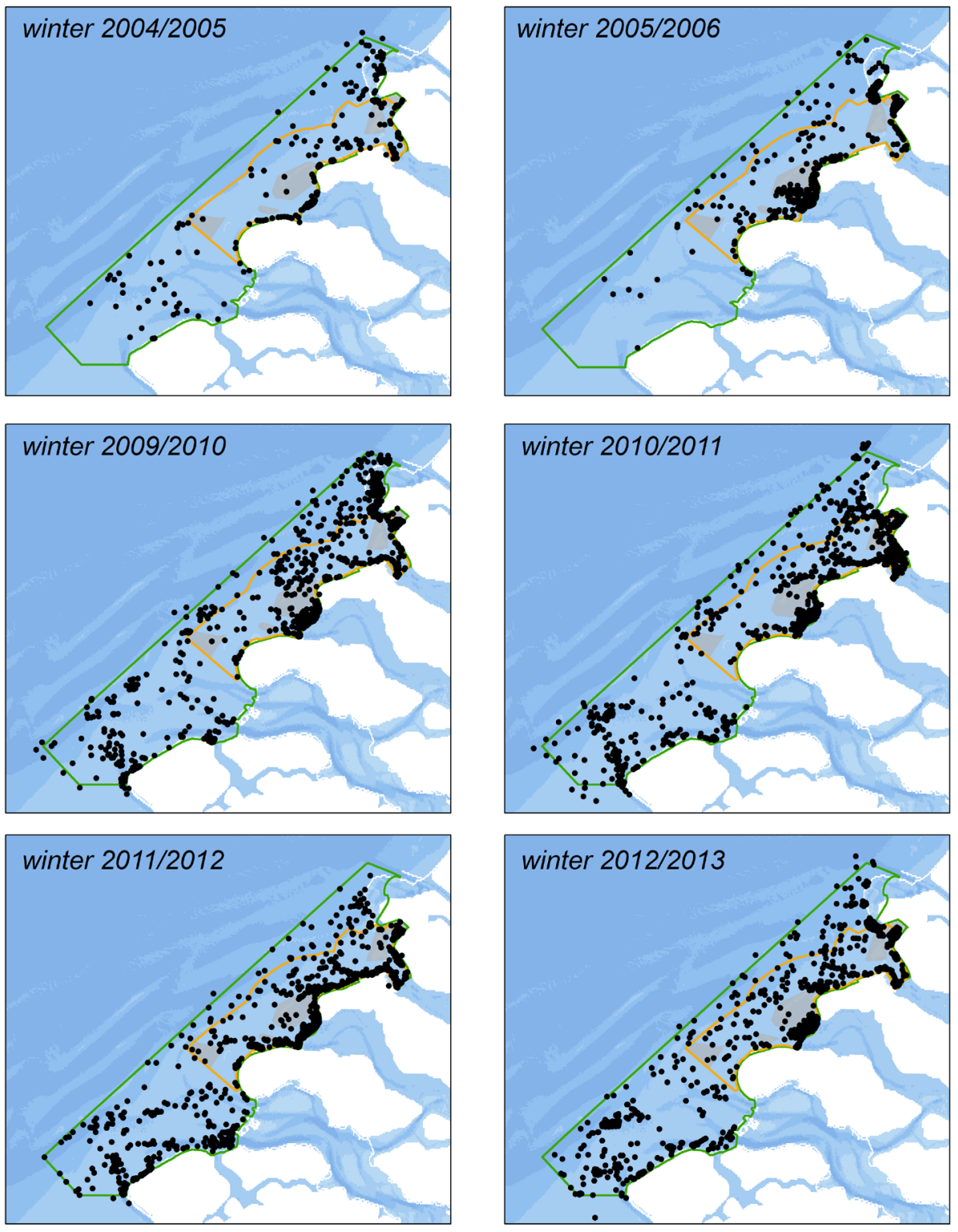

\section{Status}

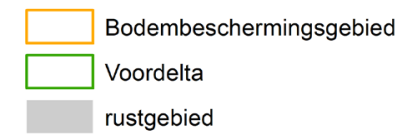

Figuur 6.18 Verstoringsbronnen in het winterhalfjaar van 2004/2005 - 2005/2006 en 2009/2010 tot en met 2012/2014 vastgesteld door middel van waarnemingen uit vliegtuig en af van de kust (Seegers et al. 2014).

In de jaren 2009-2013 zijn gegevens verzameld over de mate waarin er menselijke activiteiten met een mogelijk verstorend effect in de Voordelta plaatsvinden. In figuur 6.18 (alle tijdens gerichte landen vliegtuigwaarnemingen waargenomen activiteiten) en figuur 6.19 (schepen met AIS) is hiervan een weerslag te vinden. Voor schepen met AIS lijkt te gelden dat zij zich in belangrijke mate buiten de rustgebieden ophouden. Hierbij moet worden opgemerkt dat de kaarten in figuur 6.19 een gemiddeld beeld geven over het winterhalfjaar. De kaarten in figuur 6.18 geven een wat ander beeld: er worden, ook in de winter, in sommige delen van de Voordelta inclusief delen van rustgebieden, geregeld menselijke activiteiten vastgesteld. Dit betreft vooral kitesurfers bij de Bollen van de Ooster (Seegers et al. 2014). De AIS data geven dus niet een volledig beeld van de mogelijke verstoring van zwarte zee-eenden.

In het lopende project zal in 2018 wederom een analyse gedaan worden met gebruik van AIS-data, die nu wel in tijd en ruimte veel specifieker zullen kunnen worden benaderd. 

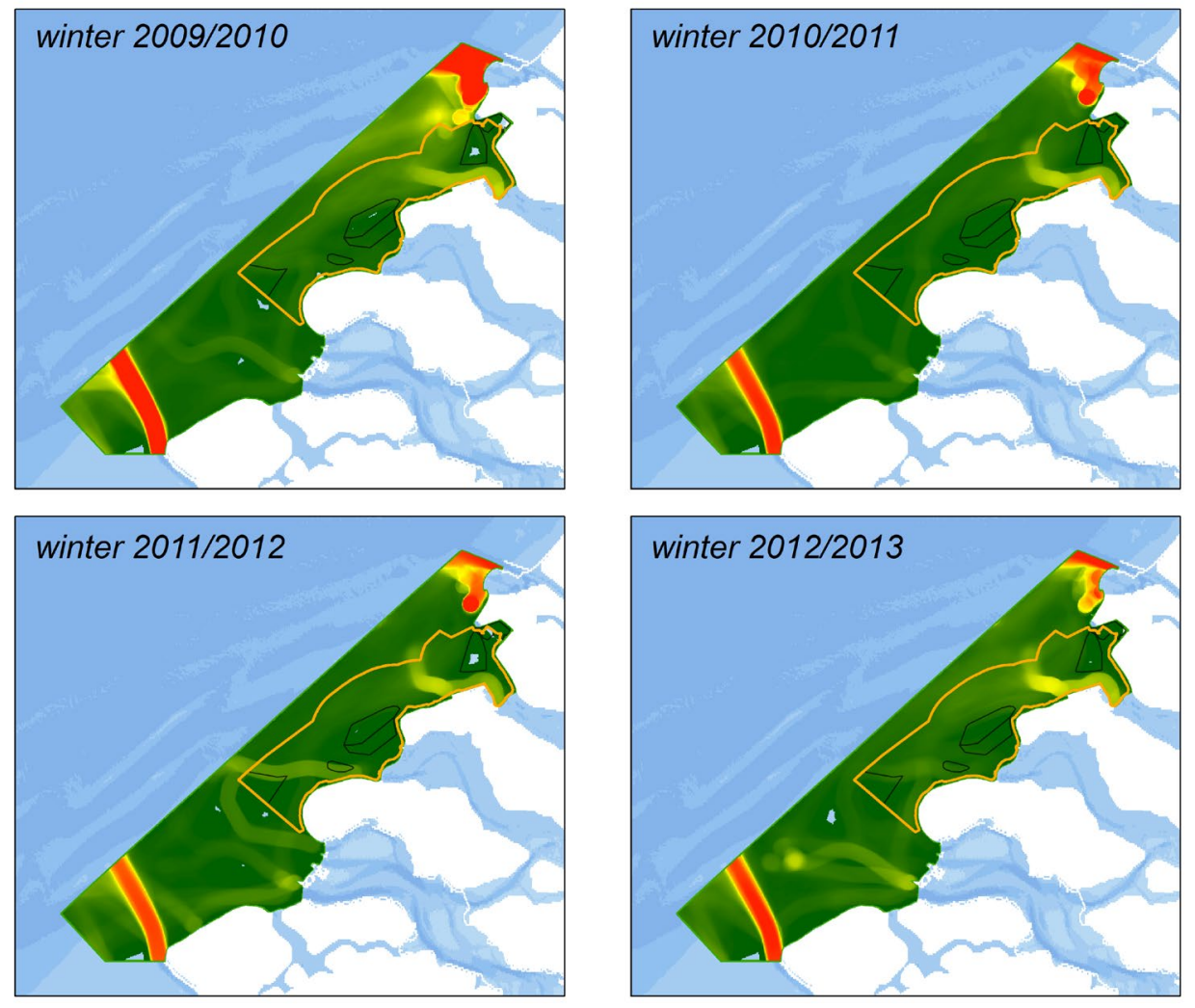

$\square$ Bodembeschermingsgebied
$\square \quad$ rustgebied

verstoring (uur/24uur)

High : 23,1839

Low : 0

Figuur 6.19 Gemiddelde verstoring in het winterhalfjaar 2009/2010-2012/2013 op basis van AIS data uitgedrukt in uur verstoord per 24 uur voor het gehele halfjaar (Seegers et al. 2014)

\subsubsection{Conclusies}

\section{Deelconclusies}

- Zee-eenden worden ook buiten de rustgebieden waargenomen

- Er kunnen nog geen duidelijke verschuivingen in aantal of ruimtegebruik worden vastgesteld die samenhangen met wijzigingen in de begrenzing van de rustgebieden in 2016.

- Rustgebieden zijn niet geheel vrij van verstoring; de mate waarin verstoring door scheepvaart optreedt wordt in 2018 nader onderzocht.

\subsection{Discussie}

In dit hoofdstuk zijn de verschillende onderzoeksvragen behandeld, zoals die in het monitoringsplan zijn afgeleid van de centrale MEP-vraag: Wordt het verlies aan foerageergebied van de zwarte zeeeend als gevolg van de aanleg en het gebruik van Maasvlakte 2 voldoende gecompenseerd?

De eerste deelvraag (a) vraagt om een nadere beschouwing van het feitelijke verlies van foerageergebied voor de zwarte zee-eend, veroorzaakt door de aanleg en het gebruik van Maasvlakte 2. Alle beschikbare gegevens (zie §6.3.2) leiden tot de eenduidige conclusie dat het gebied waarin de 
Maasvlakte 2 is aangelegd, in de periode waarvoor gegevens beschikbaar zijn (vanaf 1975) nooit van enige betekenis is geweest voor de zwarte zee-eend.

De tweede deelvraag (b) richt zich op de bijdrage van het bodembeschermingsgebied: heeft de instelling van dat gebied geleid tot een gelijkblijvende (potentiële) functie van het gebied voor zwarte zee-eenden, in termen van voedselbeschikbaarheid. De derde (c) en vierde (d) deelvraag gaan over de bijdrage van het instellen van de rustgebieden en de recente aanpassing van begrenzingen aan het verzekeren van voldoende rust (afwezigheid van verstoring) voor de zwarte zee-eend. Voor deze drie deelvragen zijn op twee manieren gegevens en resultaten gegenereerd: via monitoring in het veld van werkelijke aantallen (tellingen van zee-eenden en bemonstering benthos) en door het ontwikkelen van een draagkrachtmodel voor het schatten van de potentiële functie van de Voordelta.

Deelvraag b richt zich op de potentiële functie van de Voordelta in termen van voedselbeschikbaarheid. De monitoring in het veld laat sterk wisselende, maar over langere termijn geleidelijk afnemende, maximale aantallen zwarte zee-eenden in de Voordelta als geheel zien. De maxima zijn de laatste monitorings-jaren minder dan $20 \%$ van de maxima in de T0. Het aantal vogeldagen is echter een betere indicator voor het gebruik van het gebied omdat die een geïntegreerd beeld voor de gehele winter en voorjaar geven. Het aantal vogeldagen is in het voorjaar, met uitzondering van 2014, gedaald, maar in het winterhalfjaar is er geen sprake van een duidelijke afname.

Gegevens uit het verleden laten zien dat de Voordelta van belang was voor zwarte zee-eenden. Tussen 1975-1980 werden gemiddelde wintermaxima geteld van zo'n 15.000, en maximale aantallen tot 28.000 zwarte zee-eenden in de maanden december-maart (Baptist \& Meininger 1996). In de jaren tachtig en begin jaren negentig waren de aantallen lager met maxima tussen 2.000-10.000, met uitzonderlijk hoge aantallen in koude winters (Baptist \& Meininger 1996).

De aantallen tijdens midwintertellingen in de Voordelta tussen 1990-2006 waren sterk wisselend met maximaal zo'n 9.000 vogels (2003). In het vroege voorjaar werden gemiddeld de hoogste aantallen waargenomen, met maxima tot 25.000 in april 2002 (Berrevoets et al. 2002, Berrevoets \& Arts 2003, Hoekstein \& Lilipaly 2003), (Berrevoets et al. 2005).

De aantallen zwarte zee-eenden in de Voordelta kunnen sterk variëren als gevolg van uitwisseling met de kustgebieden van de Waddeneilanden, België en noord -Frankrijk, de Theems-monding, en jaarlijks wisselende migratie vanuit de noordelijke gebieden als de Duitse en Deense kustwateren (Leopold et al. 1995, Seys 2001). Er is geen verband gevonden tussen aantallen zwarte zee-eenden in de Voordelta en het al of niet optreden van strenge winters in Nederland (Berrevoets et al. 2002).

Hoewel er verschillende soorten schelpdieren in voor zee-eenden geschikte maten zijn aangetroffen in de monitoringperiode van PMR-NCV, bestaat in de praktijk de afgelopen jaren het voedselaanbod vrijwel uitsluitend uit Ensis. De totale hoeveelheid voedsel op bereikbare diepte $(<15 \mathrm{~m})$ is in de meeste jaren van T1-T2 lager dan in de T0. Of dat betekent dat ook de beschikbaarheid van geschikt voedsel minder is, is lastig te zeggen. Ensis ligt relatief verspreid, en het zou kunnen dat een relatief geringe afname in dichtheid gevolgen heeft voor de foerageerefficiëntie en daarmee voor de aantrekkelijkheid als prooi. De recente opkomst van een bank van Spisula subtruncata ten zuidwesten van Maasvlakte 2 heeft geleid tot een relatief grote geconcentreerde groep zwarte zeeeenden in 2016/2017 in dit deel van de Voordelta, wat er op lijkt te wijzen dat wanneer er keuze is, de zee-eenden de voorkeur geven aan Spisula-banken

Er is een draagkrachtmodel ontwikkeld voor de zwarte zee-eend. Dit model is gebaseerd op een model dat is ontwikkeld voor toepassingen voor de eidereend in de Waddenzee (Brinkman et al. 2003). Bij de ontwikkeling van dit eidereend model is intensief gebruik gemaakt van eerder onderzoek aan kuif- en toppereenden (de Leeuw 1997)). Op basis van berekeningen van de energiehuishouding van de zwarte zee-eend, kan met het model een schatting gemaakt worden van de potentiële draagkracht van de Voordelta voor zwarte zee-eenden, uitgaande van lokale omstandigheden zoals voedselaanbod, fysische factoren zoals temperatuur, diepte en stroomsnelheid en gebruik makend van aannames over het verstorende effect van scheepvaart.

De ontwikkeling van het model is gestart na afronding van de $1^{\mathrm{e}}$ fase van PMR-NCV waarin alleen tellingen van zee-eenden in de Voordelta zijn uitgevoerd. De aanleiding was de constatering dat het waarschijnlijk is dat factoren buiten de Voordelta in belangrijke mate bepalend zijn voor het feit of de 
eenden in grote aantallen in het gebied verblijven in winter en voorjaar. Dat betekent dat de werkelijk waargenomen aantallen eenden in de Voordelta niet indicatief hoeven te zijn voor de mate waarin de compensatiemaatregelen bijdragen aan de compensatie voor het verlies van foerageergebied van de zwarte zee-eend als gevolg van aanleg en aanwezigheid van Maasvlakte2. Ook de Auditcommissie heeft in haar commentaar op het eindrapport van Fase 1 gepleit voor het opzetten van een draagkrachtmodel om de potentiële aantallen zwarte zee-eenden in de Voordelta te schatten (Prins et al. 2014c)).

Een belangrijk punt bij het opzetten van het model is dat er voor veel aspecten van het foerageergedrag van de zwarte zee-eend een gebrek aan kennis is, en er noodgedwongen aannames gedaan moeten worden. Die aannames leiden tot onzekerheid in de juistheid van de hier gepresenteerde resultaten, waarbij er deels sprake kan zijn van een mogelijke overschatting van de potentiële aantallen eenden maar deels ook van een onderschatting. Het betreft hier onder meer aspecten als het voedselaanbod, gedrag en verstoring, en met name het foerageren onder water. Het ontbreekt aan kennis over het aantal prooien dat per duik gevangen wordt, het vangstsucces en hoe met aanbod van verschillende typen prooien wordt omgegaan.

In de uitgevoerde berekeningen met de Amerikaanse zwaardschede als voedsel, is er van uitgegaan dat per duik één prooi wordt gevangen. Voor de halfgeknotte strandschelp daarentegen is uitgegaan van vijf prooien per duik. Dit is een versimpeling bij gebrek aan meer specifieke kennis. Het is waarschijnlijk dat het vangstsucces en het aantal prooien per duik afhangt van de dichtheid van de schelpdieren. De aanname over het verschil in aantal prooien per duik tussen de twee soorten schelpdieren is gebaseerd op de veronderstelling dat het vangen, hanteren en inslikken van de langgerekte schelp van de zwaardschede lastiger is dan het geval is bij de kleinere strandschelp. Kennis over de verschillen in succes bij het vangen van prooien van verschillende soorten ontbreekt. Van de Amerikaanse zwaardschede is bekend dat dit een mobiele soort is die zich snel in het sediment kan terugtrekken. Er zijn daarentegen ook omstandigheden waarbij deze soort een makkelijk beschikbare prooi vormt. In het kader van dit project zijn in januari t/m maart 2012 waarnemingen door duikers gedaan op zee-eend locaties in de Voordelta (Prins \& Van der Kolff 2014, Prins et al. 2014c). Daarbij werden grote aantallen schelpen van de Amerikaanse zwaardschede waargenomen die uit het sediment staken of op het sediment lagen, met de schelp open en het vlees zichtbaar. In veel gevallen hing het vlees deels uit de schelp of lag het vlees los op de bodem. Onbekend is in welke mate deze prooien van belang zijn, wel is in het gebied bij de Brouwersdam waargenomen dat zwarte zee-eenden met grote Ensis (zonder schelp) als prooi boven water kwamen (Prins \& Van der Kolff 2014, Prins et al. 2014c).

Uit waarnemingen in de Voordelta in 2012 kwam naar voren dat zee-eenden in de helft van de gevallen met een prooi (al dan niet ingeslikt) boven water kwamen (figuur 4.14 in (Prins et al. 2014c)). Voor de andere helft van de duiken is onbekend of een of meer prooien al onder water waren ingeslikt of dat er sprake was van een niet succesvolle duik.

Het model houdt geen rekening met sterfte van prooien anders dan de predatie door de eenden. Echter, wintersterfte van Ensis spp. komt voor, maar het is onduidelijk hoe vaak dit voorkomt en wat dit in kwantitatieve zin betekent voor de beschikbaarheid van voedsel voor zee-eenden. Daarnaast is in de modelberekeningen uitgegaan van één prooisoort, waarmee het beschikbare voedsel waarschijnlijk is onderschat, omdat verondersteld kan worden dat de zee-eenden omschakelen tussen verschillende prooisoorten afhankelijk van beschikbaarheid.

In het model is rekening gehouden met effect van omgevingsfactoren zoals stroming, die er toe kunnen leiden dat eenden afdrijven van de foerageerlocatie en weer terug moeten vliegen. Dit soort verplaatsingen is bij waarnemingen in het gebied bij de Brouwersdam inderdaad vastgesteld. Bij gebrek aan kwantitatieve veldwaarnemingen is het niet eenvoudig te bepalen of het model het aantal verplaatsingen over- of onderschat, Voor het effect van menselijke verstoring is in de modelberekeningen alleen rekening gehouden met scheepvaart, op basis van een verstoringsfrequentie die gemiddeld is over de hele periode septemberapril. In die gegevens is geen rekening gehouden met de mogelijkheid dat scheepvaart slechts in een deel van die periode voorkomt in plaats van regelmatig gespreid in de tijd. De garnalenvisserij bijvoorbeeld is vooral geconcentreerd in het najaar en de vroege winter en minder actief aan het eind van de winter en het vroege voorjaar (Hoofdstuk 4). In 2018 is een meer gedetailleerde analyse voorzien van de relaties tussen het voorkomen van scheepvaart en tellingen van zwarte zee-eenden in de Voordelta. 
In de modelbenadering is evenmin rekening gehouden met gedragsaspecten. Denkbaar is dat dichtheidsafhankelijke relaties van belang zijn voor interacties tussen zwarte zee-eenden. Bekend is dat zwarte zee-eenden in groepen voorkomen en groepsgewijs foerageren (paragraaf 4.3.3 in Prins et al. 2014c). Dit is in de modelresultaten verdisconteerd door alleen groepen van meer dan 100 eenden per gridcel mee te laten tellen, en ook door de latere clustering van gridcellen in grotere aaneengesloten oppervlakken. Dit geeft een beeld waar in de Voordelta, volgens de modelresultaten, grotere groepen eenden kunnen verblijven. De potentiële dichtheden van zwarte zee-eenden die het model voorspelt zijn niet onrealistisch, maar het is onbekend wat een realistische bovengrens voor het aantal eenden in de Voordelta is, gegeven de hoeveelheden en dichtheden van het beschikbare voedsel en verstoring. De hoogste aantallen die ooit in de Voordelta zijn waargenomen, lagen in de orde van 20-30.000. Dit wijst er mogelijk op, dat processen die niet in het draagkrachtmodel zijn opgenomen (zoals bijvoorbeeld de keuze tussen verschillende overwinteringsgebieden op een grote ruimtelijke schaal), van invloed kunnen zijn op de maximale aantallen eenden in de Voordelta. Berekende potentiële aantallen die veel hoger zijn dan die 20-30.000 geven derhalve wel een schatting van de potentie van de Voordelta op basis van het voedselaanbod, maar niet noodzakelijkerwijs een voorspelling van werkelijk optredende maximale aantallen omdat die ook door processen buiten de Voordelta beïnvloed worden.

Uit de modelresultaten blijkt, dat gegeven de omstandigheden (voedsel, verstoring, abiotische omstandigheden), er geen aanwijzingen zijn dat de potentiële functie van de Voordelta als foerageeren rustgebied is verslechterd sinds de aanleg van Maasvlakte2. De jaarlijkse fluctuaties in het voedselaanbod leiden tot grote jaarlijkse verschillen in potentiële aantallen eenden maar zonder duidelijke trend. Er is ook geen aanwijzing dat een te laag voedselaanbod het behalen van het instandhoudingsdoel onmogelijk maakt. Ook het feit dat er nooit op grote schaal wintersterfte is opgetreden, en het feit dat gebieden met geschikt voedsel niet altijd benut worden door de eenden (bijvoorbeeld hoge dichtheden van de halfgeknotte strandschelp voor de Noord-Hollandse kust in 2016/2017; (Fijn et al. 2017a)) wijst in deze richting. De waarnemingen van het aantal zwarte zeeeenden in de Voordelta laten zien dat er geen significante afname is opgetreden in het aantal vogeldagen, sinds de aanleg van Maasvlakte 2 . Er is evenmin een trendbreuk in het relatieve aandeel van de Voordelta ten opzichte van de andere delen van de Nederlandse kustwateren. De daling in het aantal eenden in de Voordelta ten opzichte van waarnemingen van decennia geleden, lijken onderdeel van een trend die ook elders in Nederland en langs de kust van Frankrijk en België is waargenomen.

De deelvragen $c$ en $d$ hebben betrekking op de functie van de rustgebieden. De eenden verblijven deels in de aangewezen rustgebieden, maar altijd wordt in die gebieden minder dan 50\% van het totale aantal vogeldagen doorgebracht. Uit statistische analyses (Prins et al. 2014b, Zuur et al. 2014) komt naar voren dat naast voedsel en waterdiepte ook verstoring (rust) een belangrijke factor is. De resultaten van het draagkrachtmodel geven ook aan dat verstoring van invloed is op het potentiële aantal eenden in de Voordelta, alhoewel minder doorslaggevend dan de hoeveelheid voedsel.

\subsection{Conclusies}

a) Hoeveel potentieel foerageergebied is er daadwerkelijk verloren gegaan a.g.v. het ruimtebeslag van MV2, de ontwikkeling van de erosiekuil en het gebruik van MV2? Waarnemingen van zwarte zee-eenden in de Voordelta uit de jaren sinds 1973, gegevens van het voedselaanbod en de resultaten van het draagkrachtmodel geven aan dat het gebied waarin de Maasvlakte 2 is aangelegd geen rol speelt als foerageer- en verblijfgebied voor de zwarte zeeeend.

b) Leidt het instellen van het bodembeschermingsgebied tot een gelijkblijvende potentiële functie van de Voordelta voor de zwarte zee-eend in termen van voedselbeschikbaarheid?

Waarnemingen van het aantal vogeldagen van zwarte zee-eenden in de Voordelta sinds 2004/2005, en de resultaten van het draagkrachtmodel laten zien dat er geen verandering is in de potentiële functie van de Voordelta als foerageergebied, sinds de aanleg van Maasvlakte 2. 
c) Draagt het instellen van rustgebieden, specifiek voor de zwarte zee-eend, bij aan een gelijkblijvende potentiële functie van de Voordelta als foerageer- en rustgebied?

Uit statistische analyse van de waarnemingen blijkt dat verstoring een belangrijke verklarende factor is voor de ruimtelijke verspreiding van de zwarte zee-eend in de Voordelta. Ook uit de draagkrachtmodellering blijkt dat verstoring een effect heeft op de potentiële aantallen eenden in de Voordelta. Of de aantallen zee-eenden in de Voordelta lager zouden zijn zonder rustgebieden, kan op basis van de waarnemingen en de modelresultaten echter niet onderbouwd worden.

d) Is de aangepaste begrenzing van de extra rustgebieden vanuit PMR-NCV juist gekozen om bij te dragen aan het instandhoudingsdoel?

Er zijn slechts van 1 jaar na de verandering van de begrenzing waarnemingen beschikbaar, zodat er nog onvoldoende basis is om conclusies te trekken over het effect van die verandering. 


\section{$7 \quad$ Grote stern en visdief}

R. Fijn 1 , W. Courtens ${ }^{2}$, E. Stienen ${ }^{2}$, I. Tulp 3

${ }^{1}$ Bureau Waardenburg, 2 Instituut voor Natuur- en Bosonderzoek, ${ }^{3}$ Wageningen Marine Research

\subsection{Onderzoeksvragen}

Hieronder worden per paragraaf de MEP onderzoeksvragen uit het monitoringsplan (Tulp et al. 2015b) op een rijtje gezet. Elke vraag zal inhoudelijk behandeld worden aan de hand van de onderzoeksresultaten uit de periode 2005-2017. In de paragrafen 7.3-7.5 komt de grote stern aan bod en in de paragrafen 7.6-7.8 de visdief.

De volgende twee MEP vragen staan centraal:

3) Wordt het verlies aan foerageergebied van de grote stern als gevolg van het ruimtebeslag en het gebruik van Maasvlakte 2 voldoende gecompenseerd?

4) Wordt het verlies aan foerageergebied van de visdief als gevolg van het ruimtebeslag en het gebruik van Maasvlakte 2 voldoende gecompenseerd?

Voor de grote stern zijn de volgende deelvragen geformuleerd:

a) Hoeveel potentieel foerageergebied is er voor de grote stern daadwerkelijk verloren gegaan a.g.v. het ruimtebeslag en het gebruik van MV2?

i. Wat is op basis van voortschrijdend inzicht de betekenis van het gebied dat door de aanleg van Maasvlakte 2 verloren is gegaan in vergelijking met het nieuwe kustgebied na aanleg van Maasvlakte 2?

ii. Hoe is, op basis van voortschrijdend inzicht, het effect van de aanleg en het gebruik van Maasvlakte 2 op het instandhoudingsdoel voor deze soort te beoordelen?

b) Leidt het instellen van het bodembeschermingsgebied tot een gelijkblijvende potentiële functie van de Voordelta voor de grote stern in termen van voedselbeschikbaarheid?

i. Treden veranderingen op in broedsucces, het voedsel, de verspreidingspatronen en het aantal vogeldagen van de grote stern t.o.v. de situatie vóór de aanleg van Maasvlakte 2?

ii. Zijn deze veranderingen toe te schrijven aan (veranderingen in) de voedselbeschikbaarheid of zijn andere factoren van (groter) belang?

iii. Is er een causaal verband tussen de verschillende vormen van bodemberoerende visserij en de aanwezigheid en dichtheid van zandspiering in de Voordelta. Zandspiering lijkt een belangrijke voedselbron te zijn voor de grote stern.

c) Draagt het instellen van de rustgebieden bij aan het verbeteren van het potentiële functioneren van de Voordelta?

i. Worden de droogvallende platen in de rustgebieden gebruikt door de aanwezige grote sterns? En in welke periode houden zij zich hier op?

ii. Wat is het relatieve belang van de Voordelta voor de grote stern, welke factoren spelen daarbij een rol en wat is de jaar tot jaar variantie en zijn hierin grote veranderingen waarneembaar?

Voor de visdief zijn de volgende deelvragen geformuleerd:

a) Hoeveel potentieel foerageergebied is er voor de visdief daadwerkelijk verloren gegaan a.g.v. het ruimtebeslag en het gebruik van MV2?

i. Wat is op basis van voortschrijdend inzicht de betekenis van het gebied dat door de aanleg van Maasvlakte 2 verloren is gegaan in vergelijking met het nieuwe kustgebied na aanleg van Maasvlakte 2?

ii. Hoe is, op basis van voortschrijdend inzicht, het effect van de aanleg en het gebruik van Maasvlakte 2 op het instandhoudingsdoel voor deze soort te beoordelen? 
b) Leidt het instellen van het bodembeschermingsgebied tot een gelijkblijvende potentiële functie van de Voordelta voor de visdief in termen van voedselbeschikbaarheid?

i. Treden veranderingen op in broedsucces, het voedsel, de verspreidingspatronen en het aantal vogeldagen van de visdief in de Voordelta t.o.v. de situatie vóór de aanleg van Maasvlakte 2? Het gaat hierbij om inzicht in het functioneren van de gehele Voordelta voor deze soort.

ii. Zijn deze veranderingen toe te schrijven aan (veranderingen in) de voedselbeschikbaarheid of zijn andere factoren van (groter) belang?

c) Draagt het instellen van de rustgebieden bij aan het potentiële functioneren van de Voordelta?

i. Worden de platen in de rustgebieden gebruikt door de aanwezige visdieven? In welke periode houden zij zich hier op en wat is de functie van de aanwezigheid van droogvallende platen?

ii. Hoe is de verspreiding van de visdief in de Voordelta in relatie tot het ecologisch ruimtegebruik en zijn hierin grote veranderingen waarneembaar?

In onderstaand schema zijn de belangrijkste relaties met betrekking tot sterns in de Voordelta op hoofdlijnen weergegeven.

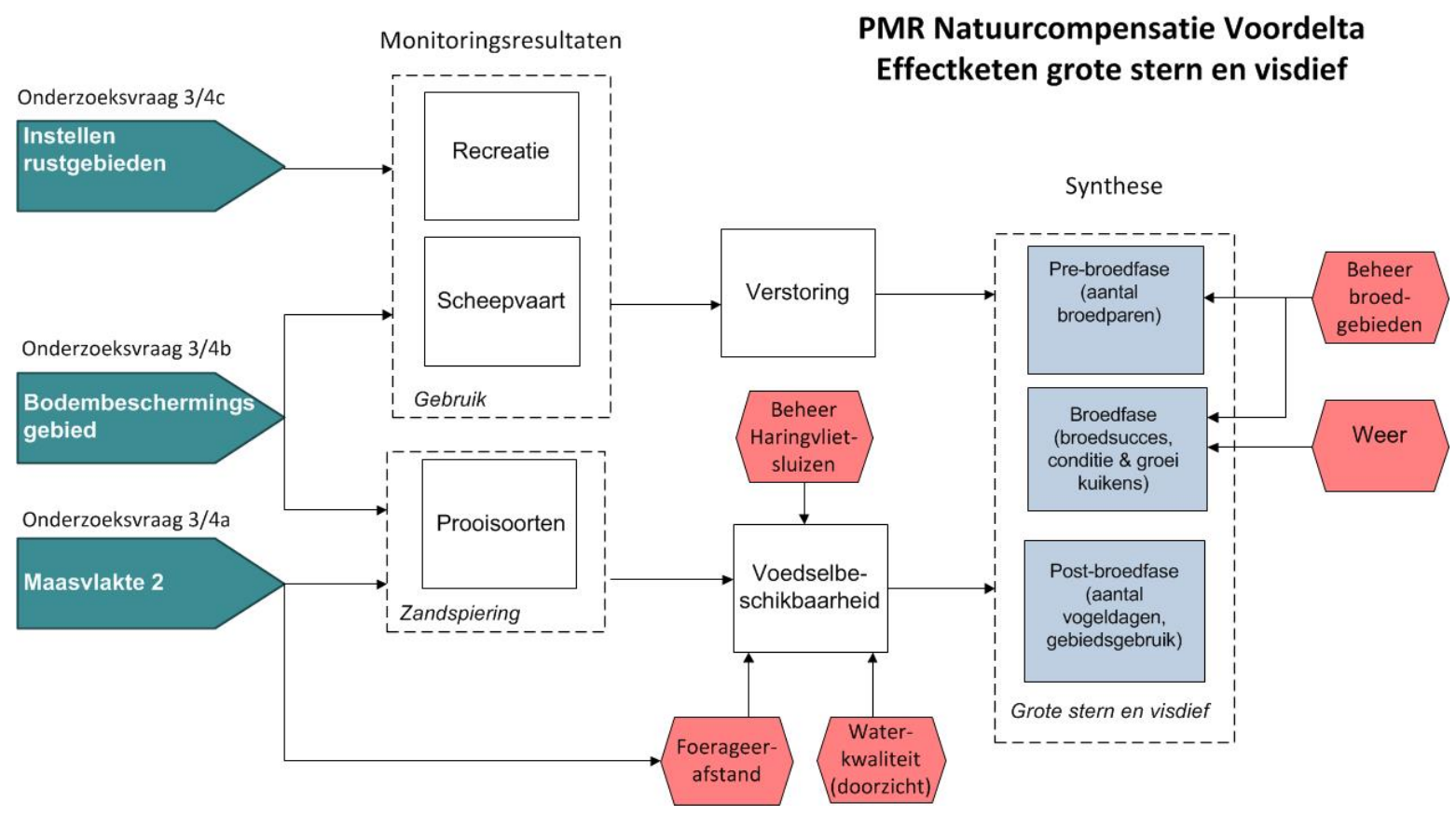

De onderzoeksactiviteiten worden beschreven in hoofdstuk 2. De analyses worden in de volgende paragrafen heel kort toegelicht. Voor uitgebreidere beschrijvingen verwijzen we naar Poot et al. (2014)). Ter verduidelijking van alle geografische termen geven we hier onder een overzichtskaart (figuur 7.1). 


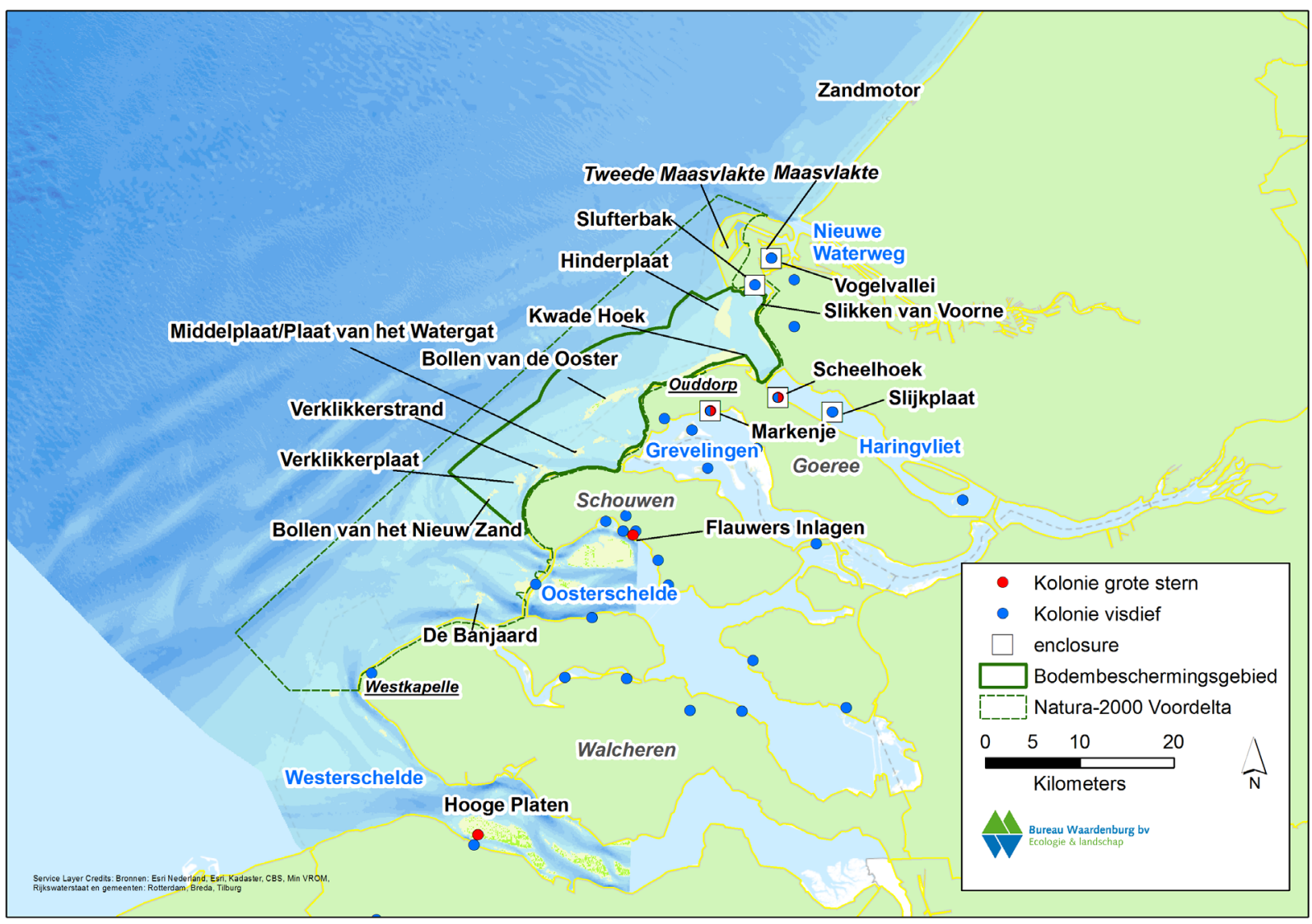

Figuur 7.1. Overzichtskaart van de Voordelta met de in dit hoofdstuk gebruikte locaties.

\subsection{Korte beschrijving van uitgevoerde monitoring en onderzoek}

De ontwikkelingen (aantallen, gebiedsgebruik, verspreiding) van grote stern en visdief in de Voordelta zijn onderzocht door middel van vliegtuigtellingen, zenderwerk en landwaarnemingen. Daarnaast is er vanaf 2009 broedbiologisch onderzoek uitgevoerd in diverse kolonies (Scheelhoek en de Slijkplaat in het Haringvliet, Markenje in de Grevelingen, afhankelijk van de vestiging van grote sterns en de onderzoeksmogelijkheden). Onderzoek aan de visdief is uitgevoerd in diverse kolonies in Haringvliet, Grevelingen, op de Maasvlakte en op het visdiefeiland in de Slufter.

Vanuit schuilhutten is vastgelegd wat er aan prooien werd meebracht voor de jongen en uit faeces is het dieet van de adulten onderzocht. Gedurende het onderzoek werden seizoensgebonden en jaarlijkse veranderingen in de samenstelling van het voedsel van zowel oudervogels (grote stern) als kuikens (grote stern, visdief) gemeten, en de effecten daarvan op de groei en overleving van de kuikens en het foerageergedrag van oudervogels. Dieet, groei en foerageergedrag zijn vergeleken tussen de deltakolonies en een referentiekolonie (Zeebrugge).

Het broedsucces van grote stern en visdief werd bepaald door onderzoek in enclosures in een aantal kolonies van de legselgrootte, de conditie van kuikens en het aantal vliegvlugge jongen, die indicatief kunnen zijn voor de relatie met voedselbeschikbaarheid. Er zijn geen systematische directe metingen aan voedselbeschikbaarheid op zee gedaan. Informatie over de voedselsituatie is afgeleid uit de aangebrachte prooien en het dieetonderzoek.

Gegevens van veldwaarnemingen (landwaarnemingen en luchtwaarnemingen) zijn gebruikt om het gebiedsgebruik rond de ingestelde rustgebieden in beeld te brengen. In kaarten is het waargenomen gebruik ruimtelijk weergegeven, waarbij vooral het plaatbezoek een belangrijke verstoring vormt voor sterns. De resultaten van de vliegtuigtellingen zijn gebruikt om te onderzoeken of er indicaties zijn van toenemende verstoring van de vogels in de rustgebieden.

Voor verdere details omtrent de gebruikte veld- en analysemethodes verwijzen we naar Poot et al. (2014)). 


\subsection{Het verdwijnen van het Maasvlakte 2 gebied: consequenties voor grote stern}

De eerste deelvraag van de MEP vraag richt zich op de betekenis van het kustgebied dat door aanleg van Maasvlakte 2 is verdwenen, als foerageergebied voor de grote stern

a) Hoe is, op basis van voortschrijdend inzicht, de inschatting van het effect van de aanleg van Maasvlakte 2 op het instandhoudingsdoel voor deze soort?

i. Wat was, in kwalitatieve termen, de betekenis van het verdwenen foerageergebied.

ii. Wat is, in kwalitatieve termen, de betekenis van het nieuwe kustgebied na aanleg van Maasvlakte 2

Tijdens de nulmeting, en de eerste en tweede fase van de PMR-NCV monitoring zijn tussen 2005 en 2017 vliegtuigtellingen uitgevoerd boven de Voordelta. Aan de hand van de waarnemingen tijdens deze tellingen kunnen in groot detail de aantallen en het gebiedsgebruik van sterns in de Voordelta, en zo ook rond de Eerste Maasvlakte en Maasvlakte 2 in kaart gebracht worden. Op basis van deze gegevens volgt onderstaand een kwalitatieve beschrijving van de betekenis van het verdwenen zeegebied.

Op basis van de gegevens uit de vliegtuigtellingen tijdens de nulmeting (2005-2006) is een gemodelleerd aantal (geëxtrapoleerd naar het hele gebied op basis van de waarnemingen tijdens de gevlogen raaien) van 0-90 vliegende grote sterns in het verdwenen zeegebied van Maasvlakte 2 berekend. Daarnaast zijn per telling ook vaak enkele tientallen rustende sterns op de zachte zeewering van Maasvlakte 1 waargenomen. Naast vliegende grote sterns, waarvan geen direct herleidbaar gedrag genoteerd is, zijn tijdens de nulmeting in het gebied van de latere Maasvlakte 2 ook foeragerende grote sterns aangetroffen (figuur 7.2). Grote sterns visten met name langs de toenmalige zachte zeewering, maar ook nabij de overgang van zachte naar harde zeewering. Dergelijk gedrag werd tijdens de aanleg in 2009 veel minder gezien, maar in de jaren daarop zijn langs (met name) de zachte zeewering weer veelvuldig vissende grote sterns gezien. De herkomst van deze groepen is onbekend, maar uit onderzoek met GPS-loggers bleek dat de zachte zeewering van Maasvlakte 2 een voorkeursfoerageergebied is voor sterns uit het Haringvliet (Fijn et al. 2017b). Terwijl de zachte zeewering van Maasvlakte 1 zuidwest-noordoost georiënteerd was, is de zachte zeewering van Maasvlakte 2 zuidoost-noordwest georiënteerd. Dit heeft mogelijk gevolgen gehad voor de manier waarop zee en wind dit stuk kust beïnvloeden. Het is lastig de verschillende kaartbeelden onderling te vergelijken (figuur 7.2) vanwege de lagere telinspanning in de latere jaren, maar het is mogelijk dat de aantallen foeragerende sterns langs de zachte zeewering toegenomen zijn (figuur 7.2 en 7.3). Onbekend is of er een verandering in prooi-aanbod is geweest waardoor de zachte zeewering deels mogelijk aantrekkelijker is geworden.

Behalve dat ze er foerageren, rustten grote sterns tijdens de nulmeting ook relatief vaak op de zachte zeewering van Maasvlakte 1 . Het zwaartepunt van rustende sterns lag op de zuidpunt, het Slufterstrand. Deze functie is overgenomen door de zachte zeewering van Maasvlakte 2 en de aantallen rustende grote sterns zijn niet significant veranderd, zowel in het gebied rond de Maasvlakte (figuur 7.4 links) als in de gehele Voordelta (figuur 7.4 rechts). Nog altijd is de kernverspreiding van rustende grote sterns in het gebied van de Maasvlakte meestal beperkt tot de zuidpunt van het slufterstrand (figuur 7.2 en 7.3). De hoeveelheid verstoring op de zachte zeewering van Maasvlakte 2 is mogelijk iets toegenomen ten op zicht van de nulmeting, maar aan de andere kant is het areaal aan potentieel rustgebied ook toegenomen (meer km strand). Tijdens de aanleg van Maasvlakte 2 in 2009 - 2011 was dit gebied geheel gesloten voor het publiek, en met name in die periode werden grote groepen rustende sterns aangetroffen (figuur 7.4 links). In 2009 rustten grote groepen sterns bijvoorbeeld op de nieuw opgespoten gebieden. Vanaf 2012 namen de aantallen rustende sterns af, en werden alleen nog rustende grote sterns aangetroffen in gebieden met weinig wandelaars (noordelijk stuk zachte zeewering en de harde zeewering), en enkele stranden in de haven van Maasvlakte 2 (figuur 7.2). 


\section{Grote stern waarnemingen Maasvlakte}
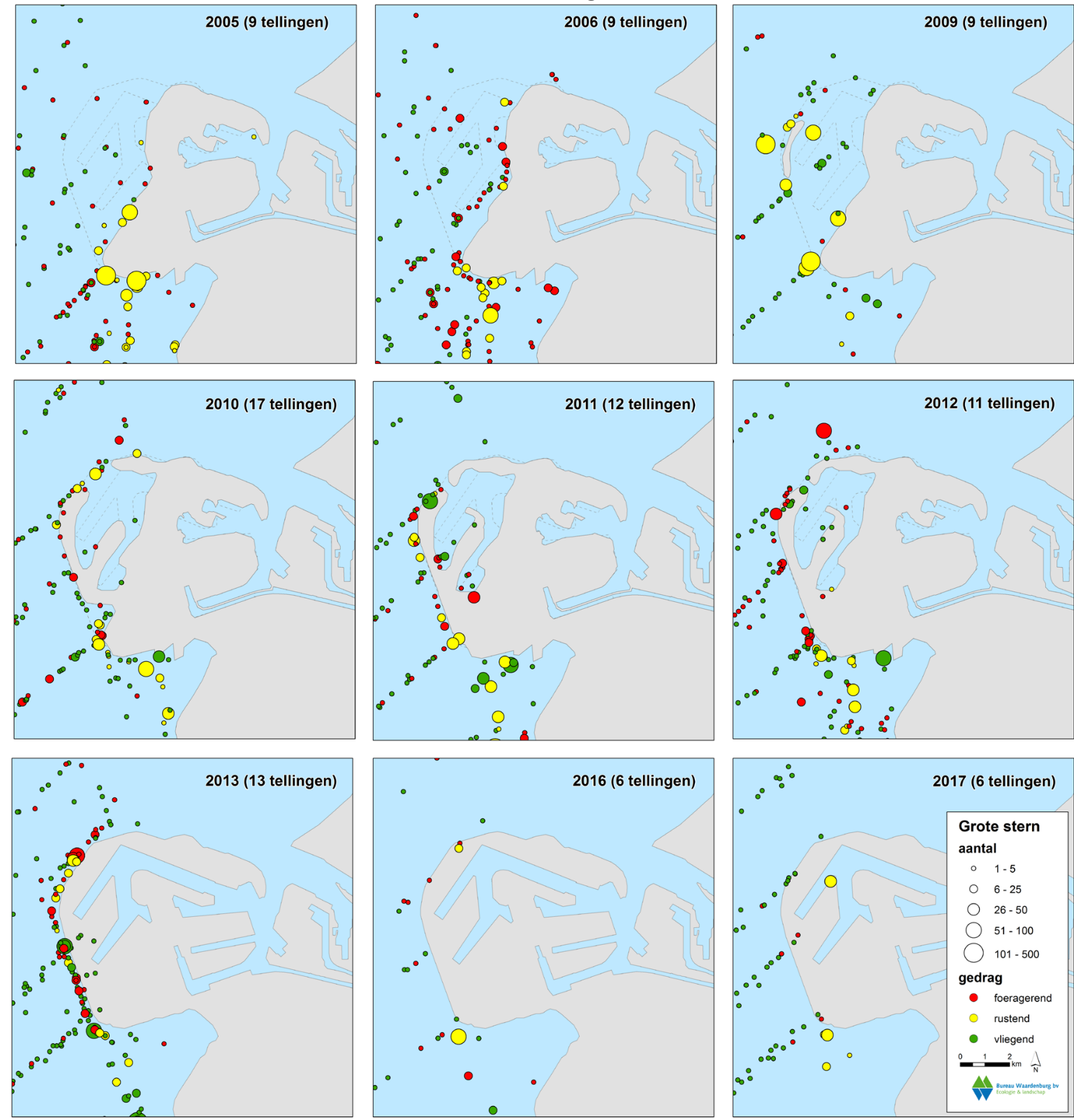

Figuur 7.2 Cumulatieve aantallen grote sterns, gesplitst per gedragscategorie, rond Maasvlakte 2 tijdens de onderzoeksjaren 2005-2006 (PMR-NCV nulmeting), 2009-2013 (PMR-NCV Fase 1), 20162017 (PMR-NCV Fase 2). Let op dat de telinspanning per jaar varieert, waardoor de jaren niet kwantitatief vergeleken kunnen worden. 


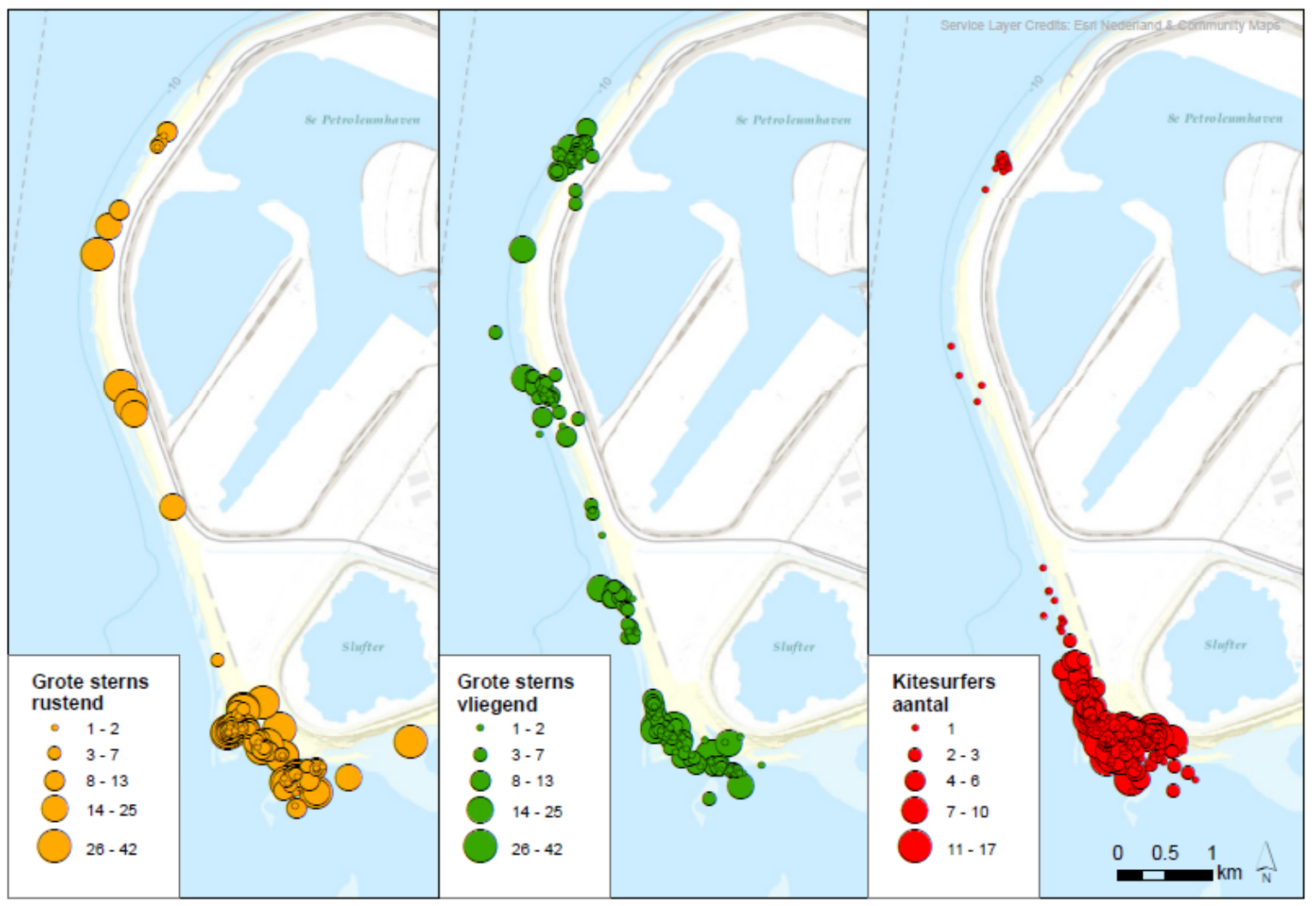

Figuur 7.3 Aantal grote sterns en kite surfers per teldatum rond Maasvlakte 2 in de periode maart augustus 2017.
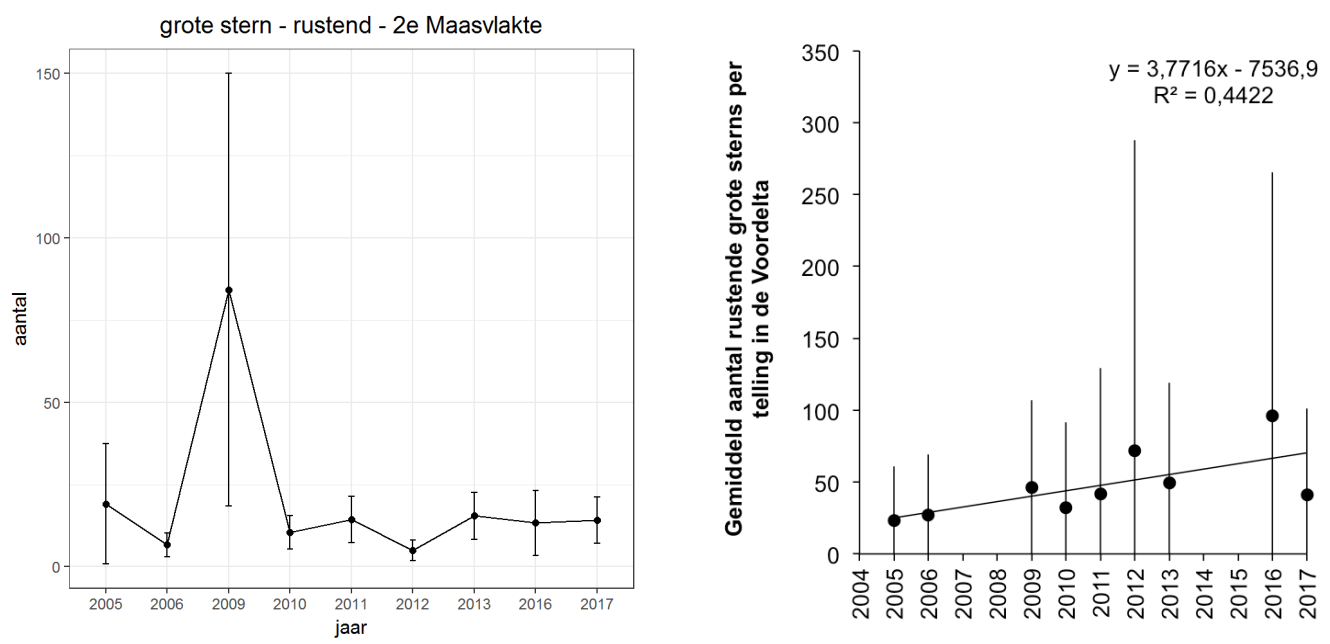

Figuur 7.4 Gemiddeld aantal rustende grote sterns per jaar in het Maasvlakte gebied (links) en in de gehele Voordelta (rechts) uitgezet voor de verschillende jaren. In 2009 was een groot opgespoten eiland beschikbaar in het Maasvlakte 2 gebied (figuur 7.2), waardoor de aantallen dat jaar heel hoog waren.

Het zeegebied en de kust van de Maasvlakte 1 werden dus tijdens de nulmeting in geringe mate gebruikt als foerageergebied door grote sterns. Daarnaast werd op de oorspronkelijke zeewering, op de toenmalige stranden ook gerust. Tijdens de aanleg van Maasvlakte 2 profiteerden rustende grote sterns van de relatieve rust op de vrij liggende nieuwe zandplaten en de afgesloten stranden. $\mathrm{Na}$ aanleg bleek de foerageerfunctie van het gebied overgenomen door met name de kuststrook van de zachte zeewering van Maasvlakte 2. De aantallen rustende sterns bleven min of meer gelijk, en de dieren zaten geconcentreerd op de zuidpunt van Maasvlakte 2, bij het Slufterstrand en de Hinderplaat.

Het Natura 2000 instandhoudingsdoel voor grote sterns in het Deltagebied is behoud van kwaliteit en omvang van het leefgebied zonder kwantitatief doel. Over de kwaliteit van het gebied in termen van 
voedselbeschikbaarheid is geen informatie verzameld, echter het gebied had geen essentiële foerageerfunctie voor grote sterns, en ook zijn er geen aanwijzingen dat het aantal foeragerende sterns is afgenomen na aanleg van Maasvlakte 2. De rust in het gebied is mogelijk wel afgenomen door de goede toegankelijkheid van de zachte zeewering van Maasvlakte 2 waardoor strandbezoek en kite-surf activiteiten zijn toegenomen (Van Oostveen \& Koolmees 2013). De aantallen rustende sterns zijn daarentegen niet significant afgenomen. De hoeveelheid potentieel rustgebied (aantal kilometer strand) is toegenomen in de nieuwe situatie, waardoor geen negatief effect is geweest op de omvang van het gebied. Samenvattend zijn er dus geen concrete aanwijzingen dat kwaliteit en omvang van het leefgebied is afgenomen, echter de ruimtelijke verdeling is wel veranderd.

\section{Deelconclusies}

- Het verdwenen zeegebied werd gebruikt door grote sterns om tussen foerageergebieden en broedgebieden heen en weer te vliegen. Daarnaast foerageerden grote sterns in mindere mate langs de zachte zeewering van Maasvlakte 1 en werd er gerust op de zeewering.

- Na aanleg van Maasvlakte 2 foerageerden grote sterns langs de gehele zeewering en rustten de dieren met name op de zuidpunt van Maasvlakte 2. De belangrijkste rustplek valt samen met de plek waar de kite-surfers zich concentreren. De aantallen rustende sterns in het Maasvlakte gebied zijn niet significant veranderd.

- Het verdwenen zeegebied had geen essentiële foerageerfunctie. Het aantal kilometer potentieel rustgebied is toegenomen, maar dit is samen gegaan met een toename in recreatie.

- Er zijn dus geen concrete aanwijzingen dat kwaliteit en omvang van het leefgebied is afgenomen, echter de verspreiding van grote sterns is wel veranderd.

\subsection{De functie van de Voordelta voor de grote stern}

De tweede deelvraag van de MEP vraag richt zich op de betekenis van de Voordelta als foerageergebied voor de grote stern

b) Leidt het instellen van het bodembeschermingsgebied tot een gelijkblijvende potentiële functie van de Voordelta voor de grote stern in termen van voedselbeschikbaarheid?

i. Treden veranderingen op in broedsucces, het voedsel, de verspreidingspatronen en het aantal vogeldagen van de grote stern t.o.v. de situatie vóór de aanleg van Maasvlakte 2?

ii. Zijn deze veranderingen toe te schrijven aan (veranderingen in) de voedselbeschikbaarheid of zijn andere factoren van (groter) belang?

iii. Is er een correlatie tussen de verschillende vormen van bodemberoerende visserij en de aanwezigheid en dichtheid van zandspiering in de Voordelta. Is het aannemelijk dat het om een causaal verband gaat?

\subsubsection{Aantallen en verspreiding foeragerende grote sterns}

Tijdens de eerste fase van de PMR-NCV monitoring tussen 2009 en 2013 werd vastgesteld dat het overgrote deel van de grote sterns die broeden in kolonies dicht aan de kust in de Delta, de Voordelta en ook gebieden verder uit de kust gebruiken als foerageergebied (Poot et al. 2014). De aantallen sterns die gebruik maken van de Voordelta zullen dan ook sterk afhangen van de populatieontwikkeling van sterns in de verschillende Delta-kolonies. De ontwikkelingen in het Nederlandse Deltagebied kunnen daarnaast niet los worden gezien van de ontwikkeling van de gehele Nederlandse en zelfs West-Europese populatie van grote sterns.

De broedpopulatie van de grote stern in het Deltagebied was eind jaren zeventig en begin jaren tachtig met ca. 4.000 paren lange tijd stabiel. Daarna volgde een afname tot ongeveer 2.500 paar, mede door de ontwikkeling van de kolonie in Zeebrugge. In de jaren negentig en het begin van de $21^{\mathrm{e}}$ eeuw was het voorkomen in het Nederlandse Deltagebied (vrijwel) beperkt tot twee grote kolonies: de Hompelvoet in het Grevelingenmeer en de Hooge Platen in de Westerschelde. Rond de eeuwwisseling bleef het aantal broedparen van de grote stern in het Deltagebied weer redelijk stabiel (ca. 6.000 paren). In 2004 brak een nieuwe, meer dynamische periode aan en tussen 2004 en 2012 wisselden perioden met hoge aantallen en lage aantallen elkaar af. Grote sterns vestigden zich in 2004 voor het 
eerst sinds decennia weer in kolonies aan het Haringvliet en de Oosterschelde en verlieten in 2005 en masse het Grevelingenmeer. In de periode 2005-2010 lag de grootste kolonie wisselend in Haringvliet, Oosterschelde en Westerschelde.

In de periode tussen de nulmeting van PMR-NCV en 2017 vertoonden de aantallen grote sterns die broeden in het Deltagebied geen duidelijke trend (totaal NL) maar hebben wel grote fluctuaties plaatsgevonden in aantallen broedparen (figuur 7.5 links) en bezetting van kolonielocaties (Fijn et al. 2016, figuur 7.10). Gemiddeld genomen zijn de aantallen voor en na de aanleg van Maasvlakte 2 ongeveer gelijk gebleven. Opvallend was dat vlak na de aanleg (2010 en 2011) de aantallen grote sterns in de Delta laag waren, terwijl juist de aantallen in 2011 in het gehele Noordzeegebied relatief hoog waren (figuur 7.5 rechts). In 2011 waren broedende grote sterns ook afwezig in het Haringvliet (figuur 7.6). In recente jaren nemen de aantallen grote sterns af in het Delta-gebied (figuur 7.5 links), mogelijk ten gevolge van een sterke toename van het beschikbare broedgebied elders in Nederland, zoals bijvoorbeeld op Texel (figuur 7.6). Dit blijkt eveneens uit de ringaflezingen in deze kolonies. Op Texel worden namelijk relatief veel vogels met kleurringen uit de Delta gezien. Op Texel is de waarneeminspanning wel groter dan in de andere kolonies waardoor de afleeskans ook groter is. De Maasvlakte 2 is aangelegd in Natura 2000-gebied Voordelta, een gebied dat is aangewezen voor onder andere grote sterns. De doelstellingen ten aanzien van grote sterns in Natura 2000-gebied Voordelta zelf zijn het "Behoud van omvang en kwaliteit leefgebied grote stern als niet-broedvogel" zonder daarbij een kwantitatieve doelstelling voor aantallen vogels. Om te bepalen of de aanleg van Maasvlakte 2 een dusdanig effect heeft gehad op het gebied dat dit instandhoudingsdoel in gevaar komt, is het aantal sterns dat voor en na de aanleg van Maasvlakte 2 gebruikt maakt van het gebied (uitgedrukt in het aantal vogeldagen per jaar) geanalyseerd. Vogeldagen worden berekend op basis van de met de methode Distance (Buckland \& Turnock 1992) gemodelleerde aantalsschattingen van de uitgevoerde tellingen tussen 1 april en 30 september van het betreffende monitoringsjaar (Poot et al. 2014). Aangezien het aantal vogeldagen in het zeegebied gecorreleerd is met de aantallen sterns die broeden in de verschillende kolonies, hebben we het aantal vogeldagen gecorrigeerd voor het aantal broedparen in de nabij gelegen kolonies om zodoende een beeld te krijgen van het gebruik van de Voordelta als foerageergebied, gewogen voor de omvang van de kolonies.
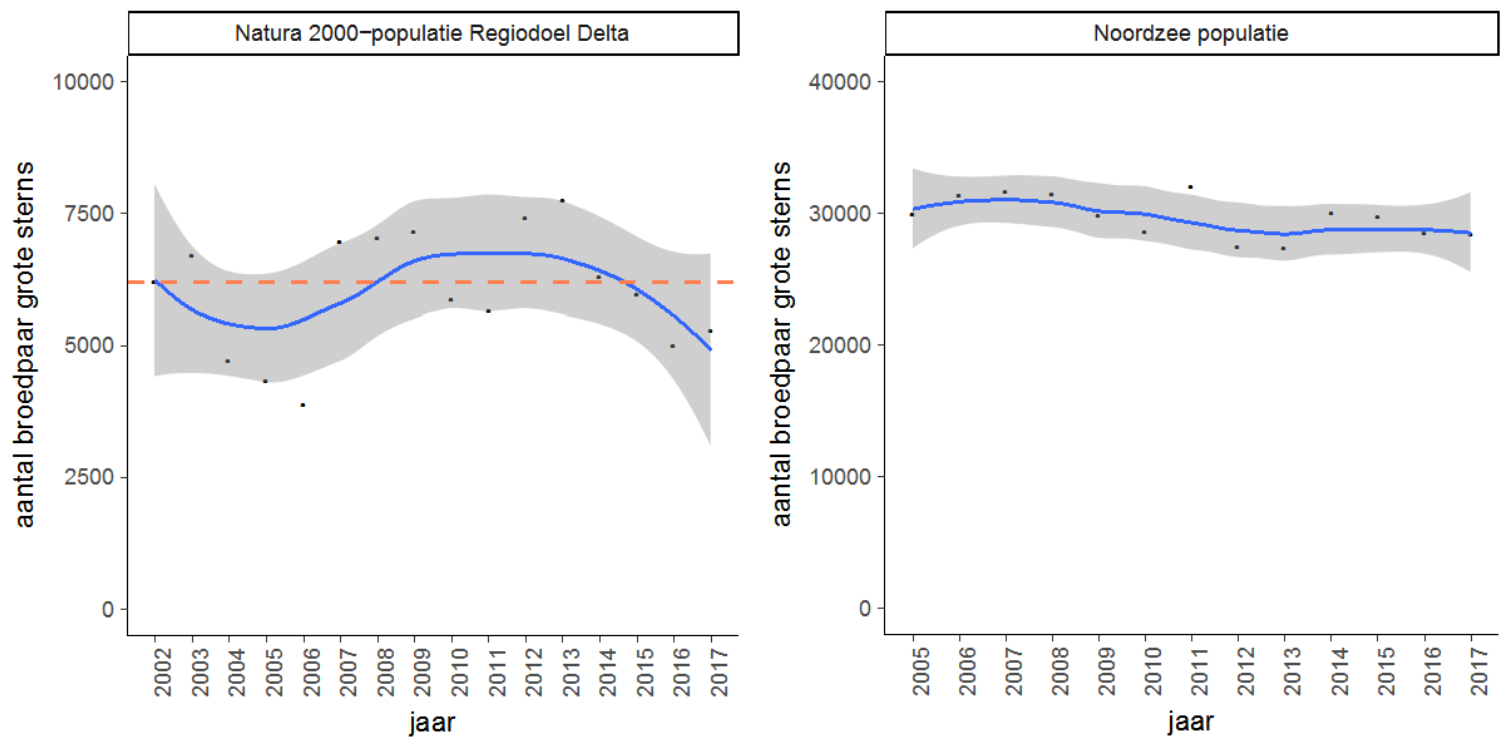

Figuur 7.5 Aantallen broedparen van grote sterns in het Deltagebied (links) en in de gehele Noordzee (rechts). Data afkomstig van P. Thellier, INBO, DPM, Zeeuws Landschap, N. Lawton (Natural England), A. Tejala (National Trust), M. Leopold (WMR), B. Spaans (VWG-Texel), M. Plomp (Vogelinformatiecentrum Texel), E. Menkveld, D. Lutterop (Natuurmonumenten), A. Brenninkmeijer $(A \& W), T$. Bregnballe, J. Gregersen (Aarhus University), B. Hälterlein (Verein Jordsand). N.B. In de Noordzee populatie ontbreken de gegevens van Niedersachsen (GER). De rode lijn geeft het regiodoel van 6200 paar weer. 

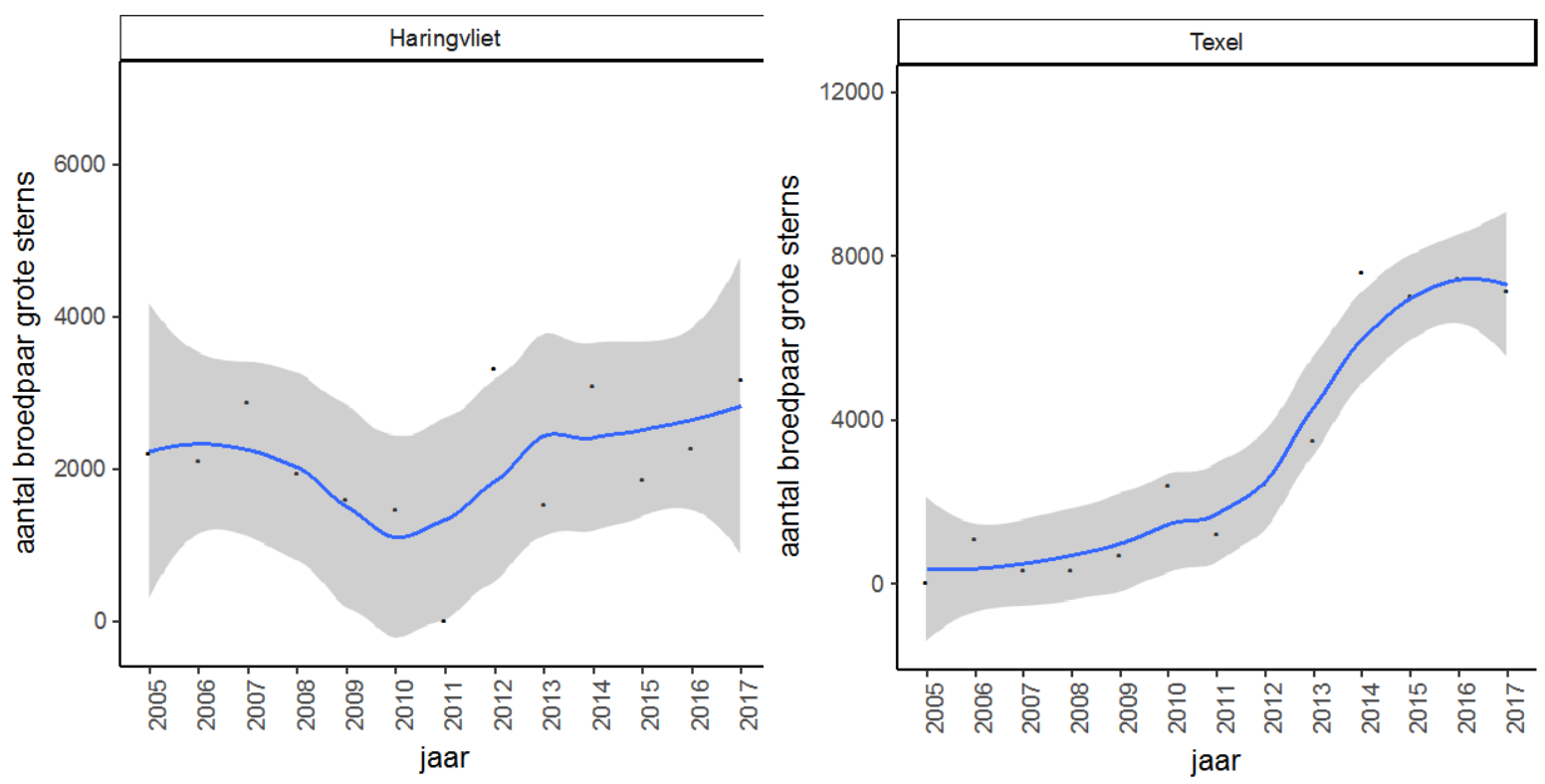

Figuur 7.6 Aantallen broedparen van grote sterns in het Haringvliet (links) en op Texel (rechts). Data afkomstig van DPM voor Haringvliet en B. Spaans (VWG-Texel), M. Plomp (Vogelinformatiecentrum Texel), E. Menkveld (Natuurmonumenten) voor Texel.

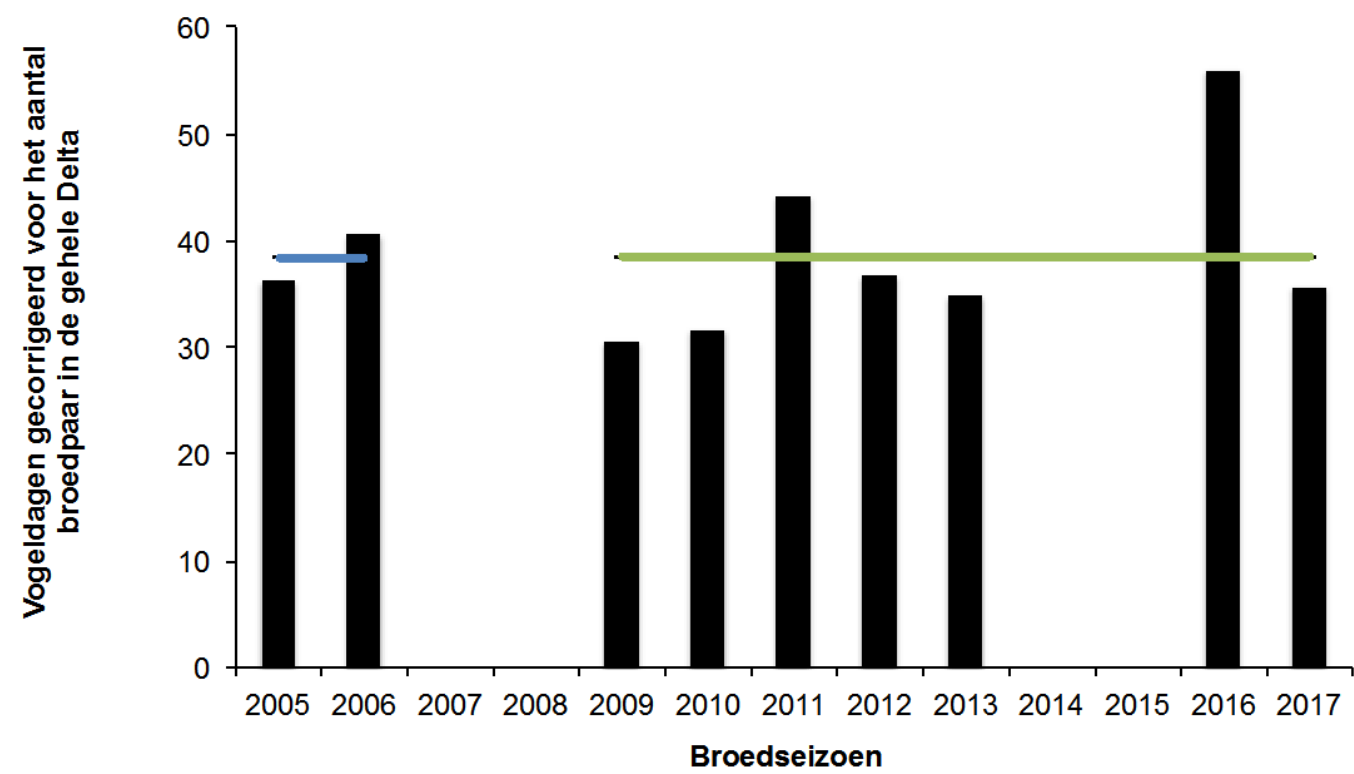

Figuur 7.7 Jaarlijks aantal vogeldagen van grote sterns in het zeegebied van de Voordelta na correctie voor het aantal broedparen in Deltakolonies. Blauwe lijn is het gemiddelde tijdens de nulmeting (2005-2006), de groene lijn het gemiddelde tijdens 2009-2017.

Het gemiddeld aantal vogeldagen van grote sterns in het zeegebied van de Voordelta is niet duidelijk veranderd na de aanleg van Maasvlakte 2 (figuur 7.7). Het aantal vogeldagen per jaar varieert sterk. Deze fluctuaties worden met name bepaald door de hoogte van de pieken in het voor- en najaar, en niet door de aanwezigheid van sterns tijdens het broedseizoen. Het optreden van deze pieken varieert per jaar, terwijl de telmomenten wel vaststaan. Het kan dus zijn dat een doortrekpiek net gemist is, wat sterk tot uitdrukking komt in het aantal vogeldagen van dat jaar.

Er zijn geen aanwijzingen dat na aanleg van Maasvlakte 2 het aantal vogeldagen van grote sterns in de Voordelta sterk is afgenomen. Hoewel het totale oppervlakte beschikbaar foerageergebied kleiner als gevolg van de aanwezigheid van Maasvlakte 2, zijn de aantallen gelijk gebleven, en is de functie (en daardoor waarschijnlijk ook de kwaliteit) van het gebied voor grote sterns behouden. Uit de vliegtuigtellingen weten we dat foeragerende sterns door de hele Voordelta gevonden kunnen worden (figuur 7.8), en van de vogels met GPS-loggers vanuit het Haringvliet weten we dat met name in de noordelijke helft van de Voordelta gefoerageerd wordt (figuur 7.9), maar uit beide bronnen blijkt ook 
dat grote sterns tot (ver) buiten de grenzen van het Natura 2000-gebied Voordelta foerageren. Ook worden foeragerende grote sterns soms in groepen van enkele tientallen vogels waargenomen, soms geassocieerd met stroomnaden of anderszins klaarblijkelijk interessante zeecondities zoals ondiep water nabij zandplaten of de spui-openingen van dammen. Daarnaast blijkt met name de kust van Maasvlakte 2 een plek waar grote sterns graag vissen (figuur 7.8 en 7.9). Het is dus aannemelijk dat er ook geen wezenlijke verandering is opgetreden in de ruimtelijke verspreiding van grote sterns in de Voordelta, anders dan de verplaatsing van de oude zeewering van Maasvlakte 1 naar de nieuwe zeewering van Maasvlakte 2.

\section{waarnemingen foeragerende grote sterns}
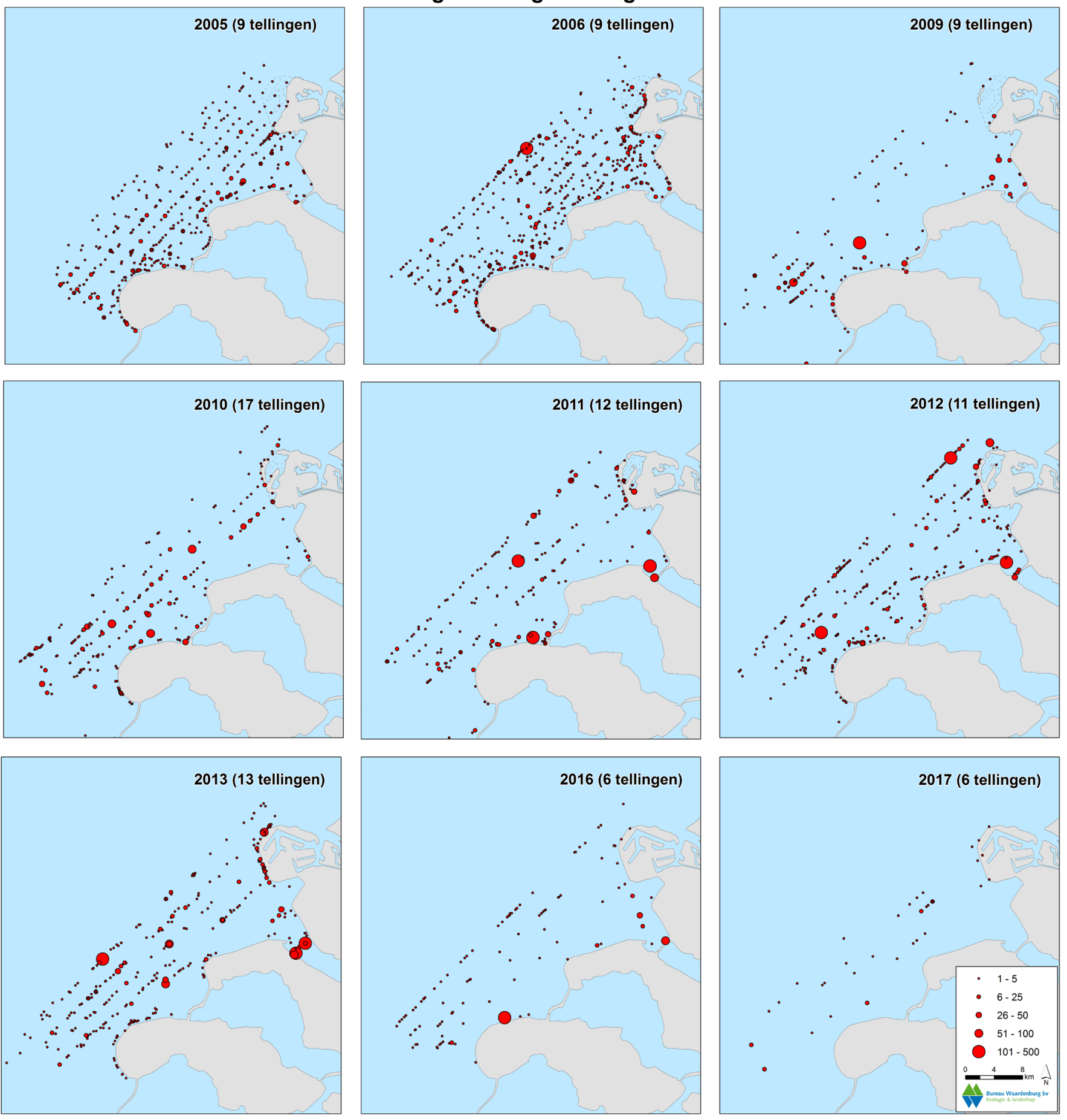

Figuur 7.8 Aantallen foeragerende grote sterns tijdens de vliegtuigtellingen in de Voordelta (aprilseptember). Let op dat de telinspanning per jaar sterk wisselt met veel tellingen in de periode tot en met 2013 en minder tellingen in 2016-2017, waardoor een kwantitatieve vergelijking tussen jaren niet gemaakt kan worden. 


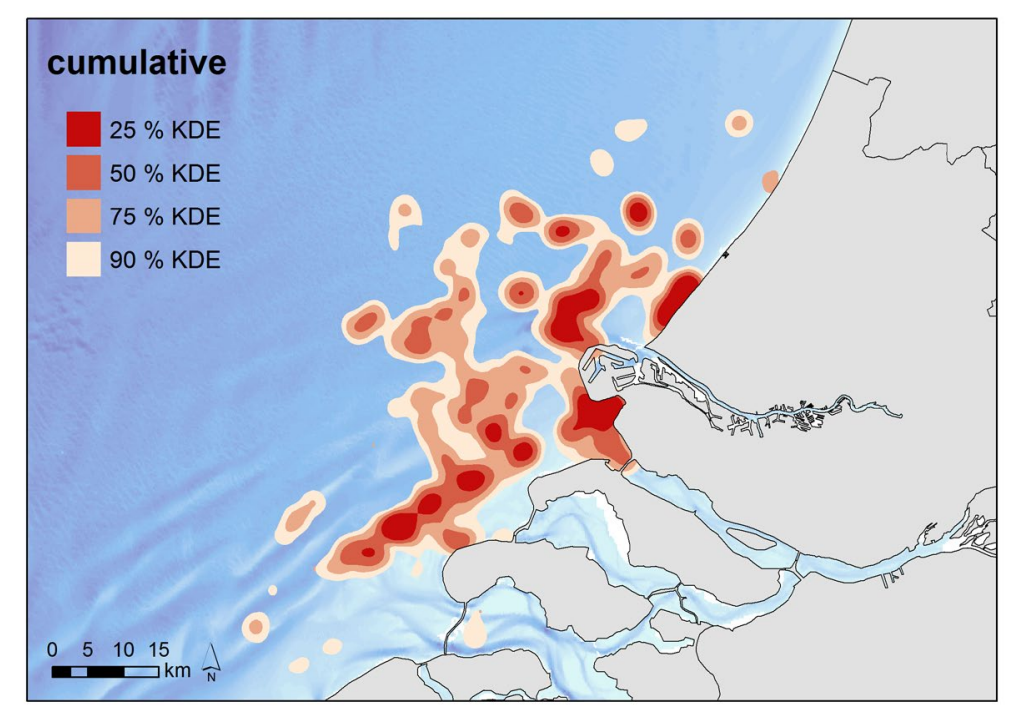

Figuur 7.9 Ligging foerageerhotspots van grote sterns met GPS-loggers. KDE staat voor Kernel Density Estimation (Worton 1989), de meest gebruikte methode om contouren te leggen om gebieden waar vogels met loggers zich het meest bevinden.

Naast de effecten van de compensatiemaatregelen op het behalen van de instandhoudingsdoelen voor grote sterns in het Natura 2000-gebied Voordelta, zijn ook effecten op sternkolonies in andere Natura 2000-gebieden, die een functionele relatie hebben met de Voordelta, van belang. Voor de grote stern zijn kwantitatieve instandhoudingsdoelstellingen geformuleerd voor de Natura 2000-gebieden Haringvliet, Grevelingenmeer, Oosterschelde en Westerschelde \& Saeftinghe tezamen, in de vorm van een 'regiodoel' voor broedvogels voor het "Behoud van omvang en kwaliteit leefgebied voor 6200 paar". Het maakt dus niet uit in welk van deze gebieden dit aantal vogels broedt, als de totale draagkracht van de regio maar voldoende is voor een populatieomvang van 6.200 paar.

Grote sterns broeden jaarlijks in drie tot vijf kolonies in de Nederlandse Delta en de aantallen variëren sterk tussen de verschillende kolonies en jaren (figuur 7.10). De aantallen broedparen schommelen meestal rond het instandhoudingsdoel, met in sommige jaren duidelijk lagere aantallen (bv 20042006, 2016-2017) en in andere jaren duidelijk hogere aantallen (2007-2009, 2012-2013) (figuur 7.5). De lagere aantallen in 2016 en 2017 worden veroorzaakt door de afwezigheid van een kolonie op Markenje, een fenomeen dat klaarblijkelijk maar gedeeltelijk wordt opgevangen door de andere kolonies in de Delta. Het gemiddelde aantal broedparen grote sterns tijdens en na de aanleg ligt iets boven het regiodoel (2009 - 2017: 6251 broedpaar). 

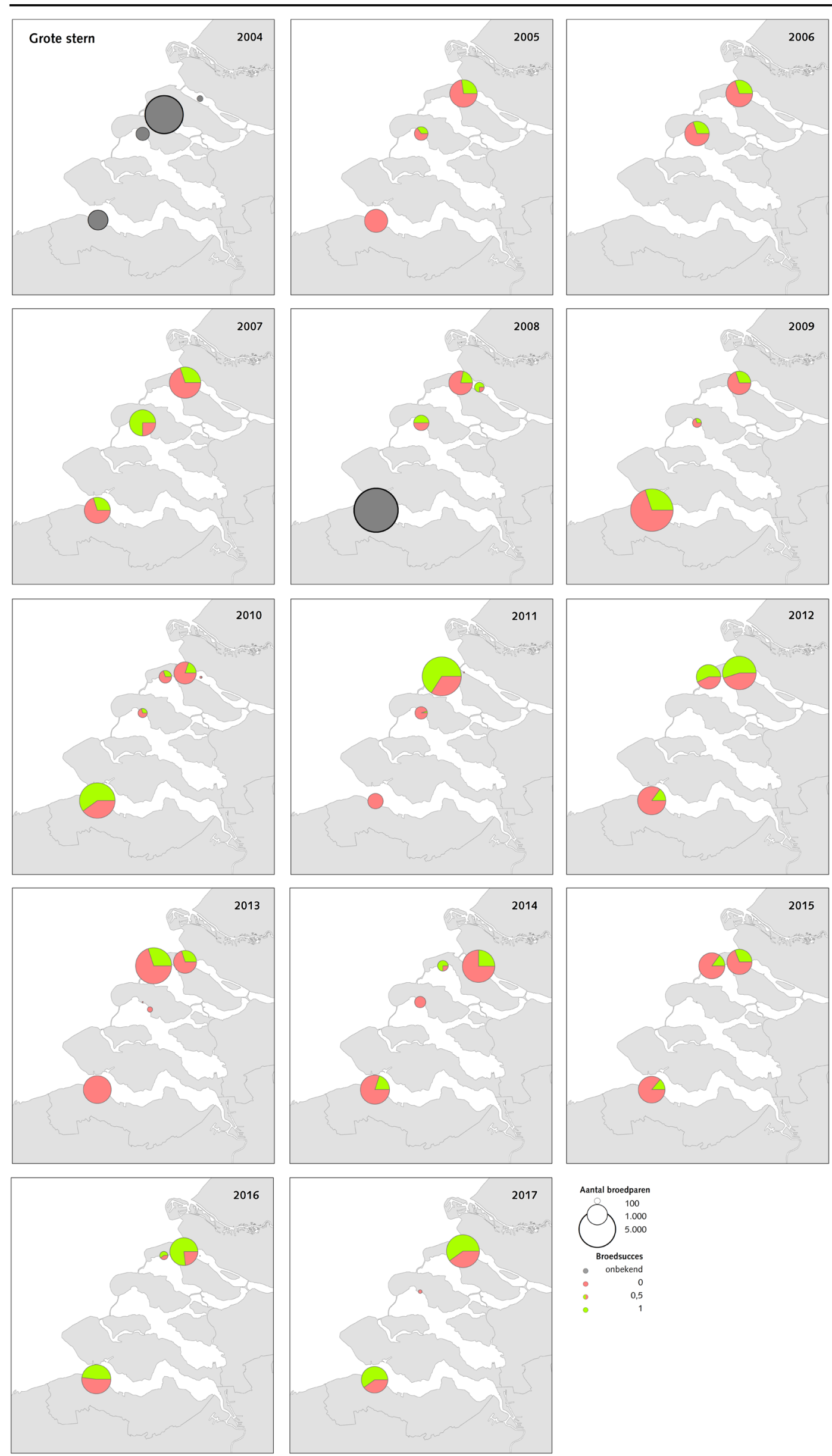

Figuur 7.10 Aantallen broedparen en kwantitatieve schatting van het broedsucces van grote sterns in de verschillende kolonies in het Deltagebied. Groen: goed broedsucces; rood: slecht broedsucces; grijs: geen informatie. De grootte van de cirkel geeft het aantal broedparen weer. 


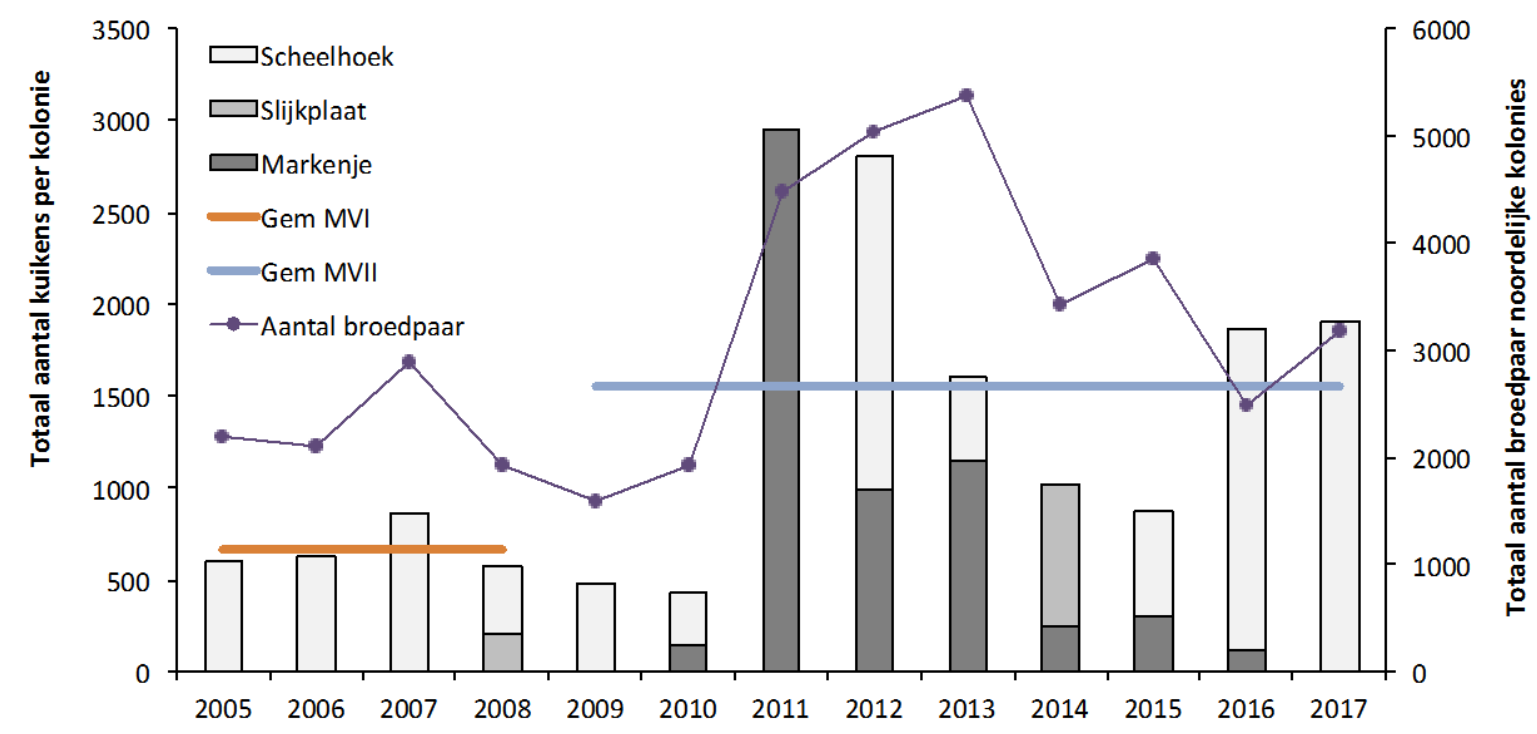

Figuur 7.11 Totaal aantal uitgevlogen jonge grote sterns (balken) en aantallen broedparen (lijnen) vanuit de kolonies in het noordelijk Deltagebied berekend door het broedsucces te vermenigvuldigen met het aantal broedparen. De oranje lijn en de blauwe lijn geven de gemiddelden weer voor respectievelijk de perioden voor de aanleg van Maasvlakte 2 en de periode tijdens en na de aanleg.

Een belangrijke voorwaarde voor het duurzaam voortbestaan van populaties is het behalen van voldoende broedsucces in de kolonies. Tijdens alle fases van PMR-NCV zijn voor alle grote stern kolonies in het Deltagebied broedsucces data verzameld tijdens de kustbroedvogelmonitoring van Rijkswaterstaat (Delta Project Management). Het totaal aantal jonge grote sterns dat jaarlijks in de noordelijke kolonies in de Delta (Scheelhoek, Slijkplaat, Markenje) wordt grootgebracht varieert tussen de 430 en 3000 en varieert sterk tussen de verschillende deelgebieden (figuur 7.11). Opvallend is de lage jongenproductie in de periode tot 2011 en de relatief succesvolle jaren vlak na de aanleg, waardoor er gemiddeld (veel) meer jongen zijn groot geworden in de jaren na aanleg van Maasvlakte 2.
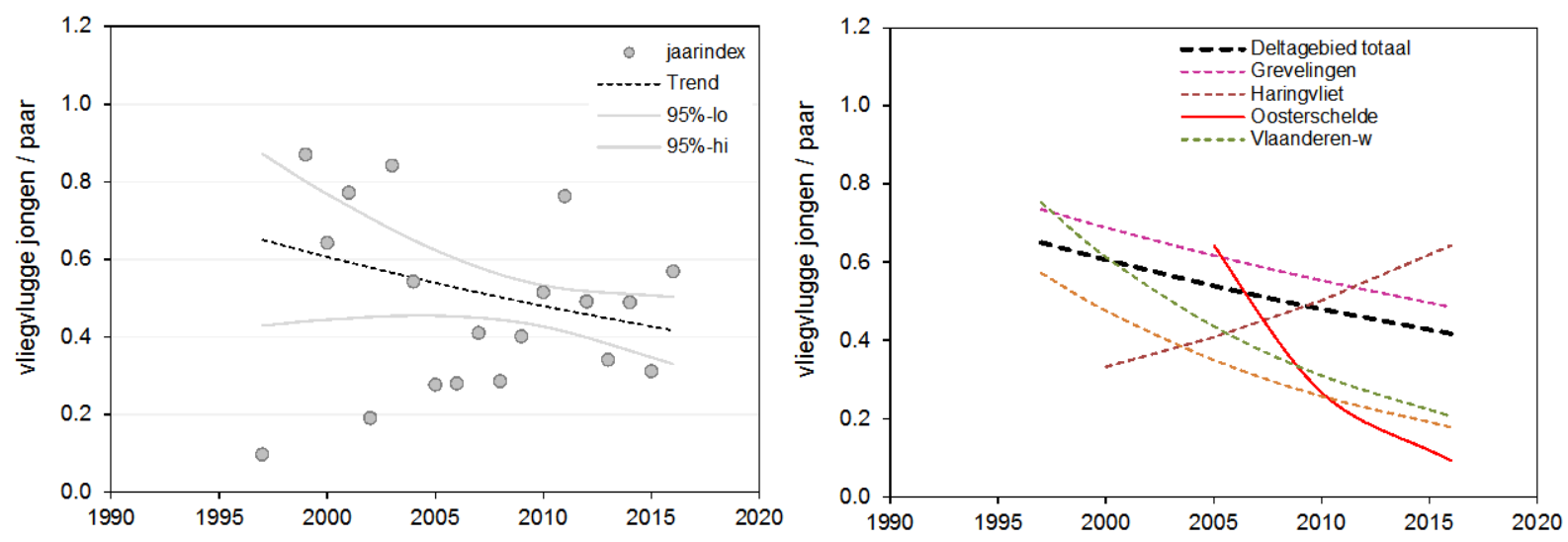

Figuur 7.12 Ontwikkeling van het reproductiesucces van Grote Sterns in het Deltagebied. Weergegeven is het jaargemiddelde (stippen) en trend met $95 \%$ betrouwbaarheidsinterval (lijnen) voor het hele Deltagebied (links) en per bekken (rechts, doorgetrokken streep is significant, gestippeld is niet significant). Overgenomen uit Schekkerman et al. (2017). 
Recent zijn door SOVON Vogelonderzoek Nederland, Vogeltrekstation, Delta Project Management en het Instituut voor Natuur- en Bosonderzoek (Schekkerman et al. 2017) de broedsuccesdata van grote sterns in de Delta geanalyseerd voor een veel langere periode. Hieruit blijkt dat het broedsucces in grote sternkolonies in het Deltagebied geen trendbreuk laat zien tussen T0 en T1 (figuur 7.12 links). Wel varieert het broedsucces in deze kolonies sterk tussen jaren en is alleen in de Oosterschelde een significante neergaande langjarige trend te zien (figuur 7.12 rechts). In het Haringvliet neemt het reproductiesucces toe, echter deze trend is niet significant. Naar verwachting is een gemiddeld broedsucces van ongeveer 0.5 jong per paar voldoende om een stabiele populatie van deze langjarige soort te kunnen waarborgen (Schekkerman et al. 2017).

\section{Deelconclusies}

- De aantallen broedparen van grote sterns fluctueren sterk van jaar tot jaar, maar liggen rond het instandhoudingsdoel voor de regio

- Het gemiddeld aantal grote stern vogeldagen in de Voordelta is niet veranderd tussen de periode voor en na de aanleg van Maasvlakte 2.

- Het totaal aantal geproduceerde jongen in de noordelijke kolonies (Slijkplaat, Scheelhoek en Markenje, die afhankelijk zijn van het gebied rond Maasvlakte 2) was hoger na de aanleg van Maasvlakte 2 ten opzichte van de periode daarvoor.

- In de periode 1997-2016 nam het broedsucces in het Deltagebied af, maar de trend is niet statistisch significant. Er is geen trendbreuk in het broedsucces van grote sterns tussen de periode vlak voor en na de aanleg van Maasvlakte 2.

\subsubsection{Voedselbeschikbaarheid aan de hand van visbemonstering}

Voor voedselbeschikbaarheid voor sterns en met name voor kuikens is de vislengte gedurende het broedseizoen van cruciaal belang. Er is geen speciaal onderzoek geweest naar veranderingen in beschikbaarheid van pelagische vis voor sterns. Als gevolg hiervan kunnen eventuele veranderingen in voedselbeschikbaarheid voor sterns niet worden bepaald. In de eerste fase is een poging gedaan om de beschikbare gegevens over de lengtefrequentieverdelingen van vis op een rij te zetten. Wat betreft de voedselbeschikbaarheid voor grote sterns is een vergelijking gemaakt tussen lengtefrequenties van haring en zandspiering gevangen tijdens de Demersal Fish Survey (DFS) met het DFS-tuig in het voorjaar (zie hoofdstuk 5), gevangen tijdens speciale pelagische trekken op plekken waar sterns foerageren en gegeten door adulten en kuikens (figuur 7.13). Hierbij moet in aanmerking genomen worden dat het DFS-tuig een bodemtuig is en suboptimaal voor het bevissen van pelagische vis.

De lengtefrequentieverdeling van haring en zandspiering uit de pelagische trekken komt in de meeste jaren niet overeen met die in het kuikendieet. In de meeste gevallen krijgen kuikens grotere vis gevoerd dan gevangen in de pelagische trekken van de DFS. De lengtefrequentie van vis uit de pelagische bemonstering komt wel goed overeen met die in het adulte dieet. De standaard DFSbemonstering levert een hoger percentage grotere vis op. Niettemin vertonen ook deze lengtefrequentieverdelingen vooral een grote overeenkomst met het adulte dieet en veel minder met het kuikendieet, dat in de meeste jaren uit haringachtigen van grotere lengteklassen bestaat dan er tijdens de visbemonsteringen worden gevangen. Vissen in de DFS-bemonsteringen zijn in elk jaar veel groter dan in de pelagische bemonstering en komen overeen met de grootste lengteklassen van het kuikendieet. Alle geselecteerde maten zijn in alle jaren wel aangetroffen, maar het seizoensverloop in de verhoudingen is niet duidelijk, net zomin als de totale voedselbeschikbaarheid en de ontwikkeling over de jaren daarin.

Mogelijkheden om voor de hele looptijd van het onderzoek in te schatten hoe goed de vissituatie in elk jaar geweest is, zijn er nog wel in onderzoek aan larvenmodellering die op dit moment uitgevoerd wordt. Daarin wordt voor elk jaar op basis van abiotische gegevens (stroming, wind) gemodelleerd hoe de larvenverspreiding is geweest en wanneer ze in de Voordelta verschijnen. Dat zou uiteindelijk een jaarlijks index kunnen geven van de beschikbaarheid van jonge haring als voedsel voor grote sterns. 
Uit het koloniewerk zijn enkele proxy's voor voedselbeschikbaarheid afgeleid, deze zijn echter niet beschikbaar voor de T0-fase. Sterns brengen prooi voor hun kuikens per stuk aan. De prooilengte (en dus de energie-inhoud) moet afgestemd zijn op de kuikenbehoefte (die afhankelijk is van de leeftijd van het kuiken). Als de voedselsituatie slechter is duurt het wellicht langer voordat ze een prooi van de juiste afmeting voor hun kuikens gevonden hebben en er mee naar de kolonie terug vliegen.

Als we de mediane of de gemiddelde tripduur voor het aanbrengen van een haringachtige van 1,75 maal de snavellengte (van een volwassen grote stern) als proxy gebruiken voor de beschikbaarheid van grotere haringachtigen blijkt er geen duidelijke trend door de jaren (figuur 7.13 links). Voor haringachtigen wordt ook niet meteen een trend verwacht daar de vislengtes waarschijnlijk eerder gerelateerd zijn aan abiotische factoren die los staan van Maasvlakte 2 of maatregelen in het BBG én omdat allicht een groot deel van de haringachtigen buiten het Natura 2000 gebied wordt gevangen. 

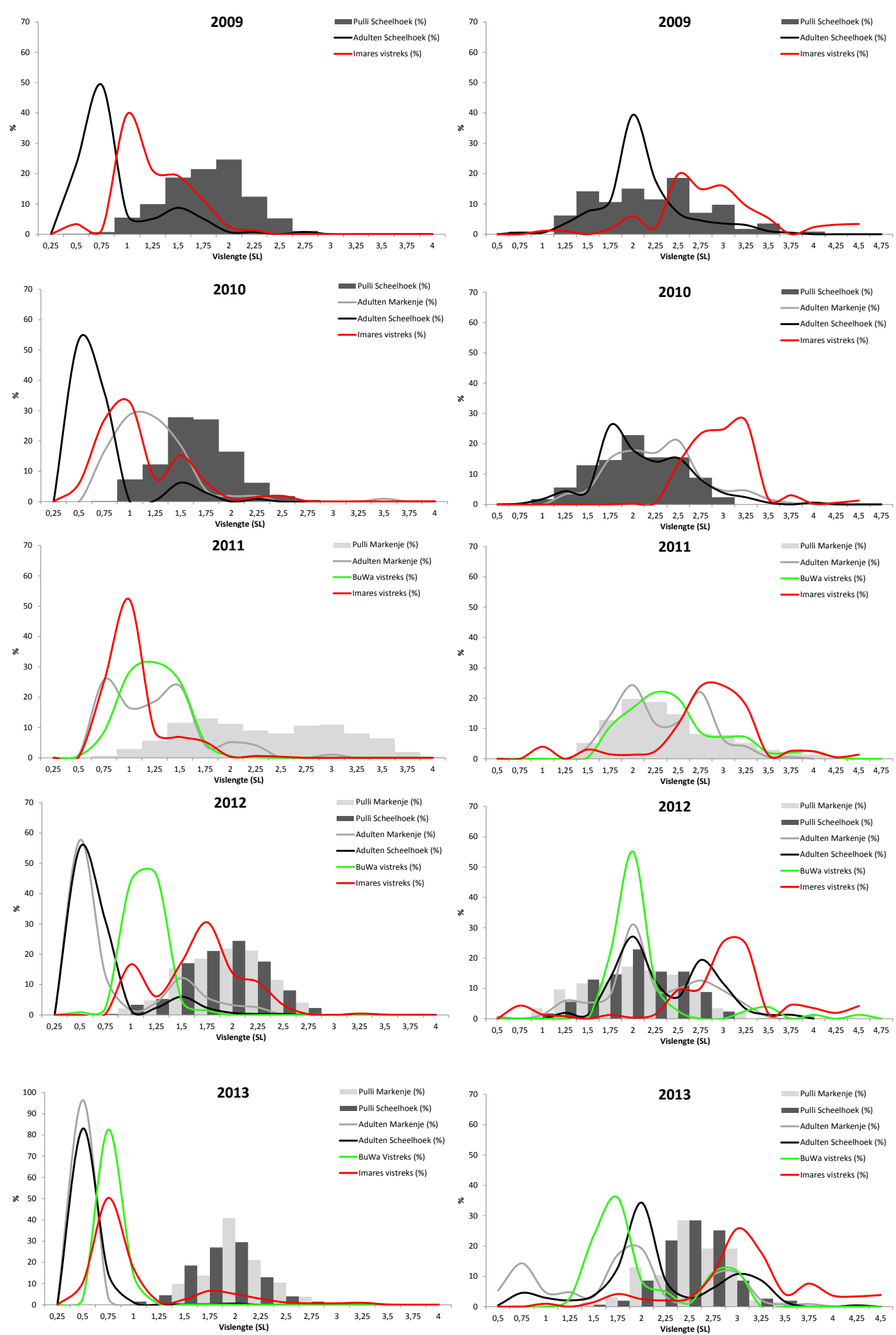

Figuur 7.13 Lengtefrequentie van haringachtigen (links) en zandspiering (rechts) in het dieet van adulte grote sterns (Scheelhoek: zwarte lijn; Markenje: grijze lijn), in het kuikendieet (Scheelhoek; zwarte kolommen) en Markenje; grijze kolommen), en de vangsten met pelagisch net (Bureau Waardenburg; groene lijn) en met garnalenboomkor door WMR in mei/juni (rode lijn). Categorie 1 snavellengte $(\mathrm{SL})=5 \mathrm{~cm}, 1,75 \mathrm{SL}=10 \mathrm{~cm}, 2,75 \mathrm{SL}=15 \mathrm{~cm}, 3,75 \mathrm{SL}=20 \mathrm{~cm}$. 


\subsubsection{Broedsucces in relatie tot voedsel}

Het aantal broedende grote sterns en het broedsucces wordt elk jaar nauwkeurig bepaald in de kolonies op de Scheelhoek (Haringvliet) en Markenje (Grevelingenmeer). Broedsucces kan worden opgesplitst in uitkomstsucces van de eieren en het uitvliegsucces van de kuikens. Alleen het uitvliegsucces wordt potentieel bepaald door de voedselbeschikbaarheid, het uitkomstsucces is vooral afhankelijk van andere factoren zoals b.v. predatie (zie §7.4.7).

Over het kwantitatieve aanbod aan pelagische vis (in dit geval haringachtigen en zandspieringachtigen) zijn geen gegevens beschikbaar, naast de informatie over lengteverdeling uit $\S 7.4 .2$. Daarom hebben we gewerkt met een aantal proxy's voor de kwaliteit en kwantiteit van het voedselaanbod. Voor de kwaliteit waren dit de dieetsamenstelling (het percentage haringachtigen) en de gemiddelde lengte van haring- en zandspieringachtigen in het kuikendieet. Voor de kwantiteit waren dit de mediane tripduur voor haringachtigen van 1.75 snavellengtes $(\mathrm{SL}, 1 \mathrm{SL}=5.43 \mathrm{~cm}$ ) en zandspieringachtigen van $2.5 \mathrm{SL}$. Deze vislengtes zijn als referentie genomen omdat ze overeenkomen met de mediane lengte van de haring- en zandspieringachtigen aangevoerd voor de kuikens. De gemiddelde tripduur voor het aanbrengen van een haringachtige van een bepaalde lengte vlakt af vanaf $1.75 \mathrm{SL}$ zodat deze ook representatief is voor de grotere lengtes (figuur 7.14). Bij zandspiering is het verband lineair.

Naast het voedselaanbod kunnen ook weersomstandigheden (temperatuur, windsnelheid en neerslaghoeveelheid) invloed hebben op het uitvliegsucces. Om het eventuele belang hiervan in te kunnen schatten zijn ook verschillende fitness- gerelateerde parameters geanalyseerd in relatie tot het voedselaanbod, namelijk: de verhoudingen kopsnavellengte-gewicht en leeftijd-gewicht van de vliegvlug geworden kuikens.

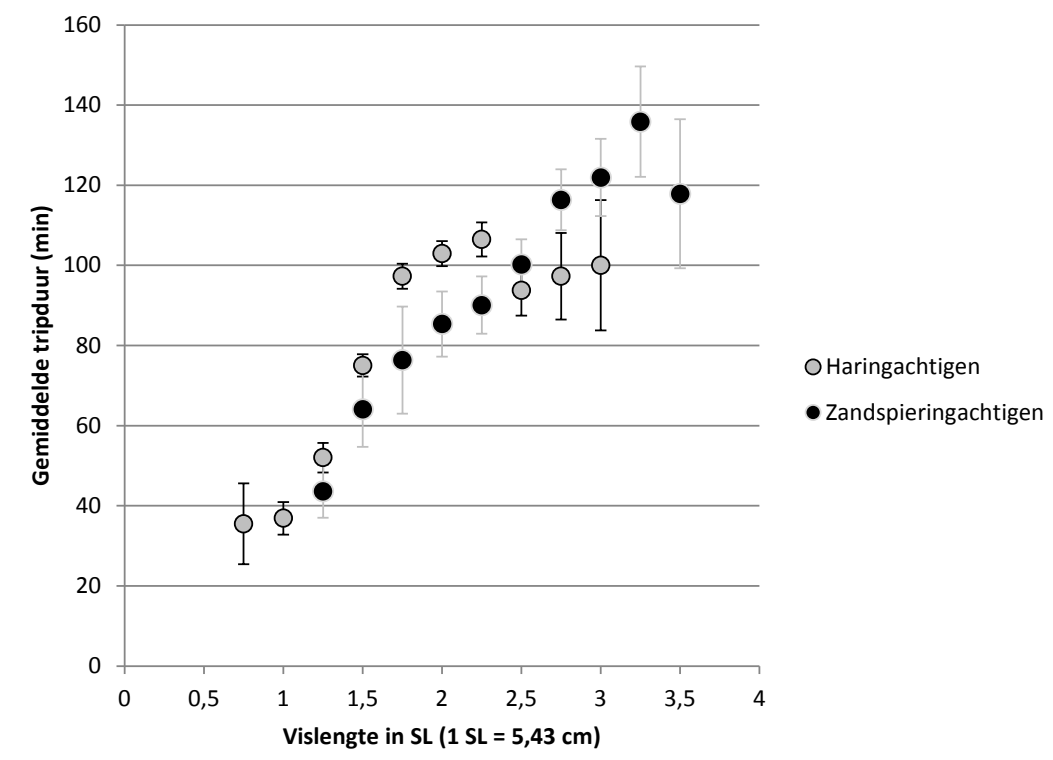

Figuur 7.14 Gemiddelde tripduur ( \pm s.d.) over alle onderzoeksjaren (2009-2017) voor het aanbrengen van haring- en zandspieringachtigen van verschillende lengtes.

\subsubsection{Broedsucces in relatie tot kwaliteit voedsel}

De gemiddelde conditie (gewicht-leeftijd) van de vliegvlug geworden kuikens en het uitvliegsucces zijn positief gecorreleerd met de gemiddelde lengte van de naar de kuikens aangebrachte haringachtigen (figuur 7.15a en $b ; R^{2}=0.66, p<0.01$, resp. $R^{2} 0.56, p<0.01$ ).). Voor zandspiering werd geen significant verband gevonden tussen de conditie-indices van kuikens en de proxy's voor de kwaliteit van het voedselaanbod. Verder is er ook een opvallend verschil tussen de kolonies op Scheelhoek en Markenje. De gemiddelde lengte van de haringachtigen aangebracht naar de kolonie op Markenje was in alle jaren groter dan op de Scheelhoek, voor de zandspieringachtigen was dit in drie van de vier jaren het geval. In overeenstemming daarmee, waren zowel de kuikenconditie als het uitvliegsucces 
steevast hoger op Markenje in de jaren dat zowel op de Scheelhoek als op Markenje een kolonie aanwezig was (zie ook §7.4.7).

$\mathrm{Er}$ is in de loop van de onderzoeksjaren geen significante trend te zien in de mediane noch in de gemiddelde tripduur om een haringachtige van $1.75 \mathrm{SL}$ (a) en een zandspieringachtige van $2.5 \mathrm{SL}$ (b) aan te brengen naar de kolonie op de Scheelhoek (figuur 7.16). De mediane en de gemiddelde tripduur voor het aanbrengen van een zandspieringachtige van 2,5 SL $(13,5 \mathrm{~cm})$ lijkt te zijn afgenomen tussen 2009 en 2017 maar door de grote variatie is dit niet significant. Het is onder de gegeven omstandigheden niet mogelijk om te zeggen of de oorzaken hiervoor moeten gezocht worden binnen de Voordelta omdat een groot deel van de aangevoerde zandspieringen buiten het Natura 2000 gebied gevangen worden.
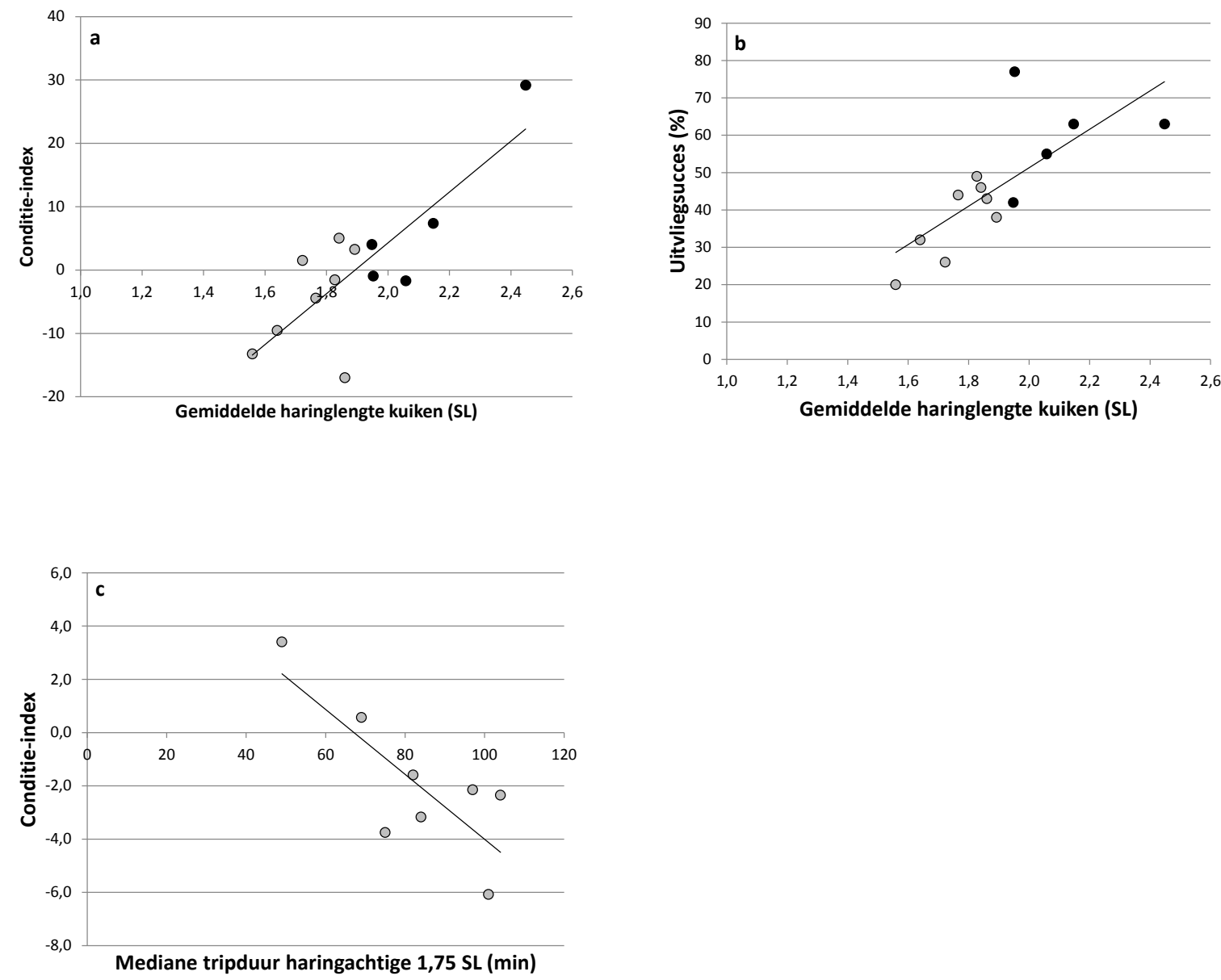

Figuur 7.15 a. Relatie tussen de gemiddelde haringlengte in het kuikendieet en de conditie van vliegvlug geworden kuikens (gewicht-leeftijd) van grote stern op Markenje (zwarte bollen) en de Scheelhoek (grijze bollen, 2009-2017). b. Relatie tussen de gemiddelde haringlengte in het kuikendieet van grote stern en het uitvliegsucces op Markenje (zwarte bollen) en de Scheelhoek (grijze bollen, 2009-2017). c. Relatie tussen de mediane tripduur voor het aanbrengen van een haringachtige van $1.75 \mathrm{SL}$ en de conditie van vliegvlug geworden kuikens (gewicht-koplengte) van grote stern op de Scheelhoek (2009-2017). 

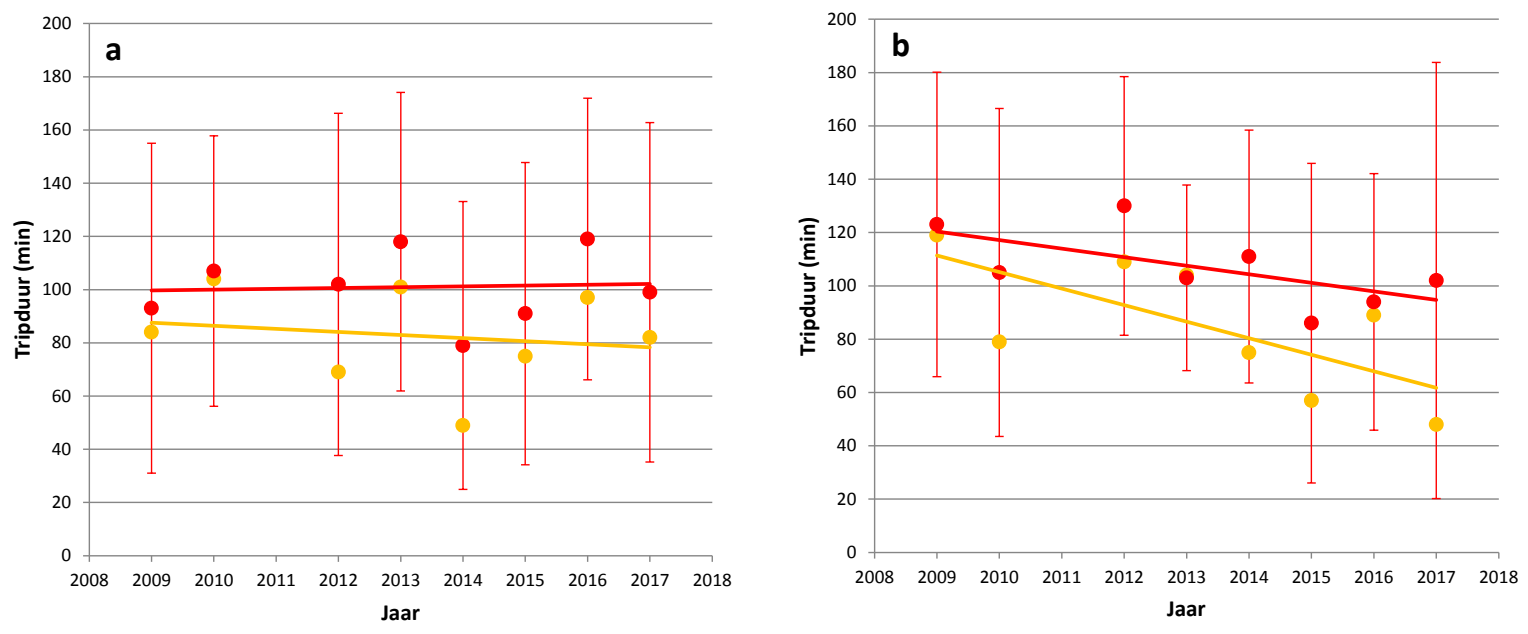

Figuur 7.16 Mediane en gemiddelde tripduur voor het aanbrengen van een haringachtige van $1.75 \mathrm{SL}$ (a. links) en een zandspieringachtige van $2.5 \mathrm{SL}$ (b. rechts) naar de kolonie grote sterns op de Scheelhoek (2009-2017). Geen van de gepresenteerde verbanden is significant.

\subsubsection{Broedsucces in relatie tot kwantiteit voedsel}

De conditie (gewicht-koplengte) van de vliegvlug geworden kuikens is negatief gecorreleerd met de tijd die nodig is om een haringachtige van $1.75 \mathrm{SL}$ aan te brengen naar de kuikens (figuur 7.16c; $\mathrm{R}^{2}$ $0.62, p<0.05$ ). Voor zandspieringachtigen werd geen relatie gevonden tussen de conditie-indices van de kuikens en de proxy voor het voedselaanbod. Dit betekent echter niet dat zandspieringachtigen geen belangrijke rol spelen voor grote sterns in de Delta. In jaren waarin weinig haringachtigen zijn aangebracht in het begin van het kuikenseizoen (bijv. in 2013) vormden zandspieringachtigen een belangrijk alternatief voor het grootbrengen van de kuikens. Voor adulte vogels is de aanwezigheid van voldoende zandspiering wellicht nog belangrijker. Tijdens de eerste weken van mei (tijdens het bebroeden van de eieren) vormen zandspieringen de belangrijkste voedselbron voor adulte vogels. In de meeste jaren verandert de samenstelling van het adulte dieet in de loop van het broedseizoen met een toenemend aandeel (kleine) haringachtigen naarmate het broedseizoen vordert (figuur 7.17, voorbeeld 2015 Scheelhoek).

De tripduur kan ook gebruikt worden om een idee te krijgen van de actieradius van grote sterns. Figuur 7.18 geeft weer wat de gemeten gemiddelde tripduur betekent in termen van potentiële foerageerafstanden vanuit de Scheelhoekkolonie (rekening houdend met een gemiddelde vliegsnelheid van $60 \mathrm{~km} / \mathrm{uur}$ ). Omdat de gemiddelde foerageerduur groter is dan de mediane foerageerduur en deze afstanden goed overeen komen met wat de loggergegevens laten zien kunnen ze als realistisch worden beschouwd. Hieruit blijkt (net zoals uit de gegevens van de vliegtuigtellingen en de loggerdata) dat grote sterns een actieradius hebben die tot ver buiten het Natura 2000 gebied Voordelta kan reiken.

In de huidige analyses is geen rekening gehouden met de invloed van weersomstandigheden, hoewel bekend is dat vooral wind een grote invloed heeft op de voedselaanvoer. 


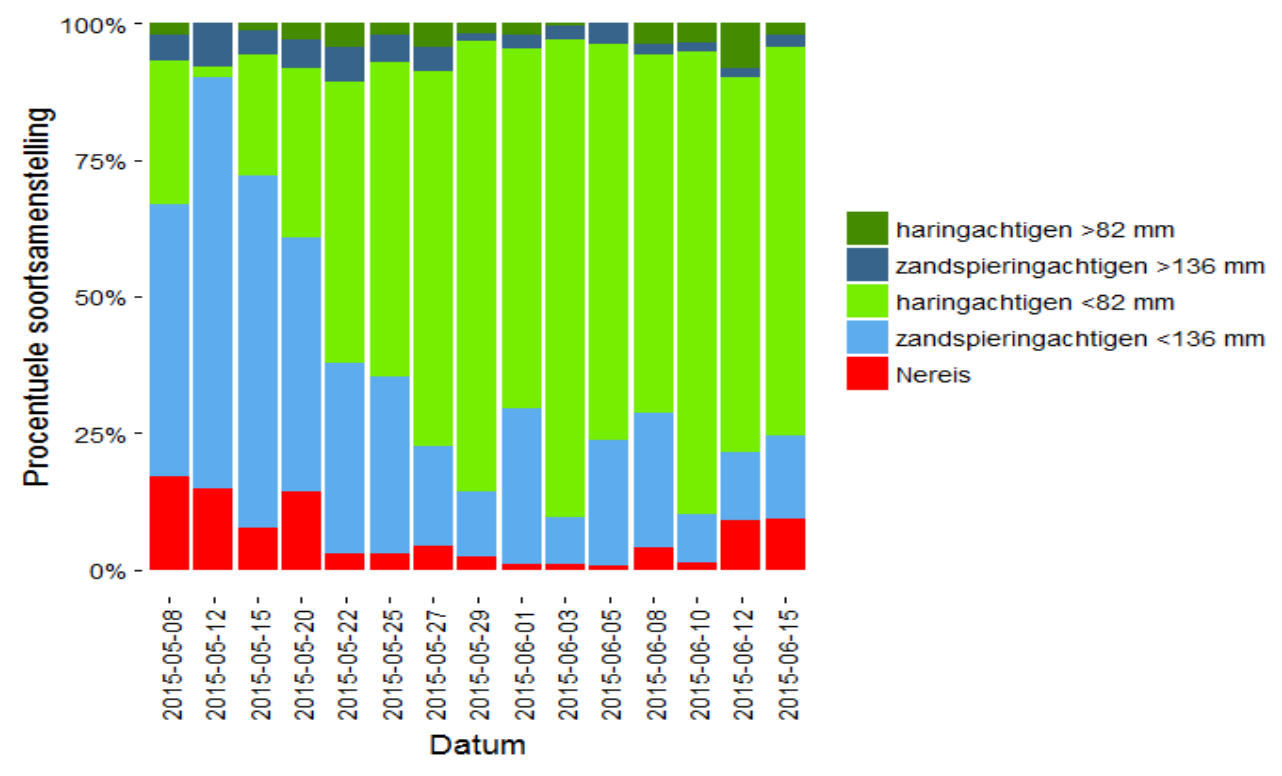

Figuur 7.17 Typische samenstelling van het dieet van broedende adulte grote sterns op de Scheelhoek (2015).

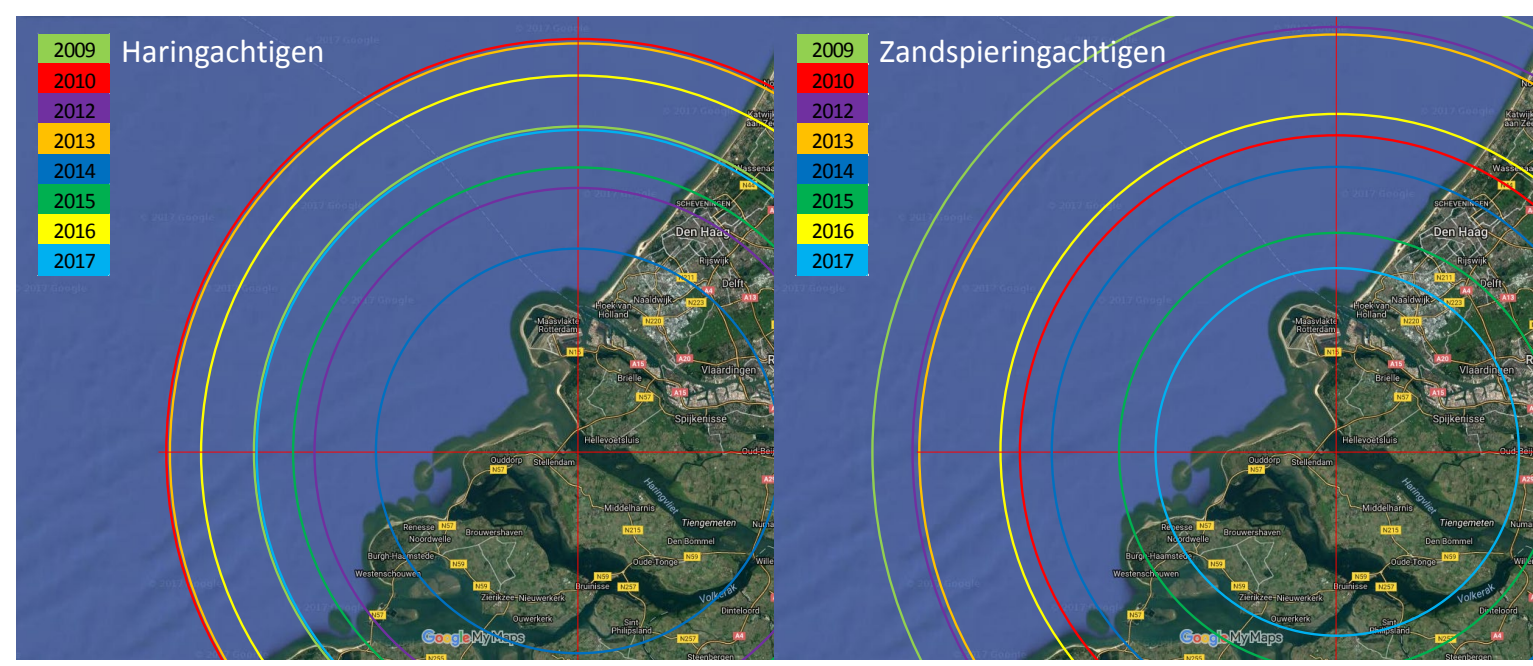

Figuur 7.18 Mediane foerageerafstand voor het aanbrengen van haringachtigen van $1.75 \mathrm{SL}$ en zandspieringachtigen van 2.5 SL naar de kolonie grote sterns op de Scheelhoek (2009-2017). Hierbij is geen rekening gehouden met de tijd nodig om te foerageren waardoor deze afstanden voor de gegeven mediane foerageerduur als maximaal dienen te worden beschouwd.

\section{Deelconclusies}

- De visbemonsteringen zijn niet optimaal om het aanbod (lengteverdeling en dichtheden) van haringachtigen en zandspiering te meten.

- De grotere haring die aan de kuikens gevoerd wordt, komt weinig voor in de visbemonstering en wordt waarschijnlijk van verder op zee uit dieper water gehaald. Dit blijkt ook uit de GPS waarnemingen en de tijd die ze nodig hebben voor het aanbrengen van voedsel.

- De kuikenconditie en het uitvliegsucces van grote sterns zijn sterk afhankelijk van de kwaliteit en de kwantiteit van het voedselaanbod in de Voordelta en daarbuiten.

- Vooral de aanvoer van haringachtigen (tripduur en prooilengte) is bepalend voor de conditie en de overleving van de kuikens en daarmee van het broedsucces. Deze aanvoer houdt waarschijnlijk rechtstreeks verband met de beschikbaarheid van de prooisoorten in de foerageergebieden. Er is geen trend in aanvoer van haringachtigen over de jaren.

- Zandspieringen zijn minder belangrijk voor de kuikens dan haringachtigen. Niettemin spelen deze bij gebrek aan (bijv. 2013) of moeilijke vangbaarheid van haringachtigen (bijv. stormperiode 2017) een belangrijke rol als voedsel voor de kuikens. 
- Zandspieringachtigen zijn de belangrijkste voedselbron voor adulte grote sterns tijdens de eerste weken van het broedseizoen.

- Voedsel is dus sterk bepalend voor het broedsucces, maar het is niet duidelijk of het voedselaanbod veranderd is na de aanleg van Maasvlakte 2.

\subsubsection{Zandspiering}

\subsubsection{Zandspiering in de Voordelta}

In de PMR benthossurvey (zie hoofdstuk 5) wordt naast bodemfauna ook zandspiering gevangen. De PMR survey vindt echter in het najaar plaats, een paar maanden na het broedseizoen waardoor deze bemonstering geen optimaal beeld geeft van de voedselbeschikbaarheid voor broedende grote sterns en kuikens. Uit de literatuur weten we dat zandspiering sterk afhankelijk is van geschikt sediment om zich in te kunnen graven en over het algemeen plaatstrouw is. Dit zijn goede redenen om aan te nemen dat de verspreiding in het najaar veel lijkt op de verspreiding in het voorjaar. De dichtheden zandspiering in de benthossurvey vertonen geen duidelijk trend voor de jaren waarvoor deze gegevens beschikbaar zijn (figuur 7.19). Voor langetermijnseries van zandspiering op basis van DFSmonitoring binnen en buiten de Voordelta verwijzen we naar hoofdstuk 5.

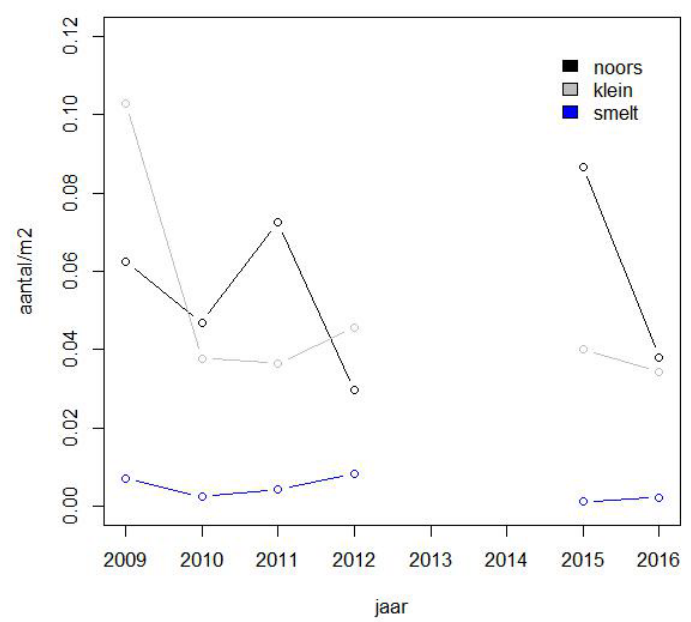

Figuur 7.19 Tijdserie drie soorten zandspiering uit de PMR benthossurvey. In 2013 is de zandspiering niet verzameld en in 2014 heeft er geen benthosbemonstering plaatsgevonden. Zie voor opzet survey en aantallen monsters hoofdstuk 5.

\subsubsection{Zandspiering langs de Nederlandse kust}

In de WOT-schelpdiersurvey die jaarlijks in het voorjaar uitgevoerd wordt, wordt net als in de PMR benthossurvey zandspiering gevangen met de benthosschaaf. In 2016 zijn in de WOT-survey voor het eerst ook de zandspieringen verzameld (hele en kapotte) en de hele zandspieringen op soortsniveau gedetermineerd. Deze set geeft een beeld van de verspreiding van de drie soorten zandspiering (kleine zandspiering Ammodytes tobianus, Noorse zandspiering A. marinus en smelt Hyperoplus lanceolatus) langs de hele kust vanaf Zeeland tot aan de Waddeneilanden (figuur 7.20). De informatie uit de WOT-survey kan gebruikt worden om te onderzoeken of de verspreiding van zandspiering uit de PMR-benthossurvey, overeenkomt met het beeld in het voorjaar. De voorjaarsperiode is veel relevanter in verband met de broed- en kuikenperiode van sterns. Ook kan de informatie gebruikt worden om het voorkomen in de Voordelta in een groter perspectief te plaatsen: hoe belangrijk is de Voordelta voor zandspiering ten opzichte van de rest van de Nederlandse kust. 

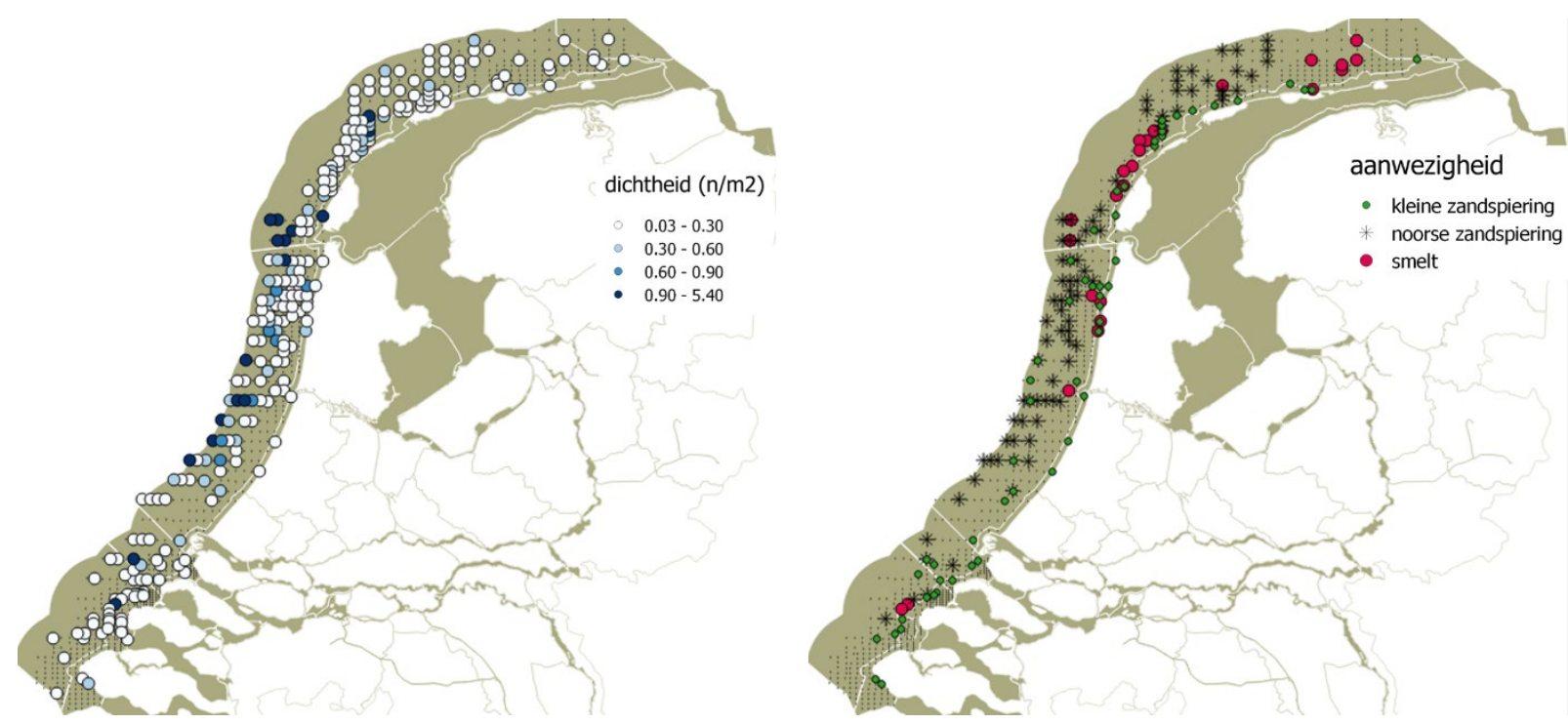

Figuur 7.20 Zandspiering aangetroffen in de WOT survey van 2016. Links: dichtheid (aantal / m2) van gevangen zandspiering, van zowel gedetermineerde Noorse en kleine zandspiering en smelt als van (ongedetermineerde) koppen van zandspiering. Rechts: het voorkomen van gevangen Noorse en kleine zandspiering en smelt. Kleine blauwe stippen zijn bemonsterde surveylocaties waar geen zandspiering is gevangen.
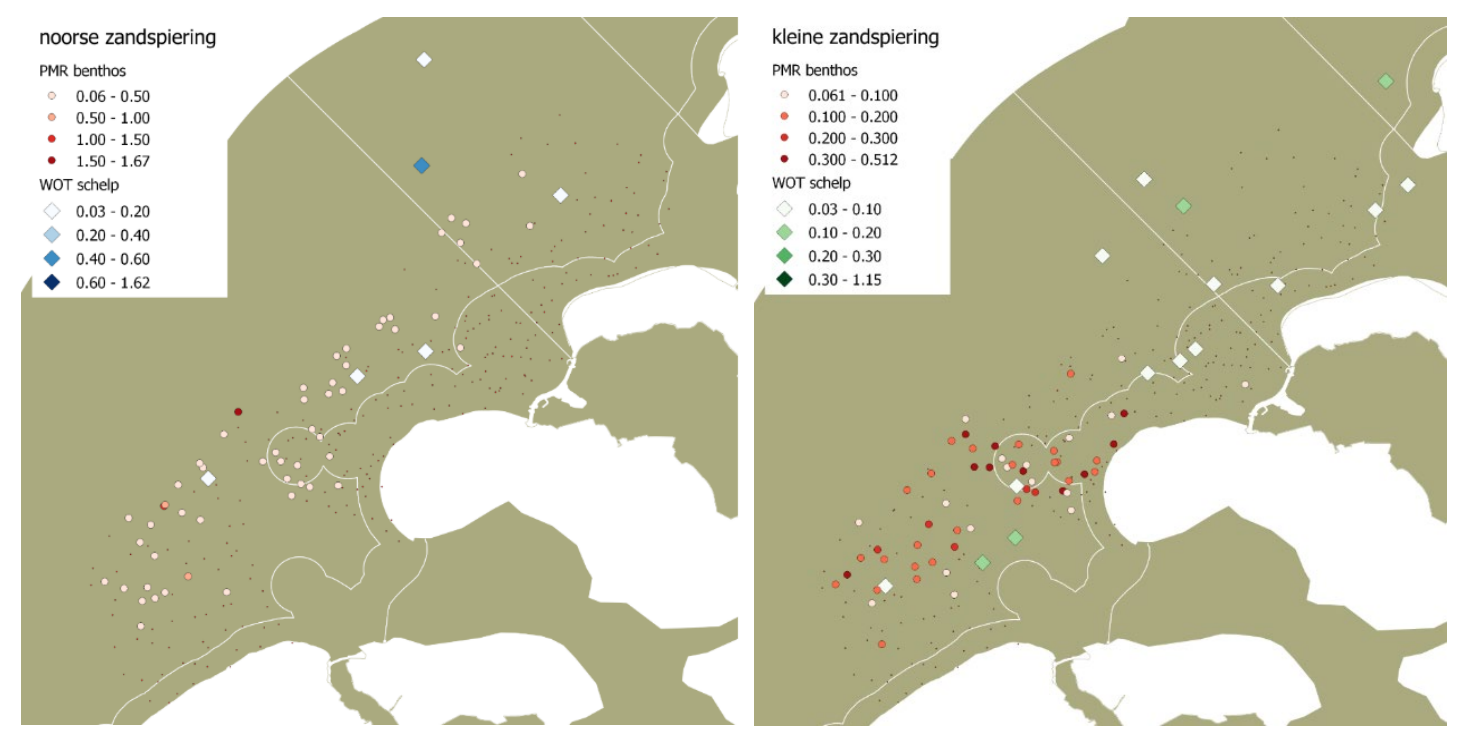

Figuur 7.21 Zandspiering (aantal/m2) aangetroffen in de WOT-schelpdiersurvey (mei/juni) en de PMR-benthossurvey (okt) van 2016. Kleine rode stippen zijn bemonsterde PMR-surveylocaties waar geen zandspiering is gevangen.

$\mathrm{Er}$ is veel overlap in bodemschaafstations in de Voordelta tussen de PMR-benthossurvey en de WOTschelpdiersurvey. De verspreiding van zandspieringen gevangen in de twee surveys in de Voordelta vertoont echter zeer weinig overlap (figuur 7.21). De oorzaak hiervan is het verschil in seizoen, de WOT survey vindt plaats in het voorjaar en waarschijnlijk zit dan nog maar een deel van de zandspiering overdag ingegraven en zwemt het merendeel in de waterkolom. Tijdens PMRbenthossurvey (i.e. in het najaar) bevindt de meeste zandspiering zich in de bodem.

\subsubsection{Voorkomen zandspieringachtigen in relatie tot abiotiek en visserij}

Het voorkomen van zandspieringachtigen in relatie tot abiotische factoren, en de invloed van visserij is onderzocht in de eerste fase van PMR-NCV (Tien et al. 2017a). Daaruit bleek dat er een negatieve 
correlatie bestond tussen het voorkomen (aan/afwezigheid) van verschillende soorten zandspiering en bodemberoerende visserij (boomkor of garnalenkor) (tabel 7.2).

Voor de meest voorkomende soort, de kleine zandspiering, is deze relatie opnieuw onderzocht (Alain Zuur, Highland Statistics) met de meest geavanceerde statistische technieken bedoeld voor analyses waarbij waarnemingen in de ruimte en in de tijd gecorreleerd zijn (met andere woorden punten die dicht bij elkaar liggen lijken meer op elkaar dan punten die verder uit elkaar liggen en waarnemingen uit opeenvolgende jaren lijken meer op elkaar dan waarnemingen met grotere tussenpozen). De verschillen tussen beide analyses worden samengevat in tabel 7.3.

Uit de verspreidingskaarten blijkt dat kleine zandspiering en boomkorvisserij in de ruimte vrijwel gescheiden voorkomen (figuur 7.22). Uit beide analyses is echter niet te ontrafelen of dat komt door een causaal verband (boomkorvisserij heeft negatief effect op voorkomen zandspiering) of door een andere factor. Zandspiering heeft bijv. een sterke voorkeur voor een bepaald type sediment (grof zand). Het is waarschijnlijk dat de vis waar de boomkorvisserij (bijv. tong) naar op zoek is juist niet veel voorkomt op een dergelijke ondergrond.

Uit de analyse van Zuur \& Ieno (2017b)) bleek dat de effecten van de covariaten (abiotische factoren, visserij) erg klein zijn vergeleken met de ruimtelijke variatie die niet door een van de covariaten verklaard wordt. Alleen mediane korrelgrootte en diepte laten een duidelijk verband zien met het voorkomen van zandspiering (figuur 7.23). Voor de effecten van de visserijdruk door beide visserijen zijn de betrouwbaarheidsintervallen erg groot wat wijst op weinig verklarende kracht.

\section{Tabel 7.2}

Samenvatting van het verband tussen het voorkomen van drie zandspieringachtigen, abiotiek en visserijdruk. Resultaat van een generalised linear mixed model met monster locatie als random variabele (uit (Tien et al. 2017a)). + geeft aan dat er een positief verband is tussen de variabele en de het voorkomen van een van de soorten, - een negatief verband, en ns=niet significant.

\begin{tabular}{|l|l|l|l|}
\hline factor & noorse zandspiering & kleine zandspiering & smelt \\
\hline \% slib & - & - & - \\
\hline \%zand & + & + & $\mathrm{ns}$ \\
\hline diepte & + & - & - \\
\hline stroomsnelheid & + & + & + \\
\hline temperatuur & $\mathrm{ns}$ & - & - \\
\hline saliniteit & + & $\mathrm{ns}$ & + \\
\hline jaar & - & - & $\mathrm{ns}$ \\
\hline visserijdruk boomkorvisserij & - & - & $\mathrm{ns}$ \\
\hline visserijdruk garnalenvisserij & $\mathrm{ns}$ & $\mathrm{ns}$ & - \\
\hline
\end{tabular}

\section{Tabel 7.3}

Kenmerken van beide analyses van het voorkomen van zandspiering in relatie tot abiotiek en visserij.

\begin{tabular}{|l|l|}
\hline Tien et $\mathbf{a l .} \mathbf{( 2 0 1 7 a ) )}$ & Zuur \& Ieno (2017b)) \\
\hline Generalised linear mixed model (GLMM) & $\begin{array}{l}\text { R-INLA (ZAP GAM hurdle model met } \\
\text { Bayesiaanse statistiek) } \\
\text { kleine zandspiering }\end{array}$ \\
\hline 3 soorten & aan/afwezigheid + dichtheid \\
\hline aan/afwezigheid & gams \\
\hline lineaire relaties & ruimtelijke aggregatie \\
\hline station als ruimtelijk component (random factor) & verklarende factoren: \\
\hline verklarende factoren: & sediment: mediane korrelgrootte \\
\hline sediment: \%slib en \%zand & diepte, temperatuur, jaar \\
\hline diepte, temperatuur, jaar & \\
\hline saliniteit, stroomsnelheid & visserij-inspanning garnalen/platvis visserij \\
\hline visserij-inspanning garnalen/platvis visserij & \\
\hline
\end{tabular}




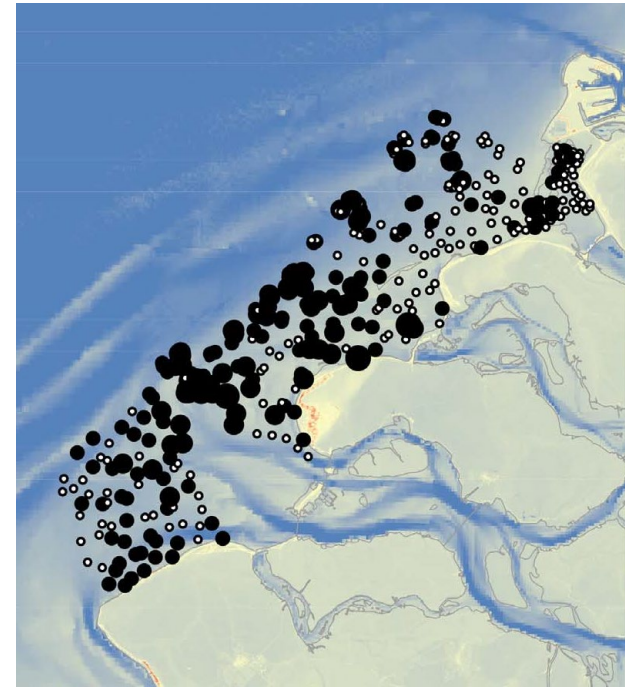

kleine zandspiering

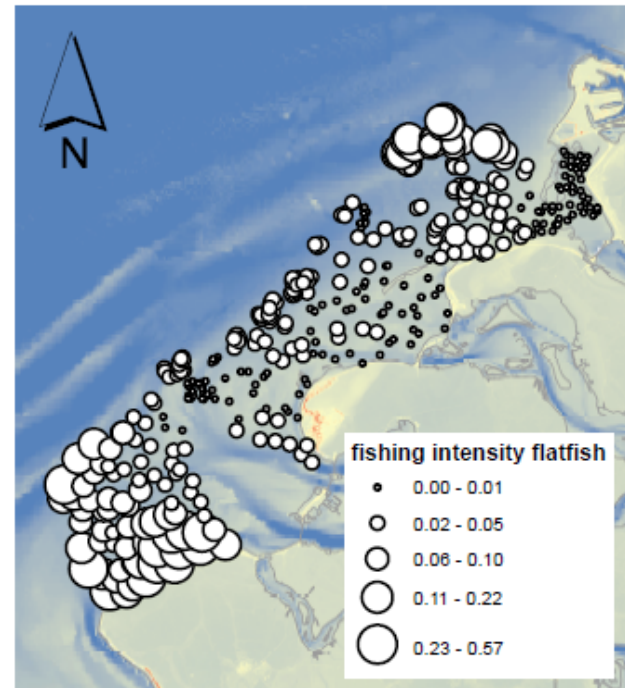

boomkorvisserij

Figuur 7.22. Verspreiding kleine zandspiering en boomkorvisserij (gemiddeld 2009-2012).

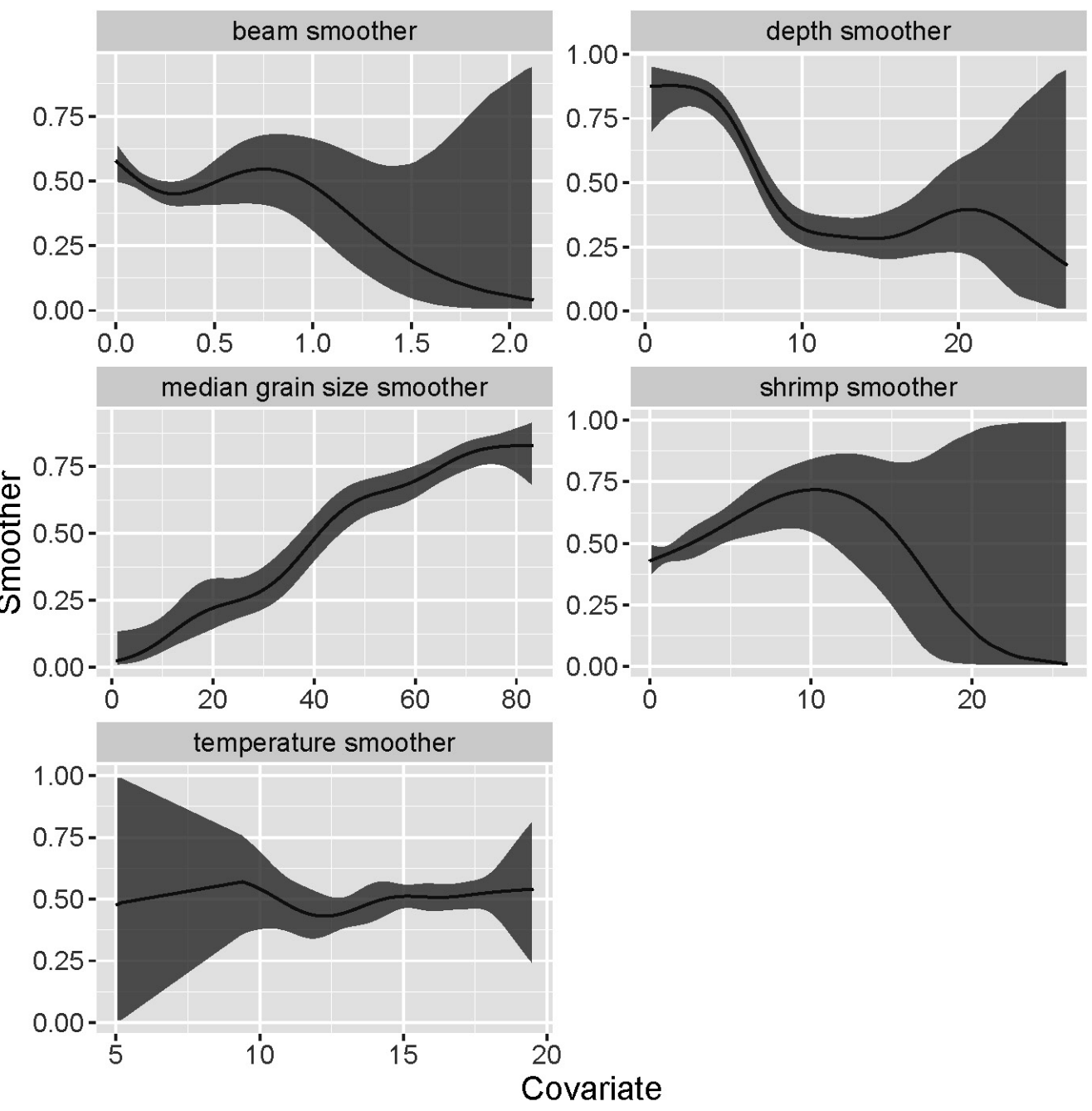

Figuur 7.23 De kans op aanwezigheid van kleine zandspiering in relatie tot covariaten: boomkorvisserij (beam), diepte (depth), mediane korrelgrootte (median grain size), garnalenvisserij (shrimp) en temperatuur (temperature) (Zuur \& Ieno 2017b). De lijn geeft de berekende effecten per covariaat met het betrouwbaarheidsinterval (donkergrijs gebied).beam=pltvias visserij; shrimp=garnalenvisserij 


\section{Deelconclusies}

- Op basis van de PMR benthos survey zijn er geen trendmatige veranderingen waarneembaar in de drie zandspieringachtigen in de periode 2009-2016.

- Uit de WOT schelpdiersurvey uit 2016 blijkt dat de drie zandspieringachtigen langs de hele Nederlandse kust voorkomen.

- Vergeleken met de variatie die verklaard kan worden door ruimtelijke patronen, is de verklaring in de verspreiding van kleine zandspiering door abiotische variabelen en visserij relatief gering.

- Of er sprake is van een causaal verband tussen visserij en de verspreiding van zandspiering is niet te zeggen. In de ruimte is er echter weinig overlap in de verspreiding van met name kleine zandspiering en boomkorvisserij.

\subsubsection{Invloed van andere factoren op broedsucces}

Zowel het aantal broedende sterns als het broedsucces (een combinatie van het uitkomst- en uitvliegsucces) worden potentieel beïnvloed door factoren als het voedselaanbod/-kwaliteit, predatie, het beheer van de kolonieplaatsen en weersomstandigheden.

De mate waarin verschillende factoren in de loop van het onderzoek bepalend waren voor het broedsucces kunnen variëren per jaar en worden voor de hele onderzoeksperiode hieronder op een rij gezet (tabel 7.4).

Beheer van de kolonies/vegetatie: Grote sterns broeden in dichte kolonies waardoor ze iets minder afhankelijk zijn van het (micro)beheer van kolonies dan visdieven (door de afzetting van faeces sterft de reeds aanwezige vegetatie vaak snel af). De aanwezigheid van enkele grote kale plekken kan voldoende zijn voor vestiging. Wel moet er enige vegetatie in de buurt van de kolonieplek aanwezig zijn om kokmeeuwen aan te trekken (grote sterns vestigden zich in de onderzochte kolonies nagenoeg uitsluitend als er ook broedende kokmeeuwen aanwezig waren). Het enige jaar waarin op de Scheelhoek mogelijk een effect van beheer van vegetatie speelde, was in 2014 toen de eilanden er bijna volledig kaal bij lagen en de kolonie zich vestigde op de Slijkplaat. Verder werd er noch op het uitkomst- noch op het uitvliegsucces een negatief effect van beheer vastgesteld. In 2011 vestigden nagenoeg alle grote sterns zich op Markenje: slechts 6 paar broedden op de Scheelhoek, dit ondanks het feit dat de eilanden er prima bij lagen. Op Markenje zaten de grote sterns zelden op een 'klassieke' plek (redelijk kaal en zanderig) maar eerder op hoog gras en vaak tussen erg hoge vegetatie. Het ontbreken van een kolonie op Markenje in 2017 heeft waarschijnlijk te maken met de hoge en dichte vegetatie op het deel van het eiland waar de vogels zich meestal vestigen, dit in combinatie met de sterke ei-predatie door zwartkopmeeuwen in de twee voorgaande jaren.

Weersomstandigheden: Een negatief effect van weersomstandigheden op het uitkomstsucces werd alleen op Markenje in 2013 vastgesteld. Na hevige neerslag was een laagje vuil afgezet op de eieren waardoor de kuikens vaak niet uit het ei konden pikken en nesten werden verlaten.

Weersomstandigheden kunnen op verschillende manieren van invloed zijn op het uitvliegsucces van de kuikens. Rechtstreekse invloed kan soms worden vastgesteld na perioden van harde regen en/of wind wanneer veel (meestal kleinere) kuikens sterven door onderkoeling. Indirecte invloeden ontstaan wanneer de ouders (bijvoorbeeld bij harde wind) meer moeite hebben om voldoende (energierijke) prooien aan te brengen voor de kuikens waardoor de kuikenconditie achterblijft en kuikens uiteindelijk sterven. Ook is er waarschijnlijk een effect van zeewatertemperatuur op het aanbod aan voldoende grote pelagische vis.

Grote sternkuikens (zeker als ze iets ouder zijn) kunnen tegen een stootje en hadden in de meeste jaren relatief weinig last van de weersomstandigheden. In drie jaren was er wel een duidelijk effect, namelijk in 2010, 2015 en vooral in 2017, als gevolg van slechte weersomstandigheden op specifieke momenten in de broed- of kuikenfase. In 2010 stierf ruim de helft van de kuikens uit eenlegsels en eerste eieren van tweelegsels (in de meeste gevallen vliegen alleen de kuikens uit deze eerste eieren uit) tijdens perioden van hevige regen en/of wind, in 2015 ruim 70\% en in 2017 was dat bijna 90\%.

Predatie: Predatie van eieren speelde op de Scheelhoek in geen enkel jaar een rol. Op Markenje daarentegen werd zowel in 2015 als 2016 een groot deel van de eieren in de kolonie gepredeerd door 
hoofdzakelijk zwartkopmeeuwen. Kuikenpredatie was in geen enkele onderzochte kolonie een probleem.

\section{Tabel 7.4}

Overzicht van het kwalitatieve negatieve effect van verschillende factoren op de vestigingskans, het uitkomst- en uitvliegsucces van grote stern in de onderzoeksperiode (2009-2017). Groen = geen/nauwelijks negatief effect, oranje = enig effect, rood = sterk effect. Er is geen kolonie geweest in 2011 en 2014 op Scheelhoek en in 2017 op Markenje. De percentages geven resp. het percentage uitkomstsucces en het percentage uitvliegsucces.

\begin{tabular}{|c|c|c|c|c|c|c|c|}
\hline \multirow[t]{2}{*}{ Jaar } & \multirow[t]{2}{*}{ Kolonie } & \multirow{2}{*}{\begin{tabular}{|l|}
\multicolumn{1}{|c|}{ Vestiging } \\
Beheer kolonie \\
\end{tabular}} & \multicolumn{2}{|r|}{ Uitkomstsucces (\%) } & \multicolumn{2}{|r|}{ Uitvliegsucces (\%) } & \multirow{2}{*}{$\begin{array}{c}\text { Broedsucces } \\
\text { (n jongen/paar) }\end{array}$} \\
\hline & & & $\%$ & Weersomstandigheden Predatie & $\%$ & Weersomstandigheden Predatie & \\
\hline 2009 & Scheelhoek & & 78 & & 44 & & 0,49 \\
\hline 2011 & Scheelhoek & - & - & - & - & - & - \\
\hline 2012 & Scheelhoek & & 95 & & 38 & & 0,57 \\
\hline 2013 & Scheelhoek & & 87 & & 43 & & 0,63 \\
\hline 2015 & Scheelhoek & & 93 & & 20 & & 0,31 \\
\hline 2016 & Scheelhoek & & 90 & & 49 & & 0,77 \\
\hline 2017 & Scheelhoek & & 86 & & 26 & & 0,38 \\
\hline 2011 & Markenje & & 86 & & 63 & & 0,85 \\
\hline 2012 & Markenje & & 88 & & 42 & & 0,54 \\
\hline 2017 & Markenje & - & - & - & - & - & - \\
\hline
\end{tabular}

\section{Deelconclusies}

- Het beheer van de kolonies heeft grote invloed op de vestiging van grote sterns, te kale of te dicht begroeide plaatsen worden gemeden. Op het broedsucces had dit tijdens de onderzoeksjaren minder effect.

- De invloed van weersomstandigheden op het broedsucces is complex (direct effect op de kuikenconditie, indirect via verminderde energie-aanvoer). Niettemin kan worden gesteld dat weersomstandigheden in een aantal jaren zeker een effect hebben gehad op het broedsucces in de onderzochte kolonies.

- $\quad$ Predatie van eieren kan in sommige jaren een grote rol spelen. 


\subsection{De functie van de rustgebieden in de Voordelta voor de grote stern}

De derde deelvraag richt zich op de functie van de rustgebieden in de Voordelta

c) Draagt het instellen van de rustgebieden bij aan het instandhoudingsdoel?

i. Worden de droogvallende platen in de rustgebieden gebruikt door de aanwezige grote sterns, en/of worden andere gebieden gebruikt om te rusten? En in welke periode houden zij zich hier op?

ii. Wat is het relatieve belang van de Voordelta voor de grote stern, welke factoren spelen daarbij een rol en wat is de jaar tot jaar variantie en zijn hierin grote veranderingen waarneembaar?

Eén van de compensatiemaatregelen betrof het instellen van rustgebieden voor sterns: de Bollen van de Ooster en de Hinderplaat. Rustende grote sterns bleken tijdens de nulmeting en fase I en II van PMR-NCV een duidelijk voorkeur te hebben voor specifieke platen en stranden binnen de Voordelta, en waren te vinden op de Bollen van het Nieuw Zand, de Verklikkerplaat, de Bollen van de Ooster, het strand van Goeree, de Kwade Hoek, de Hinderplaat en op de zachte zeeweringen van Maasvlakte 1 en Maasvlakte 2 (figuur 7.24). Per telling varieerden de aantallen rustende grote sterns sterk: tussen de 0 en 2.500 individuen. De grootste groepen zijn aangetroffen op het Verklikkerstrand, de Bollen van de Ooster en op stranden in het Maasvlakte-gebied: in 2009 op de nieuw opgespoten eilanden en de laatste jaren meer op de zuidpunt nabij de Hinderplaat. Met name in het voorseizoen (april, begin mei) en rond het uitvliegen van de jongen werd er veel gebruik gemaakt van de platen. De exacte ligging van de rustlocaties van grote sterns is niet veranderd tussen de periode van de nulmetingen en de jaren na 2009, maar er zijn wel enkele algemene patronen waargenomen. 


\section{waarnemingen rustende grote sterns}
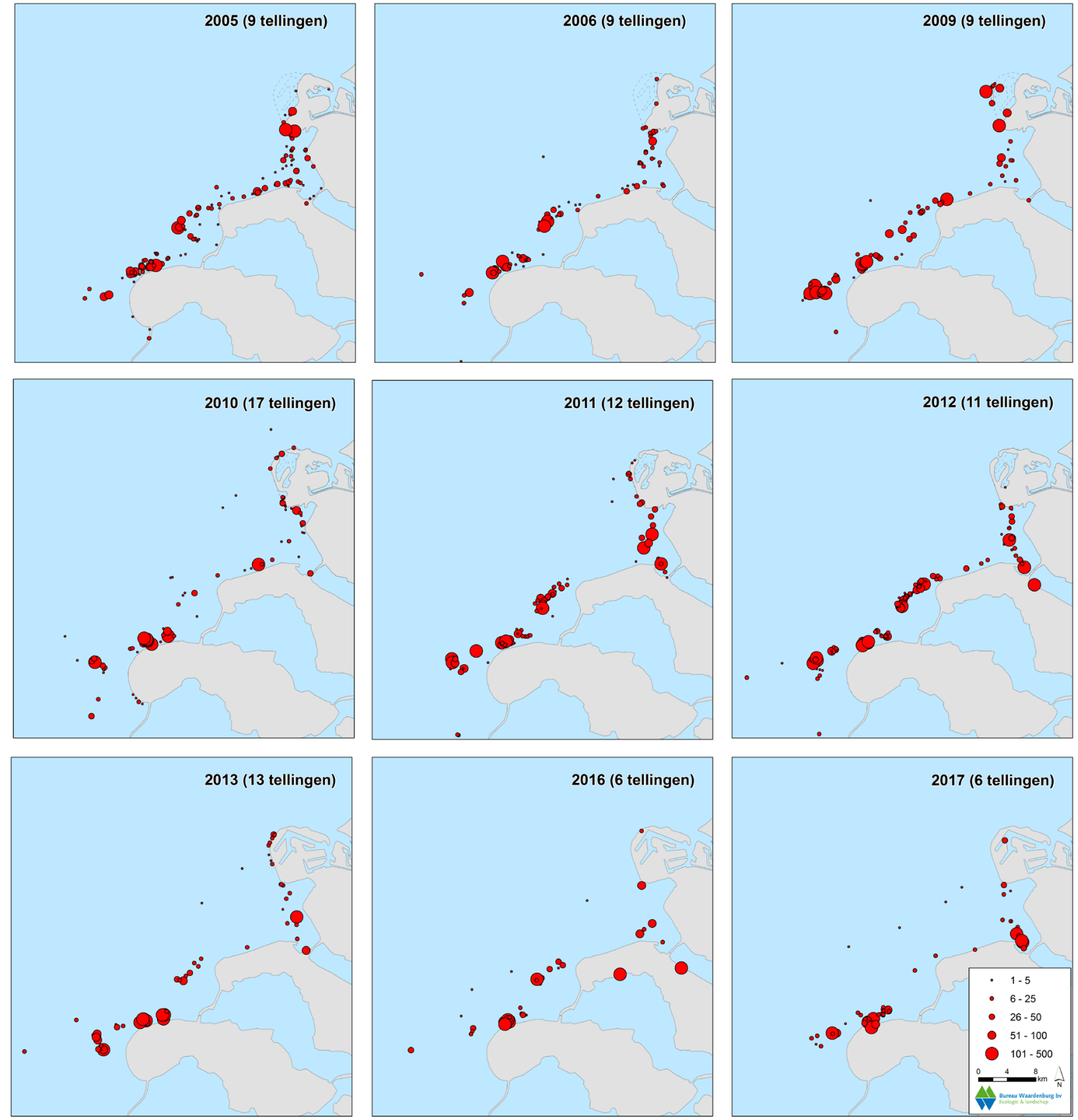

Figuur 7.24 Verspreiding van rustende grote sterns tijdens de nulmeting voor de bouw van Maasvlakte 1 en tijdens de fase I en II van PMR-NCV. Let op dat de telinspanning per jaar wisselt, zodat een kwantitatieve vergelijking tussen jaren niet direct mogelijk is.De platen waar sterns op rusten zijn niet weergegeven.

\subsubsection{Gebruik rustgebieden}

Het gebruik van aangewezen en niet aangewezen rustgebieden in de Voordelta varieert sterk per jaar (figuur 7.26). De laatste jaren lijkt het gebruik van de zachte zeewering van de Maasvlakte iets terug te lopen, maar deze afname is niet significant. Opvallend is verder dat met name de laatste jaren $(2016 / 17)$ het Verklikkerstrand enorm in trek is bij grote sterns. De aantallen op de Bollen van de Ooster vertonen grote variatie tussen jaren, met bijvoorbeeld zeer lage aantallen in 2010, 2013 en 2017, terwijl in 2011, 2012 en 2016 dit gebied één van de kernrustgebieden was. De aantallen in het recent aangewezen rustgebied Middelplaat nemen de laatste jaren toe, echter ze zijn het laagst van alle deelgebieden in de Voordelta. 

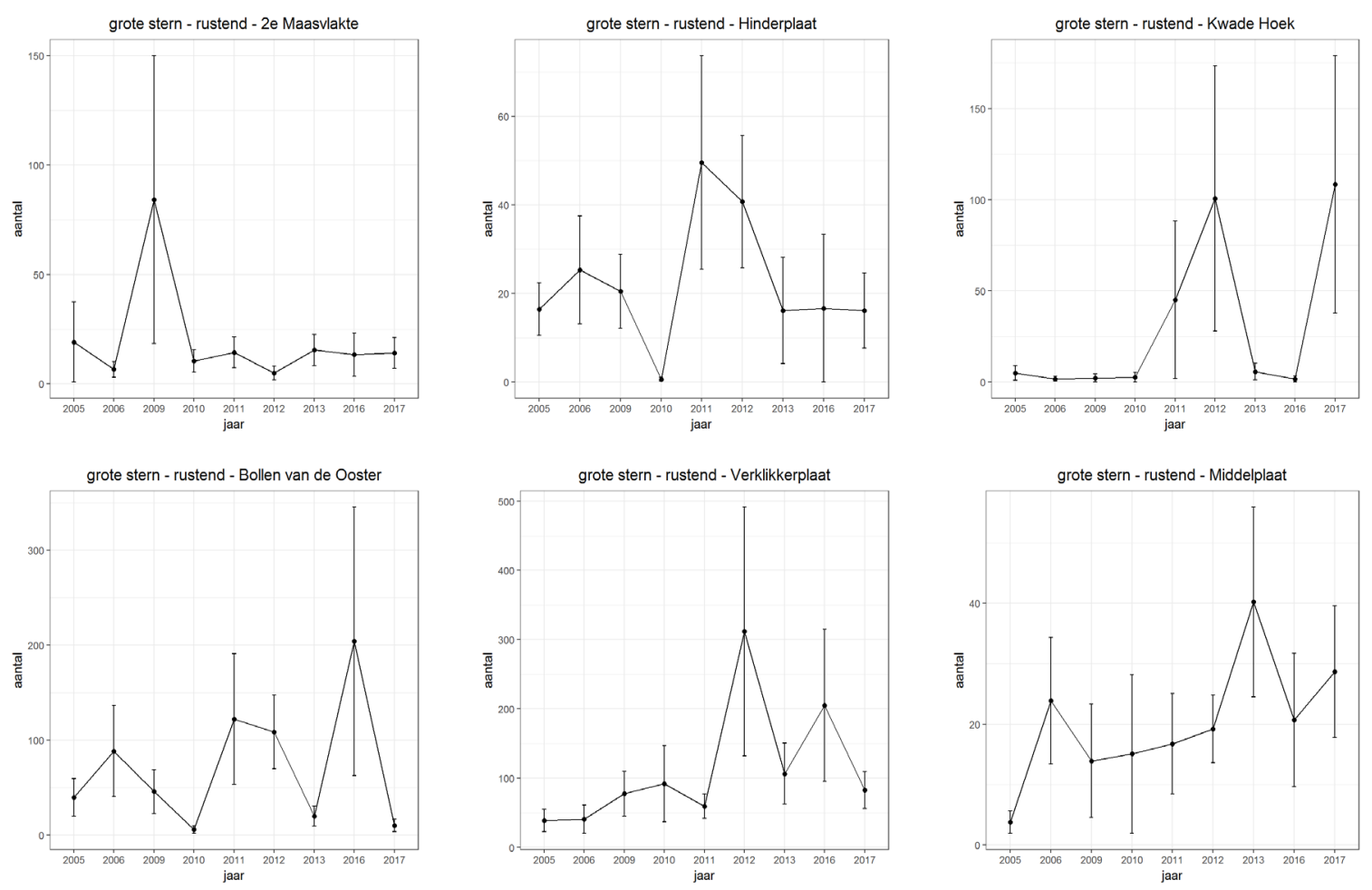

Figuur 7.25 Gemiddelde aantallen rustende grote sterns tijdens de vliegtuigtellingen uitgezet per jaar en per deelgebied. N.B. De verticale assen verschillen in schaal.

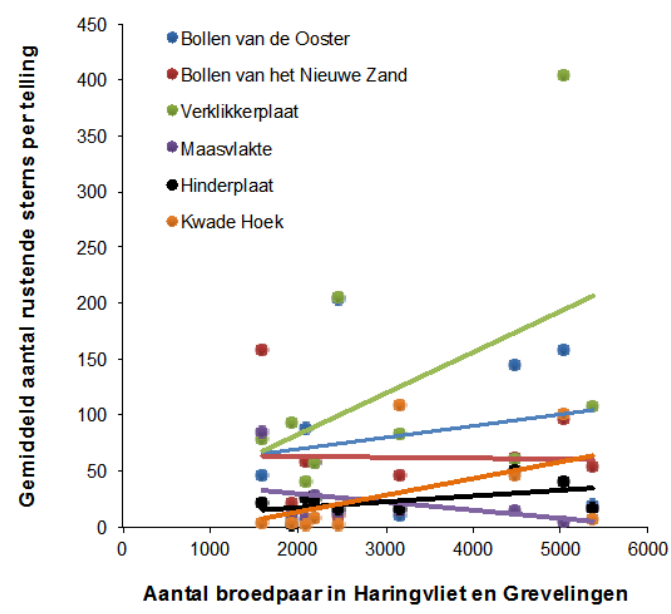

Figuur 7.26 Gemiddeld aantal rustende sterns per deelgebied uitgezet tegen het aantal broedparen in noordelijke kolonies.

Het relatieve gebruik van de verschillende rustgebieden wisselt met name onder invloed van de ligging van de broedkolonies. In jaren dat de kolonies in het noordelijk Deltagebied (Haringvliet en Grevelingenmeer) veel paren herbergen, rusten er per telling gemiddeld meer dieren op de Bollen van de Ooster, op de Verklikkerplaat en de Kwade Hoek. Op de Bollen van het Nieuwe Zand is een dergelijke stijging zeer beperkt, mogelijk ook doordat deze zandplaten maar kort beschikbaar zijn door de lage ligging, maar ze liggen ook veel verder van de kolonies af. Opvallend is dat bij hogere aantallen broedparen de aantallen op de Hinderplaat en Maasvlakte niet toenemen of zelfs afnemen (figuur 7.26).

Tijdens de nulmeting werd door grote sterns relatief weinig gebruik gemaakt van de Verklikkerplaat, terwijl dit gebied de laatste jaren veruit de hoogste aantallen rustende grote sterns herbergt. Rond het uitvliegen van de jongen begin juli, nemen de aantallen in de rustgebieden op de Bollen van de Ooster 
en de Hinderplaat toe, waarschijnlijk omdat deze het dichtst bij de kolonies op Markenje en Scheelhoek liggen.

De eerste grote sterns komen in de laatste week van maart aan in de Voordelta en al redelijk snel daarna, in de eerste twee weken van april, worden de seizoensmaxima bereikt (figuur 7.27). Waarschijnlijk is een aanzienlijk deel van deze vogels doortrekker uit noordelijkere broedgebieden. Dit is door een beperkte afleesinspanning van kleurringen, veroorzaakt door de onbereikbaarheid van verzamelplaatsen en het relatief schuwe gedrag in deze periode, echter niet met zekerheid te zeggen. In ieder geval worden in deze periode de ingestelde rustgebieden, maar met name de Verklikkerplaat (geen rustgebied), intensief gebruikt door grote aantallen grote sterns die zich hier verzamelen alvorens naar de kolonies te gaan (figuur 7.28).

Gedurende het broedseizoen maken kleinere aantallen grote sterns gebruik van de rustgebieden. Dit betreffen waarschijnlijk vooral vogels die niet gepaard zijn en/of jonge vogels die niet broeden maar uitsluitend de kolonies verkennen (kleurringgegevens Ringgroep Delta: BuWa, DPM, INBO), en vogels waarvan het broedsel verloren is gegaan (zenderdata Bureau Waardenburg).

Tijdens een periode van ongeveer twee weken rond het uitvliegen van de jongen zijn de ingestelde rustgebieden veel in gebruik door ouders met hun uitgevlogen jongen. Relatief kort na het uitvliegen lijkt het erop dat het merendeel van de lokaal geboren jongen met hun ouders de Voordelta verlaten en enerzijds naar het noorden vliegen en anderzijds en in mindere mate zuidwaarts. Later in het seizoen, in de loop van september, is er vaak nog een piek in de rustgebieden van vogels die op doortrek zijn naar zuidelijk gelegen overwinteringsplaatsen.
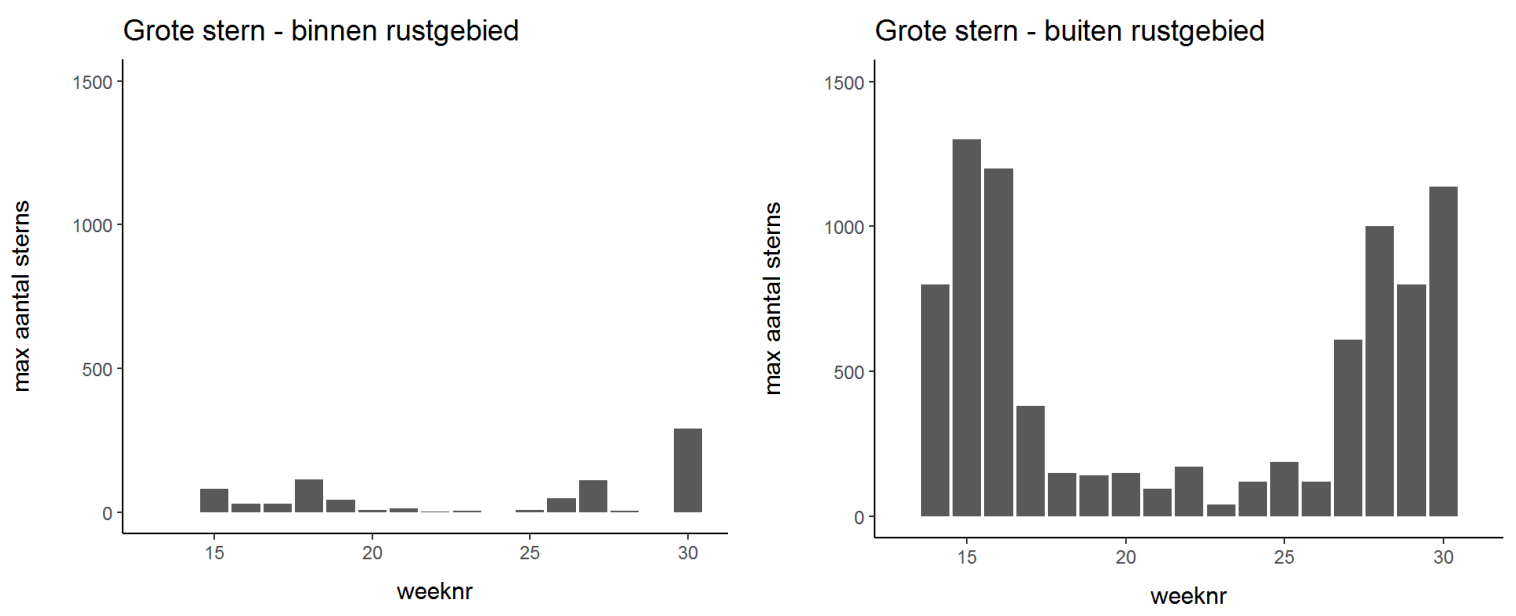

Figuur 7.27 Seizoensverloop van rustende grote sterns bınnen (Iınks) en buiten (rechts) de ingestelde rustgebieden in 2017. Let op dat in deze grafiekende de Bollen van de Ooster niet meegenomen zijn, waardoor met name de aantallen binnen de rustgebieden in week 30 (rond het uitvliegen van de jongen van de Scheelhoek) veel te laag zijn.
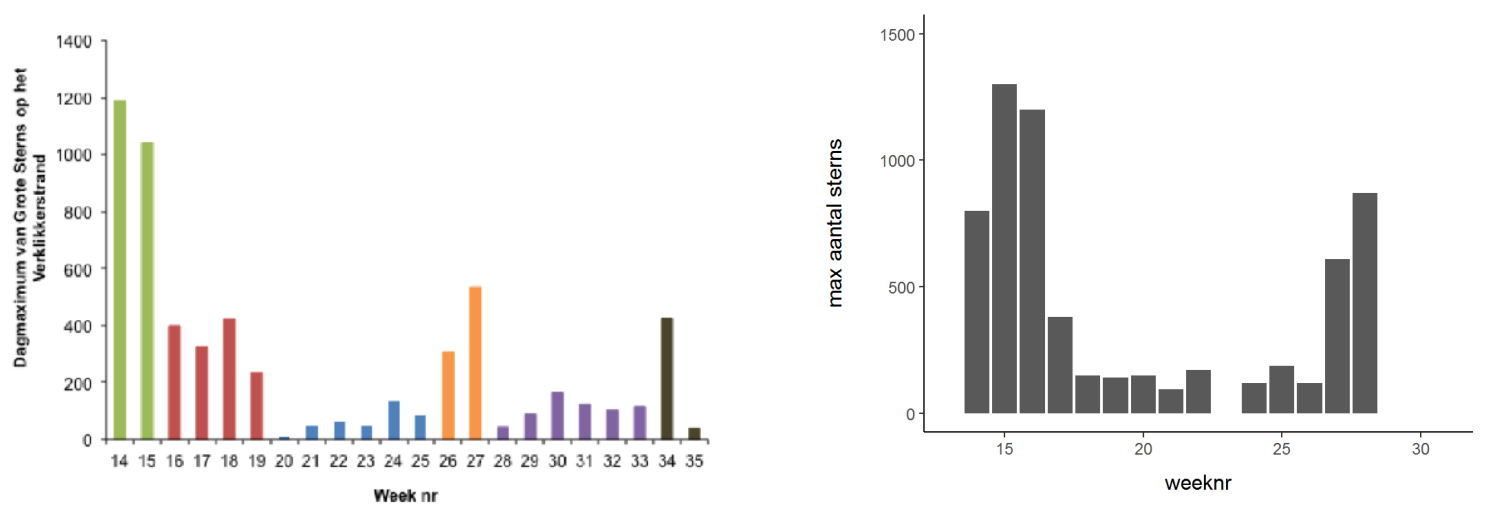

Figuur 7.28 Seizoensverloop van rustende grote sterns op het Verklikkerstrand in 2011 (links) en in 2017 (rechts).

Een implicatie van waarnemingen vanuit het vliegtuig en op land is dat aan rustende sterns niet te zien is of dit broedvogels zijn uit (Delta-)kolonies, of niet-broedende vogels, vogels waarvan het 
broedsel mislukt is, of doortrekkers. Op basis van de resultaten die het onderzoek met VHF-zenders en met name GPS-loggers op grote sterns heeft opgeleverd, weten we dat zowel mislukte broedvogels als kuikenvoerende adulten in meer of mindere mate gebruik maken van rustgebieden. Gemiddeld $4 \%$ van een foerageertocht bestaat uit rusten op zandplaten of stranden, wat neerkomt op ongeveer 5 minuten bij een gemiddelde tripduur van 134 min (Fijn et al. 2016). Mislukte broedvogels met GPSloggers maakten gebruik van een groot aantal verschillende rustplaatsen door de gehele Voordelta en (ver) daarbuiten, terwijl succesvolle broedvogels met GPS-loggers tijdens foerageertochten rustend zijn aangetroffen op met name de Bollen van de Ooster, de Hinderplaat en de stranden van Maasvlakte 2. Maar ook op de Verklikkerplaat, de Middelplaat en de Kwade Hoek werd door een enkeling gerust en buiten de Voordelta op bijvoorbeeld de Zandmotor.

In 2009, 2011-2013 en 2016 zijn landtellingen gericht op rustende juveniele grote sterns verricht, waarbij met name op de Verklikkerplaat en de Bollen van de Ooster grotere aantallen rustende grote sterns zijn aangetroffen in de eerste weken na het uitvliegen van de jongen. Het betrof hier vaak jonge vogels met kleurringen uit de Delta die werden gevoerd door hun ouders. Met name op de Bollen van de Ooster zit in deze periode van het seizoen een vaste groep van soms enkelen honderden grote sterns, maar ook op de Verklikkerplaat zijn waarnemingen gedaan van uitgevlogen juvenielen die gevoerd werden door hun ouders. Het is aannemelijk dat dit de ouders een energetische voorsprong geeft omdat ze, zeker in het geval van de Bollen van de Ooster, minder ver hoeven te vliegen naar hun jongen.

Sinds 2012 worden jaarlijks grote aantallen grote sterns in de kolonies in de noordelijke Delta van een kleurring voorzien waarmee ze relatief goed te volgen zijn tijdens hun verdere leven (tabel 7.5). Na het uitvliegen van de jongen (begin juli) zien we relatief veel terugmeldingen van deze vogels uit de Delta (waar het aantal aflezingen helaas zeer beperkt is) en de afstand tussen terugmelding en geboortegrond is relatief klein (figuur 7.29). Drie tot vier weken na uitvliegen wordt deze afstand steeds groter, en neemt ook het aantal aflezingen toe langs de Hollandse kust op makkelijk toegankelijke afleesplaatsen zoals de Zandmotor, het strand van IJmuiden, de Putten bij Petten en op Texel en Ameland (figuur 7.30). Vanaf augustus nemen de aantallen aflezingen in de Delta sterk af, en nemen tegelijkertijd het aantal aflezingen toe in Duitsland, Denemarken, Groot-Brittannië en noord Frankrijk. In september nemen de aantallen aflezingen uit het noorden weer af, en worden enkele vogels ook later in het seizoen na diverse omzwervingen opnieuw in de Delta gezien. In totaal hebben 179 adulte vogels en 2136 kuikens in de noordelijke Delta een kleurring gekregen. Van deze 2315 vogels zijn 147 individuen teruggemeld waarvan een aantal meerdere malen (totaal 177 terugmeldingen) vanuit rustgebieden in de Delta. Ook in andere Nederlandse kolonies worden grote aantallen jonge grote sterns van kleurringen voorzien. Het aantal aflezingen in de Delta is relatief het grootst van dieren die in de Delta geboren zijn, maar er worden ook sterns uit kolonies in het Waddengebied gezien (tabel 7.6). De meeste van deze dieren worden in het Deltagebied in juli gezien, maar ook een relatief groot aantal in september. Het lijkt er dus op dat vogels uit het Waddengebied niet alleen vlak na het uitvliegen de Delta aandoen, terwijl ze met hun ouders op weg zijn naar het zuiden, maar ook in de reguliere doortrekperiode in september. Over het gebruik van de Voordelta door sterns uit andere kolonies in het voorjaar is nog niets bekend.

Tabel 7.5

Aantal aangelegde kleurringen in de noordelijke Delta tussen 2010 en 2017.

\begin{tabular}{|c|c|c|c|c|c|c|c|c|}
\hline \multirow[t]{2}{*}{ Jaar } & \multicolumn{3}{|c|}{ Adult } & \multirow[b]{2}{*}{ Totaal } & \multicolumn{4}{|c|}{ Juveniel } \\
\hline & Scheelhoek & Markenje & Slijkplaat & & Scheelhoek & Markenje & Slijkplaat & Totaal \\
\hline 2010 & 16 & - & - & 16 & & & & \\
\hline 2012 & 10 & - & - & 10 & 460 & 28 & - & 488 \\
\hline 2013 & 26 & - & - & 26 & 255 & 143 & - & 398 \\
\hline 2014 & - & - & 28 & 28 & - & 32 & 298 & 330 \\
\hline 2015 & 34 & - & - & 34 & 169 & 19 & - & 188 \\
\hline 2016 & 24 & - & - & 24 & 303 & 59 & - & 362 \\
\hline 2017 & 41 & - & - & 41 & 410 & - & - & 410 \\
\hline Totalen & 151 & 0 & 28 & 179 & 1.597 & 281 & 298 & 2.136 \\
\hline
\end{tabular}


Tabel 7.6

Aflezingen in de Delta per bronkolonie.

\begin{tabular}{l|ccc}
\hline $\begin{array}{l}\text { Geringd in } \\
\text { kolonie }\end{array}$ & Aantal ringen & $\begin{array}{c}\text { Aantal afgelezen individuen in de } \\
\text { Voordelta }\end{array}$ & $\begin{array}{c}\text { Percentage aflezingen tov geringde } \\
\text { populatie }\end{array}$ \\
\hline Delta & 2315 & 147 & $6 \%$ \\
Texel & 1024 & 19 & $2 \%$ \\
Ameland & 290 & 2 & $1 \%$ \\
Griend & 360 & 3 & $1 \%$ \\
\hline
\end{tabular}

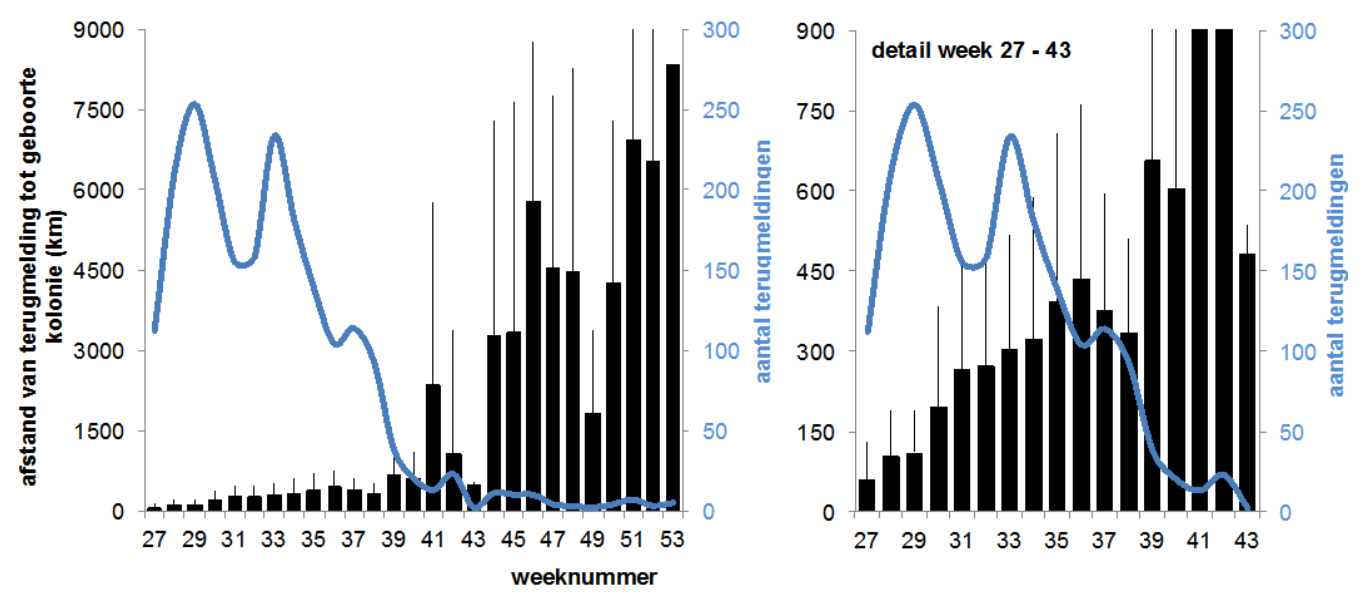

Figuur 7.29 Gemiddelde afstand ( $\mathrm{km}$ ) van terugmeldingen tot aan de geboorteplaats en het aantal teruggemelde individuen (inclusief herhaalde waarnemingen aan hetzelfde individu) in de loop van het seizoen. 

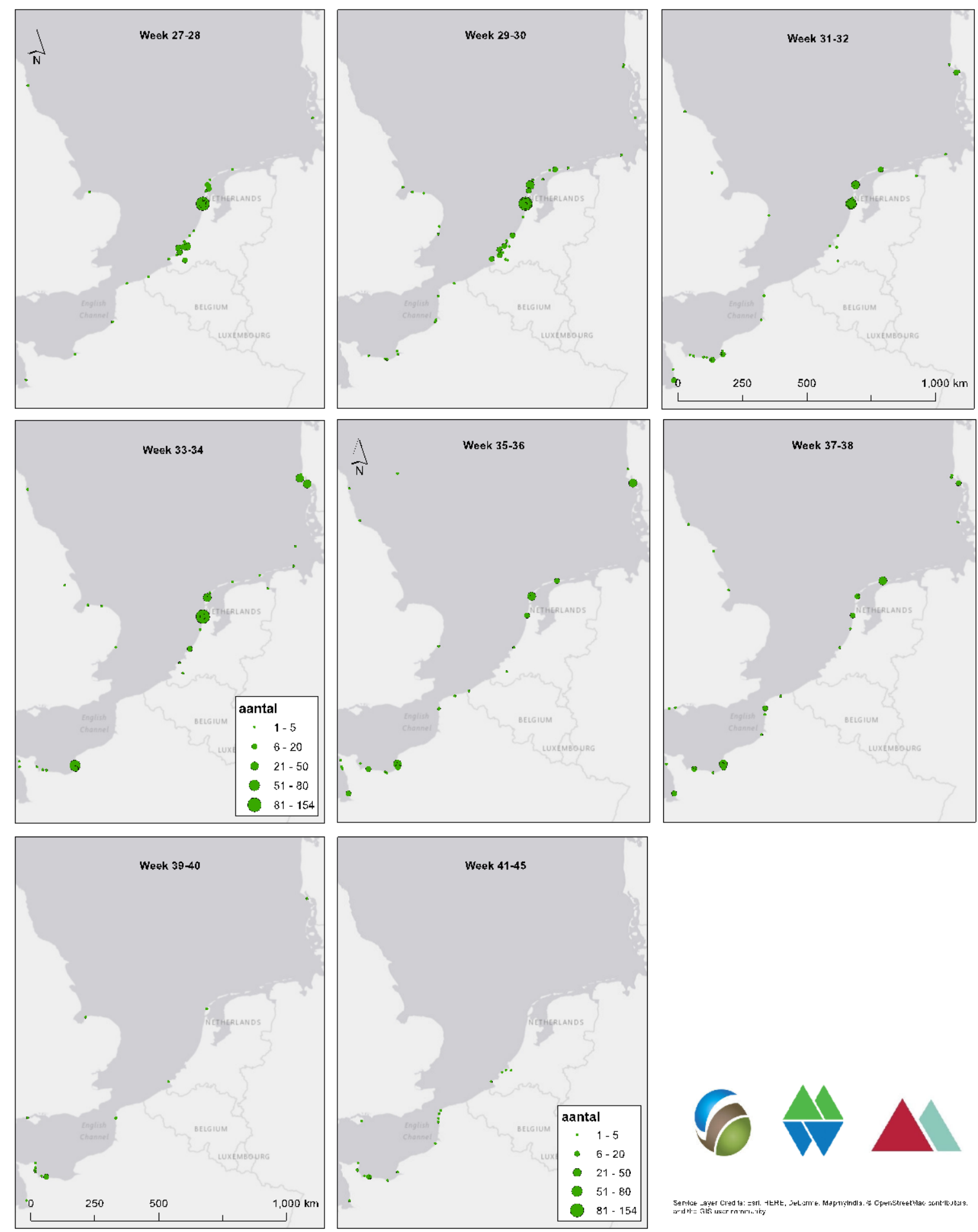

Figuur 7.30 Terugmeldingen van individuele juveniele grote sterns in de eerste 14 weken na uitvliegen uit de kolonies in de Delta.

\subsubsection{Effect van verstoring}

In eerdere jaren is met name de Hinderplaat nog frequent door mensen bezocht (Seegers et al. 2014), maar tijdens de vliegtuigtellingen van de fase II van PMR-NCV en het veldwerk hebben we dat tot nu toe niet meer vastgesteld. Het enige gebied dat regelmatig bezocht wordt is de Verklikkerplaat, maar dit gebied is sinds 2015 niet meer aangewezen als rustgebied. Daar waar strandbezoek wel is toegestaan, zoals op het Verklikkerstrand en een groot deel van de zachte zeewering van Maasvlakte 2, blijkt dat verstoring van rustende sterns wel optreedt (Fijn et al. 2016) en dan met name door wandelaars met honden. De gemiddelde verstoringsafstand van vogels is ongeveer 50-75 meter voor wandelaars, en groter voor honden en hardlopers. Verstoring van rustende sterns betekent dat de dieren opvliegen, maar uit onze waarnemingen blijkt dat grote sterns na verstoring meestal het gebied 
niet verlaten, maar ergens in de nabije omgeving relatief snel weer gaan zitten. Dit bleek ook uit eerder onderzoek naar verstoring in de Delta (Poot et al. 2014), en uit observaties in 2016 en 2017. In sommige gebieden waar grote sterns rusten, komen dergelijke lokale verstoringen veel voor, maar in deze gebieden zijn ook altijd wel stukken plaat of strand aanwezig waarop dieren kunnen rusten. Een goed voorbeeld is het relatief nieuwe ingestelde rustgebied van de Middelplaat, vlakbij het Verklikkerstrand. Ondanks dat er weinig verstoring voorkomt (slechts 1 keer vastgesteld), wordt het toch maar heel zelden gebruikt en dan ook nog door maar hele kleine aantallen grote sterns.

\section{Deelconclusies}

- De grootste aantallen rustende grote sterns zitten buiten de aangewezen rustgebieden.

- Veruit de grootste aantallen rustende sterns, en dan met name in het voorjaar, zitten elk jaar op de Verklikkerplaat/Verklikkerstrand. Dit gebied is sinds 2015 geen aangewezen rustgebied meer.

- Het rustgebied op de Hinderplaat wordt relatief weinig gebruikt door rustende grote sterns, maar was in 2016 en 2017 in trek rond de periode van het uitvliegen van de jongen begin juli.

- Het ingestelde rustgebied op de Bollen van de Ooster wordt elk jaar relatief intensief gebruikt door een groep van 100 grote sterns met jongen vlak na het uitvliegen.

- Het ingestelde rustgebied de Middelplaat wordt maar zeer zelden gebruikt en door kleine aantallen grote sterns.

- Buiten de ingestelde rustgebieden worden relatief veel rustende sterns op de zuidpunt van Maasvlakte 2 gezien, en een enkele groep op de Kwade Hoek en de kust van Goeree.

- Of de aangewezen rustgebieden essentieel zijn voor de grote stern in de Voordelta kunnen we niet kwantificeren.

- Grote sterns uit de Delta verblijven tot zo'n vier weken na het uitvliegen van de jongen in de Delta, echter een groot deel vliegt direct naar noordelijkere foerageergebieden.

- Ook door sterns van buiten de Delta wordt gebruik gemaakt van de Voordelta en de rustgebieden. 


\subsection{Het verdwijnen van het Maasvlakte 2 gebied: consequenties voor visdief}

De eerste deelvraag van de MEP vraag richt zich op de betekenis van het kustgebied dat door aanleg van Maasvlakte 2 is verdwenen, als foerageergebied voor de visdief

a) Hoe is, op basis van voortschrijdend inzicht, de inschatting van het effect van de aanleg van Maasvlakte 2 op het instandhoudingsdoel voor deze soort?

i. Wat was, in kwalitatieve termen, de betekenis van het verdwenen foerageergebied

ii. Wat is, in kwalitatieve termen, de betekenis van het nieuwe kustgebied na aanleg van Maasvlakte 2

Tijdens de nulmeting, en de eerste en tweede fase van de PMR-NCV monitoring zijn tussen 2005 en 2017 vliegtuigtellingen uitgevoerd boven de Voordelta. Aan de hand van de waarnemingen tijdens deze tellingen kunnen de aantallen en het gebiedsgebruik van sterns in de Voordelta, en zo ook rond Maasvlakte 1 en Maasvlakte 2 in kaart gebracht worden. Op basis van deze gegevens volgt onderstaand een kwalitatieve beschrijving van de betekenis van het verdwenen zeegebied.

\subsubsection{Gebruik Maasvlakte gebied}

Op basis van de gegevens uit de vliegtuigtellingen tijdens de nulmeting (2005-2006) is een aantal van 0-330 vliegende visdieven in het verdwenen zeegebied van Maasvlakte 2 berekend. Oorspronkelijk werd het zeegebied, en met name de kust van Maasvlakte 1, voornamelijk gebruikt door foeragerende visdieven (figuur 7.31). Het deel van de visdieven dat niet aan het foerageren was, is veel kleiner dan bij grote sterns, wat aangeeft dat het aantal pendelende visdieven in het gebied relatief klein is. Tijdens de aanleg van Maasvlakte 2 in 2009 en 2010 foerageerden grote aantallen visdieven in het zeegebied, en met name de zandsuppletieschepen trokken massaal foeragerende visdieven aan. Visdieven zijn liefhebbers van turbulent water en foerageren in de Voordelta met name in spuiopeningen en dichtbij de kust (net achter de branding). Na aanleg van Maasvlakte 2 zijn foeragerende visdieven met name langs de kusten van Maasvlakte 2 aangetroffen en in veel kleinere aantallen verder op zee. Tijdens de nulmeting rustten en foerageerden visdieven op en bij de zachte zeewering van de Maasvlakte 1, en lag het zwaartepunt van rustende sterns op de zuidpunt, het Slufterstrand. Deze functie is deels overgenomen door de zachte zeewering van Maasvlakte 2, maar de aantallen rustende visdieven zijn erg variabel (figuur 7.32). Nog altijd is met name de zuidpunt, het Slufterstrand, in gebruik door visdieven, maar de aantallen lijken wel wat af te nemen (figuur 7.31, 7.33). 
Visdief waarnemingen Maasvlakte
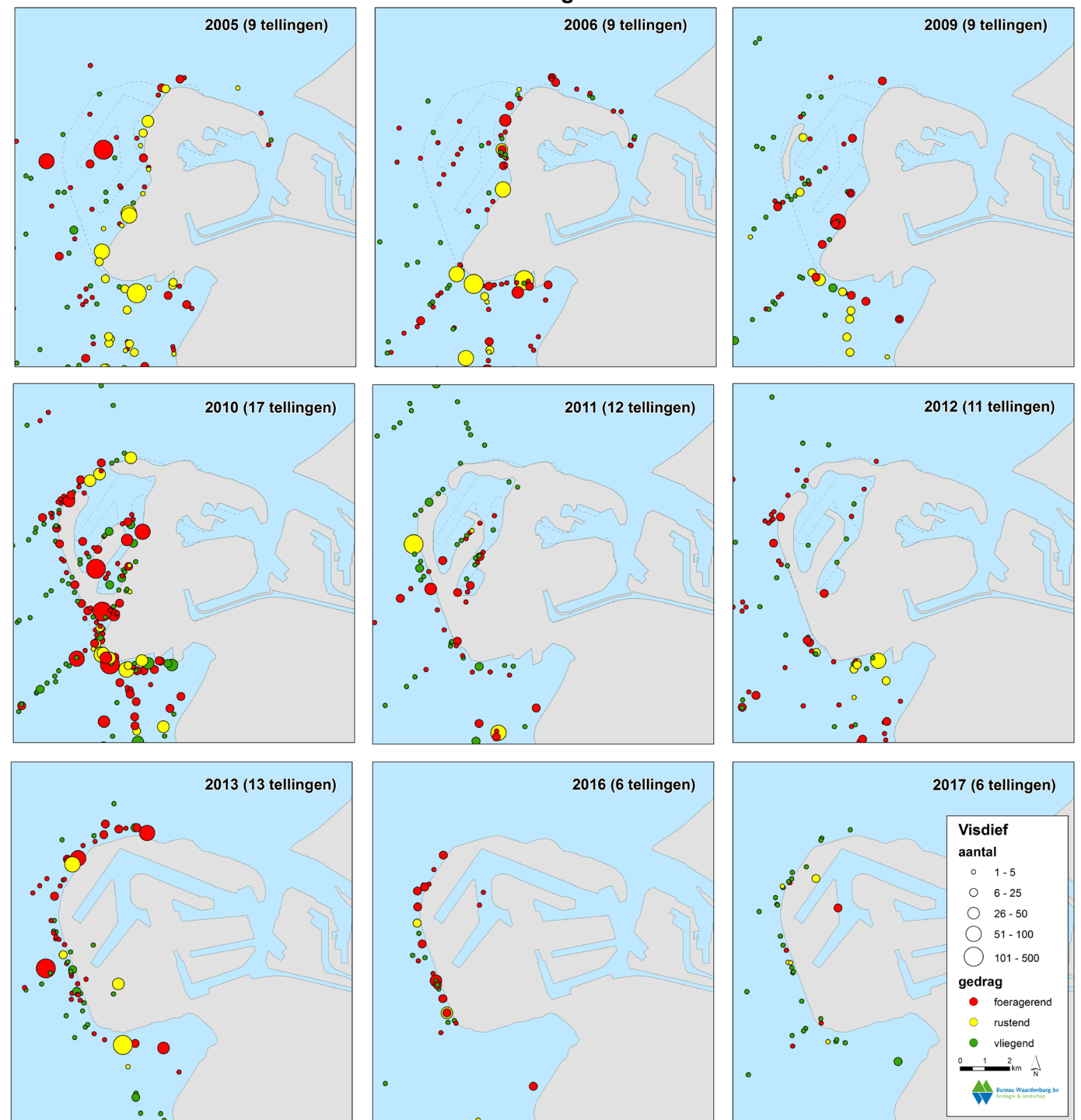

Figuur 7.31 Cumulatieve aantallen visdieven, gesplitst per gedragscategorie, rond Maasvlakte 2 tijdens de onderzoeksjaren 2005-2006 (PMR-NCV nulmeting), 2009-2013 (PMR-NCV Fase 1), 20162017 (PMR-NCV Fase 2). Het aantal telingen per jaar varieert, waardoor een kwantitatieve vergelijking tussen jaren niet direct gemaakt kan worden. 

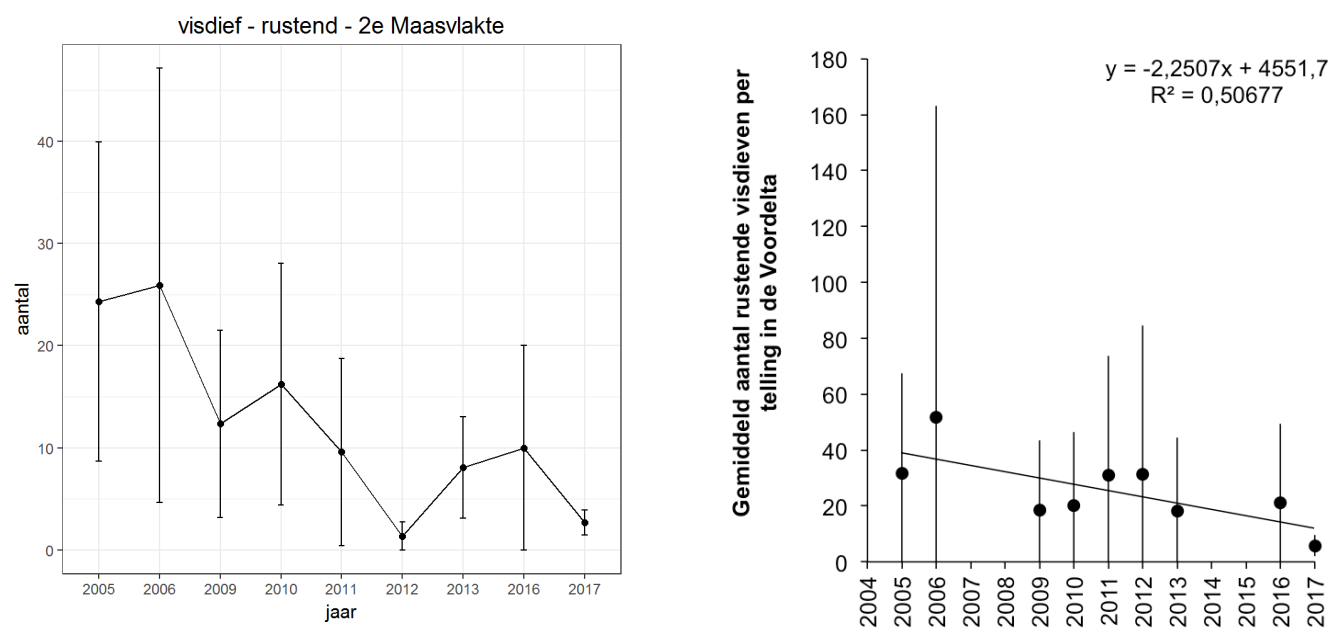

Figuur 7.32 Gemiddeld aantal rustende visdieven per vliegtuigtelling in het Maasvlakte gebied (links) en in de gehele Voordelta (rechts) uitgezet voor de verschillende jaren.

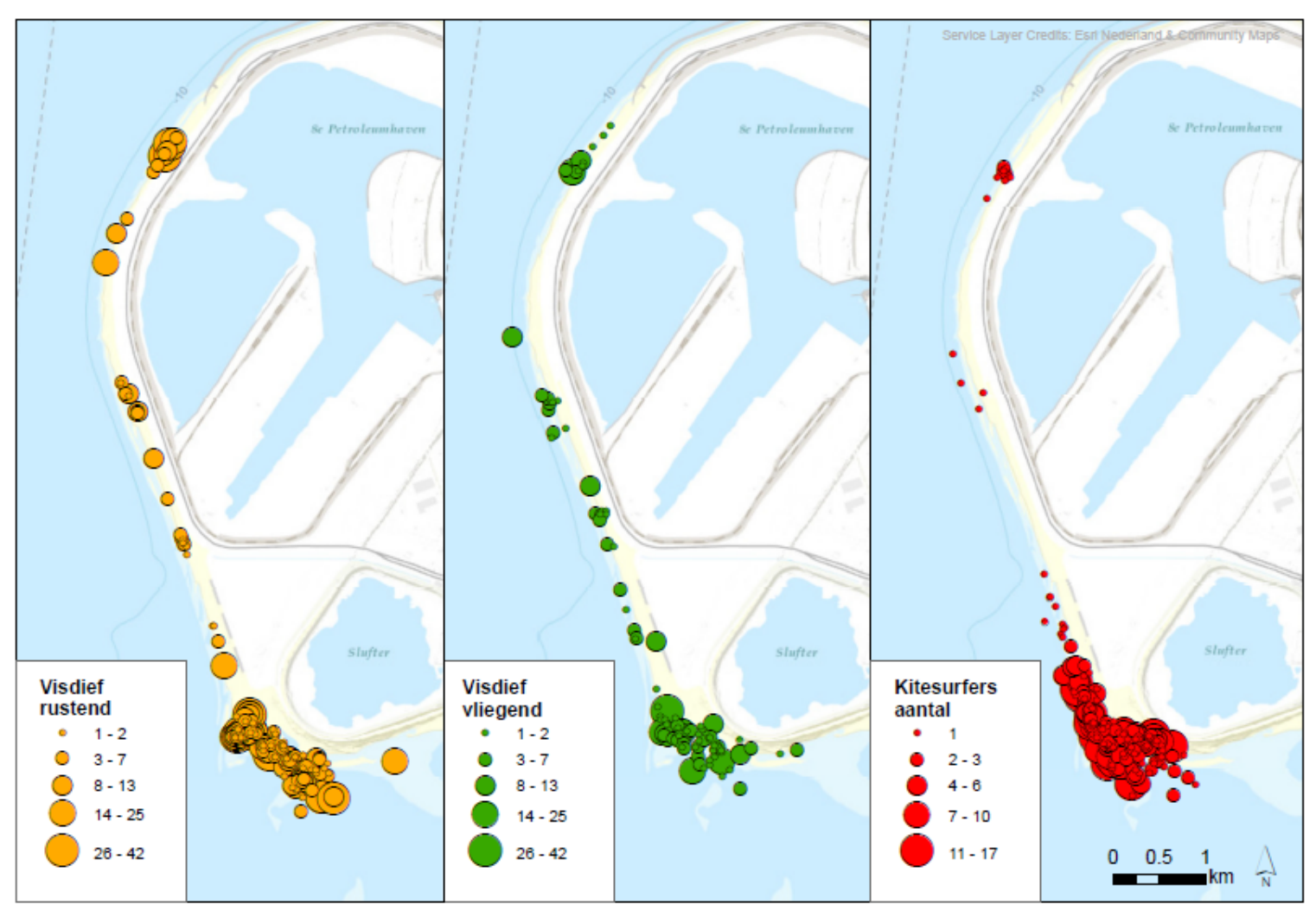

Figuur 7.33 Gemiddeld aantal visdieven en kite surfers rond Maasvlakte 2 per teldatum in de periode maart - augustus 2017.

Al met al kan worden geconcludeerd dat het zeegebied en de kust van Maasvlakte 1 (dus tijdens de nulmeting) voornamelijk in gebruik waren als foerageergebied voor visdieven. Daarnaast werd op de oorspronkelijke zeewering op de toenmalige stranden ook gerust. Tijdens de aanleg van Maasvlakte 2 profiteerden met name foeragerende visdieven van de aanleg-activiteiten en mogelijke toename van makkelijk bereikbaar voedsel. $\mathrm{Na}$ aanleg is de foerageerfunctie van het gebied overgenomen door de zachte zeewering van Maasvlakte 2, en in mindere mate de harde zeewering. Rustende visdieven zitten geconcentreerd op de zuidpunt van Maasvlakte 2, bij het Slufterstrand en de Hinderplaat, waar ook de kite-surfers geconcentreerd zijn (figuur 7.33), maar de aantallen visdieven zijn na aanleg van Maasvlakte 2 wel duidelijk afgenomen.

Het instandhoudingsdoel voor visdief in de Voordelta is behoud van kwaliteit en omvang van het leefgebied zonder kwantitatief doel. Over de kwaliteit van het gebied in termen van voedselbeschikbaarheid is geen informatie verzameld, maar we weten dat het gebied een essentiële 
foerageerfunctie had voor visdieven die broeden op de Maasvlakte. Deze functie lijkt echter volledig overgenomen door de nieuwe zeewering rond Maasvlakte 2. Daarnaast nemen de aantallen broedparen op de Maasvlakte niet af (paragraaf 7.5), dus van een kwaliteitsvermindering lijkt geen sprake. De hoeveelheid rust in het gebied is mogelijk wel afgenomen door de goede toegankelijkheid van de zachte zeewering van Maasvlakte 2 waardoor strandbezoek en kite-surf activiteiten zijn toegenomen. De aantallen rustende visdieven zijn ook afgenomen. De hoeveelheid potentieel rustgebied (aantal km strand) en mogelijk ook foerageergebied (aantal km overgang zee naar land) is wel toegenomen in de nieuwe situatie.

\section{Deelconclusies}

- Het verdwenen zeegebied diende als foerageergebied voor visdieven en er werd langs met name de zachte zeewering van Maasvlakte 1 gerust.

- Tijdens de aanleg foerageerden visdieven veel in het zeegebied van Maasvlakte 2 en dan met name rond de suppletieschepen.

- Na aanleg foerageerden visdieven langs de gehele zeewering en rustten ze vooral op de zuidpunt van Maasvlakte 2. De aantallen rustende visdieven zijn sterk afgenomen. De belangrijkste rustplek op de zuidpunt van Maasvlakte 2 valt samen met de plek waar de kite-surfers zich concentreren.

- Het verdwenen zeegebied had een essentiële foerageerfunctie voor visdieven die op de Maasvlakte broedden en die functie lijkt overgenomen door de nieuwe zeewering van Maasvlakte 2. De mate waarin is echter niet te kwantificeren. Het aantal kilometer potentieel rustgebied en mogelijk ook foerageergebied is toegenomen, maar het is wel drukker geworden in het gebied door de toename in recreatie.

\subsubsection{Effect vergroten vliegafstand visdieven van Maasvlakte 2-kolonie}

Op basis van voedselprotocollen gemaakt in 2017 is een energetisch model opgesteld voor de kolonie op het Visdiefeiland in de Slufter met als doel in te schatten wat het effect van Maasvlakte 2 kan zijn op de energieaanvoer naar de kolonie. Ook kan op basis van deze gegevens een beeld worden geschetst van het kwalitatieve belang van het nieuwe kustgebied.

Door de aanleg van Maasvlakte 2 is voor vogels van het Visdiefeiland de afstand tot hun noordwestelijk gelegen foerageergebied toegenomen. Met informatie over de aanvliegroutes van visdieven die naar de kolonie terugkeren met een prooi voor de kuikens in combinatie met de soortensamenstelling van de aangevoerde prooien, kan een relatieve inschatting gemaakt worden van het belang van de verschillende foerageergebieden in de omgeving van het Visdiefeiland. Dit biedt de mogelijkheid om de consequentie van een langere vliegroute te evalueren in energetische termen. Vooralsnog is deze benadering alleen toegepast op gegevens van 1 jaar (2017), waarbij verschillende aannames zijn gedaan. Zo zijn er bijvoorbeeld geen gegevens beschikbaar over de exacte locaties waar de visdieven foerageerden of over het aanbod aan haringachtigen vóór de aanleg van Maasvlakte 2. Ook het relatieve belang van de zachte oevers van Maasvlakte 2 ten opzichte van de extra vliegtijd langs de noordwestelijke vliegroute is niet bekend.

De meeste prooien worden via het noord- en zuidwesten naar de kolonie aangevoerd, terwijl de noordelijke route zelden wordt bevlogen (figuur 7.34a). In absolute aantallen voorzien de noordwestelijke en zuidwestelijke routes in de grootste prooiaanvoer, met een gemiddelde van respectievelijk 46 prooien/uur en 133 prooien/uur. Hoewel visdieven vaak gaan foerageren in het dichtstbij gelegen foerageergebied (Westplaat, ten zuidoosten van de Slufter) worden relatief weinig prooien aangevoerd uit die richting.

$\mathrm{Er}$ is een significant verschil in procentuele soortensamenstelling tussen de verschillende aanvoerroutes $\left(X^{2}=38,4 ; d f=6 ; p<0,001\right)$. Haringachtigen vormen behalve voor de ZO-route de grootste prooigroep. Een groot deel van de prooien die op de Westplaat worden gevangen bestaat uit wormen, garnalen, platvissen en overige rondvis.

De energieaanvoer naar de kolonie is voornamelijk afhankelijk van de noordwestelijke route (gemiddeld $1289 \mathrm{~kJ} / \mathrm{h}$ of $52 \%$ van de totale energieaanvoer) en de zuidwestelijke route (gemiddeld $957 \mathrm{~kJ} / \mathrm{h}$ of $39 \%$ van de totale energieaanvoer figuur 7.34b). Hier blijkt duidelijk het energetische belang van haringachtigen. De overige prooisoorten vertegenwoordigen respectievelijk $73 \%$ en $37 \%$ 
van de totale aantallen langs de aanvliegroutes vanuit het zuidoosten en het zuidwesten, maar leveren slechts $33 \%$ en $8 \%$ van de energietoevoer.

Hoewel het totaal aantal via de zuidwestelijke route aangebrachte haringachtigen per uur groter is, zorgt de noordwestelijke route voor de hoogste energieaanvoer. De verklaring hiervoor is dat aangebrachte haringachtigen (de voornaamste prooisoort) langs de noordwestelijke route gemiddeld 0,75 snavellengtes $(2,7 \mathrm{~cm})$ groter zijn dan deze die via het zuidwesten worden aangebracht (figuur 7.35).

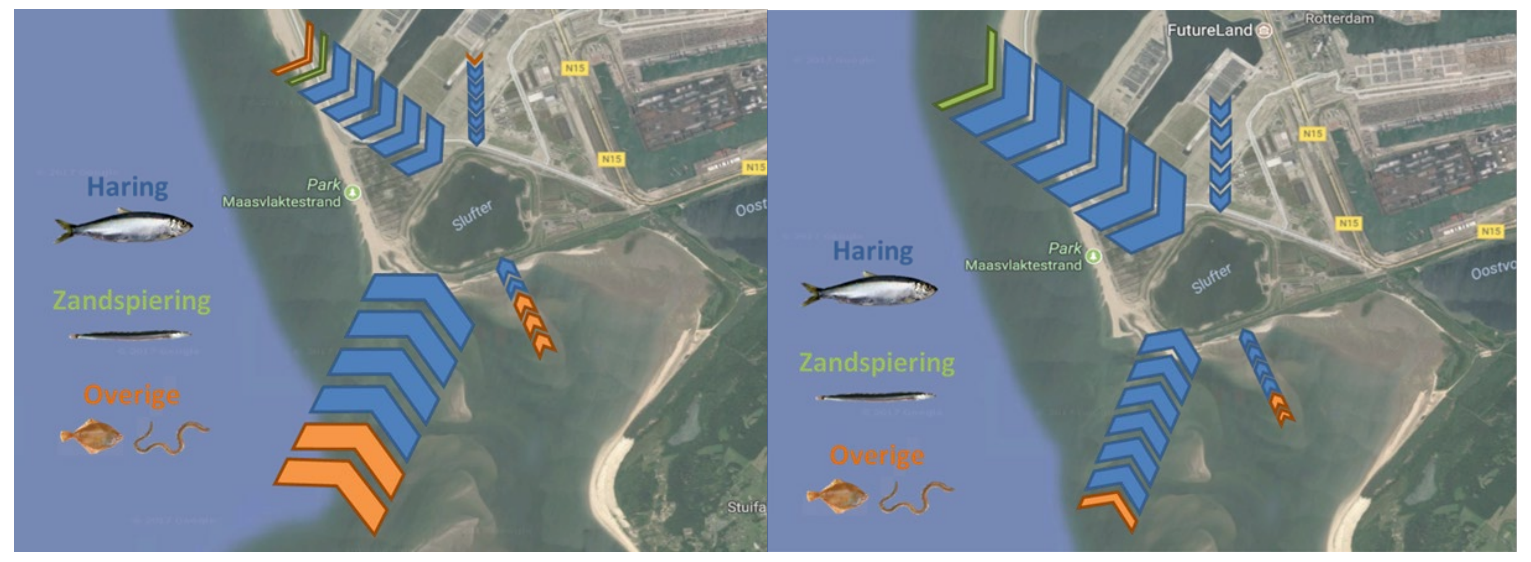

Figuur 7.34 Gemiddelde prooiaanvoer per uur (a) en gemiddelde energieaanvoer per uur (b) voor de verschillende soortgroepen en aanvoerroutes naar het Visdiefeiland in 2017.

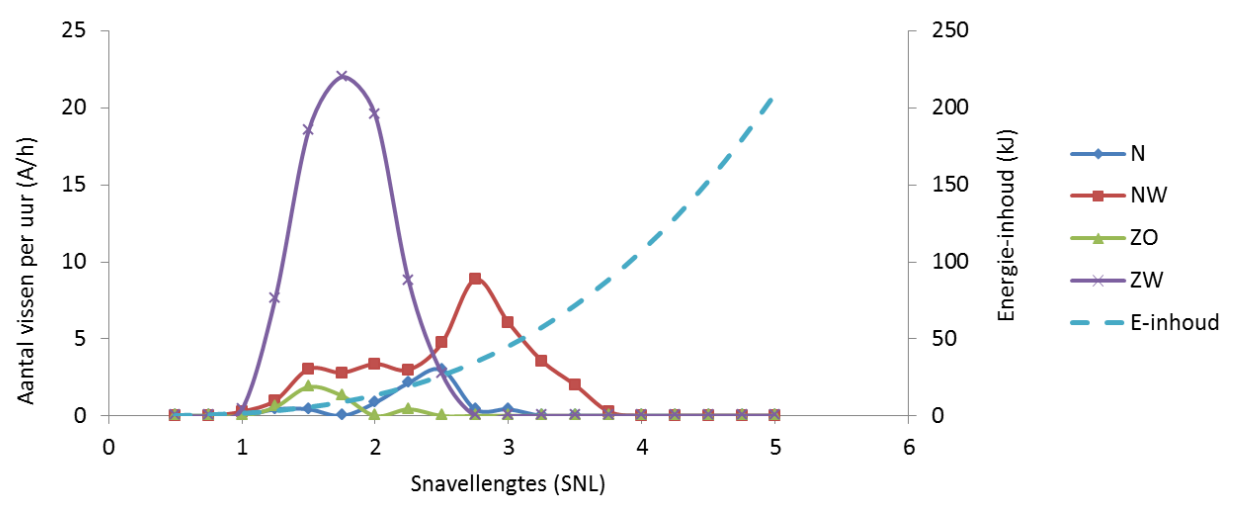

Figuur 7.35 Lengtefrequentieverdeling van haringachtigen voor de verschillende aanvoerroutes.

Door de aanleg van Maasvlakte 2 werd de noordwestelijke aanvoerroute voor het Visdiefeiland verlengd met ongeveer $7 \mathrm{~km}$, wat overeenkomt met een extra vliegtijd van 12 minuten. Gebaseerd op voedselprotocollen met individueel gemerkte adulten van de Vogelvallei in 2010, die hier noodzakelijkerwijs als referentie worden gebruikt, is een foerageertijd van 57 min voor de noordwestelijke route berekend.()Vóór aanleg van Maasvlakte 2 hadden visdieven slechts 45 min nodig voor een foerageertrip, waardoor ze respectievelijk $26 \%$ meer prooien (en dus ook meer energie) konden aanvoeren via deze route. Doordat het belang van de noordwestelijke route gedurende het broedseizoen toeneemt, kan de langere vliegafstand langs deze route vooral aan het einde van het broedseizoen een wezenlijk verschil betekenen voor het broedsucces van de kolonie. Net voor het uitvliegen van de kuikens (30/06 - 31/06) zou de verminderde energietoevoer via de noordwestelijke route een afname van 15 tot $20 \%$ van de totale energieaanvoer naar de kolonie betekenen, ten opzichte van de situatie voor aanleg van Maasvlakte 2 (Figuur 7.36). 

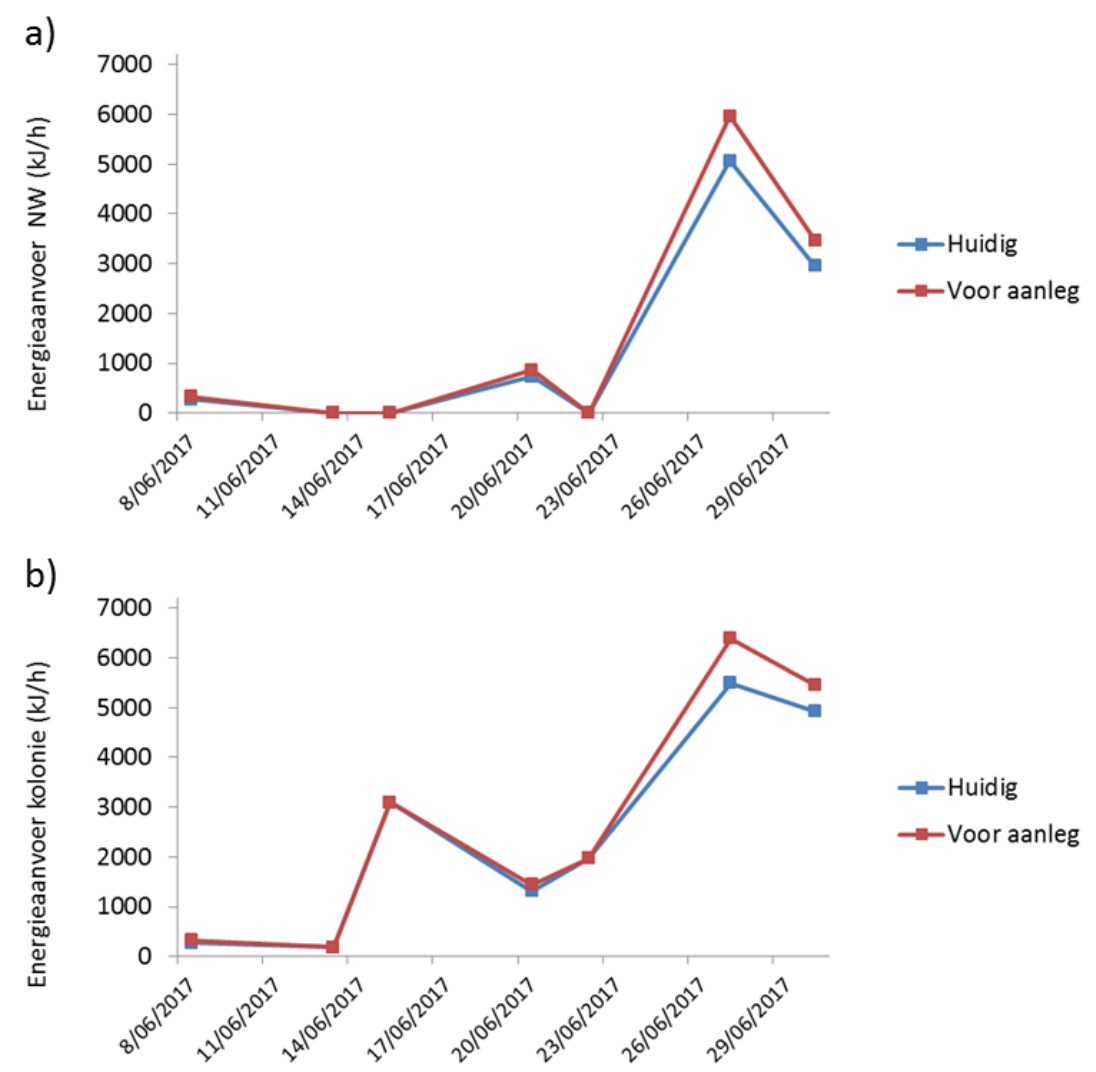

Figuur 7.36 Verschil in energieaanvoer voor en na aanleg van Maasvlakte 2 voor de noordwestelijke route (a) en voor de totale energieaanvoer naar de kolonie (b).

\section{Deelconclusies}

- In 2017 liepen de belangrijkste aanvoerroutes van voedsel voor visdief-kuikens op het Visdiefeiland via het zuid- en het noordwesten. De noordwestelijke route over Maasvlakte 2 was op energetisch vlak de belangrijkste route, omdat uit deze richting meer en grotere haringachtigen werden aangebracht dan via de andere routes.

- Uit energetische berekeningen blijkt dat de toegenomen vliegduur als gevolg van de aanleg van Maasvlakte 2 een negatieve impact gehad kan hebben op de kuikenconditie en het uitvliegsucces. Het is echter onbekend of de voedselbeschikbaarheid langs de zachte oevers anders is dan die in het foerageergebied voorafgaand aan aanleg van Maasvlakte 2.

\subsection{De functie van de Voordelta voor de visdief}

De tweede deelvraag richt zich op de functie van de Voordelta als foerageergebied

b) Leidt het instellen van het bodembeschermingsgebied tot een gelijkblijvende potentiële functie van de Voordelta voor de visdief in termen van voedselbeschikbaarheid?

i. $\quad$ Treden veranderingen op in broedsucces, het voedsel, de verspreidingspatronen en het aantal vogeldagen van de visdief in de Voordelta t.o.v. de situatie vóór de aanleg van Maasvlakte 2?

ii. Zijn deze veranderingen toe te schrijven aan (veranderingen in) de voedselbeschikbaarheid of zijn andere factoren van (groter) belang?

Tijdens de eerste fase van de PMR-NCV monitoring tussen 2009 en 2013 werd bevestigd dat de aanname uit de Passende Beoordeling, dat visdieven die broeden in kolonies dicht aan de kust in de Delta, uitsluitend de kustzone van de Voordelta gebruiken als foerageergebied, juist is gebleken (Poot et al. 2014, Fijn et al. 2016). Visdieven uit de kolonies op de Scheelhoek hebben een relatief beperkt foerageergebied dat zich concentreert rond de uitstroomopening van de Haringvlietsluizen. Tijdens hoogwater, als er weinig uitstroom van zoetwater is, wijken de dieren uit naar de Kwade Hoek en de 
Haringvlietmonding. Hetzelfde geldt voor vogels van Markenje die voornamelijk lokaal op het Grevelingenmeer en langs de Brouwersdam foerageren. Vanwege deze relatief korte foerageerafstand van visdieven tijdens het broedseizoen (tot ongeveer $10 \mathrm{~km}$ van de kolonie), verwachten we dat de meeste visdiefkolonies in het Deltagebied weinig tot geen nadeel hebben ondervonden van de aanleg van Maasvlakte 2. Alleen de kolonies op het Visdiefeiland in de Slufter en in de Vogelvallei, ondervinden potentieel hinder van de aanleg van Maasvlakte 2 omdat deze een deel van het voorheen gebruikte foerageergebied inneemt en ze dus mogelijk verder moeten vliegen.

De aantallen visdieven die gebruik maken van het zeegebied van de Voordelta zullen dan ook in mindere mate afhangen van de populatie-ontwikkeling van sterns in de diverse kolonies uit de hele Delta, maar voornamelijk worden bepaald door de aanwezigheid van incidentele groepen rustende visdieven in het voor- en naseizoen. We hebben er daarom voor gekozen om voor de visdieven niet het aantal vogeldagen te analyseren, maar ons meer te richten op de aantallen en verspreiding rond Maasvlakte 2 en de populatietrend van de kolonies in de directe omgeving.

De aantallen broedende visdieven variëren sterk tussen de verschillende jaren, en is er geen eenduidig patroon te ontdekken in de aantallen broedparen in het Nederlandse Deltagebied (figuur 7.37 links) en in de bezetting van kolonielocaties (Fijn et al. 2016). Gemiddeld genomen zijn de totale aantallen broedparen na de aanleg van Maasvlakte 2 in de gehele Delta iets lager dan daarvoor. Dit geldt zeker niet voor de aantallen op de Maasvlakte zelf, die gemiddeld iets hoger zijn dan voor de aanleg, maar wel voor de kolonies in het Haringvliet. Opvallend was dat tijdens de aanleg (2009 en 2010) de aantallen broedende visdieven in de Delta en op de Maasvlakte laag waren terwijl er in die periode wel zeer veel gebruik werd gemaakt van het zeegebied van Maasvlakte 2 door visdieven. In recente jaren nemen de aantallen broedende visdieven in het gehele Deltagebied af, maar de aantallen op en rond de Maasvlakte zijn relatief stabiel (figuur 7.37 rechts).
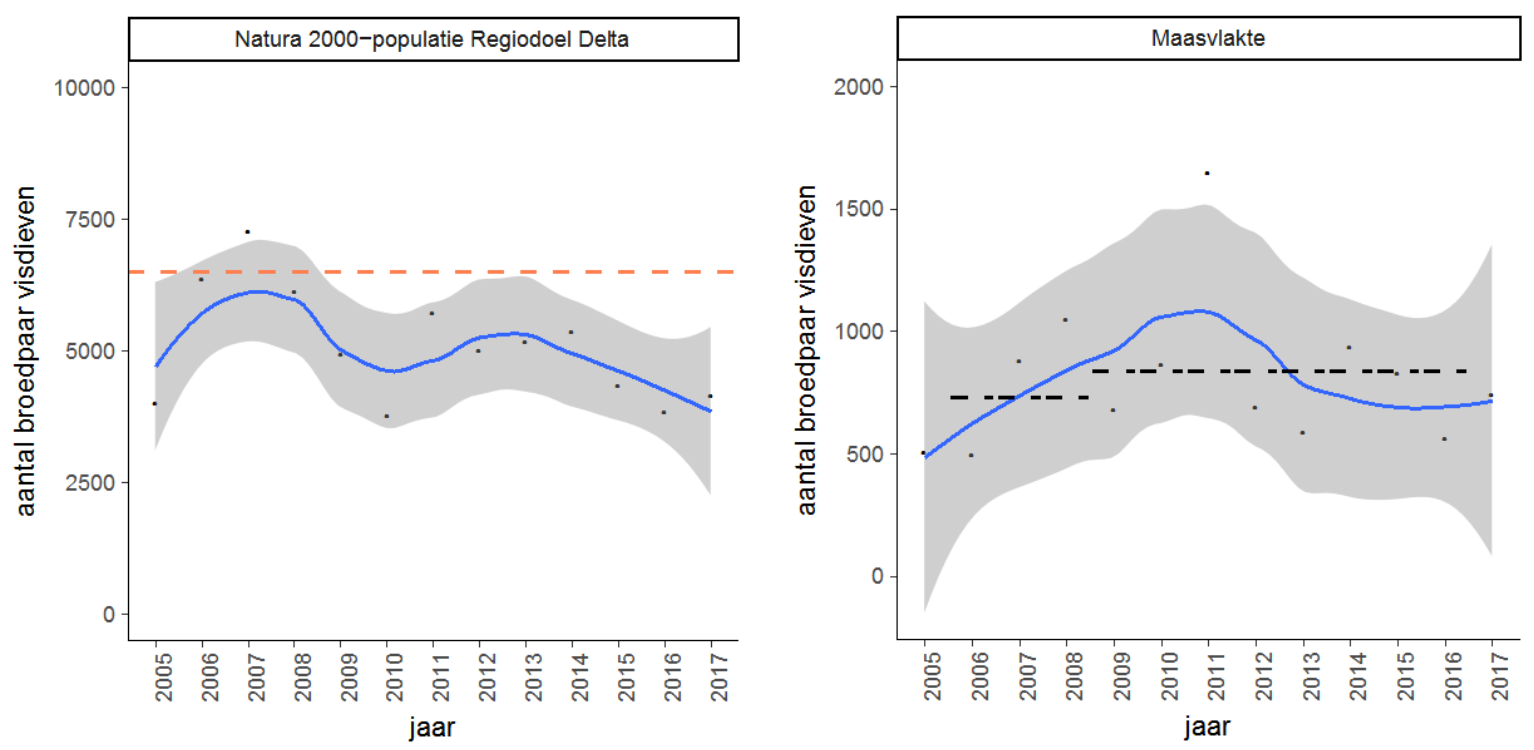

Figuur 7.37 Aantallen broedparen van visdieven binnen Natura 2000-gebieden in het Deltagebied (links) en op de Maasvlakte (rechts). De oranje stippellijn geeft het regiodoel weer van 6500 paar. De zwarte stippellijn geeft de gemiddelden voor 2005-2008 en 2009-2017.

Maasvlakte 2 is aangelegd in Natura 2000-gebied Voordelta, een gebied dat is aangewezen voor onder andere visdieven. Op basis van de aantallen vogels in de kolonies (als maat voor de aantallen die van de Voordelta als foerageergebied gebruik kunnen maken), lijkt de aanleg van Maasvlakte 2 niet tot een verslechtering van de functie van de Voordelta als foerageergebied voor visdieven te hebben geleid. De conclusie is dan ook te rechtvaardigen dat de aanleg geen effect heeft op het gestelde instandhoudingsdoel voor de foerageerfunctie voor visdieven in de Voordelta. De omvang van het 
gebied is wel afgenomen, maar de kwaliteit lijkt er niet onder te hebben geleden, want de aantallen broedparen zijn onveranderd of zelfs gestegen.

Ook uit de vliegtuigtellingen blijkt dat geen wezenlijke verandering is opgetreden in de ruimtelijke verspreiding van visdieven in de Voordelta (Fijn et al. 2016). In alle jaren worden met name langs de kust van de Voordelta vliegende/foeragerende visdieven gezien, met concentraties bij uitstroomopeningen van de dammen. Ook de rustplekken zijn in algemene zin hetzelfde gebleven. Concentraties rustende dieren worden vastgesteld op diverse stranden langs de Delta-kust, de platen die droogvallen ten oosten van de Bollen van het Nieuw Zand, grote aantallen op de Verklikkerplaat, de Middelplaat, de Bollen van de Ooster, de Kwade Hoek, de Hinderplaat en de kust van de Maasvlakte 1 en Maasvlakte 2.

Naast de effecten van de compensatiemaatregelen op het behalen van de instandhoudingsdoelen voor visdieven in het Natura 2000-gebied Voordelta, zijn ook effecten op visdiefkolonies in andere Natura 2000-gebieden, die een functionele relatie hebben met de Voordelta, van belang. Voor visdieven zijn kwantitatieve instandhoudingsdoelstellingen geformuleerd in de Natura 2000-gebieden Haringvliet, Grevelingenmeer, Oosterschelde, Westerschelde \& Saeftinghe en Krammer-Volkerak tezamen in de vorm van een 'regiodoel' voor broedvogels voor het "Behoud van omvang en kwaliteit leefgebied voor 6500 paar". Dit komt erop neer dat het niet uitmaakt in welk van deze gebieden dit aantal vogels broedt, als de totale draagkracht van de regio maar voldoende is voor een populatieomvang van 6.500 paar.

Met uitzondering van 2007 lagen de aantallen broedparen visdieven in de Delta duidelijk onder het regiodoel van 6500 paar (figuur 7.37 links). Rond de aanleg van Maasvlakte 2 (bijv. in 2010) bereikten de aantallen broedende visdieven een dieptepunt. Aangezien visdieven relatief slechts korte foerageertochten maken, is de invloed van het gebied rond Maasvlakte 2 van geringe invloed op de kolonies in het Deltagebied. Het ligt daarom niet in de lijn der verwachting dat de lage aantallen broedparen rond de aanleg daar iets mee te maken hebben. Sterker nog, de kolonies in de buurt van Maasvlakte 2 vertoonden stabiele aantallen.

Een belangrijke voorwaarde voor zichzelf in standhoudende populaties is het behalen van voldoende broedsucces in de kolonies. Tijdens alle fases van PMR-NCV zijn voor een groot aantal visdiefkolonies in het Deltagebied broedsuccesdata verzameld tijdens de reguliere tellingen. Het totaal aantal jonge grote sterns dat jaarlijks op de Maasvlakte wordt grootgebracht varieert tussen de 20 en 650 kuikens (figuur 7.38). Opvallend is de piek in 2010, toen er zeer veel gefoerageerd werd achter de zandsuppletieschepen in het Maasvlakte 2 gebied.

Recent zijn door SOVON Vogelonderzoek Nederland, Vogeltrekstation, Delta Project Management en het Instituut voor Natuur- en Bosonderzoek (Schekkerman et al. 2017) de broedsuccesdata van visdieven in de Delta geanalyseerd voor een veel langere periode. Hieruit blijkt geen trendbreuk tussen T0 en T1 in broedsucces van kolonies in het Deltagebied (figuur 7.39). Wel varieert het broedsucces in deze kolonies sterk tussen jaren en is er een algemeen neergaande langjarige trend te zien. Opvallend is dat het broedsucces in het Haringvliet juist sterk is toegenomen over de afgelopen jaren, wat hoofdzakelijk veroorzaakt wordt door het beheer van de Scheelhoekeilanden. Voor deze kolonie geldt wel dat door het beheer van de vegetatie binnen de enclosures (vegetatie wordt kort gehouden) het broedsucces altijd hoger ligt dan erbuiten. 


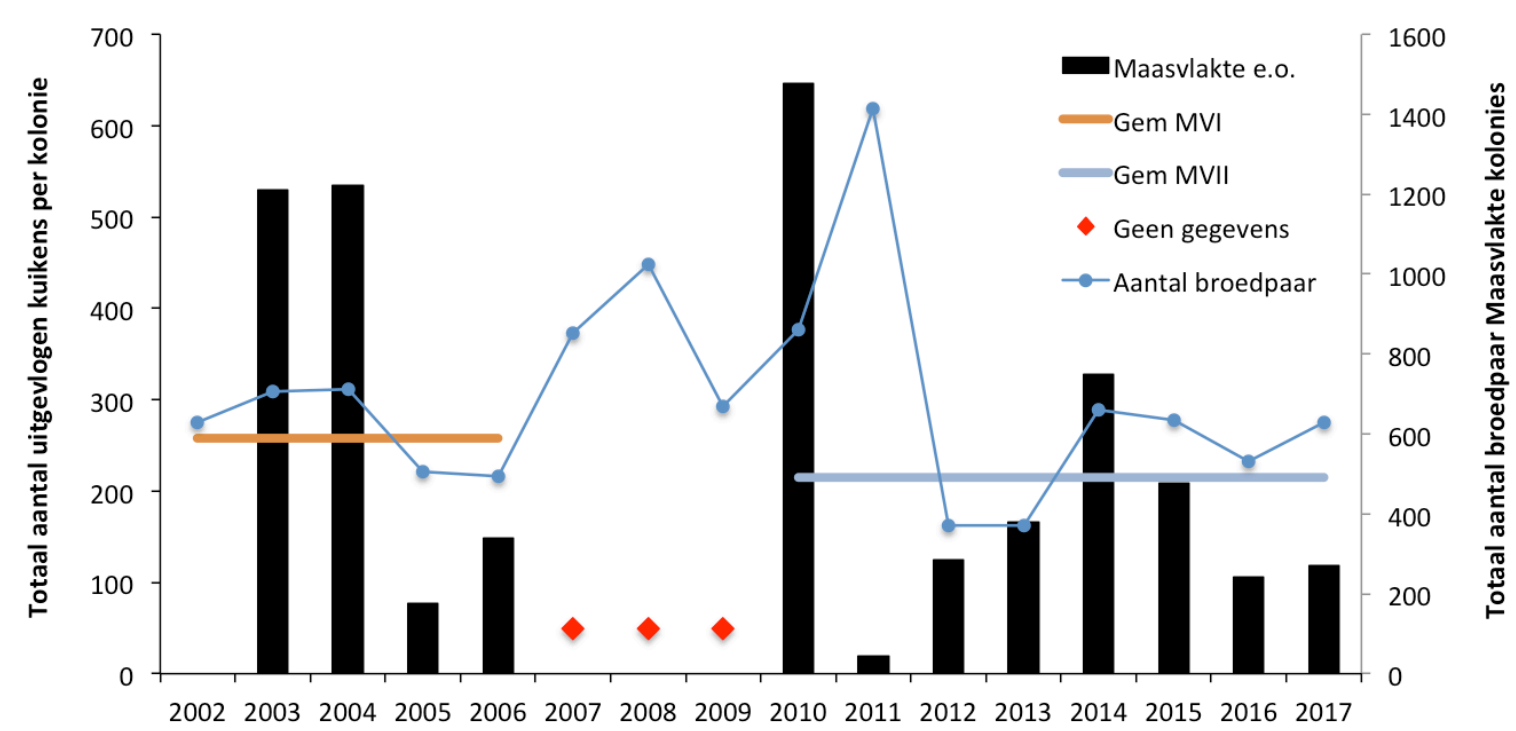

Figuur 7.38 Totaal aantal uitgevlogen jonge visdieven vanuit de kolonies in het Maasvlakte gebied. De oranje en blauwe lijnen geven de gemiddelden weer voor de betreffende perioden.
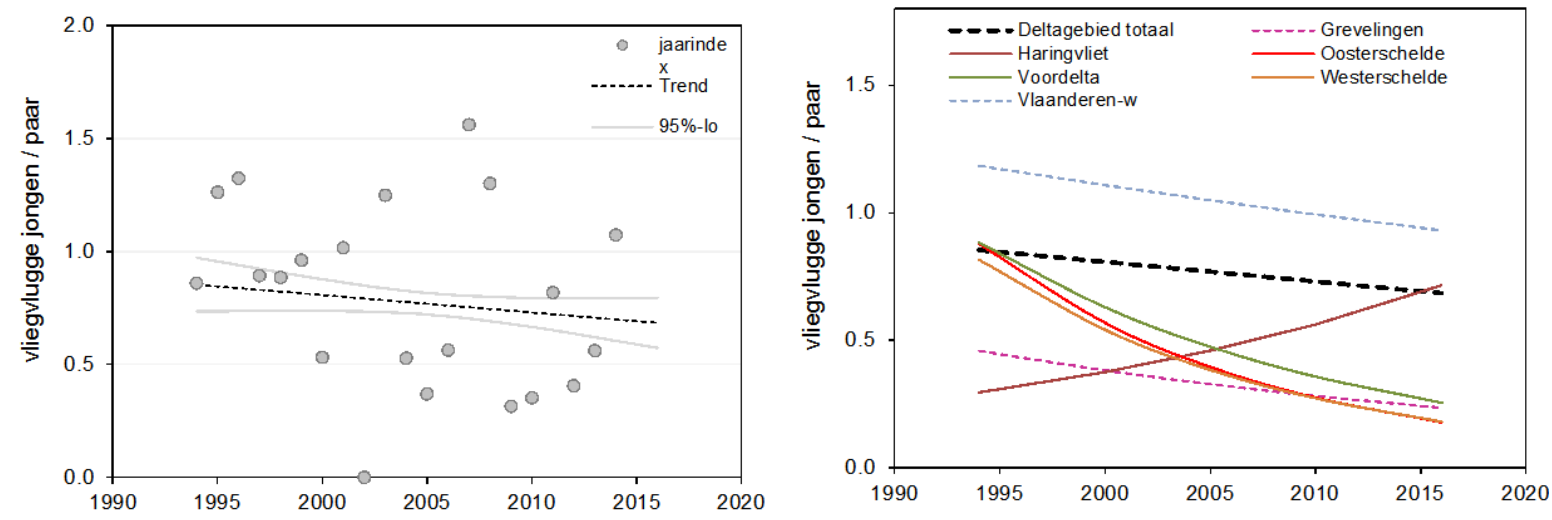

Figuur 7.39 Ontwikkeling van het reproductiesucces van Visdieven in het Deltagebied. Links: jaargemiddelden(stippen) en trend met 95\% betrouwbaarheidsinterval (lijnen) voor het Deltagebied als geheel. Rechts: trends in deelregio's met voldoende gegevens. Trends die significant afwijken van 0 (= broedsucces stabiel) zijn weergegeven als doorgetrokken lijn, overige met een gebroken lijn. Overgenomen uit Schekkerman et al. (2017).

\section{Deelconclusies}

- De aantallen broedparen fluctueren sterk van jaar tot jaar, maar nemen de laatste jaren enigszins af in de Delta.

- De aantallen broedparen op de Maasvlakte zelf zijn relatief stabiel. Deze kolonie is de enige waarvan de vogels foerageren in de buurt van het aanleggebied en waar een mogelijk effect van Maasvlakte 2 te verwachten is.

- Er is geen trendbreuk in het broedsucces van visdieven in de Delta tussen voor- en na de aanleg van Maasvlakte 2, wel neemt het broedsucces de laatste decennia af en hadden broedende visdieven op de Maasvlakte voor de aanleg een hoger broedsucces dan daarna.

- Het regiodoel voor visdief met betrekking tot het aantal broedparen in de Delta wordt niet gehaald, maar dit lijkt los te staan van Maasvlakte 2. 


\subsubsection{Broedsucces in relatie tot voedsel}

\subsubsection{Effect spuibeheer Haringvliet op foerageren Scheelhoekkolonie}

Visdieven uit de Scheelhoekkolonie foerageren voor hun kuikens heel veel op zoetwatervis. Veel van deze vis wordt tijdens het spuien bij de Haringvlietsluizen gevangen waar vaak honderden visdieven tegelijk aan het foerageren zijn. Omdat het spuiregime samenhangt met de getijdenwerking op zee (wat momenteel als proxy voor het spuiregime wordt), zien we dan ook een hogere aanvoer van zoetwatervis bij een lage waterstand, wanneer het meest wordt gespuid (figuur 7.40)

$\mathrm{Bij}$ een stijgende waterstand gaat het aandeel van zoetwatervis omlaag, en neemt het aandeel haringachtigen toe (figuur 7.41). Bij stijgende waterstand is er dus een verminderde beschikbaarheid van zoetwatervis doordat er minder gespuid wordt en wordt de focus deels verlegd naar haring.

Vanwege de correlatie met de waterstand op zee, wordt er verwacht dat ook het specifieke spuidebiet van de Haringvlietsluizen een impact zal hebben op de kolonie. In een latere fase zal dit uitgebreider worden geanalyseerd waarbij zal worden gepoogd deze impact in te schatten.

Er wordt niet verwacht dat het beheer van de Haringvlietsluizen een impact heeft op andere visdiefkolonies in de Delta.

\section{Deelconclusies}

- De waterstand op zee en het beheer van de Haringvlietsluizen heeft invloed op de voedselbeschikbaarheid van zoetwatervis en daarmee ook op de foerageerfunctie van de Voordelta voor de visdieven van de Scheelhoekkolonie.

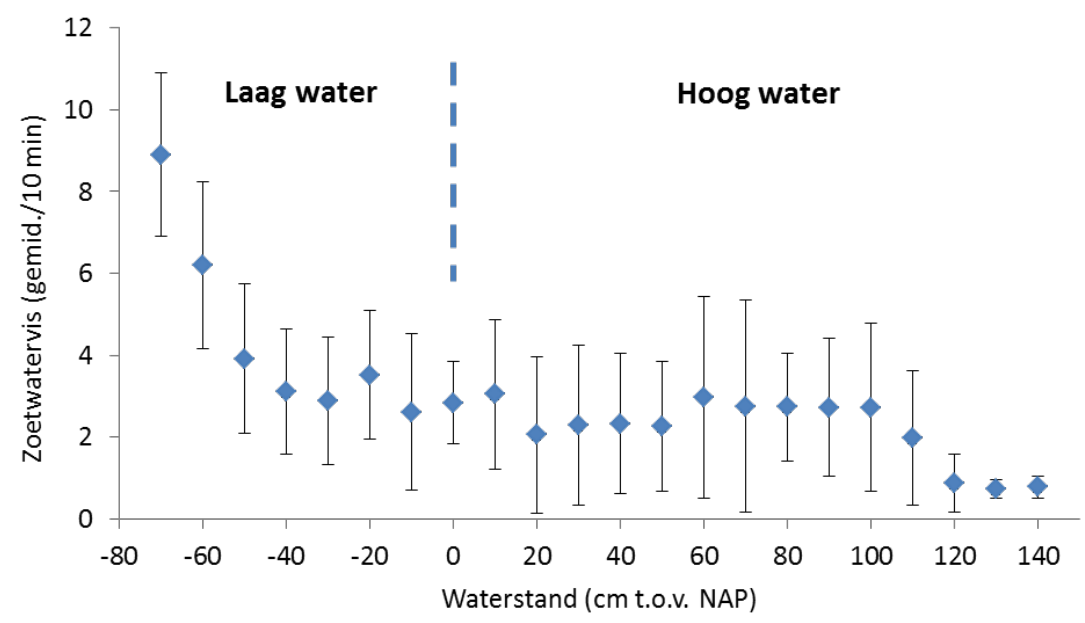

Figuur 7.40. Hoeveelheid aangebrachte zoetwatervis (gemiddeld aantal prooien per $10 \mathrm{~min}$ ) in functie van de waterstand op zee (gemeten t.h.v. de Hoek van Holland) voor de visdiefkolonie op de Scheelhoek (2009 - 2017). 


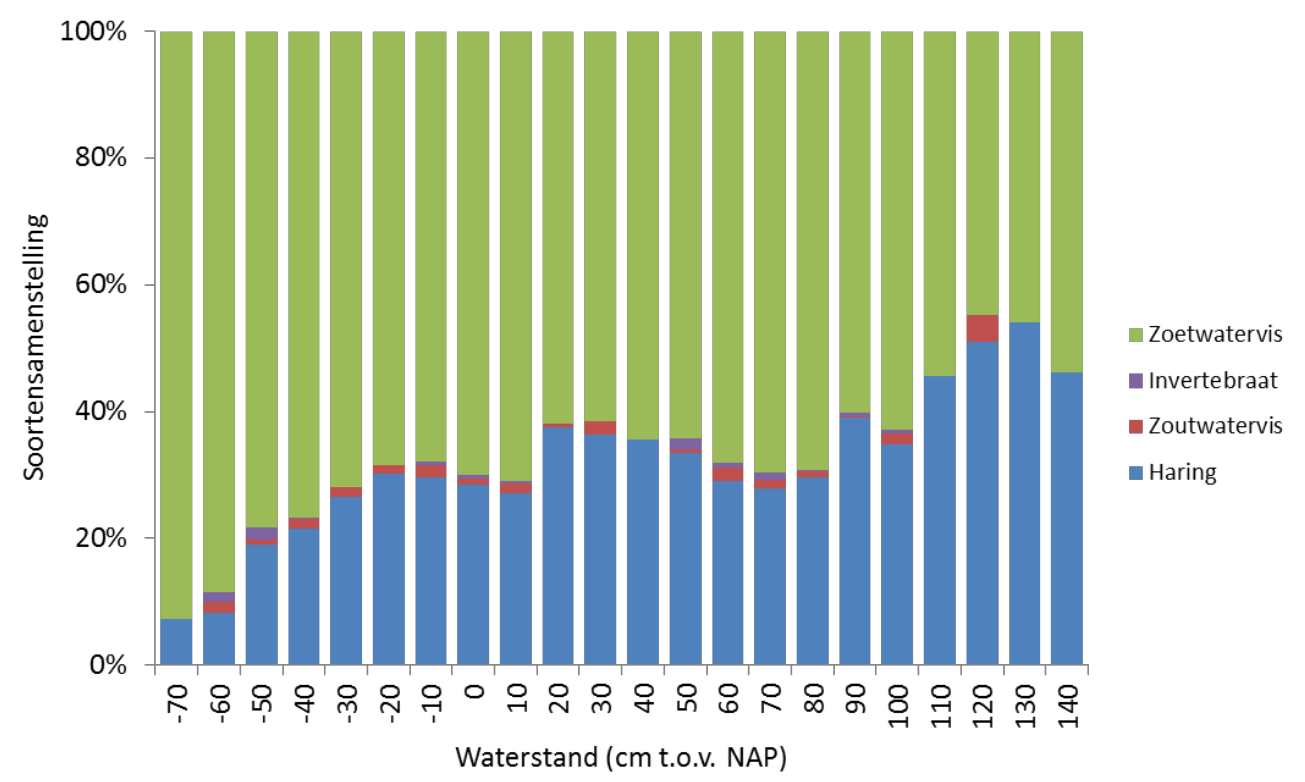

Figuur 7.41. Soortensamenstelling van de aangebrachte prooien (2009 - 2017) in functie van de waterstand op zee (gemeten t.h.v. de Hoek van Holland) voor de visdiefkolonie op de Scheelhoek.

\subsubsection{Broedsucces in relatie tot kwaliteit voedsel}

Er zijn geen directe gegevens beschikbaar over de voedselbeschikbaarheid in de T0-fase noch van na de aanleg van Maasvlakte 2. In de loop van het onderzoek is gebleken dat de dieetkeuze van visdieven erg verschilt tussen nabijgelegen kolonies in het noordelijk Deltagebied en binnen dezelfde kolonie tussen jaren (Figuur 7.42). Enerzijds is dit het gevolg van de kleinere foerageerafstand van visdieven (maximaal ongeveer $10 \mathrm{~km}$ van de kolonie tegenover $60 \mathrm{~km}$ voor grote stern) en anderzijds duidt dit erop dat ook abiotische en andere factoren (b.v. spuiregime van de Haringvlietsluizen) een belangrijke rol spelen.

Het dieet van de visdieven op de Scheelhoek bestaat in de meeste jaren uit een aanzienlijk deel zoetwatervis die vooral voor de Haringvlietsluizen en in mindere mate in het Haringvliet zelf wordt gevangen. Dat deze prooien minder energierijk zijn dan bijvoorbeeld haringachtigen, wordt gecompenseerd door een hogere aanvoerfrequentie als gevolg van de kortere tripduur. Er wordt niet verwacht dat er voor de kolonies buiten de Maasvlakte veranderingen die zijn opgetreden ten opzichte van de periode vóór de aanleg verband houden met de aanleg. De kolonies op de Maasvlakte (het Visdiefeiland in de Slufter en de Vogelvallei) vallen wel binnen de invloedzone van Maasvlakte 2.

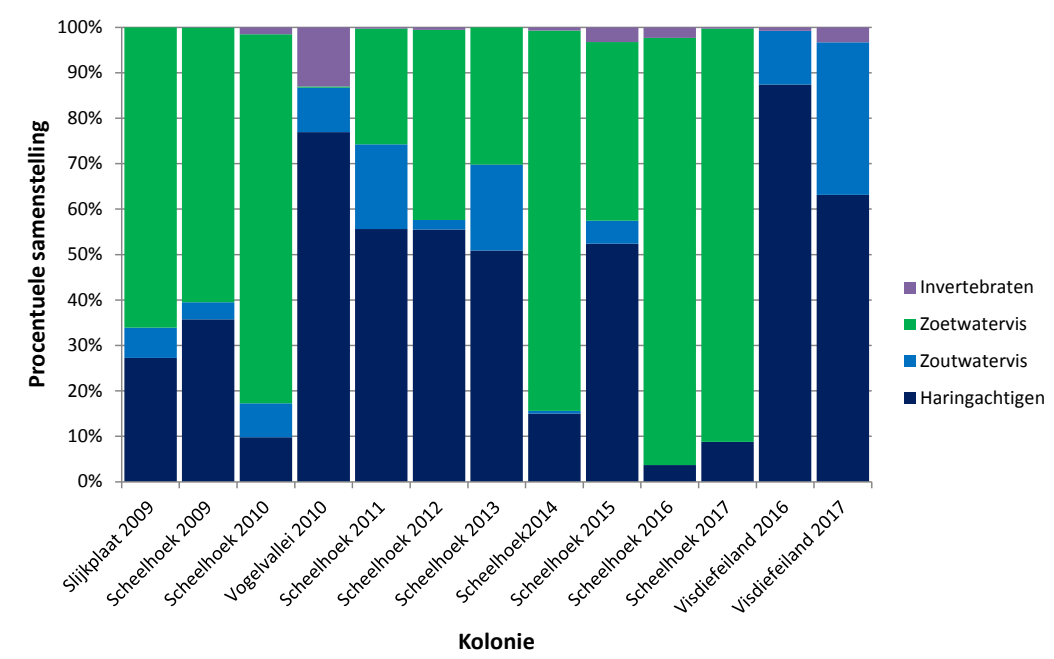

Figuur 7.42 Procentuele dieetsamenstelling van de onderzochte visdiefkolonies (2009-2017). 
Meer dan bij grote stern zijn niet aan voedsel gerelateerde factoren voor het broedsucces van visdiefkolonies in de Voordelta vaak erg bepalend. Een overzicht van deze factoren en hun invloed tijdens de onderzoeksperiode wordt hieronder besproken in paragraaf 7.8.1.

Als gevolg van de diversiteit en de flexibiliteit van het visdiefdieet, de sterke impact van niet aan voedsel gerelateerde factoren, de relatief beperkte hoeveelheid data over dieet en het ontbreken van gegevens over het voedselaanbod kan geen eenduidig beeld gegeven worden van het effect van voedsel op het broedsucces. Bij het volgende integratiemoment worden de verschillende afzonderlijk onderzochte factoren gezamenlijk geanalyseerd worden om te pogen een meer eenduidige inschatting van het belang van de factor voedsel te maken.

\section{Deelconclusie}

- Als gevolg van de diversiteit en de flexibiliteit van het visdiefdieet, de sterke impact van niet aan voedsel gerelateerde factoren, de relatief beperkte hoeveelheid data over dieet en het ontbreken van gegevens over het voedselaanbod kan geen eenduidig antwoord worden gegeven op het belang van voedsel voor het broedsucces van visdieven.

\subsubsection{Invloed van andere factoren op broedsucces}

De mate waarin verschillende factoren in de loop van het onderzoek bepalend waren voor het broedsucces kunnen variëren per jaar en worden voor de hele onderzoeksperiode hieronder op een rij gezet (tabel 7.7). Voor visdiefkuikens is het overigens moeilijker de doodsoorzaak vast te stellen dan bij grote sterns omdat kuikens vaak niet meer terug gevonden worden.

\section{Tabel 7.7}

Overzicht van het kwalitatieve negatieve effect van verschillende factoren op het uitkomst- en uitvliegsucces van visdief in de onderzoeksperiode (2009-2017). Groen = geen/nauwelijks effect, oranje $=$ medium effect, rood $=$ sterk effect. De percentages geven resp. het percentage uitkomstsucces en het percentage uitvliegsucces.

\begin{tabular}{|c|c|c|c|c|c|c|c|}
\hline \multirow[t]{2}{*}{ Jaar } & \multirow[t]{2}{*}{ Kolonie } & \multicolumn{2}{|r|}{ Uitkomstsucces (\%) } & \multicolumn{3}{|c|}{ Uitvliegsucces (\%) } & \multirow{2}{*}{$\begin{array}{l}\text { Broedsucces } \\
\text { (n jongen/paar) }\end{array}$} \\
\hline & & $\%$ & Weersomstandigheden Vegetatie Predatie & $\%$ & Weersomstandigheden Vegetatie & Predatie & \\
\hline 2009 & Slijkplaat & 83 & & 10 & & & 0,19 \\
\hline 2009 & Scheelhoek & 54 & & 30 & & & 0,37 \\
\hline 2010 & Scheelhoek & 81 & & 23 & & & 0,45 \\
\hline 2011 & Scheelhoek & 74 & & 39 & & & 0,75 \\
\hline 2012 & Scheelhoek & 80 & & 64 & & & 1,18 \\
\hline 2013 & Scheelhoek & 87 & & 38 & & & 0,75 \\
\hline 2014 & Scheelhoek & 90 & & 67 & & & 1,67 \\
\hline 2015 & Scheelhoek & 91 & & 32 & & & 0,71 \\
\hline 2016 & Scheelhoek & 87 & & 28 & & & 0,59 \\
\hline 2017 & Scheelhoek & 84 & & 70 & & & 1,57 \\
\hline 2010 & Markenje & 91 & & 18 & & & 0,41 \\
\hline 2011 & Markenje & 85 & & 0 & & & 0,0 \\
\hline 2012 & Markenje & 84 & & 22 & & & 0,45 \\
\hline 2013 & Markenje & 83 & & 29 & & & 0,49 \\
\hline 2010 & Vogelvallei & 80 & & 1 & & & 0,02 \\
\hline 2011 & Vogelvallei & 89 & & 0 & & & 0,0 \\
\hline 2012 & Vogelvallei & 32 & & 0 & & & 0,0 \\
\hline 2011 & Visdiefeiland & 86 & & 0 & & & 0,0 \\
\hline 2012 & Visdiefeiland & 87 & & 18 & & & 0,39 \\
\hline 2016 & Visdiefeiland & ca 57 & & 27 & & & 0,33 \\
\hline 2017 & Visdiefeiland & 87 & & 17 & & & 0,45 \\
\hline
\end{tabular}

Beheer van de kolonies/Vegetatie: De invloed van het vegetatiebeheer van kolonies op de vestiging van visdieven is moeilijk in te schatten omdat deze soort toleranter is voor variatie in begroeiing dan grote sterns. Niettemin wordt het beheer van kolonies in geen enkel jaar als problematisch ingeschat voor de vestiging van deze soort.

Tijdens de eifase traden in sommige jaren problemen op met snel opschietende vegetatie. Op de Scheelhoek in 2009 en op de Vogelvallei in 2012 verlieten veel adulten vroegtijdig hun nest nadat de vegetatie snel hoog was geworden en ze als het ware ingesloten werden. Op het Visdiefeiland werd dit 
in 2016 in mindere mate vastgesteld, en gebeurde dit in combinatie met harde neerslag waardoor de vegetatie over de nesten viel. In 2017 was opschietende vegetatie op de Scheelhoek een probleem buiten de enclosure (erbinnen werd de vegetatie kunstmatig kort gehouden). Daardoor was het uitkomstsucces buiten de enclosure een stuk lager dan erbinnen.

In de kuikenfase traden problemen op in dezelfde jaren als waar het in de eifase al mis liep. Door de hoge vegetatie konden ouders moeilijk prooien aanleveren of werden kuikens erg nat als het regende. In 2016 was de hoog opschietende vegetatie buiten de enclosure problematisch voor de overleving van de kuikens op Scheelhoek.

Weersomstandigheden: Tijdens de eifase hadden weersomstandigheden (en dan met name zware regenval) alleen een direct effect op het Visdiefeiland in 2016 (adulten die tussen hoge en natte vegetatie zaten te broeden waren geneigd hun nest te verlaten). Een indirect effect was merkbaar buiten de enclosure op de Scheelhoek in 2009 en 2012 toen als gevolg van de hoge waterstand van het Haringvliet een deel van de op de lagere stukken van de eilanden gelegen visdieflegsels wegspoelden.

Tijdens de kuikenfase hadden weersomstandigheden in 2011 een sterk effect op Markenje en het Visdiefeiland (nagenoeg alle kuikens gingen dood of zijn gepredeerd tijdens een stormperiode) en in 2017 op het Visdiefeiland (veel sterfte tijdens en net na stormperiode). Ook in 2009 op de Slijkplaat en in 2010 op de Scheelhoek hadden weersomstandigheden een invloed op de kuikenconditie en overleving van de kuikens.

Predatie: Predatie van eieren was vooral in 2009 op de Scheelhoek en in 2012 in de Vogelvallei problematisch, deels als gevolg van het feit dat veel nesten werden verlaten door de hoog opgeschoten vegetatie.

In de kuikenfase was predatie door meeuwen of roofvogels in veel kolonies een erg belangrijke doodsoorzaak. Zowel op Markenje, de Vogelvallei als op de Slijkplaat was dit in alle onderzoeksjaren de belangrijkste reden van kuikensterfte, in verschillende jaren zijn nagenoeg alle visdiefkuikens gepredeerd. Ook op het Visdiefeiland (2011 en 2012) en de Scheelhoek (2009 en 2010) was dit in sommige jaren het geval. Op de Scheelhoek was er slechts in drie jaar nauwelijks predatie, in de andere onderzoeksjaren zijn er regelmatig kuikens gepredeerd door roofvogels.

\section{Deelconclusies}

- Bij visdieven is het moeilijker om precieze doodsoorzaken vast te stellen dan bij grote stern omdat de kuikens vaak niet meer worden gevonden na het overlijden

- Niet aan voedsel gerelateerde factoren zijn vaak de belangrijkste oorzaak van een laag broedsucces.

- Vooral de groeisnelheid van de vegetatie, periodes met harde neerslag (voornamelijk voor jonge kuikens) en in het bijzonder kuikenpredatie hadden vaak een erg ingrijpende impact op het broedsucces.

\subsection{De functie van de rustgebieden in de Voordelta voor de visdief}

De derde deelvraag richt zich op de betekenis van de rustgebieden voor de visdief

c) Draagt het instellen van de rustgebieden bij aan het instandhoudingsdoel?

i. Worden de platen in de rustgebieden gebruikt door de aanwezige visdieven? In welke periode houden zij zich hier op en wat is de functie van de aanwezigheid van droogvallende platen?

Rustende visdieven bleken een voorkeur te hebben voor platen en stranden binnen de Voordelta, en waren te vinden op de Bollen van het Nieuw Zand, de Verklikkerplaat, de Bollen van de Ooster, het strand van Goeree, de Kwade Hoek, de Hinderplaat en op de zachte zeeweringen van Maasvlakte 1 en Maasvlakte 2, maar ook op diverse stranden (figuur 7.43). Per telling varieerden de aantallen rustende visdieven sterk tussen de 0 en 1800 individuen. De grootste groepen zijn aangetroffen op het 
Verklikkerstrand (officieel geen rustgebied meer), de Bollen van de Ooster en op stranden in het Maasvlakte-gebied: in 2009 op de nieuw opgespoten eilanden en de laatste jaren meer op de zuidpunt nabij de Hinderplaat. De rustlocaties van visdieven zijn niet veranderd tussen de periode van de nulmetingen en de jaren na 2009.

waarnemingen rustende visdieven
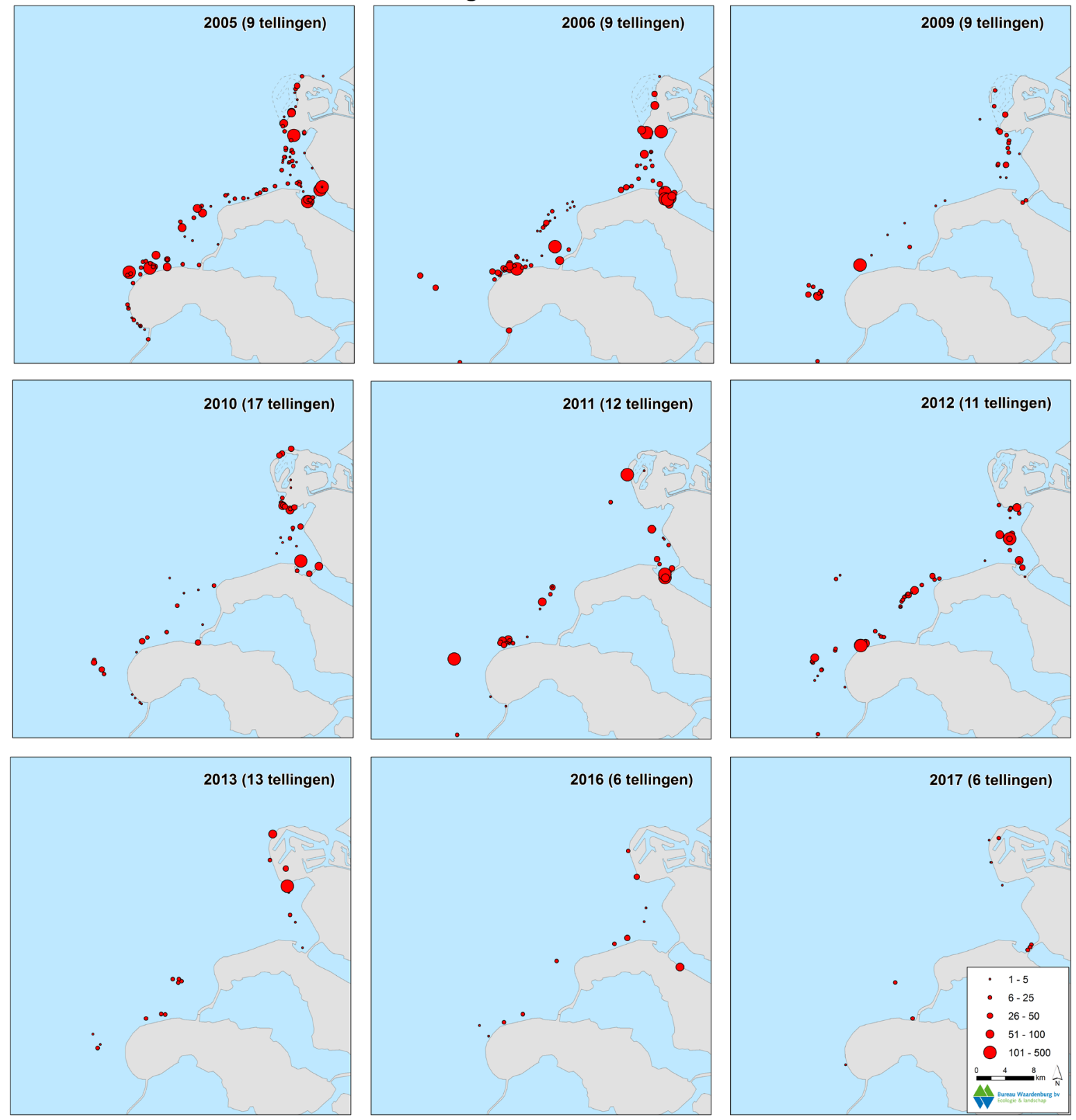

Figuur 7.43 Verspreiding van rustende visdieven tijdens de nulmeting (2005-2006) en tijdens de fase I en II (2009-2017) van PMR-NCV. Let op dat de telinspanning per jaar verschilt, zodat een kwantitatieve vergelijking tussen jaren niet direct mogelijk is. De platen waar visdieven op rusten zijn niet weergegeven.

Het gebruik van aangewezen en niet aangewezen rustgebieden in de Voordelta varieert sterk per jaar (figuur 7.44). De laatste jaren lijkt het gebruik van de zachte zeewering van de Maasvlakte sterk teruggelopen. Opvallend is verder dat met name de laatste jaren (2016/17) alle stranden en platen maar weinig gebruikt wordt door visdieven en dat de aantallen op de Bollen van de Ooster sterk variëren tussen jaren, met bijvoorbeeld zeer lage aantallen in 2009 en 2010 en hogere aantallen in 2011 en 2012. 


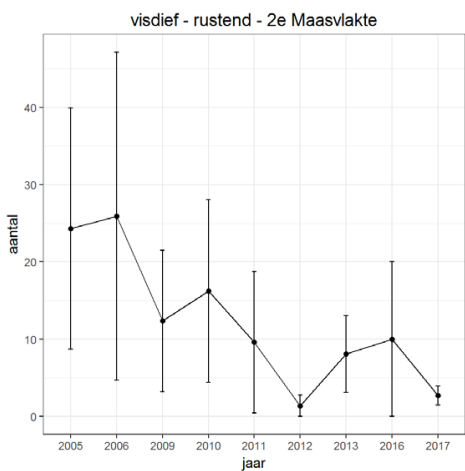

visdief - rustend - Bollen van de Ooster

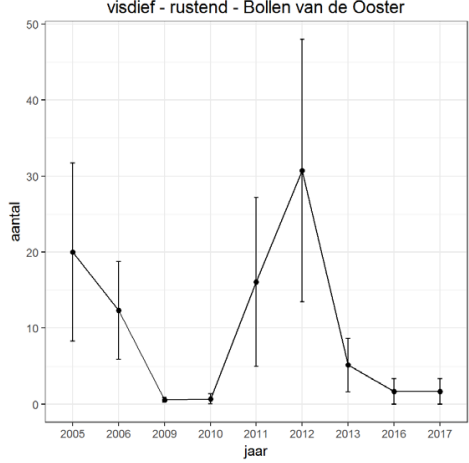

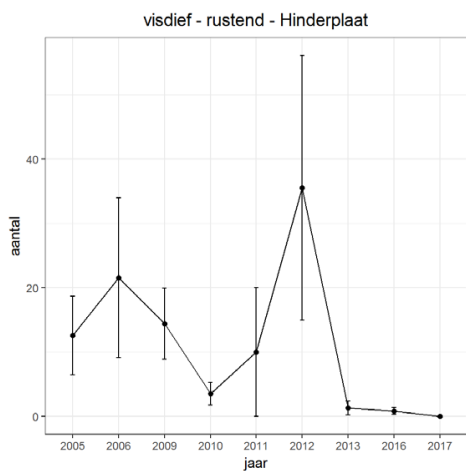

visdief - rustend - Verklikkerplaat

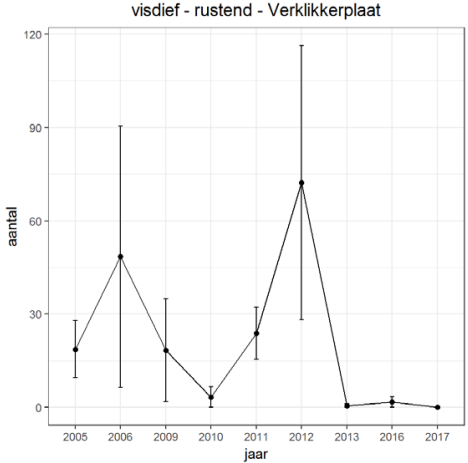

visdief - rustend - Kwade Hoek

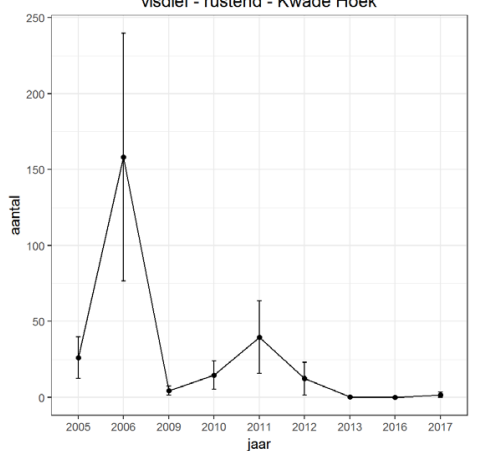

visdief - rustend - Middelplaat

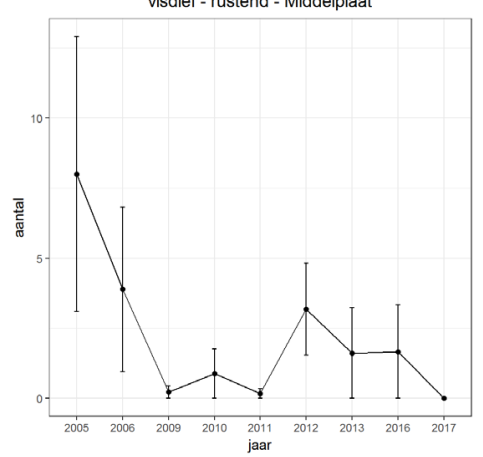

Figuur 7.44 Gemiddelde aantallen rustende visdieven tijdens de vliegtuigtellingen per jaar en per deelgebied. N.B. De verticale assen verschillen in schaal.

De eerste visdieven komen in de loop van april aan in de Delta en worden dan meteen in de verschillende rustgebieden gezien. In de loop van mei nemen de aantallen af omdat de dieren tijdens het broedseizoen met name in de kolonies en langs de kust te vinden zijn. De dieren die in deze periode gebruik maken van de rustgebieden zijn waarschijnlijk vogels met een mislukt broedsel (alhoewel op basis van de gegevens verkregen uit de VHF zenders ook bekend is dat visdieven relatief snel een nieuw broedsel in een andere kolonie kunnen starten) en vogels die dat seizoen niet tot broeden komen. De seizoensmaxima van rustende visdieven worden rond het uitvliegen van de jongen bereikt (figuur 7.45) en vanuit de kleurringdata weten we dat het hier ook om lokale dieren gaat. In tegenstelling tot de grote sterns blijven de meeste visdieven wel relatief lang in de Delta aanwezig, en worden in de loop van het seizoen aangevuld met dieren uit noordelijkere broedgebieden. Op basis van de vliegtuigtellingen en het aangevoerde voedsel in de kolonie is het onwaarschijnlijk dat visdieven tijdens foerageertochten voor hun jongen in de kolonies gebruik maken van de rustgebieden.
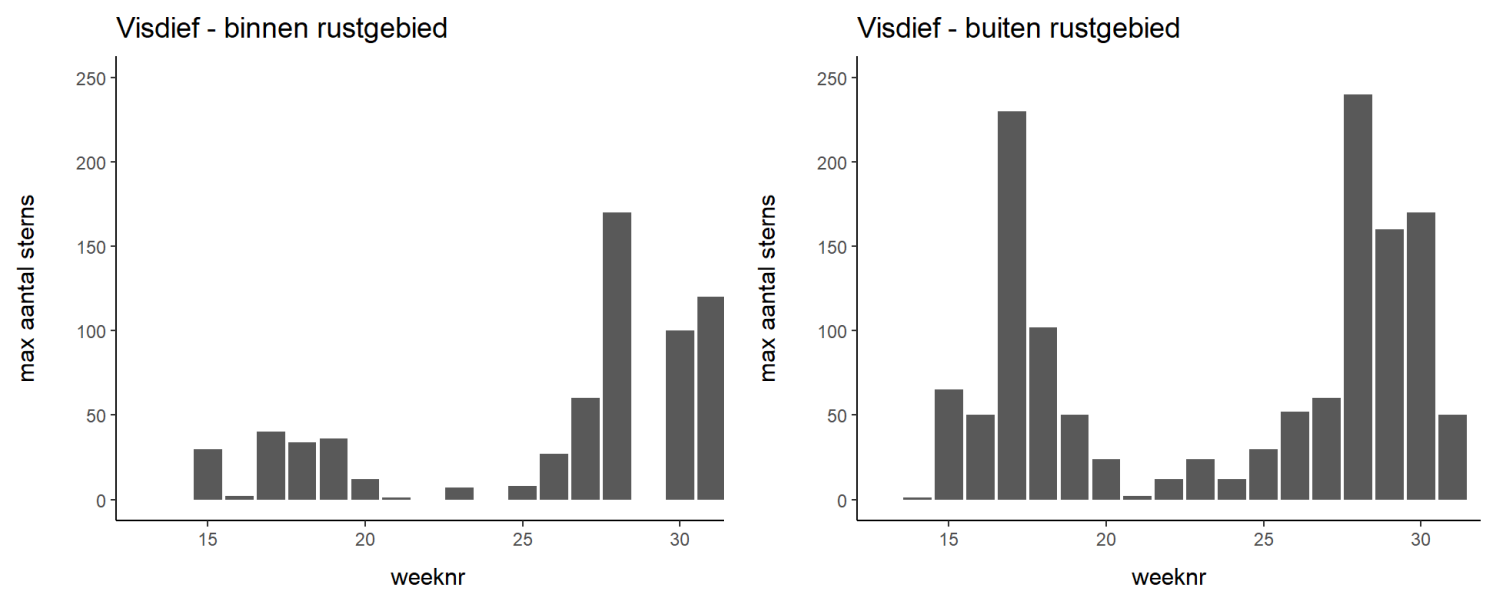

Figuur 7.45 Seizoensverloop van rustende visdieven binnen (links) en buiten (rechts) de ingestelde rustgebieden in 2017 op basis van landwaarnemingen. Let op dat in deze grafieken de Bollen van de Ooster niet meegenomen zijn, waardoor met name de aantallen binnen de rustgebieden in week 30 veel te laag zijn. 
In 2009, 2011-2013, 2016 en 2017 zijn land-tellingen van rustende juveniele grote sterns verricht, waarbij ook de visdieven zijn meegenomen. Met name op de Verklikkerplaat en de Bollen van de Ooster zijn relatief grote aantallen rustende visdieven aangetroffen na het uitvliegen van de jongen. Het betrof hier vaak adulte vogels met kleurringen uit de Delta die daar al dan niet met hun jongen aanwezig waren. Uit deze observaties blijkt dat ook voor visdieven de platen na het uitvliegen van belang zijn voor het grootbrengen van de kuikens en het is aannemelijk dat dit de ouders een energetische voorsprong geeft omdat ze, zeker in het geval van de Bollen van de Ooster, minder ver hoeven te vliegen om voedsel aan te brengen naar hun wachtende jongen.

Sinds 2012 worden jaarlijks kleine aantallen adulte visdieven in de kolonies in de noordelijke Delta van een kleurring voorzien waarmee ze goed te volgen zijn tijdens hun verdere leven. De uitwerking van deze kleurringdatabase is nog zeer beperkt. Na het uitvliegen van de jongen (juli) komen de meeste terugmeldingen van vogels die lokaal in de Delta blijven (Verklikkerstrand, inlagen). Daarna volgen aflezingen uit zuidelijkere broedgebieden en een enkele in noordelijkere gebieden zoals de Putten bij Petten en de Balgzandpolder bij Den Helder. Dit sterkt onze indruk dat visdieven veel minder dan grote sterns naar noordelijke gebieden trekken.

De reacties van visdieven en grote sterns op verstoringsbronnen op platen en stranden komt in grote lijnen overeen. De soorten zitten ook vaak in gemengde groepen. De verstoringsafstand is ongeveer hetzelfde en verstoringen worden bijna uitsluitend vastgesteld buiten de rustgebieden op de Verklikkerplaat/strand en de stranden van de zachte zeewering van Maasvlakte 2. Ook visdieven gaan relatief snel weer zitten na menselijke verstoring en verlaten het gebied meestal niet.

\section{Deelconclusies}

- Rustende visdieven worden met name aangetroffen op de Verklikkerplaat, Bollen van de Ooster, Hinderplaat/Westplaat en de stranden van Maasvlakte 2. De Verklikkerplaat en de Bollen van de Ooster worden gebruikt door ouders met jongen na het uitvliegen. Visdieven maken weinig gebruik van het ingestelde rustgebied op de Middelplaat. Buiten de ingestelde rustgebieden worden relatief veel rustende visdieven op de zuidpunt van Maasvlakte 2 gezien.

- De aantallen rustende visdieven op de stranden van Maasvlakte 2, maar ook op de andere stranden/platen lijken recent af te nemen.

- Er zijn aanwijzingen dat lokale visdieven langer in het Deltagebied blijven hangen dan grote sterns.

- Van de aangewezen rustgebieden worden visdieven het minst verstoord op de Bollen van de Ooster.

- Verstoring in andere gebieden lijkt mee te vallen. Alleen langs de zachte zeewering van Maasvlakte 2 en op het Verklikkerstrand komen veel bezoekers en worden visdieven verstoord door wandelaars.

\subsection{Discussie}

Voor de beantwoording van de vraag over het kwalitatieve belang van het, door Maasvlakte 2, verdwenen foerageergebied en het belang van het nieuw ontstane foerageergebied langs de kust van Maasvlakte 2, is gebruik gemaakt van waarnemingen van het gebiedsgebruik door grote stern en visdief. Op basis van die gegevens is een vergelijking met de T0 mogelijk, waarbij de kanttekening gemaakt moet worden dat het aantal jaren met waarnemingen in de T0 beperkt was. Belangrijke aanvullende informatie kan gehaald worden uit het functioneren van de broedkolonies die beïnvloed zouden kunnen worden door Maasvlakte 2. Hoewel ook vele andere factoren een rol spelen bij het broedsucces, zou een effect van Maasvlakte 2 zichtbaar kunnen zijn in het aantal broedparen of het broedsucces van deze kolonies.

Voor de visdiefkolonie op Vogeleiland is apart een inschatting gemaakt van het mogelijke effect van Maasvlakte 2 op vliegafstanden en daarmee samenhangende energetische kosten voor de visdieven. Deze berekening geeft een indicatie van hoe het effect van een langere vliegroute zou kunnen uitpakken. Door het ontbreken van kennis over de werkelijke voedselsituatie in de T0 periode is het echter lastig te beoordelen hoe realistisch de berekende effecten zijn. 
Voor de beantwoording van de vraag over de potentiele functie van de Voordelta als foerageergebied, is vooral gebruik gemaakt van informatie over voedselaanvoer en broedsucces als indicatoren voor voedselaanbod. Deze aanpak is gekozen vanwege de moeilijkheid/complexiteit het voedselaanbod te kwantificeren met een monitoringprogramma gericht op pelagische vis.

Voor de grote stern is het foerageergebied veel groter dan de Voordelta. Kwaliteit en kwantiteit van het voedsel (aandeel haringachtigen) is van groot belang voor de conditie van kuikens. Vanwege de pelagische leefstijl van haring is er geen relatie met de compensatiemaatregel (instellen

bodembeschermingsgebied). Zandspiering is een belangrijke voedselbron voor volwassen grote stern. Omdat zandspiering deel van de tijd ingegraven leeft is er mogelijk wel een verband met het instellen van het bodembeschermingsgebied. In de eerste fase was een negatieve correlatie gevonden tussen de aanwezigheid van zandspiering en de intensiteit van (boomkor en garnalen)visserij. Een hernieuwde analyse wijst uit dat ruimtelijke patronen veel belangrijker zijn en wijzen op een veel zwakker verband met visserij. Het is niet mogelijk om te concluderen dat er een causaal verband is tussen voorkomen van zandspiering en visserij, wel zijn verspreiding van (kleine) zandspiering en visserij ruimtelijk gescheiden.

Voor visdief zijn naast voedsel veel andere factoren van grote invloed op het broedsucces. Het is daarom niet mogelijk harde conclusies te trekken over het belang van het voedselaanbod. Ook voor visdief is een relatie met de compensatiemaatregel (instellen bodembeschermingsgebied) niet waarschijnlijk. Een effect van het beheer van de Haringvliet-sluizen op het voedselaanbod voor visdief lijkt wel aanwezig.

Voor de beantwoording van de vraag over het instellen van de rustgebieden, is vooral gebruik gemaakt van telgegevens. De resultaten wijzen op gebruik van de rustgebieden, zowel tijdens de voor- en najaarstrek als tijdens de periode waarop sterns met hun jongen uitvliegen. Het is echter niet mogelijk om het effect van het instellen van de rustgebieden te kwantificeren.

\subsection{Conclusies}

\section{Grote stern}

3a) Hoe is, op basis van voortschrijdend inzicht, de inschatting van het effect van de aanleg van Maasvlakte 2 op het instandhoudingsdoel voor deze soort?

i. Wat was, in kwalitatieve termen, de betekenis van het verdwenen foerageergebied.

ii. Wat is, in kwalitatieve termen, de betekenis van het nieuwe kustgebied na aanleg van Maasvlakte 2

Grote sterns gebruikten het gebied waar Maasvlakte 2 is aangelegd als doorvlieggebied tussen foerageergebieden en broedgebieden. Ook foerageerden ze langs de zachte zeewering van de Maasvlakte. Na aanleg foerageren grote sterns langs de gehele zachte zeewering van Maasvlakte 2, en rusten ze vooral op de zuidpunt van Maasvlakte 2 . Het verdwenen zeegebied had geen essentiële foerageerfunctie, en er is geen daling in het aantal rustende sterns in het Maasvlakte gebied. Er zijn geen concrete aanwijzingen dat kwaliteit en omvang van het leefgebied van grote sterns in de Voordelta is veranderd.

3b) Leidt het instellen van het bodembeschermingsgebied tot een gelijkblijvende potentiële functie van de Voordelta voor de grote stern in termen van voedselbeschikbaarheid?

i. $\quad$ Treden veranderingen op in broedsucces, het voedsel, de verspreidingspatronen en het aantal vogeldagen van de grote stern t.o.v. de situatie vóór de aanleg van Maasvlakte 2?

ii. Zijn deze veranderingen toe te schrijven aan (veranderingen in) de voedselbeschikbaarheid of zijn andere factoren van (groter) belang?

iii. Is er een correlatie tussen de verschillende vormen van bodemberoerende visserij en de aanwezigheid en dichtheid van zandspiering in de Voordelta. Is het aannemelijk dat het om een causaal verband gaat?

Het aantal vogeldagen van grote stern in de Voordelta is niet veranderd. Het aantal broedparen van grote sterns in het Deltagebied fluctueert rond het instandhoudingsdoel. In de noordelijke kolonies, die het meest worden beïnvloed door Maasvlakte 2, was het aantal geproduceerde jongen na de 
aanleg van Maasvlakte 2 hoger dan in de T0. Er is geen trendbreuk in het broedsucces van grote stern in het hele Deltagebied gerelateerd aan de aanleg van Maasvlakte 2. De kuikenconditie en het uitvliegsucces van grote sterns hangen sterk af van het voedselaanbod, en dan vooral de aanvoer van haringachtigen. Variatie in de aanvoer van haringachtigen hangt waarschijnlijk af van abiotische factoren. Omdat grote sterns tot ver buiten de Voordelta foerageren, is er geen relatie met de compensatiemaatregelen.

Zandspiering is de belangrijkste voedselbron voor volwassen grote sterns tijdens de eerste weken van het broedseizoen. De aanwezigheid en aantallen van zandspiering hangen vooral samen met ruimtelijke patronen, abiotische factoren en visserij hebben een geringe (statistische) invloed. Of er sprake is van een causaal verband tussen intensiteit van visserij en aanwezigheid van zandspiering valt niet te zeggen op basis van de beschikbare gegevens. Er is weinig ruimtelijke overlap tussen verspreiding van met name kleine zandspiering en visserij.

3c) Draagt het instellen van de rustgebieden bij aan het instandhoudingsdoel?

i. Worden de droogvallende platen in de rustgebieden gebruikt door de aanwezige grote sterns, en/of worden andere gebieden gebruikt om te rusten? En in welke periode houden zij zich hier op?

ii. Wat is het relatieve belang van de Voordelta voor de grote stern, welke factoren spelen daarbij een rol en wat is de jaar tot jaar variantie en zijn hierin grote veranderingen waarneembaar?

De grootste aantallen rustende grote sterns zitten buiten de aangewezen rustgebieden. Veruit de grootste aantallen rustende sterns zitten elk voorjaar op de Verklikkerplaat/het Verklikkerstrand. Dit gebied is sinds 2015 geen aangewezen rustgebied meer, maar lijkt een belangrijke rol te vervullen tijdens de paarvorming en tijdens de doortrek. Ook worden hier in juli juveniele grote sterns gevoerd door hun ouders. Het rustgebied op de Hinderplaat wordt relatief weinig gebruikt door rustende grote sterns. Het ingestelde rustgebied op de Bollen van de Ooster wordt elk jaar vlak na het uitvliegen relatief intensief gebruikt door een groep van 100 grote sterns met hun jongen. Buiten de ingestelde rustgebieden worden relatief veel rustende sterns op de zuidpunt van Maasvlakte 2 gezien. Grote sterns uit de Delta verblijven tot zo'n vier weken na het uitvliegen van de jongen in de Delta. Ook door sterns van buiten de Delta wordt gebruik gemaakt van de Voordelta en de rustgebieden. Of de aangewezen rustgebieden essentieel zijn voor de grote stern in de Voordelta kunnen we niet kwantificeren. Dat hangt er vanaf of de ruimte die buiten de rustgebieden beschikbaar is voldoende rustmogelijkheid biedt voor de aanwezige sterns.

\section{Visdief}

4a) Hoe is, op basis van voortschrijdend inzicht, de inschatting van het effect van de aanleg van Maasvlakte 2 op het instandhoudingsdoel voor deze soort?

i. Wat was, in kwalitatieve termen, de betekenis van het verdwenen foerageergebied

ii. Wat is, in kwalitatieve termen, de betekenis van het nieuwe kustgebied na aanleg van Maasvlakte 2

Het verdwenen zeegebied diende als foerageergebied voor visdieven, en op de zachte zeewering van Maasvlakte 1 werd gerust. Tijdens de aanleg foerageerden visdieven zeer veel in het zeegebied van Maasvlakte 2 en dan vooral rond de suppletieschepen. Na aanleg foerageerden ze langs de zachte zeewering en rustten de dieren met name op de zuidpunt van Maasvlakte 2. Het verdwenen zeegebied had een essentiële foerageerfunctie voor broedende visdieven op de Maasvlakte en die functie lijkt overgenomen door de nieuwe zeewering van Maasvlakte 2. De mate waarin is echter niet te kwantificeren op basis van de beschikbare informatie.

Uit energetische berekeningen op basis van waarnemingen uit 2017 blijkt dat de toegenomen vliegduur tussen de kolonie op Maasvlakte 2 en het foerageergebied als gevolg van de aanleg van Maasvlakte 2 een negatieve invloed gehad kan hebben op de kuikenconditie en het uitvliegsucces. Het is echter onbekend of de voedselbeschikbaarheid langs de zachte oevers van Maasvlakte 2 anders is dan in het foerageergebied vóór aanleg van Maasvlakte 2.

4b) Leidt het instellen van het bodembeschermingsgebied tot een gelijkblijvende potentiële functie van de Voordelta voor de visdief in termen van voedselbeschikbaarheid? 
i. Treden veranderingen op in broedsucces, het voedsel, de verspreidingspatronen en het aantal vogeldagen van de visdief in de Voordelta t.o.v. de situatie vóór de aanleg van Maasvlakte 2?

ii. Zijn deze veranderingen toe te schrijven aan (veranderingen in) de voedselbeschikbaarheid of zijn andere factoren van (groter) belang?

De aantallen broedparen lijken de laatste jaren enigszins af te nemen in de Delta. De aantallen broedparen op de Maasvlakte zelf zijn relatief stabiel. Deze kolonie is de enige waarvan de vogels in de buurt van het aanleggebied foerageren en waarvan dus een effect van Maasvlakte 2 te verwachten is.

$\mathrm{Er}$ is geen trendbreuk in het broedsucces van visdieven in de hele Delta tussen voor- en na de aanleg van Maasvlakte 2. Broedende visdieven op de Maasvlakte hadden voor de aanleg een hoger broedsucces dan daarna, echter deze trend maakt onderdeel uit van een overkoepelende neergaande trend in het gehele Deltagebied. Het instandhoudingsdoel voor visdief met betrekking tot het aantal broedparen in de Delta wordt niet gehaald, maar dit lijkt los te staan van Maasvlakte 2.

Het beheer van de Haringvlietsluizen heeft invloed op de voedselbeschikbaarheid van zoetwatervis en daarmee ook op de foerageerfunctie van de Voordelta voor de visdieven van de Scheelhoekkolonie. Niet aan voedsel gerelateerde factoren in de kolonie (zoals vegetatie, weer, predatie) zijn vaak de belangrijkste oorzaak van een laag broedsucces. Daarom is het niet mogelijk een eenduidig antwoord te geven op het belang van voedsel voor het broedsucces van visdieven.

4c) Draagt het instellen van de rustgebieden bij aan het instandhoudingsdoel?

i. Worden de platen in de rustgebieden gebruikt door de aanwezige visdieven? In welke periode houden zij zich hier op en wat is de functie van de aanwezigheid van droogvallende platen?

Rustende visdieven worden met name aangetroffen op de Verklikkerplaat, Bollen van de Ooster, Hinderplaat/Westplaat en de stranden van Maasvlakte 2. Na het uitvliegen worden met name de Verklikkerplaat en de Bollen van de Ooster gebruikt door ouders met hun jongen. Visdieven maken weinig gebruik van het ingestelde rustgebied op de Middelplaat. Buiten de ingestelde rustgebieden worden relatief veel rustende visdieven op de zuidpunt van Maasvlakte 2 gezien. Voor alle stranden en platen geldt dat het gebruik de laatste jaren is afgenomen.

Er zijn aanwijzingen dat lokaal broedende visdieven langer in het Deltagebied blijven hangen dan grote sterns. Of de aangewezen rustgebieden essentieel zijn voor de visdief in de Voordelta kunnen we niet kwantificeren. Dat hangt er vanaf of de ruimte die buiten de rustgebieden beschikbaar is voldoende rustmogelijkheid biedt voor de aanwezige visdieven. 


\section{Slotbeschouwing en aanbevelingen}

T.C. Prins ${ }^{1}$, I. Tulp ${ }^{2}$, S.D. IJff ${ }^{1}$, M.T. van der Sluis ${ }^{2}$,

${ }^{1}$ Deltares, ${ }^{2}$ Wageningen Marine Research

Het monitoringprogramma natuurcompensatie Voordelta (PMR-NCV) richt zich op het vaststellen van de effecten van de genomen natuurcompensatiemaatregelen: de instelling van het bodembeschermingsgebied en de instelling van rustgebieden voor zwarte zee-eend, grote stern en visdief. Op basis van de destijds beschikbare kennis is ingeschat dat de effecten van de aanwezigheid van Maasvlakte 2 significant negatieve effecten zou hebben voor het areaal habitattype $\mathrm{H} 1110$ en voor het areaal foerageergebied van zwarte zee-eend, grote stern en visdief (VenW 2008). De genomen maatregelen hebben het doel deze negatieve effecten te compenseren. Het beoogde effect van de instelling van het bodembeschermingsgebied is een $10 \%$ verbetering in de kwaliteit van habitat $\mathrm{H} 1110$ in dit deel van de Voordelta. Het doel van het instellen van rustgebieden is het behouden van de kwaliteit van de Voordelta als foerageergebied voor zwarte zee-eend, grote stern en visdief. Dit rapport richt zich alleen op het vaststellen van de effecten van de compensatiemaatregelen. De beoordeling of die effecten voldoende zijn om de negatieve effecten van Maasvlakte 2 te compenseren, komt in dit rapport niet aan de orde, maar maakt onderdeel uit van de evaluatie die door RWS-WVL wordt uitgevoerd.

De opzet van het monitoringprogramma PMR-NCV dat in 2009 is gestart, was beschreven in de eisen (Terms of Requirements) bij de aanbesteding van de monitoring in 2008. Het monitoringprogramma was, met de kennis van dat moment, ontworpen om zo goed mogelijk de gegevens en informatie te leveren die nodig zijn voor de effect-beoordeling. Bij het ontwerp is ook rekening gehouden met de monitoring die in de TO (2004-2007) is uitgevoerd. Na afloop van de 1e fase van PMR-NCV in 2013, zijn in 2014-2015 verschillende aanpassingen gedaan in het monitoringprogramma op basis van de ervaringen uit de 1 e fase.

Een langlopend monitoringprogramma als PMR-NCV moet het optimum vinden tussen twee uitersten. Enerzijds is het van belang om continuïteit in de metingen te hebben, omdat in een dynamisch gebied als de Voordelta met grote jaarlijkse variatie in veel van de aspecten die gemonitord worden, langjarige reeksen nodig zijn om met voldoende betrouwbaarheid uitspraken te kunnen doen. Aan de andere kant is het ook gewenst om met het monitoringprogramma adaptief in te kunnen spelen op veranderde omstandigheden, onvoorziene ontwikkelingen, nieuwe inzichten over de effecten van maatregelen en nieuwe meetmethoden en -technieken. En tot slot zijn er ook financiële en logistieke grenzen aan wat mogelijk is.

Het monitoringprogramma is geen onderdeel van een strikt gedefinieerd wetenschappelijk experiment waarbij behalve een paar experimentele omstandigheden, alle andere factoren constant worden gehouden, maar volgt de effecten van de compensatiemaatregelen in een, in vele opzichten, dynamisch gebied. Het meest in het oog springende voorbeeld daarvan is de (autonome) verandering in de boomkorvisserij. In 2009 werd er nog van uit gegaan dat een vergelijking zou kunnen worden gemaakt in de ontwikkeling van de kwaliteit van habitattype $\mathrm{H} 1110$ tussen het bodembeschermingsgebied (waar de boomkorvisserij was uitgesloten) en de rest van de Voordelta (waar de visserij onveranderd zou blijven). In de jaren 2009-2013 werd duidelijk dat deze verwachting niet klopte. In de analyses is daarom de aanpak verschoven van het maken van een vergelijking van de kwaliteit van habitattype $\mathrm{H} 1110$ tussen bodembeschermingsgebied en rest van de Voordelta, naar een analyse van veranderingen in die kwaliteit over de jaren, in relatie tot veranderingen in visserij onafhankelijk van het gebied. Een ander voorbeeld van veranderde omstandigheden hangt samen met de sterke jaarlijkse verschillen in aantallen zwarte zee-eenden in de Voordelta. Om toch een uitspraak te kunnen doen over de effecten van de compensatiemaatregelen, is ingezet op het kwantificeren van de draagkracht van de Voordelta voor zwarte zee-eenden door middel van modellering, naast het uitvoeren van waarnemingen van aantallen eenden in de Voordelta. 
Het monitoringprogramma van PMR-NCV is niet alleen ontworpen om de vragen over de effecten van de compensatiemaatregelen te kunnen beantwoorden. Het programma is breder opgezet zodat aanvullende informatie beschikbaar komt over het ecologisch functioneren van de Voordelta en de rol van menselijke activiteiten. Deze kennis is van belang om de resultaten van het onderzoek en de monitoring te kunnen beoordelen in de bredere context van de Voordelta en de Nederlandse kustwateren. In het kader van dit monitoringprogramma is ook gekeken naar ecologische ontwikkelingen elders langs de Nederlandse kust, om de resultaten uit het onderzoek in de Voordelta in een breder perspectief te kunnen plaatsen.

Die kennis is ook van belang om de in 2008 genomen compensatiemaatregelen te evalueren en indien nodig bij te stellen, zoals dat eerder is gebeurd in 2014 op basis van de resultaten uit PMR-NCV. Op grond van die tussentijdse evaluatie is de begrenzing van de rustgebieden voor zwarte zee-eenden aangepast in het Beheerplan Voordelta 2015-2021 (RWS 2016).

De huidige rapportage geeft de stand van zaken, 13 jaar na aanvang van het monitoringprogramma in 2004. Deze rapportage omvat niet voor alle metingen de volledige periode 2004-2017, omdat het onvermijdelijk is dat de analyse van een deel van de gegevens nog niet afgerond is. Het gaat hierbij vooral om gegevens uit het onderzoek aan bodemdieren, waarvan de analyse tijdrovend en arbeidsintensief is, en waarvan de gegevens verzameld in 2017 nog niet beschikbaar zijn. Uit de nu beschikbare resultaten kunnen echter wel al conclusies worden getrokken in relatie tot de MEP vragen. In de voorgaande hoofdstukken is uitgebreid ingegaan op de resultaten en conclusies voor de MEP vragen. Hieronder wordt daar nader op ingegaan, ook in het licht van de eerdere rapportages over de resultaten van PMR-NCV (Prins et al. 2014, Prins et al. 2015, Prins et al. 2016). Daarnaast worden aanbevelingen gedaan voor de resterende jaren (2018-2019) van het PMR-NCV programma.

\subsection{MEP vraag 1; kwaliteit habitattype H1110}

Wordt het verlies aan habitattype $\mathrm{H} 1110$ als gevolg van de aanleg van Maasvlakte 2 voldoende gecompenseerd?

Voor MEP vraag 1 was in 2014 de conclusie dat de oorspronkelijke opzet van het monitoringprogramma van PMR-NCV, een vergelijking tussen Bodembeschermingsgebied en rest van de Voordelta, niet meer bruikbaar was. Door de veranderingen in de boomkorvisserij in de Voordelta was er feitelijk geen onderscheid te maken tussen Bodembeschermingsgebied en het overige deel van de Voordelta, als het gaat om de mate waarin dit type visserij voorkomt (Prins et al 2014). Een gebiedsvergelijking levert daarom geen informatie op die iets zegt over het effect van de veranderingen in boomkorvisserij op de bodemdieren- en visgemeenschap. In de rapportage van 2014 zijn ook al resultaten gepresenteerd van eerste analyses waarbij gekeken is naar de correlaties tussen visserij-intensiteit (boomkor- en garnalenvisserij) en verschillende parameters voor de bodemdierenen visgemeenschap in de Voordelta. In de daarop volgende jaren is de gebiedsvergelijking Bodembeschermingsgebied-rest van Voordelta losgelaten. Vervolgens is vooral aandacht besteed aan het ontwikkelen van benaderingen waarbij veranderingen in de tijd, in de bodemdieren- en visgemeenschap, onderzocht werden en nagegaan werd in hoeverre die in verband gebracht konden worden met de waargenomen veranderingen in de boomkor- en garnalenvisserij. Tussentijdse resultaten zijn beschreven in tussentijdse rapportages (Craeymeersch et al. 2015, Prins et al. 2015, Tulp 2015, Craeymeersch et al. 2016, Prins et al. 2016).

In hoofdstuk 5 is een uitgebreid overzicht gegeven van alle analyses die recent zijn uitgevoerd met de volledige dataset van bodemdieren en vis die nu beschikbaar is. Er zijn verschillende benaderingen gebruikt om te kijken naar het verband tussen veranderingen in de intensiteit van boomkor- en garnalenvisserij in de Voordelta, en de ontwikkelingen in de bodemdieren- en visgemeenschap. Daarnaast is ook gekeken naar de ontwikkelingen langs de Zuid- en Noord-Hollandse kust in visserij, bodemdieren en vis.

Niet alleen in de Voordelta, maar ook langs de Hollandse kust is sprake van afname van de boomkorvisserij en toename van de garnalenvisserij. De analyses die zijn uitgevoerd laten echter geen duidelijke, eenduidige, verbanden zien tussen de veranderingen in visserij en veranderingen in de 
bodemgemeenschappen. In de rapportage van 2014 was nog sprake van een correlatie tussen visserij-intensiteit en de aan-/afwezigheid van zandspiering. De analyse van zandspiering data in hoofdstuk 7.4.4, laat zien dat visserij-intensiteit weinig verklarende kracht heeft. Het voorkomen van zandspiering wordt vooral verklaard door ruimtelijke patronen die niet aan visserij-intensiteit gerelateerd kunnen worden.

De conclusie in hoofdstuk 5 is dat het inzicht over het effect van verminderde boomkorvisserij op de bodemdiergemeenschap in de Voordelta is gewijzigd in de jaren na het nemen van de compensatiemaatregel, maar dat er in theorie nog steeds effecten te verwachten zijn op soortensamenstelling (o.a. aandeel langlevende soorten) en soortenrijkdom. Voor het feit dat geen duidelijke, eenduidige, veranderingen in de bodemdierengemeenschap worden waargenomen, zijn verschillende verklaringen mogelijk. Op grond van de huidige kennis en de beschikbare gegevens is het echter niet mogelijk een uitspraak te doen over de juistheid van die verklaringen.

De huidige conclusies zijn gebaseerd op een analyse van gegevens uit twee jaren in de T0 (2004, 2005), en 6 meetjaren sinds 2009 (2009-2013, 2015). Er komt nog een aanvullende analyse waarbij de dataset wordt uitgebreid met de resultaten van 2016. Het is echter niet te verwachten dat dit extra jaar tot wezenlijk andere conclusies en inzichten zal gaan leiden dan de huidige periode met een lengte van 12 jaar. Immers, er komen geen jaren bij met intensieve boomkorvisserij, en evenmin komen er jaren bij met weinig garnalenvisserij. Extra jaren, en dat geldt ook voor monitoringdata die in 2018 of later verzameld gaan worden, wijken daarmee niet af van de jaren vanaf 2009 waarin boomkorvisserij afwezig was en de garnalenvisserij relatief intensief.

Als de oorzaak voor het niet waarnemen van duidelijke, eenduidige, veranderingen in de bodemdierengemeenschap ligt in een veel langere hersteltijd dan de nu beschouwde periode 20042015, is het mogelijk dat bij voortzetting van de monitoring alsnog trends kunnen worden vastgesteld. Zeker is dit echter niet. Daarnaast wordt het steeds lastiger om optredende veranderingen in de bodemdierengemeenschap in de Voordelta te relateren aan het verdwijnen van de boomkorvisserij, ook door het ontbreken van vergelijkbare gebieden in de Nederlandse kuststrook die als referentie kunnen dienen.

\subsubsection{Aanbevelingen}

De laatste monitoring van bodemdieren en vis vindt plaats in 2018. Dat betekent dat, in aanvulling op de huidige geanalyseerde data (en de aanvulling met 2016), er nog over twee jaar $(2017,2018)$ data beschikbaar komen voor vervolganalyses. Tegelijkertijd is de vraag in hoeverre herhaling van de analyses die in hoofdstuk 5 zijn beschreven, met twee jaar extra aan data, nog tot bijstellingen van de conclusies gaan leiden.

Voor het begrip van de ontwikkelingen in de Voordelta, kan het nog nuttig zijn om meer inzicht te krijgen in de invloed die de meest dominante soort, de Amerikaanse zwaardschede, op andere soorten en op omgevingskarakteristieken heeft (Dannheim \& Rumohr 2011, Witbaard et al. 2015, Witbaard et al. 2017) op basis van de beschikbare monitoringresultaten. Dit zou mogelijk verklaringen kunnen opleveren voor de afwezigheid van duidelijk waarneembare effecten van de veranderingen in visserij. Daarnaast kan een meer modelmatige, zoals ontwikkeld in het Benthis project (Rijnsdorp et al. 2017) mogelijk nog een kwantificering van de potentiele effecten van de veranderingen in visserij op de biomassa opleveren. Met de Benthis indicator wordt het effect van visserij op de biomassa en de verdeling over kort- en langlevende soorten berekend. Met de Benthis indicator kan zowel berekend worden wat het potentiele effect is van de werkelijk opgetreden visserij, als wat het effect is van verschillende scenario's van visserij.

\subsection{MEP vraag 2; zwarte zee-eend}

Wordt het verlies aan foerageergebied van de zwarte zee-eend als gevolg van de aanleg en het gebruik van Maasvlakte 2 voldoende gecompenseerd?

Voor MEP vraag 2 werd in 2014 geconcludeerd dat er op dat moment geen aantoonbare verandering was in de potentiële functie van de Voordelta, sinds de aanleg van Maasvlakte 2 en het instellen van 
het bodembeschermingsgebied en de rustgebieden (Prins et al. 2014). Dit gold zowel voor voedselbeschikbaarheid, als in termen van rust. De voedselbeschikbaarheid varieerde sterk van jaar tot jaar zonder duidelijke trend. De zwarte zee-eenden verbleven in de Voordelta voornamelijk in gebieden met weinig verstoring en met voldoende bereikbaar voedsel, zowel binnen de rustgebieden als in delen van de Voordelta buiten de rustgebieden. De aantallen zwarte zee-eenden die in de winter en het voorjaar in de Voordelta worden waargenomen vertoonden geen trendmatige verandering. Geconcludeerd werd ook dat factoren (in overwinteringsgebieden) buiten de Voordelta waarschijnlijk in belangrijke mate bepalend zijn voor het feit of de eenden in grote aantallen in het gebied verblijven in de winter en het voorjaar. Een betere inschatting van de potentiële draagkracht van de Voordelta, los van het feit of zwarte zee-eenden daadwerkelijk in de Voordelta verblijven, leek daarom van belang om de effecten van de compensatiemaatregelen beter te kunnen beoordelen.

De afgelopen jaren is de monitoring van de zwarte zee-eenden in de Voordelta voortgezet. Daarnaast was de intentie om onderzoek te doen naar de verstorende effecten van kite-surfen (een activiteit die zich sinds de aanleg van Maasvlakte 2 sterk heeft ontwikkeld) op zwarte zee-eenden. Vanwege de relatief lage aantallen zee-eenden in de Voordelta in de laatste jaren, kon dit onderzoek niet uitgevoerd worden.

In aanvulling op de waarnemingen in de Voordelta, is een draagkrachtmodel ontwikkeld waarmee berekend kan worden hoe groot het potentiele aantal zwarte zee-eenden is dat in de Voordelta kan verblijven, bepaald door het voedselaanbod, afwezigheid van verstoring en andere omgevingsfactoren. De resultaten van de waarnemingen en modellering geven zowel inzicht in het werkelijke gebruik van de Voordelta door zwarte zee-eenden, als in de potentiele geschiktheid van de Voordelta als foerageergebied.

De conclusies uit onderzoek en monitoring van de zwarte zee-eend zijn beschreven in §6.7. Deze conclusies zijn een aanvulling op de in 2014 geformuleerde conclusies, maar leiden niet tot wezenlijk andere inzichten.

Uit analyse van waarnemingen wordt geconcludeerd dat er geen aanwijzingen zijn dat het Maasvlakte 2 gebied in het verleden gebruikt werd als foerageer- of verblijfgebied door zwarte zee-eenden. Uit de draagkrachtmodellering bleek dat op basis van het voedselaanbod in de T0 jaren $(2004,2005)$ de potentiele draagkracht van het Maasvlakte 2 gebied zo laag was dat er geen eenden gedurende het hele winterhalfjaar konden overleven.

In de Passende Beoordeling is het effect van Maasvlakte 2 als significant negatief ingeschat. Vanwege het lage aantal zwarte zee-eenden dat in het noordelijk deel van Voordelta was waargenomen, is die inschatting van de effecten gedaan op basis van het aantal hectares foerageergebied, waarbij is ingeschat dat 2,4\% van het totale potentiele foerageergebied in de Voordelta permanent verloren zou gaan als gevolg van het ruimtebeslag van Maasvlakte 2 (Heinis et al. 2007). In de Passende Beoordeling wordt al aangegeven dat de waarde van het Maasvlakte 2 gebied voor de zwarte zee-eend niet zeker is, en dat het beschreven effect het resultaat is van een worst case benadering. De modelinschatting dat de potentiele draagkracht van dit gebied voor zwarte zee-eenden niet van betekenis is, onderschrijft dat er in de Passende Beoordeling sprake was van een worst case benadering.

De waarnemingen van zwarte zee-eenden in de Voordelta laten zien dat er grote jaarlijkse verschillen zijn in aantallen eenden en in het aantal vogeldagen, maar dat er geen sprake is van een trend. Daarbij is het overigens wel zo dat door die grote jaarlijkse variatie statistisch significante trends niet snel vastgesteld zullen kunnen worden. Het instandhoudingsdoel voor de Voordelta is een midwinteraantal van 9700 zwarte zee-eenden. Dit doel is in geen van de jaren vanaf de T0 waarin tellingen zijn verricht, gehaald. Uit de modelberekeningen van de potentiele draagkracht van de Voordelta komt naar voren, dat er in het algemeen voldoende voedsel en rust in de Voordelta lijkt te zijn, en dat die potentiele draagkracht niet verminderd is na aanleg van Maasvlakte 2. Uit tellingen blijkt ook, dat in vrijwel alle jaren slechts een klein deel van de zwarte zee-eenden die in de Nederlandse kustwateren worden waargenomen, in de Voordelta verblijven. Bij het niet behalen van het instandhoudingsdoel is er daarom geen sprake van ongeschikte omstandigheden in de Voordelta, maar speelt dat er elders (en dichterbij de broedgebieden) ook geschikte of beter geschikte gebieden zijn.

Ook op de schaal van heel Nederland geldt dat de staat van instandhouding voor de zwarte zee-eend zeer ongunstig is. De in Nederland aanwezige aantallen van de soort dalen in de laatste decennia en 
zijn lager dan de Natura 2000 instandhoudingsdoelen (https://www.sovon.nl/nl/soort/2130). In het kader van het Monitoring- en Evaluatieprogramma Zandwinning wordt nu onderzoek uitgevoerd aan de zwarte zee-eend. Hierbij is een aantal zwarte zee-eenden voorzien van een zender, zodat de positie van de eenden en informatie over het foerageergedrag wordt vastgelegd gedurende een aantal maanden. De resultaten van dit onderzoek kunnen mogelijk meer inzicht geven in de uitwisseling tussen gebieden en het gedrag van de eenden.

De conclusies over de gelijkblijvende potentiële functie van de Voordelta na aanleg van Maasvlakte 2, zullen niet meer veranderen door monitoringresultaten over de komende jaren 2018-2019.

Monitoring kan nog wel meer informatie opleveren over het gebruik van de rustgebieden en de effecten van de veranderde begrenzing van die rustgebieden. Omdat de aangepaste begrenzing gekozen is op basis van de waargenomen verspreiding van zwarte zee-eenden, en de eenden dus ook al vroeger op de locaties van de huidige rustgebieden zaten, zal het echter niet mogelijk zijn om op basis van waarnemingen van eenden het effect van die veranderde begrenzing aan te tonen. Natuurlijke veranderingen in het voedselaanbod in de Voordelta, zoals de recente toename van de halfgeknotte strandschelp kunnen mogelijk zorgen voor toekomstige veranderingen in de aantallen en verspreiding van de zwarte zee-eend in de Voordelta. Ook ontwikkelingen in gebieden elders in Nederland of in NW Europa blijven van invloed op de aantallen zwarte zee-eenden in de Voordelta.

\subsubsection{Aanbevelingen}

Tot nu toe is de invloed van verstoring door scheepvaart op de verspreiding van zwarte zee-eenden in de Voordelta onderzocht aan de hand van verstoringsparameters, die een gemiddelde voor een gehele winter/voorjaarsperiode geven. Voor een beter begrip van de effecten van verstoring door scheepvaart op zwarte zee-eenden zou een meer gedetailleerde analyse van gegevens op de veel kortere tijdschaal van waarnemingsdagen mogelijk tot een betere kwantificering kunnen leiden.

Toepassing van het draagkrachtmodel op situaties met hoge concentraties zwarte zee-eenden kan van nut zijn voor verdere verbetering van de modelresultaten. Ook zijn verbeteringen in de modelformuleringen mogelijk, zodat het foerageergedrag van de zwarte zee-eend beter beschreven wordt. Voorwaarde hiervoor is wel dat er kennis beschikbaar komt over dit gedrag. Mogelijk leidt het zenderonderzoek in het kader van MEP Zandwinning tot inzichten die in de toekomst gebruikt kunnen worden om de modellering te verbeteren.

\subsection{MEP vraag 3 en 4; grote stern en visdief}

Wordt het verlies aan foerageergebied van de grote stern en visdief als gevolg van het ruimtebeslag en het gebruik van Maasvlakte 2 voldoende gecompenseerd?

Voor MEP vraag 3 en 4 werd in 2014 geconcludeerd dat er geen verandering was in de potentiële functie van de Voordelta in termen van voedselbeschikbaarheid en rust, sinds de aanleg van Maasvlakte 2 en het instellen van het bodembeschermingsgebied en de rustgebieden (Prins et al. 2014). Veranderingen in de aantallen op platen rustende sterns en het aantal vogeldagen van grote stern en visdief in de Voordelta, hingen samen met veranderingen in de bezetting van de broedkolonies in de ZW Delta en veranderingen in het plaatareaal. De aantallen broedparen van de grote stern en visdief in de ZW Delta vertoonden over de periode 2002-2012 geen duidelijke trend, en er was geen effect waarneembaar van de aanleg en aanwezigheid van Maasvlakte 2 op de kolonies in de noordelijke Deltawateren (Haringvliet en Grevelingen). Het succes van de broedkolonies, en daarmee het gebruik van de Voordelta door sterns, werd in belangrijke mate bepaald door het voedselaanbod, deels in gebieden buiten de Voordelta, naast omstandigheden in de broedkolonies (vegetatie, predatie) en algemene factoren zoals het weer.

De beschikbaarheid van de belangrijkste prooisoorten (haring, sprot, zandspiering) in de Voordelta was van belang voor het broedsucces. Voor zandspiering werd een correlatie vastgesteld met visserijdruk (garnalenvisserij en boomkorvisserij op platvis), maar nader onderzoek werd aanbevolen om na te gaan of hier sprake was van een causaal verband. 
De afgelopen jaren is de monitoring van grote stern en visdief in de Voordelta en het onderzoek in de broedkolonies voortgezet. Daarnaast zijn meer specifieke deelonderzoeken uitgevoerd. De conclusies voor de grote stern en visdief zijn beschreven in §7.9.

Ook voor grote stern en visdief is het effect van het permanente verlies van foerageergebied door het ruimtebeslag van Maasvlakte 2 als significant negatief effect beoordeeld in de Passende Beoordeling (Heinis et al. 2008). Evenals bij de zwarte zee-eend is in de Passende Beoordeling de inschatting een worst case. Uit de waarnemingen van het foerageergedrag en gebiedsgebruik door grote stern en visdief in de situatie vóór aanleg van Maasvlakte 2 is geconcludeerd dat dit gebied slechts in geringe mate werd gebruikt en er geen essentieel foerageergebied verloren lijkt te zijn gegaan. In de nieuwe situatie lijkt de zachte zeewering van Maasvlakte 2 een aantrekkelijk foerageergebied met meer areaal, en is er dus mogelijk sprake van verbeterde foerageermogelijkheden.

De potentiele functie van de Voordelta als foerageergebied voor grote stern en visdief is niet veranderd met de aanleg van Maasvlakte 2. Deze conclusie is niet gebaseerd op gegevens die direct de foerageerfunctie beschrijven, omdat dat lastig te onderzoeken is. In plaats daarvan zijn waarnemingen gedaan die de consequenties van een veranderde foerageerfunctie voor de broedkolonies in het noordelijk Deltagebied zichtbaar maken, zoals het aantal broedparen en het broedsucces in die kolonies. De kuikenconditie en het uitvliegsucces van grote sterns zijn sterk afhankelijk van de kwaliteit en de kwantiteit van het voedselaanbod in de Voordelta en daarbuiten, daarbij spelen haringachtigen een belangrijke rol, maar ook zandspiering is van belang. De aanwezigheid van zandspiering blijkt negatief gecorreleerd met bodemberoerende visserij, maar het is op basis van het uitgevoerde onderzoek niet vast te stellen of het om een causaal verband gaat. Voor de visdief zijn de Haringvlietsluizen een belangrijk foerageergebied, en het spuibeheer is van invloed op de voedselbeschikbaarheid. Een effect van de veranderingen in visserij in de Voordelta en van het instellen van het bodembeschermingsgebied op de foerageerfunctie voor grote stern en visdief is daarom niet waarschijnlijk.

Voor de visdief-kolonie in de Slufter is berekend, dat Maasvlakte 2 leidt tot langere vliegafstanden en daarmee mogelijk effecten heeft op de energie-aanvoer naar de broedkolonie. Mogelijk heeft dit een negatief effect op kuikenconditie en uitvliegsucces. Het is echter onbekend of, in de huidige situatie, de voedselbeschikbaarheid langs de zachte oever van Maasvlakte 2 anders is dan in de periode vóór aanleg, zodat het uiteindelijke effect op de voedselaanvoer niet te kwantificeren is.

De functie van de rustgebieden is onderzocht aan de hand van het gebruik van deze gebieden door rustende sterns. Dit geeft aanwijzingen over het relatieve belang van de verschillende platen en stranden. Het aantal kilometer potentieel rustgebied en mogelijk ook foerageergebied is toegenomen, maar het is wel drukker geworden in het gebied door de toename in recreatie. De aantallen rustende visdieven op de stranden van Maasvlakte 2, maar ook op de andere stranden/platen lijken recent af te nemen. De rustgebieden worden gebruikt door grote sterns maar de grootste aantallen rustende grote sterns zitten buiten de aangewezen rustgebieden. Of de aangewezen rustgebieden essentieel zijn voor de grote stern en de visdief in de Voordelta kunnen we niet kwantificeren. Grote sterns uit de Delta verblijven tot zo'n vier weken na het uitvliegen van de jongen in de Delta, echter een groot deel vliegt direct naar noordelijkere foerageergebieden. Ook door sterns van buiten de Delta wordt gebruik gemaakt van de Voordelta en de rustgebieden.

De resultaten en conclusies uit de laatste jaren zijn een aanvulling en verdere onderbouwing van de in 2014 geformuleerde conclusies, maar leiden niet tot wezenlijk andere inzichten.

We verwachten niet dat de resultaten van monitoring in de komende jaren (2018-2019) nog van invloed zullen zijn op de conclusies. Wel kunnen aanvullende analyses meer inzicht bieden in de invloed van weersomstandigheden op de overleving (uitkomst- en uitvliegsucces) van jongen. Vanwege de ingebruikname van de Kier kunnen er ook wijzigingen optreden in voedselaanbod en foerageermogelijkheden bij de Haringvlietsluizen, wat vooral van belang is voor de visdief. Onduidelijk is daarnaast wat het aanbrengen van een doorlaatmiddel in de Brouwersdam gaat betekenen voor de broedkolonies in het noordelijk Deltagebied.

\subsubsection{Aanbevelingen}

Voor de analyse van het effect van de aanleg van Maasvlakte 2 op het gebruik van het noordelijk deel van de Voordelta als foerageergebied, is gebruik gemaakt van waarnemingen van aantallen en 
foerageergedrag van grote stern en visdief in het Maasvlakte 2 gebied. Om het belang, als foerageeren rustgebied, van de zachte zeewering van Maasvlakte 2 beter te kunnen beschrijven verdient het aanbeveling om aanvullende tellingen en observaties van foerageergedrag en gevangen prooi te doen, zodat er een meer kwantitatieve beschrijving mogelijk wordt. Specifiek voor de visdief-kolonie in de Slufter, waar de meest directe effecten van de aanleg van Maasvlakte 2 verwacht kunnen worden, zou het goed zijn om in aanvulling op de waarnemingen van 2017 aan broedsucces, kuikenconditie en dieet in 2018 opnieuw waarnemingen te doen zodat er meer inzicht wordt verkregen in de effecten op deze kolonie.

Om meer inzicht te krijgen in de functie van de rustgebieden voor grote sterns die broeden in de kolonies bij de Voordelta, zou gebruik gemaakt kunnen worden van het feit dat sinds 2012 een groot aantal sterns geringd is door vrijwilligers. Door de waarnemingen van ringgegevens te analyseren en aan te vullen met extra waarnemingen in de rustgebieden, kan beter gekwantificeerd worden in welke mate de rustgebieden gebruikt worden door grote sterns uit de omgeving van de Voordelta. 


\section{$9 \quad$ Kwaliteitsborging}

Wageningen Marine Research beschikt over een ISO 9001:2008 gecertificeerd kwaliteitsmanagementsysteem (certificaatnummer: 187378-2015-AQ-NLD-RvA). Dit certificaat is geldig tot 15 september 2018. De organisatie is gecertificeerd sinds 27 februari 2001. De certificering is uitgevoerd door DNV Certification B.V. 


\section{Literatuur}

Adema, J. (2016). Datarapport PMR-NCV Perceel Abiotiek. Simulaties 2014 en analyse lange termijn trends. Arcadis, Zwolle, 1 april 2016, 64+bijlagen pp.

Adema, J. (2018). Datarapport PMR-NCV perceel Abiotiek. Simulaties 2016 en analyse alternatieve aanpak bodemschuifspanningen golven. Arcadis, Zwolle, 12 januari 2018, 46 + bijlage pp.

Aldridge, J., E. Parker, L. Bricheno, S. Green \& J. van der Molen (2015). Assessment of the physical disturbance of the northern European Continental shelf by waves and currents. Continental Shelf Research http://dx.doi.org/10.1016/j.csr.2015.03.004.

Alkyon (2006). Morfodynamische ontwikkeling Voordelta. Alkyon, Marknesse, Rapport A1698. Juni 2006, pp.

Allaire, J., J. Cheng, Y. Xie, J. McPherson, W. Chang, J. Allen, H. Wickham, A. Atkins, H. Hyndman \& R. Arslan (2017). rmarkdown: Dynamic Documents for R. R package version 1.6. https://CRAN.Rproject.org/package $=$ rmarkdown.

Asjes, J., J. Craeymeersch, V. Escaravage, R.E. Grift, I. Tulp, T. Bult \& N. Villars (2004). Strategy of approach for the baseline study Maasvlakte 2, Lot 2: benthic fauna and Lot 3: fish and fish larvae. RIVO Institute for Fisheries Research, IJmuiden, Version 30th September 2004, 86 pp.

Baptist, H.J.M. \& P.L. Meininger (1996). Vogels van de Voordelta 1975-95. RWS Rijksinstituut voor Kust en Zee, Middelburg, Rapport RIKZ 96.018, 110 pp.

Baretta-Bekker, J.G., J.W. Baretta, M.J. Latuhihin, X. Desmit \& T.C. Prins (2009). Description of the longterm (1991-2005) temporal and spatial distribution of phytoplankton carbon biomass in the Dutch North Sea. Journal of Sea Research 61: 50-59.

Beauchard, O., H. Veríssimo, A.M. Queirós \& P.M.J. Herman (2017). The use of multiple biological traits in marine community ecology and its potential in ecological indicator development. Ecological Indicators 76: 81-96.

Beauchard, O. \& P. Herman (in prep). A typology of marine benthic macroinvertebrates distriminating lifehistory strategies on continental shelves.

Berghahn, R. \& R. Vorberg (1998). Shrimp Fisheries and Nature Conservation in the National Park Wadden Sea of Schleswig-Holstein. Ministry of the Environment, Nature Conservation and Reactor Safety, Germany, Research project 10802 085/01. pp.

Bergman, M.J.N. \& J.W. van Santbrink (2000). Mortality in megafaunal benthic populations caused by trawl fisheries on the Dutch continental shelf in the North Sea in 1994. Ices Journal of Marine Science 57: 1321-1331.

Bergman, M.J.N., S.M. Ubels, G.C.A. Duineveld \& E.W.G. Meesters (2015). Effects of a 5-year trawling ban on the local benthic community in a wind farm in the Dutch coastal zone. ICES Journal of Marine Science: Journal du Conseil 72: 962-972.

Berrevoets, C.M., R.C.W. Strucker \& P.L. Meininger (2002). Watervogels in de zoute Delta 2000/2001. RWS Rijksinstituut voor Kust en Zee, Middelburg, Rapport RIKZ/2002.002, 86 pp.

Berrevoets, C.M. \& F.A. Arts (2003). Midwintertelling van zee-eenden in de Waddenzee en de Nederlandse kustwateren, januari 2003. RWS Rijksinstituut voor Kust en Zee, Middelburg, Rapport RIKZ/2003.008, 20 pp.

Berrevoets, C.M., R.C.W. Strucker, F.A. Arts, S.J. Lilipaly \& P.L. Meininger (2005). Watervogels en zeezoogdieren in de zoute Delta 2003/2004, inclusief de tellingen in 2002/2003. RWS Rijksinstituut voor Kust en Zee, Middelburg, Rapport RIKZ/2005.011, 134 pp.

Beukema, J.J. (1979). Biomass and species richness of the macrobenthic animals living on a tidal flat area in the Dutch Wadden Sea: Effects of a severe winter. Netherlands Journal of Sea Research 13: 203223.

Beukema, J.J., R. Dekker \& C.J.M. Philippart (2010). Long-term variability in bivalve recruitment, mortality, and growth and their contribution to fluctuations in food stocks of shellfish-eating birds. Marine Ecology Progress Series 414: 117-130.

Beyst, B., J. Mees \& A. Cattrijsse (1999). Early postlarval fish in the hyperbenthos of the Dutch Delta (southwest Netherlands). Journal of the Marine Biological Association of the United Kingdom 79: 709-724.

Bierman, S., D. Miller, F. Quirijns \& R. Van Hal (2009). Intensiteit boomkorvisserij in de Voordelta. IMARES, IJmuiden, Rapport C144/09, 41 pp.

Bivand, R. \& N. Lewin-Koh (2015). maptools: Tools for Reading and Handling Spatial Objects. R package version 0.8-37. http://CRAN.R-project.org/package=maptools. pp.

Bolam, S., R. Coggan, J. Eggleton, M. Diesing \& D. Stephens (2014). Sensitivity of macrobenthic production to trawling in the English sector of the Greater North Sea:A biological trait analysis. Journal of Sea Research 85: 162-177. 
Bolam, S.G., C. Garcia, J. Eggleton, A.J. Kenny, L. Buhl-Mortensen, G. Gonzalez-Mirelis, T. van Kooten, G. Dinesen, J. Hansen, J.G. Hiddink, M. Sciberras, C. Smith, N. Papadopoulou, A. Gumus, G. Van Hoey, O.R. Eigaard, F. Bastardie \& A.D. Rijnsdorp (2017). Differences in biological traits composition of benthic assemblages between unimpacted habitats. Marine Environmental Research 126: 1-13.

Bolle, L. (2016). PMR vismonitoring 2015: Rapport veld- en labwerkzaamheden. Werkdocument, 6 pp.

Boos, K., L. Gutow, R. Mundry \& H.D. Franke (2010). Sediment preference and burrowing behaviour in the sympatric brittlestars Ophiura albida Forbes, 1839 and Ophiura ophiura (Linnaeus, 1758)

(Ophiuroidea, Echinodermata). Journal of Experimental Marine Biology and Ecology 393: 176-181.

Borcard, D., F. Gillet \& P. Legendre (2011). Numerical Ecology with R. Springer. New York, 306 pp. ^ 306 pp.

Borkenhagen, K., N. Guse, N. Markones, K. Witte \& S. Garthe (2016). Monitoring von Seevögeln im Offshore-Bereich der schleswig-holsteinischen Nordsee im Rahmen von NATURA 2000. , Tönning. . Landesbetrieb für Küstenschutz, Nationalpark und Meeresschutz Schleswig-Holstein (LKN), Tönning. , Jahresbericht für die Nationalparkverwaltung, pp.

Bremner, J., S.I. Rogers \& C.L.J. Frid (2006a). Methods for describing ecological functioning of marine benthic assemblages using biological traits analysis (BTA). Ecological Indicators 6: 609-622.

Bremner, J., S.I. Rogers \& C.L.J. Frid (2006b). Matching biological traits to environmental conditions in marine benthic ecosystems. Journal of Marine Systems 60: 302-316.

Bremner, J. (2008). Species' traits and ecological functioning in marine conservation and management. Journal of Experimental Marine Biology and Ecology 366: 37-47.

Brenninkmeijer, A. \& E.W.M. Stienen (1992). Ecologisch profiel van de grote stern (Sterna sandvicensis). DLO-Instituut voor Bos- en Natuuronderzoek, Arnhem, RIN-rapport 92/17, 110 pp.

Brinkman, A.G., B.J. Ens \& R. Kats (2003). Modelling the energy budget and prey choice of Eider ducks. Alterra, Wageningen, Alterra-rapport $839135 \mathrm{pp}$.

Brinkman, A.G., J.J. De Leeuw, M.F. Leopold, C.J. Smit \& I.Y.M. Tulp (2007). Voedselecologie van een zestal schelpdieretende vogels IMARES, Den Burg, Texel, Rapport C078/07, 122 pp.

Brinkman, A.G. (2015). Voorstel draagkrachtmodel Zwarte Zee-eend in de Voordelta. IMARES, IJmuiden, Rapport C053/15, 57 pp.

Buckland, S.T. \& B.J. Turnock (1992). A robust line transect method. Biometrics 48: 901-909.

Buhs, F. \& K. Reise (1997). Epibenthic fauna dredged from tidal channels in the Wadden Sea of Schleswig Holstein: spatial patterns and a long-term decline. Helgolander Meeresuntersuchungen 51: 343359.

Cadée, G.C. (2002). Massaal aanspoelen van juveniele Ensis directus. Het Zeepaard 62: 120-124.

Catchpole, T.L., A.S. Revill, J. Innes \& S. Pascoe (2008). Evaluating the efficacy of technical measures: a case study of selection device legislation in the UK Crangon crangon (brown shrimp) fishery. Ices Journal of Marine Science 65: 267-275.

Collie, J.S., S.J. Hall, M.J. Kaiser \& I.R. Poiner (2000). A quantitative analysis of fishing impacts on shelf-sea benthos. Journal of Animal Ecology 69: 785-798.

Couperus, A.S., A. Dijkman-Dulkes, N. Hintzen, T. Leijzer, T. Pasterkamp, H.J. Westerink \& J. Van Willigen (2007). Baseline studie vis MVII: veldwerkrapportage najaar 2007 IMARES, IJmuiden, Rapport C132/07, 9 pp.

Couperus, A.S., C.J.G. Van Damme, I.Y.M. Tulp, S.V. Tribuhl, I. Pennock \& H.J.L. Heessen (2008). Vis in de Voordelta: nulmetingen 2007 in het kader van de aanleg van de Tweede Maasvlakte. IMARES, IJmuiden, Rapport C06/08, $61 \mathrm{pp}$.

Craeymeersch, J. \& V. Escaravage (2014). Perceel Benthos.In: PMR Monitoring natuurcompensatie Voordelta. Eindrapport 1e fase 2009-2013 deel B. ; Prins, T. en van der Kolff, G. (eds.). Deltares, Delft. Deltares rapport 1200672-ZKS-0043, p. 19-154. p: 19-154.

Craeymeersch, J., V. Escaravage, J. Adema, M. van Asch, I. Tulp \& T. Prins (2015a). PMR Monitoring natuurcompensatie Voordelta - bodemdieren 2004-2013. IMARES/NIOZ Rapport C091/15. IMARES/NIOZ, pp.

Craeymeersch, J.A., O. Hamerlynck, K. Hostens, A. Vanreusel \& M. Vincx (1990a). De ekologische ontwikkeling van de Voordelta. Deelrapport 1. De huidige ekologische situatie van de Voordelta. DIHO, RU Gent, Yerseke, 92 pp.

Craeymeersch, J.A., O. Hamerlynck, K. Hostens, A. Vanreusel \& M. Vincx (1990b). De ekologische ontwikkeling van de Voordelta. Deelrapport 1. De huidige ekologische situatie van de Voordelta. Delta Instituut voor Hydrobiologisch Onderzoek - Rijksuniversiteit Gent, Sektie Mariene Biologie. 92 pp. pp.

Craeymeersch, J.A., E.B.M. Brummelhuis, W. Dimmers, A. Engelberts, M.M. Markusse, P. Schout \& J.M. Verschuure (1996). Effecten van de schelpdiervisserij op het bodemleven in de Voordelta. Fase rapport over de onderdelen 'natuurlijke ontwikkeling' en effecten schelpdiervisserij'. NIOO-CEMO, Yerseke, $48 \mathrm{pp}$. 
Craeymeersch, J.A. (1999a). The use of macrobenthic communities in the evaluation of environmental change. PhD Thesis, University of Gent. 254 pp. pp.

Craeymeersch, J.A. (1999b). The use of macrobenthic communities in the evaluation of environmental change. Gent, Marine biology section, Department of biology, Gent University, PhD Thesis, 254 pp.

Craeymeersch, J.A. \& M. Rietveld (2005). Dog whelks in Dutch coastal waters. MARBEF Newsletter 3: 2224.

Craeymeersch, J.A., V. Escaravage, J. Adema, M. van Asch, I. Tulp \& T. Prins (2015b). PMR Monitoring natuurcompensatie Voordelta - bodemdieren 2004-2013. IMARES Rapport C091/15. 171pp.

Craeymeersch, J.A., J. Perdon, J. Jol, E. Brummelhuis \& M. van Asch (2016a). PMR Monitoring Natuurcompensatie Voordelta - bodemdieren. Datarapport campagne bodemschaaf 2015multivariate analyse 2004-2013. IMARES rapport C073.16. 38 pp. pp.

Craeymeersch, J.A.M., V. Escaravage \& J. Perdon (2004). Baseline study MEP-MV2. Veldwerkrapportage najaar 2004. IMARES, Yerseke, Rapport C085/04, 19 pp.

Craeymeersch, J.A.M., V. Escaravage \& J. Perdon (2005). Baseline study MEP-MV2. Veldwerkrapportage bodemdieren najaar 2005. IMARES, Yerseke, Rapport C079/05, 18 pp.

Craeymeersch, J.A.M., V. Escaravage, J. Steenbergen, J.W.M. Wijsman, S. Wijnhoven \& B. Kater (2006). De bodemfauna in het Nederlands deel van de Scheldemonding. VLIZ Special Publication 35: 85-105.

Craeymeersch, J.A.M., J. Perdon, J. Jol, E.B.M. Brummelhuis \& M. Van Asch (2016b). PMR Monitoring Natuurcompensatie Voordelta - bodemdieren. Datarapport campagne bodemschaaf 2015 multivariate analyses 2004-2013 IMARES, Yerseke, in prep., 35 pp.

Dänhardt, A. \& P.H. Becker (2011). Herring and Sprat Abundance Indices Predict Chick Growth and Reproductive Performance of Common Terns Breeding in the Wadden Sea. Ecosystems 14: 791803.

Dankers, N. \& H.J.M. Baptist (2010). "Het verdwijnen van zeemos velden."

Dannheim, J. \& H. Rumohr (2011). The fate of an immigrant: Ensis directus in the eastern German Bight. Helgoland Marine Research 66: 307-317.

De Jong, P.D. (1997). Aantalsfluctuaties van enige niet commerciële vissoorten in het Schelde estuarium en de Voordelta, 1987-1995. RIVO, IJmuiden, Rapport C024/97, 46 pp.

de Leeuw, J.J. (1997). Demanding divers. Ecological energetics of food exploitation by diving ducks. Universiteit Groningen, PhD thesis Thesis, $178 \mathrm{pp}$.

Deceuninck, B., G. Quaintenne, A. Ward, C. Dronneau \& S. Dalloyau (2016). Synthèse des dénombrements d'Anatidés et de foulques hivernant en France à la mi-janvier 2015. Ligue pour la Protection des Oiseaux, Rochefort, WI, LPO, DEB, pp.

Dekker, R. \& J.J. Beukema (1999). Relations of summer and winter temperatures with dynamics and growth of two bivalves, Tellina tenuis and Abra tenuis, on the northern edge of their intertidal distribution. Journal of Sea Research 42: 207-220.

Delany, S. \& D. Scott, Eds. (2006). Waterbird Population Estimates. Wetlands International, Wageningen, pp.

Diesing, M., D. Stephens \& J. Aldridge (2013). A proposed method for assessing the extent of the seabed significantly affected by demersal fishing in the Greater North Sea. Ices Journal of Marine Science 70: 1085-1096.

Dirksen, S., P.W. Van Horssen, R. de Jong \& E. van der Zee (2017). PMR NCV monitoring zwarte zee-eenden Voordelta. Jaarrapport 2016-2017. Altenburg \& Wymenga ecologisch onderzoek, Feanwâlden A\&W-rapport 2379, $26 \mathrm{pp}$.

Drew, G.A. (1907). The habits and movements of the razor-shell clam, Ensis directus. Con. Biol. Bull. XII (3): $127-142$.

Duplisea, D.E., S. Jennings, K.J. Warr \& T.A. Dinmore (2002). A size-based model of the impacts of bottom trawling on benthic community structure. Canadian Journal of Fisheries and Aquatic Sciences 59: 1785-1795.

Eigaard, O.R., F. Bastardie, M. Breen, G.E. Dinesen, N.T. Hintzen, P. Laffargue, L.O. Mortensen, J.R. Nielsen, H.C. Nilsson, F.G. O'Neill, H. Polet, D.G. Reid, A. Sala, M. Sköld, C. Smith, T.K. Sørensen, O. Tully, M. Zengin \& A.D. Rijnsdorp (2016). Estimating seabed pressure from demersal trawls, seines, and dredges based on gear design and dimensions. ICES Journal of Marine Science: Journal du Conseil 73: i27-i43.

Eigaard, O.R., F. Bastardie, N.T. Hintzen, L. Buhl-Mortensen, P. Buhl-Mortensen, R. Catarino, G.E. Dinesen, J. Egekvist, H.O. Fock, K. Geitner, H.D. Gerritsen, M.M. González, P. Jonsson, S. Kavadas, P. Laffargue, M. Lundy, G. Gonzalez-Mirelis, J.R. Nielsen, N. Papadopoulou, P.E. Posen, J. Pulcinella, T. Russo, A. Sala, C. Silva, C.J. Smith, B. Vanelslander \& A.D. Rijnsdorp (2017). The footprint of 
bottom trawling in European waters: distribution, intensity, and seabed integrity. Ices Journal of Marine Science 74: 847-865.

Elias, E.P.L. \& A.J.F. Van der Spek (2014). Grootschalige morfologische veranderingen in de Voordelta 1964 - 2013. . Deltares, Delft, 1207724-001, 57 + fig pp.

Elias, E.P.L., A.J.F. van der Spek \& M. Lazar (2016). The 'Voordelta', the contiguous ebb-tidal deltas in the SW Netherlands: large-scale morphological changes and sediment budget 1965-2013; impacts of large-scale engineering. Netherlands Journal of Geosciences - Geologie en Mijnbouw: 1-27.

Elliott, M. \& K.L. Hemingway, Eds. (2002). Fishes in estuaries. Wiley-Blackwell, Oxford, 656 pp.

EZ (2014). Profieldocument H1110 Permanent overstroomde zandbanken. Ministerie van Economische Zaken, Versie 2014, 20 pp.

http://www.synbiosys.alterra.nl/natura2000/documenten/profielen/habitattypen/Profiel_habitattype _1110_2014.pdf

EZ (2016). (Toegangsbeperkingsbesluit Bollen van de Ooster en Bollen van het Nieuwe Zand. Staatscourant, Nr. 57780, 31 oktober 2016, pp.

Field, J.G., K.R. Clarke \& R.M. Warwick (1982). A Practical Strategy for Analyzing Multispecies Distribution Patterns. Marine Ecology Progress Series 8: 37-52.

Fijn, R., M. Leopold, S. Dirksen, F. Arts, M. Van Asch, M. Baptist, J. Craeymeersch, B. Engels, P. Van Horssen, J. De Jong, J. Perdon, E. van der Zee \& N. van der Ham (2017a). Een concentratie van Zwarte Zee-eenden in de Hollandse kustzone toont het belang aan van schelpdieren en rust Limosa 90: 97-117.

Fijn, R.C., J. De Jong, R.J. Jonkvorst, B. Engels, A. Gyimesi, C. Heunks, T.J. Boudewijn, M.J.M. Poot, W. Courtens, H. Verstraete, N. Vanermen, E.W.M. Stienen, P.A. Wolf, M.S.J. Hoekstein \& S.J. Lilipaly (2016). PMR-NCV Jaarrapport Vogels 2015. Voortgang onderzoek sterns \& zee-eenden in de Voordelta en Delta. Bureau Waardenburg, Culemborg, Rapport nr 16-080, 83 pp.

Fijn, R.C., J. de Jong, W. Courtens, H. Verstraete, E.W.M. Stienen \& M.J.M. Poot (2017b). GPS-tracking and colony observations reveal variation in offshore habitat use and foraging ecology of breeding Sandwich Terns. Journal of Sea Research 127: 203-211.

Garthe, S., N. Sonntag, P. Schwemmer \& V. Dierschke (2007). Estimation of seabird numbers in the German North Sea throughout the annual cycle and their bio-geographic importance. 12: 163-178

Gaudard, C., G. Quaintenne, B. Deceuninck, A. Ward, C. Dronneau \& S. Dalloyau (2017). Synthèse des dénombrements d'Anatidés et de foulques hivernant en France à la mi-janvier 2016. Ligue pour la Protection des Oiseaux, Rochefort, WI, LPO, DEB, pp.

Ghosh, J. \& M.A. Clyde (2011). Rao-Blackwellization for Bayesian Variable Selection and Model Averaging in Linear and Binary Regression: A Novel Data Augmentation Approach. Journal of the American Statistical Association 106: 1041-1052.

Glorius, S., J. Craeymeersch, T. van der Hammen, A. Rippen, J. Cuperus, B. van der Weide, J. Steenbergen \& I. Tulp (2015). Effecten van garnalenvisserij in Natura 2000 gebieden. IMARES-rapport Rapport C013/15. pp.

Green, R.H. (1979). Sampling design and statistical methods for environmental biologists. WileyInterscience. Chichester, England, pp. ^ pp.

Greenslade, P.J.M. (1983). Adversity Selection and the Habitat Templet. American Naturalist 122: 352-365.

Grift, R.E. \& I.Y.M. Tulp (2004). Nulmetingen Maasvlakte 2: meetstrategie vissen. RIVO, IJmuiden, pp.

Hamerlynck, O. \& J. Mees (1991). Temporal and spatial structure in the hyperbenthic community of a shallow coastal area and its relation to environmental variables. Oceanologica Acta Sp. No 11: 205212.

Hamerlynck, O., K. Hostens, J. Mees, R.V. Arellano, A. Cattrijsse, P. Van de Vyver \& J.A. Craeymeersch (1992). The ebb tidal delta of the Grevelingen: a man-made nursery for flatfish? Netherlands Journal of Sea Research 30: 191-200.

Hamerlynck, O., K. Hostens, R.V. Arellano, J. Mees \& P.A. Van Damme (1993). The mobile epibenthic fauna of soft bottoms in the Dutch delta (south-west Netherlands): spatial structure. Netherlands Journal of Aquatic Ecology 27: 343-358.

Harvey, A.C. (1989). Forecasting, structural time series models and the Kalman filter. Cambridge University Press. Cambridge, pp. ^ pp.

Heessen, H.J.L. \& R.G. Jak (2009). Plan van Aanpak PMR monitoring natuurcompensatie Voordelta. Deel B: Uitvoeringsplannen per perceel. IMARES, IJmuiden, $137 \mathrm{pp}$.

Heinis, F., C.T.M. Vertegaal, C.R.J. Goderie \& P.C. Van Veen (2007). Habitattoets, Passende Beoordeling en uitwerking ADC-criteria ten behoeve van vervolgbesluiten van Maasvlakte 2. Havenbedrijf Rotterdam, Projectorganisatie Maasvlakte 2, Rotterdam, 9S0134.A0/Nb-wet/R0019/PVV/Rott1, $232 \mathrm{pp}$.

Hendrick, V.J., Z.L. Hutchison \& K.S. Last (2016). Sediment Burial Intolerance of Marine Macroinvertebrates. Plos One 11. 
Herman, P., H. Meijer-Holzhauer, S. Vergouwen, J. Wijsman \& M.J. Baptist (2016). Ecologische effecten van kustsuppleties; Systeembeschrijving (deel A), onderzoeksprioriteiten (deel B) en ontwerp uitvoeringsplan (deel C). Deltares. pp.

Hiddink, J.G., S. Jennings, M.J. Kaiser, A.M. Queiros, D.E. Duplisea \& G.J. Piet (2006). Cumulative impacts of seabed trawl disturbance on benthic biomass, production, and species richness in different habitats. Canadian Journal of Fisheries and Aquatic Sciences 63: 721-736.

Hiddink, J.G., S. Jennings, M. Sciberras, C.L. Szostek, K.M. Hughes, N. Ellis, A.D. Rijnsdorp, R.A. McConnaughey, T. Mazor, R. Hilborn, J.S. Collie, C.R. Pitcher, R.O. Amoroso, A.M. Parma, P. Suuronen \& M.J. Kaiser (2017). Global analysis of depletion and recovery of seabed biota after bottom trawling disturbance. Proceedings of the National Academy of Sciences 114: 8301-8306.

Hijmans, R. (2016). raster: Geographic Data Analysis and Modeling. R package version 2.5-8. https://CRAN.R-project.org/package=raster.

Hintzen, N.T., P. de Vries, D. Looije \& S.T. Glorius (2014). Vergelijking visserij - intensiteit op basis van AIS -VMS in de Voordelta. IMARES, IJmuiden, rapport nr C068/14, 50 pp.

Hinz, H., L.G. Murray, F.R. Malcolm \& M.J. Kaiser (2012). The environmental impacts of three different queen scallop (Aequipecten opercularis) fishing gears. Marine Environmental Research 73: 85-95.

Hoekstein, M.S.J. \& S.J. Lilipaly (2003). Vliegtuigtellingen van watervogels en zeezoogdieren in de Voordelta, 2001/2002. Rijksinstituut voor Kust en Zee, Middelburg, Rapport RIKZ/2002.051, 50 pp.

Holzhauer, H. \& T.C. Prins (2009). Plan van Aanpak PMR monitoring natuurcompensatie Voordelta. Deltares, Delft, rapport 1200672-008-ZKS-0002, 39 pp.

Hughes, K.M., M.J. Kaiser, S. Jennings, R.A. McConnaughey, R. Pitcher, R. Hilborn, R.O. Amoroso, J. Collie, J.G. Hiddink, A.M. Parma \& A. Rijnsdorp (2014). Investigating the effects of mobile bottom fishing on benthic biota: a systematic review protocol. Environmental Evidence 3: 23.

ICES (2005). Report of the Working Group on Seabird Ecology (WGSE), 29 March - 1 April 2005, Texel, The Netherlands. ICES, Copenhagen, ICES CM 2005/G:07, 49 pp.

ICES (2017). EU request on indicators of the pressure and impact of bottom-contacting fishing gear on the seabed, and of trade-offs in the catch and the value of landings. . ICES Advice, International Council for the Exploration of the Sea, Copenhagen, $201729 \mathrm{pp}$.

Jongman, R.H.G., C.J.F. ter Braak \& O.F.R. van Tongeren (1987). Data analysis in community and landscape ecology. Pudoc. Wageningen, 299 pp. ^ 299 pp.

Kaiser, M.J., K.R. Clarke, H. Hinz, M.C.V. Austen, P.J. Somerfield \& I. Karakassis (2006). Global analysis of response and recovery of benthic biota to fishing. Marine Ecology-Progress Series 311: 1-14.

Kamermans, P., E. Brummelhuis \& M. Dedert (2013). Effect of algae- and silt concentration on clearanceand growth rate of the razor clam Ensis directus, Conrad. Journal of Experimental Marine Biology and Ecology 446: 102-109.

Kater, B. (2007). De power van de nulmeting macrobenthos. Poweranalyses ten behoeve van de effectmeting macrobenthos in het kader van de natuurcompensatie van de aanleg van de Tweede Maasvlakte. Alkyon, Marknesse, Rapport A1867, 38 pp.

Kersten, M., A. Brenninkmeijer \& R.M.G. Van der Hut (2006). Ecoprofielen van zeevogels ten behoeve van een zeereservaat in de Voordelta. Altenburg \& Wymenga ecologisch onderzoek, Veenwouden, A\&W-rapport 804, $46 \mathrm{pp}$.

Kohsiek, L.H.M. \& J.P.M. Mulder, Eds. (1989). De Voordelta; een watersysteem verandert. RWS Dienst Getijdewateren, Middelburg, $24 \mathrm{pp}$.

Krijgsveld, K.L., R.R. Smits \& J. Van der Winden (2008). Verstoringsgevoeligheid van vogels. Update literatuurstudie naar de reacties van vogels op recreatie. Bureau Waardenburg, Culemborg, rapport nr. 08-173, $250 \mathrm{pp}$.

Kröncke, I., H. Reiss \& J.W. Dippner (2013). Effects of cold winters and regime shifts on macrofauna communities in shallow coastal regions. Estuarine, Coastal and Shelf Science 119: 79-90.

Lavaleije, M.S.S. \& N. Dankers (1993). Voorstudie naar de effecten van de garnalenvisserij op de bodemfauna, met advies over te sluiten gebieden en uit te voeren onderzoek. Terra Incognita, Book no L2651-6671. pp.

Legendre, P. \& L. Legendre (1998). Numerical Ecology. Second English Edition. Elsevier B.V. Amsterdam, 853 pp. ^ $853 \mathrm{pp}$.

Leopold, M.F., H.J.M. Baptist, P.A. Wolf \& H.R. Offringa (1995). De Zwarte Zee-eend Melanitta nigra in Nederland. Limosa 68: 49-64.

Leopold, M.F. (1996). Spisula subtruncata als voedselbron voor zee-eenden in Nederland. BEON, Den Haag, Rapport nr. 96-2, pp.

Leopold, M.F., M.R. Van Stralen \& J. De Vlas (2008). Zee-eenden en schelpdiervisserij in de Voordelta. IMARES, Texel, Rapport C008/08, $50 \mathrm{pp}$.

Leopold, M.F., R.S.A. Van Bemmelen \& S.C.V. Geelhoed (2011). Zeevogels op de Noordzee. Achtergronddocument bij Natuurverkenning 2011. Wettelijke Onderzoekstaken Natuur \& Milieu, Wageningen, WOt-werkdocument 257, 48 pp. 
LNV (2008). Profieldocument Habitattype H1110. Ministerie van LNV, Den Haag, H1110 versie 18 dec 2008, 15 pp.

Mulder, J.P.M., J. Cleveringa, M.D. Taal, B.K. Van Wesenbeeck \& F. Klijn (2010). Sedimentperspectief op de Zuidwestelijke Delta. Deltares, Delft, 1203404-000, 64 pp.

Nash, R.D.M., A.H. Valencia \& A.J. Geffen (2006). The origin of Fulton's condition factor - Setting the record straight. Fisheries 31: 236-238.

O'Neill, F.G. \& A. Ivanović (2016). The physical impact of towed demersal fishing gears on soft sediments. ICES Journal of Marine Science: Journal du Conseil 73: i5-i14.

Oksanen, J., F. Blanchet, R. Kindt, P. Legendre, P. Minchin, R. O'Hara, G. Simpson, P. Solymos, M. Stevens \& H. Wagner (2016). vegan: Community Ecology Package. R package version 2.3-3. https://CRAN.Rproject.org/package=vegan. pp.

Pebesma, E.J., R. Bivand, B. Rowlinson \& V. Gómez-Rubio (2009). The sp Package. Classes and methods for spatial data (downloaded 10 February 2009, http://www.r-project.org/). 83 pp. pp.

Perdon, K.J., K. Troost, v.M. Asch \& J. Jol (2016). WOT schelpdiermonitoring in de Nederlandse kustzone in 2016. Wageningen Marine Research, Den Helder, pp. urn:nbn:nl:ui:32510066http://library.wur.nl/WebQuery/wurpubs/510066

Petersen, I.K. \& R.D. Nielsen (2011). Abundance and distribution of selected waterbird species in Danish marine areas. National Environmental Research Institute, Aarhus University, Aarhus, Report commissioned by Vattenfall A/S, 62 pp.

Petitgas, P., A.D. Rijnsdorp, M. Dickey-Collas, G.H. Engelhard, M.A. Peck, J.K. Pinnegar, K. Drinkwater, M. Huret \& R.D.M. Nash (2013). Impacts of climate change on the complex life cycles of fish. Fisheries Oceanography 22: 121-139.

Pitcher, C.R., N. Ellis, S. Jennings, J.G. Hiddink, T. Mazor, M.J. Kaiser, M.I. Kangas, R.A. McConnaughey, A.M. Parma \& A.D. Rijnsdorp (2017). Estimating the sustainability of towed fishing-gear impacts on seabed habitats: a simple quantitative risk assessment method applicable to data-limited fisheries. Methods in Ecology and Evolution 8: 472-480.

Poot, M.J.M., C. Heunks, P.W. Van Horssen, H.A.M. Prinsen \& T.J. Boudewijn (2005). Evaluatierapportage: november 2004 t/m juni 2005, Perceel 4: Vogels, Nulmeting in kader van Monitoring en Evaluatie Programma, Project Mainport Rotterdam - MEP MV2. Bureau Waardenburg, Culemborg, Rapport 05-170, $184 \mathrm{pp}$.

Poot, M.J.M., C. Heunks, H.A.M. Prinsen, P.W. Van Horssen \& T.J. Boudewijn (2006). Zeevogels in de Voordelta in 2004/2005 en 2005/2006. Nulmeting in het kader van Monitoring en Evaluatie Programma, Project Mainport Rotterdam - MEP MV2 (Perceel 4: Vogels). Bureau Waardenburg, Culemborg, Rapport nr. 06-244, 184 pp.

Poot, M.J.M., R.C. Fijn, T.J. Boudewijn, J. de Jong, P.W. van Horssen, M. Japink, B. van den Boogaard, J. Bergsma, E.W.M. Stienen, W. Courtens, N. Vanermen, H. Verstraete, P.A. Wolf, M.S.J. Hoekstein \& S.J. Lilipaly (2014). Perceel vogels - Grote stern en visdief.In: PMR monitoring natuurcompensatie Voordelta. Eindrapport 1e fase 2009-2013. Deel B; Prins, T.G.v.d.K. (eds.). p: 419-659.

Poot, M.J.M. \& P.W. Van Horssen (2014). Effect aanpassing rustgebieden voor zwarte zee-eenden in de Voordelta. Scenarioberekeningen op basis van een statistisch habitatmodel in het kader van de Natuurcompensatie Tweede Maasvlakte. Bureau Waardenburg, Culemborg, rapport nr. 14-168 36 pp.

Prins, T., G. van der Kolff, A. Boon, J. Reinders, C. Kuijper, G. Hendriksen, H. Holzhauer, V. Langenberg, J. Craeymeersch, I. Tulp, M. Poot, H. Seegers \& J. Adema (2014a). PMR Monitoring natuurcompensatie Voordelta. Eindrapport 1e fase 2009-2013. Deltares, Delft. Deltares rapport 1200672-000-ZKS-0042. 209 pp. pp.

Prins, T.C., X. Desmit \& J.G. Baretta-Bekker (2012). Phytoplankton composition in Dutch coastal waters responds to changes in riverine nutrient loads. Journal of Sea Research 73: 49-62.

Prins, T.C. \& G.H. Van der Kolff, Eds. (2014). PMR Monitoring natuurcompensatie Voordelta. Eindrapportage $1^{\text {e }}$ fase 2009-2013 deel B. Deltares, Delft, Rapport nr 1200672-000-ZKS-0043, 940 pp. http://kennisonline.deltares.nl/product/30737

Prins, T.C., G.H. van der Kolff, A.R. Boon, J. Reinders, C. Kuijper, G. Hendriksen, H. Holzhauer, V.T. Langenberg, J.A.M. Craeymeersch, I. Tulp, M.J.M. Poot, H.C.M. Seegers \& J. Adema (2014b). PMR Monitoring natuurcompensatie Voordelta Eindrapport 1e fase 2009-2013. pp.

Prins, T.C., G.H. Van der Kolff, A.R. Boon, J. Reinders, C. Kuijper, G. Hendriksen, H. Holzhauer, V.T. Langenberg, J.A.M. Craeymeersch, I.Y.M. Tulp, M.J.M. Poot, H.C.M. Seegers \& J. Adema (2014c). PMR Monitoring natuurcompensatie Voordelta. Eindrapportage $1^{\mathrm{e}}$ fase 2009-2013. Deltares, Delft, Rapport nr 1200672-000-ZKS-0042, 207 pp. http://kennisonline.deltares.nl/product/30731

Prins, T.C., G.H. Van der Kolff, I.Y.M. Tulp \& J.A.M. Craeymeersch (2015). PMR monitoring natuurcompensatie Voordelta. Samenvattende rapportage 2014. Deltares, Delft, 1209129-000ZKS-0034, 45 pp. 
Prins, T.C., A.R. Boon \& V. Escaravage (2016a). Indicatoren voor de kwaliteit van habitat type H1110 in PMR Natuurcompensatie Voordelta. Deltares, Delft, 1209129-000-ZKS-0031, 49 pp.

Prins, T.C., I.Y.M. Tulp \& M.T. Van der Sluis (2016b). PMR monitoring natuurcompensatie Voordelta. Samenvattende rapportage 2015. Deltares, Delft, 1220260-000-ZKS-0016, 49 pp.

R Core Team (2013). R: A language and environment for statistical computing, version 3.0.0 Patched (2013-04-29 r62694). R Foundation for Statistical Computing, Vienna, Austria. URL http://www.Rproject.org. .

Ramsay, K., M.J. Kaiser, A.D. Rijnsdorp, J.A. Craeymeersch \& J. Ellis (2000). Impact of trawling on populations of the invertebrate scavenger Asterias rubens.In: In: The effects of fishing of nontarget species and habitats / Kaiser, M.J. and S.J. de Groot. - Oxford : Blackwell Science, 2000 (eds.). p: 151-162.

Reiss, H., K. Meybohm \& I. Kröncke (2006). Cold winter effects on benthic macrofauna communities in nearand offshore regions of the North Sea. Helgoland Marine Research 60: 224-238.

Riesen, W. \& K. Reise (1982). Macrobenthos of the subtidal Wadden Sea - revisited after 55 years. Helgolander Meeresuntersuchungen 35: 409-423.

Rijnsdorp, A.D., M. Van Stralen, D. Baars, R. Van Hal, H. Jansen, M.F. Leopold, P. Schippers \& E. Winter (2006). Rapport Inpassing Visserijactiviteiten Compensatiegebied MV2. IMARES, IJmuiden, Rapport C047/06, 123 pp.

Rijnsdorp, A.D., S.G. Bolam , C. Garcia, J.G. Hiddink, N. Hintzen, P.D. van Denderen \& v.K. T. (2018). Estimating the sensitivity of seafloor habitats to disturbance by bottom trawl fisheries based on the longevity of benthic fauna. Ecological Applications (submitted).

RIKZ (2007). Natuurcompensatie Maasvlakte Twee in de Voordelta; De inzet van kennis over de ecologie en morfologie van de Voordelta om het maatregelenpakket ter compensatie van de natuureffecten van de Tweede Maasvlakte te verantwoorden. RWS Rijksinstituut voor Kust en Zee, Den Haag, Rapport RIKZ/2007.006, 301 pp.

Ripley, R. \& M. Lapsley (2015). RODBC: ODBC Database Access. R package version 1.3-12. https://CRAN.Rproject.org/package $=$ RODBC. pp.

RWS (2016). Beheerplan Natura 2000 Voordelta 2015-2021. Rijkswaterstaat, Den Haag, februari 2016, $154 \mathrm{pp}$.

Schekkerman, H., F.A. Arts, H. van der Jeugd, E.W.M. Stienen \& M. van Roomen (2017). Naar een demografische analyse van populaties van karakteristieke vogels in het Deltagebied. Sovon-rapport 2017/58, CAPS-rapport 2017/01. Sovon Vogelonderzoek Nederland/Vogeltrekstation/Delta Project Management/Instituut voor Natuur en Bosonderzoek, Nijmegen. . pp.

Schuijer, M. (2015). Density-dependent growth in North Sea plaice. MSc report, University of Amsterdam. $\mathrm{pp}$.

Schwemmer, P., B. Mendel, N. Sonntag, V. Dierschke \& S. Garthe (2011). Effects of ship traffic on seabirds in offshore waters: implications for marine conservation and spatial planning. Ecological Applications 21: 1851-1860.

Sciberras, M., J. Hiddink, S. Jennings, C.L. Szostek, K.M. Hughes, B. Kneafsey, L. Clarke, N. Ellis, A. Rijnsdorp, R.A. McConnaughey, R. Hilborn, J.S. Collie, C.R. Pitcher, R.O. Amoroso, A.M. Parma, P. Suuronen \& M.J. Kaiser (2018). Response of benthic fauna to experimental bottom fishing: a global meta-analysis. Fish and Fisheries: n/a-n/a.

Seegers, H.C.M., M.C. Hoogvliet \& L.A. Dam (2006). Nulmeting Gebruiksfuncties Voordelta, eindrapportage. CSO, Bunnik, Rapport 04.W029.00/2, 96 pp.

Seegers, H.C.M., L.M. Van Calsteren-De Bruijn \& J. Schuur (2014). Perceel Gebruik.In: PMR Monitoring natuurcompensatie Voordelta. Eindrapportage $1^{\mathrm{e}}$ fase 2009-2013 deel B; Prins, T.C. en Van der Kolff, G.H. (eds.). Deltares, Delft. Rapport nr. 1200672-000-ZKS-0043, p: 893-940. http://kennisonline.deltares.nl/product/30737

Seys, J. (2001). Sea- and coastal bird data as tools in the policy and management of Belgian marine waters Gent, Faculteit Wetenschappen Gent, PhD Thesis, $133+$ LXIX pp.

Skov, H., J. Durinck, A. Erichsen, R.M. Kloster, F. Møhlenberg \& S.B. Leonhard (2008). Horns Rev II Offshore Wind Farm. Food Basis for Common Scoter. Baseline Studies 2007-08. Orbicon, DHI Copenhagen, $47 \mathrm{pp}$.

Smit, C.J., A.G. Brinkman, B.J. Ens \& R. Riegman (2011). Voedselkeuzes en draagkracht: de mogelijke consequenties van veranderingen in de draagkracht van Nederlandse kustwateren op het voedsel van schelpdieretende wad- en watervogels. IMARES, Texel, Rapport C155/11, 197 pp.

Southwood, T.R.E. (1977). Habitat, Templet for Ecological Strategies - Presidential-Address to BritishEcological-Society, 5 January 1977. Journal of Animal Ecology 46: 337-365.

Southwood, T.R.E. (1988). Tactics, Strategies and Templets. Oikos 52: 3-18.

Steenbergen, J. \& V. Escaravage (2006). Baseline study MEP-MV2; Lot 2 bodemdieren. Eindrapportage Campagnes 2004-2005. IMARES, Yerseke, Rapport C053/06, pp. 
Stienen, E.W.M. \& A. Brenninkmeijer (1992). Ecologisch profiel van de visdief (Sterna hirundo). DLO Instituut voor Bos- en Natuuronderzoek, Arnhem, Rapport IBN-DLO 92/18, pp.

Stienen, E.W.M. (2006). Living with gulls : trading off food and predation in the Sandwich Tern Sterna sandvicensis. Groningen, Groningen, PhD Thesis, $192 \mathrm{pp}$.

Stienen, E.W.M., A. Brenninkmeijer \& J. Van der Winden (2009). De achteruitgang van de Visdief in de Nederlandse Waddenzee. Exodus of langzame teloorgang? Limosa 82: 171-186.

Strucker, R.C.W., M.S.J. Hoekstein \& P.A. Wolf (2008). Kustbroedvogels in het Deltagebied in 2008. Delta Project Management, Culemborg, RWS Waterdienst BM 09.05, 97 pp.

Strucker, R.C.W., M.S.J. Hoekstein \& P.A. Wolf (2012). Kustbroedvogels in het Deltagebied in 2011. Delta Project Management, Culemborg, RWS Waterdienst BM 12.22, $104 \mathrm{pp}$.

Teal, L.R., S. Marras, M.A. Peck \& P. Domenici (2015). Physiology-based modelling approaches to characterize fish habitat suitability: Their usefulness and limitations. Estuarine Coastal And Shelf Science.

Tien, N., J. Craeymeersch, C. van Damme, A.S. Couperus, J. Adema \& I. Tulp (2017a). Burrow distribution of three sandeel species relates to beam trawl fishing, sediment composition and water velocity, in Dutch coastal waters. Journal of Sea Research.

Tien, N., N. Hintzen, R. Verkempynck, M. Kraan, B. Trapman, J. Craeymeersch \& M. van Asch (2017b). De bodemberoerende visserij in de Voordelta sinds 2004 Wageningen Marine Research, IJmuiden, rapport C105/17, 106 pp.

Troost, K., K.J. Perdon, J. van Zwol, J. Jol \& M. Van Asch (2017). Schelpdierbestanden in de Nederlandse kustzone in 2017. Centrum voor Visserijonderzoek, Stichting Wageningen Research, IJmuiden, CVO rapport 17.014, 3 pp. https://doi.org/10.18174/423592

Tulp, I., J. Craeymeersch, M. Leopold, C. van Damme, F. Fey \& H. Verdaat (2010). The role of the invasive bivalve Ensis directus as food source for fish and birds in the Dutch coastal zone. Estuarine, Coastal and Shelf Science 90: 116-128.

Tulp, I., N. Tien \& C. van Damme (2014). PMR monitoring natuurcompensatie Voordelta. Eindrapport 1e fase 2009-2013. Perceel vis. Deel B. IMARES report C089.16. pp.

Tulp, I. (2015a). Analyse visgegevens DFS (Demersal Fish Survey) ten behoeve van de compensatiemonitoring Maasvlakte2. IMARES rapport C080/15. IMARES, pp.

Tulp, I., T. Prins, J. Craeymeersch \& M. van der Sluis (2015a). Monitorings- en onderzoeksplan vervolg monitoring PMR-NCV. IMARES rapport C135/15, Deltares: 1220510-000-ZKS-0003. pp.

Tulp, I., S. Glorius, A. Rippen, D. Looije \& J. Craeymeersch (submitted). Short term effects of shrimp fisheries on benthic macrofauna in shallow coastal areas. Ices Journal of Marine Science.

Tulp, I.Y.M., C.J.G. Van Damme, F.J. Quirijns, E. Binnendijk \& L. Borges (2006). Vis in de Voordelta: nulmetingen in het kader van de aanleg van de Tweede Maasvlakte. IJmuiden, IMARES rapport C081/06, $108 \mathrm{pp}$.

Tulp, I.Y.M. (2015b). Analyse visgegevens DFS survey ten behoeve van de compensatiemonitoring Maasvlakte2. IMARES, IJmuiden, Rapport nr C080/15, $47 \mathrm{pp}$.

Tulp, I.Y.M., T.C. Prins, N.S.H. Tien, J.A.M. Craeymeersch \& M.T. Van der Sluis (2015b). Monitorings- en onderzoeksplan vervolg monitoring PMR-NCV. IMARES, IJmuiden, IMARES rapport nr C135a/15

Deltares rapport 1220510-000-ZKS-0003, $90 \mathrm{pp}$.

Underwood, A. (1992). Beyond BACI: the detection of environmental impacts on populations in the real but variable, world. Journal of Experimental Marine Biology and Ecology 161: 145-178.

Underwood, A. (1996). On beyond BACI. Sampling designs that might reliably detect environmental disturbances.In: Detecting ecological impacts. Concepts and applications in coastal habitats; Schmitt, R.J. en Osenberg, C.W. (eds.). Academic Press, San Diego. p: 151-175.

van Aken, H.M. (2010). Meteorological forcing of long-term temperature variations of the Dutch coastal waters. Journal of Sea Research 63: 143-151.

Van Calsteren-De Bruijn, L. (2014). Kitesurfen in het noordelijk deel van de Voordelta. Onderzoek met behulp van interviews. LievenseCSO, Bunnik, 22 pp.

van de Wolfshaar, K.E., D.P.L.D. Benden \& A.G. Brinkman (2018). Potentiële draagkracht voor de Zwarte Zee-eend van de Voordelta en de Tweede Maasvlakte. Wageningen Marine Research, IJmuiden, Wageningen University \& Research Rapport C005/18, 36 pp.

van Denderen, P.D., N.T. Hintzen, A.D. Rijnsdorp, P. Ruardij \& T. van Kooten (2014). Habitat-Specific Effects of Fishing Disturbance on Benthic Species Richness in Marine Soft Sediments. Ecosystems 17: 1216-1226.

van Denderen, P.D., S.G. Bolam, J.G. Hiddink, S. Jennings, A. Kenny, A.D. Rijnsdorp \& T. van Kooten (2015). Similar effects of bottom trawling and natural disturbance on composition and function of benthic communities across habitats. . Marine Ecology Progress Series 541: 31-43. 
van der Kaaij, T., T. van Kessel, T. Troost, P. Herman, L. van Duren \& N. Villars (2017). Modelondersteuning MER winning suppletie- en ophoogzand Noordzee 2018 - 2027. Deltares, Delft, Rapport nr 1230888-002-ZKS-0006, 75 pp.

Van Duren, L., T. Van Kessel, T.A. Troost, A.N. Blauw, L. Kramer, J. Van Gils \& P.M.J. Herman (2017). Scenariostudies ter ondersteuning van de MER-Zandwinning 2018-2027. Deltares, Delft, Report 1230888-000-ZKS-0014, 94 pp.

van Keeken, O.A., M. van Hoppe, R.E. Grift \& A.D. Rijnsdorp (2007). Changes in the spatial distribution of North Sea plaice (Pleuronectes platessa) and implications for fisheries management. Journal of Sea Research 57: 187-197.

Van Kooten, T. \& H.M. Janssen (2015). Reguleringsmechanismen in het kustecosysteem van de Voordelta. IMARES, IJmuiden, nr. C095/15, pp.

Van Oostveen, M. \& E. Koolmees (2013). Evaluatie Natura-2000 beheerplan Voordelta 2008-2014. Royal HaskoningDHV, RD-EW 20130824, december 2013, 127 + bijlagen pp. http://www.voordelta.nl/topics/voordelta/informatie/downloadoverzicht/index/evaluatie_beheerplan _voordelta_20131231.pdf

van Oostveen, M., D. van Bentum \& R. Veldhuizen (2014). Gebruikstoets Voordelta. Tweede Beheerplan Voordelta. RoyalHaskoningDHV, Amersfoort, Augustus 2014, $75+$ bijlagen pp.

VenW (2009). Monitoring- en Evaluatieprogramma Maasvlakte 2. Natuurcompensatie Voordelta. pp.

Vorberg, R. (2000). Effects of shrimp fisheries on reefs of Sabellaria spinulosa (Polychaeta). Ices Journal of Marine Science 57: 1416-1420.

Wang, Z.B., J.G. De Ronde, A.J.F. Van der Spek \& E.P.L. Elias (2009). Responses of the Dutch coastal system to the (semi-)closures of tidal basins. Proceedings of ICEC 2009, Sendai, Japan 1: 203-210.

Wetlands International (2016). Waterbird Population Estimates. wpe.wetlands.org, 13 Dec 2016, pp.

Wijnhoven, S. \& H. Hummel (2008). Historische ontwikkeling macrofauna levensgemeenschappen Rijn-Maasmonding KNAW-NIOO, Centrum voor Estuariene en Mariene Ecologie, Yerseke, Monitor Taskforce Publication Series 2008 - 12, 121 pp.

Witbaard, R., G.C.A. Duineveld, M.J.N. Bergman, H.I.J. Witte, L. Groot \& M.J.C. Rozemeijer (2015). The growth and dynamics of Ensis directus in the near-shore Dutch coastal zone of the North Sea. Journal of Sea Research 95: 95-105.

Witbaard, R., M.J.N. Bergman, E. van Weerlee \& G.C.A. Duineveld (2017). An estimation of the effects of Ensis directus on the transport and burial of silt in the near-shore Dutch coastal zone of the North Sea. Journal of Sea Research 127: 95-104.

Wolff, W.J. (1973). The estuary as a habitat. An analysis of data on the soft-bottom macrofauna of the estuarine area of the rivers Rhine, Meuse, and Scheldt. Zoölogische Verhandelingen 126: 1-242.

Worton, B.J. (1989). KERNEL METHODS FOR ESTIMATING THE UTILIZATION DISTRIBUTION IN HOMERANGE STUDIES. Ecology 70: 164-168.

WVL, R. (2013). Evaluatie MEP Aanleg Maasvlakte 2 2013. Rijkswaterstaat Water, Verkeer en Leefomgeving, $73 \mathrm{pp}$.

Zuur, A.F., E.N. Ieno, N.J. Walker, A.A. Saveliev \& G.M. Smith (2009). Mixed effects models and extensions in ecology with $R$. Springer. New York, pp. ^ pp.

Zuur, A.F., P.W. Van Horssen, E.N. Ieno, A.A. Saveliev \& M.J.M. Poot (2014). Zero-inflated and spatial correlated Common Scoter data.In: A Beginner's Guide to Generalized Additive Mixed Models with R; Zuur, A.F., Saveliev, A.A. en Ieno, E.N. (eds.). Highland Statistics Ltd., Newburgh, UK. p: 285318.

Zuur, A.F. \& E.N. Ieno (2017a). Analysis of PMR monitoring data -Fisheries effects on marine benthic fauna. Highland Statistics Itd., pp.

Zuur, A.F. \& E.N. Ieno (2017b). Analysis of PMR monitoring data - Fisheries effects on marine benthic fauna. Highland Statistics, September 2017, 59 pp.

Zuur, A.F., E.N. Ieno \& A.A. Saveliev (2017). Spatial, Temporal and Spatial-Temporal Ecological Data Analysis with R-INLA. Highland Statistics Ltd, pp. ^ pp. 


\section{Verantwoording}

Rapportnummer:

$\mathrm{C} 014 / 18$

Projectnummer:

4316100065

Dit rapport is met grote zorgvuldigheid tot stand gekomen. De wetenschappelijke kwaliteit is intern getoetst door een collega-onderzoeker en het verantwoordelijk lid van het managementteam van Wageningen Marine Research

Akkoord:

Luca van Duren

Expert onderzoeker

Handtekening:

Datum:

maart 2018

Akkoord:

Robbert Jak

Onderzoeker

Handtekening:

Datum:

01 maart 2018

Akkoord:

Drs. J. Asjes

Manager Intergratie

Handtekening:

Datum:

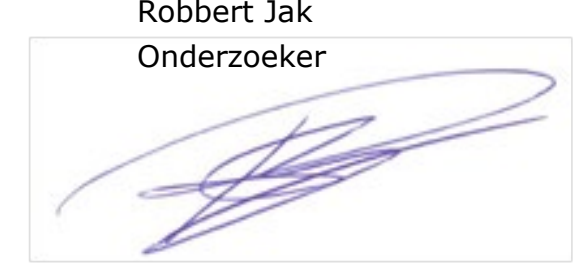

Manager Intergratie

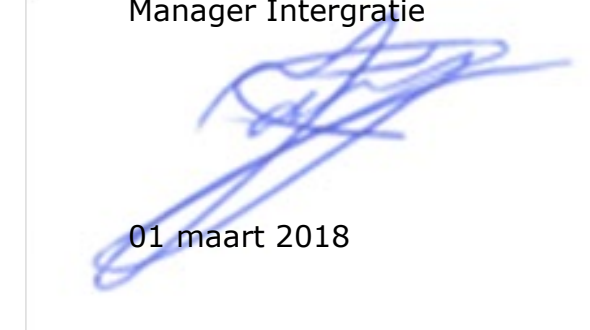




\section{Bijlage 1 Onderzoeks- en MEP-vragen}

$H 1110$

\begin{tabular}{|c|c|}
\hline Evaluatievragen & Onderzoeksvragen \\
\hline $\begin{array}{l}\text { 1) Wordt het verlies aan habitattype } \mathrm{H} 1110 \text { als } \\
\text { gevolg van de aanleg van Maasvlakte } 2 \text { voldoende } \\
\text { gecompenseerd? }\end{array}$ & $\begin{array}{l}\text { 1) Wordt het verlies aan habitattype } \mathrm{H} 1110 \mathrm{~B} \text { als } \\
\text { gevolg van de aanleg van Maasvlakte } 2 \text { voldoende } \\
\text { gecompenseerd? }\end{array}$ \\
\hline $\begin{array}{l}\text { a) Is het verlies aan oppervlak van habitattype } \\
\text { H1110 a.g.v. het ruimtebeslag, de ontwikkeling } \\
\text { van de erosiekuil en de toename van de getijslag } \\
\text { inderdaad } 2455 \text { ha? }\end{array}$ & a) wordt behandeld in MEP-Aanleg \\
\hline $\begin{array}{l}\text { b) Wat is het daaraan gerelateerde verlies aan } \\
\text { bodemdieren, in termen van typische soorten, } \\
\text { kenmerken van een goede structuur en functie en } \\
\text { voedsel voor vissen en vogels? }\end{array}$ & b) wordt behandeld in MEP-Aanleg \\
\hline $\begin{array}{l}\text { c) Zijn er positieve trends waar te nemen in de } \\
\text { aanwezigheid en dichtheid van typische soorten en } \\
\text { in de kenmerken van een goede structuur en } \\
\text { functie van het habitattype H1110B in de Voordelta } \\
\text { sinds het begin van de afname van de } \\
\text { boomkorvisserij uit de Voordelta rond de laatste } \\
\text { eeuwwisseling? }\end{array}$ & $\begin{array}{l}\text { c) Zijn er positieve trends waar te nemen in } \\
\text { kwaliteit van het Habitat } 1110 \mathrm{~B} \text { ( zoals deze wordt } \\
\text { gedefinieerd in het profieldocument H1110 (versie } \\
18 \text { december 2008)), in de Voordelta sinds het } \\
\text { begin van de afname van de boomkorvisserij uit de } \\
\text { Voordelta rond de laatste eeuwwisseling? }\end{array}$ \\
\hline $\begin{array}{l}\text { d) Zijn de waargenomen trends toe te schrijven } \\
\text { aan de afgenomen bodemberoering ten gevolge } \\
\text { van de afname van de grote boomkorvisserij met } \\
\text { wekkerkettingen in de gehele Voordelta of ook aan } \\
\text { andere factoren? }\end{array}$ & d) onderzoeksvraag is gelijk aan evaluatievraag \\
\hline $\begin{array}{l}\text { e) Wat is het effect van verschillende vormen van } \\
\text { bodemberoerende visserij op het ecosysteem (in } \\
\text { termen van geschatte bijvangst, onttrekking van } \\
\text { vis, verstoring) geweest in de periode T0 (2004- } \\
2008) \text {, T1 (2009-2013) en T2 (2014-2018)? }\end{array}$ & $\begin{array}{l}\text { e) Hoe groot was de onttrekking van vis en andere } \\
\text { (bij)vangsten in de periode T0 (2004-2008), T1 } \\
\text { (2009-2013) en T2 (2014-2018)? }\end{array}$ \\
\hline
\end{tabular}


2) Wordt het verlies aan foerageergebied van de zwarte zee-eend als gevolg van de aanleg en het Wordt het verlies aan foerageergebied van de gebruik van Maasvlakte 2 voldoende gecompenseerd? zwarte zee-eend als gevolg van de aanleg en het gebruik van Maasvlakte 2 voldoende gecompenseerd?

a) Hoeveel potentieel foerageergebied is er

a) Onderzoeksvragen zijn gelijk aan daadwerkelijk verloren gegaan a.g.v. het evaluatievragen ruimtebeslag van $M V 2$, de ontwikkeling van de erosiekuil en het gebruik van MV2?

i) Wat is op basis van voortschrijdend inzicht de betekenis van het gebied dat verloren is gegaan voor de zwarte zee-eend in termen van voedselbeschikbaarheid en rust?

ii) Hoe is, op basis van voortschrijdend inzicht, het effect van de aanleg en het gebruik van Maasvlakte 2 op het instandhoudingsdoel voor deze soort te beoordelen?

b) Leidt het instellen van het bodembeschermingsgebied tot een gelijkblijvende potentiële functie van de Voordelta voor de zwarte zee-eend in termen van voedselbeschikbaarheid?

i) Is de potentiële draagkracht van het gebied toegenomen door de ingestelde maatregelen n.l. het beperken van de grote boomkorvisserij? Het gaat hier om de potentiële draagkracht met betrekking tot de voedselvoorziening van deze soort in relatie tot het instandhoudingsdoel; dit betekent niet de jaarlijkse aanwezigheid van de zwarte zee-eend in het gebied volgens het instandhoudingsdoel.

ii) Zijn andere factoren dan voedselbeschikbaarheid binnen en buiten de Voordelta bepalend voor het al dan niet aanwezig zijn van deze soort in de Voordelta? iii) Is er voldoende oogstbaar voedsel in de totale Voordelta voor het aantal vogels volgens het instandhoudingsdoel ${ }^{7}$ ?

c) Draagt het instellen van rustgebieden, specifiek voor de zwarte zee-eend, bij aan een gelijkblijvende potentiële functie van de Voordelta als foerageer- en rustgebied?

i) Is de potentiële draagkracht van de Voordelta gelijk gebleven door het instellen van de rustgebieden? Voor het begrip potentiële draagkracht, zie hierboven.

ii) Is er voldoende rust in de Voordelta om de draagkracht voor het gestelde aantal vogels in het instandhoudingsdoel te kunnen waarborgen?

\footnotetext{
${ }^{7}$ Met oogstbaar voedsel wordt bedoeld dat deel van de bodemfauna van de juiste afmeting, in de juiste dichtheid, van de juiste soort en op de juiste diepte.
}

b) Onderzoeksvragen zijn gelijk aan evaluatievragen c) Onderzoeksvragen zijn gelijk aan evaluatievragen 
d) Is de aangepaste begrenzing van de extra rustgebieden vanuit PMR-NCV juist gekozen om bij te dragen aan het instandhoudingsdoel?

i) Worden de aangepaste rustgebieden gebruikt door de aanwezige zwarte zee-eenden? In welke periode houden zij zich hier op en welke ecologische functies vervullen de rustgebieden voor deze soort?

ii) Hoe is de verspreiding van de zwarte zee-eend in de Voordelta in de wintermaanden (oktobermaart) en daarbuiten (april-september)? d) Draagt de aangepaste begrenzing van de rustgebieden, specifiek voor de zwarte zee-eend, bij aan een gelijkblijvende potentiële functie van de Voordelta als foerageer- en rustgebied?

i) Worden de aangepaste rustgebieden gebruikt door de aanwezige zwarte zee-eenden? In welke periode houden zij zich hier op en welke ecologische functies vervullen de rustgebieden voor deze soort?

ii) Hoe zijn zwarte zee-eenden verspreid over de Voordelta in de overwinteringsperiode (oktober$\left.\mathrm{mei}^{8}\right)$ ?

sterns

\begin{tabular}{|c|c|}
\hline Evaluatievragen & Onderzoeksvragen \\
\hline $\begin{array}{l}\text { 3) Wordt het verlies aan foerageergebied van de } \\
\text { grote stern als gevolg van het ruimtebeslag en het } \\
\text { gebruik van Maasvlakte } 2 \text { voldoende } \\
\text { gecompenseerd? }\end{array}$ & $\begin{array}{l}\text { 3) Wordt het verlies aan foerageergebied van de } \\
\text { grote stern als gevolg van het ruimtebeslag en het } \\
\text { gebruik van Maasvlakte } 2 \text { voldoende } \\
\text { gecompenseerd? }\end{array}$ \\
\hline $\begin{array}{l}\text { a) Hoeveel potentieel foerageergebied is er voor de } \\
\text { grote stern daadwerkelijk verloren gegaan a.g.v. } \\
\text { het ruimtebeslag en het gebruik van MV2? } \\
\text { i) Wat is op basis van voortschrijdend inzicht de } \\
\text { betekenis van het gebied dat door de aanleg van } \\
\text { Maasvlakte } 2 \text { verloren is gegaan in vergelijking } \\
\text { met het nieuwe kustgebied na aanleg van } \\
\text { Maasvlakte } 2 \text { ? } \\
\text { ii) Hoe is, op basis van voortschrijdend inzicht, het } \\
\text { effect van de aanleg en het gebruik van } \\
\text { Maasvlakte } 2 \text { op het instandhoudingsdoel voor } \\
\text { deze soort te beoordelen? }\end{array}$ & $\begin{array}{l}\text { a) Hoe is, op basis van voortschrijdend inzicht, de } \\
\text { inschatting van het effect van de aanleg van } \\
\text { Maasvlakte } 2 \text { op het instandhoudingsdoel voor } \\
\text { deze soort? } \\
\text { i) Wat was, in kwalitatieve termen, de betekenis } \\
\text { van het verdwenen foerageergebied } \\
\text { ii) Wat is, in kwalitatieve termen, de betekenis van } \\
\text { het nieuwe kustgebied na aanleg van Maasvlakte } 2\end{array}$ \\
\hline $\begin{array}{l}\text { b) Leidt het instellen van het } \\
\text { bodembeschermingsgebied tot een gelijkblijvende } \\
\text { potentiële functie van de Voordelta voor de grote } \\
\text { stern in termen van voedselbeschikbaarheid? } \\
\text { i) Treden veranderingen op in broedsucces, het } \\
\text { voedsel, de verspreidingspatronen en het aantal } \\
\text { vogeldagen van de grote stern t.o.v. de situatie } \\
\text { vóór de aanleg van Maasvlakte } 2 \text { ? } \\
\text { ii) Zijn deze veranderingen toe te schrijven aan } \\
\text { (veranderingen in) de voedselbeschikbaarheid of } \\
\text { zijn andere factoren van (groter) belang? } \\
\text { iii) Is er een causaal verband tussen de } \\
\text { verschillende vormen van bodemberoerende } \\
\text { visserij en de aanwezigheid en dichtheid van } \\
\text { zandspiering in de Voordelta. Zandspiering lijkt een } \\
\text { belangrijke voedselbron te zijn voor de grote stern. }\end{array}$ & $\begin{array}{l}\text { b) Leidt het instellen van het } \\
\text { bodembeschermingsgebied tot een gelijkblijvende } \\
\text { potentiële functie van de Voordelta voor de grote } \\
\text { stern in termen van voedselbeschikbaarheid? } \\
\text { i) onderzoeksvraag is gelijk aan evaluatievraag } \\
\text { ii) onderzoeksvraag is gelijk aan evaluatievraag } \\
\text { iii) Is er een correlatie tussen de verschillende } \\
\text { vormen van bodemberoerende visserij en de } \\
\text { aanwezigheid en dichtheid van zandspiering in de } \\
\text { Voordelta. Is het aannemelijk dat het om een } \\
\text { causaal verband gaat? }\end{array}$ \\
\hline
\end{tabular}

\footnotetext{
${ }^{8}$ De monitoring is beperkt tot de periode oktober-mei, omdat de compensatieopgave gericht is op overwinterende zee-eenden
} 
c) Draagt het instellen van de rustgebieden bij aan het verbeteren van het potentiële functioneren van de Voordelta?

i) Worden de droogvallende platen in de rustgebieden gebruikt door de aanwezige grote sterns? En in welke periode houden zij zich hier op?

ii) Wat is het relatieve belang van de Voordelta voor de grote stern, welke factoren spelen daarbij een rol en wat is de jaar tot jaar variantie en zijn hierin grote veranderingen waarneembaar?

4) Wordt het verlies aan foerageergebied van de visdief als gevolg van het ruimtebeslag en het gebruik van Maasvlakte 2 voldoende gecompenseerd?

a) Hoeveel potentieel foerageergebied is er voor de visdief daadwerkelijk verloren gegaan a.g.v. het ruimtebeslag en het gebruik van MV2?

i) Wat is op basis van voortschrijdend inzicht de betekenis van het gebied dat door de aanleg van Maasvlakte 2 verloren is gegaan in vergelijking met het nieuwe kustgebied na aanleg van Maasvlakte 2?

ii) Hoe is, op basis van voortschrijdend inzicht, het effect van de aanleg en het gebruik van Maasvlakte 2 op het instandhoudingsdoel voor deze soort te beoordelen?

b) Leidt het instellen van het bodembeschermingsgebied tot een gelijkblijvende potentiële functie van de Voordelta voor de visdief in termen van voedselbeschikbaarheid?

i) Treden veranderingen op in broedsucces, het voedsel, de verspreidingspatronen en het aantal vogeldagen van de visdief in de Voordelta t.o.v. de situatie vóór de aanleg van Maasvlakte 2? Het gaat hierbij om inzicht in het functioneren van de gehele Voordelta voor deze soort.

iI) Zijn deze veranderingen toe te schrijven aan (veranderingen in) de voedselbeschikbaarheid of zijn andere factoren van (groter) belang?

c) Draagt het instellen van de rustgebieden bij aan het potentiële functioneren van de Voordelta?

i) Worden de platen in de rustgebieden gebruikt door de aanwezige visdieven? In welke periode houden zij zich hier op en wat is de functie van de aanwezigheid van droogvallende platen?

ii) Hoe is de verspreiding van de visdief in de Voordelta in relatie tot het ecologisch ruimtegebruik en zijn hierin grote veranderingen waarneembaar? c) Draagt het instellen van de rustgebieden bij aan het instandhoudingsdoel?

i) Worden de droogvallende platen in de rustgebieden gebruikt door de aanwezige grote sterns, en/of worden andere gebieden gebruikt om te rusten? En in welke periode houden zij zich hier op?

ii) onderzoeksvraag is gelijk aan evaluatievraag

4) Wordt het verlies aan foerageergebied van de visdief als gevolg van het ruimtebeslag en het gebruik van Maasvlakte 2 voldoende gecompenseerd?

a) Hoe is, op basis van voortschrijdend inzicht, de inschatting van het effect van de aanleg van Maasvlakte 2 op het instandhoudingsdoel voor deze soort?

i) Wat was, in kwalitatieve termen, de betekenis van het verdwenen foerageergebied

ii) Wat is, in kwalitatieve termen, de betekenis van het nieuwe kustgebied na aanleg van Maasvlakte 2

Leidt het instellen van het

bodembeschermingsgebied tot een gelijkblijvende potentiële functie van de Voordelta voor de visdief in termen van voedselbeschikbaarheid?

i) Treden veranderingen op in broedsucces, het voedsel, de verspreidingspatronen en het aantal vogeldagen van de visdief in de Voordelta t.o.v. de situatie vóór de aanleg van Maasvlakte 2? Het gaat hierbij om inzicht in het functioneren van de gehele Voordelta voor deze soort.

ii) Zijn deze veranderingen toe te schrijven aan (veranderingen in) de voedselbeschikbaarheid of zijn andere factoren van (groter) belang?

Draagt het instellen van de rustgebieden bij aan het instandhoudingsdoel?

i) Worden de platen in de rustgebieden gebruikt door de aanwezige visdieven? In welke periode houden zij zich hier op en wat is de functie van de aanwezigheid van droogvallende platen? 


\section{Bijlage 2 Monsterprogramma Benthos}

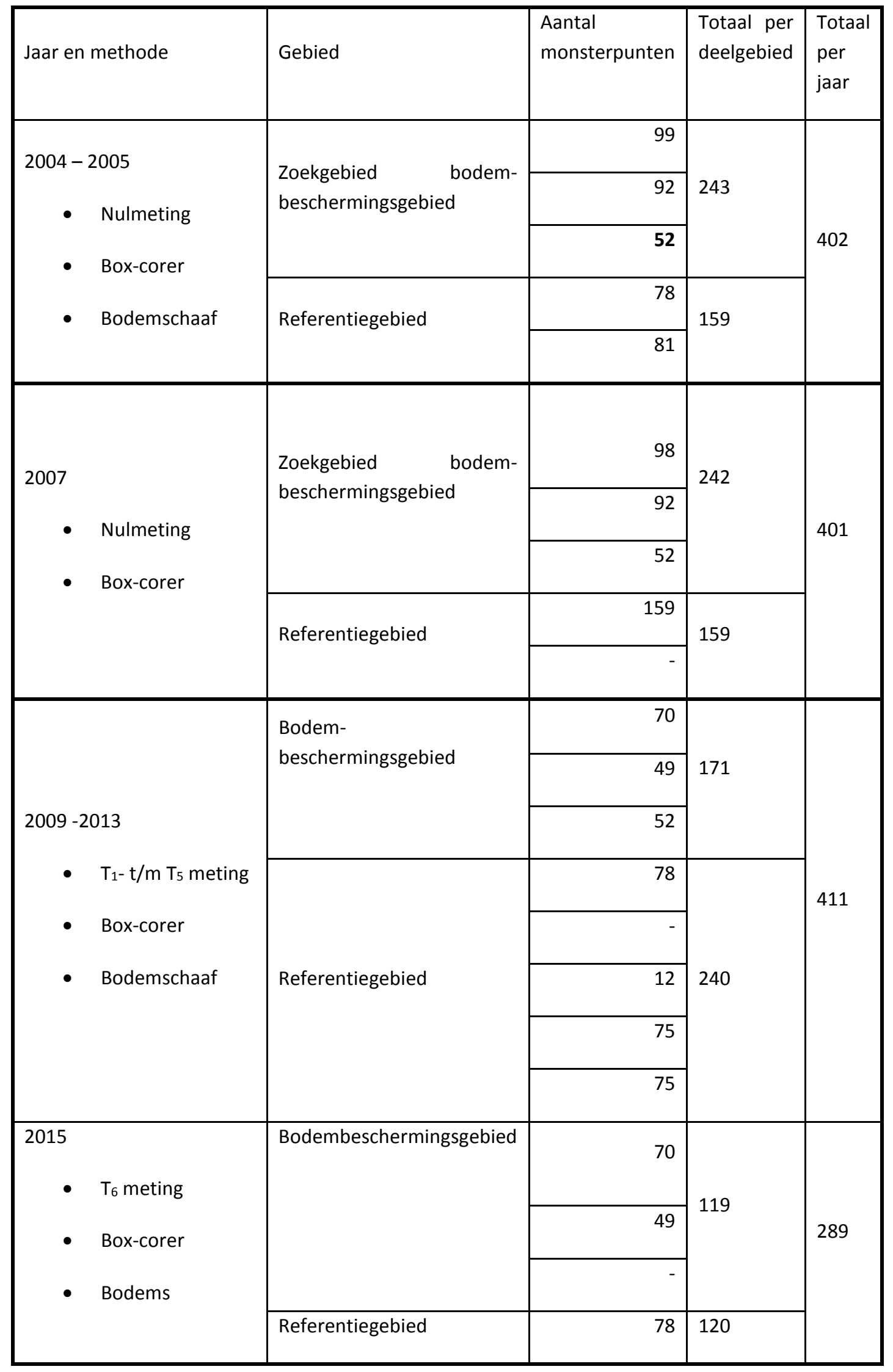




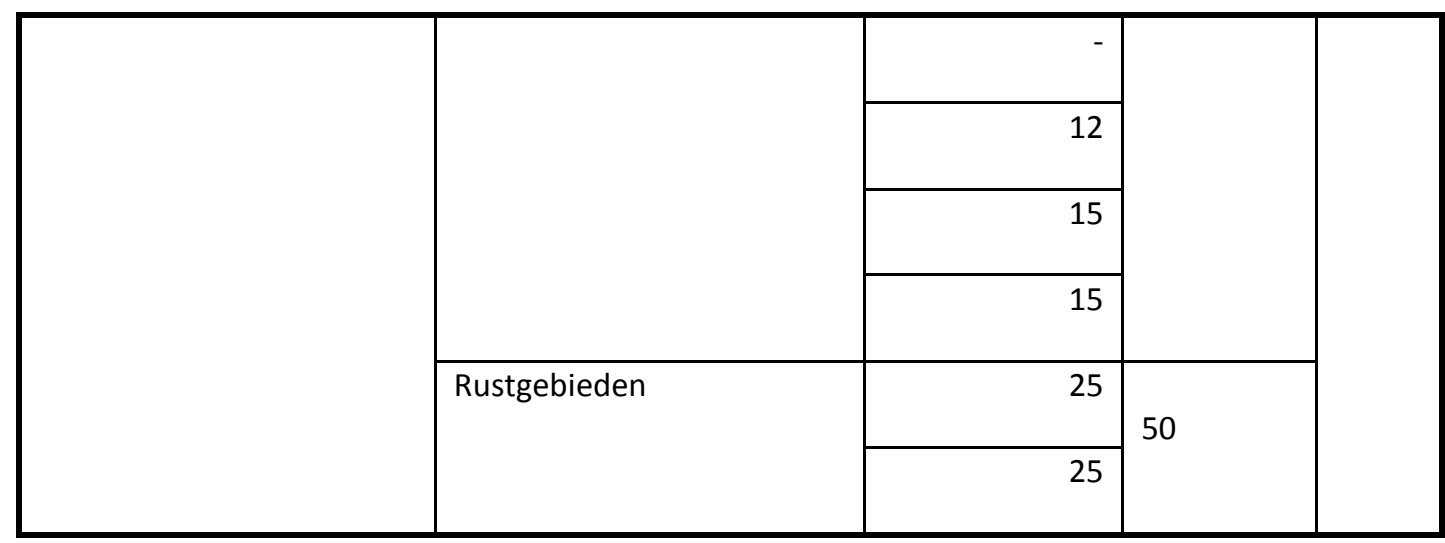




\section{Bijlage 3 Soorten en parameters perceel vis}

Lijst van typische en beschermde soorten en van soorten bemonsterd in het monitoringprogramma. De laatste drie kolommen geven aan welke parameters van de betreffende soort gemeten zijn. De extra soorten zijn de soorten die niet op de lijst van habitatrichtlijn of typische soorten voorkomen, maar wel zijn bemonsterd.

\begin{tabular}{|c|c|c|c|c|c|c|}
\hline groep & Nederlandse naam & Wetenschappelijke naam & $\begin{array}{l}\text { H1110A/ } \\
\text { B }\end{array}$ & $\begin{array}{l}\text { dichtheid/ } \\
\text { lengte- } \\
\text { frequentie } \\
\text {-verdeling }\end{array}$ & $\begin{array}{l}\text { dieet (alleen } \\
\text { eerste fase) en } \\
\text { gewicht }\end{array}$ & $\begin{array}{l}\text { otolieten, sexe } \\
\text { en geslachts- } \\
\text { rijpheid }\end{array}$ \\
\hline \multirow[t]{18}{*}{ Typische soorten H1110 } & haring & Clupea harengus & $A, B$ & ja & nee & ja \\
\hline & spiering & Osmerus eperlanus & $A$ & ja & nee & nee \\
\hline & wijting & Merlangius merlangus & $B$ & ja & ja & ja \\
\hline & grote zeenaald & Syngnathus acus & $A$ & ja & nee & nee \\
\hline & kleine zeenaald & Syngnathus rostellatus & $A$ & ja & nee & nee \\
\hline & zeedonderpad & Myoxocephalus scorpius & $A$ & ja & nee & nee \\
\hline & slakdolf & Liparis liparis & $A$ & ja & nee & nee \\
\hline & puitaal & Zoarces viviparus & $A$ & ja & nee & nee \\
\hline & botervis & Pholis gunnelis & $A$ & ja & nee & nee \\
\hline & kleine zandspiering & Ammodytes tobianus & $\mathrm{B}$ & ja & nee & nee \\
\hline & noorse zandspiering & Ammodytes marinus & $\mathrm{B}$ & ja & nee & nee \\
\hline & kleine pieterman & Echiichthys vipera & $\mathrm{B}$ & ja & ja & ja \\
\hline & pitvis & Callionymus lyra & $B$ & ja & ja & ja \\
\hline & dikkopje & Pomatoschistus minutus & $A$ & ja & ja & ja \\
\hline & bot & Platichthys flesus & $A$ & ja & ja & ja \\
\hline & schol & Pleuronectes platessa & $A, B$ & ja & ja & ja \\
\hline & tong & Solea vulgaris & $\mathrm{B}$ & ja & ja & ja \\
\hline & dwergtong & Buglossidium luteum & $\mathrm{B}$ & ja & ja & ja \\
\hline \multirow[t]{4}{*}{ Habitatrichtlijnsoorten } & elft & Alosa alosa & & ja & nee & nee \\
\hline & fint & Alosa fallax & & ja & nee & nee \\
\hline & rivierprik & Lampetra fluviatilis & & ja & nee & nee \\
\hline & zeeprik & Petromyzon marinus & & ja & nee & nee \\
\hline \multirow[t]{3}{*}{ Extra soorten } & schurftvis & Arnoglossus laterna & & ja & ja & ja \\
\hline & schar & Limanda limanda & & ja & ja & ja \\
\hline & gewone garnaal & Crangon crangon & & ja & nee & nee \\
\hline
\end{tabular}


Standaard metingen tijdens de visbemonsteringen. Van alle gevangen soorten is de dichtheid en de lengte-frequentieverdeling bepaald. 1 betekent alleen in de $1^{e}$ fase gemeten, 2 betekent alleen in de tweede fase gemeten, + betekent in beide fasen gemeten, DFS betekent dat voor die soorten de gegevens standaard in de DFS worden verzameld.

\begin{tabular}{|l|l|l|l|l|}
\hline soort & $\begin{array}{l}\text { dieet (alleen } \\
\text { eerste fase) }\end{array}$ & gewicht & otolieten & $\begin{array}{l}\text { geslacht/ } \\
\text { geslachtsrijpheid }\end{array}$ \\
\hline haring & & & 1 & 1 \\
\hline wijting & 1 & + & + & + \\
\hline kleine pieterman & 1 & + & + & + \\
\hline pitvis & 1 & + & + & + \\
\hline grondels & 1 & + & & + \\
\hline bot & 1 & + & + & + \\
\hline schar & 1 & + & + & + \\
\hline schol & 1 & + & + & + \\
\hline tong & 1 & + & + & + \\
\hline dwergtong & 1 & + & + & + \\
\hline schurftvis & 1 & + & + & + \\
\hline tarbot & & DFS & DFS & DFS \\
\hline griet & & DFS & DFS & DFS \\
\hline Noorse zandspiering & & 2 & 2 & 2 \\
\hline kleine zandspiering & & 2 & 2 & 2 \\
\hline
\end{tabular}

